\title{
СТОЙКИЕ ОРГАНИЧЕСКИЕ ЗАГРЯЗНЯЮЩИЕ ВЕЩЕСТВА (СОЗ) В ДАЛЬНЕВОСТОЧНОМ РЕГИОНЕ: МОРЯ, ОРГАНИЗМЫ, ЧЕЛОВЕК
}

\author{
Монография \\ Научный редактор \\ В.Ю. Цыганков
}

Владивосток

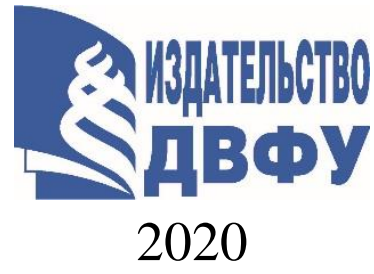


УДК 504.054:547(517.6)

ББК 20.18(255)

$\mathrm{C} 81$

Монография подготовлена и опубликована

при финансовой поддержке гранта РНФ (соглашение № 18-14-00120)

Авторский коллектив:

В.Ю. Цыганков, М.М. Донец, Н.К. Христофорова, Ю.П. Гумовская, А.В. Полевщиков, А.Н. Гумовский, М.Д. Боярова, А.П. Черняев, М.С. Лягуша, О.Ю. Бусарова, В.А. Лях, А.В. Литвиненко, П.Ф. Кику, И.П. Коваль, В.В. Усов

\section{Рецензенты:}

Г.А. Софронов, д-р мед. наук, профессор, заслуженный деятель науки РФ, академик РАН и РАМН, генерал-майор медицинской службы;

С.В. Сенотрусова, д-р биол. наук, профессор

Стойкие органические загрязняющие вещества (СО3) в ДальнеС81 восточном регионе: моря, организмы, человек : монография / В.Ю. Цыганков, М.М. Донец, Н.К. Христофорова [и др.] ; науч. ред. В.Ю. Цыганков. - Владивосток : Изд-во Дальневост. федерал. ун-та, 2020. - 344 с. : ил.

ISBN 978-5-7444-4891-2.

DOI: $10.24866 / 7444-4891-2$.

В монографии систематизированы результаты исследований СО3 в абиотических и биотических компонентах водной среды, возможных рисках для здоровья жителей прибрежных районов, которые оказываются в сфере воздействия этих опасных поллютантов. В частности, выявлены удобные организмыиндикаторы (из числа видов рыб, птиц и млекопитающих), свидетельствующие о загрязнении региона; показаны возможные пути переноса ксенобиотиков из моря на сушу; определены организмы-мишени, подверженные воздействию CO3 на живые организмы; установлена давность циркуляции поллютантов в биосфере; составлен список «приоритетных» токсикантов для региона на основе качественного скрининга; оценены риски для здоровья человека, связанные с употреблением загрязненных гидробионтов; измерены уровни содержания СO3 в организме человека.

Монография предназначена для специалистов агропромышленного комплекса, аквакультуры и медицины, преподавателей и аспирантов вузов, научных работников, интересующихся проблемами стойких органических загрязняющих веществ (СO3).

УДК 504.054:547(517.6)

ББК 20.18(255) 
Far Eastern Federal University

\title{
PERSISTENT ORGANIC POLLUTANTS (POPS) IN THE FAR EASTERN REGION: SEAS, ORGANISMS, HUMAN
}

\author{
Monograph \\ Scientific editor \\ Vasiliy Yu. Tsygankov
}

Vladivostok

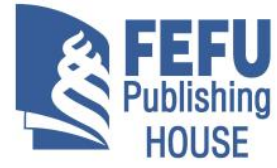

2020 
UDC 504.054:547(517.6)

LBC 20.18(255)

$\mathrm{P} 47$

The monograph was prepared and published with the financial support

by Russian Science Foundation (agreement No. 18-14-00120)

Authors:

V.Yu. Tsygankov, M.M. Donets, N.K. Khristoforova, Yu.P. Gumovskaya, A.V. Polevshchikov, A.N. Gumovsky, M.D. Boyarova, A.P. Chernyaev, M.S. Lyagusha, O.Yu. Busarova, V.A. Lyakh, A.V. Litvinenko, P.F. Kiku, I.P. Koval, V.V. Usov,

Reviewers:

Genrikh A. Sofronov, Dr. Sci., Professor, Honored Scientist of the Russian Federation, Academician of RAS and RAMS, Major General of the Medical Service; Svetlana V. Senotrusova, Dr. Sci., Professor

Persistent organic pollutants (POPs) in the Far Eastern Region: Seas, P47 Organisms, Human : monograph / V.Yu. Tsygankov, M.M. Donets, N.K. Khristoforova [et al.] ; edited by V.Yu. Tsygankov. - Vladivostok : Publishing House of the Far Eastern Federal University, 2020. - 344 p. : il.

ISBN 978-5-7444-4891-2.

DOI: $10.24866 / 7444-4891-2$.

In the monograph, the results on the fate of POPs in the abiotic and biotic components of the aquatic environment, possible health risks for coastal residents exposed to these hazardous pollutants are systematized. In particular, indicator organisms (fish, birds and mammals), indicating the pollution of the region were identified; the possible ways of xenobiotic transfer from the sea to the land are shown; the targets of POPs impact were determined; the time of circulation of pollutants in the biosphere was determined; a list of "priority" toxicants for the region based on quality screening was compiled; the risks to human health from the consumption of contaminated aquatic organisms were assessed; the levels of POPs in the human body were measured.

The book will be interesting for specialists in the agro-industrial complex, aquaculture and medicine, teachers and graduate students of universities, researchers, which interested in the problems of persistent organic pollutants (POPs).

UDC 504.054:547(517.6)

LBC 20.18(255) 


\section{ОГЛАВЛЕНИЕ}

Предисловие.

ГЛАВА 1. «Грязная дюжина» Стокгольмской конвенции. Химия и токсикология стойких органических загрязняющих веществ (CO3): обзор литературы

1.1. «Грязная дюжина» Стокгольмской конвенции.................................. 13

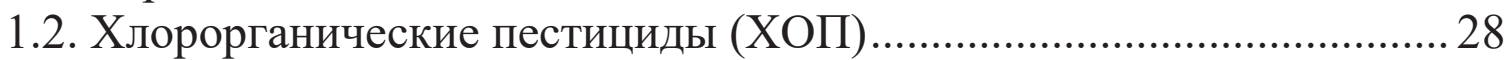

1.2.1. Физико-химические свойства ХОП ......................................... 28

1.2.2. Закономерности распространения ХОП в окружающей среде 32

1.2.3. Метаболизм и деградация ХОП........................................................ 36

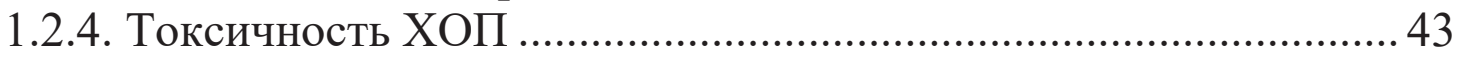

1.3. Полихлорированные бифенилы (ПХБ) .............................................. 47

1.3.1. Физико-химические свойства ПХБ ............................................ 47

1.3.2. Распространение, метаболизм и деградация ПХБ...................... 49

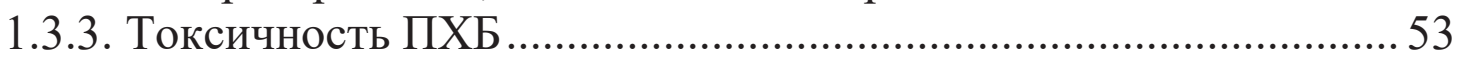

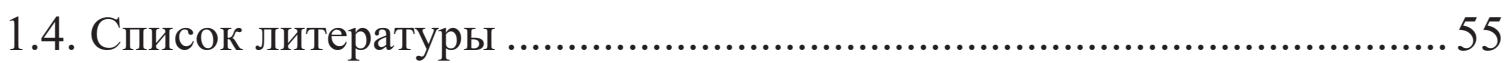

ГЛАВА 2. Методы определения стойких органических загрязняющих веществ (CO3) в различных компонентах экосистем

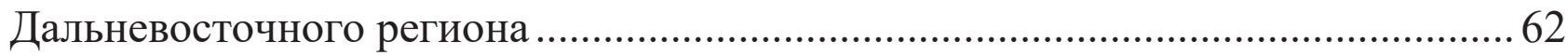

2.1. Подготовка проб биологических образцов гидробионтов................ 63

2.2. Подготовка проб биологических жидкостей человека .......................64 64

2.3. Приготовление стандартных растворов СО3 ....................................65

2.4. Хроматографический анализ и расчет содержания СО3 ..................66 66

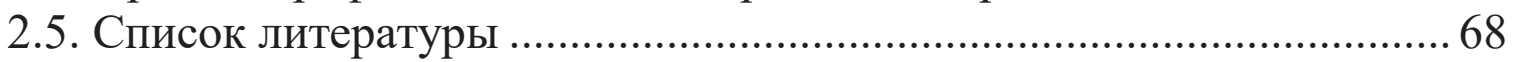

ГЛАВА 3. Стойкие органические загрязняющие вещества (СО3) в звеньях трофических цепей Азиатско-Тихоокеанского региона: краткий обзор

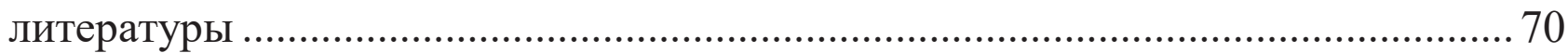

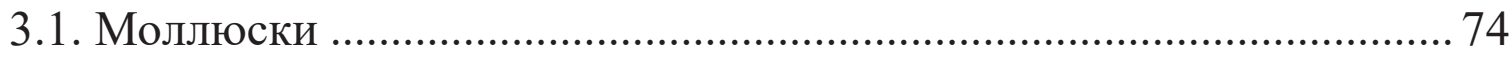

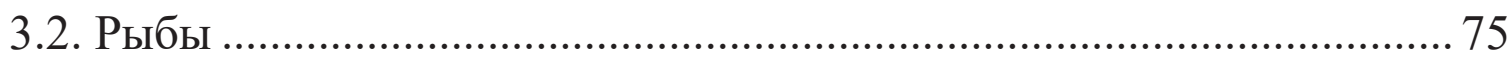

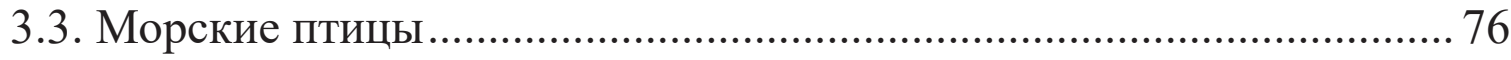

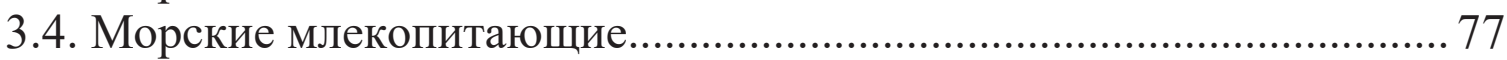

3.5. Список литературы …….................................................................... 79

ГЛАВА 4. Уровни хлорорганических пестицидов (ХОП) в морских экосистемах дальневосточных морей России (2000-2016): обзор литературы .. 83

4.1. Моллюски и рыбы Японского моря ………...................................... 90

4.2 Тихоокеанские лососи Охотского и Берингова морей......................93

4.3. Морские птицы Охотского моря ………………................................95

4.4. Морские млекопитающие Берингова моря ………………………..... 96

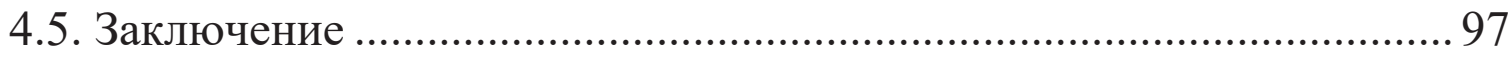

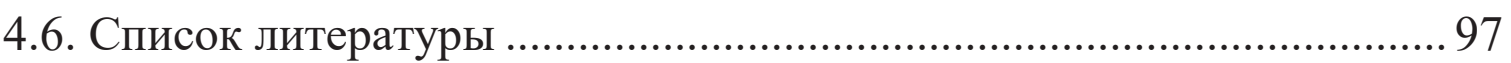

ГЛАВА 5. Современные уровни хлорорганических пестицидов (ХОП) в абиотических компонентах экосистем северо-западной части Тихого океана 101

5.1. Загрязнение морей и океанов ......................................................... 105

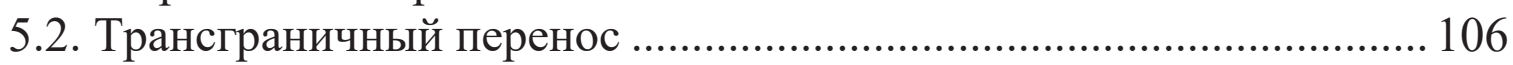


5.3. Мониторинг поверхностных вод и донных отложений

5.4. Физико-географическая характеристика Японского

и Охотского морей

5.5. ХОП в северо-западной части Тихого океана................................ 109

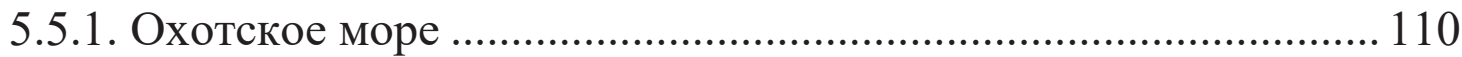

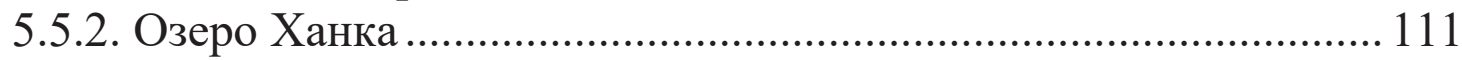

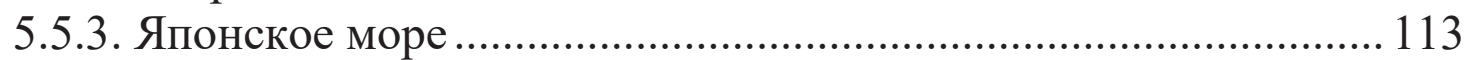

5.5.4. Трансграничный перенос в СЗТО ……..................................... 121

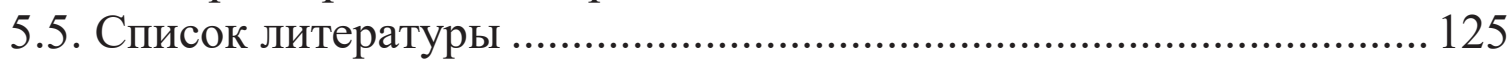

ГЛАВА 6. Современные уровни стойких органических загрязняющих веществ (СО3) в рыбах дальневосточных морей России ................................... 128

6.1. Тихоокеанские лососи (род Oncorhynchus) .................................... 130

6.1.1. Внутривидовые различия аккумуляции СО3

тихоокеанскими лососями Охотского и Берингова морей

6.1.2. Межвидовые различия аккумуляции СО3

тихоокеанскими лососями Охотского и Берингова морей ......................... 167

6.2. Камбалы (род Hippoglossoides) ....................................................... 175

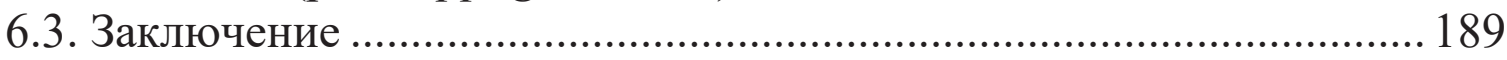

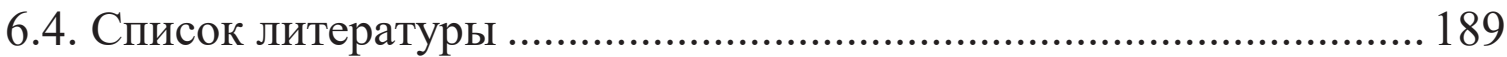

ГЛАВА 7. Биотранспорт стойких органических загрязняющих веществ (CO3) тихоокеанскими лососями северо-западной части Тихого океана ......... 195

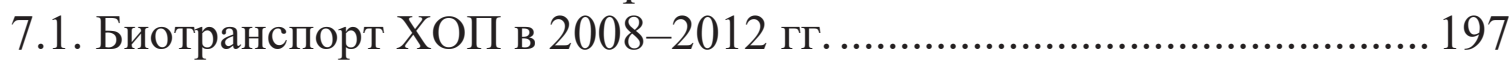

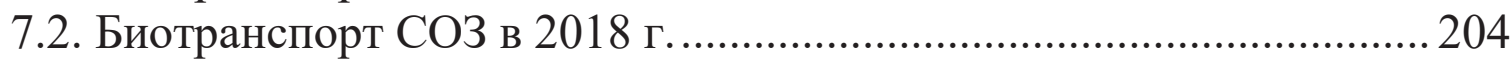

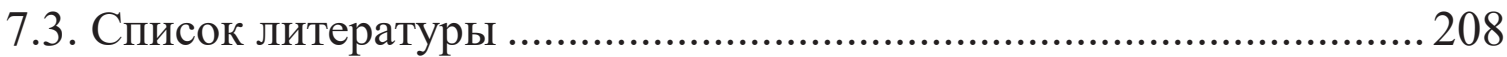

ГЛАВА 8. Хлорорганические пестициды (ХОП) в морских птицах и млекопитающих Охотского и Берингова морей ...............................................221

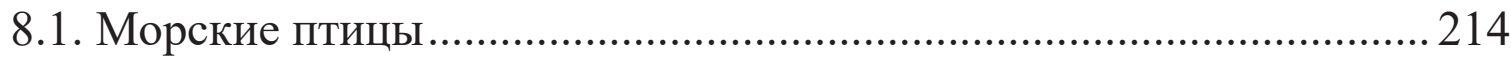

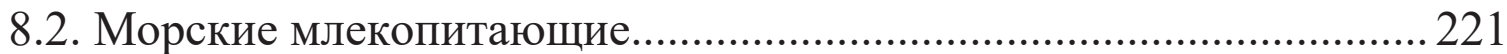

8.2.1. Серый кит (Eschrichtius robustus)..........................................222

8.2.2. Тихоокеанский морж (Odobenus rosmarus divergens) ............... 225

8.2.3. Анализ ХОП в органах серого кита и тихоокеанского моржа

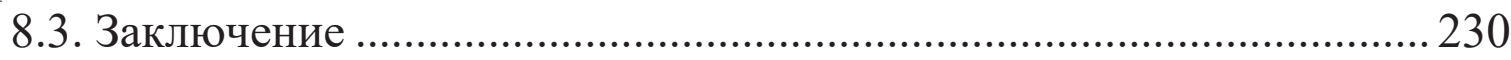

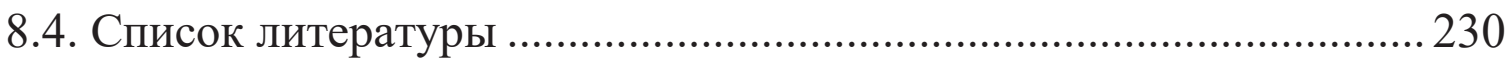

ГЛАВА 9. Биотрансформация стойких органических загрязняющих

веществ (СО3) в морских организмах дальневосточных морей ........................2234

9.1. Биотрансформация СО3 в организмах дальневосточных морей .. 239

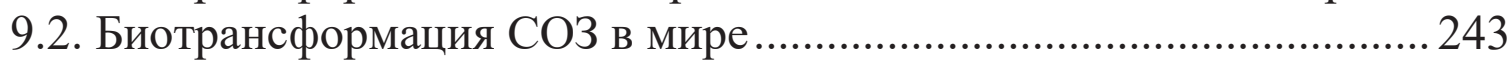

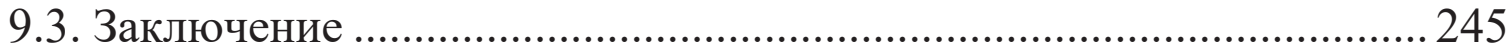

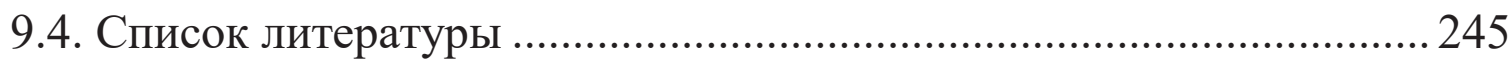

ГЛАВА 10. Нецелевой скрининговый анализ «новых» стойких

органических загрязняющих веществ (СО3) в дальневосточных морях ..........2249

10.1. «Новые» СОЗ в дальневосточных морях России...........................2. 251

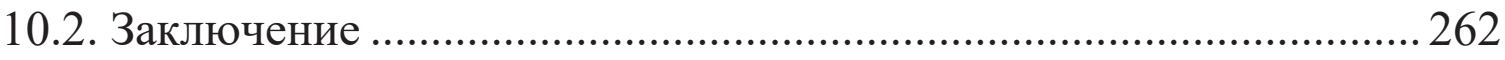

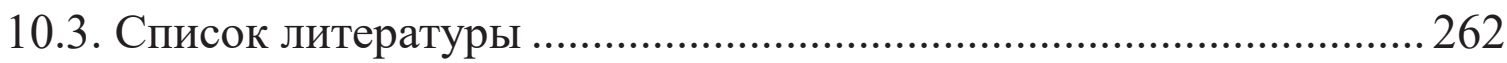


ГЛАВА 11. Экологические риски от стойких органических загрязняющих веществ (СО3) в морских организмах северо-западной части Тихого океана . 263

11.1. Методика расчета экологического риска для здоровья ................265

11.2. Экологические риски от СОЗ для здоровья жителей

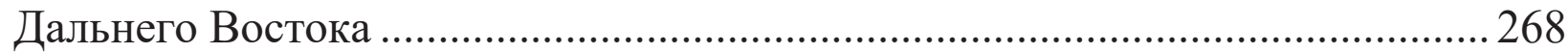

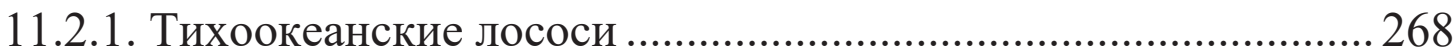

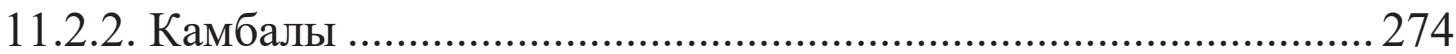

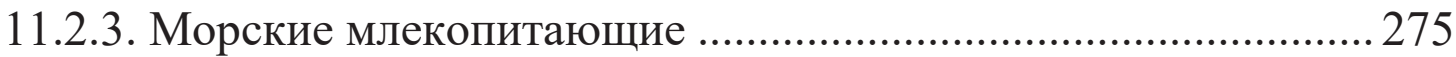

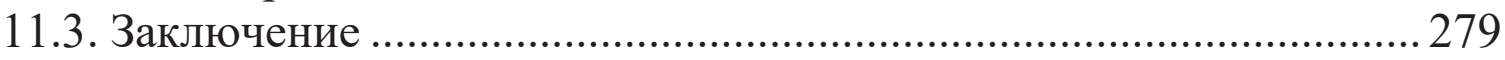

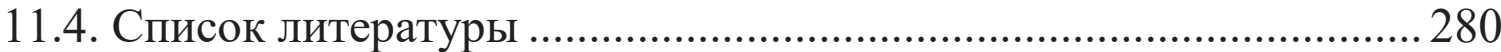

ГЛАВА 12. Стойкие органические загрязняющие вещества (СО3) в организме человека: опыт России и бывших советских республик ................2283

12.1. Распространенность и использование СОЗ в России .................... 286

12.2. Биомониторинг СО3 в организме человека ................................228

12.3. Российские исследования воздействия СО3 на организм ........... 293

12.3.1. Кожный покров (дерма)........................................................2 293

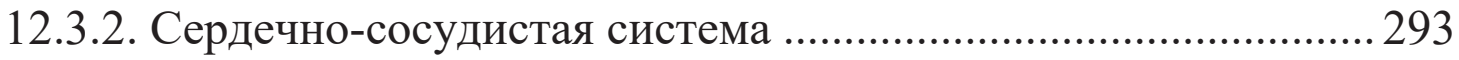

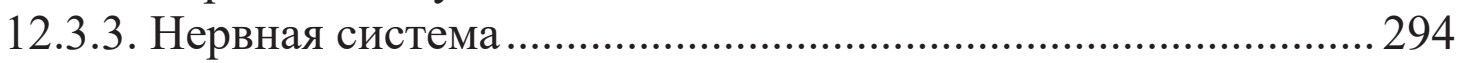

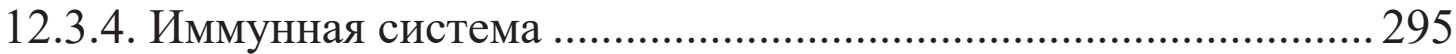

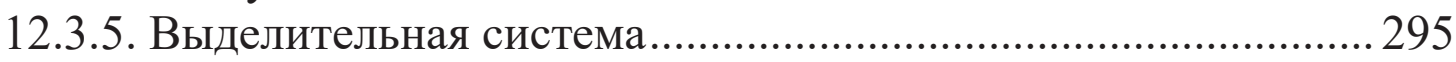

12.3.6. Репродуктивное здоровье мужчин ........................................296

12.3.7. Пищеварительный тракт ………..............................................2 297

12.3.8. Онкологические заболевания..............................................2 298

12.3.9. Репродуктивное здоровье женщин и беременность............... 298

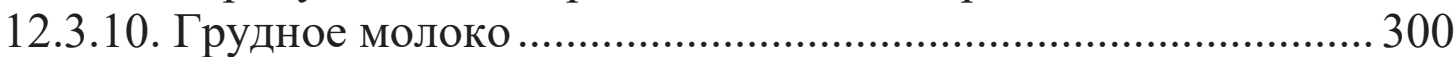

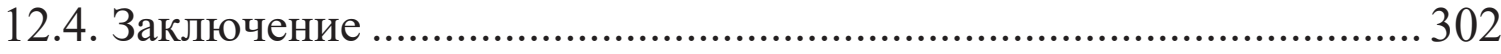

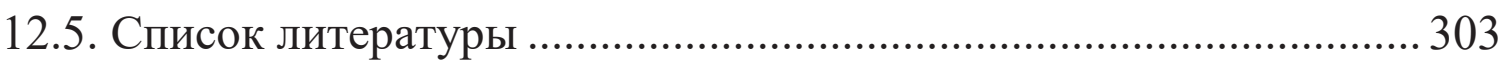

ГЛАВА 13. Стойкие органические загрязняющие вещества (CO3)

в организме жителей прибрежных районов Дальнего Востока России ............ 317

11.1. СОЗ в крови жителей Дальнего Востока ......................................... 319

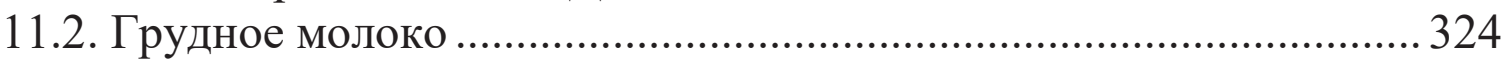

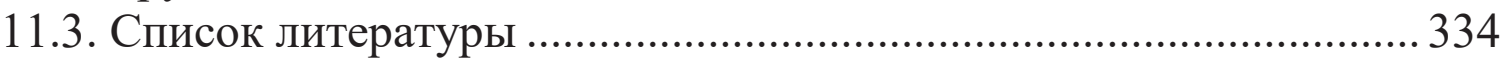




\section{CONTENTS}

CHAPTER 1. The Dirty Dozen of the Stockholm Convention. Chemistry and Toxicology of Persistent Organic Pollutants (POPs): A Review.....

CHAPTER 2. Methods for the persistent organic pollutants (POPs) determination in various components of the ecosystems of the Far Eastern region.

CHAPTER 3. Persistent organic pollutants (POPs) in food webs in the Asia-Pacific region: a brief review.

CHAPTER 4. Levels of organochlorine pesticides (OCPs) in the marine ecosystems of the Russian Far Eastern Seas (2000-2016): a review

CHAPTER 5. Current levels of organochlorine pesticides (OCPs) in the abiotic components of the Northwest Pacific ecosystems

CHAPTER 6. Current levels of persistent organic pollutants (POPs) in fish of the Russian Far Eastern Seas

CHAPTER 7. Biotransport of Persistent Organic Pollutants (POPs) by Pacific

Salmon of the Northwest Pacific.

CHAPTER 8. Organochlorine pesticides (OCPs) in seabirds and marine mammals from the Sea of Okhotsk and the Bering sea

CHAPTER 9. Biotransformation of persistent organic pollutants (POPs) in marine organisms of the Far Eastern Seas

CHAPTER 10. Non-targeting screening analysis of "new" persistent organic pollutants (POPs) in the Far Eastern Seas

CHAPTER 11. Environmental health risks from persistent organic pollutants (POPs) in marine organisms from the Northwest Pacific Ocean.

CHAPTER 12. Persistent organic pollutants (POPs) in the human body: the experience of Russia and the ex-USSR republics

CHAPTER 13. Persistent organic pollutants (POPs) in the body of residents of the Russian Far East coastal regions 


\section{ПРЕДИСЛОВИЕ}

Сегодня ежегодно синтезируются миллионы новых химических соединений, востребованных в различных отраслях промышленности. Стремление человека ускорить процесс их внедрения зачастую приводит к нежелательным последствиям для окружающей среды и здоровья людей, поскольку существенная их часть - стойкие органические загрязняющие вещества (СО3). Такими поллютантами среди множества СО3 являются хлорорганические соединения (ХОС): дихлордифенилтрихлорэтан (ДДТ) и его метаболиты (ДДД и ДДЕ), изомеры гексахлорциклогексана (ГХЦГ), конгенеры полихлорированных бифенилов (ПХБ). Пик их популярности пришелся на вторую половину ХХ века: ДДТ и ГХЦГ широко применялись в сельском хозяйстве по всему миру из-за инсектицидных свойств, высокой эффективности и низкой стоимости. Позднее их стали применять в здравоохранении для контроля переносчиков малярии и других опасных заболеваний, для лечения некоторых болезней - чесотки и педикулеза. ПХБ активно применялись в электроэнергетике как присадки или добавки из-за их хорошей теплопроводности, химической и электрической устойчивости. Однако сегодня все эти соединения запрещены к применению во многих странах мира и включены в Стокгольмскую конвенцию о стойких органических загрязнителях (2002) из-за острой токсичности, стойкости в окружающей среде, способности к биоаккумуляции и биомагнификации.

Несмотря на общий запрет производства и применения, несколько стран в Азии, Африке и Индии сохранили право использования ДДТ для контроля переносчиков опасных болезней до тех пор, пока не будет найдена столь же дешевая и эффективная альтернатива. ГХЦГ до сих пор содержится в составе некоторых средств от чесотки и вшей. Полихлори- 
рованные бифенилы продолжают применяться в старых образцах электрооборудования.

Несмотря на огромный интерес научного сообщества к особенностям аккумуляции, токсичности и распределению СО3, некоторые территории, где широко применялись ДДТ, ГХЦГ и ПХБ, исследованы фрагментарно и неполно. Особенно это касается территории России, в частности - Дальнего Востока, граничащего с потенциальными производителями и потребителями этих ксенобиотиков. Удаленность этого региона страны замедляет продвижение государственных мер по изъятию и уничтожению опасных для здоровья веществ, предотвращению их попадания в окружающую среду на территорию России.

Известно, что Дальний Восток России - это край рыбы, леса и полезных ископаемых. Рыбные богатства обеспечиваются уникальностью природных условий - морями Тихого (Японское, Охотское и Берингово моря) и Северного Ледовитого океанов. Продуктивность этих морей влияет на социально-экономическое положение региона. Вылавливаемые гидробионты служат пищей для всей России, а также и для граничащих стран (Япония, Корея, Китай, США, Канада).

В этой работе мы систематизировали результаты, полученные нами и другими авторами, о судьбе СО3 в абиотических и биотических компонентах водной среды, возможных рисках для здоровья жителей прибрежных районов, которые оказываются в сфере воздействия этих опасных поллютантов. В частности, мы выявили удобные организмы-индикаторы (из числа видов рыб, птиц и млекопитающих), свидетельствующие о загрязнении региона; показали возможные пути переноса ксенобиотиков из моря на сушу; определили мишени воздействия СО3; установили давность циркуляции поллютантов в биосфере; составили список «приоритетных» токсикантов для региона на основе качественного скрининга; оценили риски для здоровья человека от употребления загрязненных гидробионтов; измерили уровни содержания СО3 в организме человека.

Главы 2, 4, 6-8, 10-13 настоящей монографии выполнены при финансовой поддержке Российского научного фонда (РНФ) № 18-14-00120 «Стойкие органические загрязняющие вещества (СО3) в экосистемах дальневосточных морей России: аккумуляция, биотрансформация, транспорт и экологический риск».

Я благодарю авторов, внесших существенный вклад в создание этой монографии, ценные и критические замечания, моральную поддержку. 
Выражаю глубокую благодарность коллективу лаборатории экобиотехнологии Департамента пищевых наук и технологий Школы биомедицины Дальневосточного федерального университета (ДВФУ). Отдельно благодарю научного руководителя и учителя, доктора биологических наук, профессора Надежду Константиновну Христофорову.

Научный редактор Василий Юрьевич Цьганков, канд. биол. наук, дочент 


\section{ГЛАВА 1}

\section{«ГРЯЗНАЯ ДЮЖИНА» СТОКГОЛЬМСКОЙ КОНВЕНЦИИ. ХИМИЯ И ТОКСИКОЛОГИЯ СТОЙКИХ ОРГАНИЧЕСКИХ ЗАГРЯЗНЯЮЩИХ ВЕЩЕСТВ (СОЗ): ОБЗОР ЛИТЕРАТУРЫ}

\section{В.Ю. Циганков}

В главе представлена информация о Стокгольмской конвенции, этапах ее формирования и "грязной дюжине". Описаны физико-химические свойства, распределение в окружающей среде, метаболизм и деградация, токсичность основных стойких органических загрязняющих веществ (CO3), таких как хлорорганические пестициды (ХОП) и полихлорированные бифенилы (ПХБ).

Ключевые слова: «грязная дюжина»; Стокгольмская конвенция; CO3; ХОП; ПХБ; физико-химические свойства; распределение в окружающей среде; метаболизм и деградация; токсичность.

${ }^{1}$ Школа биомедицины и Школа естественных наук, Дальневосточный федеральный университет (ДВФУ), 690922, Владивосток, о. Русский, п. Аякс, 10. E-mail: tsig_90@mail.ru.

${ }^{1}$ School of Biomedicine and School of Natural Sciences, Far Eastern Federal University, 10 Ajax Bay, Russky Island Vladivostok, Russia, 690922. E-mail: tsig_90@mail.ru.

Для циитирования: Цыганков В.Ю. «Грязная дюжина» Стокгольмской конвенции. Химия и токсикология стойких органических загрязняющих веществ (СО3): обзор литературы // Стойкие органические загрязняющие вещества (CO3) в Дальневосточном регионе: моря, организмы, человек : монография / В.Ю. Цыганков, М.М. Донец, Н.К. Христофорова [и др.] ; науч. ред. В.Ю. Цыганков. - Владивосток : Изд-во Дальневост. федерал. ун-та, 2020. - С. 12-61. -https://doi.org/10.24866/7444-48912/12-61.

For citing: Tsygankov V.Yu. The Dirty Dozen of the Stockholm Convention. Chemistry and Toxicology of Persistent Organic Pollutants (POPs): A Review // Persistent organic pollutants (POPs) in the Far Eastern Region: Seas, Organisms, Human : monograph / V.Yu. Tsygankov, M.M. Donets, N.K. Khristoforova [et al.] ; ed. by V.Yu. Tsygankov. - Vladivostok : Publishing House of the Far Eastern Federal University, 2020. - P. 12-61. - https://doi.org/10.24866/7444-4891-2/12-61. 


\section{CHAPTER 1. THE DIRTY DOZEN OF THE STOCKHOLM CONVENTION. CHEMISTRY AND TOXICOLOGY OF PERSISTENT ORGANIC POLLUTANTS (POPS):} A REVIEW

\section{V.Yu. Tsygankov ${ }^{1}$}

In the chapter, the "dirty dozen" of the Stockholm Convention and the stages of its formation are presented. The physical and chemical properties, distribution in the environment, metabolism and degradation, toxicity of the main persistent organic pollutants (POPs), such as organochlorine pesticides (OCPs) and polychlorinated biphenyls (PCBs), are described.

Keywords: "dirty dozen"; Stockholm Convention; POPs; OCP; PCBs; physical and chemical properties; distribution in the environment; metabolism and degradation; toxicity.

\section{1. «Грязная дюжина» Стокгольмской конвенции}

Из всех поллютантов, поступающих в окружающую среду в результате деятельности человека (промышленность, сельское хозяйство или инфекционный контроль), СОЗ являются самыми опасными. За последние несколько десятилетий эти высокотоксичные химикаты нанесли огромный вред живой природе и здоровью людей, вызывая рак и повреждая нервную, репродуктивную и иммунную системы, провоцируя появление некоторых врожденных патологий.

Следовые количества этих веществ можно обнаружить у всех людей, кроме того, они способны концентрироваться в организме путем биоаккумуляции.

Хотя отдельные химикаты были запрещены во многих развитых и некоторых развивающихся странах с 1970-х гг., то обстоятельство, что эти вещества могут «прыгнуть» через атмосферу и преодолеть границы био- 
тических и экологических сред, требует юридически обязывающего соглашения между всеми нациями. Подобное соглашение должно быть обязательным для всех участников и одновременно учитывать специфические социально-экономические и политические условия в отдельных государствах. При сложившихся обстоятельствах нет другой альтернативы, кроме принятия такого международного документа для контроля над применением СO3.

В мае 1995 г. Управляющий совет UNEP в Решении 18/32 предписал необходимость международной оценки первоначального списка СО3, требующих принятия срочных защитных мер. В него вошли альдрин, хлордан, ДДТ, дильдрин, диоксины, эндрин, фураны, ГХБ, гептахлор, мирекс, ПХБ и токсафен. Совет UNEP дал распоряжение Межправительственному форуму по химической безопасности (IFCS) не позднее 1997 г. разработать рекомендации по проведению международных акций, направленных на уменьшение рисков воздействия на здоровье человека и состояние окружающей среды 12 перечисленных CO3. В июне 1996 г. IFCS представил на рассмотрение Управляющему совету UNEP и Всемирной ассамблее здравоохранения требуемый документ.

В феврале 1997 г. Управляющий Совет UNEP предложил созвать Межправительственную комиссию уполномоченных (INC) с целью подготовки юридического механизма для проведения международных мероприятий, первоначально сосредоточенных на 12 соединениях. Комиссии также было предписано создать экспертную группу для разработки критериев и процедуры идентификации других СО3, объектов будущих международных акций. Первая встреча INC состоялась в июне 1998 г. в Монреале, Канада. В результате была сформирована Экспертная группа по критериям (CEG). Следующие встречи INC прошли в Найроби (Кения, январь 1999 г.), Женеве (Швейцария, сентябрь 1999 г.), Бонне (Германия, март 2000 г.) и Йоханнесбурге (Южно-Африканская Республика, декабрь 2000 г.). Во время двух встреч: в Бангкоке (Таиланд) в октябре 1998 г. и Вене (Австрия) в июне 1999 г. - INC представляли эксперты CEG. B июне 2000 г. INC провела встречу 18 стран в Вевее (Швейцария) для обсуждения финансовых вопросов.

Конвенция была принята и открыта для подписания на конференции, проходившей 22-23 мая 2001 г. в Стокгольме (Швеция). 23 мая 2001 г. Конвенцию подписали 92 государства. Она оставалась открытой 
«ГРЯЗНАЯ ДЮЖИНА» СТОКГОЛЬМСКОЙ КОНВЕНЦИИ. ХИМИЯ И ТОКСИКОЛОГИЯ СТОЙКИХ ОРГАНИЧЕСКИХ ЗАГРЯЗНЯЮЩИХ ВЕЩЕСТВ (СОЗ): ОБЗОР ЛИТЕРАТУРЫ

для подписания в Штабе ООН в Нью-Йорке с 24 мая 2001 г. до 22 мая 2003 г. За это время число стран-участников соглашения увеличилось до 151. Было провозглашено, что Конвенция вступит в силу спустя 90 дней после подачи ратификационных документов правительствами 50 государств.

Сначала страны-участники ратифицировали и подписали 30 статей и 6 приложений. Контролировать исполнение международной политики по Конвенции и предпринимать временные действия до момента вступления соглашения в силу были уполномочены UNEP и INC. 17 февраля 2004 г. Франция стала 50-м государством, ратифицировавшим соглашение. 18 февраля 2004 г. в Женеве/Найроби Совет UNEP объявил о том, что Конвенция станет юридически обязательной с 17 мая 2004 г. К 23 июля 2005 г. соглашение ратифицировали 103 страны.

Правительства безотлагательно начали действия в рамках соглашения во время Первой сессии Конференции сторон Конвенции (СОР 1) в Пунта-дель-Эсте (Уругвай) 2-6 мая 2005 г. В результате был принят широкий спектр решений, в том числе утверждено Руководство по национальным исполнительным планам (NIPs) и технической помощи, a также создан Комитет по CO3 (POPRC). Приоритетной задачей Конференции было рассмотрение возможностей развивающихся стран выполнять предписания без технической помощи, в частности, лучших доступных технологий и лучшей экологической практики, с целью сокращения объемов выбросов диоксинов и фуранов - двух токсичных групп СO3.

Главная цель Конвенции заключается в немедленном запрете большинства из 12 СО3. Тем не менее, согласно решению Всемирной организации здравоохранения (BО3), ДДТ может применяться для борьбы с насекомыми-переносчиками инфекций, поскольку во многих странах этот пестицид остается главным средством уничтожения малярийных комаров. Это дает возможность правительствам защищать своих граждан от малярии, бича тропических регионов, до тех пор, пока не будет найден экономически рентабельный и экологически чистый альтернативный заменитель ДДТ химической или нехимической природы. Между тем, Конвенция обязуется способствовать проведению непосредственных исследований, направленных на поиск и разработку более эффективного средства против малярии. 
Кроме запрета применения подобных химикатов соглашение также акцентирует внимание на уничтожении лишних и вышедших из употребления хранилищ пестицидов и токсичных соединений, количество которых в некоторых развивающихся странах продолжает расти. Обязав правительства государств прекратить производство и выбросы этих веществ в окружающую среду, Стокгольмская Конвенция принесет большую пользу делу охраны здоровья человека и окружающей среды, укрепит авторитет и усилит эффективность международного экологического права.

Еще одна ключевая задача Конвенции - окончательное оформление руководящих указаний для обеспечения «лучшей экологической практики» и «лучших доступных технологий» для сокращения и прекращения выбросов диоксинов и фуранов (возможно, самых токсичных из всех CO3), имеющих широкий спектр промышленных и других источников, например, открытые свалки городских и других отходов в развивающихся странах. Правительства стран-участниц соглашения также должны сокращать применение ПХБ-содержащего электрооборудования, внедряя его заменители, и утилизировать ПХБ экологически чистым способом не позднее 2028 г.

К счастью, существуют альтернативы СОЗ. Высокая стоимость, отсутствие общественной компетентности и соответствующей инфраструктуры часто мешали их предпочтению. В Конвенции указано, что подходящие решения должны соответствовать специфическим свойствам и областям применения каждого вещества, так же как климатическим и социально-экономическим потребностям каждой страны.

Для гарантии исполнения решений, финансирующие государства приняли обязательства субсидировать сотни миллионов долларов в течение следующих нескольких лет. Главной организацией временного финансового механизма Конвенции является GEF. Уже привлечены ресурсы для поддержки проектов по исследованию СО3, например Африканская программа ликвидации хранилищ, более чем в 100 странах. Подержанная альянсом развитых и развивающихся стран и имеющая индустриальные и экологические группы в руководстве, Стокгольмская Конвенция гарантирует мир без СОЗ для будущих поколений.

Ниже дана краткая характеристика каждого 12 CO3, входящих в состав «грязной дюжины» этих веществ: 


\section{Альдрин}

Традиционные названия: гексахлородиметанонафталин, альдрекс, октален, 22-ДН, эрузин, вератокс, аглюкон, картофин, ГГДН

Систематическое наименование: $1,2,3,4,10,10$-гексахлоро-1,4,4a,5,8,8aгексагидро-1,4-эндо,экзо-5,8-диметанонафталин

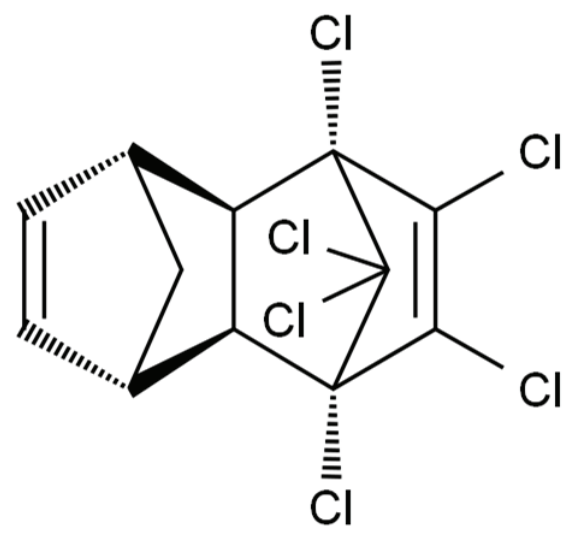

Альдрин обычно применяется для борьбы с термитами, червями, долгоносиками и саранчой, а также для защиты урожаев зерновых культур и картофеля от разнообразных почвенных насекомых. Он легко метаболизируется растениями и животными до дильдрина. Альдрин связывается с донными осадками и поэтому редко вымывается в грунтовые воды, но может испаряться с поверхности грунтов и перераспределяться воздушными потоками, загрязняя территории, удаленные от источников поступления. Острое отравление альдрином способно вызвать гибель птиц, рыбы, человека. Хроническая интоксикация происходит через загрязненную пищу. Это соединение запрещено в большинстве развитых стран, но его продолжают использовать в качестве термитицида во многих развивающихся странах Азии и Африки. Хотя альдрин высокотоксичен, его действие избирательно. Часто он может вызывать поражение печени [56]. Кроме того, альдрин является канцерогеном и способен приводить к неврологическим и репродуктивным расстройствам. Альдрин запрещен в ряде стран, в том числе Болгарии, Эквадоре, Венгрии, Сингапуре, Швейцарии, и строго ограничен к применению в таких странах, как Аргентина, Канада, Япония, Новая Зеландия, США и др. 


\section{Хлордан}

Традиционные названия: хлортокс, октахлор, Shell SD-5532, вельзикол 1068, велискол 1068

Систематическое наименование: $1,2,4,5,6,7,8,8$-октахлоро-2,3,3a,4,7,7aгексагидро-4,7-метаноинден
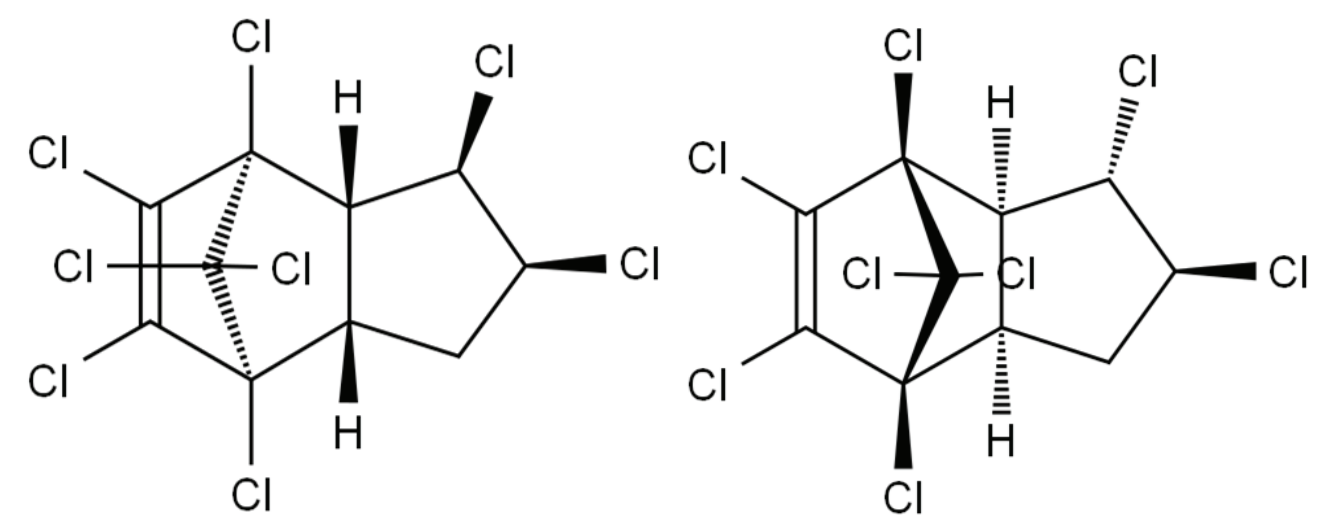

Хлордан - инсектицид широкого спектра действия, используется для защиты сельскохозяйственных угодий и борьбы с термитами. Хлордан нерастворим в воде, но растворим в органических растворителях и полулетуч. Он связывается с донными осадками и биоконцентрируется в жировых тканях организмов. Воздействие на людей происходит главным образом воздушным путем. Острые токсические эффекты видоспецифичны. Хлордан считается канцерогеном, может вызывать незначительные неврологические расстройства, способен имитировать половые стероиды или изменять их уровни в особях, подвергшихся его воздействию. Применение хлордана было запрещено в отдельных странах, в том числе Бразилии, Нидерландах, Филиппинах, Сингапуре, Испании, Швеции. Его использование строго ограничено применением в несельскохозяйственных целях в Аргентине, Канаде, Китае, Новой Зеландии, США и др. 


\section{ДДТ}

Систематическое наименование: $1,1,1$-Трихлор-2,2-ди(n-хлорфенил)этан

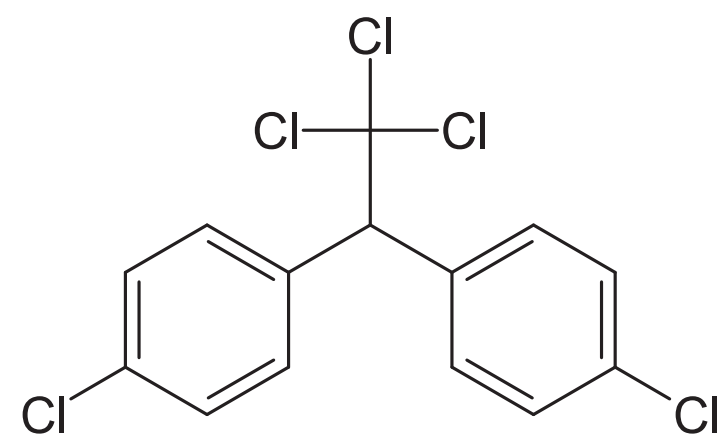

ДДТ является, возможно, самым печально известным стойким органическим загрязнителем. Сначала его применили во время Второй мировой войны для защиты войск и граждан от малярии, брюшного тифа, вшей и других болезней, переносимых насекомыми. После войны ДДТ широко использовался в сельском хозяйстве в качестве инсектицида. Он высокоустойчив в почве. Будучи самым первым, хорошо известным и одним из самых распространенных пестицидов, ДДТ вызвал широкомасштабное загрязнение водных и почвенных ресурсов, что привело к серьезному ухудшению здоровья людей и животных. Поскольку ДДТ является высокоэффективным инсектицидом, ВОЗ не может рекомендовать правительствам государств полностью запретить его использование, настаивая на ограничении его применения лишь в общественных здравоохранительных мероприятиях и внутри помещений. ДДТ легко метаболизируется в стабильное и столь же токсичное соединение ДДЕ (дихлордифенилдихлорэтилен). Пища является основным путем поступления ДДТ и ДДЕ в живые организмы. Оба эти соединения жирорастворимы и накапливаются в жировой ткани. ДДТ вызывает репродуктивные и эмбриональные нарушения у животных и человека, а также нарушения деятельности иммунной системы. Подобно другим ХОС, ДДТ поражает нервную систему. Хроническое воздействие приводит к печеночной и почечной недостаточности. К 1995 г. применение ДДТ было запрещено в 34 странах и строго ограничено еще в 34 странах [60]. После введения запрета остаточные уровни ДДТ продолжают обнаруживаться во всех образцах окружающей среды и биоты, включая грудное женское молоко, что вызывает особое беспокойство по поводу его потенциального воздействия на детей. 


\section{Дильдрин}

Традиционные названия: Дильдрин, диелдрин, диэлдрин, инсекталак, окталокс, альвит, ENT 16.

Систематическое название: $1,2,3,4,10,10$-гексахлоро-6,7-эпокси-

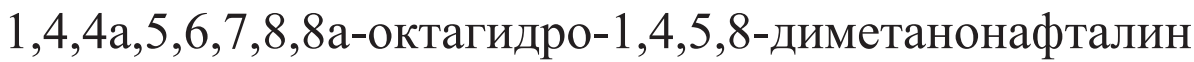

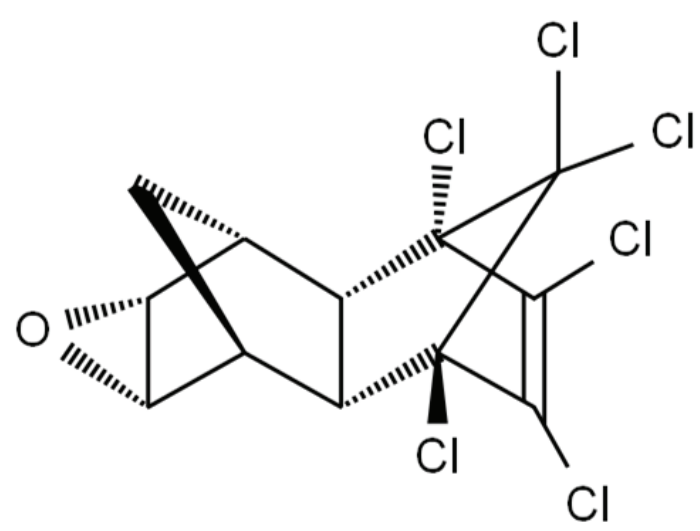

Дильдрин в основном применялся в сельском хозяйстве для уничтожения почвенных насекомых и некоторых насекомых-переносчиков инфекций. В окружающей среде и живых тканях пестицид альдрин быстро превращается в дильдрин, поэтому концентрации дильдрина в окружающей среде выше, чем первого. Остаточные количества дильдрина в тканях, по всей видимости, являются аддитивным эффектом альдрина и прямого воздействия дильдрина. Остаточный дильдрин обнаружен в воздухе, воде, почве, в организмах птиц, млекопитающих и людей, куда он попадает вместе с пищей. Дильдрин запрещен к применению во многих странах EC, Сингапуре, строго ограничен в Аргентине, Канаде, Австрии, Колумбии, Индии, Новой Зеландии, США и др. 


\section{Эндрин}

Традиционные названия: Мендрин, Нендрин, Гексадрин, ENT-17251

Систематическое наименование: $3,4,5,6,9,9$-гексахлоро1a,2,2a,3,6,6a, 7,7a-октагидро-2,7:3,6-диметанонафто[2,3-b]оксирен

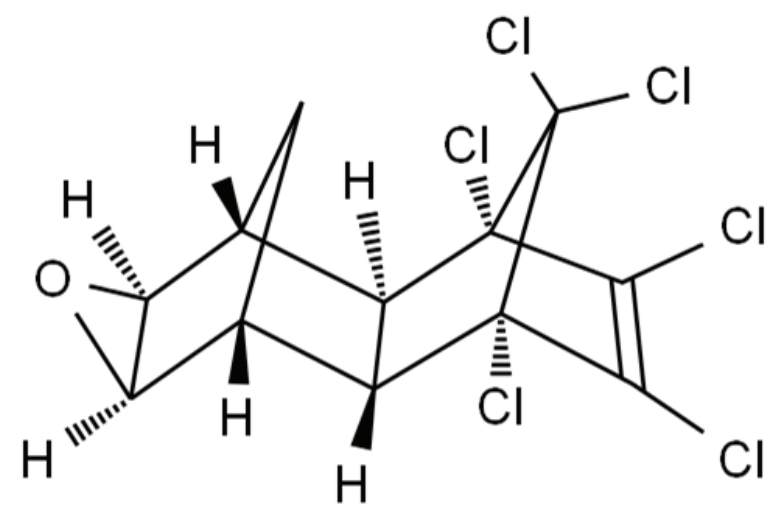

Эндрин является родентицидом, который используется для уничтожения мышей и полевок. Он распрыскивается на листья культур типа хлопка и хлебных злаков. В отличие от других ХОС с подобными структурами эндрин быстро метаболизируется животными и не накапливается в жировых тканях в больших концентрациях. Однако эндрин более токсичен, чем близкородственные альдрин и дильдрин, особенно высокотоксичен для рыб. Через пищу может попасть в организм человека. После обработки эндрином злаков у крыс, мышей и хомяков отмечались поражение мозга, печеночные и эмбриональные нарушения. Эндрин запрещен во многих странах, в том числе Финляндии, Израиле, Филиппинах и Сингапуре, и строго ограничен в Аргентине, Канаде, Чили, Индии, Японии, Пакистане, США и др. 


\section{Гептахлор}

Традиционные названия: Гептахлор, велзикол 104, Е-3314, гептазол, гептанал

Систематическое наименование: $1,4,5,6,7,8,8$-гептахлоро-3a,4,7,7aтетаргидро-4,7-метано-1Н-инден

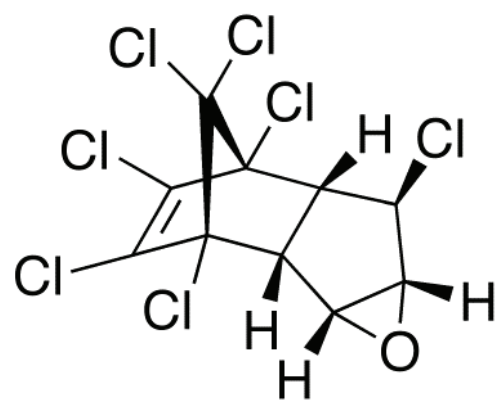

Гептахлор использовался для уничтожения насекомых-вредителей хлопка, саранчи и малярийных комаров. Это желудочный и контактный инсектицид, легколетучий и крайне нерастворимый в воде, но растворимый в органических растворителях. Прочно связывается с донными осадками, распределяется в атмосфере, биоконцентрируется в жировых тканях. Эпоксид гептахлора - метаболит гептахлора в живых тканях - также токсичен и биоаккумулятивен, как родительское соединение. У крыс наблюдалось влияние гептахлора на уровни прогестерона и эстрогена. Он высокотоксичен для человека, вызывает перевозбуждение центральной нервной системы и повреждение печени. Возможно, он обладает канцерогенными свойствами. Пища является основным путем поступления в организмы людей. Применение гептахлора было запрещено более чем в 12 странах и строго ограничено в странах ЕС, Канаде, Японии, Новой Зеландии, США и др. 


\section{Гексахлорбензол}

Традиционные названия: перхлорбензол

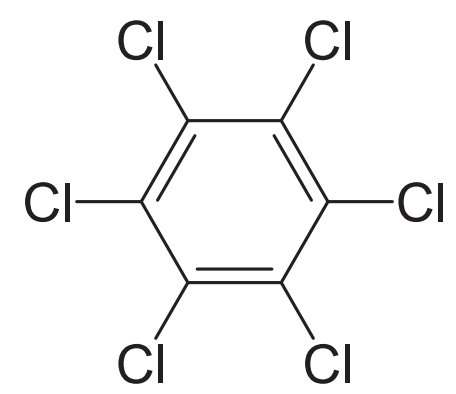

Гексахлорбензол - фунгицид, который использовался для обработки семян в конце 1940-х гг. Это побочный продукт синтеза и производства промышленных химикатов, таких как тетрахлорид углерода, перхлорэтилен, трихлорэтилен и пентахлорбензол, а также примесь в ряде пестицидных составов. Гексахлорбензол обнаружен во всех видах пищи. Установлено, что его высокие дозы смертельны для некоторых животных, в более низких концентрациях он вызывает поражения кожи у человека и серьезные репродуктивные нарушения у многих животных. Это соединение очень устойчиво и переносится на большие расстояния, имеет высокий коэффициент распределения, что приводит к его высокой биоконцентрации. Гексахлорбензол запрещен к применению в Австрии, Бельгии, Дании, странах ЕС, Нидерландах, Панаме, Великобритании, а также строго ограничен в Аргентине, Новой Зеландии, Швеции и др. 


\section{Мирекс}

Традиционные названия: додекахлорпентациклодекан Систематическое название: $1,1 \mathrm{a}, 2,2,3,3 \mathrm{a}, 4,5,5,5 \mathrm{a}, 5 \mathrm{~b}, 6-$ додекахлороктагидро-1,3,4-метен-1Н-циклобутапентален

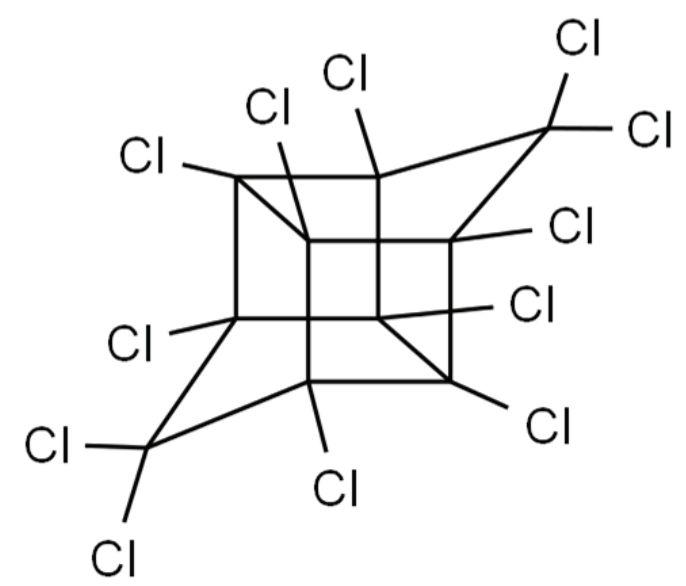

Мирекс является протравочным инсектицидом малой контактной активности. Его применяют главным образом против муравьев, ос, клопов и термитов, используют в промышленности в качестве антипирена в пластиковых, резиновых, красочных и электрических изделиях. В присутствии света мирекс разлагается с образованием фотомирекса, который более токсичен. Мирекс - один из самых стабильных и стойких пестицидов, очень устойчив к разложению, нерастворим в воде, обладает способностью к биоаккумуляции, прочно связывается с донными осадками. Это соединение разрушает эндокринную систему животных, подавляет иммунитет, обладает канцерогенными и тератогенными свойствами. Данные по неблагоприятному воздействию мирекса на человека ограничены. Это вещество попадает в организм главным образом через пищу, в частности, мясо, рыбу и дичь. 


\section{Полихлорированные бифениль}

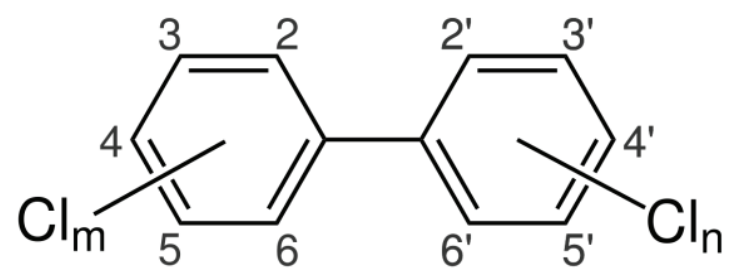

Полихлорированные бифенилы - это смеси хлорированных углеводородов. С 1930-х гг. ПХБ широко используются в промышленных целях, например, в электрических трансформаторах и конденсаторах, в красителях, копировальных бумагах и пластмассах. Теоретически возможно существование 209 изомеров ПХБ - от трех монохлорированных изомеров до полностью хлорированного декахлорбифенила. С увеличением числа атомов хлора уменьшается растворимость в воде и давление пара, повышается растворимость в липидах. На практике коммерческие смеси разнообразных торговых марок в разных странах содержат различное число изомеров. Обычно ПХБ выделяются в окружающую среду в виде неочищенной смеси, содержащей другие реагенты. Они обладают невысокой летучестью и относительной персистентностью, химически стабильны и устойчивы к нагреванию, что создает угрозу окружающей среде. ПХБ без орто-заместителей (копланарные) проявляют диоксиноподобную токсичность. Известно 13 таких соединений, остальные являются некопланарными. Полихлорированные бифенилы нерастворимы в воде, склонны к адгезии на органических частицах в окружающей среде и биоаккумулируются в жировой ткани животных. Пища - основной путь их поступления в организм человека. Агентство по охране окружающей среды США относит ПХБ к веществам-канцерогенам, опасным для людей. Они нейротоксичны и вызывают внутриутробное поражение плода. Видимые изменения нервной системы по вине ПХБ наблюдались у животных, в том числе мышей, крыс, обезьян и перепелов [36, 48, 57]. Кроме того, несомненен гормоноподавляющий эффект ПХБ. 


\section{Полихлорированные дибензо-п-диоксины (ПХДД) и фураны (ПХДФ)}
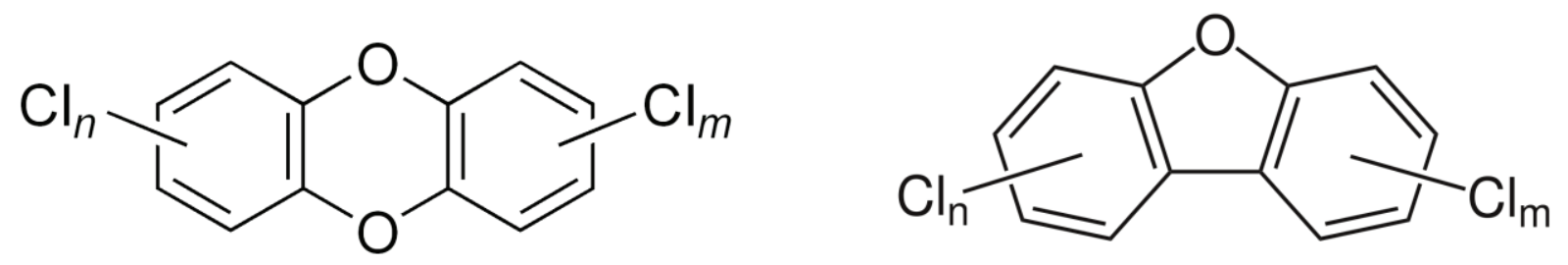

Полихлорированные дибензо-пара-диоксины (диоксины) и полихлорированные дибензофураны (фураны) представляют две группы планарных трициклических соединений с очень сходными химическими структурами и свойствами. Ни диоксины, ни фураны не производятся в промышленности и не имеют коммерческого применения. Это побочные продукты неполного сгорания медицинских и бытовых отходов, а также производства нескольких хлорированных соединений. Существует 75 различных диоксинов и 135 изомеров фуранов. Минимум 20 соединений считаются потенциально токсичными. Приблизительно в 90\% случаев поступления в организм человека происходит через пищу, в частности мясо животных. Ежедневная экспозиция приводит к накоплению ПХДД и ПХДФ в липидах, женском молоке и крови. Грудные дети получают более высокие дозы, поскольку материнское молоко часто бывает сильно загрязнено $[49,64]$. Общую токсичность диоксинсодержащих смесей принято выражать в виде токсического эквивалента (ТЭК) определенному количеству чистого 2,3,7,8-тетрахлордибензо-n-диоксина (ТХДД) - самого токсичного и хорошо изученного диоксина [38]. Доказано, что эти вещества вызывают хлоракне у людей. Диоксины могут непосредственно влиять на рост и дифференциацию раковых клеток путем дисрегуляции генов, они также являются хорошо известными эндокрино- и иммунодепрессантами. 


\section{Токсафен}

Традиционные названия: Полихлоркамфен; токсафен; полихлоркамфан; октахлоркамфен; муртокс; мелипакс; фенантокс; аллотокс; хлорфен; меликапс

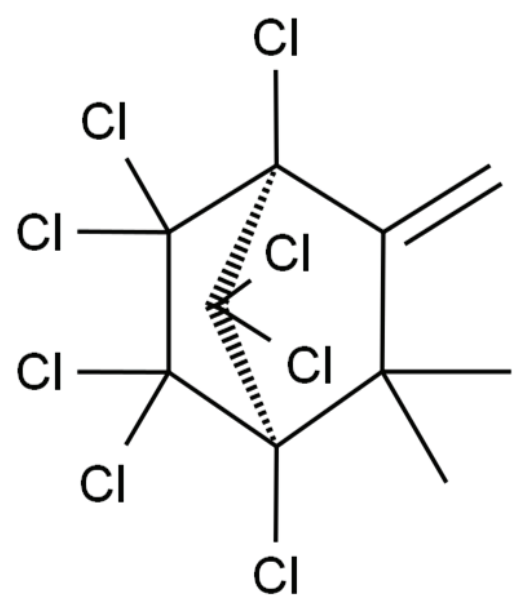

Токсафен - соматический и контактный инсектицид, применяющийся для уничтожения вредителей хлопка, фруктов и т.д., а также клещей, поражающих сельскохозяйственных и домашних животных. Токсафен не токсичен для растительности. Низкая растворимость в воде, высокая стабильность и летучесть способствуют переносу токсафена, как и других пестицидов, на большие расстояния. Несмотря на то, что токсафен прекратили применять около 20 лет назад, в некоторых странах разрешается его использование в малых количествах. Токсафен индуцирует активность видоизмененных ферментов в печени и вызывает, в зависимости от дозы, неблагоприятные изменения в почках, щитовидной железе и нервной системе. Сообщалось о некоторых эстрогенных эффектах токсафена и его связи с возникновением раковых опухолей у животных [31]. Это вещество запрещено в нескольких странах, в том числе Египте, Индии, Корее, Сингапуре, в ЕС, его применение ограничено в Аргентине, Пакистане, Южной Африке, Турции и др. 


\section{Список данных соединений приведен в Конвенции в качестве} приложений:

1. Приложение A (запрещение производства и ликвидация - альдрин, дильдрин, эндрин, хлордан, мирекс, токсафен, гептахлор);

2. Приложение В (ограничение использования - ДДТ);

3. Приложение С (непреднамеренное производство - ГХБ, ПХБ и ПХДД/ПХДФ).

После четвертого съезда сторон Конвенции, состоявшегося 4-8 мая 2009 г., было принято решение (индекс SC-4/12) о включении 9 дополнительных органических соединений:

1. Приложение А - $\alpha$-ГХЦГ, $\beta$-ГХЦГ, Линдан ( $\gamma$-ГХЦГ), хлордекан, гексабромбифенил, гекса- и гептахлорбифениловый эфиры, пентахлорбензол, тетрабромдифениловый и пентабромдифениловый эфиры.

2. Приложение В - перфтороктановый сульфонат и его соли, перфтороктановый сульфонилфторид.

3. Приложение $\mathrm{C}$ - пентахлорбензол.

\section{2. Хлорорганические пестициды (ХОП)}

\subsection{1. Физико-химические свойства ХОП}

Хлорорганические пестициды (ХОП) - большая группа химических веществ, представленная галогенпроизводными алициклических и ароматических соединений. ХОП являются веществами антропогенного происхождения, т.е. не образуются в природе и попадают в окружающую среду в результате хозяйственной деятельности человека. Благодаря ярко выраженным инсектицидным свойствам, на протяжении 1940-1960 гг. хлорорганические пестициды дихлордифенилтрихлорэтан (ДДТ) и гексахлорциклогексан (ГХЦГ) (рис. 1.1) являлись наиболее распространенными и широко используемыми препаратами. ХОП представляют собой твердые кристаллические вещества, которые обладают высокой термостабильностью, низким давлением насыщенного пара, плохой растворимостью в воде, но хорошей растворимостью в жирах и липидах. Физико-химические свойства соединений группы ДДТ, изомеров ГХЦГ представлены в таблице 1.1. 


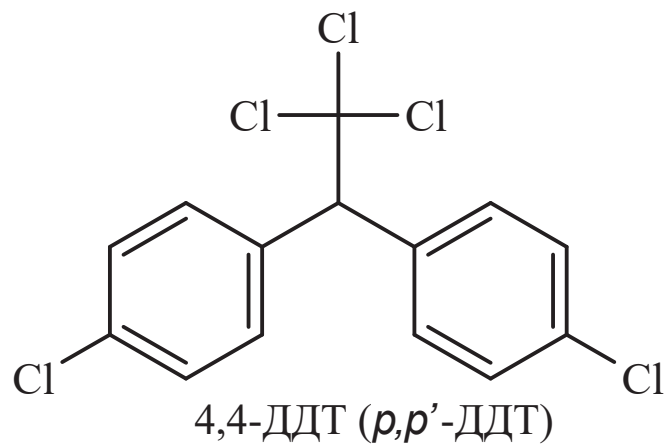<smiles>Clc1ccc(C(c2ccc(Cl)cc2)C(Cl)Cl)cc1</smiles>

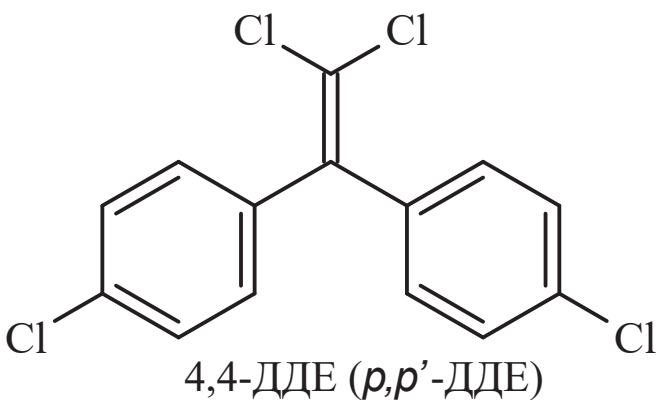<smiles>Cl[C@H]1[C@H](Cl)[C@H](Cl)[C@@H](Cl)[C@@H](Cl)[C@H]1Cl</smiles>

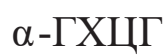<smiles>Cl[C@H]1[C@H](Cl)[C@H](Cl)[C@@H](Cl)[C@@H](Cl)[C@H]1Cl</smiles>

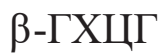<smiles>Clc1ccc(C(c2ccccc2Cl)C(Cl)(Cl)Cl)cc1</smiles><smiles>Clc1ccc(C(c2ccccc2Cl)C(Cl)Cl)cc1</smiles>

2,4-ДДД (o,p'-ДДД)

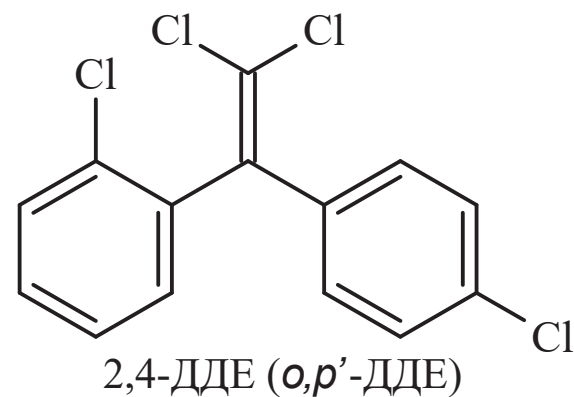<smiles>Cl[C@H]1[C@H](Cl)[C@H](Cl)[C@@H](Cl)[C@@H](Cl)[C@H]1Cl</smiles>

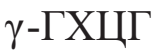<smiles>Cl[C@H]1[C@H](Cl)[C@H](Cl)[C@@H](Cl)[C@@H](Cl)[C@H]1Cl</smiles>

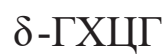<smiles>Cl[C@H]1[C@H](Cl)[C@H](Cl)[C@@H](Cl)[C@@H](Cl)[C@H]1Cl</smiles>

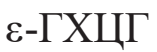

Puc. 1.1. Структурные формулы изомеров ГХЦГ, ДДТ и его метаболитов 


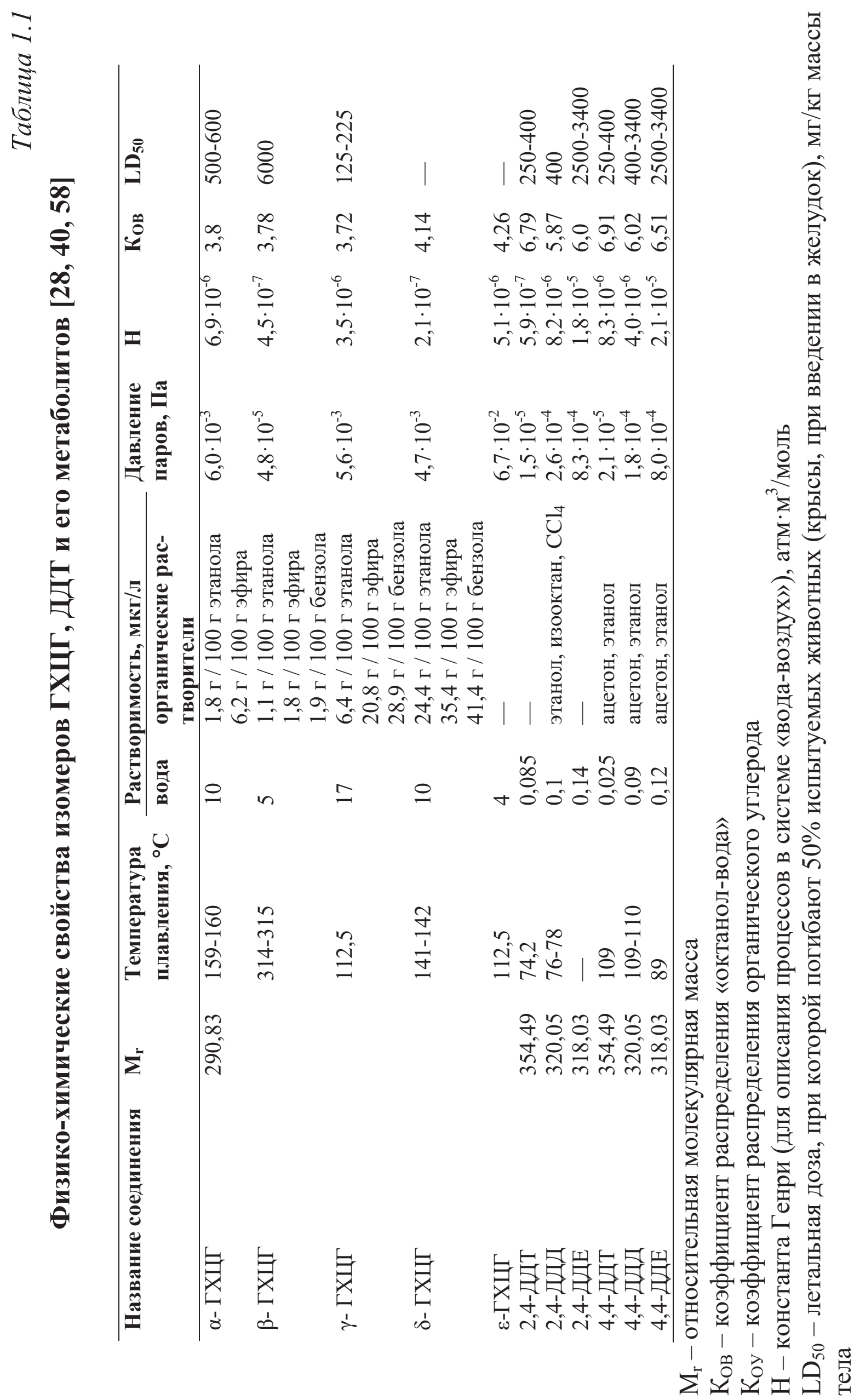


По своим химическим свойствам ХОП в обычных условиях очень инертны и практически не разлагаются под действием концентрированных кислот, щелочей и воды. Исключением являются изомеры ГХЦГ, которые при температуре $100^{\circ} \mathrm{C}$ и выше гидролизуются с образованием трихлорбензолов и трихлорфенолов и выделением хлористого водорода. Деструкция ХОП наступает в восстановительной среде и идет более интенсивно в присутствии катализаторов при повышенной температуре. Так, например, в спиртовом растворе едкой щелочи ДДТ количественно переходит в ДДЕ (реакция дегидрохлорирования). При нагревании бензольного раствора ДДТ с безводным хлористым алюминием наблюдается разложение ДДТ, о чем свидетельствует появление оранжевой окраски раствора. В присутствии сильных окислителей (азотной кислоты, оксидов хрома) разложение ДДТ и его метаболитов происходит с образованием бензофенолов [19].

При нагревании до температуры разложения, ГХБ разлагается с выделением ядовитых паров хлоридов, при $65^{\circ} \mathrm{C}$ бурно взаимодействует с диметилформамидом (ДМФА). ГХБ получают в промышленности хлорированием бензола избытком хлора в присутствии катализатора - хлорида алюминия [29].

В состав технической смеси ГХЦГ входили различные изомеры ГХЦГ различающиеся конформацией цикла, в технической смеси, полученной в результате фотохимического хлорирования, $\alpha$-ГХЦГ составлял

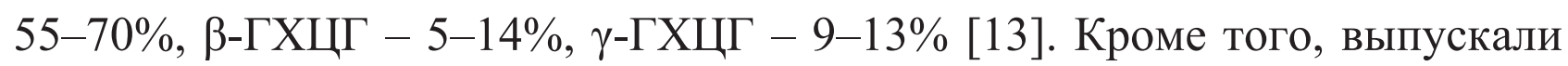
препараты другого состава, содержащие 25\% и 90-99\% (линдан) $\gamma$-ГХЦГ в качестве активного действующего вещества [72].

Основу технического препарата ДДТ составлял дихлордифенилтрихлорэтан, который был представлен двумя изомерами $n, n^{\prime}$-ДДТ $[1,1,1$ трихлор-2,2-бис(n-хлорфенил)этан] $\quad$ и $\quad o, n^{\prime}-Д Д Т ~[1,1,1-\quad$ трихлор-2-(nхлорфенил)-2-(o-хлорфенил)этан], различающимися положением атомов хлора в бензольных кольцах. В состав технического препарата ДДТ, кроме этих двух изомеров, входили $n, n$ '-ДДД [1,1-дихлор-2,2-бис $(n$ хлорфенил)этан], o,n'-ДДД [1,1-дихлор-2-(o-хлорфенил)-2-( $n$ - хлорфенил)этан], n,n'-ДДЕ [1,1-дихлор-2,2-бис(n-хлорфенил)этилен], o,n'- ДДЕ [1,1-дихлор-2-(o-хлорфенил)-2-(n-хлорфенил)этилен]. Обычный состав технического ДДТ следующий: $n, n^{\prime}$-ДДТ - 77.1\%,o,n'-ДДТ - 14,9\%, n, n'ДДД $-0,3 \%, o, n^{\prime}$-ДДД - $0,1 \%, n, n^{\prime}$-ДДЕ - 4,0\%, o, ' -ДДЕ - $0,1 \%$ и следовые концентрации других соединений [23]. 


\subsection{2. Закономерности распространения ХОП в окружающей среде}

Стойкие органические соединения, попав в биосферу, вовлекаются в различные физико-химические процессы. Устойчивость СОЗ по отношению к фотохимическому, химическому и биологическому разложению в атмосфере, водной фазе и почве приводит к продолжительным срокам их циркуляции в окружающей среде. Несмотря на то, что рассматриваемая группа CO3 имеет низкие значения давления паров, они все-таки обладают заметной способностью переходить в парогазовую фазу, т. е. испаряться в атмосферный воздух, например, с поверхности почвы, воды и т. д. и циркулировать между различными составляющими окружающей среды $[19,32,69]$. Они переносятся внутри различных составляющих биосферы (почва, водные системы, атмосфера) и из одной подсистемы в другую. В настоящее время CO3 распространены повсеместно, о чем свидетельствуют факты их обнаружения как в абиотических, так и в биологических образцах из различных точек земного шара. О глобальном распределении СО3 свидетельствуют факты их обнаружения в Арктике и Антарктике, регионах географически удаленных от возможных источников эмиссии этих соединений $[35,52,55$, 66]. Липофильность СО3 приводит к их биоаккумуляции, т. е. накоплению в растениях или живых организмах (в основном, в жировых тканях) и увеличению концентраций данных соединений при переходе от низшего к высшему трофическому уровню пищевой цепи (биомагнификации).

Поведение ХОП, а также и ПХБ, в окружающей среде и распределение в различных составляющих природных экосистем определяются физикохимическими свойствами данных соединений (табл. 1.1). Закономерности распределения СО3 в окружающей среде характеризуются различными показателями, важнейшими из которых являются растворимость в воде, коэффициент распределения октанол/вода, константа Генри и давление насыщенных паров [42]. Данные показатели для группы рассматриваемых здесь СО3 представлены в табл. 1.1.

Коэффициент распределения октанол/вода - показатель липофильности соединения, который характеризует распределение вещества между водой и органическим веществом и определяется как отношение равновесной концентрации данного вещества в октаноле $\left(\mathrm{C}_{\mathrm{o}}\right)$ к его концентрации в воде $\left(\mathrm{C}_{\mathrm{B}}\right)$ :

$$
\mathrm{K}_{\mathrm{OB}}=\mathrm{C}_{\mathrm{o}} / \mathrm{C}_{\mathrm{B}} \text {. }
$$


«ГРЯЗНАЯ ДЮЖИНА» СТОКГОЛЬМСКОЙ КОНВЕНЦИИ. ХИМИЯ И ТОКСИКОЛОГИЯ

СТОЙКИХ ОРГАНИЧЕСКИХ ЗАГРЯЗНЯЮЩИХ ВЕЩЕСТВ (СОЗ): ОБЗОР ЛИТЕРАТУРЫ

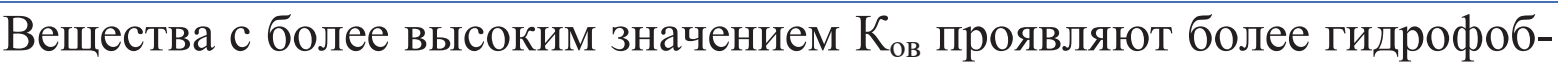
ные свойства и легче связываются органическим веществом матрицы (почв, донных отложений, живых организмов и т. д.).

Константа Генри имеет большое значение при описании процессов распределения в системе вода-воздух. Согласно закону Генри, отношение парциального давления вещества в воздухе $\left(\mathrm{P}_{\mathrm{a}}\right)$ к его концентрации в воде $\left(\mathrm{C}_{\mathrm{B}}\right)$ равно отношению давления его насыщенного пара $\left(\mathrm{P}^{\circ}\right)$ к его растворимости $(\mathrm{S})$ :

$$
\mathrm{P}_{\mathrm{a}} / \mathrm{C}_{\mathrm{B}}=\mathrm{P}^{\circ} / \mathrm{S}=\mathrm{H} \text {, где } \mathrm{H}-\text { константа Генри. }
$$

Вещества с более высокими значениями константы Генри легче переходят в газовую фазу.

Давление насыщенных паров - максимальное давление паров данного соединения при переходе его в газовую фазу из твердого (сублимация) или жидкого состояния (испарение) при определенной температуре. Ведущие ученые Норвегии и Канады [69], основываясь на давлении паров, разделили соединения на группы по их поведению в атмосфере (перераспределение между газовой и аэрозольной фазами в атмосфере). Согласно им, соединения с давлением паров в интервале $10^{-2}-10^{-4}$ Па при $25^{\circ} \mathrm{C}$, т.е. ГХЦГ и некоторые ПХБ, способны находиться в атмосфере как в газовой, так и в аэрозольной фазе. Соединения с давлением паров ниже, чем $10^{-4}$ Па при $25^{\circ} \mathrm{C}$ (соединения группы ДДТ и высокохлорированные ПХБ) могут находиться в атмосфере только в аэрозольной фазе.

Чрезвычайная персистентность ХОП стала причиной их повсеместного распространения в биосфере в результате процессов растворения, сорбции, биоаккумуляции, испарения. Высокие значения $\mathrm{K}_{\text {ов }}$ и низкие растворимости в воде соединений группы ДДТ и изомеров ГХЦГ (табл. 1.1) способствуют тому, что в окружающей среде эти соединения связываются частицами почвы, донных отложений, взвешенными частицами в воде и воздухе [59, 71]. Адсорбция на твердых частица имеет важное значение при перераспределении в окружающей среде. Максимальной адсорбционной способностью обладают тяжелые хорошо гумусированные почвы и донные отложения с высоким содержанием органического углерода [19]. В водоемах ХОП сорбируются аллохтонными и автохтонными частицами и оседают на дно водоема. В результате испарения и ветровой эрозии из почвы и водоемов ХОП поступают в атмосферу. Кроме того, они могут вовлекаться в повторные процессы испарения-конденсации и переноситься на большие 
расстояния от источников, порождая региональное и глобальное загрязнение биосферы. Как и другие СО3, ХОП подвергаются глобальному перераспределению и переносятся в полярные регионы, в результате чего они обнаруживаются в различных объектах окружающей среды в Арктике [26, $47,52,54]$. Процессы перераспределения СО3 в окружающей среде зависят от температуры. Давление паров любого вещества увеличивается с увеличением температуры. Повышение температуры окружающей среды способствует переходу вещества в парогазовую фазу, тогда как при понижении температуры происходит процесс конденсации (рис. 1.2) [69].

Так, концентрации СО3 в атмосферном воздухе проявляют сезонную зависимость и в теплое время года концентрации выше, чем в холодное. Температура воды на планете изменяется от примерно $+30^{\circ} \mathrm{C}$ в районе экватора до $-1,7^{\circ} \mathrm{C}$ в полярных регионах, тогда как температура воздуха изменяется в зависимости от сезона и географических координат в интервале от $-90^{\circ} \mathrm{C}$ до $+50^{\circ} \mathrm{C}$ [52]. Такой градиент температур обуславливает миграцию СО3 из теплых регионов планеты в холодные, причем наблюдается перераспределение («фракционирование») этих соединений в зависимости от их физико-химических свойств $[42,69]$. В настоящее время накопилось достаточное количество публикаций, доказывающих существование перераспределения СО3 в глобальном масштабе [35, 37, 50]. Разные соединения в зависимости от физико-химических свойств проявляют различную способность переходить в парогазовую фазу и мигрировать от мест первоначального попадания в природную среду. Одновременное определение и анализ распределения СО3 в донных отложениях и воде показали, что ДДТ и ПХБ имеют низкий потенциал к перераспределению и миграции от первоначальных источников. Распределение СО3 между водой и донными отложениями обусловлено физико-химическим свойствами соединений и может быть описано показателем распределения октанол/вода $\left(\mathrm{K}_{\mathrm{oв}}\right)$. Персистентные соединения с низкими значениями $\mathrm{K}_{\text {ов }}$ в водоемах находятся преимущественно в водной фазе (в меньшей степени в донных отложениях), из которой способны переходить в парогазовую фазу и вовлекаться в атмосферный перенос. 


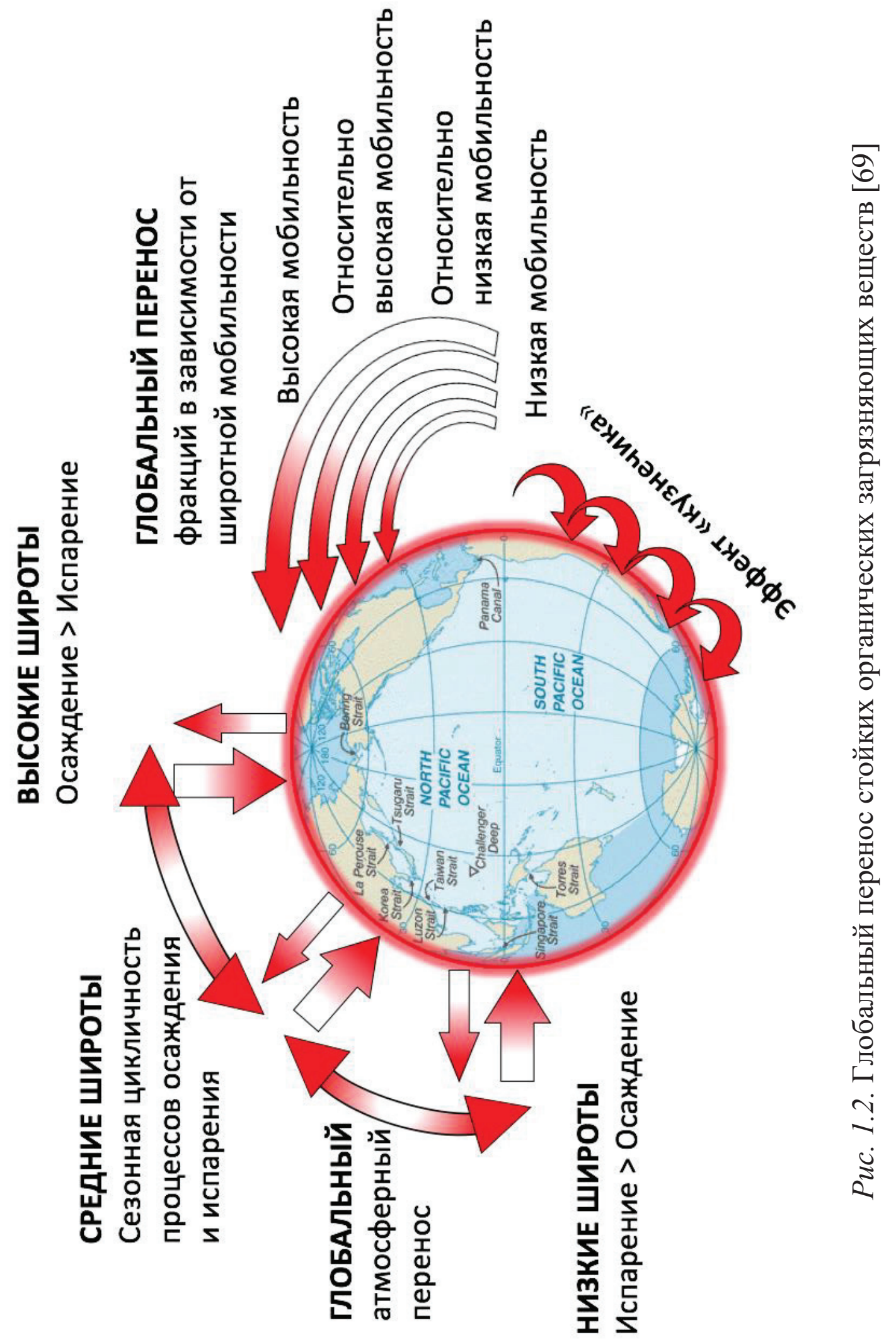




\subsection{3. Метаболизм и деградация ХОП}

Основные механизмы разрушения ХОП в окружающей среде можно условно разделить на абиотические - фотохимические реакции - и биотические процессы метаболического распада с участием живых организмов.

Фотохимическое разложение ХОП, в молекулах которых содержатся ароматические группировки и ненасыщенные химические связи, происходит в результате поглощения солнечной энергии в ультрафиолетовой и видимых областях спектра (рис. 1.3) [11,21].

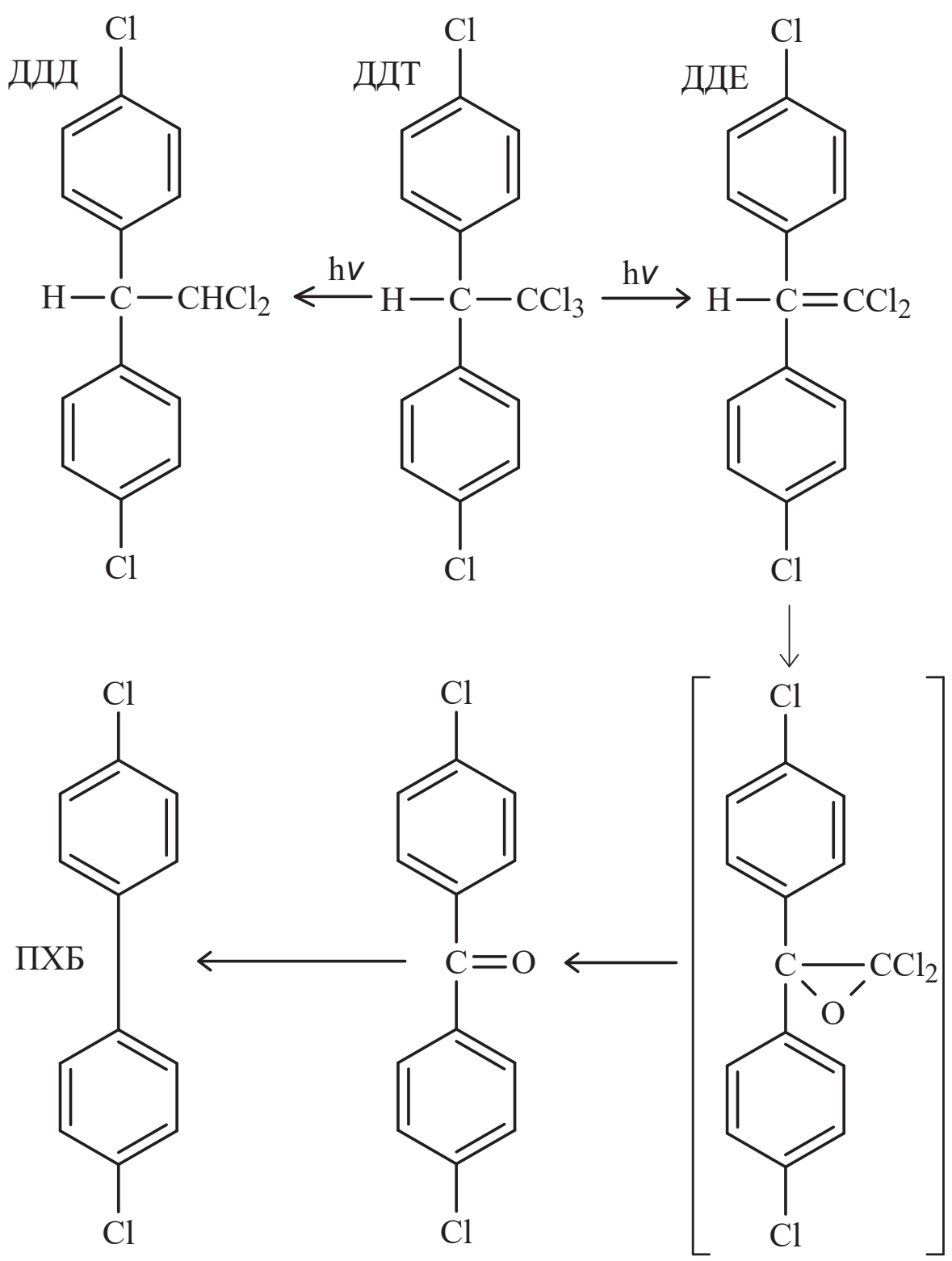

Рис. 1.3. Схема фотохимических превращений ДДТ [11] 
Скорость фотохимического распада, а также состав конечных продуктов этой реакции зависят от среды, в которой происходит данный процесс. Исследования показали, что после облучения УФ $(\lambda=254$ нм $)$ в течение 48 ч. 80 \% ДДТ разлагается, а среди продуктов найдены ДДЕ (основное количество), ДДД и кетоны. Дальнейшие эксперименты показали, что ДДД очень устойчив по отношению к УФ-излучению, а ДДЕ постепенно превращается в целый ряд соединений, среди которых обнаружены полихлорированные бифенилы (ПХБ). Большинство компонентов ПХБ, находящихся в атмосферном воздухе в газовой фазе, не претерпевают существенных изменений от воздействия света. ПХБ относятся к продуктам промышленного производства. Применение ПХБ основано на их химической инертности, негорючести, устойчивости до температур порядка $500^{\circ} \mathrm{C}$. Пестицид применяется в качестве фунгицида для защиты дерева от микробиологического разрушения и др. Способность морских организмов накапливать ПХБ оценивают по конгенерам отличающихся по числу и положению атомов хлора в молекуле [9].

Линдан $(\gamma$-ГХЦГ) при УФ-облучении изомеризуется в $\alpha$-ГХЦГ $[11,21,39]$.

Химическая деструкция большинства ХОП обычно происходит в восстановительной среде (для некоторых веществ деструкция возможна также и в окислительных условиях) и идет более интенсивно в присутствии катализаторов и при повышенной температуре. Повышение $\mathrm{pH}$, содержания кислорода, наличие солей тяжелых металлов ускоряют деструкцию ХОП $[5,6,16]$.

В окислительной среде гидролитические превращения происходят с заменой атомов галогена на гидроксильную группу. Скорость гидролиза зависит от $\mathrm{pH}$ среды и температуры. Так, в кислых почвах и при низких температурах хлорорганические пестициды сохраняются значительно дольше [7].

У животных степень накопления ХОП определяется соотношением двух процессов - поглощения и выведения. Проникая в организм, химические соединения претерпевают изменения, идущие по двум направлениям: окисление, восстановление и гидролиз; конъюгация - образования комплексов в клетках с некоторыми низкомолекулярными соединениями.

Основным органом метаболизма ксенобиотиков в некоторых морских организмах (рыбах, млекопитающих) является печень, главным обра- 
зом благодаря разнообразию и высокой активности находящихся здесь ферментов биотрансформации.

Продукты первого этапа метаболизма поступают в кровоток и способны оказывать действие на органы и системы. Печень выбрасывает в кровь также продукты второго этапа метаболизма. Из крови продукты превращения могут захватываться почками, легкими, другими органами, повторно печенью для экскреции с желчью. С желчью же метаболиты поступают в кишечник, где частично реабсорбируются и повторно поступают в печень (цикл печеночной рециркуляции).

Общая тенденция метаболизма заключается в превращении экзогенного вещества в более полярное соединение с последующим связыванием образовавшегося продукта с высокополярным фрагментом, облегчающим его выделение. У растений, не имеющих систем выделения, обычно происходит конъюгирование экзогенных веществ (или их метаболитов) с углеводами и депонирование их в местах, не связанных с общим метаболизмом [9].

У насекомых набор гидролаз меньше, чем у млекопитающих. В связи с этим у насекомых быстрое обезвреживание не происходит, например, ХОП и фосфорорганические пестициды они могут накапливать до летальных концентраций [9].

Окислительные процессы являются самыми распространенными направлениями трансформации химических соединений в организмах. Часто при этом происходит детоксикация ксенобиотиков. Основные типы окислительных процессов обозначаются как оксигеназные, оксидазные (дегидрогеназные) и пероксидазные. Окислительные процессы в клетках растений в основном катализируются пероксидазами. Восстановительные процессы в организмах исследованы не так хорошо, как окислительные. Известно, что в анаэробных условиях в почве происходит разложение циклических и ароматических углеводородов с промежуточным образованием циклогексанона. Предполагается, что у растений нитросоединения восстанавливаются нитро- и азотредуктазами. У животных происходит также восстановление сульфидов [9, 62].

Гидролиз ускоряется под действием ферментов гидролаз. Активность гидролиза зависит от характера заместителей в молекуле расщепляемого соединения: объемные заместители по соседству с отщепляемой группировкой стерически затрудняют гидролиз, поэтому ХОП, имеющие 
ГРЯЗНАЯ ДЮЖИНА» СТОКГОЛЬМСКОЙ КОНВЕНЦИИ. ХИМИЯ И ТОКСИКОЛОГИЯ

СТОЙКИХ ОРГАНИЧЕСКИХ ЗАГРЯЗНЯЮЩИХ ВЕЩЕСТВ (СОЗ): ОБЗОР ЛИТЕРАТУРЫ

такие заместители в своей структуре, устойчивы к гидролизу и накапливаются в жировых тканях.

В результате ферментативного окисления ХОП микроорганизмами образуются различные метаболиты, которые могут оказаться как безвредными веществами, так и более опасными и токсичными, чем их предшественники.

У животных метаболизм ХОП контролируется ферментами, которые содержатся главным образом в печени и в меньшей степени в кишечнике и почках. Их активность у представителей разных систематических групп существенно различается, и у млекопитающих и птиц гораздо выше, чем у рыб и амфибий. В живых организмах главные направления разложения ДДТ можно представить следующей схемой (рис. 1.4).

У рыб отсутствуют некоторые ферменты метаболизма ксенобиотиков, не развита система образования водорастворимых метаболитов и конъюгатов, которые могли бы выводиться из организма. В связи с этим рыбы выделяют липофильные соединения в окружающую воду благодаря пассивной диффузии. Но это не защищает их от высокого уровня загрязнения такими соединениями, как ДДТ, альдрин, которые накапливаются в большом количестве из воды. В отличие от абиотических компонентов экосистем, период полураспада ДДТ в организме рыб составляет примерно 30 суток [19]. ДДЕ и ДДД менее токсичны для рыб, чем исходное соединение. Липофильные хлорорганические пестициды накапливаются в печени взрослых рыб и переносятся в гонады, оказывают негативное воздействие на репродуктивную функцию рыб [18].

Накопление ДДТ зависит от содержания липидов в органах и тканях гидробионтов. Например, зависимость накопления ДДТ можно расположить в следующем порядке: жир $\rightarrow$ печень $\rightarrow$ мышцы. Повышенное содержание липидов в рыбах из загрязненных пестицидами районов можно расценивать как ожирение и адаптацию к условиям существования [14].

ГХЦГ менее стоек, чем ДДТ, и легче подвергается микробиологическому разложению. Исследования, проведенные в модельных водоемах по определению содержания ГХЦГ в различных объектах экосистем, выявили основные факторы, влияющие на метаболизм этого пестицида. По экспериментальным данным [5], через сутки после внесения $\gamma$-ГХЦГ в модельный водоем концентрации в воде уменьшаются от 0,50 до 0,27 мг/л, в иле возрастают от 0 до 0,34 мг/кг, в высших водных растениях - от 0 до 
2,3 мг/кг. Коэффициент накопления $\left(K_{\mathrm{H}}\right) \gamma$-ГХЦГ для грунтов составил 1,34, для водных растений - от 8 до 67.

Коэффициент накопления $\mathrm{K}_{\mathrm{H}}$ рассчитывают по формуле:

$$
\mathrm{K}_{\mathrm{H}}=\frac{\mathrm{C}_{\Gamma}}{\mathrm{C}_{\mathrm{B}}}
$$

где $\mathrm{C}_{\Gamma}$ - концентрация пестицида в гидробионтах, мг/кг; $\mathrm{C}_{\mathrm{B}}-$ концентрация пестицида в воде, мг/л.

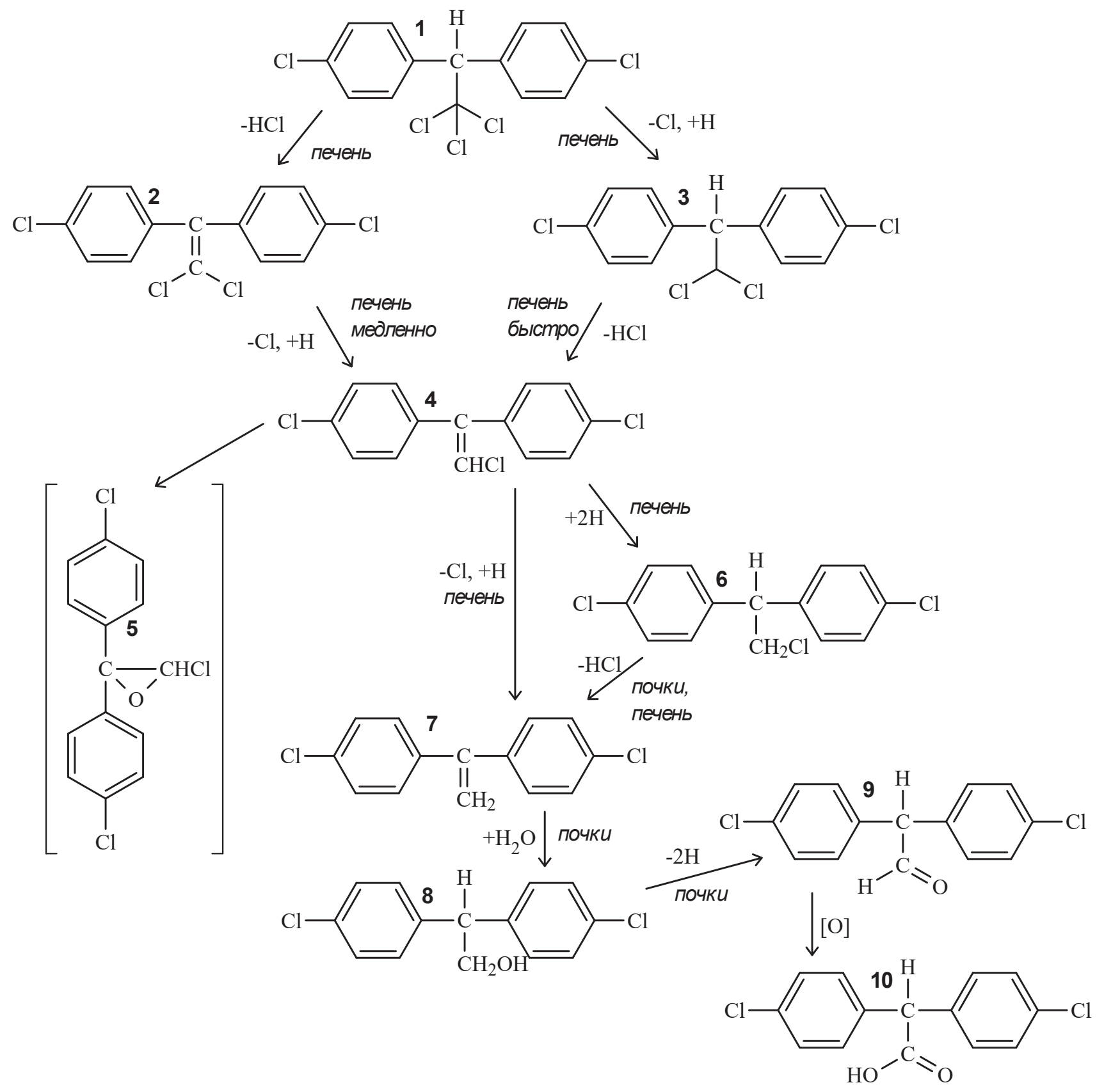

Puc. 1.4. Схема метаболических превращения ДДТ в организме животных [28, 45, 68]: 1 - ДДТ; 2 - ДДЕ; 3 - ДДД; 4 -дихлордифенилхлорэтилен; 5 - эпоксид дихлордифенилхлорэтилена; 6 -дихлордифенилхлорэтан;

7 - дихлордифенилэтилен; 8 - дихлордифенилэтанол; 9 - дихлордифенилэтаналь; 10 - дихлордифенилэтановая (дихлордифенилуксусная) кислота 
ГРЯЗНАЯ ДЮЖИНА» СТОКГОЛЬМСКОЙ КОНВЕНЦИИ. ХИМИЯ И ТОКСИКОЛОГИЯ

СТОЙКИХ ОРГАНИЧЕСКИХ ЗАГРЯЗНЯЮЩИХ ВЕЩЕСТВ (СОЗ): ОБЗОР ЛИТЕРАТУРЫ

На примере экосистемы северо-западной части Тихого океана выявлено, что в поверхностных водах и зоопланктоне преобладает $\alpha$-изомер $55-56 \%$, $\gamma$-изомер составляет 35-40 \%, доля $\beta$-изомера была наименьшей менее $10 \%$. У головоногих моллюсков количество $\beta$-изомера выше и составляет около $20 \%$. В тканях полосатого дельфина соотношение изомеров иное - преобладает $\beta$-изомер - до $80 \%$, затем следует $\alpha$-изомер - 10 $15 \%, \gamma$-изомер находится в минимальном содержании [63].

При внесении ГХЦГ в почву отмечается снижение концентрации $\alpha$ изомера в пробах через 20 недель в анаэробных условиях на $30 \%$, а в аэробных - на $55 \%$ [41].

При внесении линдана ( $\gamma$-ГХЦГ) на поверхность почвы наибольшая часть препарата исчезает из почвы в первые дни, через три месяца остается только $10 \%$ [4].

Процессы превращения $\gamma$-ГХЦГ под влиянием культуры бактерий Pseudomonas aeruginosa в первые три дня протекают с образованием $\alpha-, \beta-$, $\gamma$-ГХЦГ, а также хлорциклогексана и тетрахлорбензола. При высоких концентрациях $\gamma$-ГХЦГ (400 мг/кг) наблюдается ускорение роста грамположительных бактерий [41].

Основные направления метаболизма линдана в объектах окружающей среды представлены на рис. 1.5.

При разложении $\gamma$-ГХЦГ образуется пентахлорциклогексан, который превращается в зависимости от условий среды преимущественно в ди- или трихлорбензол (в растениях); ди-, три- и тетрахлорфенол (под действием микроорганизмов); тиофенолы (в организмах насекомых). Промежуточное соединение пентахлорфенол относится к сильнодействующим ядовитым веществам (ЛД $50=29-36$ мг/кг) [46], но информации о его заметных количествах в объектах среды в литературе не встречается. Вероятно, это соединение быстро разлагается, в отличие от продуктов его дальнейшего превращения. В организмах различных животных и растений обнаружены ди-, три- и тетрахлорфенолы, ди- и тетрахлорбензолы [17], которые относятся к средне- и высокотоксичным соединениям. Образующийся при разложении линдана гексахлорбензол малотоксичен, но является высокоперсистентным, канцерогенным для млекопитающих [15]. Такими же свойствами обладает и образующийся при дальнейшем разложении пентахлорбензол. 


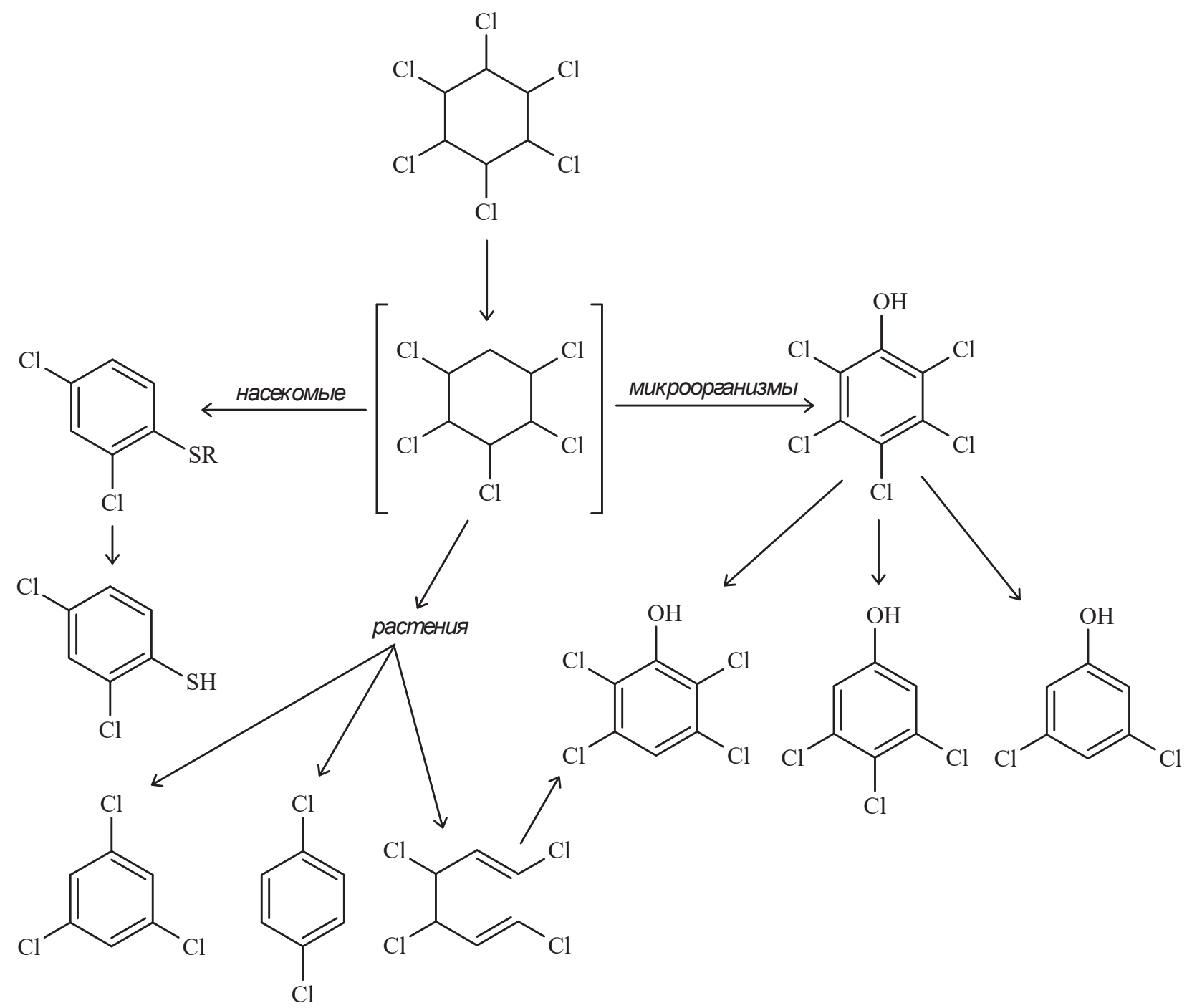

Puc. 1.5. Схема метаболизма линдана в объектах окружающей среды $[17,19]$

Концентрация и соотношение изомеров ГХЦГ в компонентах морской среды, открытых и закрытых водоемов и живых организмах зависят от многих факторов - физико-химических свойств воды и грунтов, освещенности, видовых особенностей процессов биотрансформации, а также от продолжительности нахождения пестицидов в среде. В экосистемах дельт рек и эстуариев, на границе река-море, где соленость резко возрастает, происходит основной переход во взвесь растворенных в речной воде ХОП. С увеличением солености растворимость ХОП в воде уменьшается, и они переходят во взвесь [8]. С этим связывают повышенное содержание ХОП в органах речных и эстуарных видов по сравнению с морскими видами [14].

Воздействие перечисленных и многих других факторов приводит к тому, что со временем и при продвижении по пищевой цепи накапливает- 
ГРЯЗНАЯ ДЮЖИНА» СТОКГОЛЬМСКОЙ КОНВЕНЦИИ. ХИМИЯ И ТОКСИКОЛОГИЯ

СТОЙКИХ ОРГАНИЧЕСКИХ ЗАГРЯЗНЯЮЩИХ ВЕЩЕСТВ (СОЗ): ОБЗОР ЛИТЕРАТУРЫ

ся наиболее устойчивая $\beta$-форма ГХЦГ [63]. Для оценки давности поступления пестицидов в экосистему используют отношение концентраций $\alpha-$ и $\gamma$-изомеров ГХЦГ. Высокое значение коэффициента, более единицы свидетельствует о давнем присутствии ХОП в среде; значение ниже единицы, т.е. преобладание $\gamma$-изомера, характерны для «свежего» поступления [19].

ДДТ существует в виде основного продукта и его метаболитов ДДД и ДДЕ. О времени существования ДДТ в объектах судят по отношению концентраций ДДТ и продукта его деградации ДДЕ. Высокие значения коэффициента ДДТ/ДДЕ свидетельствуют о недавнем поступлении ДДТ в среду, низкое - о его длительном пребывании в системе и постепенном превращении в ДДЕ.

Относительная стабильность ДДЕ и $\beta$-ГХЦГ в окружающей среде определяется как химическими, так и физическими факторами. Устойчивость ДДЕ обусловлена низкой реакционоспособностью $\pi-\pi$ и $\pi$ - $n$ сопряженной системы связей, характерной для винильных соединений галогенов. Устойчивость $\beta$-изомера гексахлорциклогексана вызвана его малой растворимостью в водных системах и соответственно меньшей доступностью для дальнейшей химической и биохимической трансформации.

Основными биологическими механизмами разрушения ХОП в окружающей среде являются процессы метаболического распада с участием микроорганизмов. Почвенные микроорганизмы Aerobacter aerogenes, Pseudomonas fluorescens, E. coli и Klebsiella pneumoniae способны разлагать ДДТ в аэробных и анаэробных условиях, образуя 4-хлорбензойную кислоту и ДДЕ, соответственно, в качестве основных метаболитов. ДДЕ, основной метаболит ДДТ, чрезвычайно устойчив к биодеградации. В лесной почве период полураспада ДДт был равен 20-30 годам [23].

Таким образом, концентрация и соотношение изомеров и производных ХОП в экосистеме постоянно меняются и зависят от физикохимических свойств воды и грунтов, а также от продолжительности нахождения пестицидов в среде.

\subsection{4. Токсичность ХОП}

Наиболее часто используемой характеристикой опасности химиката является количественная информация о его острой токсичности для некоторых лабораторных животных. Но для адекватной оценки влияния на по- 
пуляцию, сообщества и экосистемы требуются более обширные эксперименты с привлечением не только животных, но и микроорганизмов и растений. В странах ЕС, например, принято использовать набор стандартных тестов, дающих необходимый минимум информации для итоговой оценки токсичности веществ. Для новых пестицидов, в частности, должны проводиться следующие тесты на летальные (Л) или эффективные (Э) дозы (ЛД, ЭД) и концентрации [9]:

1) на величину ЛД 50 для млекопитающих (орально на крысах);

2) ЛК 50 для млекопитающих (ингаляционно на крысах);

3) ЛК 50 для земляных червей;

4) ЭД

5) ЛД

6) ЛК

7) ЛК 50 в течение 96 ч для рыб;

8) ЛК 50 в течение 48 ч для дафний;

9) $Э K_{50}$ в опытах по ингибированию роста микроводорослей.

По каждому из тестов получают соответствующие оценки, которые суммируются и дают фактор эффективности воздействия $(E F)$. Последний, а также фактор экспозиции $(E)$ могут быть вычислены для каждой среды отдельно. Затем для этих сред вычисляют факторы риска:

$$
\begin{gathered}
X=E F_{s} E_{s} \text { (почва), } \\
Y=E F_{w} E_{w} \text { (вода), } \\
Z=E F_{a} E_{a} \text { (воздух), }
\end{gathered}
$$

которые нормализуются в факторы растворимости $-S_{x}, S_{y}$ и $S_{z}$ (принимается, что максимальные значения $X, Y$ и $Z$ равны 1 , а минимальные - 0 ).

Предварительные заключения о токсичности или риске делаются на основании полученных величин: риск считается высоким при $S_{i} \geq 0,55$, потенциально значимым - при $0,55<S_{i} \geq 0,30$, незначительным или отсутствующим - при $S_{i}<0,30$ [9].

В середине XX века наиболее полно выявлена опасность хлорорганических соединений для наземных и водных организмов. Опасность инсектицидов для рыб и водных беспозвоночных начала проявляться уже в результате исследовании в 1940-1950-х гг. В 60-е гг. было установлено, что острое токсическое влияние этих веществ на наиболее чувствительных гидробионтов проявляется в диапазоне концентрации от $10^{-3}$ до $10^{-12}$ г/л $[2,3]$. Столь высокая чувствительность к малым концентрациям 
ГРЯЗНАЯ ДЮЖИНА» СТОКГОЛЬМСКОЙ КОНВЕНЦИИ. ХИМИЯ И ТОКСИКОЛОГИЯ

СТОЙКИХ ОРГАНИЧЕСКИХ ЗАГРЯЗНЯЮЩИХ ВЕЩЕСТВ (СОЗ): ОБЗОР ЛИТЕРАТУРЫ

определяется, с одной стороны, чрезвычайной токсичностью этих веществ, с другой - специфическим характером их действия на жизненные функции. Они легко поражают любых представителей членистоногих, в частности ракообразных, представители которых составляют основную часть морского и пресноводного зоопланктона.

Гибель гидробионтов массовых видов понижает способность экосистемы к самоочищению, поскольку жизнедеятельность таких водных организмов, как бактерии, водоросли, ракообразные, моллюски, обеспечивает трансформацию органического вещества в водоеме.

Широкое применение пестицидов создает необходимость тщательного изучения их вредного воздействия на организм человека с учетом как ближайших, так и отдаленных последствий. В связи с этим необходим жесткий контроль их содержания в пищевых продуктах.

Контроль загрязнения окружающей среды основывается на санитарногигиенических нормативах допустимого содержания вредных химических веществ в воздухе, в воде, почве, и в продуктах питания. В основе нормирования лежит установление минимальных значений концентраций загрязняющих веществ, которые гарантируют безопасность для здоровья человека и среды его обитания. Безопасные уровни содержания ХОП в воздухе, воде, почве, кормах сельскохозяйственных животных приведены во многих работах и нормативных документах (табл. 1.2).

Таблица 1.2

\section{Значение гигиенических нормативов - безопасные уровни содержания ХОС в окружающей среде $[1,15,16,19]$}

\begin{tabular}{|c|c|c|c|}
\hline Норматив/среда & ГХЦГ & ДДТ & ПХБ \\
\hline ПДК/ Воздух & $0,001 \mathrm{M \Gamma} / \mathrm{M}^{3}$ & $0,001 \mathrm{M \Gamma} / \mathrm{M}^{3}$ & $0,001 \mathrm{M \Gamma} / \mathrm{M}^{3}$ \\
\hline ПДК/ Вода & $0,002 \mathrm{мг} /$ дм $^{3}$ & $0,1 \mathrm{мг/дм^{3 }}$ & $0,001 \mathrm{мг} /$ дм $^{3}$ \\
\hline ПДК/ Почва & 0,1 мг/кг & $0,1 \mathrm{мг} / \mathrm{к \Gamma}$ & 0,00006 мг/кг \\
\hline
\end{tabular}

В таблице 1.3 представлены установленные в РФ гигиенические нормативы (предельно допустимые концентрации (ПДК) токсичных веществ) безопасности пищевых продуктов для человека, требования по соблюдению этих нормативов при изготовлении, ввозе и обороте пищевых продуктов [20]. 
ПДК хлорорганических пестицидов и полихлорированных бифенилов в пищевых продуктах, мг/кг сырой массы [20]

\begin{tabular}{lllll}
\hline Норматив & $\begin{array}{l}\text { Изомеры } \\
\text { ГХЦГ }\end{array}$ & $\begin{array}{l}\text { ДДТ и его } \\
\text { метаболиты }\end{array}$ & $\begin{array}{l}\text { Конгенеры } \\
\text { ПХБ }\end{array}$ & Примечание \\
\hline ПДК, мясо & 0,1 & 0,1 & - & \\
ПДК, яйца & 0,1 & 0,1 & & \\
ПДК, молоко & 0,05 & 0,05 & & Морская \\
ПДК, рыба & 0,2 & 0,2 & 2,0 & Осетровые, \\
& 0,2 & 2,0 & & лососевые, сельдь \\
& & & & Пресноводная \\
& 0,03 & 0,3 & & Морские животные \\
ПДК, мясо & 0,2 & 0,2 & & \\
ПДК, икра рыб & 0,2 & 2,0 & 5,0 & \\
ПДК, печень & 1,0 & 3,0 & & \\
рыб & & & & \\
ПДК, зерно & 0,5 & 0,02 & & \\
ПДК, овощи & 0,1 & 0,1 & & \\
ПДК, фрукты & 0,05 & 0,1 & & \\
\hline
\end{tabular}

Действующие нормы ДДТ и его метаболитов (ДДЕ, ДДД), принятые в различных международных организациях по одним наименованиям продуктов такие же, как и в России (фрукты и овощи, молоко), а по другим (яйца, мясо, крупы) приблизительно в 5 раз выше (табл. 1.4).

Таблища 1.4

Действующие нормы ДДТ и его метаболитов (ДДЕ, ДДД), принятые различными международными организациями [10]

\begin{tabular}{ll}
\hline Источник сведений или организация & Норма ДДТ и метаболитов \\
\hline ФАО/ВОЗ, допустимое дневное потребление & 20 мкг/кг \\
ВОЗ, Руководство по питьевой воде & 1 мкг/л \\
Руководство ВОЗ по ДДТ, молоко (в жире) & 1 мкг/г жира \\
US EPA*, минимальный уровень риска (MRL) & 0,5 нг/кг/день \\
US EPA, Фрукты и овощи & $0,1-0,5$ мг/кг \\
US EPA, Яйца, крупы & 0,5 мг/кг \\
US EPA, Молоко & 0,05 мг/кг \\
US EPA, Мясо & 5,0 мг/кг
\end{tabular}

*US EPA - Агентство по защите окружающей среды США 
ПДК по содержанию ДДТ и его метаболитов, установленные СанПиН 2.3.2.1078-01, более низкие для некоторых продуктов, чем нормы US EPA (яйца, мясо). Содержание ГХЦГ в международных стандартах не нормируется, так как считается, что его уровень низкий.

\section{3. Полихлорированные бифенилы (ПХБ)}

\subsection{1. Физико-химические свойства ПХБ}

ПХБ использовались как электропроводящие жидкости в электрооборудовании, смазочно-охлаждающие жидкости, а также при производстве пластификаторов, пестицидов, красок, лаков $[19,22]$. ПХБ, как правило, представляют собой тяжелые высококипящие маслообразные жидкости с диэлектрическими свойствами. ПХБ чрезвычайно инертны и плохо растворяются в воде [30]. Физико-химические свойства ПХБ представлены в таблице 1.5 .

Таблица 1.5

Физико-химические свойства полихлорированных бифенилов $[30,58]$

\begin{tabular}{lllll}
\hline Группа конгенеров & $\begin{array}{l}\text { Молеку- } \\
\text { лярная } \\
\text { масса }\end{array}$ & $\begin{array}{l}\text { Давление } \\
\text { паров, } \\
\text { Па }\end{array}$ & $\begin{array}{l}\text { Растворимость } \\
\text { в воде, мг/л }\end{array}$ & $\log$ Ков \\
\hline Монохлорбифенил & 188,7 & $0,9-2,5$ & $1,21-5,5$ & $4,3-4,6$ \\
Дихлорбифенил & 223,1 & $0,008-0,60$ & $0,06-2,0$ & $4,9-5,3$ \\
Трихлорбифенил & 257,5 & $0,003-0,22$ & $0,015-0,4$ & $5,5-5,9$ \\
Тетрахлорбифенил & 292,0 & 0,002 & $0,0043-0,010$ & $5,6-6,5$ \\
Пентахлорбифенил & 326,4 & $0,0023-$ & $0,004-0,02$ & $6,2-6,5$ \\
& & 0,051 & & \\
Гексахлорбифенил & 360,9 & $0,0007-$ & $0,0004-0,0007$ & $6,7-7,3$ \\
& & 0,012 & & \\
Гептахлорбифенил & 395,3 & 0,00025 & 0,000045 & $6,7-7$ \\
Октахлорбифенил & 429,8 & 0,0006 & $0,0002-0,0003$ & 7,1 \\
Нонахлорбифенил & 464,2 & - & $0,00018-0,0012$ & $7,2-8,16$ \\
Декахлорбифенил & 498,7 & 0,00003 & 0,000001 & 8,26 \\
\hline
\end{tabular}


Индивидуальные ПХБ различаются количеством $n$ (от 1 до 10) и положением атомов хлора в молекуле. Теоретически возможно существование 209 индивидуальных ПХБ (рис. 1.6), отличающихся различным количеством атомов хлора и их положением в молекуле, однако только около 130 из них были идентифицированы в объектах окружающей среды до настоящего времени. Ныне принятая ИЮПАК нумерация конгенеров ПХБ была предложена в 1980 г. [44].

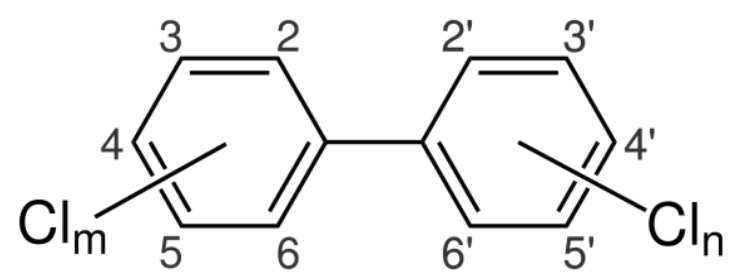

Puc. 1.6. Обобщенная структурная формула полихлорированных бифенилов (ПХБ)

Индивидуальные конгенеры ПХБ проявляют различные физикохимические свойства, которые, в конечном счете, обуславливают различное поведение в окружающей среде и токсичность. Состав технических смесей зависит от условий синтеза и обычно включает чрезвычайно широкий спектр ПХБ. ПХБ имеют низкую растворимость в воде, которая уменьшается с увеличением числа атомов хлора в молекуле [44].

Два бензольных кольца в молекуле бифенилов могут располагаться в одной плоскости или под углом друг к другу (до 90). Количество и расположение заместителей влияет на степень поворота бензольных колец относительно оси связи. Так, отсутствие атомов хлора в орто-положениях или наличие лишь одного заместителя в орто-положении (моноортозамещенные бифенилы) способствует сохранению плоской структуры, и такие ПХБ называют планарными или копланарными конгенерами [30, 53]. Ранее считалось, что токсичность ПХБ увеличивается с увеличением числа атомов хлора в молекуле, однако было доказано, что устойчивость, способность к биоаккумуляции и токсичность индивидуальных изомеров зависят от положения атомов хлора в молекуле. Обнаружено, что наиболее токсичными являются ПХБ, не содержащие атомов хлора в ортоположениях, и моноортозамещенные ПХБ (копланарные ПХБ) [44].

В объектах окружающей среды ПХБ присутствуют в виде смесей отдельных изомеров, которые обладают различной токсичностью. Поэто- 
ГРЯЗНАЯ ДЮЖИНА» СТОКГОЛЬМСКОЙ КОНВЕНЦИИ. ХИМИЯ И ТОКСИКОЛОГИЯ

СТОЙКИХ ОРГАНИЧЕСКИХ ЗАГРЯЗНЯЮЩИХ ВЕЩЕСТВ (СОЗ): ОБЗОР ЛИТЕРАТУРЫ

му для оценки общей токсичности ПХБ в данной системе используют систему токсических показателей, которые были определены в результате токсикологических исследований для различных орто-незамещенных, моно-орто- и ди-орто-замещенных ПХБ [65].

В результате горения ПХБ могут образовываться вещества более токсичные хлороводород, диоксины и дибензофураны. Обнаружено, что пиролиз технических смесей ПХБ приводил к образованию некоторых дифензофуранов. Дибензофураны являются также побочными продуктами технического синтеза ПХБ [30].

\subsection{2. Распространение, метаболизм и деградация ПХБ}

ПХБ распространены повсеместно в окружающей среде. Атмосферный транспорт играет важнейшую роль при глобальном распределении ПХБ. Индивидуальные конгенеры ПХБ по-разному распределяются в атмосфере в зависимости от количества атомов хлора в молекуле [69]. Так, монохлорбифенилы находятся преимущественно в атмосфере, ортозамещенные ПХБ с 1-4 атомами хлора переносятся к полярным полюсам в результате повторных процессов испарения-конденсации между воздухом и водой/почвой. ПХБ с 4-8 атомами хлора находятся в средних широтах, а ПХБ с 8-9 атомами хлора остаются в местах их первичного попадания в окружающую среду. В атмосфере ПХБ находятся в виде паров и аэрозольных ассоциатов. ПХБ в виде паров более мобильны и способны переноситься воздушными массами на большие расстояния, чем в составе аэрозольных ассоциатов. ПХБ с давлением паров более $10^{-4}$ мм рт. ст. (моно- и дихлорбифенилы) в атмосфере находятся практически только в виде паров, тогда как ПХБ с давлением паров менее $10^{-8}$ мм рт. ст. (три-, тетра-, пента, гекса- и гептахлорбифенилы) - в виде аэрозольных ассоциатов, а ПХБ с давлением паров от $10^{-4}$ до $10^{-8}$ могут находиться как в виде паров, так и в составе аэрозольных частиц [43]. Таким образом, низкохлорированные ПХБ легче подвергаются атмосферному переносу.

ПХБ поступают в водоемы из атмосферы с мокрыми и сухими выпадениями, а также в результате вымывания из почвы. В водоемах ПХБ перераспределяются между водой и донными отложениями. Высокохлорированные ПХБ, не имеющие заместителей в орто-положениях и характеризующиеся низкой растворимостью в воде и высоким коэффициентом 
распределения октанол/вода $\left(\mathrm{K}_{\text {ов}}\right)$, склонны сорбироваться в донных отложениях, тогда как низкохлорированные ПХБ с более высокой растворимо-

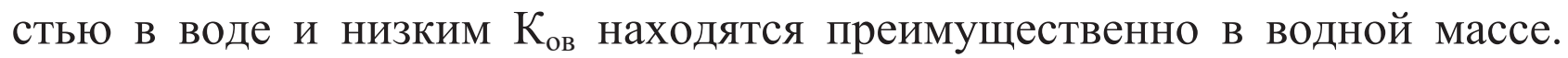
В верхних слоях донных отложений ПХБ легче подвергаются вымыванию и вовлекаются в процессы перераспределения [25, 33, 36].

Устойчивость ПХБ в окружающей среде зависит от количества атомов хлора и расположения их в молекуле. В атмосфере преобладающим процессом трансформации ПХБ является взаимодействие с гидроксилрадикалом, тогда как роль фотолиза в разложении ПХБ, находящихся в атмосфере, оказалась незначительна. Расчетные значения периодов полураспада для различных ПХБ в результате взаимодействия с гидроксилрадикалом увеличивались с увеличением числа атомов хлора в молекуле от 2 дней для бифенила до 75 дней для гексахлорбифенила, а общая деструкция ПХБ в результате данной реакции составила 8300 т в год $[27,30]$.

В воде преимущественным механизмом абиотического разложения ПХБ является фотолиз, а вклад процессов гидролиза и окисления незначителен (ATSDR, 2000). В процессе фотолиза происходит разрушение хлоруглеродной связи и поэтапное замещение атомов хлора водородом [34]. Биодеградация ПХБ в поверхностной воде обычно является аэробным процессом и зависит от структуры отдельных изомеров и условий окружающей среды. Известно, что низкохлорированные ПХБ (моно- и дизамещенные) легче подвергаются биоразложению деградации, чем высокохлорированные [22].

Биодеградация ПХБ является основным механизмом разложения ПХБ в донных отложениях и почве и может протекать в анаэробных и аэробных условиях. Аэробная деградация ПХБ обычно идет в два этапа: преобразование ПХБ в соответствующие бензойные кислоты и затем минерализация хлорбензоатов до диоксида углерода и неорганических хлоридов. В анаэробных условиях происходит восстановительное дехлорирование ПХБ, в результате которого происходит отщепление атомов хлора без разрушения бензольных колец и образуются менее токсичные моно- и дихлорбифенилы. Скорость биодеградации ПХБ также определяется положением и количеством атомов хлора в молекуле. Возрастающее количество хлорзаместителей в целом в молекуле и орто-положениях в частности существенно ингибирует биодеградацию ПХБ (рис. 1.7) [22, 24, 70$]$.

Глобальное перераспределение ПХБ было зафиксировано с помощью использования полупроницаемых мембранных устройств для отбора 
ГРЯЗНАЯ ДЮЖИНА» СТОКГОЛЬМСКОЙ КОНВЕНЦИИ. ХИМИЯ И ТОКСИКОЛОГИЯ СТОЙКИХ ОРГАНИЧЕСКИХ ЗАГРЯЗНЯЮЩИХ ВЕЩЕСТВ (СОЗ): ОБЗОР ЛИТЕРАТУРЫ

проб атмосферного воздуха, которые были зафиксированы через определенные расстояния с юга Англии до севера Норвегии [35]. В пробах воздуха, отобранных таким образом, качественный состав изомеров ПХБ в воздухе изменялся с юга на север и в более северных точках наблюдалось увеличение доли низкохлорированных ПХБ.
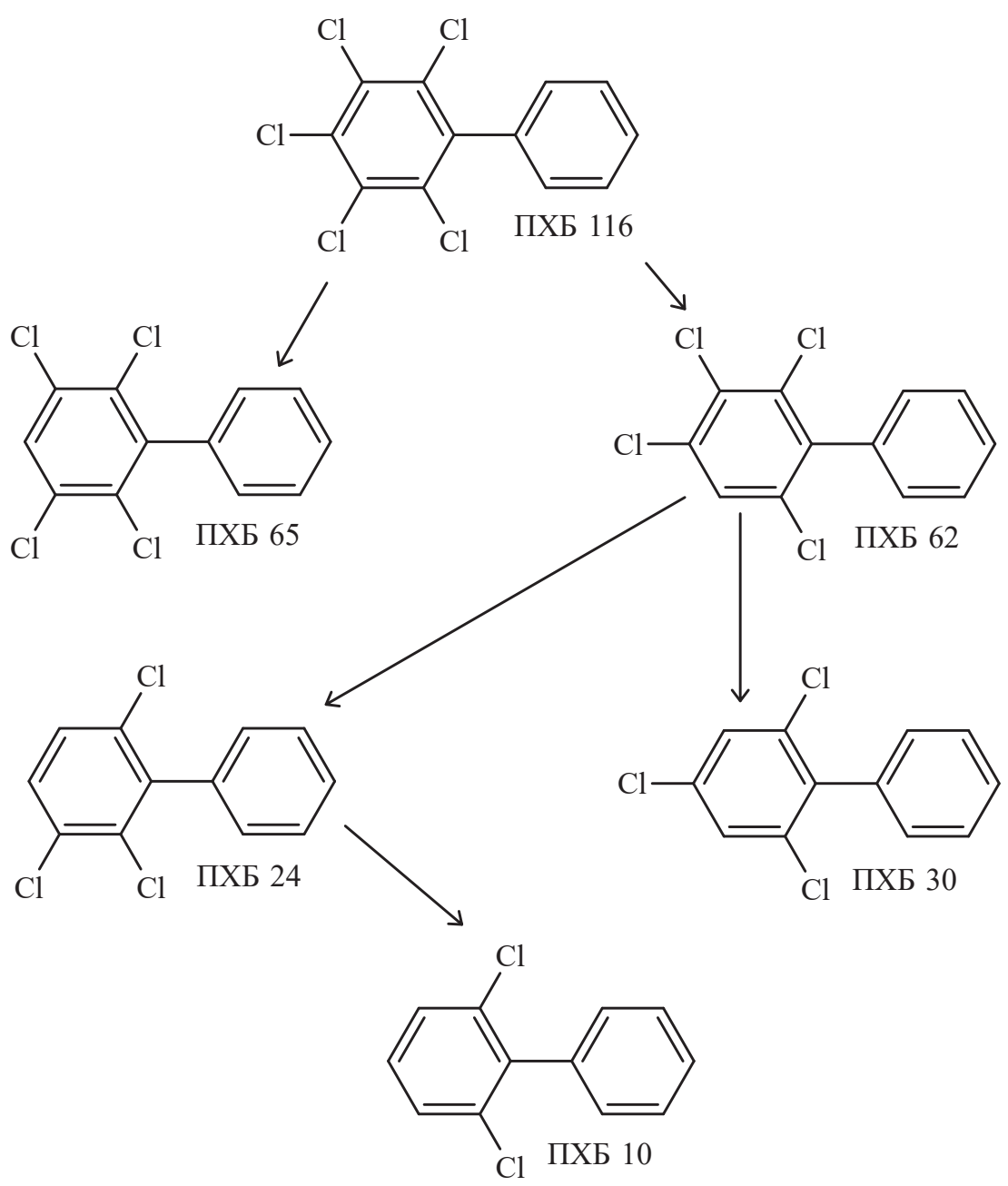

Puc. 1.7. Схема метаболических превращения ПХБ микроорганизмами [67]

ПХБ обычно считаются стойкими органическими загрязнителями, однако многие конгенеры ПХБ, включая хиральные ПХБ (оба фенильных кольца имеют несимметричный характер замещения относительно оси, образованной центральной С-С-связью бифенильной системы и составляют до 6\% по массе технических смесей ПХБ и подвергаются значительному атропоизомерному обогащению у диких животных, лабораторных животных и людей), биотрансформируются посредством сложного, видозависимого метаболического пути в гидроксилированные, метилсульфонилированные, сульфатированные, глюкуронидированные и другие метаболиты (рис. 1.8) [51]. 
липидные, белковые и ДНК-аддукты<smiles>CC[NH3+]</smiles><smiles>[R16]c1c(Cl)ccc(Cl)c1-c1c(Cl)c(O)c(O)c(Cl)c1Cl</smiles><smiles>ClC1=C(Cl)C2OC2C(c2ccc(Cl)c(-c3c(Cl)cccc3Cl)c2Cl)C(Cl)=C1c1c(Cl)ccc(Cl)c1Cl</smiles>

ПХБ 136 эпоксид

ПХБ 136 глутатионовый конъюгат

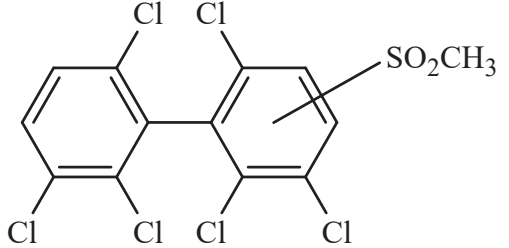

$\mathrm{MeSO}_{2}$-ПХБ 136

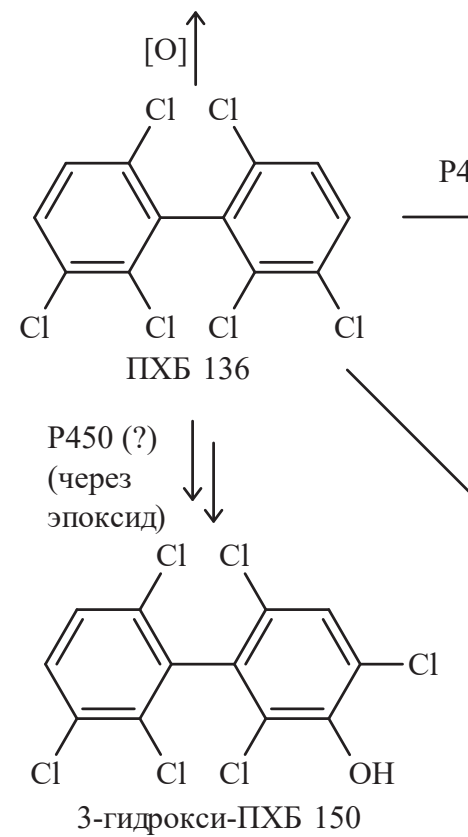

P450
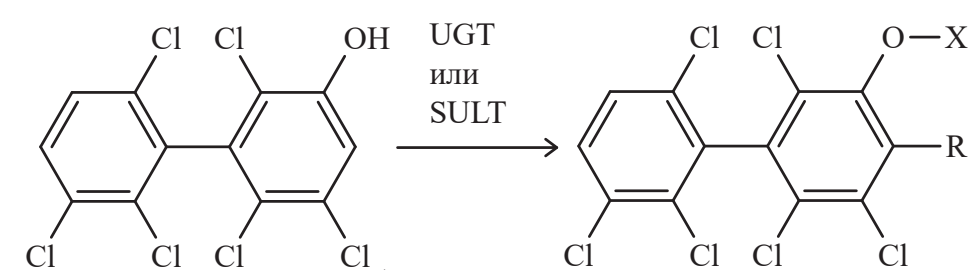

5-гидрокси-ПХБ 136

Глюкуродиндный и сульфатный конъюгаты

P450 (?)

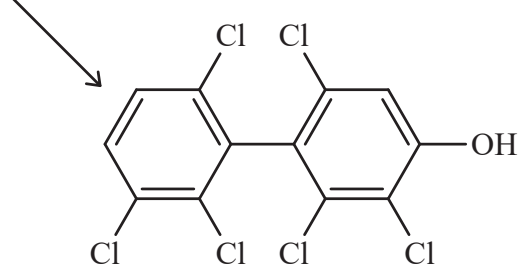

4-гидрокси-ПХБ 136

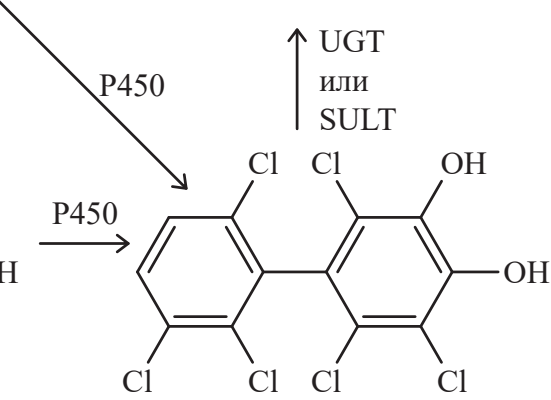

4,5-гидрокси-ПХБ 136

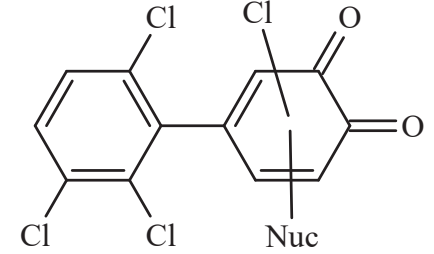

Глутатионовые и липидные конъюгаты, белковые и ДНК-аддукты

Pис. 1.8. Упрощенная схема метаболизма ПХБ 136 [51]: Nuc - клетосный Nили S-нуклеофил; P450 - цитохром P450 (CYP2Bs) фермент; GST - глутатионS-трансфераза; UGT - глюкуронозилтрансфераза; SULT - сульфотрансфераза; ДНК-аддукты - соединение какой-либо молекулы с ДНК ${ }^{1}$

${ }^{1}$ Бывают малые и объемные. Образование ДНК-аддуктов в организме часто происходит под действием канцерогенов, их метаболитов, либо провоцируется канцерогенами, и ведет к изменению структуры, невозможности правильного протекания процессов транскрипции ДНК и мутациям. 
Окисление хиральных ПХБ, в особенности тех, которые имеют 2,3,6трихлорзамещенную структуру в одном бензольном кольце, до гидроксиПХБ широко изучалось с использованием рекомбинантных ферментов, микросом печени, изолированных гепатоцитов, печени, гиппокампа и кожных срезов, полученных из млекопитающих. Насколько известно, окисление ПХБ у амфибий, рыб или птиц до настоящего времени не исследовалось. Косвенные данные, например, из токсикокинетических исследований, позволяют предположить, что ПХБ также подвержены биотрансформации у многих видов животных.

Например, ПХБ 136 может быть окислен путем направленного введения кислорода в мета-С-Н связь, или путем образования эпоксидных промежуточных продуктов. Эпоксиды ПХБ 136 могут либо перегруппировываться с образованием гидрокси-ПХБ 136, либо подвергаться 1,2сдвигу с образованием 3-гидрокси-ПХБ 150 из эпоксида дигидродиола и реагировать с клеточными нуклеофилами, такими как глутатион. Гидрокси-ПХБ далее окисляются до дигидроксилированных метаболитов, таких как 4,5-дигидрокси-ПХБ 136. Альтернативно, моно- и дигидроксилированные метаболиты ПХБ 136 могут подвергаться второй стадии метаболизма до конъюгатов глюкуронида или сульфата. Подобно другим дигидроксилированным метаболитам ПХБ, 4,5-дигидрокси-ПХБ 136, вероятно, может быть окислен через радикал семихинона до хинонов ПХБ, которые впоследствии будут реагировать с клеточными нуклеофилами посредством реакции замещения хлора. Конъюгаты глутатиона, образующиеся из эпоксидов ПХБ 136, будут метаболизироваться в несколько этапов до соответствующих метилсульфонильных метаболитов.

\subsection{3. Токсичность ПХБ}

ПХБ обладают низкой токсичностью при однократном воздействии, но высокой кумулятивной способностью при длительном контакте. Ocновные каналы поступления в организм человека - через кожу, легкие, а также через трофические цепи в загрязненных районах.

Наиболее опасными считаются копланарные изомеры, которые имеют не более одного атома хлора в орто-положении $\left(2,2^{\prime}, 6,6^{\prime}\right)$. По токсичности они идентичны полихлорированным дибензо- $n$-диоксинам и полихлорированным дибензофуранам. Токсичность ПХБ измеряется по 
шкале токсичности, сходной со шкалой для диоксинов/фуранов. Эквиваленты токсичности разработаны для 12 конгенеров ПХБ.

Характерная черта поведения ПХБ в окружающей среде - их очень медленное разложение. Имея выраженные липофильные свойства, ПХБ обладают высокой способностью к биоаккумуляции в жиросодержащих компонентах (коэффициент накопления в некоторых биологических объектах достигает десятков миллионов). Выявлены высокие содержания ПХБ в грудном молоке, жировых тканях людей. ПХБ способны проникать через плаценту и концентрироваться в тканях плода [61, 65].

Уже в 1930-е гг. были зарегистрированы случаи отравления ПХБ рабочих, контактировавших с этими соединениями в производственных условиях. В 1963 г. стали известны массовые отравления рабочих на японских предприятиях по производству конденсаторов. Известен пример массового отравления людей ПХБ вследствие нарушения герметичности теплообменной аппаратуры в процессе рафинирования рисового масла. Этот случай, вошедший в историю как «инщидент Ющо», произошел в Японии в 1968 г. Признаками отравления были увеличение и гиперсекреция грудных желез, тошнота, рвота, расширение и порфирия печени, патологические изменения периферийной нервной системы и состава крови, нарушение функции надпочечников [12].

Из симптомов профессионального отравления, вызываемого ПХБ у рабочих, соприкасающихся с этим продуктом в условиях производственной деятельности, чаще всего отмечаются хлоракне (поражение кожи), а также неврологические явления в виде головных болей, утомляемости, чувства ползания мурашек в конечностях.

Острые токсикозы проявляются в поражении кожи, печени, почек, легких, центральной нервной системы. Попадая в организм, ПХБ хорошо всасываются в желудочно-кишечном тракте, в легких, проникают через кожу и накапливаются в основном в жировой ткани. В большинстве проб жировой ткани содержание ПХБ составляет 1 мг/кг или менее (содержание в крови - 0,3 мкг/100 мл), большие количества - до 700 мг/кг - обнаруживали в образцах жировой ткани людей, подвергавшихся профессиональному воздействию (содержание в крови - 200 мкг/100 мл) [12].

ПХБ относятся к иммунотоксикантам. Их опасность для здоровья человека заключается, прежде всего, в том, что они являются мощными факторами подавления иммунитета («химический» СПИД). ПХБ облада- 
ГРЯЗНАЯ ДЮЖИНА» СТОКГОЛЬМСКОЙ КОНВЕНЦИИ. ХИМИЯ И ТОКСИКОЛОГИЯ

СТОЙКИХ ОРГАНИЧЕСКИХ ЗАГРЯЗНЯЮЩИХ ВЕЩЕСТВ (СОЗ): ОБЗОР ЛИТЕРАТУРЫ

ют выраженным эмбриотоксическим и потенциальным канцерогенным эффектами (ЛД 50 варьирует от 0,79 до 11 г/кг). Попадая в организм плода и ребенка, ПХБ способствуют развитию врожденного уродства и детской патологии (отставанию в развитии, снижению иммунитета, поражению кроветворения). Кроме того, ПХБ вызывают снижение числа мест имплантации, количества новорожденных и увеличение продолжительности беременности. При длительном введении ПХБ обезьянам до и во время беременности, а также в период лактации наблюдались ранние выкидыши, преждевременные роды, гибель плодов вскоре после рождения. Однако, самое опасное влияние ПХБ на человека заключается в их мутагенном действии, что негативно сказывается на здоровье последующих поколений людей $[30,44]$.

Установлено, что эта группа соединений может вмешиваться в гормональный механизм и вызывать эндокринные поломки, кроме того, ПХБ могут имитировать или блокировать действие тиреоидных гормонов.

Период полувыведения у человека составляет 5 лет.

\section{4. Список литературы}

1. Беспамятов, Г.П. Предельно допустимые концентрации химических веществ в окружающей среде / Г.П. Беспамятов, Ю.А. Кротов. - Л.: Химия, 1985. - 528 с.

2. Брагинский, Л.П. Миграция стойких пестицидов в пресноводных экосистемах / Л.П. Брагинский, Ф.Я. Комаровский, Ю.К. Пищолка, О.В. Маслова // Миграция загрязняющих веществ в почвах и сопредельных средах: труды всесоюзного совещания. - Л.: Гидрометеоиздат, 1980. - С. 226-231.

3. Брагинский, Л.П. Теоретические аспекты проблем «нормы и патологии» в водной экотоксикологии / Л.П. Брагинский // Теоретические вопросы водной токсикологии: Материалы 3-го советско-американского симпозиума. - Л.: Наука, 1981. - С. 29-40.

4. Вирченко, Е.П. Поведение изомеров в ГХЦГ в почвах / Е.П. Вирченко, Ц.И. Боровиков // Тр. ИЭМ. - М.: Гидрометеоиздат, 1985. № 13/118. - С. 18-23. 
5. Врочинский, К.К. Гидробиологическая миграция пестицидов / К.К. Врочинский, М.М. Телитченко, А.И. Мережко. - М.: МГУ, 1980. $120 \mathrm{c}$.

6. Галиулин, Р.В. Биогеохимический подход к экологическому нормированию стойких хлорорганических соединений в агроландшафтах / Р.В. Галиулин // Биохимические основы экологического нормирования. М.: Наука, 1993. - С. 49-64.

7. Зеленин, К.Н. Что такое химическая экотоксикология / К.Н. Зеленин // Соровский образовательный журнал. - 2000. - Т. 6. - № 6. - С. 32-36.

8. Израэль, Ю.А. Антропогенная экология океана / Ю.А. Израэль, А.В. Цыбань. - М.: Флинта: Наука, 2009. - 532 с.

9. Исидоров, В.А. Введение в химическую экотоксикологию / В.А. Исидоров. - СПб.: Химиздат, 1999. - 351 с.

10. Конвенция о принятии международных мер в отношении отдельных стойких органических загрязнителей. - Стокгольм, 2001. - 44 с.

11. Кросби, Д. Перенос и превращение пестицидов в атмосфере / Д. Кросби. // Миграция и превращения пестицидов в окружающей среде: труды I Всесоюзного совещания. - М.: Гидрометеоиздат, 1979. - С. 5-10.

12. Кухарчик, Т.И. Полихлорированные бифенилы в электрооборудовании / Т.И. Кухарчик, С.В. Какарека, П.В. Цытик. - Минск, 2003. - 28 с.

13. Лобов, В.П. Пестициды. / В.П. Лобов, Г.А. Ефимов. - Киев: Гостехиздат УССР, 1963. - 276 с.

14. Маслова, О.В. Зависимость накопления ДДТ от содержания липидов в тканях эстуарных рыб / О.В. Маслова // Гидробиологический журнал. - 1981. - Т. 17. - № 4. - С. 75-77.

15. Мельников, Н.Н. Пестициды и окружающая среда / Н.Н. Мельников, А.И. Волков, О.А. Короткова - М.: Химия, 1977. - 240 с.

16. Мельников, Н.Н. Химия и технология пестицидов / Н.Н. Мельников. - М.: Химия, 1974. - 765с.

17. Основные токсичные метаболиты пестицидов, широко применяемых в народном хозяйстве / Гидрометеорология. Сер. 87. Мониторинг состояния окружающей природной среды: Обзорная информация. - Обнинск, 1989. - Вып. 2. - 51 с.

18. Попова, Г.В. Накопление пестицидов в воспроизводительной системе рыб и их гонадотоксические действия / Г.В. Попова, Л.Д. Шамрова // Экспериментальная водная токсикология. - 1987. - № 12. - С. 191-201. 
19. Ровинский, Ф.Я. Фоновый мониторинг загрязнения экосистем суши хлорорганическими соединениями / Ф.Я. Ровинский, Л.Д. Воронова, М.И. Афанасьев, А.В. Денисова, И.Г. Пушкарь. - Л.: Гидрометеоиздат, 1990. -270 c.

20. СанПиН 2.3.2.1078-01 Санитарно-эпидемиологические правила и нормативы (с изменениями на 6 июля 2011 года). - М.: Минздрав России, 2002. - 154 с.

21. Тинсли, И. Поведение химических загрязнителей в окружающей среде / И. Тинсли. - М.: Мир, 1982. - 280 с.

22. Фидлер, Х. Материалы Субрегионального совещания по выявлению и оценке выбросов стойких органических загрязнителей / Х. Фидлер. - М., 1998. - 233 с.

23. Цыденова, О.В. Хлорорганические соединения в экосистемах озера Байкал и его бассейна: автореф. дис. ... канд. хим. наук / О.В. Цыденова. - Барнаул, 2005. - 23 с.

24. Abramowicz, D.A. Aerobic and Anaerobic PCB Biodegradation in the Environment / D.A. Abramowicz // Environmental Health Perspectives Supplements. - 1995. - V. 103. - № 5. - P. 97-99.

25. Achman, D.R. Exchange of polychlorinated biphenyls between sediment and water in the Hudson River estuary / D.R. Achman, B.J. Brownawell, L. Zhang // Estuaries. - 1996. - V. 19. - P. 950-965.

26. Allen-Gil, S.M. Organochlorine pesticides and polychlorinated biphenyls (PCBs) in sediments and biota from four US Arctic lakes / S.M. AllenGil, C.P. Gubala, R. Wilson [et al.] // Archives of Environmental Contamination and Toxicology. - 1997. - V. 33. - No. 4. - P. 378-387.

27. Atkinson, R. Atmospheric Chemistry of PCBs, PCDDs, and PCDFs. / R. Atkinson. - In: Chlorinated Organic Micropollutants // Environmental Science \& Technology, 1995. - P. 53-72.

28. ATSDR. Toxicological profile for DDT, DDE, DDD / Agency for Toxic Substances and Disease Registry (ATSDR). - Atlanta, GA: U.S. Department of Health and Human Services, Public Health Service, 2002.

29. ATSDR. Toxicological profile for hexachlorobenzene / Agency for Toxic Substances and Disease Registry. - Atlanta, GA: U.S. Department of Health and Human Services, Public Health Service, 2002.

30. ATSDR. Toxicological profile for polychlorinated biphenyls (PCBs) / Agency for Toxic Substances and Disease Registry. - Atlanta, GA: U.S. Department of Health and Human Services, Public Health Service, 2000. 
31. ATSDR. Toxicological profile for toxaphene / Agency for Toxic Substances and Disease Registry. - Atlanta, GA: U.S. Department of Health and Human Services, Public Health Service, 2014.

32. Axelman, J. A review of processes involved in the exchange of persistent organic pollutants across the air-sea interface / J. Axelman, F. Wania, D. Broman // Environmental Pollution. - 1998. - V. 102. - P. 3-23.

33. Baker, J.E. Concentrations and fluxes of polycyclic aromatic hydrocarbons and polychlorinated biphenyls across the air-water interface of Lake Superior / J.E. Baker, S.J. Eisenreich // Environmental Science \& Technology. - 1990. - V. 24. - P. 342-352.

34. Barr, J.R. Photolysis of environmentally important PCBs / J.R. Barr, T. Oida, K. Kimata // Organohalogen Compounds. - 1997. - V. 33. - P. 199-204.

35. Bidleman, T.F. Atmospheric transport and air-surface exchange of pesticides / T.F. Bidleman // Water, Air, \& Soil Pollution. - 1999. - No. 115. P. 115-166.

36. Burgess, R.M. Enrichment of marine sediment colloids with polychlorinated biphenyls: Trends resulting from PCB solubility and chlorination / R.M. Burgess, R.A. McKinney, W.A. Brown // Ibid. - 1996. - V. 30. P. 2556-2566.

37. Burkow, I.C. Sources and transport of persistent pollutants to the Arctic / I.C. Burkow, R. Kallenborn // Toxicology Letters. - 2000. - P. 112-113.

38. Chen, M.-W. Association between Organochlorine Pesticide Levels in Breast Milk and Their Effects on Female Reproduction in a Taiwanese Population / M.-W. Chen, H. Santos, D. Que [et al.] // International Journal of Environmental Research and Public Health. - 2018. - V. 15. - P. 931.

39. Crosby, D.C. Atmospheric reactions of pesticides / D.C. Crosby // Pesticide Chemistry: Human Welfare and Environment. - 1983. - V. 3. P. 327-332.

40. DDT and its derivatives: environmental aspects. - WHO: World Health Organization, 1989. - 98 p.

41. Doelman, P. Rate of microbial degradation of high concentration of $\alpha$ hexachlorocyclohexane in soil under aerobic and anaerobic conditions / P. Doelman, E. Haanstra // Chemosphere. - 1985. - V. 14. - № 5. - P. 565-570.

42. Erdman, L. Atmospheric Input of Persistent Organic Pollutants to the Mediterranean Sea / L. Erdman, A. Gusev, N. Pavlova. Technical Report Series UNEP/WMO/MSC-E. - Athens, 1999. 
43. Erickson, M.D. Analytical chemistry of PCBs. / M.D. Erickson. Boca Raton, FL: Lewis Publishers, 1992. - 667 p.

44. Giesy, J.P. Dioxin-like and non-dioxin-like toxic effects of polychlorinated biphenyls (PCBs): implications for risk assessment / J.P. Giesy, K. Kannan // Critical Reviews in Toxicology. - 1998. - V. 28. - №6. - P. 511-569.

45. Gold, B. Metabolism of a DDT metabolite via a chloroepoxide / B. Gold, T. Leuschen, G. Brunk, R. Gingell // Chemico-Biological Interactions. - 1981. - V. 35. - P. 159-176.

46. Gunter, F.A. Residue of pesticides and other contaminants in the total environment / F.A. Gunter, J.D. Gunter // Residue Reviews. N.-Y. - 1979. V. 72. - P. 71-72.

47. Harner, T. Organochlorine contamination of the Canadian Arctic, and speculation on future trends / T. Harner // Ibid. - 1997. - V. 8 (1/2).- P. 51-73.

48. Hartwell, S.I. Benthic habitat contaminant status and sediment toxicity in Bristol Bay, Alaska / S.I. Hartwell, A.D. Apeti, A.S. Pait, T. Radenbaugh, R. Britton // Regional Studies in Marine Science. - 2018. - V. 24. - P. 343-354.

49. Health Canada Federal Contaminated Site Risk Assessment in Canada, Part II: Health Canada Toxicological Reference Values (TRVs) and Chemical-Specific Factors, Version 2.0 [электронный ресурс]. - Режим доступа: https://www.canada.ca/en/health-canada.html

50. Jones, K. C. Persistent organic pollutants (POPs): state of the science / K. C. Jones, Voogt P. // Environmental Pollution. - 1999. - V. 100. - P. 209-221.

51. Kania-Korwel, I. Chiral polychlorinated biphenyls: absorption, metabolism and excretion - a review / I. Kania-Korwel, H.-J. Lehmler // Environmental Science and Pollution Research. - 2016. - V. 23. - P. 2042-2057.

52. Macdonald, R.W. Contaminants in the Canadian Arctic: 5 years of progress in understanding sources, occurrence and pathways / R.W. Macdonald, L.A. Barrie, T.F. Bidleman [et al.] // Science of the Total Environment. 2000. - V. 254. - P. 93-234.

53. Mizukami, Y. Exploratory ab initio MO calculations on the structures of polychlorinated biphenyls (PCBs): a possible way to make a coplanar PCB stable at coplanar conformation / Y. Mizukami // Journal of Molecular Structure: THEOCHEM. - 1999. - V. 488. - P. 11-19.

54. Muir, D.C.G. Spatial trends and historical profiles of organochlorine pesticides in Arctic lake sediments / D.C.G. Muir, N.P. Grift, W.L. Lockhart // Ibid. - 1995. - V. 160/161. - P. 447-457. 
55. Negoita, T.G. Distribution of polychlorinated biphenyls (PCBs) and organochlorine pesticides in soils from the East Antarctic coast / T.G. Negoita, A. Covaci, A. Gheorghe, P. Schepens // Journal of Environmental Monitoring. - 2003. - V. 5. - No. 2. - P. 281-286.

56. Orris, P. Persistent Organic Pollutants and Human Health / P. Orris, L.K. Chary, K. Perry, J. Ausbury. - A Publication of the World Federation of Public Health Association's Persistent Organic Pollutants Project, 2000 - 38 p.

57. Porpora, M. Placental Transfer of Persistent Organic Pollutants: A Preliminary Study on Mother-Newborn Pairs / M. Porpora, R. Lucchini, A. Abballe [et al.] // International Journal of Environmental Research and Public Health. - 2013. - V. 10. - No. 2. - P. 699-711.

58. PubChem - open chemistry database at the National Institutes of Health (NIH). Режим доступа: https://pubchem.ncbi.nlm.nih.gov/

59. Quemerais, B. Concentrations and sources of PCBs and organochlorine pesticides in the St. Lawrence River (Canada) and its tributaries / B. Quemerais, C. Lemieux, K.R. Lum // Chemosphere. - 1994. - V. 29. - No. 3. P. 591-610.

60. Ritter, L. An assessment report on DDY-Aldrin-Dieldrin-EndrinChlordane-Heptachlor-Hexachlorobenzene-Mirex-Toxaphene-Polichlorinated Biphenyls-Dioxins and Furans / L. Ritter, K.R. Solomon, J. Forget. - The International Program on Chemical Safety (IPCS) within the Framework of the Inter-Organization Program for the Sound Management of Chemicals (IOMC), 1995. $-24 \mathrm{p}$.

61. Tanabe, S. Bioindicators of POPs / S. Tanabe, A. Subramanian. - Japan: Kyoto University Press and Trans Pacific Press, 2006. - 190 p.

62. Tanabe, S. Contamination by Persistent Toxic Substances in the Asia-Pacific Region / S. Tanabe // Persistent Organic Pollutants in Asia: Sources, Distributions, Transport and Fate. - A. Li, S. Tanabe, G. Jiang, J.P. Giesy and P.K.S. Lam (Editors). - Developments in Environmental Science. - 2007. - V. 7. - P. 773-817.

63. Tanabe, S. Polychlorobiphenyls, DDT and hexachlorocyclohexane isomers in the Western North Pacific ecosystem / S. Tanabe, H. Tanaka, R. Tatsukawa // Archives of Environmental Contamination and Toxicology. 1984. - V. 13. - P. 731-738.

64. Tsygankov, V.Yu. Hexachlorocyclohexane $(\mathrm{HCH})$ in human blood in the south of the Russian Far East / V.Yu. Tsygankov, M.D. Boyarova, 
P.F. Kiku, M.V. Yarygina // Environmental Science and Pollution Research. 2015. - V. 22. - P. 14379-14382.

65. Van den Berg, M. Toxic equivalency factors (TEF) for PCBs, PCDDs, PCDFs for humans and wildlife / M. Van den Berg, L. Birnbaum, A.T.C. Bosveld [et al.] // Environmental Health Perspectives. - 1998. V. 106. - P. 775-792.

66. Van den Brink, N.W. Directed transport of volatile organochlorine pollutants to polar regions: the effect on the contamination pattern of Antarctic seabirds / N.W. Van den Brink // Science of the Total Environment. - 1997. V. 198. - No. 1. - P. 43-50.

67. Van Dort, H.M. Priming Microbial meta- Dechlorination of Polychlorinated Biphenyls That Have Persisted in Housatonic River Sediments for Decades / H.M. Van Dort, L.A. Smullen, R.J. May, D.L. Bedard // Environmental Science \& Technology. - 1997. - V. 31. - P. 3300-3307.

68. Walker, C.H. Variation in the intake and elimination of pollutants Organochlorine insecticide / C.H. Walker // Persistent organic pollutants. N.-Y.: Academic Press, 1975. - P. 73-131.

69. Wania, F. Tracking the distribution of persistent organic pollutants / F. Wania, D. Mackay // Environmental Science \& Technology. - 1996. V. 30. - No. 9. - P. 390-396.

70. Williams, W.A. Low-temperature microbial aerobic degradation of polychlorinated biphenyls in sediment / W.A. Williams, R.J. May // Environmental Science \& Technology. - 1997. - V. 31(12). - P. 3491-3496.

71. Zeng, E. In situ measurements of chlorinated hydrocarbons in the water column off the Palos Verdes Peninsula, California / E. Zeng, C. Yu, K. Tran // Ibid. - 1999. - V. 33. - P. 392-398.

72. Zhulidov, A.V. Levels of DDT and hexachlorocyclohexane in burbot (Lota lota L.) from Russian Arctic rivers / A.V. Zhulidov, R.D. Robarts [et al.] // Science of The Total Environment. - 2002. - V. 292. - P. 231-246. 
https://doi.org/10.24866/7444-4891-2/62-69

\title{
ГЛАВА 2
}

МЕТОДЫ ОПРЕДЕЛЕНИЯ СТОЙКИХ

ОРГАНИЧЕСКИХ ЗАГРЯЗНЯЮЩИХ ВЕЩЕСТВ (СОЗ)

В РАЗЛИЧНЫХ КОМПОНЕНТАХ ЭКОСИСТЕМ

ДАЛЬНЕВОСТОЧНОГО РЕГИОНА

\author{
В.Ю. Цыганков ${ }^{1,2}$, М.Д. Боярова ${ }^{1}$, М.М. Донещ, \\ А.Н. Гумовский ${ }^{1}$ Ю.П. Гумовская ${ }^{1}$
}

Показаны методы определения стойких органических загрязняющих веществ в различных компонентах экосистем Дальневосточного региона России. Описаны методы подготовки проб биологического материла, хроматографический анализ и расчеты СО3.

Ключевые слова: СОЗ, методы пробоподготовки, хроматография.

1 Школа биомедицины, Дальневосточный федеральный университет (ДВФУ), 690922, Владивосток, о. Русский, п. Аякс, 10. E-mail: tsig_90@mail.ru.

${ }^{2}$ Школа естественных наук, Дальневосточный федеральный университет (ДВФУ), 690922, Владивосток, о. Русский, п. Аякс, 10.

${ }^{1}$ School of Biomedicine, Far Eastern Federal University, 10 Ajax Bay, Russky Island Vladivostok, Russia,690922. E-mail: tsig_90@mail.ru.

${ }^{2}$ School of School of Natural Sciences, Far Eastern Federal University, 10 Ajax Bay, Russky Island Vladivostok, Russia, 690922.

Для цитирования: Цыганков В.Ю., Боярова М.Д., Донец М.М., Гумовский А.Н., Гумовская Ю.П. Методы определения стойких органических загрязняющих веществ (СО3) в различных компонентах экосистем Дальневосточного региона // Стойкие органические загрязняющие вещества (CO3) в Дальневосточном регионе: моря, организмы, человек : монография / В.Ю. Цыганков, М.М. Донец, Н.К. Христофорова [и др.] ; науч. ред. В.Ю. Цыганков. - Владивосток : Изд-во Дальневост. федерал. ун-та, 2020. - С. 62-69. - https://doi.org/10.24866/7444-4891-2/62-69.

For citing: Tsygankov V.Yu., Boyarova M.D., Donets M.M., Gumovskiy A.N., Gumovskaya Yu.P. Methods for the persistent organic pollutants (POPs) determination in various components of the ecosystems of the Far Eastern region // Persistent organic pollutants (POPs) in the Far Eastern Region: Seas, Organisms, Human : monograph / V.Yu. Tsygankov, M.M. Donets, N.K. Khristoforova [et al.] ; ed. by V.Yu. Tsygankov. - Vladivostok : Publishing House of the Far Eastern Federal University, 2020. - P. 6269. - https://doi.org/10.24866/7444-4891-2/62-69. 


\section{CHAPTER 2. METHODS FOR THE PERSISTENT ORGANIC POLLUTANTS (POPS) DETERMINATION IN VARIOUS COMPONENTS OF THE ECOSYSTEMS OF THE FAR EASTERN REGION}

\section{V.Yu. Tsygankov ${ }^{1,2}$, M.D. Boyarova ${ }^{1}$, M.M. Donets ${ }^{1}$, A.N. Gumovskiy ${ }^{1}$, Yu.P. Gumovskaya ${ }^{1}$}

Methods for determination of persistent organic pollutants in various components of ecosystems of the Russian Far East region are shown. Methods for preparing samples of biological material, chromatographic analysis and POP calculations are described.

Key words: POPs, methods of sample preparation, chromatography.

Определение массового содержания стойких органических загрязняющих веществ (CO3) в биологических образцах выполняют как правило методом газовой хроматографии с детектором электронного захвата и масс-селективным детектором. В наших исследованиях мы использовали нижеприведенные методы.

\section{1. Подготовка проб биологических образцов гидробионтов}

Цель пробоподготовки состоит в экстракции липидов ацетоном и гексаном с последующим разрушением жировых компонентов концентрированной серной кислотой.

Замороженные пробы $\left(-20^{\circ} \mathrm{C}\right)$ доставлялись в лабораторию. Навеску образца ткани (10 г) гомогенизировали в микроизмельчителе тканей в течение 5 мин в смеси $20 \mathrm{~cm}^{3}$ ацетона и $10 \mathrm{~cm}^{3}$ гексана. После этого сосуд с гомогенатом помещали в центрифугу, центрифугировали в течение 15 мин (3000 об/мин) и переносили жидкую часть в делительную воронку объемом 
$250 \mathrm{~cm}^{3}$. К остатку биологического материала в сосуде добавляли смесь из $20 \mathrm{~cm}^{3}$ гексана и $2 \mathrm{~cm}^{3}$ диэтилового эфира, гомогенизировали в течении 5 мин, центрифугировали, жидкую часть соединяли с первой порцией, остаток в сосуде промывали смесью $10 \mathrm{~cm}^{3}$ гексана и $1 \mathrm{~cm}^{3}$ диэтилового эфира. К объединенным экстрактам добавляли $60 \mathrm{~cm}^{3} 0,9 \%$-ного раствора хлорида натрия и содержимое встряхивали в течение 2-5 мин. Отделяли гексановый слой, водно-ацетоновый экстрагировали еще дважды порциями гексана по $10 \mathrm{~cm}^{3}$. Гексан отгоняли на роторном испарителе и взвешивали навеску получившегося жира. Далее снова заливали гексаном.

Гексановый экстракт очищали концентрированной серной кислотой до получения бесцветного слоя серной кислоты. Гексановые слои отмывали от кислоты раствором бикарбоната натрия, затем дистиллированной водой до нейтральной реакции по универсальному индикатору. Отмытый экстракт сушили, фильтруя через безводный сернокислый натрий. Очищенный гексановый экстракт упаривали на роторном испарителе. Полученный экстракт разделяли неполярными (для ПХБ) и полярными (для ХОП) растворителями на хроматографической колонке с сорбентом Florisil $®$ [1, 3, 4, 6].

\section{2. Подготовка проб биологических жидкостей человека}

Кровь отбирают в пробирки Vaccuete с цитратом натрия (объем $9 \mathrm{~cm}^{3}$ ). Грудное молоко собирают в контейнеры для биологического материала, замораживают и транспортируют в лабораторию.

Навеску крови вносят сразу в колбу с ацетоном напрямую. Например, в образец крови 9 г пропорционально вносят $18 \mathrm{~cm}^{3}$ ацетона, интенсивно встряхивают и добавляют 13,5 cм ${ }^{3}$ гексана, помещают на шейкер на 30 мин., затем отстаивают 15 мин. Жидкую фазу гомогената декантируют через простой фильтр (Белая лента), смоченный гексаном, в делительную воронку. Содержимое воронки двухкратно промывают порциями гексана по 2-3 см ${ }^{3}$. В делительную воронку вносят $50 \mathrm{~cm}^{3} 1 \%$ раствор $\mathrm{KCl}$, встряхивают и отстаивают до разделения фаз. После разделения водноацетоновый слой удаляют. Далее проводят отмывку концентрированной 
серной кислотой и разделение на колонке с сорбентом по принципу работы с биологическими образцами гидробионтов.

Навеску мочи заливают ацетоном, встряхивают, добавляют гексан и экстрагируют на шейкере на 30 мин., переносят в делительную воронку и отстаивают 15 мин. После разделения фаз водно-ацетоновый слой удаляют. Далее проводят отмывку концентрированной серной кислотой и разделение на колонке с сорбентом по принципу работы с биологическими образцами гидробионтов.

Для подготовки проб грудного молока в делительную воронку вносят 2-5 $\mathrm{cm}^{3}$ грудного молока, $1 \mathrm{~cm}^{3} 5 \%$ оксалата калия и $5 \mathrm{~cm}^{3}$ этанола. Воронку встряхивают в течение 1 мин. После этого в воронку вносят $10 \mathrm{~cm}^{3}$ диэтилового эфира и встряхивают 1 мин., затем $5 \mathrm{~cm}^{3} n$-гексана и встряхивают 1 мин. После разделения фаз эфирный слой сливают. Оставшийся в воронке слой фильтруют через безводный сульфат натрия, смоченный в гексане и ставят на роторный испаритель до полного выпаривания гексана. После стабилизации веса липофильного экстракта колбу взвешивают для определения навески липидов. Далее снова заливают гексаном и проводят отмывку концентрированной серной кислотой и разделение на колонке с сорбентом по принципу работы с биологическими образцами гидробионтов $[1,2]$.

\section{3. Приготовление стандартных растворов СO3}

Для приготовления стандартных растворов ХОП и ПХБ использовались стандартные образцы (Dr. Ehrenstorfer и AccuStandard) $\alpha$-ГХЦГ, $\beta$ -

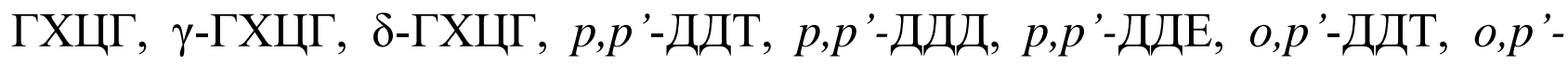
ДДД, $о, p$ '-ДДЕ и смесь 28, 52, 155, 101, 118, 143, 153, 138, 180*, 207 ПХБ конгенеров, с установленными метрологическими характеристиками - содержание основного вещества 99,4-99,6 \% с погрешностью определения $0,4 \%$. Для хроматографии использовались рабочие стандартные растворы ХОП и ПХБ с концентрацией 20 нг/мл, приготовленные путем разбавления стандартных растворов соответствующим объемом $n$-гексана. Также использовалась библиотека «Pesticides».

*Индикаторные ПХБ. 


\section{4. Хроматографический анализ и расчет содержания СО3}

Определение содержания хлорорганических пестицидов (ХОП) и полихлорированных бифенилов в биологических образцах выполняли на газовом хроматомасс-спектрометре Shimadzu GC MS-QP 2010 Ultra с автодозатором AOC-5000 [5]. Для исследования использовали капиллярную колонку SLB-5, газ-носитель - гелий (скорость потока 1 мл/мин) Температуры инжектора и детектора составляли 250 и $150^{\circ} \mathrm{C}$, соответственно. Программа нагрева - увеличение температуры до $100^{\circ} \mathrm{C}$ в течение 4 мин, нагрев до $310^{\circ} \mathrm{C}$ со скоростью $7^{\circ} \mathrm{C} /$ мин, и удерживание конечной температуры в течение 6 мин. 2 мкл исследуемой смеси вносились в режиме без разделения, с последующим открытием разделяющего порта через 1 минуту. Ионизация веществ в газовой фазе осуществлялась в режиме электронной ионизации. Мониторинг избранных ионов (SIM) был разработан согласно настройкам и пределам обнаружения прибора. Для каждого уровня хлорирования отслеживались два иона $(\mathrm{M}+$ и $[\mathrm{M}+2]+$ ионы). Для идентификации исследуемого соединения в качестве подтверждающих критериев использовались время выхода, масса и относительное содержание подтверждающего иона. Площади пиков измерялись программой GCMS Postrun Analysis.

Полученные результаты проверялись на газовом хроматографе Shimadzu GC-2010 Plus с детектором электронного захвата ECD. Капиллярная колонка Shimadzu HiCap CBP5. Температура колонки $210^{\circ} \mathrm{C}$, инжектора $250^{\circ} \mathrm{C}$, детектора - $280^{\circ} \mathrm{C}$. Газ-носитель - аргон, давление на вхо-

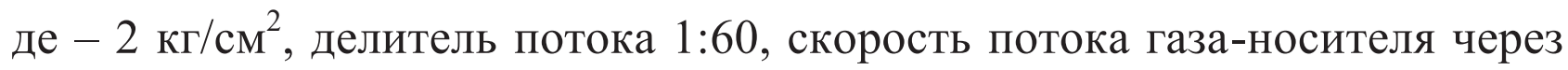
колонку - 0,5 мл/мин $[5,6]$.

Хроматографы калибровали по стандартным растворам СО3 (рис. 2.1). Идентификацию проводили по относительному времени удерживания. Количественное определение проводили согласно калибровочному графику, построенному на основе стандартных растворов пестицидов.

Для оценки качества использованной методики применялся метод стандартных добавок. К мышечным тканям минимум 7 (от 7 до 10) образцов биоматериала добавлялись известные количества исследуемых соединений. Пробоподготовка и исследование смешанных образцов осуществлялась по указанному выше методу. 


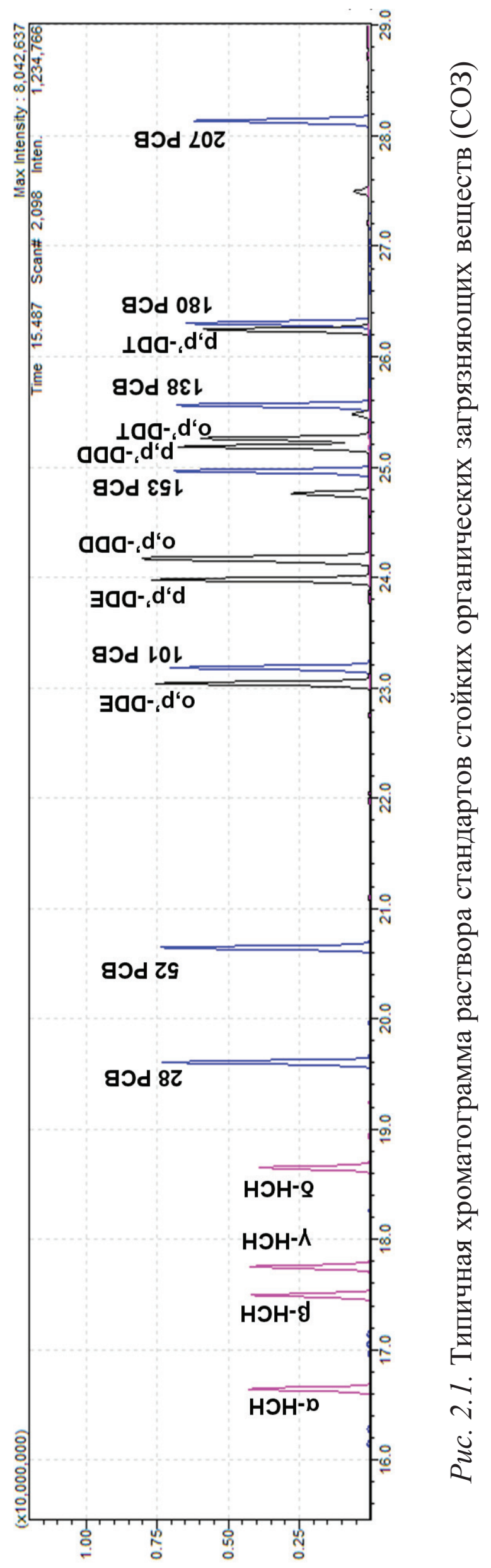


Результаты показали, что средняя воспроизводимость концентраций аналитов варьировала от 94,6 до 103,7\%, что говорит о надежности полученных данных, о воспроизводимости и эффективности аналитических методов. Пределы обнаружения рассчитывались, как 3 стандартных отклонения 7-10 проб в смешанных со стандартами образцах. Для аналитов, которые не определялись в смешанных пробах, пределы обнаружения определялись как количество аналита в образце в соответствии с минимальной концентрацией калибровочного стандарта. Для исследованных ХОП и ПХБ пределы обнаружения составили: $\alpha$-ГХЦГ - 0,2-0,3, $\beta$-ГХЦГ -

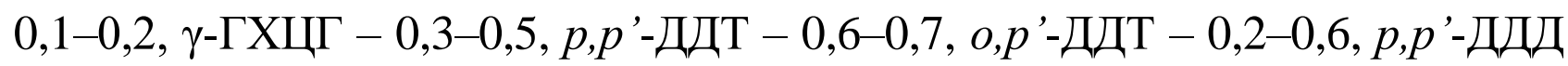
- 0-0,1, o, $p^{\prime}$-ДДД - 0,1-0,2, p, $p^{\prime}$-ДДЕ - 0,1-0,2, o, $p^{\prime}$-ДДЕ - 0,1-0,4 нг/г; 28 ПХБ - 0,5-0,6, 52 ПХБ - 0,4-0,7, 155 ПХБ - 0,1-0,5, 101 ПХБ - 0,6-0,8, 118 ПХБ - 0,7-0,8, 143 ПХБ - 0,2-0,7, 153 ПХБ - 0-0,1, 138 ПХБ - 0,2-0,3, 180 ПХБ $-0,5-0,6$ и 207 ПХБ $-0,7-0,8$ нг/г.

Статистический анализ результатов осуществлялся с помощью программного обеспечения IBM SPSS Statistics для Mac OS и Windows. Достоверность данных оценивали с помощью двустороннего критерия Краскала-Уоллиса с уровнем значимости $\mathrm{p} \leq 0,05$, непараметрического критерия Манна-Уитни с уровнем значимости $\mathrm{p} \leq 0,05$, и коэффициента корреляции Спирмена. Результаты представлены в виде диапазона концентраций (min$\max )$ и среднего значения со стандартным отклонением (Mean $\pm \mathrm{SD})$.

\section{5. Список литературы}

1. Гумовская, Ю.П. Способ подготовки пробы для газохроматографического определения хлорорганических соединений в биоматериале / Ю.П. Гумовская, А.Н. Гумовский, В.Ю. Цыганков, М.М. Донец, М.Д. Боярова. - М.: Федеральный институт промышленной собственности (ФИПС). - Патент № 2713661 RU от 06.02.2020.

2. Гумовская, Ю.П. Способ подготовки пробы для газохроматографического определения хлорорганических соединений в биоматериале / Ю.П. Гумовская, А.Н. Гумовский, В.Ю. Цыганков, М.М. Донец, М.Д. Боярова. - М.: Федеральный институт промышленной собственности (ФИПС). - Патент № 2727589 RU от 22.07.2020.

3. Клисенко, М.А. Методы определения микроколичеств пестицидов в продуктах питания, кормах и внешней среде / М.А. Клисенко, 
А.А. Калинина, К.Ф. Новикова, Г.А. Хохолькова. - М.: Колос, 1992. T. $1 .-566 \mathrm{c}$.

4. Цыганков, В.Ю. Способ подготовки пробы для газохроматографического определения пестицидов в биоматериале / В.Ю. Цыганков, М.Д. Боярова. - М.: Федеральный институт промышленной собственности (ФИПС). - Патент № 2543360 RU от 27.01.2015.

5. Tsygankov, V.Yu. Organochlorine pesticide accumulation in seabirds and marine mammals from the Northwest Pacific / V.Yu. Tsygankov, O.N. Lukyanova, M.D. Boyarova // Marine Pollution Bulletin. - 2018. V. 128. - P. 208-213.

6. Tsygankov, V.Yu. Sample Preparation Method for the Determination of Organochlorine Pesticides in Aquatic Organisms by Gas Chromatography / V.Yu. Tsygankov, M.D. Boyarova // Achievements in the Life Sciences. 2015. - V. 9. - No. 1. - P. 65-68. 


\section{ГЛАВА 3}

\section{СТОЙКИЕ ОРГАНИЧЕСКИЕ ЗАГРЯЗНЯЮЩИЕ ВЕЩЕСТВА (СОЗ) В ЗВЕНЬЯХ ТРОФИЧЕСКИХ ЦЕПЕЙ АЗИАТСКО-ТИХООКЕАНСКОГО РЕГИОНА: КРАТКИЙ ОБЗОР ЛИТЕРАТУРЫ}

\section{В.Ю. Циганков}

Представлены современные исследования стойких органических загрязняющих веществ (СО3) в различных звеньях трофических цепей Азиатско-Тихоокеанского региона (АТР).

Ключевые слова: СОЗ; АТР; пищевые цепи; моллюски; рыбы; птицы; млекопитающие.

${ }^{1}$ Школа биомедицины и Школа естественных наук, Дальневосточный федеральный университет (ДВФУ), 690922, Владивосток, о. Русский, п. Аякс, 10. E-mail: tsig_90@mail.ru.

${ }^{1}$ School of Biomedicine and School of Natural Sciences, Far Eastern Federal University, 10 Ajax Bay, Russky Island Vladivostok, Russia, 690922. E-mail: tsig_90@ mail.ru.

Для циитирования: Цыганков В. Ю. Стойкие органические загрязняющие вещества (СО3) в звеньях трофических цепей Азиатско-Тихоокеанского региона: краткий обзор литературы // Стойкие органические загрязняющие вещества (CO3) в Дальневосточном регионе: моря, организмы, человек : монография / В.Ю. Цыганков, М.М. Донец, Н.К. Христофорова [и др.] ; науч. ред. В.Ю. Цыганков. Владивосток : Изд-во Дальневост. федерал. ун-та, 2020. - С. 70-82. - https://doi.org/10.24866/74444891-2/70-82.

For citing: Tsygankov V. Yu. Persistent organic pollutants (POPs) in food webs in the Asia-Pacific region: a brief review // Persistent organic pollutants (POPs) in the Far Eastern Region: Seas, Organisms, Human : monograph / V.Yu. Tsygankov, M.M. Donets, N.K. Khristoforova [et al.] ; ed. by V.Yu. Tsygankov. - Vladivostok : Publishing House of the Far Eastern Federal University, 2020. - P. 70-82. https://doi.org/10.24866/7444-4891-2/70-82. 


\section{CHAPTER 3. PERSISTENT ORGANIC POLLUTANTS (POPS)} IN FOOD WEBS IN THE ASIA-PACIFIC REGION:

\section{A BRIEF REVIEW}

\section{V.Yu. Tsygankov}

The modern studies of persistent organic pollutants (POPs) in various links of the trophic chains of the Asia-Pacific region (APR) are presented.

Keywords: POPs; APR; food chains; shellfish; fish; birds; mammals.

Стойкие органические загрязняющие вещества (CO3) за счет своей липофильности способны к биомагнификации, т.е. накоплению от низших трофических уровней к высшим с большей концентрацией. Попадая в водную среду, большая часть СОЗ связываются с частицами взвеси и оседают на дно, накапливаясь в донных отложениях. В реках, как правило, содержание СО3 выше, чем в море. Это связано с тем, что токсиканты смываются с полей в реки, и только потом поступают в море.

Например, Китай имеет долгую историю производства СО3, и с 1945 по 1983 гг. он был вторым в мире производителем ГХЦГ и ДДТ [12]. За этот период в Китае было произведено около 490 тыс. тонн ГХЦГ, 40 тыс. тонн ДДТ и 10 тыс. тонн ПХБ [17]. Среди хлорорганических пестицидов производство ГХЦГ и ДДТ составляло $33 \%$ и 20\% от общего мирового производства, соответственно [7]. Из-за значительных объемов производства и использования этих соединений, остатки СО3 в высоких концентрациях обнаружены в различных компонентах окружающей среды, таких как почва, вода и даже продукты питания в некоторых местах в Китае [17]. Провинции Китая, окружающие Желтое и Бохайское моря, имеют давнюю историю производства и использования СО3, и в некоторых районах отмечается высокая концентрация ХОП и ПХБ.

Так, концентрации ХОП в почвах в 2013 г. составляли до 179,96 нг/г сухой массы, ПХБ - до 385,67 нг/Г сухой массы: 16,98 нг/г сухой массы 


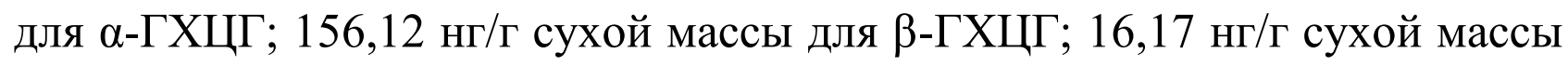
для $\gamma$-ГХЦГ; 56,24 нг/г сухой массы для $\delta$-ГХЦГ; 91,23 нг/г сухой массы для $p, p^{\prime}$-ДДЕ; 116,2 нг/г сухой массы для $p, p^{\prime}-$ ДДД; 10,42 нг/г сухой массы для $p, p^{\prime}$-ДДТ (рис. 3.1).

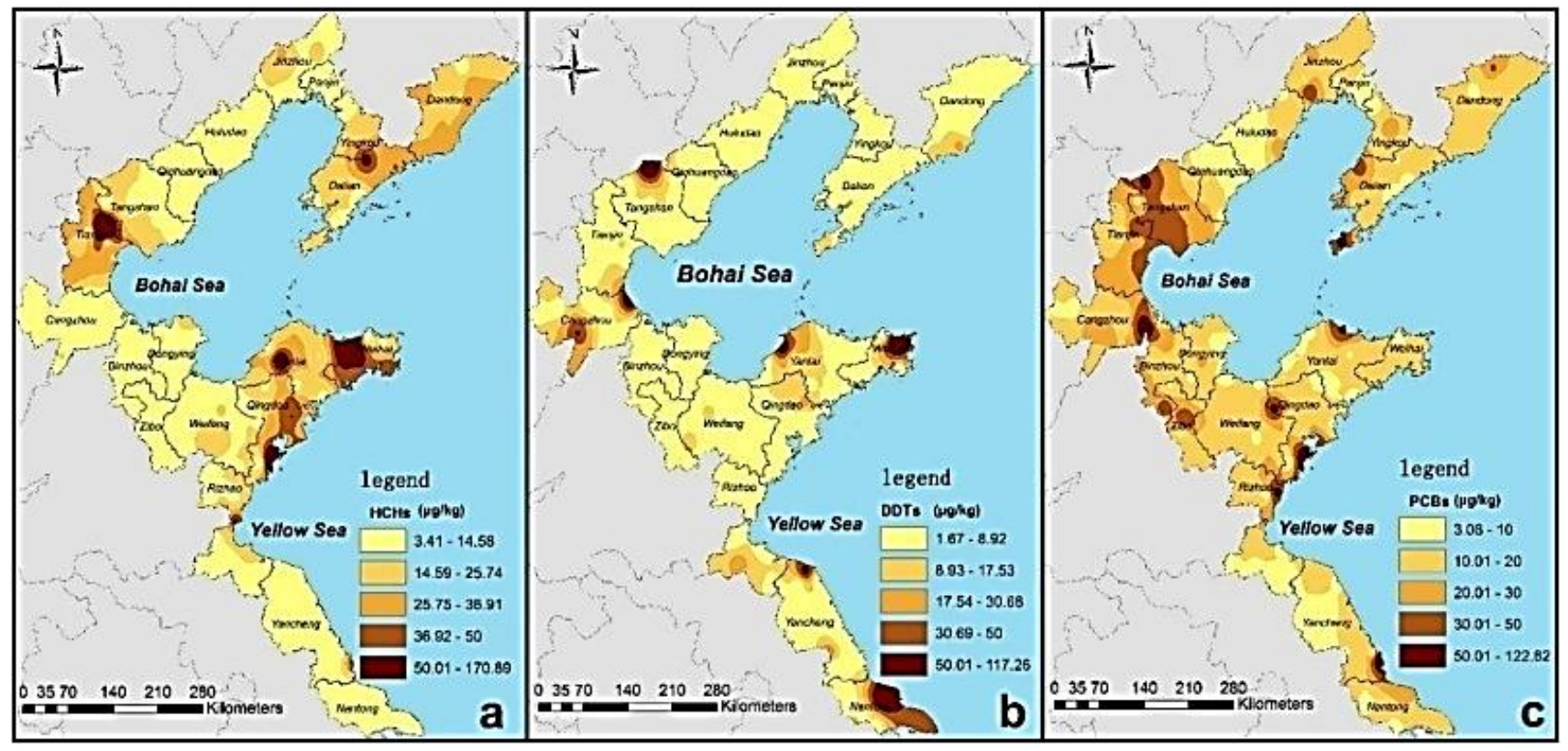

Рис. 3.1. Пространственное распределение (a) ГХЦГ, (b) ДДТ и остатков ПХБ (c) в почвах вокруг Желтого и Бохайского морей (Китай) [17]

Во Вьетнаме СО3 также широко использовались до их запрета. $\gamma$ ГХЦГ и $p, p^{\prime}$-ДДТ, как правило, составляли большую часть от общего количества ГХЦГ и ДДТ. Эти инсектициды были запрещены во Вьетнаме в 1995 г., однако продолжали существовать запасы химикатов, включающие линдан и технические смеси ДДТ. Выщелачивание из стоков и мест захоронения твердых бытовых отходов являются возможными путями транспорта этих CO3, что приводит к их аккумуляции в эстуарных отложениях.

На побережье Восточно-Китайского моря концентрация ХОП в донных отложениях находилась в пределах 0,1-7,2 мкг/кг сухой массы [18], на севере Южно-Китайского моря - от 0,04 до 3,9 мкг/кг [6], в северозападной части Желтого моря - от 0,2 до 9,3 мкг/кг сухой массы [12]. В эстуарных зонах рек залива Петра Великого (Японское море) максимальное содержание ХОП отмечено в р. Раздольная $(45,4$ мкг/кг сухой массы) [2]. В Беринговом море концентрации ДДТ и ПХБ в 2010 г. составляли 89 и 88 пг/г сухой массы, в 2012 г. -5 и 32 пг/г сухой массы, со- 
ответственно. В Беринговом проливе в 2010 г. - 81 и 219 пг/г сухой массы, в 2012 г. - 116 и 708 пг/г сухой массы, соответственно [19].

Хлорорганические соединения способны проникать в любые уголки планеты, в том числе в самые глубокие части Тихого океана. Джемисон с соавторами [13] исследовали концентрации индикаторных ПХБ во множественных образцах амфипод в двух самых глубоких желобах - олиготрофном Марианском желобе (7841 и 10250 м) в северной части Тихого океана и более эвтрофном Кермадеке (7227 и 10000 м) в южной части Тихого океана. ПХБ присутствовали во всех образцах, во всех видах и на всех глубинах в обоих траншеях (рис. 3.2). Концентрации $\Sigma П Х Б_{7}$ варьировали от 18,03-42,85 нг/Г сухой массы в Кермадеке до 147,3-905 нг/г сухой массы в Мариане, со средними значениями 25,24 и 382,28 нг/г сухой массы, соответственно. Среди отдельных конгенеров, ПХБ 153 был обнаружен в самой высокой концентрации. Конгенеры ПХБ 138 и 153 составляли $65 \%$ от общего содержания.
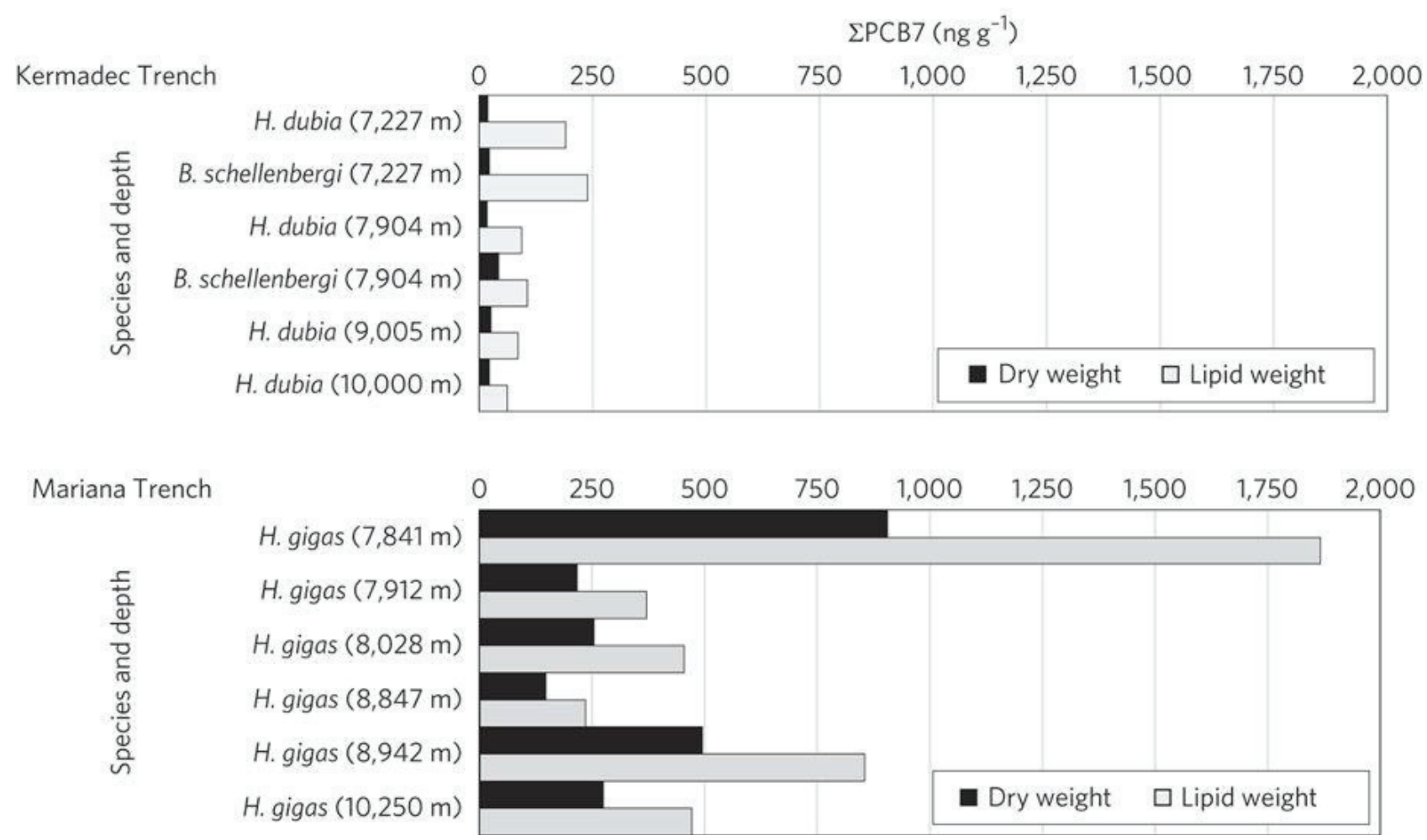

Pис. 3.2. Концентрации ПХБ, обнаруженные в амфиподах из желобов Марианский и Кермадек [13] 


\section{1. Моллюски}

Хлорорганические соединения захватываются организмами различных трофических уровней. По этой причине, двустворчатые моллюски, например, успешно и широко применяются в качестве биоиндикаторов для мониторинга ХОП в природных водах.

По Азиатско-Тихоокеанской программе наблюдения за моллюсками (APMW) в течение 1997-2000 гг. осуществлялся мониторинг загрязнения морской среды. Для определения состояния прибрежных морских вод проводился мониторинг с использованием в качестве биоиндикаторов мидий и устриц. Хлорорганические соединения были обнаружены во всех образцах мидий в странах, участвующих в программе (Камбоджа, Китай, Гонконг, Индия, Индонезия, Япония, Корея, Малайзия, Филиппины, Россия (Дальний Восток), Сингапур, Вьетнам) [24].

Во многих образцах обнаружены значительные остаточные концен-

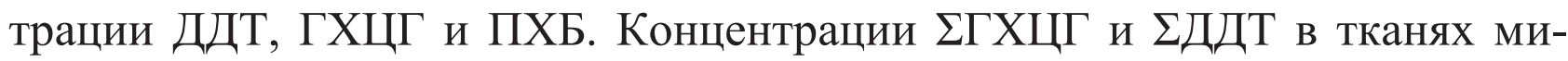
дий, отобранных в водах развивающихся стран Азии, были выше, чем в особях из развитых стран. $\Sigma$ ПХБ, напротив, обнаруживалась в максимальных концентрациях в моллюсках из стран с развитой энергосетью и промышленностью, и в минимальных - из стран с развитым сельским хозяйством. Например, максимальное содержание ГХЦГ в мидии Perna viridis составило 430 нг/г липидов в Индии и 20 нг/г липидов - в Корее и Японии. ДДТ в максимальных концентрациях обнаружен в Гонконге (61000 нг/г липидов), Китае (34000 нг/г липидов), тогда как в Японии всего 100 нг/г липидов. Наибольшие концентрации ПХБ обнаружены в Японии (12000 нг/Г липидов) и России (3700 нг/г липидов), наименьшие - в Индонезии (210 нг/г липидов), Камбодже (220 нг/г липидов) и Малайзии (250 нг/г липидов). В мидиях рода Mytilus содержание ДДТ составило в Китае 29000 нг/г липидов, в Гонконге - 8000 нг/г липидов, на тихоокеанском побережье России - 900 нг/г липидов, а в Индии, Японии, Корее, Вьетнаме, Сингапуре, Малайзии, Индонезии, Камбодже - менее 800 нг/г липидов [20]. ГХЦГ в вышеперечисленных странах не превышал 120 нг/г липидов (Индия) [25]. 


\section{2. Рыбы}

Рыбы, являясь частью трофической цепи, накапливают в своих органах и тканях стойкие органические загрязняющие вещества в процессе биомагнификации. Рыбы распространены повсеместно и в большинстве случаев отражают уровни содержания СО3 в среде. Содержание поллютантов в тканях организмов зависит от многих факторов, одним из которых является миграция объектов. Японские ученые провели ряд исследований мигрирующих и оседлых видов, и выявили более низкие концентрации СО3 в первых (табл. 3.1) [25].

Таблища 3.1

\begin{tabular}{|c|c|c|}
\hline Вид & 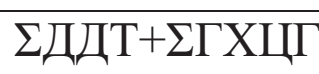 & $\Sigma \Pi Х Б$ \\
\hline \multicolumn{3}{|c|}{ Мигрирующие } \\
\hline Анчоус Diaphus theta & 180 & 250 \\
\hline Анчоус Ceratoscopelus warmingi & 38 & 40 \\
\hline \multicolumn{3}{|c|}{ Оседлые } \\
\hline $\begin{array}{l}\text { Стенобрахиус Stenobrachius } \\
\text { nannochir }\end{array}$ & 300 & - \\
\hline Лампаникт Lampanyctus regalis & 310 & - \\
\hline
\end{tabular}

Йено с соавторами [27] использовали полосатого тунца для мониторинга прибрежных районов Японии, о. Тайвань, Филиппин, Индонезии, Сейшельских о-вов, Бразилии и Индии в качестве биоиндикатора. Максимальное содержание ХОП выявлено в китайских рыбах (700 нг/Г липидов), ПХБ - у тайваньских рыб (980 нг/г липидов).

Тихоокеанские лососи - одни из самых массовых промысловых рыб. Содержание хлорорганических поллютантов в них распределяется таким образом, что у «жирных» видов (чавыча и нерка) концентрации выше, чем у более «постных» (кета, горбуша). Например, суммарные концентрации ХОП и ПХБ в чавыче из моря Селиш (Вашингтон) составляют 2420 и 1675 нг/г липидов [9], в нерке с американского побережья Берингова моря - 1911 нг/г липидов [4], а в кете и горбуше оттуда же - 243 и 80 нг/г липидов, соответственно [8]. 
Ли и др. [16] провели исследование накопления СО3 в 13 видах акул с разным спектром питания. Авторы показали, что хищные виды имеют более высокие концентрации СОЗ. Так, более высокие уровни $\Sigma$ ПХБ и

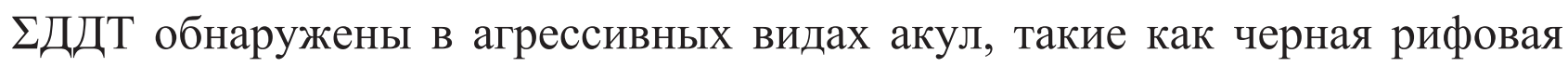
акула (Carcharhinus melanopterus) и голубая акула (Prionace glauca). Скорее всего, это связано с организмами, составляющими рацион питания акул. Основной добычей агрессивных видов являются хищные костистые рыбы, которые содержат более высокие уровни СО3 [16]. Скорость роста и региональный статус также являются важными факторами в исследовании аккумуляции СО3 акулами.

\section{3. Морские птицы}

Птицы могут быть как промежуточным, так и завершающим звеном трофической цепи. Питаясь живыми организмами, они в процессе биомагнификации накапливают в своих органах токсичные поллютаны.

Тип питания (травоядные, насекомоядные, рыбоядные) и характер миграций (перелетные и локальные) определяют содержание ХОП в органах и тканях. Например, в печени бургомистра из Баренцева моря, питающегося рыбой, падалью и яйцами других птиц, максимальная суммарная концентрация ХОП составила 735674 нг/г липидов, ПХБ - 4273992 нг/г липидов [14]. В работе Ямашита и др. [28] анализировался перьевой жир толстоклювой кайры (Uria lomvia), алеутского пыжика (Ptychoramphus aleuticus), пестролицего буревестника (Calonectris leucomelas), черноногого альбатроса (Phoebastria nigripes), черноспинного альбатроса (Phoebastria immutabilis), белой крачки (Gygis alba), темной крачки (Onychoprion fuscatus), клинохвостого буревестника (Ardenna pacifica), бурой олуши (Sula leucogaster), тупика носорога (Cerorhinca monocerata), чернохвостой чайки (Larus crassirostris) и японского баклана (Phalacrocorax capillatus), пойманных на территории Тихого Океана. Максимальные суммарные концентрации ХОП и ПХБ составили: в толстоклювой кайре - 520 и 171 нг/г липидов; в алеутском пыжике - 581 и 146 нг/г; в пестролицем буревестнике 1175 и 1556 нг/г; в черноногом альбатросе - 11912 и 8476 нг/г; в черно- 
спинном альбатросе - 995 и 2864 нг/г; в белой крачке - 396 и 158 нг/г; в темной крачке - 35 и 36 нг/г; в клинохвостом буревестнике - 462 и 195 нг/г; в бурой олуше - 62 и 100 нг/г; в тупике носороге - 10633 и 5633 нг/г; в чернохвостой чайке - 5413 и 3345 нг/г; в японском баклане - 22900 и 3229 нг/г липидов, соответственно. Высокие концентрации пестицидов в перьевом жире исследованных птиц в большей степени связаны с накоплением ксенобиотиков в процессе миграций.

В то же время, тип питания (основа рациона - рыбы и моллюски) также оказывает влияние на накопление токсикантов. Высокие концентрации ПХБ в перьевом жире объясняются поведением исследованных птиц. Так, черноногий альбатрос и японский баклан часто следуют за кораблями, поэтому судовые отбросы и отходы промысла в питании этих видов занимают большую часть. Наименьшие концентрации ХОП и ПХБ обнаружены в темной крачке. Это мигрирующая птица, жизнь и размножение которой проходит в тропиках. При этом на ногах этого вида отсутствуют перепонки, в связи с чем контакт с морской средой минимален. Эти факторы могут объяснять столь незначительные концентрации поллютантов в перьевом жире. Такие насекомоядные птицы, как китайский волчок и длиннохвостый сорокопут из Тайланда, содержат в своем теле гораздо меньше поллютантов - 580,7 и 37,3 нг/г липидов [5], что, безусловно, связано с питанием.

\section{4. Морские млекопитающие}

Все СО3 являются высоколипофильными соединениями, а жировые запасы в подкожных слоях морских млекопитающих действуют как их накопители. Млекопитающие по сравнению с большинством других морских организмов живут дольше, следовательно, подвергаются более длительному воздействию ксенобиотиков и аккумулируют их на протяжении всей жизни. Морских млекопитающих можно считать важными видами для мониторинга долгосрочных проявлений ХОП в морской среде и использовать как индикаторы глобального загрязнения $[25,26]$.

Хотя, в морских млекопитающих с продолжительным жизненным циклом обнаружены высокие концентрации СО3, содержание поллютан- 
тов в самках и самцах существенно различается. В целом, концентрации CO3 сравнимы в неполовозрелых самцах и самках и увеличиваются до наступления половой зрелости животных. После этого у самцов продолжается увеличение концентрации, а в самках выходит на плато или незначительно уменьшается (рис. 3.3) [11]. Обнаружены более высокие концентрации СО3 в самках белокрылой морской свиньи в случае отсутствия овуляции (до 120000 нг/Г липидов) по сравнению со здоровым репродуктивным циклом (до 3000 нг/г липидов) [25].

Помимо половых различий, в накоплении ХОП морскими млекопитающими имеет огромное значение характер питания. В целом рыбоядные накапливают более высокие концентрации, чем питающиеся ракообразными $[3,25]$. Например, в бесперой морской свинье, питающейся преимущественно ракообразными и головоногими организмами, содержание ХОП составило 48000 нг/г липидов [21]. У косатки, хищника с широким спектром питания (рыбы, ластоногие и т.д.), концентрация ХОП достигала 161300 нг/г липидов [15]. У ларги, питающейся преимущественно рыбой, содержание токсикантов было еще выше и составило 382600 нг/г липидов [1].

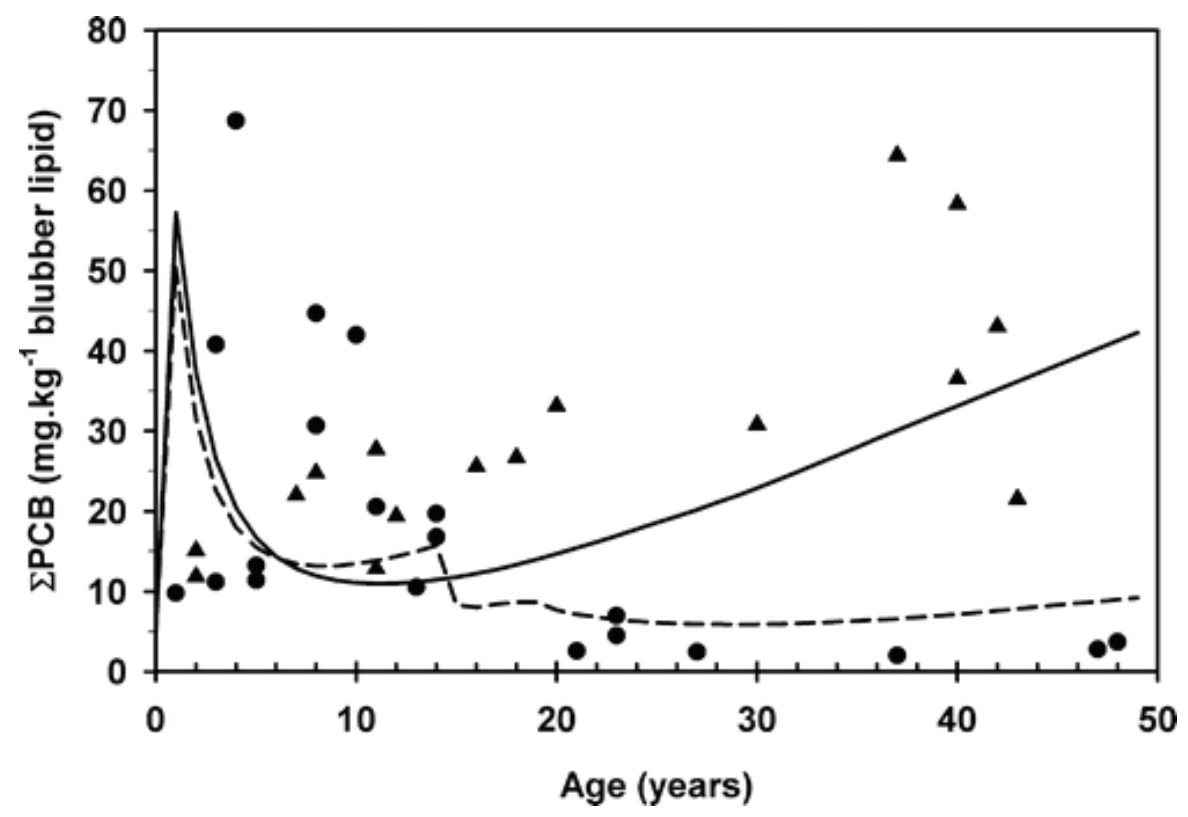

Puc. 3.3. Зависимость концентрации ПХБ в липидной фракции от возраста самцов(-) и самок(--) косатки (Orcinus orca) северо-восточной части Тихого океана [11]

В современных исследованиях СО3 в млекопитающих Южно-Китайского моря [10] показано высокое содержание поллютантов в бесперой мор- 
ской свинье (максимальные концентрации СО3 достигали 750000 нг/Г липидов). Основную часть метаболитов ДДТ (746 000 нг/г липидов) составили p,p'-ДДЕ (416 000 нг/г липидов), p,p'-ДДТ (173000 нг/г липидов) и р,p'-ДДД (113000 нг/г липидов). Концентрации ПХБ достигали 4300 нг/г липидов. В жировой ткани детенышей кашалота (до 1 года) концентрации СО3 достигали 3640 нг/г липидов: ПХБ, ДДТ и ГХЦГ составили 646, 2107 и 887 нг/Г липидов, соответственно [29]. В жире северного морского котика, пойманного во время охотничьего промысла местного населения Аляски, суммарные концентрации ПХБ, ДДТ и ГХЦГ составили 4410, 156000 и 736 нг/г липидов, соответственно [22].

\section{5. Список литературы}

1. Боярова, М.Д. Хлорированные углеводороды в тканях и органах ларги (Phoca largha) из Японского моря / М.Д. Боярова, А.М. Трухин // Морские млекопитающие Голарктики: сборник научных трудов VI международной конференции. - Калининград, 2010. - С. 87-90.

2. Лукьянова, О.Н. Стойкие органические загрязняющие вещества в донных отложениях эстуарных зон трех рек залива Петра Великого (Японское море) / О.Н. Лукьянова, Е.С. Бродский, Г.М. Чуйко // Вестник Тюменского государственного университета. - 2012. - № 12. - С. 119-126.

3. Цыганков, В.Ю. Стойкие токсические вещества в мышцах и печени тихоокеанского моржа Odobenus rosmarus divergens Illiger, 1815 из Берингова моря / В.Ю. Цыганков, М.Д. Боярова, О.Н. Лукьянова // Биология моря. - 2014. - Т. 40. - № 2. - С. 158-161.

4. Apeti, D.A. Assessment of contaminant body burdens and histopathology of fish and shellfish species frequently used for subsistence food by Alaskan Native communities / D.A. Apeti, S.I. Hartwell, S.M. Myers [et al.]. North Pacific Research Board Final Report, 2013. - 63 p.

5. Chaiyarat, R. Bioaccumulation of organochlorine pesticides in the liver of birds from Boraphet wetland, Thailand / R. Chaiyarat, C. Sookjam, K. EiamAmpai, P. Damrongphol // ScienceAsia. - 2014. - V. 40. - P. 198-203.

6. Chen, S.J. Distribution and mass inventories of polycyclic aromatic hydrocarbons and organochlorine pesticides in sediments of the Pearl River Estuary 
and the Northern South China Sea / S.J. Chen, X.J. Luo, B.X. Mai [et al.] // Environmental Science and Technology. - 2006. - V. 40. - P. 709-714.

7. $\mathrm{Fu}, \mathrm{J}$. Persistent organic pollutants in environment of the Pearl River Delta, China: an overview / J. Fu, B. Mai, G. Sheng [et al.] // Chemosphere. 2003. - V. 52. - P. 1411-1422.

8. Gerlach, B. Fish Monitoring Program / B. Gerlach. - Alaska Department of Environmental Conservation. Fish Tissue Testing Program, 2013.

9. Good, T.P. Persistent organic pollutants in forage fish prey of rhinoceros' auklets breeding in Puget Sound and the northern California Current / T.P. Good, S.F. Pearson, P. Hodum [et al.] // Marine Pollution Bulletin. - 2014. V. 86. - P. 367-378.

10. Gui, D. Potential association between exposure to legacy persistent organic pollutants and parasitic body burdens in Indo-Pacific finless porpoises from the Pearl River Estuary, China / D. Gui, J. He, Q. Tu [et al.] // Science of the Total Environment. - 2018. - V. 643. - P. 785-792.

11. Hickie, B.E. Killer Whales (Orcinus orca) Face Protracted Health Risks Associated with Lifetime Exposure to PCBs / B.E. Hickie, P.S. Ross, R.W. Macdonald, J.K.B. Ford // Environmental Science \& Technology. - 2007. V. 41. - P. 6613-6619.

12. $\mathrm{Hu}, \mathrm{L} . \mathrm{M}$. Occurrence and distribution of organochlorine pesticides (OCPs) in surface sediments of the Bohai Sea, China / L.M. Hu, G. Zhang, B.H. Zheng [et al.] // Chemosphere. - 2009. - V. 77. - P. 663-672.

13. Jamieson, A.J. Bioaccumulation of persistent organic pollutants in the deepest ocean fauna / A.J. Jamieson, T. Malkocs, S.B. Piertney, T. Fujii, Z. Zhang // Nature Ecology \& Evolution. - 2017. - V. 1. - P. 0051.

14. Knudsen, L.B. Halogenated organic contaminants and mercury in dead or dying seabirds on Bjornoya (Svalbard) / L.B. Knudsen, K. Sagerup, A. Polder [et al.] - Norwegian polar institute, 2007. -45 p.

15. Krahn, M.M. Effects of age, sex and reproductive status on persistent organic pollutant concentrations in "Southern Resident" killer whales / M.M. Krahn, M.B. Hanson, R.W. Baird [et al.] // Marine Pollution Bulletin. 2009. - V. 58. - P. 1522-1529.

16. Lee, H.K. Persistent organochlorines in 13 shark species from offshore and coastal waters of Korea: species-specific accumulation and contributing factors / H.K. Lee, Y. Jeong, S. Lee [et al.] // Ecotoxicology and Environmental Safety. - 2015. - V. 115. - P. 195-202. 
17. Li, Q. Distribution, source, and risk of organochlorine pesticides (OCPs) and polychlorinated biphenyls (PCBs) in urban and rural soils around the Yellow and Bohai Seas, China / Q. Li, Y. Lu, P. Wang [et al.] // Environmental Pollution. - 2018. - V. 239. - P. 233-241.

18. Lin, T. Distribution and sources of organochlorine pesticides in sediments of the coastal East China Sea / T. Lin, L. Hu, X. Shi [et al.] // Marine Pollution Bulletin. - 2012. - V. 64. - P. 1549-1555.

19. Ma, Y. Persistent organic pollutants in ocean sediments from the North Pacific to the Arctic Ocean / Y. Ma, C.J. Halsall, J.D. Crosse [et al.] // Journal of Geophysical Research: Oceans. - 2015. - V. 120. P. 2723-2735.

20. Monirith, I. Asia-Pacific mussel watch: monitoring contamination of persistent organochlorine compounds in coastal waters of Asia countries / I. Monirith, D. Ueno, S. Takahashi [et al.] // Marine Pollution Bulletin. 2003. - V. 46. - P. 281-300.

21. Park, B. Organohalogen contaminants in finless porpoises (Neophocaena phocaenoides) from Korean coastal waters: Contamination status, maternal transfer and ecotoxicological implications / B. Park, G. Park, Y. An, H. Choi [et al.] // Marine Pollution Bulletin. - 2010. - V. 60. - P. 768-774.

22. Reiner, J.L. Organohalogen Contaminants and Vitamins in Northern Fur Seals (Callorhinus ursinus) Collected During Subsistence Hunts in Alaska / J.L. Reiner, P.L. Becker, M.O. Gribble [et al.] // Archives of Environmental Contamination and Toxicology. - 2016. - V. 70. - P. 96-105.

23. Takahashi, S. Organochlorine and butyltin residues inmesopelagic myctophid fishes from the western North Pacific / S. Takahashi, S. Tanabe, K. Kawaguchi // Environmental Science \& Technology. - 2000. - V. 34. P. 5129-5136.

24. Tanabe, S. Asia-Pacific mussel watch progress report / Tanabe S. // Marine Pollution Bulletin. - 2000. - V. 40. - P. 651.

25. Tanabe, S. Bioindicators of POPs / S. Tanabe, A. Subramanian. - Japan: Kyoto University Press and Trans Pacific Press, 2006. - 190 p.

26. Tanabe, S. Contamination by Persistent Toxic Substances in the AsiaPacific Region / S. Tanabe // Persistent Organic Pollutants in Asia: Sources, Distributions, Transport and Fate. - A. Li, S. Tanabe, G. Jiang, J.P. Giesy and P.K.S. Lam (Editors). - Developments in Environmental Science. - 2007. V. 7. - P. 773-817. 
27. Ueno, D. Global pollution monitoring and organochlorine pesticides using skipjack tuna as a bioindicator / D. Ueno, S. Takahashi, H. Tanaka [et al.] // Archives of Environmental Contamination and Toxicology. - 2003. - V. 45. P. 378-389.

28. Yamashita, R. Global monitoring of persistent organic pollutants (POPs) using seabird preen gland oil / R. Yamashita, H. Takada, A. Nakazawa [et al.] // Archives of Environmental Contamination and Toxicology. - 2018. V. 75. - P. 545-556.

29. Zhan, F. Tissue distribution of organic contaminants in stranded pregnant sperm whale (Physeter microcephalus) from the Houizhou coast of the south China / F. Zhan, X. Yu, X. Zhang [et al.] // Marine Pollution Bulletin. 2019. - V. 144. - P. 181-188. 


\section{ГЛАВА 4}

\section{УРОВНИ ХЛОРОРГАНИЧЕСКИХ ПЕСТИЦИДОВ (ХОП) В МОРСКИХ ЭКОСИСТЕМАХ ДАЛЬНЕВОСТОЧНЫХ МОРЕЙ РОССИИ (2000-2016): ОБЗОР ЛИТЕРАТУРЫ}

\section{В.Ю. Цыганков 1}

Показано распределение ХОП в компонентах экосистем дальневосточных морей России - Японском, Охотском и Беринговом - в период 2000-2016 гг. В Охотском и Беринговом морях содержание ХОП в морских организмах ниже, чем в других регионах мирового океана, и в частности, в Японском море. Концентрации ХОП в Охотском и Беринговом морях можно считать фоновыми, в то время как Японское море испытывает воздействие стран, использующих эти вещества в сельском хозяйстве.

Ключевые слова: хлорорганические пестициды, ГХЦГ, ДДТ, морские экосистемы, Охотское море, Берингово море, Японское море

${ }^{1}$ Школа биомедицины и Школа естественных наук, Дальневосточный федеральный университет (ДВФУ), 690922, Владивосток, о. Русский, п. Аякс, 10. E-mail: tsig_90@mail.ru.

${ }^{1}$ School of Biomedicine and School of Natural Sciences, Far Eastern Federal University, 10 Ajax Bay, Russky Island Vladivostok, Russia, 690922. E-mail: tsig_90@mail.ru.

Для иитирования: Цыганков В. Ю. Уровни хлорорганических пестицидов (ХОП) в морских экосистемах дальневосточных морей России (2000-2016): обзор литературы // Стойкие органические загрязняющие вещества (CO3) в Дальневосточном регионе: моря, организмы, человек : монография / В.Ю. Цыганков, М.М. Донец, Н.К. Христофорова [и др.] ; науч. ред. В.Ю. Цыганков. - Владивосток : Изд-во Дальневост. федерал. ун-та, 2020. - С. 83-100. - https://doi.org/10.24866/7444-4891-2/83-100.

For citing: Tsygankov V. Yu. Levels of organochlorine pesticides (OCPs) in the marine ecosystems of the Russian Far Eastern Seas (2000-2016): a review // Persistent organic pollutants (POPs) in the Far Eastern Region: Seas, Organisms, Human : monograph / V.Yu. Tsygankov, M.M. Donets, N.K. Khristoforova [et al.] ; ed. by V.Yu. Tsygankov. - Vladivostok : Publishing House of the Far Eastern Federal University, 2020. - P. 83-100. - https://doi.org/10.24866/7444-4891-2/83-100. 


\section{CHAPTER 4. LEVELS OF ORGANOCHLORINE PESTICIDES (OCPS) IN THE MARINE ECOSYSTEMS OF THE RUSSIAN FAR EASTERN SEAS (2000-2016): A REVIEW}

\section{V.Yu. Tsygankov}

The distribution of OCPs in the ecosystem components of the Russian Far Eastern seas - the Sea of Japan/East Sea, the Sea of Okhotsk and Bering Sea - in the period 2000-2016 are presented. In the Sea of Okhotsk and Bering Sea, the content of OCPs in marine organisms is lower than in other regions of the oceans, and in particular, in the Sea of Japan. The concentrations of OCPs in the Okhotsk and Bering Seas can be considered background, while the Sea of Japan is affected by countries using these substances in agriculture.

Keywords: organochlorine pesticides, HCH, DDT, marine ecosystems, Sea of Okhotsk, Bering Sea, Sea of Japan

В дальневосточных морях России исследования хлорорганических соединений в морских экосистемах проводились фрагментарно. Некоторые данные об уровнях ХОП в компонентах экосистем Японского моря приведены в работах А.В. Ткалина с соавторами [21, 22]. Более подробный мониторинг ХОП в Японском море приведен в работах М.Д. Бояровой и О.Н. Лукьяновой с соавторами $[1-4,8,10,19]$. Современные данные о содержании ХОП в экосистемах Берингова и Охотского морей представлены в наших работах [7, 9, 12-14, 18, 23-28].

В Беринговом море за последние годы исследовалась аккумуляция, биотрансформация и транспорт ХОП в тихоокеанских лососях и морских млекопитающих; в Охотском море - в морских птицах и тихоокеанских лососях (табл. 4.1), в Японском море - в моллюсках и рыбах (табл. 4.2) (рис. 4.1-4.3). 


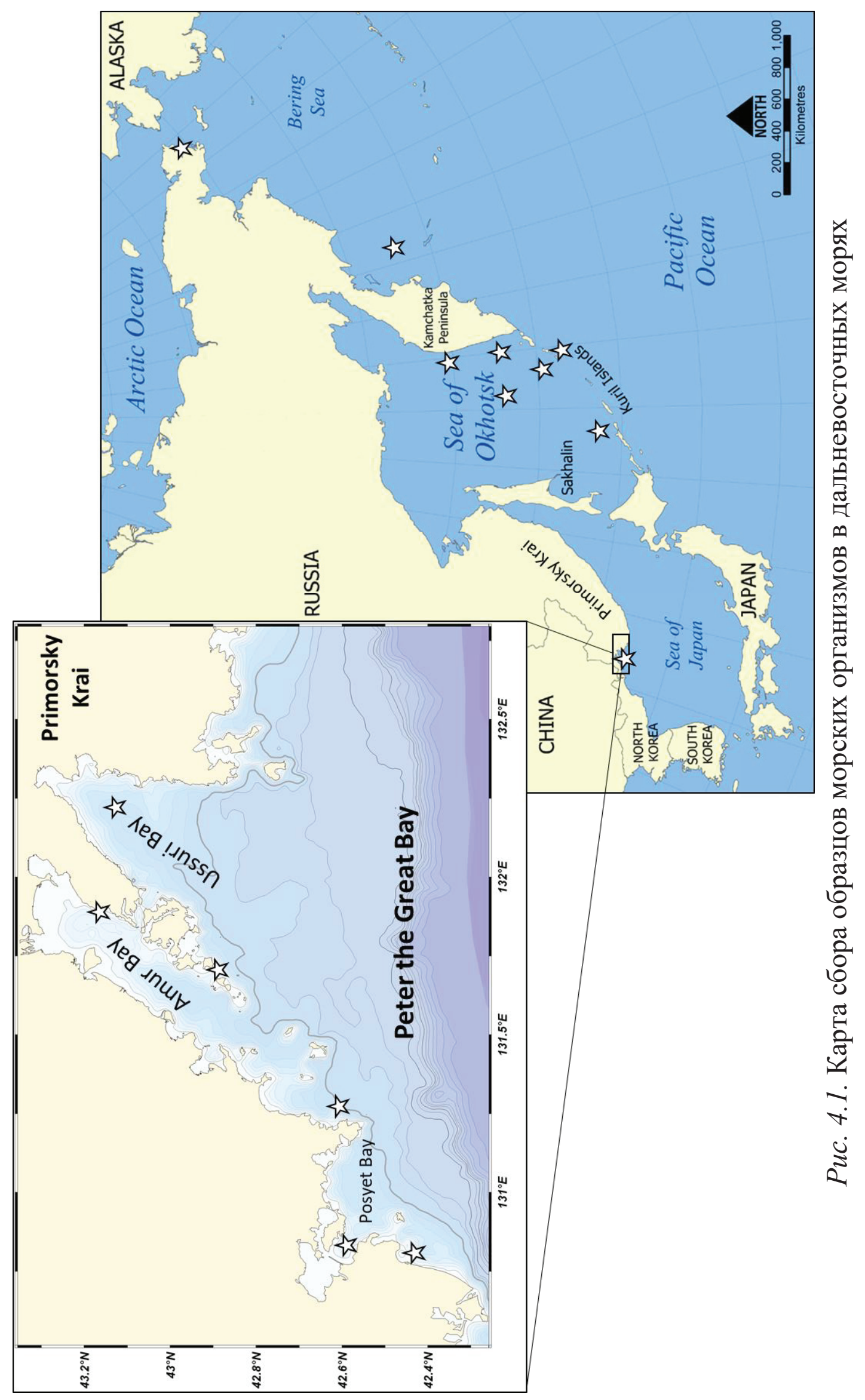




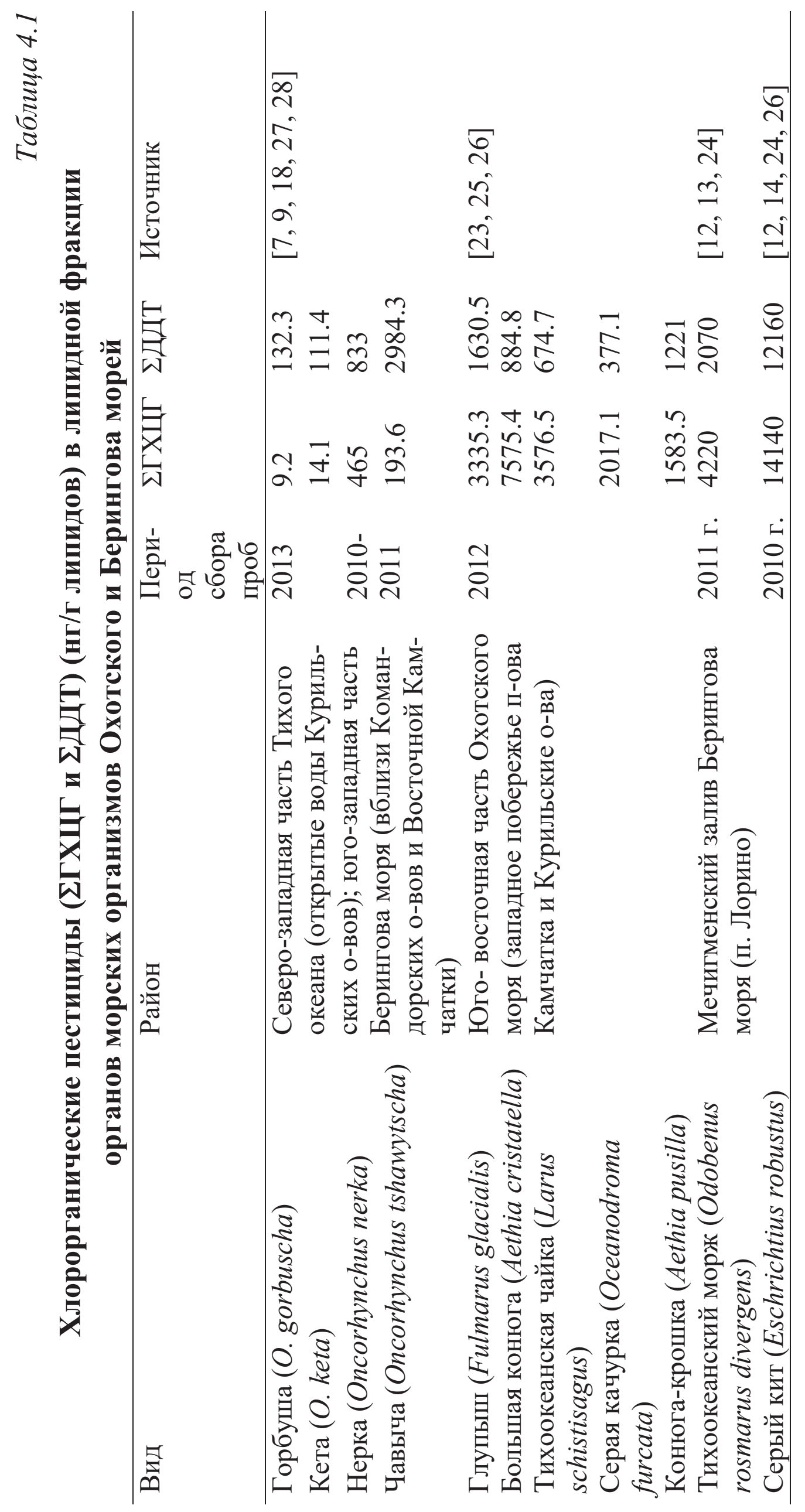




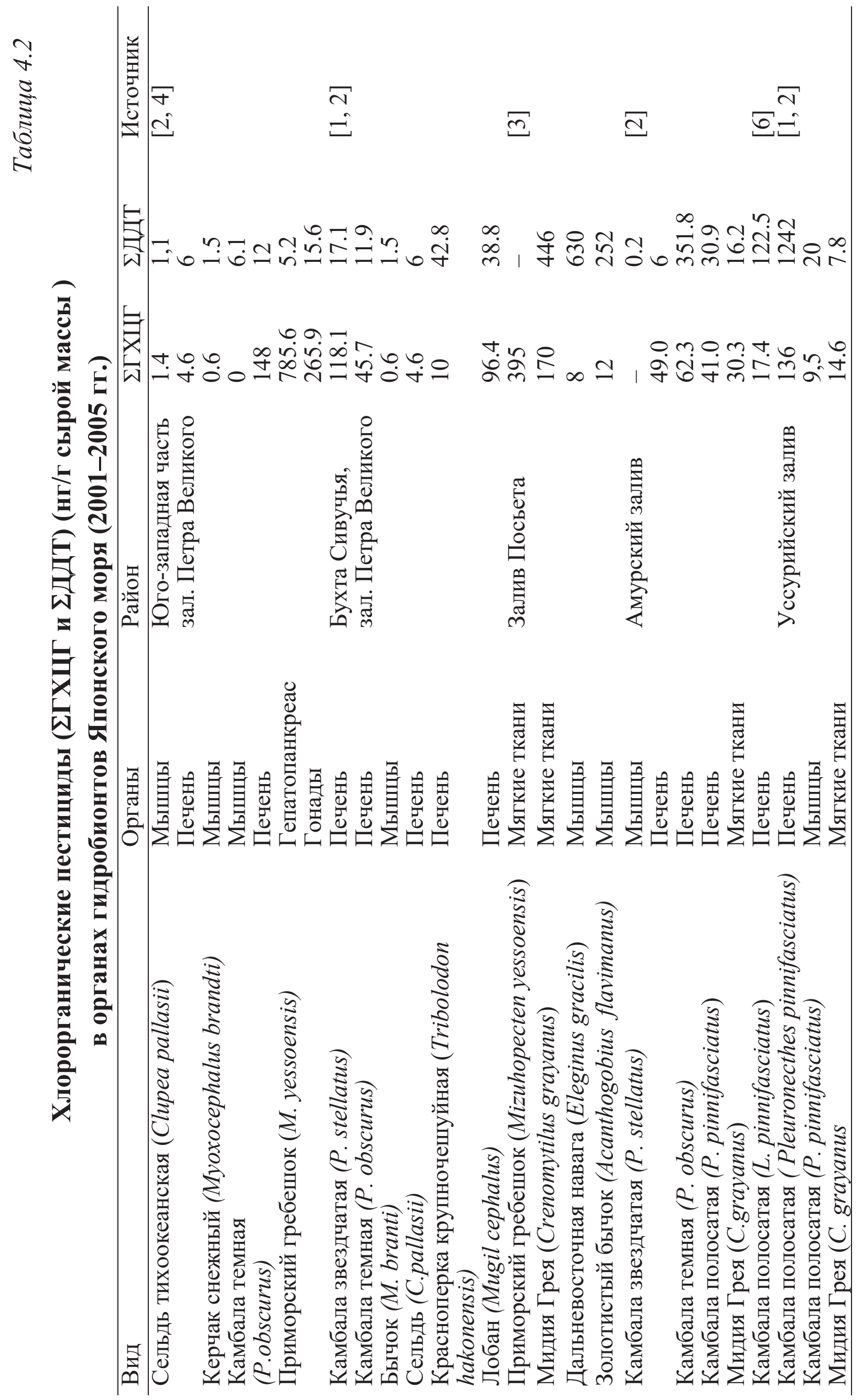




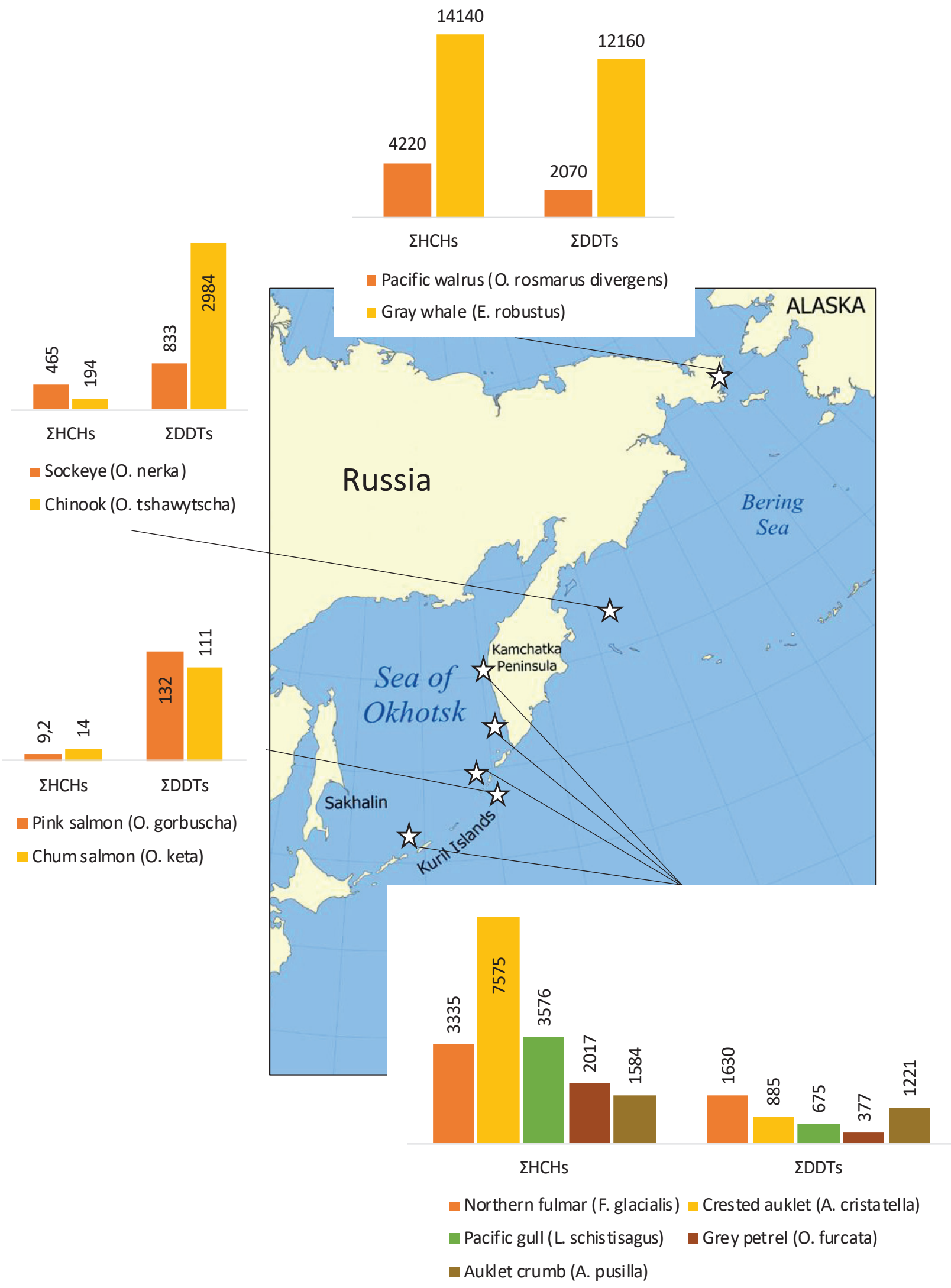

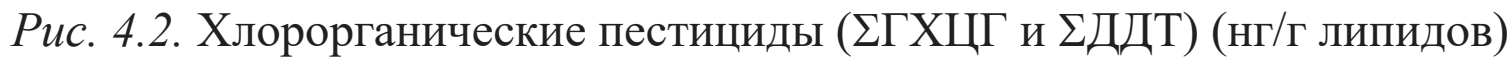
в липидной фракции органов морских организмов Охотского и Берингова морей 

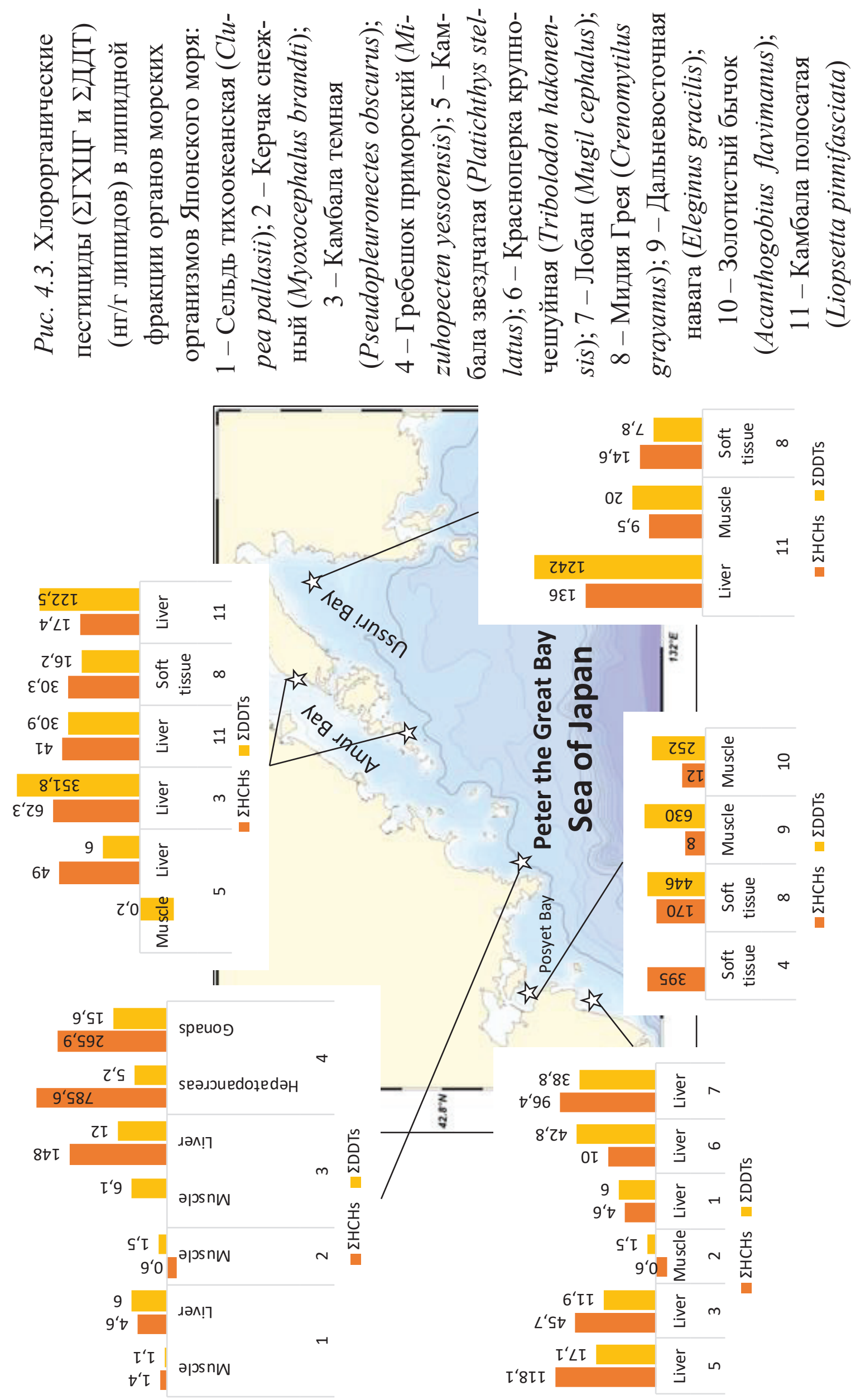
В Японском море моллюски и рыбы были собраны в отдельных районах залива Петра Великого - в заливах Посьета, Амурском и Уссурийском заливах. Образцы млекопитающих (серый кит и тихоокеанский морж) были собраны в Беринговом море в Мечигменском заливе, вблизи пос. Лорино, тихоокеанские лососи (нерка Oncorhynchus nerka и чавыча O. tshawytscha) - в юго-западной части моря вблизи Командорских о-вов и Восточной Камчатки. Также, тихоокеанские лососи (горбуша $O$. gorbuscha, кета O. keta, нерка O. nerka и чавыча O. tshawytscha) и морские птицы (глупыш Fulmarus glacialis, большая конюга Aethia cristatella, конюга-крошка Aethia pusilla, тихоокеанская чайка Larus schistisagus, серая качурка Oceanodroma furcata) были собраны в Охотском море, близ западного побережья полуострова Камчатка, вдоль западной части Курильских островов в прибрежных районах и около о. Хоккайдо, в экспедициях ТИНРО-Центра.

\section{1. Моллюски и рыбы Японского моря}

Суммарное содержание ХОП у мидий из разных районов зал. Петра Великого, особенно вблизи г. Владивосток, за последние десятилетия увеличилось почти в 10 раз. По данным А.В. Ткалина с соавторами [22], в 1996 г. общее содержание ХОП в мягких тканях мидии Грея из Амурского и Уссурийского заливов составляло около 4,5 нг/г. По нашим данным, в 2004 г. суммарное содержание ХОП у мидий из Амурского залива было около 50,0 нг/г, из Уссурийского залива - около 20,0 нг/г.

В 1998 г. в мягких тканях мидий, собранных в прибрежных водах о. Рейнеке, концентрация ХОП не превышала 0,8 нг/г [21], в 2004 г. содержание достигло 25,8 нг/г [1]. Повышение суммарного содержания ХОП в мидиях как из внутренних районов Амурского и Уссурийского заливов, так и в условно-фоновом районе о. Рейнеке можно считать отражением продолжающейся хозяйственной деятельности на юге Приморского края, атмосферный перенос и морские течения из районов, где продолжается использование ХОП (Индия и Китай). Не стоит забывать и о длительности распада соединений в окружающей среде, который составляет несколько десятков лет. Разная концентрация также может быть связана с разными методическими подходами и инструментальным определением. 
Высокое суммарное содержание ХОП (616 нг/г) с абсолютным преобладанием ДДТ и его метаболитов (450 нг/г) обнаружено в мидиях из зал. Посьета, что может быть связано с влиянием реки Туманной, выносящей в море большое количество различных загрязняющих веществ. Концентрации ХОП у мидий из зал. Посьета были значительно выше, чем у мидий из Амурского и Уссурийского заливов. Таким образом, трансграничный перенос загрязняющих веществ имеет большое значение в прибрежных водах Приморья [3].

Анализ соотношений количества ДДТ и его метаболитов и изомеров ГХЦГ в органах моллюсков показывает, что в мидиях из зал. Посьета, находящихся под влиянием трансграничного переноса загрязнения, преобладает группа ДДТ, как и у животных из других прибрежных зон азиатских стран. При этом сумма изомеров ГХЦГ в мидиях из зал. Петра Beликого была значительно выше, чем у моллюсков из районов других стран. Данное обстоятельство, возможно, отражает меньшее использование линдана в сельском хозяйстве азиатских стран.

Полученные значения максимальных концентраций ХОП у мидий из зал. Петра Великого относительно малы по отношению к величинам токсичности и $\mathrm{LD}_{50}$ для человека, которые по ДДТ и его метаболитам составляют 250-400 мг/кг, по ГХЦГ - 300-500 мг/кг [11]. Таким образом, уровень загрязнения моллюсков пестицидами в настоящее время не представляет опасности для здоровья человека.

При изучении ХОП в мышцах рыб прибрежных морских вод Приморья максимальные суммарные концентрации (638 нг/г) были определены в дальневосточной наваге, выловленной в зал. Посьета. В мышцах золотистого бычка из того же залива количество ХОП также было высоким и составляло 264 нг/г. В мышцах лобана из бухты Сивучьей концентрация пестицидов была 88 нг/г. Во всех трех видах рыб, выловленных в прибрежных водах юго-западного Приморья, в сумме ХОП преобладали ДДТ и его метаболиты, как и у мидий из зал. Посьета.

В большинстве исследованных районов (б. Сивучья, заливы Посьета, Амурский и Уссурийский) были собраны несколько видов камбал. Максимальные концентрации ХОП (150 нг/г) были определены в мышцах камбал, выловленных в Амурском заливе. В отличие от рыб южного Приморья, в камбалах Амурского залива преобладала сумма изомеров ГХЦГ 106,9 нг/г, причем на долю основного $\gamma$-изомера приходилось 74 \%. 
Во всех образцах печени рыб из зал Петра Великого были определены практически все изомеры ГХЦГ и ДДТ и метаболиты. Максимальные концентрации ХОП обнаружены в печени камбалы полосатой из Амурского залива (379-736 нг/г).

Тихоокеанская сельдь является важным промысловым объектом. Определение токсикантов в этом виде представляет интерес с точки зрения безопасности для здоровья человека. Суммарное содержание ХОП в мышцах тихоокеанской сельди, выловленной в зал. Петра Великого, составляло 2,5 нг/г сырой массы, что на два порядка ниже, чем в сельди Балтийского моря [20].

В 2008 году исследовано содержание ХОП в органах мелкочешуйной красноперки (Tribolodon brandtii) из эстуариев рек Раздольная и Артемовка. Суммарные максимальные концентрации ХОП были обнаружены в печени красноперок из эстуария р. Раздольная, в среднем 1700 нг/г сырого веса, у рыб из эстуария р. Артемовка сумма ХОП составляла в среднем около 1000 нг/г. В мышцах рыб сумма ХОП значительно ниже, чем в печени, и не превышает норматива СанПиН - 200 мг/кг сырой массы. В мышцах рыб из Раздольной она составляет в среднем 70 нг/г, из Артемовки - 57 нг/г. Основными загрязняющими веществами являются ДДТ и ДДЕ.

При сравнении содержания ХОП в органах эстуарных видов рыб красноперок - с морскими рыбами - полосатой камбалой из Уссурийского и Амурского заливов, можно отметить, что эстуарные виды рыб накапливают ХОП в значительно большей степени, чем морские рыбы, что соответствует известной закономерности аккумуляции и седиментации ХОП на границе смешения морских и пресных вод.

Результаты исследований содержания ХОП в биоте зал. Петра Великого свидетельствуют, что в моллюсках уровень поллютантов меньше по сравнению с прибрежной зоной стран АТР, а в рыбах соответствует интервалу содержания этих веществ, определяемых в других районах Мирового океана в настоящее время. 


\section{2. Тихоокеанские лососи Охотского и Берингова морей}

Среднее содержание пестицидов (табл. 4.1, рис. 4.2), суммарные зна-

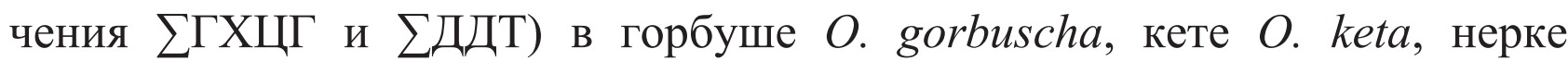
O. nerka и чавыче O. tshawytscha составило 141.5, 125.5, 1298, 3177.9 нг/Г липидов, соответственно. Сопоставление общего количества ХОП в мышцах и печени всех четырех видов рыб из Охотского и Берингова морей показало, что у горбуши и кеты средние значения значимо не различаются, но они достоверно меньше $(p \leq 0,05)$, чем у чавычи, а у последней - меньше, чем у нерки. Возрастание концентрации происходит в следующей последовательности: кета $\leq$ горбуша < чавыча $<$ нерка, при этом диапазон суммарной концентрации ХОП, например, в мышцах составлял 78.8$174.1 ; 89.3-222.8 ; 265.0-2435.4 ; 165.7-3020.1$ нг /Г липидов соответственно $[9,18,25,28]$.

При сравнении мягких тканей кеты и горбуши достоверно $(p \leq 0,05)$ большее количество пестицидов обнаружено у кеты, что может быть связано как с большей массой и жирностью кеты, так и длительностью нахождения особей данного вида в море. Горбуша имеет однолетний годовой цикл и возвращается на нерест на следующий год после ската молоди в море, кета же может нагуливаться от двух до пяти лет. Средняя масса кеты составляла 1863 г., горбуши - 1130 г. По мере роста, с увеличением веса, наряду с аккумуляцией липидов, в органах происходит и накопление различных поллютантов. Горбуша и кета были собраны в начале лета в районе Южных Курил, во время завершения нерестовых миграций, когда органы уже начинают расходовать липиды. Перед нерестом лососи расходуют до 80\% своих резервных липидов, при этом удельная концентрация токсиканта на 1 г липидов увеличивается и может достигать значений, опасных для здоровья рыб [16].

Образцы нерки и чавычи были собраны в западной части Берингова моря и в Охотском море осенью, в октябре-ноябре, когда рыбы нагуливаются в море, где могут провести несколько лет. За это время концентрация токсикантов в органах последовательно возрастает, не только в метаболически активной печени, но и в резервных мышцах. Чавыча, например, 99\% всех токсикантов накапливает за время обитания в море [17].

Количество лососей, мигрирующих к российскому побережью, варьирует год от года, но структура подхода сохраняется $-60-65 \%$ составляет 
горбуша, 20-25\% - кета, 10-12\% нерка, и небольшая доля приходится на кижуча и чавычу. Кета и горбуша составляют основу подхода на восточной Камчатке, восточном Сахалине, материковом побережье Охотского моря, в бассейне Амура [15]. В четном 2008 году общий вылов составил 258 тыс. т, в рекордном нечетном 2009 году - 542 тыс. т, в 2010 - 324 тыс. т. Количество рыбы, пропущенной на нерест в отдельных районах Дальнего Востока в 2008-2010 годах, приводится в ежегодниках Северо-тихоокеанской комиссии по анадромным рыбам NPAFC. Именно эта рыба останется после нереста на нерестилищах и послужит пищей для многих организмов, связывая таким образом морские и наземные пищевые цепи, или иначе говоря, перенося органическое вещество из океана на сушу.

Концентрация ХОП как средняя сумма ГХЦГ +ДДЕ для самцов и самок в целой горбуше составляла 68,85 нг/г, кеты - 182,5 нг/г сырой массы. Средняя масса одного экземпляра горбуши равна 1,3 кг, нерестовой кеты - 3,5 кг. Расчеты показывают, что одна горбуша содержит до 90 мкг пестицидов, а одна кета - до 640 мкг [7]. Тогда общее количество ХОП, переносимое, например, в 2009 г., только этими двумя видами лососей на восточную Камчатку составляет 10,4 кг, в бассейн Амура - более 13 кг, на материковое побережье Охотского моря - 8,1 кг [9].

В 2008 г. поступление пестицидов за счет лососей в различные районы тихоокеанского побережья России варьировало от 520 г до 4 кг, а в 2009 - от 470 г до 13 кг, в 2010 - от 350 г до 7,75 кг. За три года наибольшее количество пестицидов пришло в бассейн Амура, около 23 кг. Высокие подходы лососей в последние годы определяют ежегодный перенос пестицидов на сушу от 13 до 30 кг.

Таким образом, в лососях северо-западной части Тихого океана обнаружены хлорорганические соединения, что является отражением глобального фона пестицидов, сформировавшегося как на планете в целом, так и в Мировом океане. Аккумуляция подобных стойких высокотоксичных соединений может оказывать влияние на здоровье взрослых особей, успешность их размножения, выживание потомства. Перенос токсикантов из моря на сушу лососями в ходе биотранспорта создает угрозу загрязнения нерестилищ. Продолжение мониторинга биоаккумуляции пестицидов у лососевых непосредственно на нерестилищах в наших дальнейших исследованиях даст новые сведения об этом малоизученном факторе, способном оказать влияние на общий запас и вылов ценной группы промысловых рыб. 


\section{3. Морские птицы Охотского моря}

Среднее содержание пестицидов в глупыше Fulmarus glacialis, большой конюге Aethia cristatella, тихоокеанской чайке Larus schistisagus, серой качурке Oceanodroma furcata и конюге-крошке Aethia pusilla составило 5206, 8460, 4542, 2417, 2804 нг/г липидов, соответственно [23, 25].

Исследованные виды птиц из Охотского моря имеют разные размеры, следовательно содержание подкожного жира у них различно. Известно, что ХОП концентрируются, преимущественно, в подкожном жире. Поэтому у более крупных птиц содержание ХОП выше (табл. 4.1, рис. 4.2). Тихоокеанская чайка (средняя длина тела - 64 см) и глупыш (47 см) в пере с кожей имеют сходные концентрации ХОП (5962 и 5949 нг/г липидов, соответственно). В качурке (22 см), которая значительно меньше этих видов птиц, содержание пестицидов составило 3128 нг/г липидов. Различные уровни трофических связей у этих видов, также являются причиной разной степени аккумуляции. Среднее содержание пестицидов во внутренних органах птиц отражает разный спектр питания. К кормовым объектам глупыша относятся организмы, имеющие высокий коэффициент накопления ХОП (рыбы, икра рыб, моллюски, ракообразные и другие беспозвоночные, падаль, внутренности китов, различные жирные отбросы и т.д.), следствием чего является высокое содержание пестицидов во внутренних органах (5874 нг/г). Большая конюга, конюгакрошка и качурка питаются мелкими ракообразными, морскими беспозвоночными, амфиподами и др., которые аккумулируют пестициды в меньшей степени, чем кормовые объекты глупыша. Следовательно, и содержание ХОП во внутренних органах этих видов птиц меньше: 1730, 2804 и 1705 нг/Г липидов, соответственно. Накопление и распределение пестицидов в органах птиц может регулироваться и другими дополнительными факторами. Так, например, у большой конюги, размером 26 см, содержание ХОП в пере с кожей составило 15604 нг/г. Установление причин высоких концентраций ХОП у данного вида требует дальнейших исследований [23].

Аккумуляция пестицидов у птиц влияет на различные стороны их физиологии, например, вызывает серьезное ухудшение репродуктивной функции и истончение скорлупы яиц, что приводит к нарушению эмбрионального развития и потере потомства. Обнаружение заметных концентраций ХОП в морских птицах из Охотского моря, удаленного от активной сельскохозяйственной деятельности, служит проявлением общего глобального фона СО3, сформировавшегося на планете в настоящее время. 


\section{4. Морские млекопитающие Берингова моря}

В органах серого кита содержание липидов составило от 1 до 4\% в мышцах, и до 8\% в печени. В органах тихоокеанского моржа содержание липидов составило от 1 до 6\% в мышцах, и до 10\% в печени. Расчеты показали (табл. 4.1), что в среднем, общая сумма ХОП в жире серого кита составляла 6290 нг/г, тихоокеанского моржа - 26300 нг/г [12, 13, 24, 25].

Разный уровень аккумуляции пестицидов у серого кита и тихоокеанского моржа из Берингова моря в первую очередь отражает различную степень загрязнения районов обитания особей этими поллютантами. Видовые особенности в аккумуляции липофильных ксенобиотиков в немалой степени обусловлены также общим содержанием жира в подкожной клетчатке и в отдельных органах. Большое значение имеет и степень половой зрелости особей. Исследованные нами виды имеют сходный ареал, содержание жира в их органах отличается незначительно и составляет 8-10\%, и существенные различия в содержании пестицидов могут быть связаны со стадией репродуктивного цикла и характером питания. Пищей серых китов служат в основном донные ракообразные и другие мелкие бентосные организмы, обитающие как на поверхности, так и в толще мягких грунтов (инфауна). Основу рациона моржа составляют донные беспозвоночные: двустворчатые моллюски, некоторые виды креветок, лангустов, многощетинковых червей и приапулид, осьминоги и голотурии, а также некоторые виды рыб. Кроме того, иногда моржи поедают других тюленей: известны случаи нападения на кольчатую нерпу и детеныша гренландского тюленя [5]. Кормовые объекты моржа аккумулируют больше пестицидов в теле, чем компоненты рациона серого кита, т.к. коэффициенты накопления поллютантов у моллюсков и рыб выше, чем у ракообразных. На основании этого можно заключить, что пищевой фактор является определяющим в различиях биоаккумуляции пестицидов у китов и моржей $[24,25]$.

При сравнении полученных результатов с результатами для других морских млекопитающих видно, что у морских млекопитающих Берингова моря концентрации ХОП меньше, чем таковые у млекопитающих из других районов Мирового океана. Это подтверждает, что уровень загрязнения ХОП Берингова моря можно рассматривать как фоновый. 


\section{5. Заключение}

Аккумуляция ХОП происходит наиболее активно у морских млекопитающих и птиц, находящихся на вершине пищевой пирамиды. Органические поллютанты оказываются прочно встроенными в направленный транспорт биогенов, осуществляемый лососями и связывающий океанические и наземные экосистемы. Ежегодное попадание пестицидов в районы нерестилищ и постоянное увеличение их концентрации в локальных зонах определяет возможность экологического риска для определенных популяций, успех нереста которых может быть снижен вследствие токсичности среды. Морские моллюски, рыбы, млекопитающие и птицы являются биоиндикаторами ХОП в глобальном и долгосрочном масштабе. Именно эти организмы позволяют изучать интегрированные временные тенденции распространения пестицидов в морской среде, особенно в океанах. В настоящее время уровни содержания СО3 в организмах дальневосточных морей ниже регламентируемых значений технического регламента Таможенного союза для морепродуктов.

Концентрации ХОП в Охотском и Беринговом морях можно считать «фоновыми», в то время как Японское море испытывает воздействие стран, использующих эти вещества в сельском хозяйстве.

\section{6. Список литературы}

1. Боярова, М.Д. Современные уровни содержания хлорорганических пестицидов в водных организмах залива Петра Великого (Японское море) и озера Ханка: автореф. дис. ... канд. биолог. наук / М.Д. Боярова. Владивосток, 2008. - 25 с.

2. Боярова, М.Д. Хлорированные углеводороды в гидробионтах залива Петра Великого Японского моря / М.Д. Боярова, И.Г. Сясина, Ю.В. Приходько, О.Н. Лукьянова // Экологическая химия. - 2004. - Т. 13. № 2. - C.117-124. 
3. Боярова, М.Д. Хлорированные углеводороды в гидробионтах залива Посьета Японского моря / М.Д. Боярова, О.Н. Лукьянова // Известия ТИНРО. - 2006. - Т. 145. - С. 271-278.

4. Боярова, М.Д. Хлорорганические пестициды в двустворчатых моллюсках и рыбах залива Петра Великого / М.Д. Боярова, О.Н. Лукьянова // Современное экологическое состояние залива Петра Великого Японского моря / под ред. Н.К. Христофоровой. - Владивосток: Изд-во ДВФУ, 2012. - С. 334-345.

5. Бурдин, А.М. Морские млекопитающие России: справочникопределитель / А.М. Бурдин, О.А. Филатова. - Киров: Кировская областная типография, 2009. - $206 \mathrm{c.}$

6. Ващенко, М.А. ДДТ и гексахлорциклогексан в донных осадках и печени камбалы Pleuronectes pinnifasciatus из Амурского залива (залив Петра Великого, Японское море) / М.А. Ващенко, И.Г. Сясина, П.М. Жадан // Экология. - 2005. - Т. 36. - № 1. - С. 64-68

7. Лукьянова, О.Н. Биотранспорт пестицидов тихоокеанскими лососями в северо-западной Пацифике / О.Н. Лукьянова, В.Ю. Цыганков, М.Д. Боярова, Н.К. Христофорова // Доклады Академии наук. - 2014. Т. 456. - № 3. - С. 363-365.

8. Лукьянова, О.Н. Стойкие органические загрязняющие вещества в донных отложениях эстуарных зон трех рек залива Петра Великого (Японское море) / О.Н. Лукьянова, Е.С. Бродский, Г.М. Чуйко // Вестник Тюменского государственного университета. - 2012. - № 12. - С. 119-126.

9. Лукьянова, О.Н. Тихоокеанские лососи рода Oncorhynchus как вектор переноса стойких загрязняющих веществ в океане / О.Н. Лукьянова, В.Ю. Цыганков, М.Д. Боярова, Н.К. Христофорова // Вопросы ихтиологии. - 2015. - Т. 55. - № 3. - С. 351-355.

10. Лукьянова, О.Н. Хлорорганические пестициды в водных экосистемах Дальнего Востока России / О.Н. Лукьянова, М.Д. Боярова, А.П. Черняев, Е.И. Барабанщиков, С.А. Алешко // Использование и охрана природных ресурсов в России. - 2007. - № 2. - С. 31-35.

11. Справочник химика. Том 6. Сырье и продукты промышленности органических веществ / под ред. Б.П. Никольского, В.А. Рабиновича. 2-е изд. - Ленинград: Химия, 1967. - 1009 с.

12. Цыганков, В.Ю. Гексахлорциклогексан и ДДТ в морских организмах Охотского и Берингова морей / В.Ю. Цыганков, М.Д. Боярова, 
О.Н. Лукьянова, Н.К. Христофорова. // Известия ТИНРО. - 2014. T. 176. - P. 225-232.

13. Цыганков, В.Ю. Стойкие токсические вещества в мышцах и печени тихоокеанского моржа Odobenus rosmarus divergens Illiger, 1815 из Берингова моря / В.Ю. Цыганков, М.Д. Боярова, О.Н. Лукьянова // Биология моря. - 2014. - Т. 40. - № 2. - С. 158-161.

14. Цыганков, В.Ю. Хлорорганические пестициды и тяжелые металлы в органах серого кита из Берингова моря / В.Ю. Цыганков. // Известия ТИНРО. - Т. 170. - 2012. - С. 202-209.

15. Шунтов, В.П. Тихоокеанские лососи в морских и океанических экосистемах / В.П. Шунтов, О.С. Темных. - Владивосток: ТИНРО-Центр, 2008. - T. 1. $-481 \mathrm{c}$.

16. Brett J.R. Energetics / In: Groot C., Margolis L., Clarke W.C. eds. Physiological ecology of Pacific salmon. - University of British Columbia, Vancouver, BC, Canada, 1995. - P. 3-68.

17. Cullon, D.L. Persistent organic pollutants in chinook salmon (Oncorhynchus tshawytscha): implications for resident killer whales of British Columbia and Adjacent waters / D.L. Cullon, M.B. Yunker, C. Alleyne [et al.] // Environmental Toxicology and Chemistry. - 2009. - V. 28. - No. 1. - P. 148-161.

18. Lukyanova, O.N. Bioaccumulation of HCHs and DDTs in organs of Pacific salmon (genus Oncorhynchus) from the Sea of Okhotsk and the Bering Sea / O.N. Lukyanova, V.Y. Tsygankov, M.D. Boyarova, N.K. Khristoforova // Chemosphere. - 2016. - V. 157. - P. 174-180.

19. Lukyanova, O.N. Persistent organic pollutants in marine ecosystems in Russian Far East: Sources, transport, biological effects / O.N. Lukyanova. LAP Lambert Academic Publishing, 2013. - 108 p.

20. Roots, O. Persistent organic pollutants in the Baltic Sea (1969-2002)/ O. Roots // Environmental Chemistry (Ekologicheskaya khimiya). - 2004. V. 13. - No. 1. - P. 54-66.

21. Tkalin, A.V. New date on organochlorine distributions in the marine environment near Vladivostok / A.V. Tkalin, D.P. Samsonov, T.S. Lishavskaya, G.V. Ghenrik // Marine Pollution Bulletin. - 2000. - V. 40. P. 879-881.

22. Tkalin, A.V. Organochlorine pesticides in mussels and bottom sediments from Peter the Great Bay near Vladivostok / A.V. Tkalin, T.S. Lishavskaya, J.W. Hills // Ocean Research. - 1997. - V. 19. - No. 2. - P. 115-119. 
23. Tsygankov, V.Yu. Bioaccumulation of organochlorine pesticides (OCPs) in the northern fulmar (Fulmarus glacialis) from the Sea of Okhotsk / V.Yu. Tsygankov, M.D. Boyarova, O.N. Lukyanova // Marine Pollution Bulletin. $-2016 .-$ V. 110. - P. 82-85.

24. Tsygankov, V.Yu. Bioaccumulation of Persistent Organochlorine Pesticides (OCPs) by Gray Whale and Pacific Walrus from the Western Part of the Bering Sea / V.Yu. Tsygankov, M.D. Boyarova, O.N. Lukyanova // Marine Pollution Bulletin. - 2015. - V. 99. - P. 235-239.

25. Tsygankov, V.Yu. Bioindicators of organochlorine pesticides (OCPs) in the Sea of Okhotsk and the western Bering Sea / V.Yu. Tsygankov, M.D. Boyarova, O.N. Lukyanova, N.K. Khristoforova // Archives of Environmental Contamination and Toxicology. - 2017. - V. 73. - P. 176-184

26. Tsygankov, V.Yu. Organochlorine Pesticide Accumulation in Seabirds and Marine Mammals from the Northwest Pacific / V.Yu. Tsygankov, M.D. Boyarova, O.N. Lukyanova // Marine Pollution Bulletin. - 2018. V. 128. - P. 208-213.

27. Tsygankov, V.Yu. The Kuril Islands as a Potential Region for Aquaculture: Organochlorine Pesticides in Pink and Chum Salmon / V.Yu. Tsygankov. // Journal of Aquaculture Research \& Development. 2016. - V. 7. - N 8. - P. 442.

28. Tsygankov, V.Yu. The Sea of Okhotsk and the Bering Sea as the region of natural aquaculture: Organochlorine pesticides in Pacific salmon / V.Yu. Tsygankov, O.N. Lukyanova, N.K. Khristoforova // Marine Pollution Bulletin. - 2016. - V. 113. - P. 69-74. 


\title{
ГЛАВА 5
}

\section{СОВРЕМЕННЫЕ УРОВНИ ХЛОРОРГАНИЧЕСКИХ ПЕСТИЦИДОВ (ХОП) В АБИОТИЧЕСКИХ КОМПОНЕНТАХ ЭКОСИСТЕМ СЕВЕРО-ЗАПАДНОЙ ЧАСТИ ТИХОГО ОКЕАНА}

\author{
М.С. Лягуша ${ }^{1}$, А.П. Черняев ${ }^{1}$
}

Исследовано содержание хлорорганических пестицидов (ХОП) изомеров ГХЦГ и ДДТ и его метаболитов в абиотических компонентах речных и морских экосистем акватории Японского и Охотского морей. Дана оценка длительности нахождения и поступлении токсикантов в акватории морей. Рассчитаны коэффициенты, указывающие на давность поступления ХОП в экосистемы.

Ключевые слова: ГХЦГ, ДДТ, вода, донные отложения, Японское море, Охотское море.

1 Школа естественных наук, Дальневосточный федеральный университет (ДВФУ), 690922, Владивосток, о. Русский, п. Аякс, 10. E-mail: s-i-o@inbox.ru.

${ }^{1}$ School of School of Natural Sciences, Far Eastern Federal University, 10 Ajax Bay, Russky Island Vladivostok, Russia, 690922. E-mail: s-i-o@inbox.ru.

Для иитирования: Лягуша М.С., Черняев А.П. Современные уровни хлорорганических пестицидов (ХОП) в абиотических компонентах экосистем северо-западной части Тихого океана // Стойкие органические загрязняющие вещества (CO3) в Дальневосточном регионе: моря, организмы, человек : монография / В.Ю. Цыганков, М.М. Донец, Н.К. Христофорова [и др.] ; науч. ред. В.Ю. Цыганков. - Владивосток : Изд-во Дальневост. федерал. ун-та, 2020. - С. 101-127. https://doi.org/10.24866/7444-4891-2/101-127.

For citing: Liagusha M.S., Cherniaev A.P. Current levels of organochlorine pesticides (OCPs) in the abiotic components of the Northwest Pacific ecosystems // Persistent organic pollutants (POPs) in the Far Eastern Region: Seas, Organisms, Human : monograph / V.Yu. Tsygankov, M.M. Donets, N.K. Khristoforova [et al.] ; ed. by V. Yu. Tsygankov. - Vladivostok : Publishing House of the Far Eastern Federal University, 2020. - P. 101-127. - https://doi.org/10.24866/7444-4891-2/101-127. 


\section{CHAPTER 5. CURRENT LEVELS OF ORGANOCHLORINE PESTICIDES (OCPS) IN THE ABIOTIC COMPONENTS OF THE NORTHWEST PACIFIC ECOSYSTEMS}

M.S. Liagusha ${ }^{1}$, A.P. Cherniaev ${ }^{1}$

The content of organochlorine pesticides (OCPs) such as $\mathrm{HCH}$ isomers and DDT metabolites in abiotic components of aquatic ecosystems of the Sea of Japan / East Sea and the Sea of Okhotsk was studied. Estimation of the duration of the presence and intake of toxicants in the water area of the seas was given. The coefficients indicating the time of OCPs circulation in ecosystems were calculated.

Keywords: HCHs, DDTs, water, bottom sediments, the Sea of the Japan, the Sea of the Okhotsk.

Пестициды - особая группа химических соединений, которые преднамеренно вносят в окружающую среду с целью уничтожения определенных живых организмов. Помимо необходимых человеку эффектов (защита урожая и уничтожение вредителей), эти соединения загрязняют биоту и абиотические компоненты экосистем, снижая устойчивость и биоразнообразие экосистем. Кроме того, многие пестициды способные отрицательно влиять на здоровье человека, вызывая отравления или повышая риск развития онкологических заболеваний [17].

Пестициды широко применяются в сельском хозяйстве в борьбе с вредителями зерновых, зернобобовых, технических культур, плодовых деревьев и виноградников, овощных и полевых культур.

Хлорорганические пестициды (ХОП) признаны одними из самых опасных за счет своей высокой токсичности, биологической активности, устойчивости в окружающей среде, способностям к биоаккумуляции и биомагнификации. Продукты их распада или трансформации, более стабильные, чем исходные пестициды также являются опасными для здоровья человека. Примеры ХОП - известный ДДТ (n,n-дихлордифенилтрихлорэтан) и 
хлорпроизводные диоксина. Отдельные представители этого класса веществ сильнейшие яды, в десятки тысяч раз токсичнее цианистого калия [13].

Хлорорганические пестициды в основном проникают в организм человека посредством дыхания, дермального контакта и с пищей. Основные пути выведения ХОП - почки и желудочно-кишечный тракт. К хлорорганическим соединениям существует индивидуальная, видовая и возрастная чувствительность [1]. ХОП обладают политропныл действием, являются паренхиматозными ядами, поражают центральную нервную систему, печень, почки, мышцу сердца, слизистую оболочку желудка и кишечника, органы внутренней секреции (главным образом надпочечники, щитовидную железу, яичники). Выраженные морфологические изменения в организме теплокровных при отравлении ХОП варьируют от незначительных расстройств кровообращения и обратимых дистрофических изменений до очаговых некрозов, что зависит от организма, дозы, длительности экспозиции и других факторов [23].

Эффективность пестицидов зависит от их способности проникать в целевой организм, транспортироваться в нем к месту действия и подавлять жизненно важные процессы, от количества применяемого вещества (измеряется дозой в мг на весь организм или единицу его веса, либо концентрацией действующего вещества в рабочем растворе) и времени воздействия. Мера активности пестицидов - ЛД 50 или $\mathrm{CK}_{50}$ (летальная доза или средняя концентрация раствора, вызывающая гибель 50 \% организмов, соответственно), на практике - норма расхода действующего вещества на единицу площади (массы, объема), при которой достигается необходимый защитный эффект [26].

Экологическая безопасность пестицидов связана с их избирательностью, а также большей или меньшей персистентностью - способностью сохраняться определенное время в окружающей среде, не теряя своей биологической активности. Персистентность одного и того же пестицида может существенно меняться в различных объектах окружающей среды и в различных климатических условиях [26].

Многие пестициды токсичны для людей и теплокровных. По острой пероральной токсичности (измеряемой чаще всего на крысах) для пестицидов в СССР была принята следующая классификация: чрезвычайно опасные - ЛД 50 до 15 мг/кг, высокоопасные 15-150 мг/кг, умеренноопасные - 150-5000 мг/кг, малоопасные - выше 5000 мг/кг [26]. 
Наибольшее внимание ученых и общественности вызвал инсекцид под сокращенным названием ДДТ - дихлордифенилтрихлорметилметан. Оценка перспективности и безопасности этого соединения быстро сменялась от надежды и восторженных отзывов до горького разочарования и обвинений. Пестициды назвали чудом современной химии и непростительной ошибкой ученых [19].

ДДТ обладает высокой устойчивостью к разложению: ни критические температуры, ни ферменты, ни свет не способны оказать на процесс разложения этого соединения заметного эффекта. В результате, попадая в окружающую среду, ДДТ так или иначе попадает в пищевую цепь, где накапливается в значительных количествах сначала в растениях, затем в животных, и наконец, в человеческом организме [3].

ГХЦГ (гексахлорциклогексан, гексахлоран) представляет собой смесь нескольких стереоизомеров. В чистом виде получено восемь изомеров этого вещества, из которых только $\gamma$-изомер (линдан) обладает выраженными инсектицидными свойствами. ГХЦГ относится к токсичным соединениям кожно-резорбтивного действия. Обладает выраженными кумулятивными свойствами. Вызывает гиперемию кожи, отечность, появление пузырьков и пустул, раздражение конъюнктивы глаз. ГХЦГ длительно задерживается в органах и тканях организма (особенно в жировой ткани), выделяется через почки, толстую кишку, переходит в молоко кормящих женщин и т. д. В отдельных странах разрешено применение линдана. Он высокотоксичен для млекопитающих (ЛД ${ }_{50}-25-200$ мг/кг) [5].

ХОП обладают высокой химической стойкостью к воздействию различных факторов внешней среды, относятся к группе высоко- и сверхвысокостабильных пестицидов. Обладая этими свойствами, они накапливаются в гидробионтах и передаются по пищевой цепи, увеличиваясь примерно на порядок в каждом последующем звене. Однако не все хлорорганические соединения обладают одинаковой персистентностью и кумулятивными свойствами. В гидросфере и организме гидробионтов они постепенно разлагаются с образованием метаболитов. По вышеназванным причинам в зонах интенсивного земледелия остатки ХОП и их метаболитов в организме гидробионтов обнаруживаются постоянно, что следует учитывать при диагностике отравлений [2].

В пресных и морских водоемах, а также гидробионтах, помимо хлорорганических пестицидов, встречаются сходные с ними полихлориро- 
ванные бифенилы (ПХБ) и терфенилы (ПХТ), используемые в промышленности. По своим физико-химическим свойствам и физиологическому действию на организм, а также методам анализа они весьма близки к хлорорганическим пестицидам. Поэтому необходима дифференциация этих групп хлорированных углеводородов [2].

\section{1. Загрязнение морей и океанов}

Загрязненность морских экосистем такими ХОП, как ДДТ и ГХЦГ, стала их неотъемлемой особенностью и приобрела глобальные масштабы. Обусловлено это множеством факторов - непрекращающимся применением ХОП, их чрезвычайно высокой стабильностью, способностью кумулироваться в живых организмах, а также большими масштабами атмосферного, гидродинамического переноса и высокой миграционной способностью внутри экосистем [23].

Хотя, на первый взгляд, уровни содержания ХОП в морских водах представляются незначительными, вследствие их биоконцентрации и биоаккумуляции в морских организмах, эти соединения способны отрицательно воздействовать на экосистемы Мирового океана.

В приводном слое атмосферы над Мировым океаном постоянно в ультрамалых концентрациях обнаруживаются ДДТ и его метаболиты. Над наиболее загрязненной частью Мирового океана - акваторией Северной Атлантики - концентрация аэрозольной фракции находилась в интервале 0,002-0,02 нг/м³ (в период 1970-1980 гг.) [23].

ХОП концентрируются в поверхностном микрослое (ПМС) воды и над так называемым слоем скачка плотности (обычно от десятков до 150200 м). Значительная их часть включена в биохимические циклы, находясь в составе взвеси, донных отложений и в морских организмах. Наибольшая аккумуляция характерна для ДДТ, присутствие изомеров ГХЦГ обнаружено в отдельных пробах зоопланктона и рыбы в виде $\gamma$-формы. Таким образом, очевидна потенциальная опасность загрязнения морей и океанов в глобальном, и в региональном масштабах [23]. 


\section{2. Трансграничный перенос}

Несмотря на то, что ХОП имеют низкое давление насыщенных паров, они способны испаряться с поверхности почвы и воды в воздух. В особенности значительные количества этих соединений поступают в атмосферу при применении сельскохозяйственной авиации, поскольку при распылении они способны переноситься на тысячи километров с воздушными потоками.

ХОП хорошо адсорбируются органическим веществом почвы или донным илом и за счет этого способны переноситься с поверхностными водами. Степень адсорбции ХОП увеличивается в ряду «песок-донные отложения-почва».

Весьма значимой характеристикой переноса ХОП в окружающей среде считается их концентрация в атмосферных осадках. Загрязнение водоемов обусловлено главным образом поверхностным стоком загрязняющих веществ, а также их осаждением из атмосферы. Попадая в водоемы, эти соединения активно перераспределяются между водой и донными отложениями. Одна существенная доля ХОП интенсивно поглощается гидробионтами и со временем метаболизируется, другая - адсорбируется на взвешенных в воде частицах и оседает на дно водоемов, где сохраняется десятки и даже сотни лет. Наибольшие концентрации ХОП в поверхностных водах наблюдаются в периоды половодья. Самые высокие уровни этих поллютантов обнаружены в Африке, Латинской Америке, Китае, Индии что является результатом активного использования пестицидов в этих регионах [4].

\section{3. Мониторинг поверхностных вод и донных отложений}

Несмотря на то, что в общем балансе гидросферы Мировой океан занимает основное место, немаловажное значение для биосферы в целом играет пресная вода, в связи с чем особое внимание уделяется исследованию водоемов на загрязненность стойкими в окружающей среде ксенобиотиками.

Природная вода представляет собой систему открытого типа, обменивающуюся веществами и энергией с другими средами (атмосфера, вод- 
ные объекты, донные отложения) и с ее биологическими составляющими. Кроме того, в природной воде присутствует множество взвешенных частиц и микропузырьков. Многие ХОП загрязняют грунтовые воды, при этом их концентрация может достигать нескольких нг/л.

Наиболее важным источником поступления хлорорганических пестицидов на орошаемые поля могут служить ирригационные воды. Для донных отложений оросительных полей также характерно высокое содержание ХОП, что связано с выносом пестицидов поверхностными стоками и их дальнейшим депонирование в донные отложения. Следствием этого является переход пестицидов из донных осадков в воду. Высокие уровни ХОП обнаруживаются в тех водных объектах, которые в большей степени подвергаются загрязнению за счет повторного использования воды на орошение. В общем балансе ХОП доля метаболитов значительно выше таковой для самих пестицидов [12].

В настоящее время отмечено распространение на большие расстояния многих поллютантов. Загрязнение окружающей среды из-за миграции загрязняющих веществ между природными средами носит комплексный характер. Опыт экологических исследований показывает, что антропогенному воздействию независимо от источников подвергаются все элементы биосферы: поверхностные и подземные воды, атмосфера, почвенные экосистемы, растения и др.

\section{4. Физико-географическая характеристика Японского и Охотского морей}

Японское море является обширной глубоководной впадиной, отделенной от океана и Охотского моря Сахалино-Японской островной дугой. Его площадь оценивается от 1008 до 1062 тыс. км², объем вод - от 1360 до 1700 тыс. км ${ }^{3}$, максимальная глубина - от 3669 до 3695 м [27].

Берег северо-западной части Японского моря большей частью высокий, обрывистый. В зал. Петра Великого выступает обширный полуостров Муравьева-Амурского. Этот полуостров разделяет залив на два больших залива: Амурский и Уссурийский [9]. 
Береговая линия Японского моря в целом, слабо изрезана. Все это отражается на формировании характера циркуляции во и особенностях биологии гидробионтов [27].

Заливы Амурский, Уссурийский и Находка являются приемниками нормативно-очищенных и загрязненных сточных вод городов Владивосток, Находка, Артем, Большой Камень, Фокино, Шкотовского, Хасанского, Надеждинского муниципальных районов.

Одним из основных источников эмиссии поллютантов в морскую среду являются терригенные стоки, в большинстве своем попадающие в реки, пресноводные озера, водохранилища и далее в моря. Одной из самых крупных пресноводных экосистем Приморского края является бассейн озера Ханка (Охотское море).

Озеро Ханка - самое крупное озеро Приморского края располагается в центре Приханкайской низменности на границе с Китайской Народной Республикой провинции Хэйлунцзян. Северная часть озера принадлежит территории Китая. Форма озера - грушевидная с расширением в северной его части. Площадь поверхности воды непостоянна, она меняется в зависимости от климатических условий. В среднем сток в озеро равен 1,94 км за год, из озера около - 1,85 км. Таким образом источники эмиссии поллютантов могут находиться и на территории России, и на территории КНР. На берегах озера активно занимаются выращиванием риса и сои. В прибрежной зоне много промышленных предприятий, кроме того оз. Ханка является крупной рекреационной зоной. В связи с этим воды озера принимают огромное количество загрязнителей разных классов: токсичные элементы, хлорорганические соединения (пестициды), углеводороды различного происхождения [15].

Охотское море - типичное материково-окраинное море, далеко вдающееся в азиатский материк и почти повсеместно имеющее естественные сухопутные границы, за исключением узких проливов, соединяющих его с Тихим океаном и Японским морем. Площадь моря составляет по оценкам разных авторов от 1579,9 до 1603,2 тыс. км², длина береговой линии 10460 км, средняя глубина 821 м, наибольшая 3916 м, объем вод 1318 тыс. км ${ }^{3}$ [27].

Охотское море - самое холодное из дальневосточных морей. Обоснованно считается, что его климат, а также термический режим в зимнее время мало отличается от обстановки в арктических морях [6]. Этим оно обязано в первую очередь своим физико-географическим особенностям. 
Море сильно вдается в материк, поэтому располагается близко от полюса холода северного полушария. Глубинная циркуляция вод Охотского моря изучена очень слабо. Ее формируют тихоокеанские воды, заходящие в море через глубоководные проливы Курильских островов, при этом подвергающиеся сильной трансформации в результате вертикальной динамики и смешения с охотоморскими промежуточными водами [27].

\section{5. ХОП в северо-западной части Тихого океана}

Пробоподготовку и анализ ХОП проводили согласно ПНД Ф 14.1:2:3:4.204-04 [20] на газовом хроматографе Agilent 6850 с детектором электронного захвата (Agilent Technologies, USA).

Прибрежные районы залива Петра Великого Японского моря являются одним из самых густонаселенных мест Дальнего Востока. Хозяйственная деятельность приводит к интенсивному антропогенному воздействию на акваторию залива и его бухты вдоль береговой полосы. Основными загрязнителями морских вод являются промышленные (предприятия электроэнергетики, судостроительной, химической и угольной промышленности, машиностроения и металлообработки, а также торговый, военный, рыболовецкий и маломерный флот) и муниципальные (коммунальные сбросы жилых массивов) сточные воды, речной и ливневый сток, сброс твердых отходов и мусора в море. Существенный вклад в загрязнение прибрежной зоны залива вносят реки. Около двух сотен водопользователей Приморского края сбрасывают сточные воды в поверхностные водные объекты более чем пятью сотнями организованных выпусков [7].

В Российской Федерации ограничительные нормы содержания хлорорганических пестицидов в водах акваторий рыбохозяйственного значения регламентируются Приказом Министерства сельского хозяйства Российской Федерации от 13 декабря 2016 года № 552 [21] Предельно допустимые концентрации в воде водоемов для ДДТ $=0,000001$ мг/л, для ГХЦГ =0,00001 мг/л, для ГХБ =0,00001 мг/л.

Для удобства читателя информация разделена по блокам: бассейн Охотского моря (водосборный бассейн озера Ханка), бассейн Японского 
моря (Залив Петра Великого и водосборные бассейны его заливов второго порядка - Амурский, Уссурийский, заливы Находка, Посьета).

\subsection{1. Охотское море}

Содержание пестицидов в Охотском море оценивали только в морской воде. Районами исследования являлись: прибрежные акватории северо-восточной части острова Сахалина, центральная часть моря.

«Сахалин-3»- перспективный нефтегазовый проект на побережье острова Сахалин. В него входит четыре блока месторождений: Киринский, Венинский, Айяшский и Восточно-Одоптинский на шельфе Охотского моря. Нужно отметить, что под названием «Сахалин-3» скрыто три огромных нефтегазовых проекта, соразмерных проектам «Сахалин-1» и «Сахалин-2», инвестиции в которые - десятки миллиардов долларов [30]. Прогнозные извлекаемые ресурсы превышают 700 млн т нефти и 1,3 трлн. $\mathrm{M}^{3}$ природного газа [31].

Лицензиями на Киринский, Аяшский и Восточно-Одоптинский владеет ОАО «Газпром», на Венинский блок - компания «Роснефть». Газ месторождений OAO «Газпром» участка «Сахалин-3» является основной ресурсной базой для наполнения газопровода «Сахалин-ХабаровскВладивосток» [32].

Так или иначе во время деятельности нефтегазового комплекса в прибрежном зоне и на морском шельфе возможны аварийные ситуации, сопровождающиеся выбросом буровых растворов и отработанных масел, в том числе трансформаторных, в следствии чего для защиты крайне чувствительных экосистем севера острова Сахалин необходим постоянный мониторинг их состояния. Данное намерение согласуется с рекомендациями группы экспертов штата Аляска (США) на осуществление экологического мониторинга при добычи нефти на шельфе о. Сахалин [8]. В ходе работы нам не удалось установить связи с географическим расположением станций и обнаружением на них ХОП. 


\subsection{2. Озеро Ханка}

Еще одной серьезной проблемой влияния хозяйственной деятельности на экологическое благополучие региона является загрязнение оз. Ханка. По данным Приморского центра мониторинга загрязнения окружающей среды, вода оз. Ханка характеризуется как «очень загрязненная». Водоем уже не может самостоятельно ассимилировать загрязнение, поступающее в него с хозяйственно-бытовыми и поверхностными стоками. Серьезный урон окружающей среде наносят применяемые методы обустройства мелиоративных систем на возделываемых вблизи озера рисовых чеках, вынос плодородного слоя с которых (в сбросные каналы и далее в само озеро) негативно воздействует на окружающую среду, ее растительный и животный мир из-за применения большого количества пестицидов и агрохимикатов китайской стороной, а так же нарушение условий хранения и использования пестицидов на российской территории.

Содержание ДДТ в водах оз. Ханка варьировались в пределах - от 0,0000249 до 0,0000496 мг/л, ДДД - от 0,0000202 до 0,0000341 мг/л, ГХБ (гексахлорбензол) - от 0,0000061 до 0,000025 мг/л, $\gamma$-ГХЦГ - от 0,000003

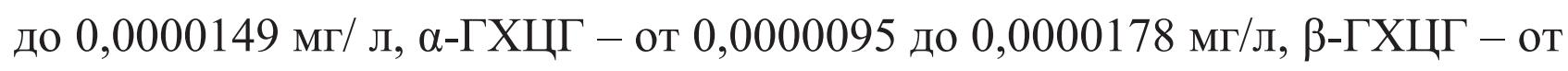
0,0000157 до 0,0000649 мг/л (рис. 5.1). С точки зрения времени нахождения ГХЦГ применялись относительно давно, о чем свидетельствует коэффициент отношения $\gamma$-формы к сумме $\alpha$ - и $\beta$-изомеров. На всех исследованных станциях он не превышал 0,2, что говорит о давности поступления активного изомера - линдана. Напротив отношение ДДТ/(ДДЕ+ДДД) было выше 2,5, что несомненно подтверждает активное использование ДДТ в настоящее время в сельском хозяйстве в качестве инсектицида, несмотря на ратификацию Стокгольмской конвенции о стойких органических загрязнителях.

Наиболее загрязненной точкой оказалась р. Астраханка протекающая возле одноименного села около оз. Ханка. Сумма содержания хлорорганических пестицидов составила 0,001034 мг/л. Превышение ПДК ГХЦГ в 38 раз, ДДТ в 315 раз и ГХБ в 32 раза. Поступление ДДТ в р. Астраханку считается относительно давним, а вот ГХЦГ - «свежим».

Ерик - небольшая нерестовая река, впадающая в оз. Ханка вблизи села Камень-Рыболов. В прибрежной ее части, как в прочем и везде, в Приханской низменности, расположены зоны, на которых ведется актив- 
ное сельское хозяйство. Визуальный осмотр показал, что воды с сельскохозяйственных территорий беспрепятственно поступают в этот водоток. Содержание нетрасформированного ДДТ - 0,0000619 мг/л. Метаболитов ДДТ обнаружено не было, что является прямым свидетельством незаконного применения запрещенного инсектицида в агрохимических целях на территории Приморского края. В донных отложениях этой реки были обнаружены все изомеры ГХЦГ $(\alpha-0,0105$ мг/кг, $\beta-0,0084$ мг/кг, $\gamma-0,0050$ мг/кг) - поступление оценивается как давнее, метаболиты ДДТ (ДДТ - 0,0172 мг/кг, ДДЕ - 0,0072 мг/кг, ДДД - 0,0160 мг/кг) и гексахлорбензол. Суммарное содержание ХОП составила 0, 0677 мг/кг, а соотношение трансформированных изомеров и метаболитов говорит о хроническом загрязнении.

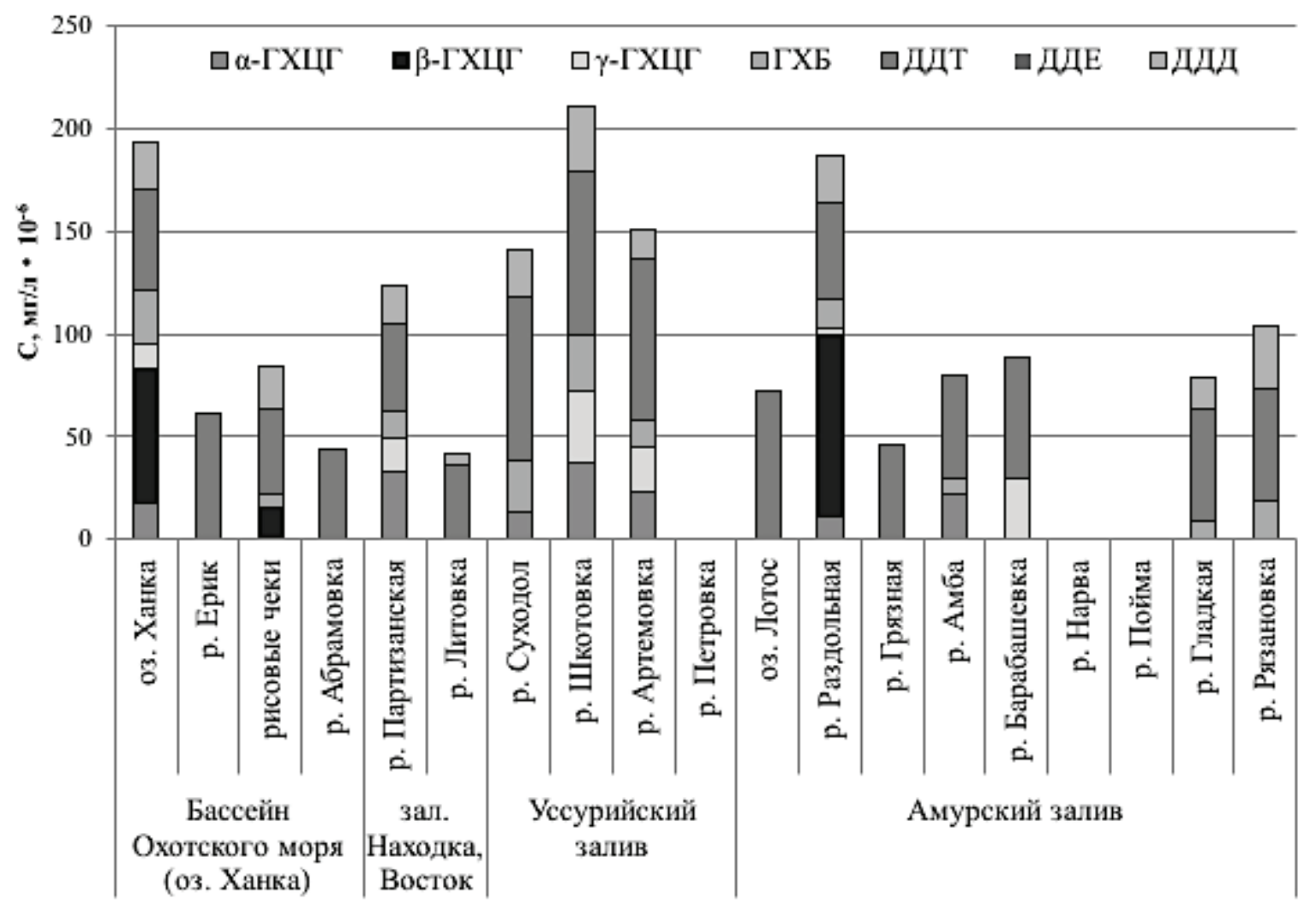

Puc. 5.1. Содержание ХОП в исследованных образцах воды (реки)

Схожая ситуация была зафиксирована в экосистеме р. Абрамовка. Содержание ДДТ было несколько ниже - 0,0000437 мг/ л, метаболитов ДДТ также не обнаружено. Несмотря на то, что в воде не было обнаружено ГХЦГ и гексахлорбензола, в донных отложениях их концентрации со- 
ставили 0,0117 мг/кг и 0,0045 мг/кг соответственно. Концентрации ДДД сопоставимы с таковыми для ДДТ. Общее содержание пестицидов в донных осадках составило 0,0467 мг/кг.

\subsection{3. Японское море}

Основным поставщиком хлорорганических пестицидов в акваторию Японского моря со стороны Российской Федерации является залив Петра Великого (ЗПВ), поэтому основное внимание было уделено акваториям, входящим в залив и испытывающих сильный антропогенный стресс.

Наиболее крупными заливами второго порядка ЗПВ, на берегах которых расположены крупные промышленные предприятия, являются Амурский залив, Уссурийский залив, залив Находка, залив Посьета.

Уссурийский залив является частью ЗПВ. К его западному берегу выходит восточная часть г. Владивостока, а также расположен рекультивированный в 2011 г. полигон твердых бытовых отходов города. В северную часть залива - б. Муравьиную впадают р. Артемовка с крупным притоком р. Кневичанкой, собирающих стоки г. Артема и его пригородов. В восточную часть залива впадает р. Шкотовка, куда сбрасывают сточные воды п. Шкотово. Еще южнее на восточном побережье залива располагается бух. Суходол с одноименной рекой, которая несет загрязнения от пос. Смоляниново и с. Романовка. На берегу бухт Большого камня и Андреева расположен г. Большой камень, известный своим предприятием - центром судостроения и судоремонта ОАО Дальневосточный завод «Звезда» [18].

Основное антропогенное влияние в результате сброса загрязненных сточных вод испытывают следующие водные объекты округа: р. Артемовка, p. Шкотовка, p. Суходол, р. Рязановка. Река Раздольная с притоками является приемником загрязненных и недостаточно очищенных сточных вод г. Уссурийска и Октябрьского муниципального района; р. Партизанская - г. Партизанска и его муниципального района [7]. В бассейне р. Раздольной находятся МУП Водоканал, АО «Приморский сахар», АО «Дальсоя», картонная фабрика и другие предприятия - водопользователи, которые забирают чистую воду реки для производства, затем сбрасывают сточные воды с недостаточной степенью очистки обратно. Сточные воды не всегда сбрасываются непосредственно в реку или ее притоки, доста- 
точно часто приемником их служит рельеф местности и тогда загрязнения попадают в реку с ливневыми стоками [25].

Результаты расчета показали (рис. 5.1), что свежего поступления $\gamma$ ГХЦГ в воды р. Артемовки, р. Шкотовки, р. Суходол в исследованный период не было, а содержание $\alpha$-изомера составило 0,0000228 мг/л, 0,0000370 мг/л и 0,0000133 мг/ л соответственно. Напротив ДДТ был обнаружен в водах всех рек, и его содержание составило 0,0000640-0,0000796 мг/л. Содержания ГХБ (гексахлорбензол) варьировались в пределах - от 0,0000128 мг/л до 0,000027 мг/л. Известно, что ДДТ достаточно устойчив в окружающей среде, его трансформация происходит в течение длительного времени. Обнаруженные содержания метаболита ДДД в водах этих рек было достаточно высоким и достигало 0,0000314 мг/ л (р. Шкотовка). Таким образом загрязнение с одной стороны является острым (превышение ПДК по ДДТ составило в 31 раз), с другой стороны - хроническим из-за сопоставимого с ДДТ содержанием глубоко трансформированного метаболита ДДД. Согласно количественным отношениям концентраций изомеров ГХЦГ можно сделать вывод о том, что линдан практически перестал использоваться на территориях сельхозугодий в пределах водосборного бассейна этих рек, а поступление соединений, образовавшихся в результате изомеризации ГХЦГ с течением времен, все еще существенно.

В донных отложениях рек Уссурийского залива ситуация была менее критична, хотя достаточно высокие концентрации ХОП были обнаружены в донных отложениях р. Шкотовки, р. Артемовки, р. Партизанской. Однако здесь общее содержание не превышало 0,0947 мг/кг, а поступление ДДТ и ГХЦГ было оценено как давнее. Источником загрязнения донных отложений исследованных акваторий несомненно является активное сельское хозяйство на берегах рек, а также деятельность крупных предприятий энергетики и рыбоперерабатывающей промышленности.

Основными эмитентами хлорорганических пестицидов в воды Амурского залива являются выпуски сточных воды Владивостока и Уссурийска. Вклад г. Уссурийска обусловлен стоком р. Раздольной, а вклад Владивостока - с выпусками недостаточно очищенных или неочищенных вод в черте города: «Верхне-Портовый», «Первая Речка», «Вторая Речка», «Де-Фриз».

Содержание хлорорганических пестицидов в кутовой части Амурского залива (эстуарная зона реки Раздольная) составляет 0,0001868 мг/л и 
по отдельным компонентам превышает ПДК в 160 раз. В донных отложениях эстуария реки Раздольная суммарное содержание ХОП 0,0326 мг/кг. Расчет коэффициентов давности поступления свидетельствуют о том, что ДДТ все еще продолжает поступать в воды залива (терригенный сток с сельскохозяйственных угодий). Загрязнение ГХЦГ можно оценить как относительно давнее, однако суммарное содержание его изомеров свидетельствует о хроническом загрязнении. В центральной части залива содержание хлорированных пестицидов несколько снижается, но остается существенным даже в открытой части залива. Так в водах западной части островных территорий (о. Рейнеке и Рикорда) суммарное содержание ХОП превышало значение, зафиксированное в кутовой части, и составило более 0,000025 мг/л. Вероятно такая высокая концентрация связана со стоянкой судов на рейде, незаконной бункеровкой и сбросом льяльных вод в этом районе.

Гексахлорбензол был обнаружен в водах всех исследованных акваторий Амурского залива. Его содержание составляло до 0,0000270 мг/л и превышало ПДК в 2,7 раза.

Одна из крупных и освоенных бухт острова Русский - б. Новик, глубоко вдающаяся в северную часть западного берега острова. Содержания $\gamma$-ГХЦГ находились в пределах - от 0,0000072 до 0,0000105 мг/л, $\alpha$ - ГХЦГ от 0,0000041 до 0,0000082 мг/л. ГХБ (гексахлорбензол) был обнаружен только в восточной части бухты - 0,0000065 мг/л, там же был обнаружен метаболит ДДД - 0,0000064 мг/л. На остальных станциях ДДТ, ДДЕ и $\beta$ ГХЦГ обнаружены не были, их содержание находилось ниже границы определяемых концентраций. Сумма хлорорганических пестицидов находилась в диапазоне от 0,0000112 до 0,0000271 мг/л (рис. 5.2).

Результаты расчета показали относительно «свежее» поступление $\gamma$ ГХЦГ на всех исследованных станциях. Поступление ДДТ на всех станциях оказалось давним. Превышение ПДК метаболита ДДД составило 6,4 раза.

Таким образом, самой загрязненной частью бухты оказался прибрежный район ее восточной части. Наличие загрязнения вероятнее всего связано с рекреационной нагрузкой, активным судоходством маломерных судов, строительством объектов, принадлежащих кампусу ДВФУ на побережье бухты Лесника, а также несанкционированным сбросом сточных вод на рельеф, постепенно стекающих в б. Новик. По оценкам отходы жизнедеятельности населения о. Русского составляют не менее 10 тыс. м 
ежедневно, или 4 млн. ${ }^{3}$ в год. Эти объемы грязной пресной воды могут существенно изменить экологическую ситуацию в узкой, мелководной бухте Новик. Таким образом, через несколько лет безусловно возникнет необходимость в оценке состояния вод б. Новик, а также в регулярном контроле состояния среды и биоты, позволяющем отследить формирующиеся тенденции в экосистеме бухты [24].

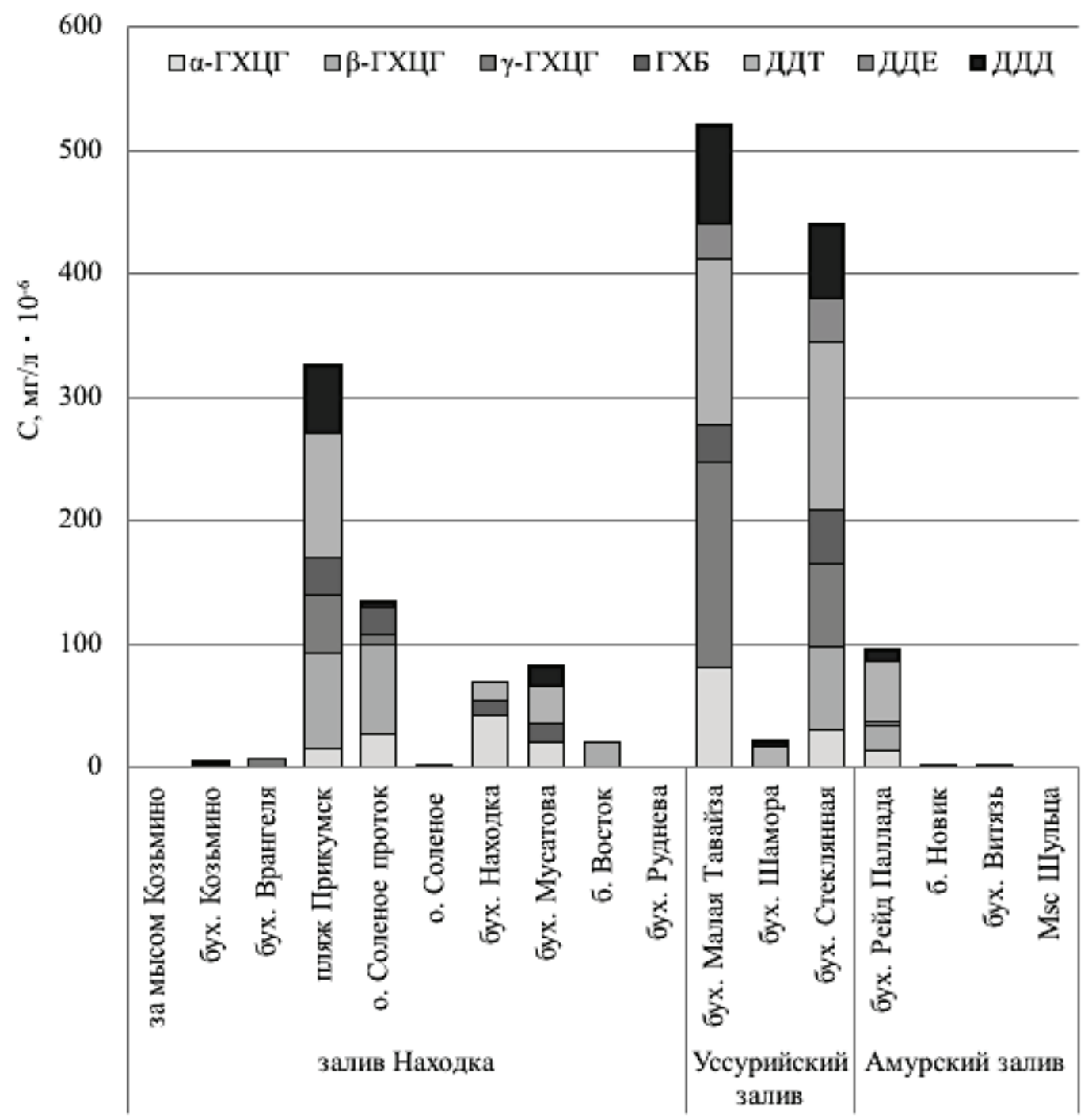

Рuc. 5.2. Содержание ХОП в исследованных образцах воды (морская вода)

Как уже говорилось выше, основными «поставщиками» ХОП в Амурский залив является терригенный сток, однако нельзя забывать и о чрезвычайно негативном воздействии морских портов, железнодорожного транспорта и активно развивающейся дорожной сети (мостовые переходы, развязки, скоростные трассы, проходящие в прибрежной части залива). 
В отличие от морской воды, содержание хлорорганических пестицидов в донных отложениях значительно меньше подвержено колебаниям и может достовернее характеризовать уровень и степень загрязнения.

В исследованных донных отложениях на всех станциях зафиксированы $\alpha$ - и $\beta$-изомеры ГХЦГ (0,0050-0,0017 мг/кг). Линдан был обнаружен только в грунтах открытой части залива (0,0404-0,1211 мг/кг). Причем отношение, свидетельствующее о давности поступления, было значительно выше единицы, что в целом нехарактерно для исследованных экосистем. Происхождение загрязнения линданом части Амурского залива с достаточно активным гидрохимическим режимом может иметь только одно объяснение. На берегах юго-западной части Амурского залива расположены ремонтные предприятия в пгт. Славянка имеют в своем составе очистные сооружения с механическими и биологическими методами очистки промышленных и бытовых стоков предприятий и жилой застройки. Выделенные в процессе очистки осадки вывозятся с очистных сооружений и дальнейшей утилизации не подвергаются. Очищенные сточные воды используются для технологических целей и сбрасываются в прибрежные воды Амурского залива [16]. По данным водного бассейнового управления Росводресурсов по Приморскому краю (государственная статистическая отчетность по использованию воды, форма 2ТП-водхоз) в зал. Посьета в 2013 г. осуществляли сброс сточных вод 6 предприятий - ООО «Зарубинская база флота», ООО «Морской порт», тепловой район «Хасанский» КГУП «Примтепло-энергия», ОАО «Славянка», торговый порт «Посьет», ООО «Акватехнологии». Наибольшее количество сточные воды сбрасывают предприятия водно-коммунального хозяйства (тепловой район «Хасанский» и филиал уссурийского ОАО «Славянка»), что составляет порядка 75 \% от общего стока. Сточные воды, сбрасываемые в зал. Посьета, имеют категорию «без очистки» и «недостаточно очищенные» [16].

В донных отложениях рек бассейна Амурского залива суммарное содержание хлорорганических пестицидов варьировалось от 0,0049 до 0,1850 мг/кг. Наиболее загрязненными являлись грунты рек Раздольная и Барабашевка. Максимально содержание ХОП в донных отложениях зафиксировано в р. Пойме - 0,1850 мг/кг. Причем поступление ГХЦГ и ДДТ оценивается как давнее. Одним из возможных эмитентов ХОП, являются тихоокеанские лососи, накапливающие пестициды в тканях в местах нагула и переносящие их в районы нереста. [29] По уровню загрязнения 
ХОП реки можно расположить в следующем порядке: Нарва и Пойма (не обнаружено $)<$ Грязная $(0,0000465$ мг/л) < Гладкая $(0,0000789$ мг/л) < Амба $(0,0000798$ мг/л) < Барабашевка $(0,0000885$ мг/л) $<$ Рязановка $(0,0001035$ мг/л) < Раздольная $(0,0001868$ мг/л). В отношении донных отложений, как свидетельство о хроническом загрязнении, порядок рек будет иной: Рязановка $(0,0057$ мг/ кг) $<$ Грязная $(0,0168$ мг/кг $)<$ Раздольная $(0,0326$ мг/кг) < Нарва $(0,0491$ мг/кг) < Барабашевка $(0,0553$ мг/кг $)<$ Пойма $(0,1850$ мг/кг).

Река Туманная большей своей частью является водной границей между КНР и КНДР, в низовьях и эстуарной части - между КНДР и Россией. 70\% водостока реки формируется на территории КНР и почти $30 \%-$ на территории КНДР. Доля России в формировании водосбора составляет менее $1,0 \%$. Согласно расчетным данным годовой сток реки Туманной составляет $5,7 \mathrm{Kм}^{3}$ [22].

Экологическое состояние реки можно расценивать как катастрофическое. Обнаруженная концентрация ХОП составила 0,005636 мг/л. ПДК для ГХЦГ было превышено в 4470 раз, ДДТ в 65 раз, ГХБ в 85 раз. Показано, что практически все пестициды претерпели серьезную трансформацию: обнаружены значительные содержания $\alpha$ - и $\beta$-изомеров ГХЦГ $(0,0007663$ мг/л и 0,00208 мг/л соответственно) и метаболитов ДДТ (ДДЕ - 0,0001651 мг/л, ДДД - 0,0000803 мг/л), что может свидетельствовать о сокращении использования этих пестицидов в КНР и КНДР, но чрезвычайно серьезное загрязнение в настоящий момент территории водосборного бассейна реки Туманной в КНР и КНДР еще долго будет негативно сказываться на экологическом состоянии не только вод реки, но и вод Залива Петра Великого, куда она впадает и эмитирует высокотоксичные продукты трансформации ХОП. Со стороны Российской Федерации река Туманная не является судоходной, на ее берегах отсутствуют крупные населенные пункты. Таким образом вывод о том, что основное загрязнение поступает со стороны правого рукав реки, распложенного на территории КНР, где в последние годы идет интенсивное развитие промышленности, является вполне логичным.

В пробах воды, взятых в озере Лотос, расположенном всего в нескольких сотнях метров от реки Туманной, содержание ХОП почти в сто раз меньше, чем в водах р. Туманной. Зафиксирован был только ДДт, что свидетельствует о остром загрязнении (отбор проб воды производился в 
период сильных ливневых дождей и нетрасформированный ДДТ попал с терригенным стоком).

В одном из излюбленные мест отдыха туристов, в б. Витязь, расположенной на юго-западе зал. Петра Великого, в отношении загрязнения ХОП ситуация относительно благополучная. Общее содержание ХОП в воде находилось на уровне 0,00005 мг/л. Самой чистой частью Амурского залива являются прибрежные воды м. Шульца - содержание пестицидов было ниже предела обнаружения.

Таким образом по уровню загрязнения хлорорганическими пестицидами Амурский залив относится к акваториям, испытывающим сильнейший антропогенный стресс. Полученные данные свидетельствуют о хроническом характере загрязнения этой акватории.

Залив Находка является одной из наиболее освоенных акваторий в Приморском крае. На его побережье расположены порты и промышленные предприятия, в акватории - рыбопромысловые участки по добыче биоресурсов. Восточное побережье сильно подвержено рекреационному воздействию. Источником загрязнения также является р. Партизанская, впадающая в залив. С ее водами выносятся стоки г. Партизанска и близлежащих сельскохозяйственных угодий. [14]

В настоящее время экологическое состояние б. Козьмина, расположенной на крайнем востоке зал. Петра Великого, представляет большой интерес и требует постоянного контроля. Это связано с ее активным производственным и хозяйственным освоением и, как следствие, с возрастающим антропогенным воздействием на воды как непосредственно самой бухты, так и всего зал. Находка, юго-восточной, частью которого она являются [30].

Одной из самых загрязненных исследованных акваторий зал. Находка оказалось оз. Второе. Суммарное содержание пестицидов составило 0,003171 мг/л. Поступления пестицидов, как ДДТ, так и ГХЦГ по расчетным данным является давним. Превышение ПДК для вод рыбохозяйственных акваторий составило для $\gamma$-ГХЦГ более, чем в 300 раз, для ДДТ - в 120 раз, а для ГХБ более чем в 60 раз. Экологическое неблагополучие данного района безусловно связано с деятельностью промышленных предприятий г. Находка, расположенных на берегах озера, а также активным терригенным стоком. 
Река Партизанская является, пожалуй, одним из основных поставщиков ХОП в акваторию зал. Находка. Летом в период тайфунов и сильных ливневых дождей содержание $\gamma$-ГХЦГ составило 0,0000156 мг/л, обнаружен $\alpha$-изомер - 0,0000334 мг/л, ГХБ 0,0000131 мг/л, ДДТ - 0,0000426 мг/л и ДДД - 0,0000188 мг/л. Суммарное содержание ХОП составило 0,0001234 мг/л, что сопоставимо с выносом пестицидов р. Артемовкой, Шкотовкой, Суходол. Поступление ДДТ оценивалось как «свежее», а ГХЦГ - давнее. В грунтах р. Партизанской были обнаружены $\alpha$-ГХЦГ, что говорит о хроническом загрязнении этим пестицидом (0,0058 мг/кг) и ДДТ $(0,0097$ мк/кг), что напротив свидетельствует о его недавнем поступлении (метаболиты ДДД и ДДЕ обнаружены не были).

В относительно небольших акваториях водосборного бассейна залива Находка суммарное содержание пестицидов в среднем не превышало 0,0001 мг/л за исключением аномально высоких содержаний в прибрежных водах причала Прикумск (б. Врангеля). По загрязненности воды исследованные районы бухты Находки расположились в следующем порядке: м. Козьмина (не обнаружено) < б. Козьмина $(0,0000049$ мг/л) < б. Врангеля, Восточный порт $(0,0000066$ мг /л) < м. Петровского $(0,0000181$ мг/л) < оз. Соленое $(0,0000274$ мг/л) < б. Мусатова $(0,0000822$ мг/л) < м. Шефнера $(0,0000823$ мг/л) < протока оз. Соленого $(0,0001359$ мг/л) < причал Прикумск

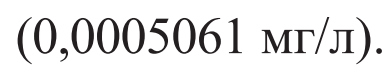

По загрязненности донных отложений порядок был несколько иной, самым загрязненным районом оказался м. Шефнера $(0,1387$ мг/кг), а наиболее чистым порт Восточный $(0,0172$ мг/кг), что также вполне объяснимо тем, что акватория зал. Находка эксплуатируется гораздо дольше и активнее, чем б. Врангеля, на берегах которой расположен топливноналивной комплекс, продолжается активное строительство терминалов, и характер загрязнения еще не успел перейти в разряд хронического, чему могут свидетельствовать коэффициенты трансформации ХОП, которые были выше единицы. 


\subsection{4. Трансграничный перенос в СЗТО}

С точки зрения глобального переноса загрязнения, в том числе и хлорорганических пестицидов, Российскую Федерацию не следует относить к основным странам-эмитентам ХОП. Несмотря на то, что значительная часть России расположена в Азии, большая часть ее территории никогда не подвергалась антропогенному воздействию, сельскохозяйственные угодья, где могли бы быть использованы пестициды, значимо меньше, чем у странсоседей. Однако из-за особенностей геофизических, гидрологических и атмосферных факторов на территорию России переносятся значительные массы загрязняющих веществ от промышленно развитых азиатских стран. Краткая характеристика возможных путей переноса поллютантов в азиатско-тихоокеанском регионе представлена на рисунке 5.3.

Основным приемником и как следствие источником трансграничного переноса стойких органических загрязнителей, безусловно, являются водные массы Мирового океана. Во-первых, это связано с огромным объемом Мирового океана, разными гидрологическими гидрохимическими режимами его акваторий, что позволяет переносить даже практически нерастворимые вещества на дальние расстояния. Во-вторых, Мировой океан является приемником терригенных сточных вод с территорий, на которых расположены крупные промышленные предприятия, являющиеся одним из важнейших эмитентов СО3 антропогенного происхождения, так или иначе попадающих в воды океанов. На достаточно сложном пути от выброса CO3 до их растворения в водах океана происходит ряд зачастую плохо поддающихся описанию и существующим методам моделирования химических превращений, среди которых фотохимическая деградация, микробиальная деструкция, взаимодействия с компонентами экосистем. В связи с наличием огромного количества этих факторов предсказать конечную судьбу CO3 бывает очень сложно. Однако последние годы все чаще упоминается проблема трансграничного переноса поллютантов различного происхождения на значительные расстояния. Так полихлорированные бифинилы, диоксины, хлорорганические пестициды, полиароматические углеводороды, алкилфенолы обнаружены в живых организмах, льдах, водах, донных отложений в Арктике и Антарктике, где они никогда не производились. Поэтому проблема изучения трансграничного переноса является крайне важной. 
Моря Китайское и Желтое, в зависимости от господствующих в них муссонных ветров, имеют и течения периодического характера. В Китайском море зимой течение идет от Тайваньского пролива вдоль материка Азии на юг. А у берегов Вьетнама течение разделяется: одна ветвь идет на Борнео и, повернув около него на север, проходит вдоль Филиппинских островов, образуя круговорот против часовой стрелки.

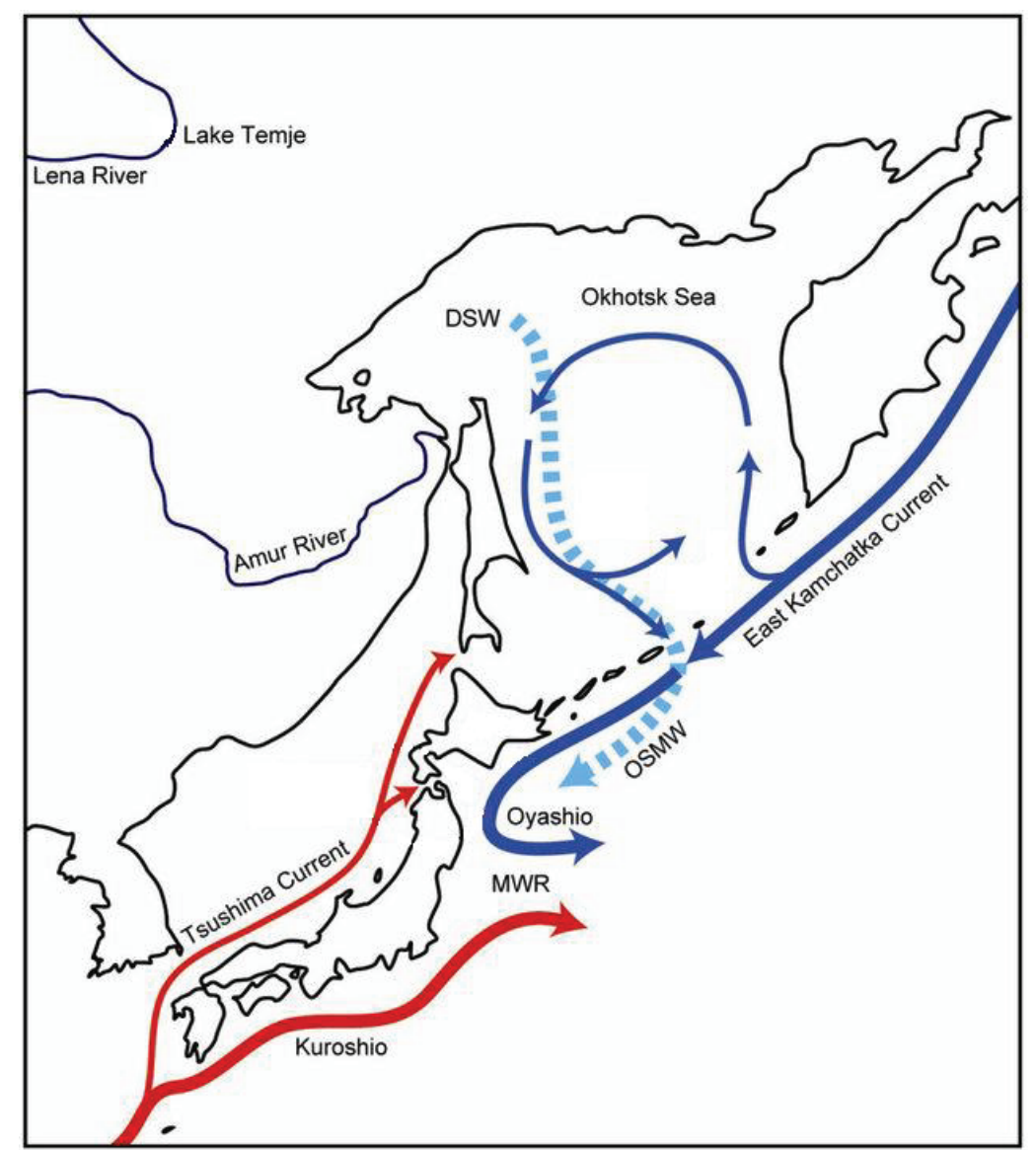

Puc. 5.3. Карта течений в северо-западной части Тихого океана. Холодные (синие стрелки) и теплые (красные стрелки) поверхностные течения, смешанная водная область (MWR) у слияния Куросио-Оясио. Пунктирная синяя стрелка схематически иллюстрирует опускание плотных шельфовых вод (DSW) и отток воды Охотского морского режима (OSMW) в северо-западную часть Тихого океана [28].

Зимой от Тайваньского пролива к северу в Желтом море существуют два течения. Первое - холодное течение идет вдоль материка Азии на се- 
вер, оно в Тайваньском проливе придерживается берега Азии. Есть следствие существования здесь рукава теплой воды Японского течения (Куросио), которое, таким образом, омывает и восточный и западный берег Тайваня. Второе течение Желтого моря образовано ветвью Японского течения (Куросио), отходящей от него влево и идущей вдоль Кореи. Таким образом, и в Желтом море образуется круговорот против часовой стрелки.

В Желтом море при северо-западном муссоне, наблюдается общее движение вод на север вдоль Кореи, оно образовано ветвью Японского теплого течения совместно с течением, идущим на юго-восток из Китайского моря через Тайваньский пролив.

В Японском море идет ветвь Японского течения (Куросио), входящая в него с юга через Корейский пролив под именем Цусимского течения. В Японском море это течение уклоняется вправо и идет вдоль берега Японии. Большая часть теплой воды Цусимского течения выходит в океан через Сангарский пролив (пролив между японскими островами Хонсю и Хоккайдо, соединяет Японское море с Тихим океаном), остальное же течение идет до пролива Лаперуза (между о. Хоккайдо и Сахалин) и через него частью выходит в Охотское море. У берегов материка в Японском море наблюдаются холодные воды, обуславливаемые, по всей вероятности, поднятием воды с глубин. Во всяком случае, некоторое движение вод на юг вдоль русских берегов и части Кореи существует, также подтверждается, что часть Цусимского течения проходит вдоль Сахалина на север в Татарский залив.

В Охотском море течение вдоль западного берега Камчатки идет на север, а по берегу материка и Сахалина - на юг, образуя круговорот против часовой стрелки.

В Беринговом море сколько-нибудь ясно выраженных и сильных течений не существует. По восточному берегу моря и вдоль Камчатки замечается движение холодной воды на юг, которое продолжается и далее вдоль океанической окраины Курильских островов и северных Японских, давая начало холодному течению Ойясио, получающему также воду из Сангарского пролива от ветви Цусимского течения.

В Беринговом проливе господствуют приливо-отливные течения, так же, как и по всему американскому побережью этого моря. Течение у берега Азии имеет направление на юг, а у берега Америки - на север. Никакой 
ветви теплого Японского течения (Куросио) не проходит в Берингово моpe, и, следовательно, такой ветви не может быть и в Беринговом проливе.

Сельскохозяйственные угодья расположены в основном на прибрежных равнинах и в долинах рек, поэтому неудивительно, что реки принимают сельскохозяйственные стоки и выносят остатки пестицидов в эстуарии и прибрежные зоны морей. Пестициды в речных стоках выносятся в море в растворенном состоянии и сорбированными на взвеси.

Река Чжуцзян Китай собирает воду с обширных плодородных земель и потенциально выносит остатки пестицидов в Южно-Китайское море. Далее речные стоки поступают в открытую часть Южно-Китайского моря и подхватываются течением, которое идет от Тайваньского пролива к северу в Желтое море. Течение Желтого моря, образованное ветвью Японского течения (Куросио) идет вдоль Кореи. Желтое море - район интенсивного судоходства между промышленно развитыми регионами Китая и Южной Кореи. Кроме того, из-за интенсивного судоходства здесь нередко происходят техногенные катастрофы. Таким образом, воды Желтого моря подвергаются загрязнениям пестицидами. Ветвь Японского течения (Куросио) Желтого моря подхватывает загрязнения, поступившие из Южно-Китайского моря и вдоль берегов Кореи через Корейский пролив входит в Японское море под именем Цусимского течения. Большая часть Цусимского течения выходит в открытую часть Тихого океана через Сангарский пролив, небольшая часть остального течения выходит в Охотское море. Воды Охотского моря по сравнению с водами Японского моря являются более чистыми, и их основное загрязнение может быть связано с трансграничным переносом морскими течениями и воздушными массами. Пестициды, поступившие в Охотское море с течениями, переносятся Приморским течением к берегам Приморского края в зал. Петра Великого. Несмотря на загрязненность вод зал. Петра Великого обоснованных общностью некоторых рек с Китаем, сток которых направляется непосредственно в залив, также большое влияние на загрязненность оказывает трансграничный перенос загрязняющих веществ с берегов Южно-Восточной Азии.

Таким образом, предпринята попытка описать источники эмиссии ХОП в северо-западной части Тихого океана, пути поступления поллютантов, их трансформацию и перенос с водными массами из загрязненных акваторий юго-восточной Азии в воды исключительной экономической зоны Российской Федерации. 
Океан остается конечным резервуаром, принимающим стойкие органические загрязнители, и биоаккумуляция пестицидов в океане по пищевым цепям продолжается. На глубинах от 0 до 100 м могут концентрироваться атмосферные выпадения и осевшие на частицы взвеси поллютанты, а также токсичные продукты разложения пластика, которые могут аккумулироваться гидробионтами [10].

Присутствие пестицидов в районах обитания гидробионтов, удалённых от хозяйственной деятельности, является следствием их глобального переноса ветрами и течениями из районов использования (тропическая и субтропическая зоны) в умеренные широты. Кроме того, мигрирующие рыбы осуществляют биотранспорт органических загрязнителей от субтропических к субарктическим экосистемам [11].

\section{5. Список литературы}

1. Артамонова, В.Г. Профессиональные болезни: изд. 4-е перераб. и доп. / В.Г. Артамонова, Н.А. Мухин. - М.: Медицина, 2004. - 480 с.

2. Болезни рыб: справочник / Г. В. Васильков, Л. И. Грищенко, В. Г. Енгашев [и др.]. - М. : Агропромиздат, 1989. - 288 с.

3. ДДТ (инсектицид) / Академик [Электронный ресурс] : электронная энциклопедия. - Режим доступа : http:/dic.academic.ru/dic.nsf/ru wiki/1473761.

4. Галиулин, Р.В. Импактные зоны стойких хлорорганических соединений в окружающей среде / Р.В. Галиулин, Р.А. Галиулина // Агрохимия. - 2011. - № 3. - С. 83-89.

5. Гексахлорциклогексан (ГХЦГ)/Химик [Электронный ресурс] : сайт о химии. - Режим доступа : http:/www.xumuk.ru/toxicchem/161.html.

6. Добровольский, А. Д. Моря СССР / А.Д. Добровольский, Б.С. Залогин. - М.: Изд. Московского университета, 1982. - 191 с.

7. Качество морских вод по гидрохимическим показателям. Ежегодник 2015. / под ред. А.Н. Коршенко. - М.: «Наука», 2016. - 184 с.

8. Лоан . Д. Сахалинская нефть: как обеспечить безопасность / Д. Лоан, Р. Штайнер, Д.Уэллс. - Валдез, Аляска. - 1999. - 42 с. 
9. Лоция северо-западного берега Японского моря (№ 1401) / под общ. ред. Ю.В. Старкова. - СПб.: ЦКФ ВМФ, 2005. - 395 с.

10. Лукьянова, О.Н. Биотранспорт пестицидов Тихоокеанскими лососями в северо-западной пацифике / О.Н. Лукьянова, В.Ю. Цыганков, М.Д. Боярова, Н.К. Христофорова // Доклады академии наук. - 2014. Т. 456. - №. 3. - С. 363-365.

11. Лукьянова, О.Н. Тихоокеанские лососи рода Oncorhynchus как вектор переноса стойких загрязняющих веществ в океане / О.Н. Лукьянова, В.Ю. Цыганков, М.Д. Боярова, Н.К. Христофорова // Вопросы ихтиологии. - 2015. - Т. 55. - №. 3. - С. 351-355.

12. Майстренко, В.Н. Эколого-аналитический мониторинг супертокикантов / В.Н. Майстренко, Р.З. Хамитов, Г.К. Будников. - М.: Химия, 1996. -319 c.

13. Максименко, О. Пестициды с точки зрения химика /О. Максименко // Наука и жизнь. - 2003. - №. 3. - С. 56-57.

14. Наумов, Ю.А., Экологическое состояние залива Находка / Ю.А. Наумов, Т.Х. Найденко // Известия ТИНРО. - 1997. - Т. 122. C. 524-537.

15. Нгуен, Д.К. Влияние температуры воды на формирование биологической и промысловой продуктивности Южно-Китайского моря / Д.К. Нгуен, В.Н. Малинин, С.М. Гордеева // Ученые записки Российского государственного гидрометеорологического университета. - 2016. № 42. - С. 64-73.

16. Нигматулина, Л.В. Загрязнение прибрежных вод залива Посьета (залив Петра Великого, Японское море) в условиях современной хозяйственной деятельности / Л.В. Нигматулина, А.П. Черняев // Известия ТИНРО. - 2015. - Т. 182. - С. 162-171.

17. Ноймайстер, Л. Руководство к действию в области пестицидов / Л. Ноймайстер. - Гамбург. : PAN Germany, 2003. - 47 с.

18. Патрушева, О.В. Нефтеуглеводороды в водах Уссурийского залива / О.В. Патрушева, Е.Н. Чернова, О.Н. Бабичева // Новая наука: современное состояние и пути развития. - 2015. - Вып. 6-3. - С. 5-10.

19. Пестициды: вчера, сегодня, завтра / МСХА им. К.А. Тимирязева [Электронный ресурс] : сайт зооинженерного факультета. - Режим доступа: http://www.activestudy.info/pesticidy-vchera-segodnya-zavtra/. 
20. ПНД Ф 14.1:2:3:4.204-04 Количественный химический анализ вод. Методика измерения массовых концентраций хлорорганических пестицидов и полихлорированных бифенилов в пробах питьевых, природных и сточных вод методом газовой хроматографии.

21. Приказ Министерства сельского хозяйства РФ от 13 декабря 2016 г. N 552 "Об утверждении нормативов качества воды водных объектов рыбохозяйственного значения, в том числе нормативов предельно допустимых концентраций вредных веществ в водах водных объектов рыбохозяйственного значения"

22. Труды туманганской экспедиции // www.imb.dvo.ru.

23. Федоров, Л.А. Пестициды - токсический удар по биосфере и человеку / Л.А. Федоров, А.В. Яблоков. - М. : Наука, 1999. - 461 с.

24. Христофорова, Н.К. Химико-экологическое состояние вод бухты Новик (остров Русский, зал. Петра Великого, Японское море) / Н.К. Христофорова, Ю.Е. Дегтева, К.С. Бердасова, А.А. Емельянов, А.Ю. Лазарюк // Известия ТИНРО. - 2016. - Т. 186. - С. 135-144.

25. Хмельницкий, В.К. Проблемы утилизации промышленных и бытовых сточных вод прибрежных территорий Амурского и Уссурийского заливов / В.К. Хмельницкий // Технические проблемы освоения Мирового океана. - 2005. - Вып. 1. - С. 304-309.

26. Швиндлерман, Г.С. Пестициды / Г.С. Швиндлерман // Химик [Электронный ресурс] : сайт о химии. - Режим доступа : http://www.xumuk.ru/encyklopedia/2/3298.html.

27. Шунтов, В.П. Биология дальневосточных морей России / В.П. Шунтов. - Владивосток: ТИНРО-центр, 2001. - Т. 1. - 579 с.

28. Rella, S.F. A Southern Ocean trigger for Northwest Pacific ventilation during the Holocene? / S.F. Rella, M. Uchida // Scientific Reports. - 2014. V.4. No. 4046. - P. 1-11.

29. Tsygankov, V.Yu. Organochlorine pesticides in commercial Pacific salmon in the Russian Far Eastern seas: Food safety and human health risk assessment / V.Yu. Tsygankov, O.N. Lukyanova, M.D. Boyarova [et al.] // Marine pollution bulletin. - 2019. - V. 140. - P. 503-508.

30. http://www.sakhalin.ru/

31. https://oilcapital.ru/

32. http://www.gazprom.ru/about/production/projects/deposits/sakhalin3/ 


\title{
ГЛАВА 6
}

\section{СОВРЕМЕНЫЕ УРОВНИ СТОЙКИХ ОРГАНИЧЕСКИХ ЗА- ГРЯЗНЯЮЩИХ ВЕЩЕСТВ (СОЗ) В РЫБАХ ДАЛЬНЕВО- СТОЧНЫХ МОРЕЙ РОССИИ}

\author{
В.Ю. Цыганков ${ }^{1,2}$, М.Д. Боярова ${ }^{1}$, М.М. Донещ \\ Ю.П. Гумовская ${ }^{1}$, А.Н. Гумовский ${ }^{1}$, В.А. Лях ${ }^{1}$, А.В. Литвиненко \\ О.Ю. Бусарова ${ }^{4}$, Н.К. Христофорова ${ }^{2}$
}

\footnotetext{
${ }^{1}$ Школа биомедицины, Дальневосточный федеральный университет (ДВФУ), 690922, Владивосток, о. Русский, п. Аякс, 10. E-mail: tsig_90@mail.ru.

${ }^{2}$ Школа естественных наук, Дальневосточный федеральный университет (ДВФУ), 690922, Владивосток, о. Русский, п. Аякс, 10.

3 Институт естественных наук и техносферной безопасности, Сахалинский государственный университет (СахГУ), 693008, г. Южно-Сахалинск, ул. Пограничная, 68.

${ }^{4}$ Институт рыболовства и аквакультуры, Дальневосточный государственный технический рыбохозяйственный университет (Дальрыбвтуз), 690087, г. Владивосток, ул. Луговая, д. 52 Б.

${ }^{1}$ School of Biomedicine, Far Eastern Federal University, 10 Ajax Bay, Russky Island, Vladivostok, Russia,690922. E-mail: tsig_90@mail.ru

${ }^{2}$ School of School of Natural Sciences, Far Eastern Federal University, 10 Ajax Bay, Russky Island Vladivostok, Russia, 690922.

${ }^{3}$ Institute of Natural Sciences and Technosphere Safety, Sakhalin State University, 68 Pogranichnaya St., 693008, Yuzhno-Sakhalinsk, Russia

${ }^{4}$ Fishery and Aquaculture Institute, Far Eastern State Technical Fisheries University, 52B. Lugovaya st., 690087, Vladivostok, Russia.

Для иитирования: Цыганков В.Ю., Боярова М.Д., Донец М.М., Гумовская Ю.П., Гумовский А.Н., Лях В.А., Литвиненко А.В., Бусарова О.Ю., Христофорова Н.К. Современные уровни стойких органических загрязняющих веществ (CO3) в рыбах дальневосточных морей России // Стойкие органические загрязняющие вещества (CO3) в Дальневосточном регионе: моря, организмы, человек : монография / В.Ю. Цыганков, М.М. Донец, Н.К. Христофорова [и др.] ; науч. ред. В.Ю. Цыганков. Владивосток : Изд-во Дальневост. федерал. ун-та, 2020. - С. 128-194. - https://doi.org/10.24866/74444891-2/128-194.

For citing: Tsygankov V.Yu., Boyarova M.D., Donets M.M., Gumovskaya Yu.P., Gumovskiy A.N., Lyakh V.A., Litvinenko A.V., Busarova O.Yu., Khristoforova N.K. Current levels of persistent organic pollutants (POPs) in fish of the Russian Far Eastern Seas // Persistent organic pollutants (POPs) in the Far Eastern Region: Seas, Organisms, Human : monograph / V.Yu. Tsygankov, M.M. Donets, N.K. Khristoforova [et al.] ; ed. by V.Yu. Tsygankov. - Vladivostok : Publishing House of the Far Eastern Federal University, 2020. - P. 128-194. https://doi.org/10.24866/7444-4891-2/128-194.
} 
В главе показаны исследования содержания изомеров ГХЦГ, ДДТ и его метаболитов, конгенеров ПХБ в органах и тканях тихоокеанских лососей и камбал из дальневосточных морей России. Описаны внутривидовые, межвидовые и географические различия в накоплении опасных токсикантов.

Ключевые слова: ГХЦГ; ДДТ; ПХБ; тихоокеанские лососи; камбала; дальневосточные моря.

\title{
CHAPTER 6. Current levels of persistent organic pollutants (POPs) in fish of the Russian Far Eastern Seas
}

\author{
V.Yu. Tsygankov ${ }^{1,2}$, M.D. Boyarova ${ }^{1}$, M.M. Donets ${ }^{1}$, \\ Yu.P. Gumovskaya ${ }^{1}$,A.N. Gumovskiy ${ }^{1}$, V.A. Lyakh ${ }^{1}$, A.V. Litvinenko ${ }^{3}$, \\ O.Yu. Busarova ${ }^{4}$, N.K. Khristoforova ${ }^{2}$
}

In the chapter, research of the isomers of $\mathrm{HCH}$, DDT and its metabolites, $\mathrm{PCB}$ congeners content in the organs and tissues of Pacific salmon and flounders from the Far Eastern Seas of Russia are presented. Intraspecific, interspecific and geographical differences in the accumulation of dangerous toxicants are described.

Keywords: HCHs; DDTs; PCBs; Pacific salmon; flounder; Far Eastern Seas.

Для снижения уровня холестерина и высокого давления крови, укрепления стенок сосудов медики многих стран рекомендуют регулярно еженедельно употреблять рыбу с высоким содержанием омега-3 полиненасыщенных жирных кислот. Такими кислотами богаты жирные рыбы - сельди, макрели и лососи. Употребление этих рыб и соответственно омега-3 жирных кислот (эйкозапентаеновая и докозагексаеновая кислоты) помогает не только снизить риск сердечнососудистых заболеваний и эндометриального рака, но и повысить уровень микроэлементов, крайне необходимых человеку, прежде всего калия и фосфора, усилить умственные и познавательные способности, а также оказывает еще ряд позитивных эффектов [29, 30, 35]. Несмотря на очевидную пользу и необходимость регулярного включения 
этих жирных рыб в диету, их использование вызывает в некоторых случаях беспокойство, что связано с биоаккумуляцией в их тканях контаминантов окружающей среды, таких как стойкие органические загрязняющие вещества (СО3) [30, 32]. До 90\% этих поллютантов поступают в организм человека с пищей. Конечным «депо» $\mathrm{CO} 3$ в окружающей среде являются морские экосистемы, следовательно, данные вещества могут накапливаться в различных объектах морского промысла [34, 45, 46].

Дальневосточные моря (Японское, Охотское и Берингово моря) являются основными промысловыми зонами Российской Федерации. Среди вылавливаемых объектов тихоокеанские лососи - наиболее массовая и потому очень важная в промысловом отношении группа. Их уловы на 90\% обеспечиваются тремя главными видами: горбушей, кетой и неркой. Горбуша - самый многочисленный, наиболее мелкий и быстрорастущий вид. В российских водах горбуша имеет ведущее промысловое значение. На втором месте по численности после горбуши стоит кета, более распространенная, по сравнению с другими представителями рода..

Вылавливаемые на Дальнем Востоке камбалы также относятся к наиболее значимым для промысла объектам, они составляют 9,5\% от общего объема вылова рыбы на Дальнем Востоке [1]. Объем вылова, разнообразие видов и невысокая цена на рынке предопределяют их особую важность в структуре питания местного населения. Одним из наиболее востребованных видов камбал является палтусовидная камбала (Hippoglossoides robustus), широко распространенная в Охотском, Японском морях и Татарском проливе.

\section{1. Тихоокеанские лососи (род Oncorhynchus)}

В рамках нашего исследования для анализа на содержание СО3 отобраны следующие виды: горбуша (Oncorhynchus gorbuscha), кета (O. keta), сима (O. masou), чавыча (O. tshawytscha) и нерка (O. nerka). Образцы рыб отбирались в течение 2010-2018 гг. в различных частях дальневосточных морей: в западной части Берингова моря (2010-2011 гг.); прикурильских водах Охотского моря (2012-2013 гг.); озере Азабачье (2017 г.); устье р. Бахура (Охотское море) (2017); устье р. Поронай (залив Терпения, Охотское море) (2017 г.); и р. Камчатка (Восточная часть п-ова Камчатка) (2018 г.). Исследо- 
вались мышцы, печень, гонады самцов, икра. В рыбах 2010-2013 гг. вылова анализировались только ХОП. Из ДДТ и его метаболитов исследовались только $p$,p'-изомеры. В особях 2017-2018 гг. вылова, помимо ХОП, определялись конгенеры ПХБ (28, 52, 155, 101, 153, 118, 143, 138, 180 и 207 ПХБ).

\subsection{1. Внутривидовые различия в аккумуляции СОЗ тихоокеанскими лососями Охотского и Берингова морей}

Горбуша (O. gorbuscha). Образцы отбирались в южной части Охотского моря (прикурильские воды), оз. Азабачье (п-ов Камчатка) и устье р. Поронай (залив Терпения, Охотское море). СО3 обнаружены во всех исследованных образцах (табл. 6.1, 6.2).

В горбуше из прикурильских вод Охотского моря ХОП обнаруживались во всех образцах, изменяясь в диапазоне от 60,9 до 715,2 (среднее 295,2士203,6) нг/Г липидов. Их основную часть составляли изомеры ГХЦГ, суммарные концентрации которых варьировали от 60,9 до 666,6 (среднее $277,0 \pm 188,4)$ нг/Г липидов. Среди изомеров ГХЦГ обнаружены $\alpha-, \beta-$ и $\gamma$-формы в диапазонах 60,9-446,8 нг/г, 4,4-171 нг/г и 5,2-65,6 нг/г липидов со средними значениями $199,8 \pm 130,1,50,5 \pm 48,6,33,3 \pm 20,9$ нг/г липидов, соответственно. Доминирующим изомером был $\alpha$-ГХЦГ, что указывает на длительную циркуляцию исходного вещества в среде и процесс его деградации. Из метаболитов ДДТ во всех образцах обнаружен только ДДЕ в диапазоне от

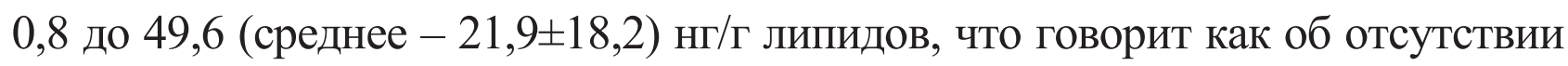
«свежего» загрязнения экосистемы, так и о деструкции исходного ДДТ.

В мышцах рыб из прикурильского района обнаружены минимальные (среди органов) концентрации ХОП ( $\mathrm{p} \leq 0,05)$, их диапазон варьировал в пределах 89,3-222,8, среднее - 141 \pm 46 нг/г липидов (рис. 6.1). Суммарная концентрация ГХЦГ составила $132 \pm 49$, ДДЕ - 9,0 46,0 нг/Г липидов. В печени

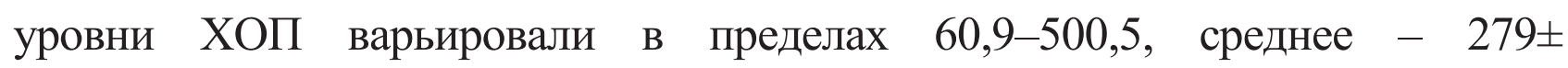
166 нг/г липидов. Суммарная концентрация ГХЦГ достигала $259 \pm 144$, ДДЕ $30 \pm 21$ нг/Г липидов. В икре и гонадах горбуши из Охотского моря диапазон концентраций ХОП изменялся от 131,5 до 399,4 и от 588,4 до 715,2 нг/Г липидов со средними значениями $285 \pm 138$ и $645 \pm 65$ нг/Г липидов, соответственно, являющимися максимальными показателями для всех исследованных органов. Концентрации изомеров ГХЦГ в икре и гонадах $-279 \pm 139$ и $600 \pm 60$ нг/Г

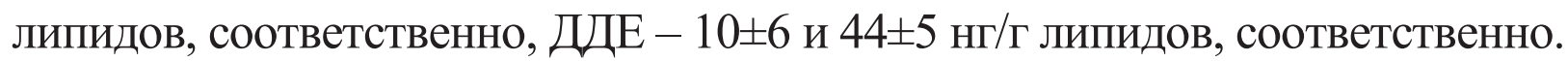




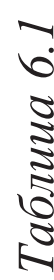

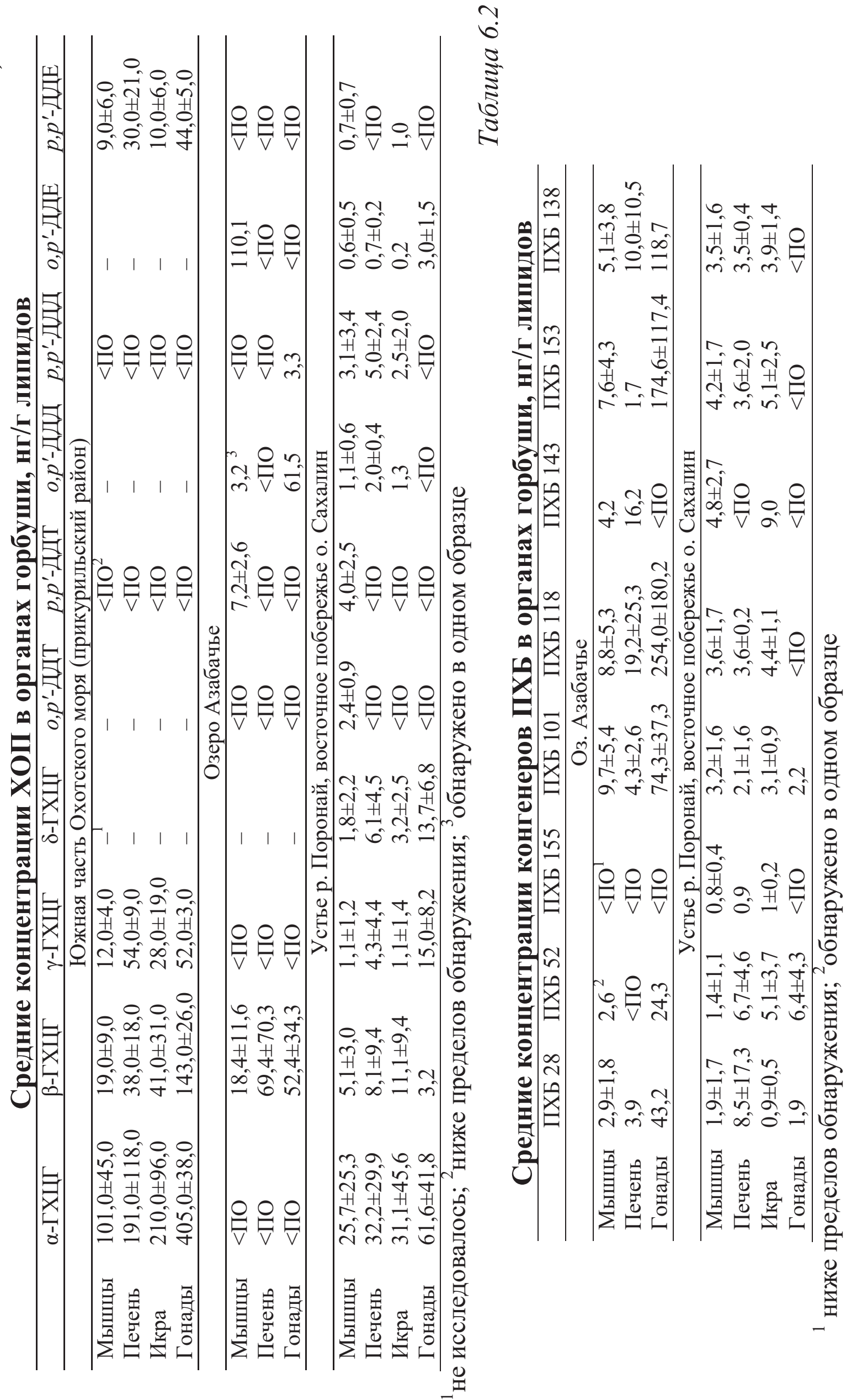


В горбуше из оз. Азабачье диапазон ХОП во всех органах варьиро-

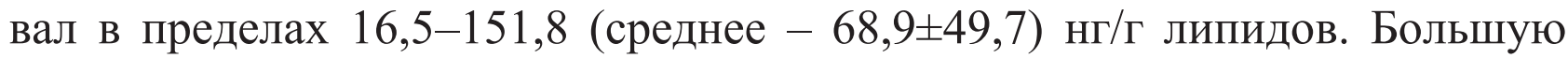
часть ХОП составлял ГХЦГ, представленный только наиболее устойчивой

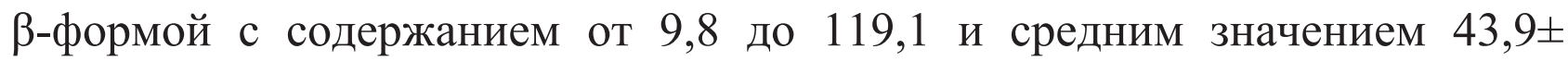
39,7 нг/г липидов. ДДТ и его метаболиты обнаруживались эпизодически,

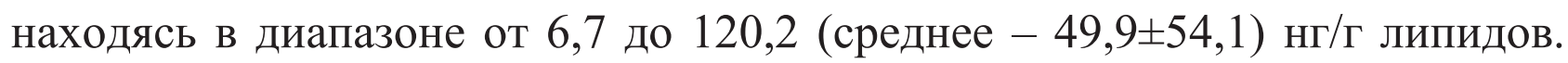
Наиболее часто встречался метаболит $p$,p'-ДДТ, концентрации которого варьировали в мышцах от 4,9 до 10,1 (среднее - 7,2 2,6) нг/Г липидов. $o, p$ '-ДДД обнаружен в двух образцах с концентрациями 3,2 и 61,5 нг/Г липидов.

В мышцах горбуши из оз. Азабачье диапазон концентраций ХОП ва-

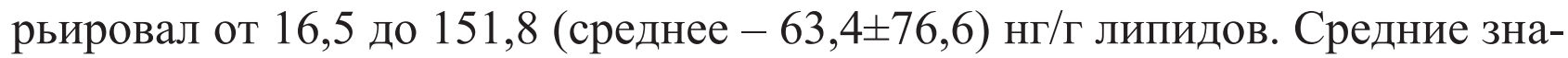

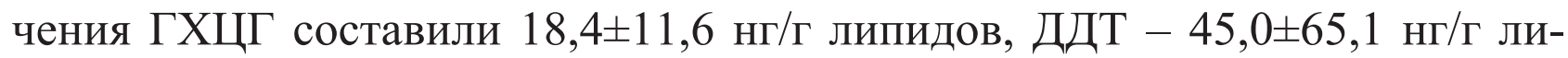
пидов (рис. 6.2). В печени ХОП были представлены только $\beta$-ГХЦГ $69,4 \pm 70,3$ нг/г липидов. В гонадах содержание ХОП изменялось от 57,4 до

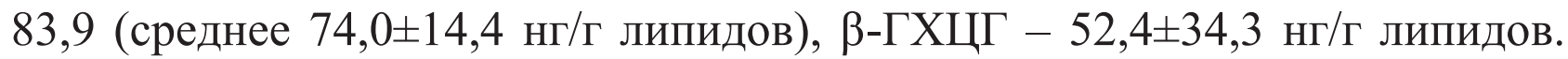
Из ДДТ и его метаболитов обнаружены $o, p$ '-ДДД и $p, p$ '-ДДД с концентрациями 61,5 и 3,3 нг/г липидов, соответственно.

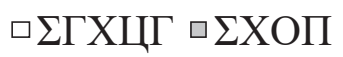

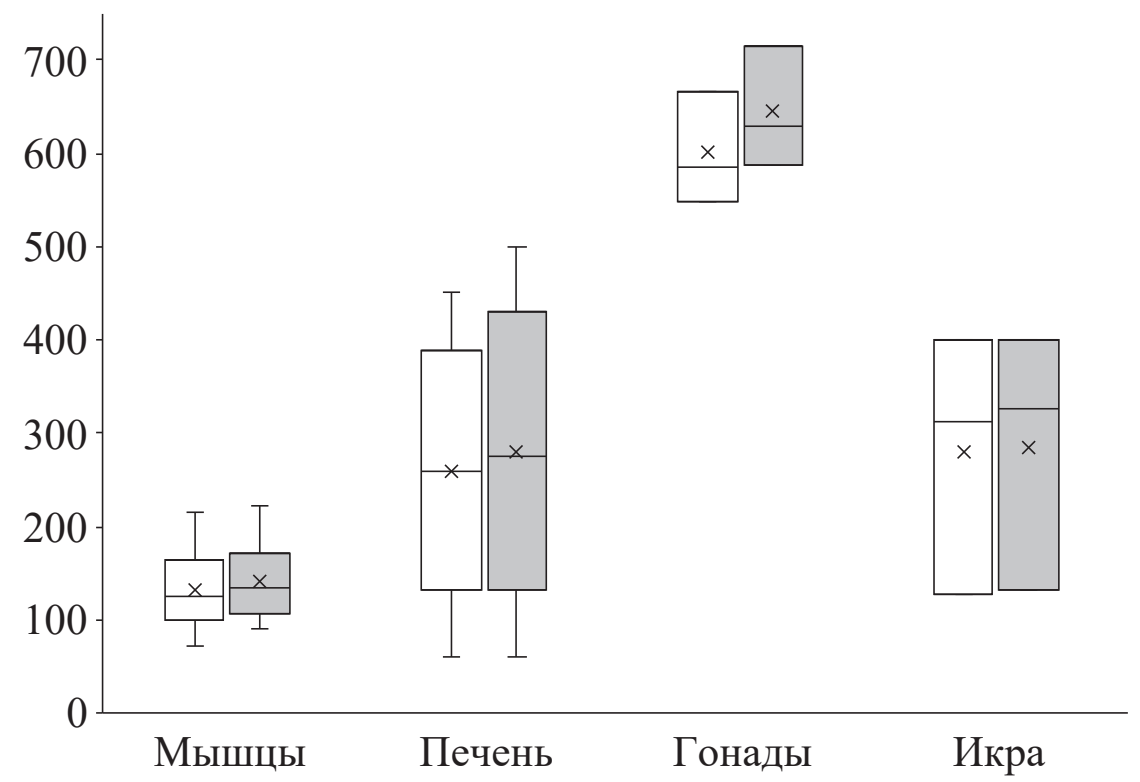

Puc. 6.1. Средние суммарные концентрации ГХЦГ и ХОП (медианы) в органах горбуши из южной части Охотского моря (прикурильский район), нг/Г липидов 


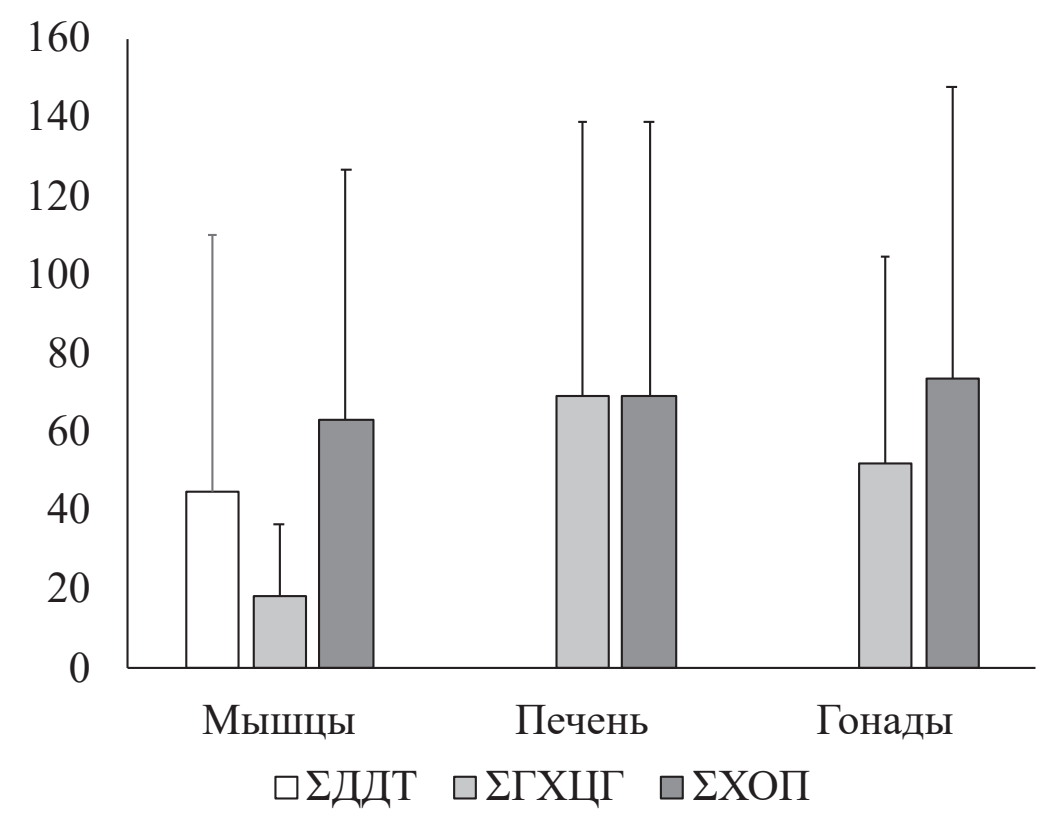

Puc. 6.2. Средние суммарные концентрации ДДТ, ГХЦГ и ХОП в органах горбуши из оз. Азабачье, нг/г липидов

Суммарные концентрации ПХБ в органах горбуши из оз. Азабачье варьировали от 9,6 до 739,7 (среднее $-175,4 \pm 272,0)$ нг/г липидов. Наиболее часто выявлялись ПХБ 101 и ПХБ 118, уровни которых составляли 23,8 $\pm 34,5$ и $74,0 \pm 131,1$ нг/Г липидов, соответственно. 52 и 143 ПХБ конгенеры обнаруживались эпизодически, с концентрациями: 2,6 и 24,3; 4,2 и 16,2 нг/Г липидов, соответственно. 155, 180 и 207 ПХБ конгенеры не выявлялись, находясь на уровнях ниже пределов обнаружения во всех образцах.

В мышцах суммарные концентрации ПХБ варьировали от 17,3 до 50,3

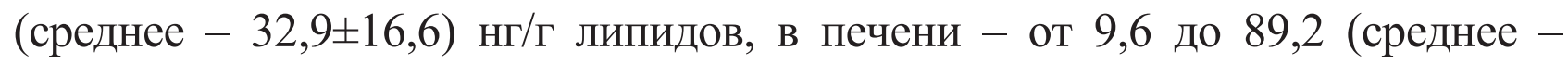
$37,4 \pm 44,9)$ нг/г липидов, в гонадах - от 452,3 до 739,7 (среднее - 596,0 $\pm 203,2$ ) нг/Г липидов. В основном, определялись «тяжелые» ПХБ (рис. 6.3).

В мышцах уровни ХОП варьировали от 2,5 до 83,9 со средним значением $27,8 \pm 28,1$ нг/г липидов. Суммарная концентрация ГХЦГ составила

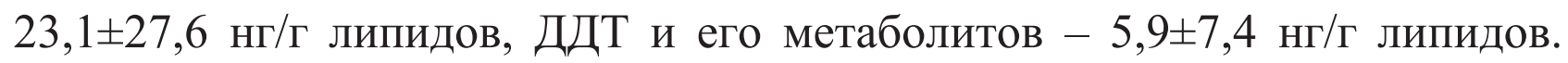
В печени уровни ХОП (6,7-135,3 со средним значением 48,3 $\pm 40,3$ нг/г липидов) достоверно $(\mathrm{p} \leq 0,05)$ выше, чем в мышцах. Суммарная концентрация ГХЦГ составила 45,2 $\pm 39,7$ нг/г липидов, ДДТ и его метаболитов $4,5 \pm 3,7$ нг/г липидов. В икре и гонадах горбуши ХОП находились на уровне 12-150,1 (среднее - 42,2 $\pm 53,8$ ) и 42,7-117,4 (среднее - 85,8 $\pm 36,9$ ) нг/Г липидов. Суммарная концентрация ГХЦГ в икре $-39,3 \pm 53,3$ нг/г 
липидов, в гонадах $-83,6 \pm 36,6$ нг/г липидов. Из ДДТ и его метаболитов, $o, p$ '-ДДТ и $p, p^{\prime}$-ДДТ были ниже переделов обнаружения во всех половых продуктах. $о, p$ '-ДДД, $о, p^{\prime}$-ДДЕ и $p, p^{\prime}$-ДДЕ в икре обнаружены единично в концентрациях 1,3, 0,2 и 1 нг/Г липидов, соответственно. $p, p$ '-ДДД $-2,5 \pm 2,0$ нг/г липидов. В гонадах обнаружен только $о, p$ 'ДДЕ - 3,0土1,5 нг/г липидов.

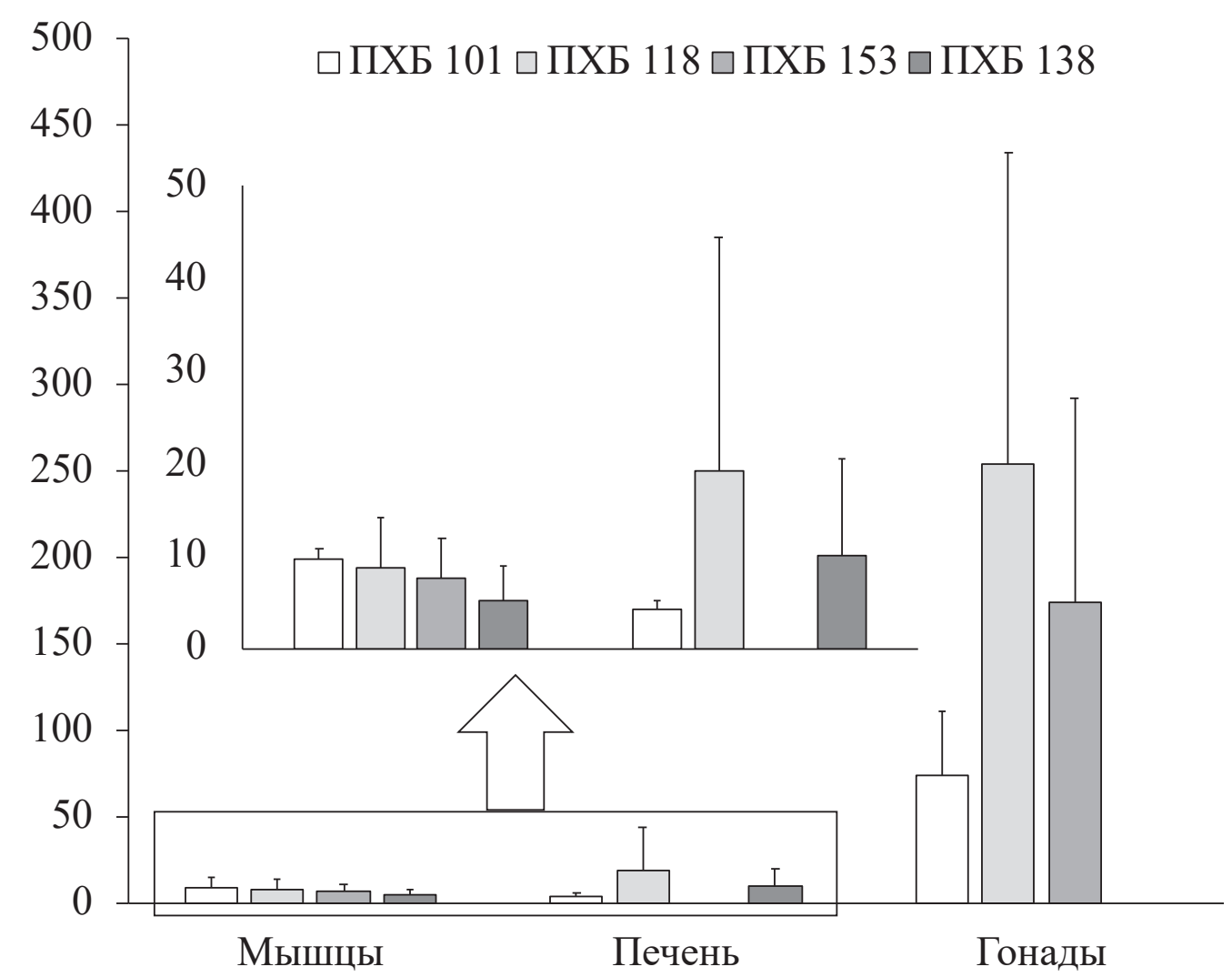

Puc. 6.3. Средние концентрации наиболее определяемых конгенеров ПХБ в органах горбуши из оз. Азабачье, нг/г липидов

Диапазоны суммарных концентраций ПХБ в горбуше из устья р. По-

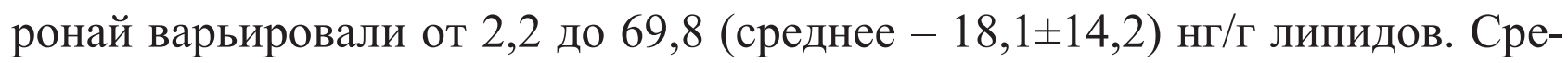
ди всех образцов наименее определяемым конгенером являлся ПХБ 143. ПХБ 180 и 207 не обнаружены ни в одной исследованной пробе.

В мышцах суммарные концентрации ПХБ варьировали от 9 до 33,5 со средним значением 19,1 $\pm 8,0$ нг/Г липидов (рис. 6.5). Во всех образцах обнаружены 28, 52, 155, 101, 118, 153, 138 конгенеры. В печени суммарные концентрации ПХБ находились в диапазоне от 2,5 до 69,8 со средним значением 17,9 $\pm 21,2$ нг/г липидов. Наиболее определяемыми были 28, 52, 101, 118, 153 и 138 конгенеры. В половых продукта суммарные концен- 
трации ПХБ варьировали: в икре - от 13,3 до 41,5 (среднее - 24,8 $\pm 10,5$ ); гонадах - от 2,2 до 11,3 (среднее - 5,8 $\pm 4,0$ ) нг/г липидов, соответственно. Наиболее определяемыми ПХБ в икре являлись 28, 52, 155, 101, 118, 153 и 138 конгенеры. Во всех образцах гонад концентрации ПХБ 155, 118, 143, 153 и 138 были ниже пределов обнаружения.

Концентрации $\alpha$ - и $\gamma$-ГХЦГ достоверно $(p \leq 0,05)$ выше в горбуше из прикурильских вод Охотского моря, чем из устья р. Поронай (рис. 6.6).

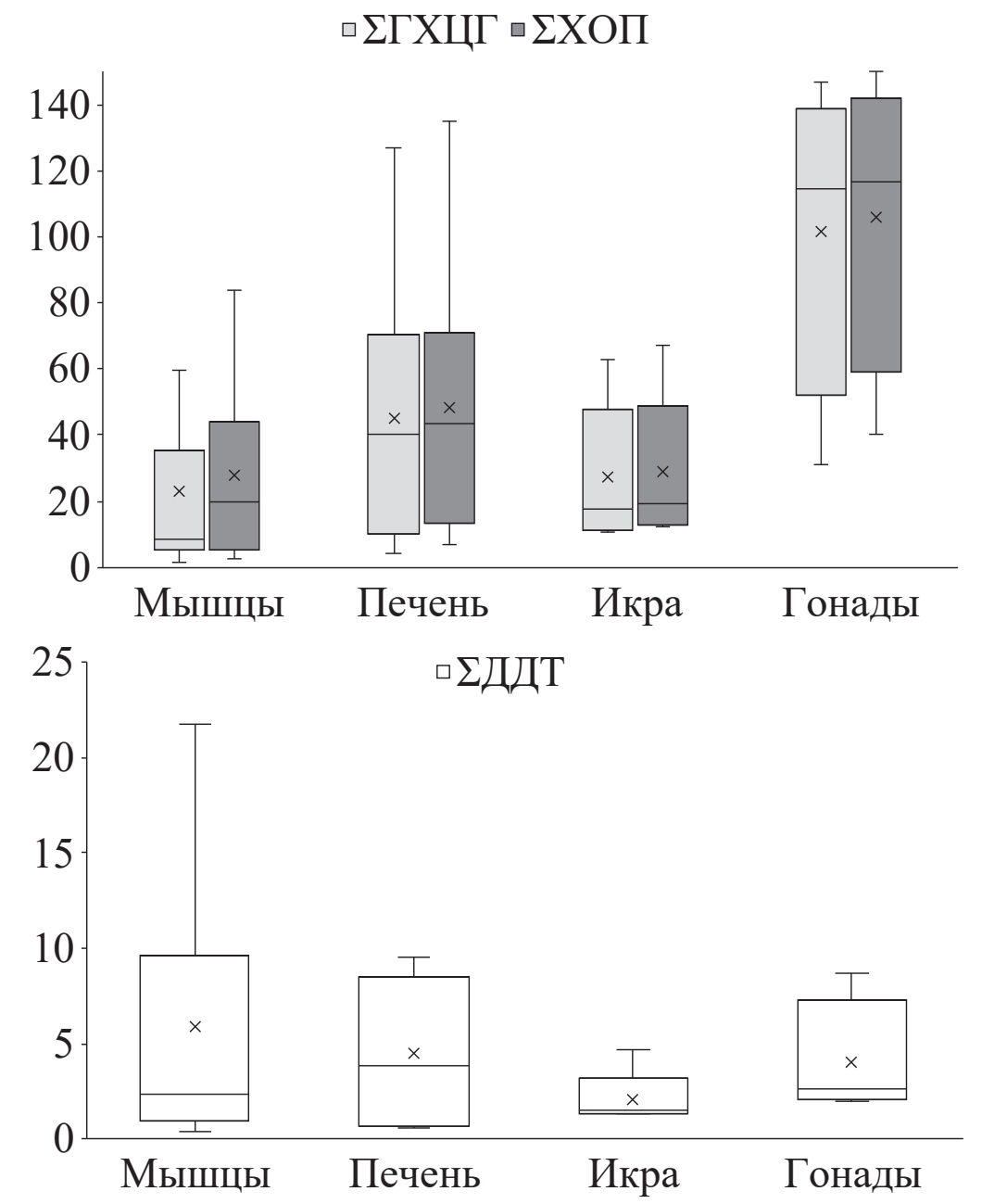

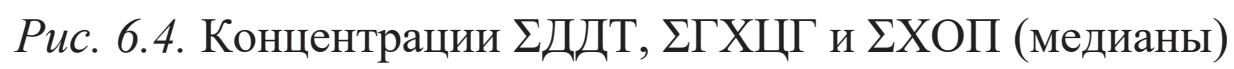
в органах горбуши из устья р. Поронай, нг/г липидов

Значимые различия в концентрациях могут быть связаны с тем, что рыбы, отобранные в Охотском море, во время нагула прошли через Тихоокеанское мусорное пятно - огромные количества пластика, плавающие на поверхности Тихого Океана. Известно, что частицы пластика способны адсорбировать на себе от пико- до нанограммов CO3 [42]. Учитывая жизненную стратегию тихоокеанских лососей (преимущественное обитание в 
зоне от 0 до 50 м, где и находится большая часть пластика), влияние Тихоокеанского мусорного пятна - наиболее вероятное объяснение повышения уровней СО3 в органах горбуши из Охотского моря.

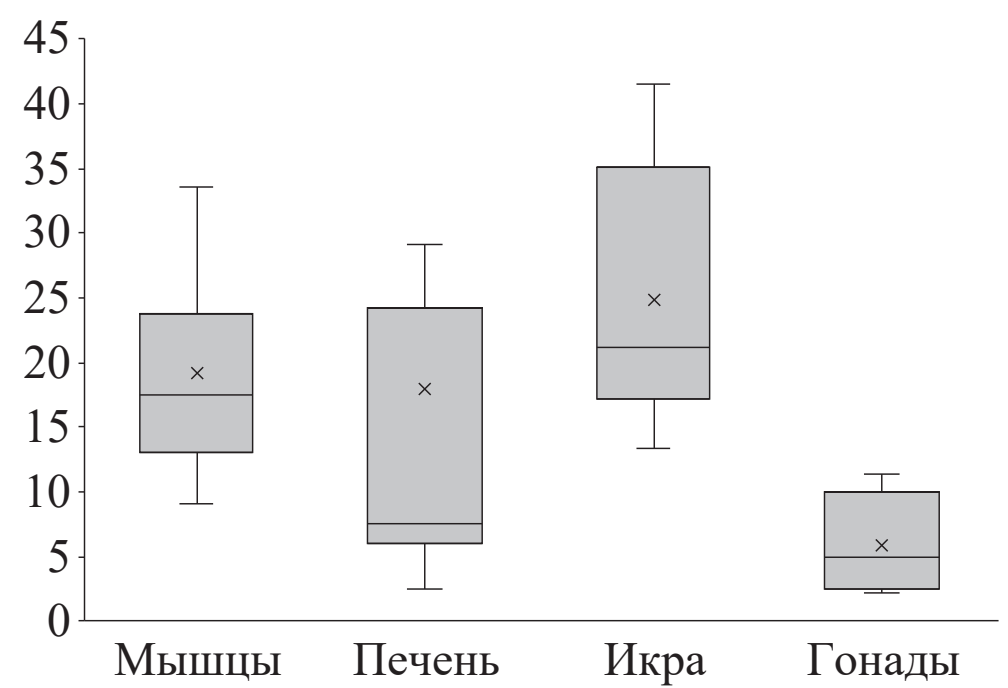

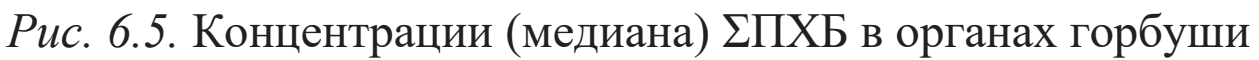
из р. Поронай, нг/г липидов

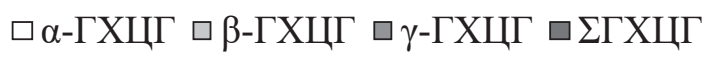

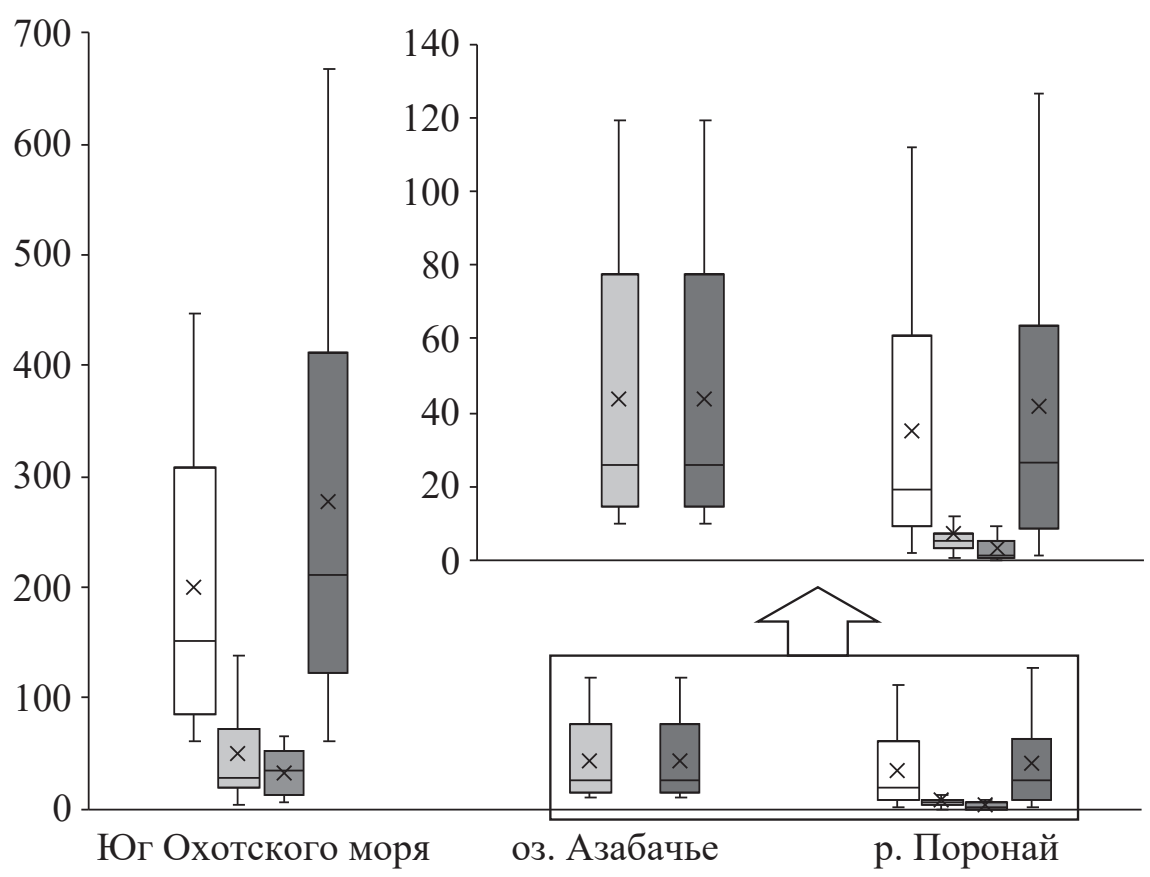

Puc. 6.6. Концентрации (медианы) ГХЦГ в горбуше из различных районов дальневосточных морей, нг/г липидов 
Уровни $\beta$-ГХЦГ достоверно больше в горбуше из оз. Азабачье, чем в рыбах из прикурильских вод Охотского моря и зал. Терпения. Озеро Азабачье находится внутри материка, основной водообмен осуществляется с p. Камчатка, впадающей в Камчатский залив. На п-ове Камчатка и, в частности, в долине реки Камчатка отсутствуют крупные сельскохозяйственные предприятия. Таким образом, можно предположить, что основными источниками поступления ХОП и ПХБ в экосистемы реки и озера могут выступать атмосферный перенос, биотранспорт мигрирующими видами и стоки со свалок твердых бытовых отходов. ГХЦГ в оз. Азабачье был представлен только $\beta$-изомером, указывающим на давнее загрязнение и деградацию исходного $\gamma$-ГХЦГ до наиболее стойкой формы.

Концентрации всех ДДТ в рыбе находились в следующем порядке: устье р. Поронай < юг Охотского моря < оз. Азабачье $(\mathrm{p} \leq 0,05)$ (рис. 6.7). Это может быть связано с более сложными метаболическими процессами при разрушении ДДТ, по сравнению с ГХЦГ. В оз. Азабачье обнаружен, в основном, ДДТ, что указывает на недавнее поступление этого токсиканта в экосистему водоема. В прикурильских водах Охотского моря обнаружен только ДДЕ, что свидетельствует о деструкции исходного соединения. В устье р. Поронай обнаружены почти все метаболиты ДДТ. Несмотря на небольшие концентрации, это может говорить о постоянном поступлении токсикантов в среду и продолжающейся деградации промежуточных соединений (ДДД).

Концентрации ПХБ в горбуше из оз. Азабачье достоверно выше $(\mathrm{p} \leq 0,05)$, чем в устье $\mathrm{p}$. Поронай (рис. 6.8). Это может быть связано с ограниченным водообменом озера. В случае пестицидов он уменьшает возможное их поступление с водными массами реки. При этом локальных источников этих соединений рядом с водоемом нет. ПХБ, в свою очередь, широко использовались на всей территории СССР. При этом ПХБсодержащие трансформаторы до сих пор применяются на территории России. Попадая в экосистему озера, ПХБ остаются в ней, за счет слабого испарения при низкой температуре, и аккумулируются в тканях рыб. Низкие концентрации ПХБ в горбуше из устья р. Поронай могут свидетельствовать о малых их концентрациях в открытых водах Мирового океана.

Анализ изменения концентраций ХОП в горбуше дальневосточных морей России показывает, что суммарные концентрации ГХЦГ и ДДТ в 2017 г. значительно меньше $(\mathrm{p} \leq 0,05)$ таковых в 2012 г. При этом снижения 
уровней ГХЦГ и ДДТ не одинаковы: уменьшение концентраций у первого происходит активнее, чем у последнего.

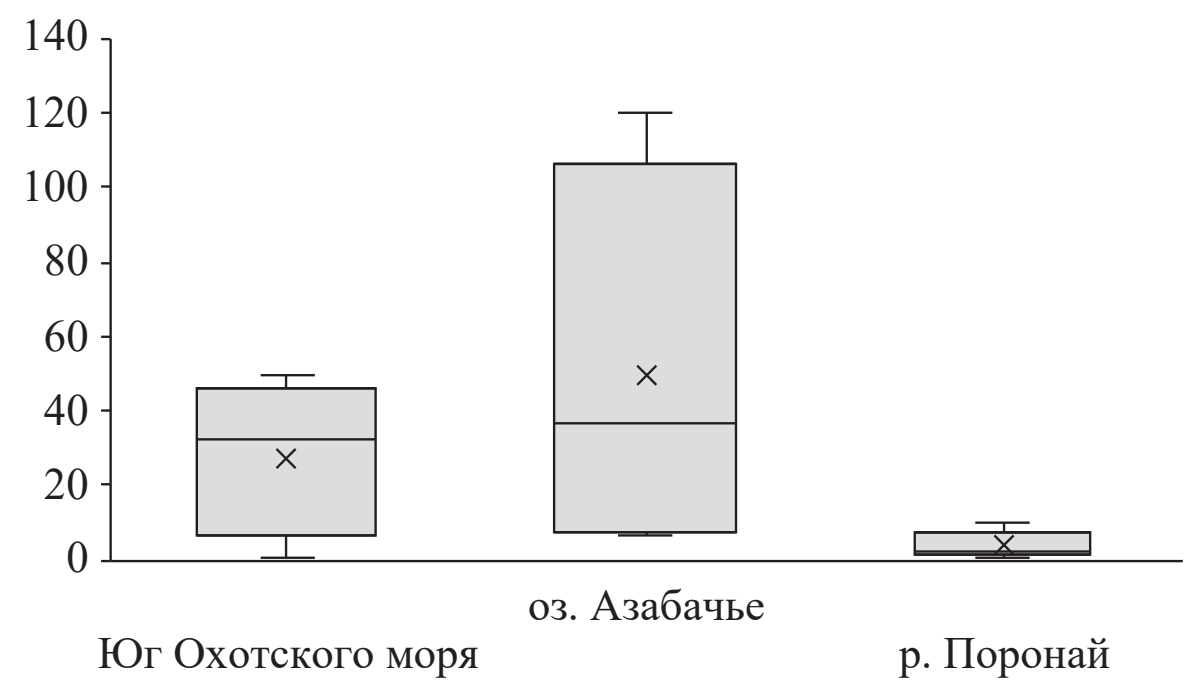

Puc. 6.7. Суммарные концентрации (медианы) ДДТ в горбуше из районов исследования, нг/г липидов

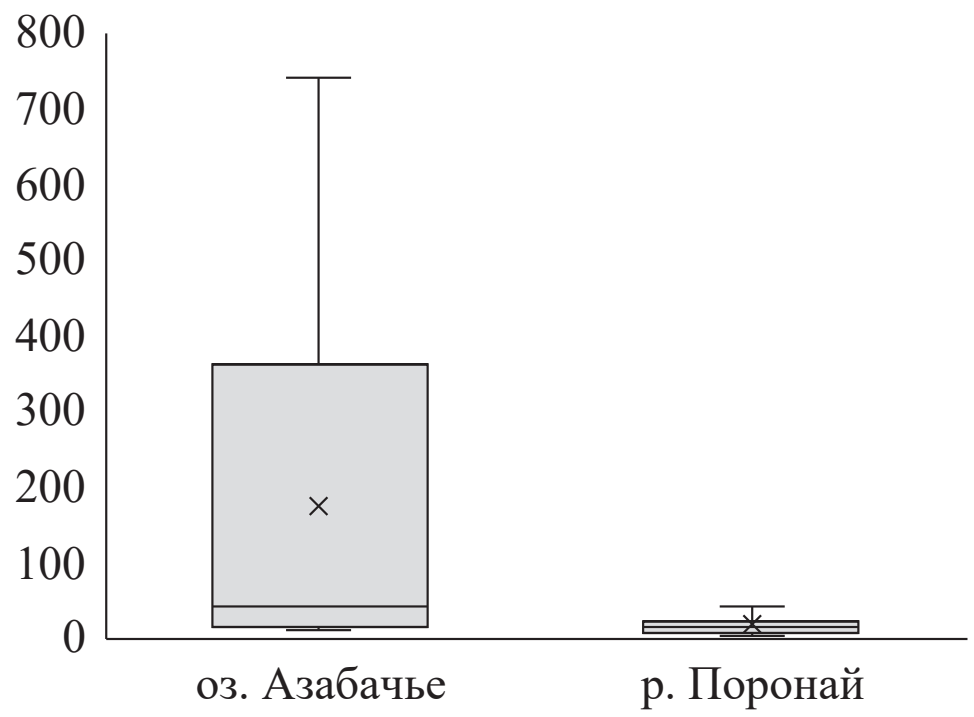

Puc. 6.8. Суммарные концентрации (медианы) ПХБ в горбуше из оз. Азабачье и устья р. Поронай, нг/г липидов

Оценить изменения концентрации полихлорированных бифенилов во времени не представляется возможным, так как рыбы, в которых проводилось измерение ПХБ были собраны в одно время. Что касается ХОП, то для них на сегодняшний день явно видна тенденция к снижению уровней в горбуше дальневосточных морей России за последние 5 лет. 
Чтобы определить возможные источники поступления ХОП и ПХБ в организм рыб, проведена корреляция между обнаруженными соединениями. Взаимосвязь изомеров ГХЦГ между собой объясняется единым источником поступления в экосистему. Корреляция между ДДЕ и изомерами ГХЦГ также говорит о едином источнике загрязнения. Вероятнее всего, основным путем поступления пестицидов в воды Охотского моря являются атмосферный перенос и морские течения.

Среди пестицидов в рыбе озера Азабачье (табл. 6.3) обнаружена значимая $(\mathrm{p} \leq 0,01)$ корреляция между $\beta$-ГХЦГ и о, $p$ '-ДДЕ. Взаимосвязь между двумя соединениями может говорить о сходных путях деградации, одновременном появлении в органах и/или о едином источнике поступления. Первое наиболее вероятно, так как среди всех метаболитов ДДТ только $o, p$-ДДЕ показал сильную $(\mathrm{p} \leq 0,01)$ корреляцию с $\beta$-ГХЦГ. Между $o, p$ 'ДДД и $p, p^{\prime}$-ДДТ очень сильная положительная прямая связь $(\mathrm{p} \leq 0,01)$, что, вероятнее всего, говорит о едином источнике поступления (атмосферный перенос) в экосистему. о, $p^{\prime}$-ДДЕ показал очень сильную отрицательную корреляцию с $p, p^{\prime}$-ДДТ, что, очевидно, свидетельствует о деградации $p, p^{\prime}-$ ДДТ до $o, p^{\prime}$-ДДЕ в организмах рыб.

Среди ПХБ обнаружены очень сильные корреляции между всеми конгенерами на уровнях $\mathrm{p} \leq 0,01$ и $\mathrm{p} \leq 0,05$, что говорит о едином источнике поступления этих соединений в организм горбуши. Корреляции между ПХБ и ХОП варьировали от средних до очень сильных на уровнях $\mathrm{p} \leq 0,01$ и $\mathrm{p} \leq 0,05$. Известно, что эти соединения используются в разных отраслях промышленности и попадают в экосистемы из разных источников. Наиболее вероятным объяснением полученных результатов является присутствие на территории п-ова Камчатка могильников твердых бытовых отходов, в которых могут находиться ХОП и ПХБ одновременно. Стоки с таких свалок могут быть основной причиной совместного поступления пестицидов и промышленных отходов в экосистемы и организм рыб.

В горбуше из устья р. Поронай обнаружены сходные корреляции между соединениями, как и в других районах (табл. 6.4). Изомеры ГХЦГ коррелировали друг с другом (положительно) на уровне $\mathrm{p} \leq 0,01$, причем $\delta$ форма коррелировала со всеми изомерами. Среди метаболитов ДДТ положительная корреляция $(\mathrm{p} \leq 0,01)$ обнаружена между $o, p^{\prime}-и$, $p$, $p^{\prime}$-изомерами, что, как и в других районах, свидетельствует о сходном источнике поступления $\mathrm{CO} 3$ в среду. 


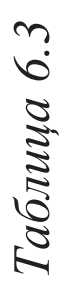


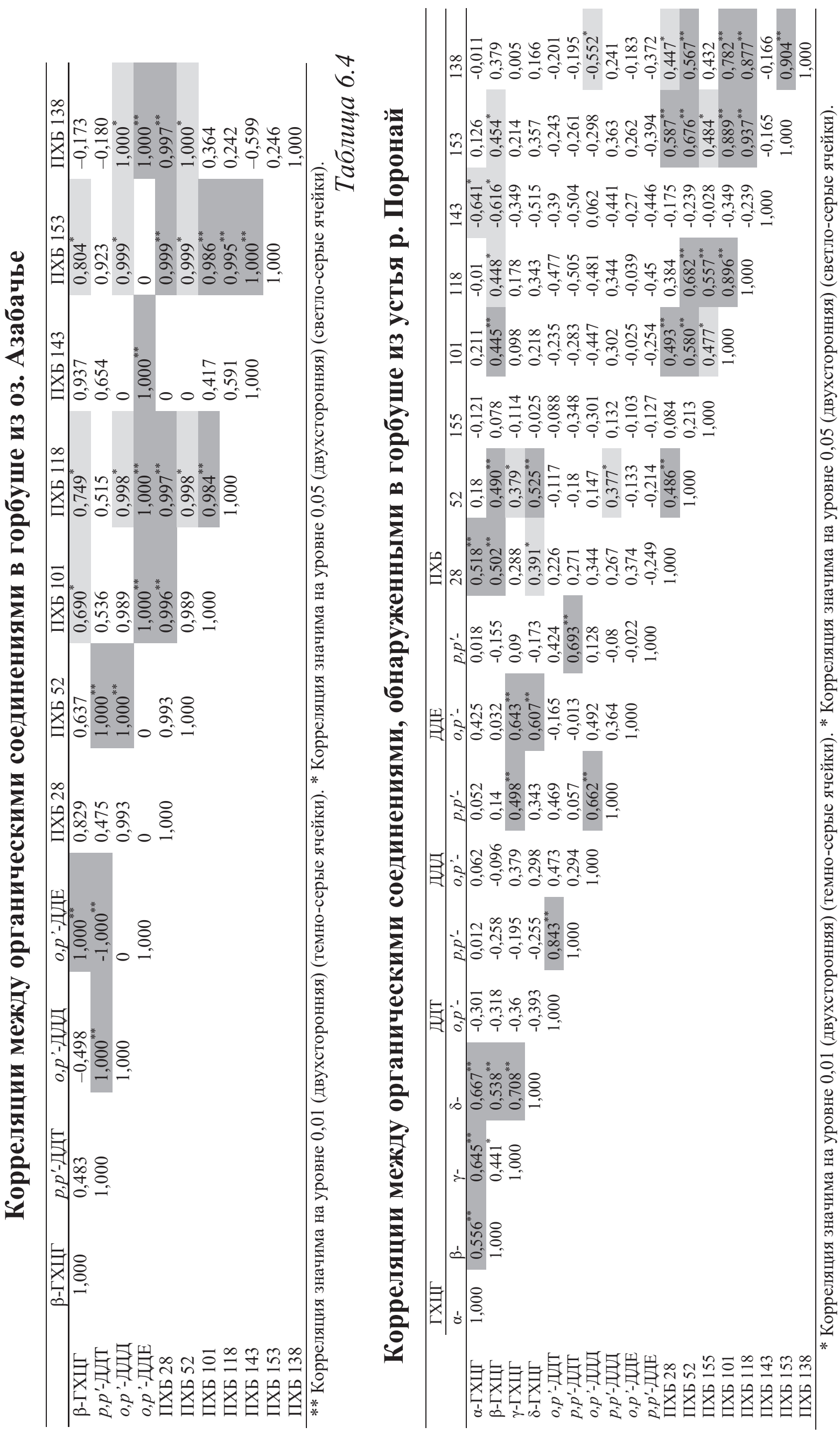
Среди конгенеров ПХБ также видна достоверная корреляция, причем с увеличением уровня хлорирования увеличивается количество конгенеров, с которыми коррелирует соединение. Наиболее важными являются данные об отрицательных корреляциях $(\mathrm{p} \leq 0,05)$ между ПХБ 143 с $\alpha$ и $\beta$-ГХЦГ; ПХБ 138 и ПХБ 101 с $о, p$ '-ДДД. Первая может свидетельствовать о возможном распаде ПХБ 143 до ГХЦГ с последующим переходом одного изомера в другой, либо о различных источниках поступления токсикантов. Вторая - о возможной деградации о, $p^{\prime}$-ДДД до высокохлорированных ПХБ 138 и 101 в процессе метаболических преобразований.

Таким образом, источники поступления токсикантов в организм горбуши сходны для всех исследованных районов и отражают глобальное распространение СО3 и локальное загрязнение от могильников твердых бытовых отходов.

Кета (Oncorhynchus keta). Образцы кеты отбирались на юге Охотского моря (прикурильские воды) в 2013 г и в р. Камчатка (п-ов Камчатка) в 2018 г. Анализу подвергались мышцы, печень, икра и гонады. Во всех исследованных образцах обнаружены СО3 (табл. 6.5, 6.6).

В кете из прикурильских вод Охотского моря ХОП обнаружены во всех исследованных образцах в диапазоне от 56 до 4223 со средним значением $841,7 \pm 1209,9$ нг/Г липидов. Основную часть ХОП составляли изомеры ГХЦГ, суммарная концентрация которых варьировала от 39,1 до 3850,3 со средним значением 775,6 $\pm 1110,2$ нг/Г липидов. ГХЦГ был представлен $\alpha$-, $\beta$ - и $\gamma$-изомерами. ДДТ был представлен только $p, p$ '-ДДЕ в диапазоне $6,5-372,7$ со средним значением $85,0 \pm 135,6$ нг/г липидов.

В мышцах кеты из прикурильских вод Охотского моря уровни ХОП варьировали от 78,8 до 174,1 (среднее - 125,4 $\pm 34,7$ ) нг/г липидов и были наименьшими ( $\leq \leq 0,05)$, среди всех исследованных органов (рис. 6.9).

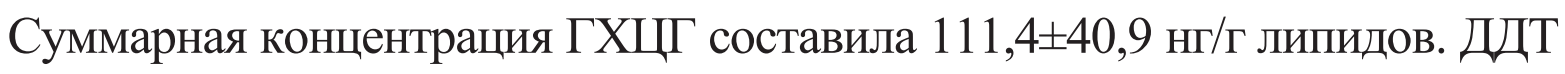

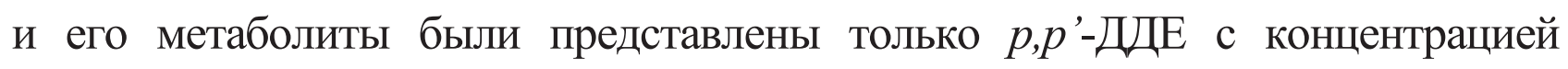
$14,1 \pm 6,6$ нг/Г липидов. В печени уровни ХОП составили 56-294,1 со средним значением 183,5 $\pm 84,2$ нг/Г липидов. Суммарные концентрации ГХЦГ и ДДЕ составили $166,0 \pm 80,0$ и 21,0 $\pm 9,0$ нг/г липидов, соответственно. В икре кеты из Охотского моря уровни ХОП варьировали в пределах 793,7-1825,4 со средним значением 1472,0 $\pm 587,0$ нг/г липидов и были представлены только изомерами ГХЦГ. В гонадах ХОП находились в диапазоне от 1485,3 до 4223,0 (среднее $2961,0 \pm 1381,0)$ нг/Г липидов, что является максимальным показателем среди 
всех исследованных органов. Суммарные концентрации ГХЦГ и ДДЕ в гонадах составили $2628,0 \pm 1342$ и $333,0 \pm 40,0$ нг/г липидов, соответственно.

В кете из р. Камчатка диапазон ХОП во всех органах варьировал в пределах 1-20,7 со средним значением 6,2 6,1 нг/г липидов. Большую

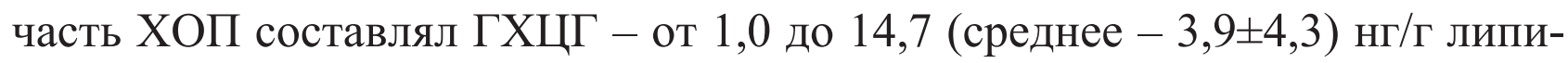
дов. ДДТ и его метаболиты обнаруживались фрагментарно в диапазоне от 0,3 до 9,2 (среднее - 3,0 $\pm 3,4$ ) нг/г липидов. Наиболее определяемым метаболитом был $о, p^{\prime}$-ДДЕ - от 0,3 до 2,5 со средним значением $1,2 \pm 0,8$ нг/г липидов. $o, p$ '-ДДТ, $о, p$ '-ДДД обнаружены в одном образце печени в концентрациях 1,3 и 1,6 нг/г липидов, соответственно.

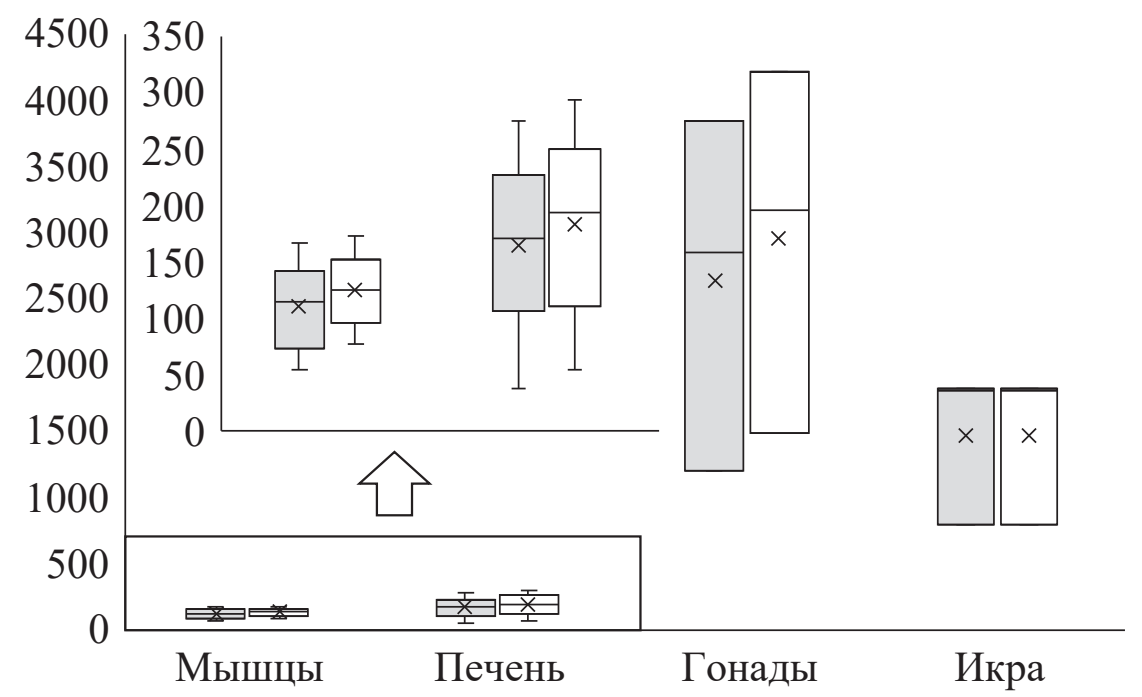

Puc. 6.9. Суммарные концентрации ХОП и ГХЦГ в органах кеты из южной части Охотского моря, нг/Г липидов

В мышцах кеты из р. Камчатка уровень ХОП варьировал от 2,5 до 10,3 со средним значением $5,9 \pm 4,0$ нг/г липидов (рис. 6.10). Средняя концентрация ГХЦГ составила $2,1 \pm 1,7$ нг/г липидов. $\alpha$ - и $\beta$-изомеры обнаружены в одной пробе - 0,3 и 3,3 нг/г липидов, соответственно. Средние уровни ДДТ и его метаболитов в мышщах составили $3,8 \pm 4,7$ нг/Г липидов и были представлены только o,p'-ДДЕ $(1,4 \pm 0,6$ нг/г липидов) и $p, p$-ДДЕ (7,2 нг/г липидов). В печени концентрации ХОП варьировали от 1,3 до 20,7 нг/г липидов (среднее $-9,4 \pm 10,1)$ нг/Г липидов. Средний уровень ГХЦГ и ДДТ составил $6,4 \pm 7,3$ и 3,0 $\pm 2,9$ нг/г липидов, соответственно. Из метаболитов ДДТ обнаружены $o, p$ '-ДДТ (1,3 нг/г липидов), o, p'-ДДД (1,6 нг/г липидов и ), o, $p^{\prime}$-ДДЕ $(1,3 \pm 1,1$ нг/г липидов) и $p, p$-ДДЕ (0,6 и 1,5 нг/г липидов). В гонадах диапазон концентраций ХОП был представлен только ГХЦГ - от 1,0 до 4,7 со средним значе-

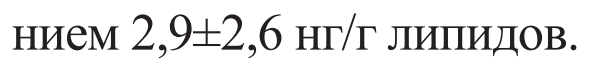




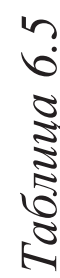

$\sqrt{2}$
0
0
0
0
0
0
0
0
0

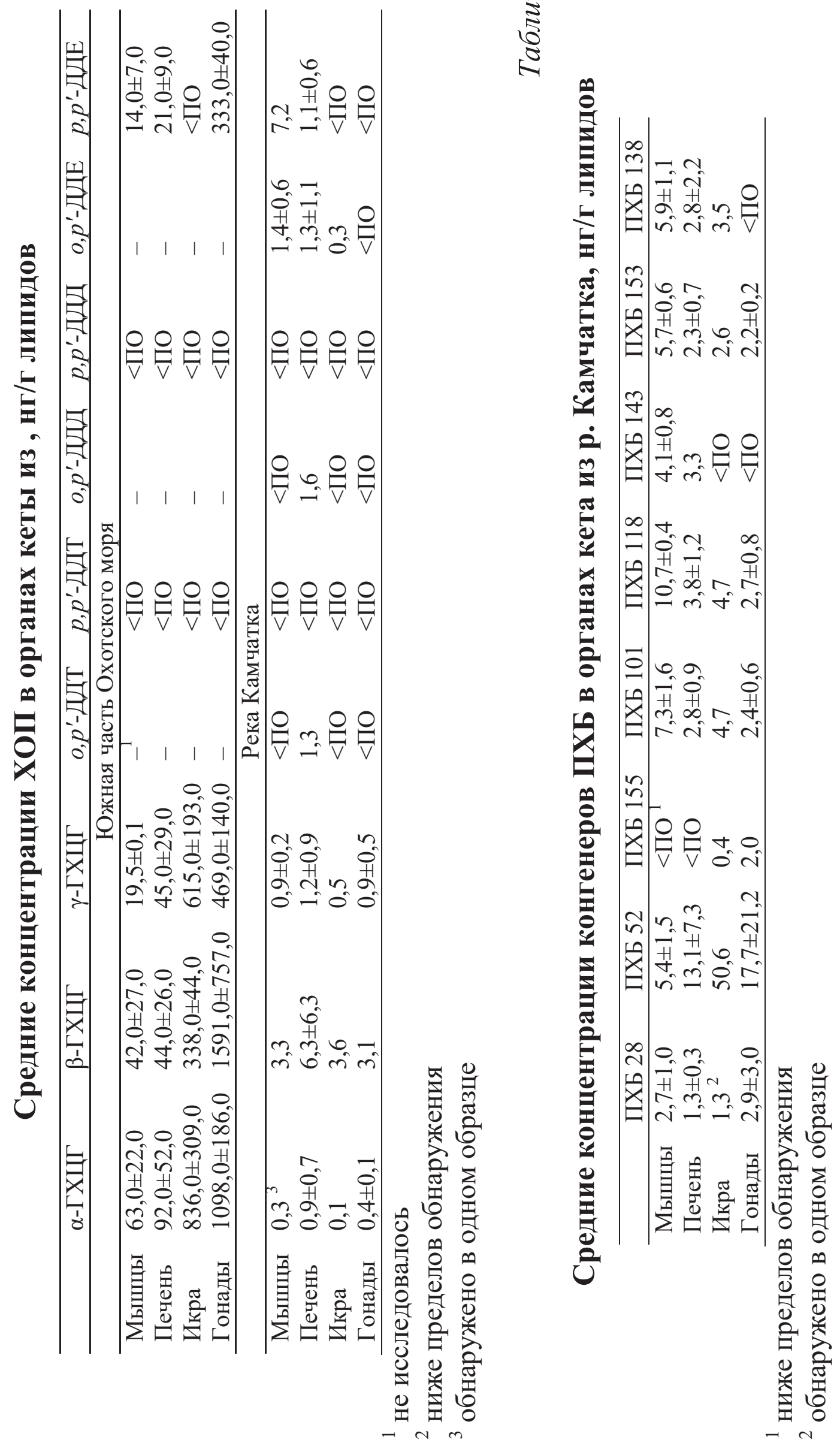


Суммарные концентрации ПХБ в органах кеты из р. Камчатка варьировали от 9,5 до 67,6 со средним значением $36,5 \pm 17,1$ нг/г липидов. 28, 52, 101, 118 и 153 конгенеры ПХБ обнаружены во всех исследованных образцах с суммарными концентрациями $2,1 \pm 1,4,15,7 \pm 16,3,4,4 \pm 2,5,6,0 \pm 3,7$ и $3,4 \pm 1,8$ нг/г липидов, Наименее определяемым конгенером был ПХБ 155, обнаруженный в двух образца с концентрациями 0,37 и 2 нг/г липидов. 180 и 207 конгенеры ПХБ были ниже пределов обнаружения во всех исследованных образцах.

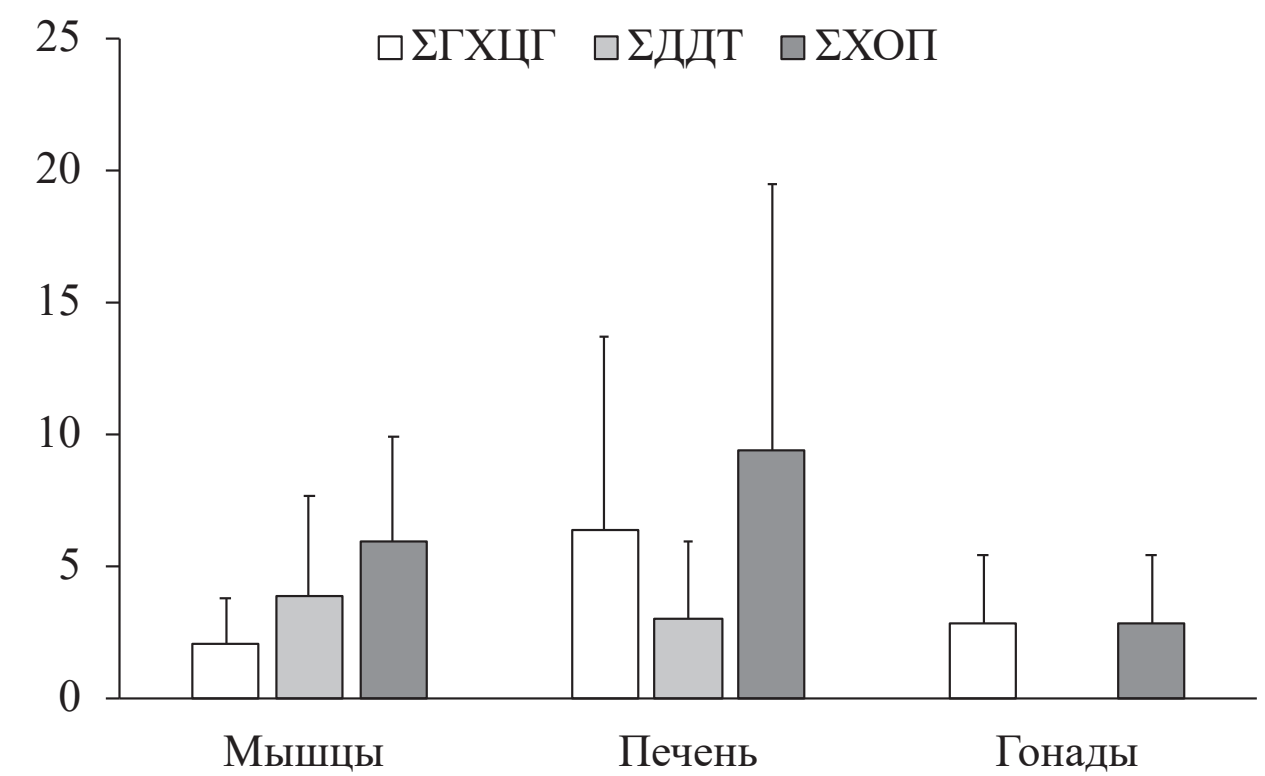

Pис. 6.10. Средние суммарные концентрации ДДТ, ГХЦГ и ХОП в органах кеты из р. Камчатка, нг/г липидов

В мышцах суммарные концентрации ПХБ находились в пределах 34,544,9 (среднее - 40,5 5 5,4) нг/г липидов. Из всех исследованных конгенеров, не обнаружены только 155, 180 и 207 конгенеры ПХБ (рис. 6.11). В печени концентрации ПХБ варьировали от 18,2 до 35,6 со средним значением $27,2 \pm 8,7$ нг/г липидов. ПХБ 143 обнаружен в одном образце с концентрацией 3,3 нг/г липидов. В гонадах суммарный диапазон ПХБ варьировал от 9,5 до 48,1 (среднее - 28,8 27,3 ) нг/Г липидов. ПХБ 155 обнаружен в одном образце с концентрацией 2,0 нг/г липидов. ПХБ 138 был ниже пределов обнаружения.

Сравнение результатов показало, что концентрации $\alpha$-, $\beta$-, $\gamma$ изомеров ГХЦГ и ДДЕ достоверно $(\mathrm{p} \leq 0,05)$ выше в органах кеты из прикурильских вод Охотского моря, чем из р. Камчатка (рис. 6.12). Сравнить уровни накопления полихлорированных бифенилов в рыбах разных годов вылова невозможно, так как в кете из южной части Охотского моря определение уровней ПХБ не проводилось. 
В целом, основным источником поступления ХОП в рыб из прикурильских вод Охотского моря можно считать перенос водными и воздушными массами.

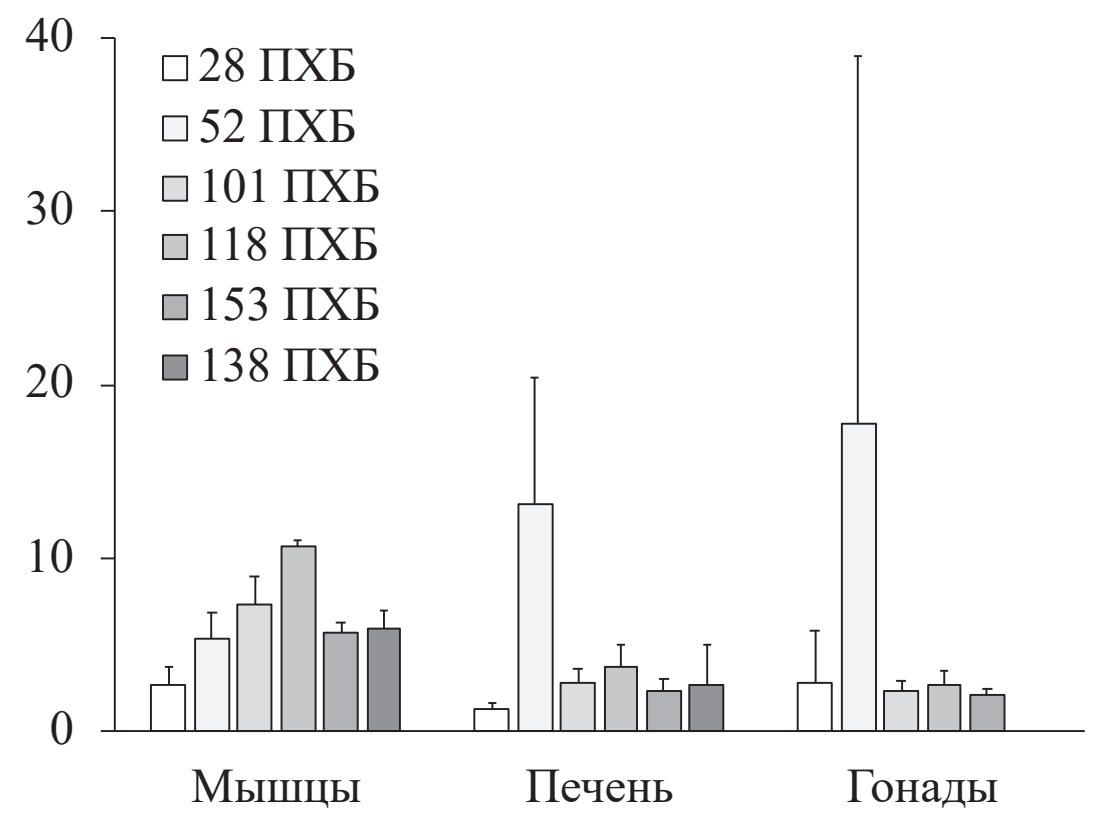

Рис. 6.11. Концентрации наиболее определяемых конгенеров ПХБ в органах кеты из р. Камчатка, нг/г липидов

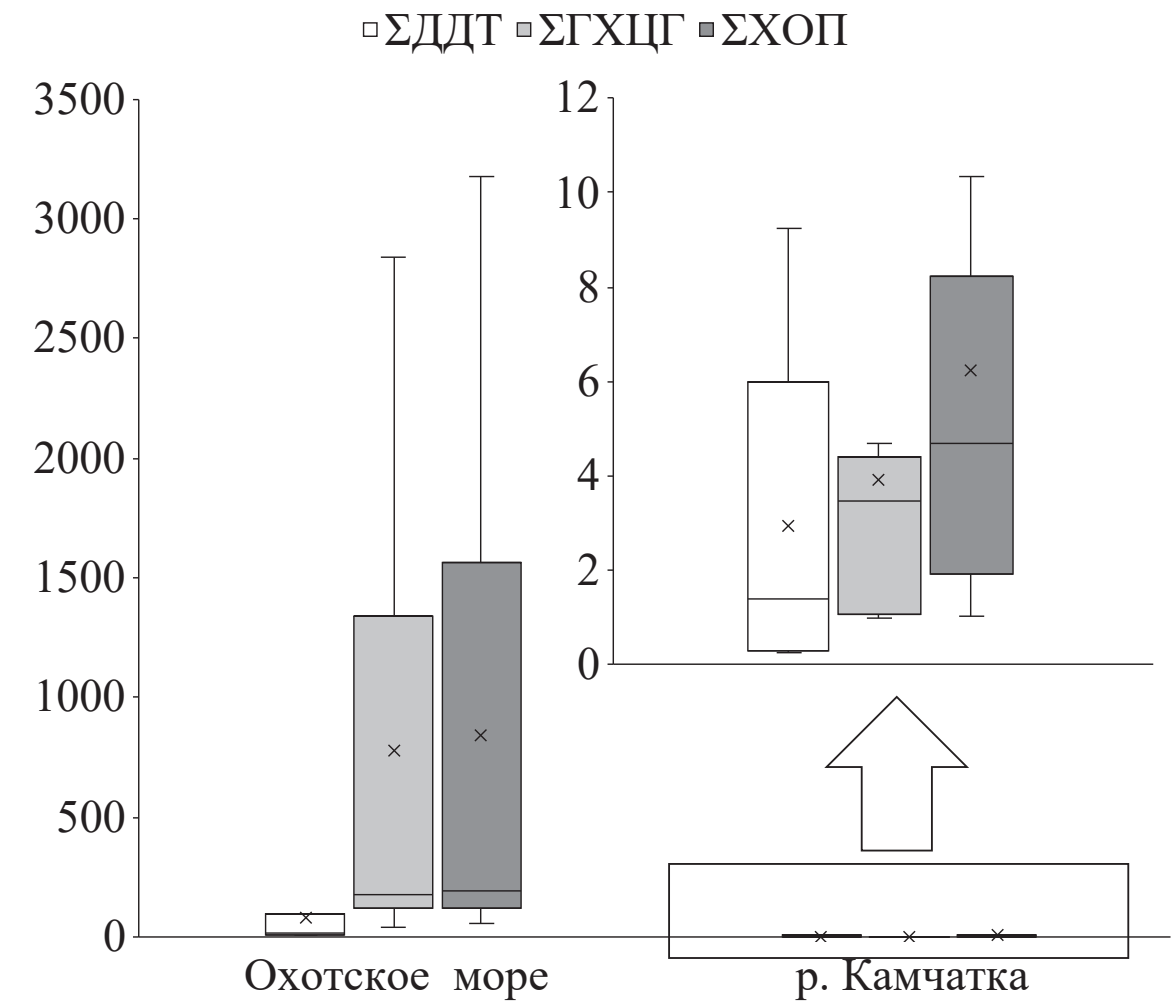

Puc. 6.12. Суммарные концентрации ДДТ, ГХЦГ и ХОП в кете 2013 (Охотское море) и 2018 (р. Камчатка) гг. вылова, нг/г липидов 
Обнаруженные концентрации ХОП в кете из р. Камчатка может отражать как атмосферный перенос СО3, так и влияние стоков со свалок твердых бытовых отходов. Это подтверждается последним отчетом администрации Камчатского края, где указано, что помимо существующих санкционированных свалок, гражданами ежегодно создаются и несанкционированные, зачастую содержащие опасные вещества. При этом стоит отметить, что район р. Камчатка не подвергается воздействию Козельского полигона (могильник пестицидов, включая ХОП), так как он находится в нижней части п-ова Камчатка. ПХБ, в свою очередь, могут поступать в реку со стоками свалок или из ПХБ-содержащих масел и пришедших в негодность трансформаторов [17].

Если рассмотреть временные тенденции в изменении концентраций CO3 в органах кеты, то явно видна тенденция к снижению количества ХОП от 2013 года к 2018. В кете наблюдается снижение уровней как ГХЦГ, так и ДДТ, причем, в отличие от горбуши, концентрации ДДТ снижаются более интенсивно, чем ГХЦГ, что может быть связано с различиями в биологии этих рыб (разница в продолжительности жизни и местах нагула).

Согласно таблице корреляций между соединениями в органах кеты из прикурильских вод Охотского моря (табл. 6.7), очень сильные положительные корреляции обнаружены между всеми индивидуальными соединениями на уровне $\mathrm{p} \leq 0,01$, что свидетельствует о едином источнике поступления в экосистему и организм рыб.

При анализе таблицы корреляций между индивидуальными соединениями в рыбах из р. Камчатка (табл. 6.8), среди пестицидов видна сильная положительная корреляция между $\alpha$-и $\gamma$-ГХЦГ $(\mathrm{p} \leq 0,05), \gamma$-ГХЦГ и $o, p$-ДДЕ $(\mathrm{p} \leq 0,05)$ и очень сильная отрицательная корреляция между $\beta$ ГХЦГ и $p, p^{\prime}$-ДДЕ $(\mathrm{p} \leq 0,01)$. Первые 2 взаимосвязи отражают единый источник поступления, последняя - вероятнее всего указывает на раздельное поступление соединений.

ПХБ 28, 52, 101, 118, 153 и 138 не показали достоверных корреляций с ГХЦГ и ДДТ. ПХБ 155 показал очень сильную положительную корреляцию $(\mathrm{p} \leq 0,01)$ с $\alpha$ - и $\gamma$-ГХЦГ и очень сильную отрицательную $(\mathrm{p} \leq 0,01)-\mathrm{c}$ $\beta$-изомером. Первые две могут свидетельствовать о едином источнике поступления соединений в то время, как последняя может указывать на возможное разрушение дифенильной основы ПХБ с последующим образованием $\beta$-ГХЦГ. ПХБ 143 показал очень сильную отрицательную корреля-

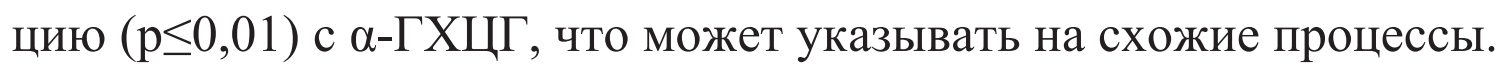


ПХБ 28 показал очень сильную положительную корреляцию $(\mathrm{p} \leq 0,01)$ с ПХБ 155, что, скорее всего свидетельствует о едином источнике поступления. В свою очередь ПХБ 52 показал очень сильную отрицательную корреляцию(p $\leq 0,01)$ с ПХБ 155, что скорее всего указывает на то, что деградация последнего происходит с промежуточным образованием 52 конгенера. С 155 ПХБ очень сильные отрицательные корреляции ( $\mathrm{p} \leq 0,01)$ показали более высокохлорированные ПХБ 101, 118 и 153, что указывает на деградацию и уменьшение хлора в кольце 155 ПХБ. При этом 101, 118, 153, 138, 118 и 153 ПХБ показали очень сильную положительную связь ( $\mathrm{p} \leq 0,01-0,05)$ между собой, что также говорит о совместном поступлении в экосистему.

Таким образом, поступление ХОП и ПХБ в организм кеты из р. Камчатка имеет различные источники, связанные с атмосферным переносом (в случае ХОП) и местным загрязнением (стоки со свалок и поврежденных трансформаторов, в случае ПХБ).

Сима (Oncorhynchus masu). Образцы симы отбирались в 2017 году в устье р. Бахура (Долинский округ) на восточном побережье о. Сахалин.

СО3 обнаружены во всех исследованных образцах (табл. 6.9, 6.10). Диапазон ХОП во всех исследованных образцах варьировал от 4,1 до 479,7 со средним значением $107,9 \pm 147,1$ нг/Г липидов. Большую часть ХОП составляли изомеры ГХЦГ с диапазоном концентраций 2,8-479,7 (среднее - 104,3 $\pm 149,3$ ) нг/Г липидов. $\alpha$-изомер был доминирующей формой ГХЦГ. ДДТ и его метаболиты обнаруживались фрагментарно, главным образом в мышцах. Суммарные концентрации ДДТ варьировали от

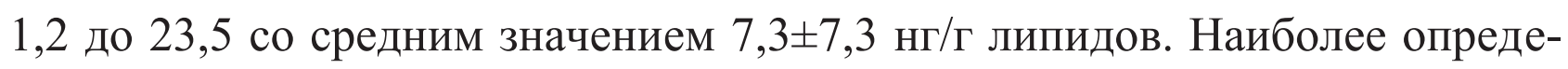
ляемым был $p, p$ '-ДДД со средней концентрацией 4,4 44,2 нг/г липидов.

В мышцах симы уровни ХОП варьировали от 4,1 до 35,4 (среднее значение $-20,1 \pm 11,0)$ нг/Г липидов (рис. 6.13). Суммарная концентрация ГХЦГ составила $11,8 \pm 11,5$ нг/Г липидов. Среди ДДТ и его метаболитов обнаружены

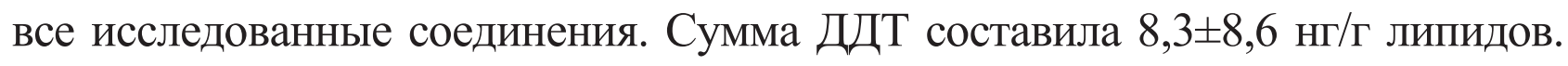
Наиболее определяемым метаболитом был $p$, $p$-ДДД, с концентрацией 4,9 44,7 нг/г липидов. В печени уровни ХОП варьировали от 32,2 до 141,7 со средним значением 76,1 $\pm 45,2$ нг/Г липидов. ГХЦГ составил 74,7 $\pm 46,4$ нг/г липидов. В гонадах диапазон концентраций ХОП варьировал в пределах 22,2-479,7 $(305,5 \pm 179,1)$ нг/Г липидов, в икре $-16,5-17(16,8 \pm 0,4)$ нг/Г липидов. ХОП в гонадах были представлены только ГХЦГ $(305,5 \pm 179,1)$, в икре - ГХЦГ и ДДЕ $(13,6 \pm 1,8$ и 3,2 $\pm 1,4$ нг/г липидов, соответственно). 


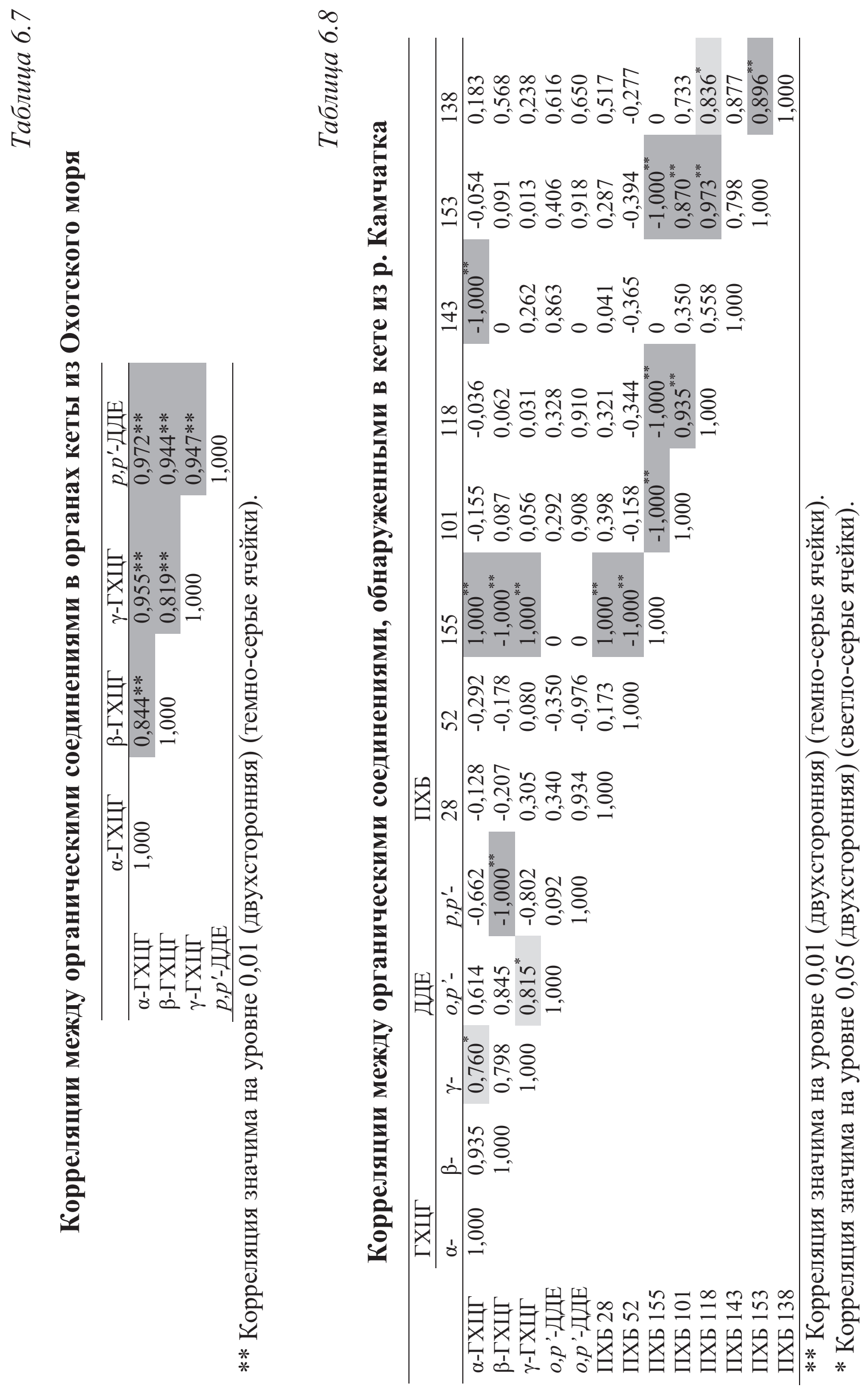




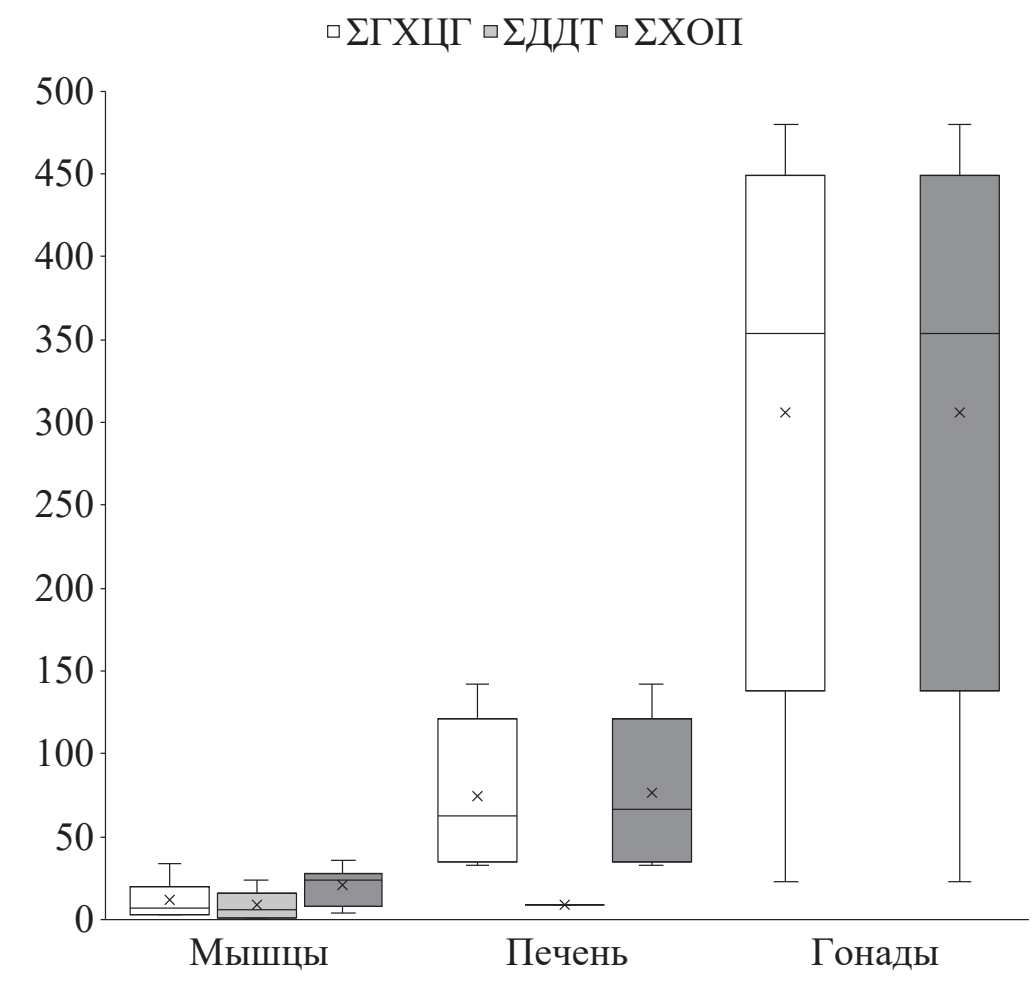

Puc. 6.13. Средние суммарные концентрации ДДТ, ГХЦГ и ХОП в органах симы, нг/г липидов

Суммарные концентрации ПХБ в органах симы варьировали от 3,3

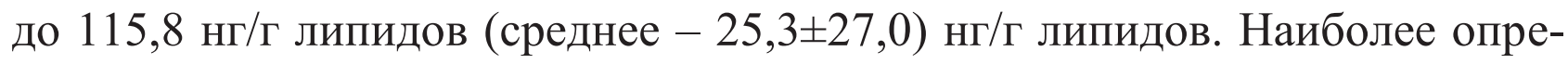
деляемыми среди всех образцов были ПХБ 52 и ПХБ 101, с концентрациями 10,3 $\pm 12,3$ и 5,8 $\pm 7,8$ нг/г липидов, соответственно. ПХБ 143, 180 и 207 были ниже пределов обнаружения.

Суммарные концентрации ПХБ в мышцах находились в диапазоне

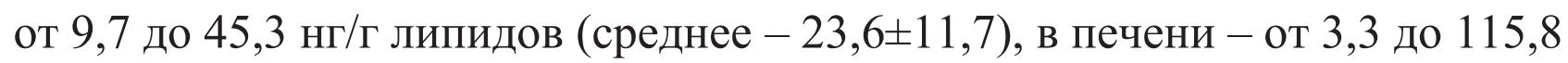

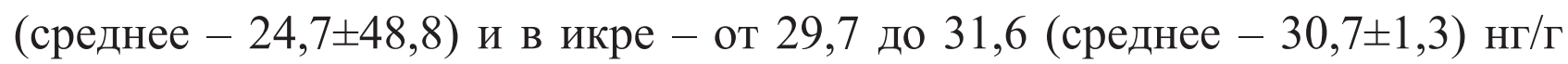
липидов. Большая часть конгенеров ПХБ обнаружена в мышцах

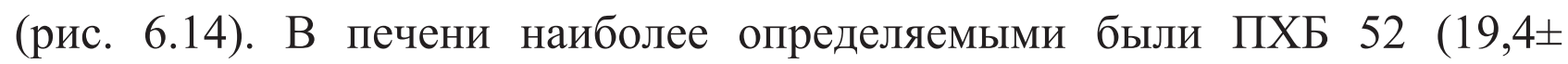

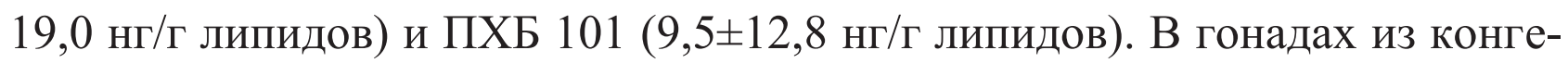
неров ПХБ найден только ПХБ 52 (29,9 нг/г липидов). В икре не обнаружен только 143 ПХБ.

При сравнении уровней СО3 в различных органах, обнаружено, что в гонадах концентрации всех изомеров ГХЦГ достоверно $(\mathrm{p} \leq 0,05)$ выше, чем в печени, икре и мышцах. ДДТ и его метаболиты обнаружены, в основном, в мышцах. ПХБ также обнаружены в основном в мышцах. 
0
0
0
0
0
0
0
0
0
0

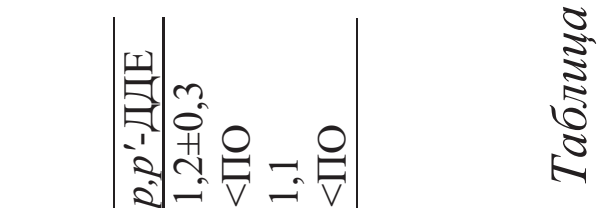

-2
0
0
0
0
$\frac{1}{3}$
0
0

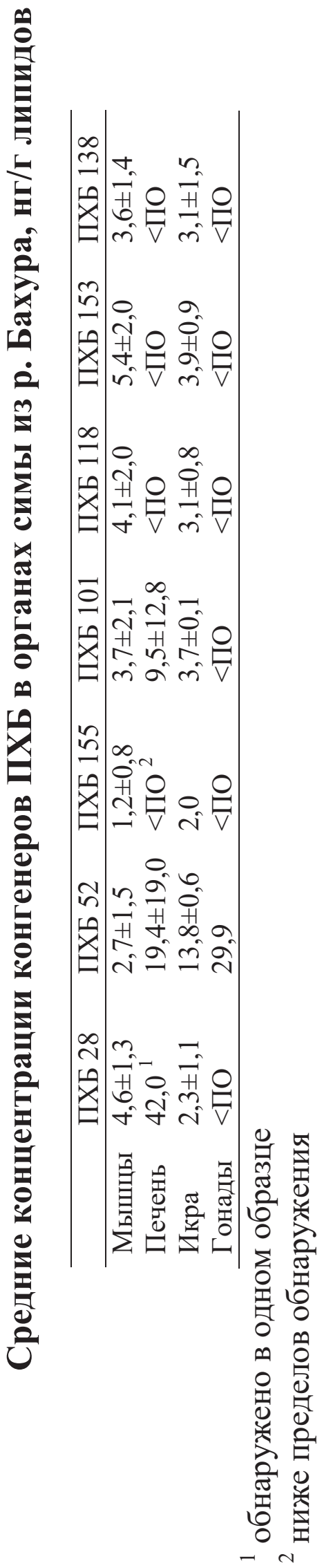




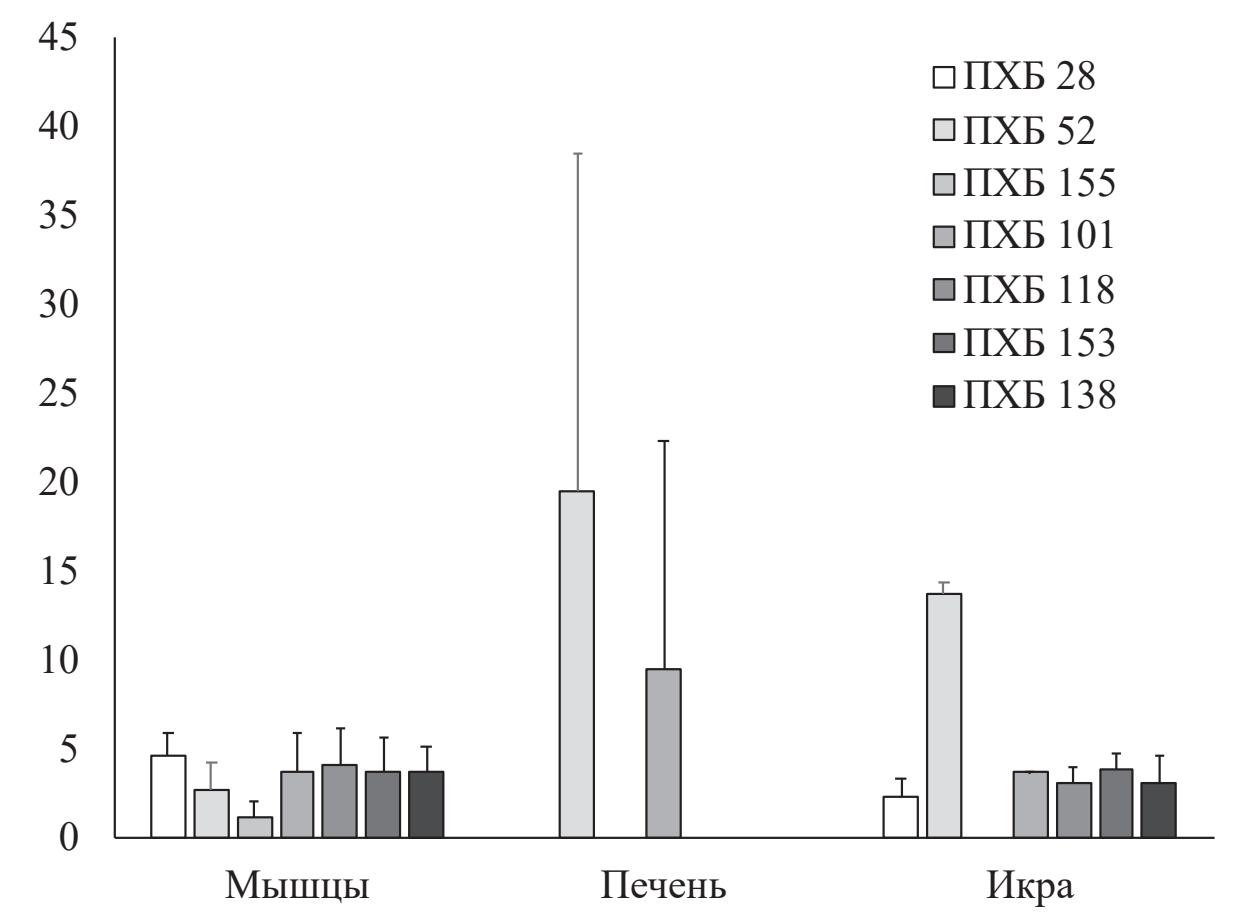

Puc. 6.14. Средние концентрации конгенеров ПХБ в органах симы из р. Бахура, нг/г липидов

Корреляции между индивидуальными соединениями СО3 представлены в таблице 6.11 .

Из пестицидов, все изомеры ГХЦГ показали средние и сильные положительные корреляции на уровне значимости от $\mathrm{p} \leq 0,05$ до $\mathrm{p} \leq 0,01$, что свидетельствует о совместном поступлении пестицидов в организм симы. Такая же зависимость наблюдается и между $о, p^{\prime}$-ДДД и $p, p^{\prime}$-ДДД $(\mathrm{p} \leq 0,01) . p, p^{\prime}$-ДДЕ показал очень сильную корреляцию $(\mathrm{p} \leq 0,01)$ с $\alpha$-ГХЦГ, что вероятно связано с совместным поступление токсикантов из хранилищ запрещенных к применению пестицидов, существующих на территории Сахалинской области [8].

ПХБ 155 и ПХБ 101 показали очень сильную отрицательную корреляцию $(\mathrm{p} \leq 0,01)$ с $p, p^{\prime}$-ДДЕ. Это может быть связано с возможным образованием этих конгенеров из $p, p^{\prime}$-ДДЕ в организме рыб. В то же время, ПХБ 101 показал среднюю положительную корреляцию $(\mathrm{p} \leq 0,05)$ с $\delta$-ГХЦГ, ПХБ 52 и ПХБ 155, что может говорить не только о совместном поступлении, но и о том, что эти соединения появляются в организме рыбы одновременно в процессе деградации исходных, поступивших из среды СО3. ПХБ 118 показал очень сильные корреляции $(\mathrm{p} \leq 0,01)$ с 153 и 138 ПХБ, что, вероятнее всего, говорит о едином источнике поступления, как и в случае высокохлорированных ПХБ в рыбах других районов. 


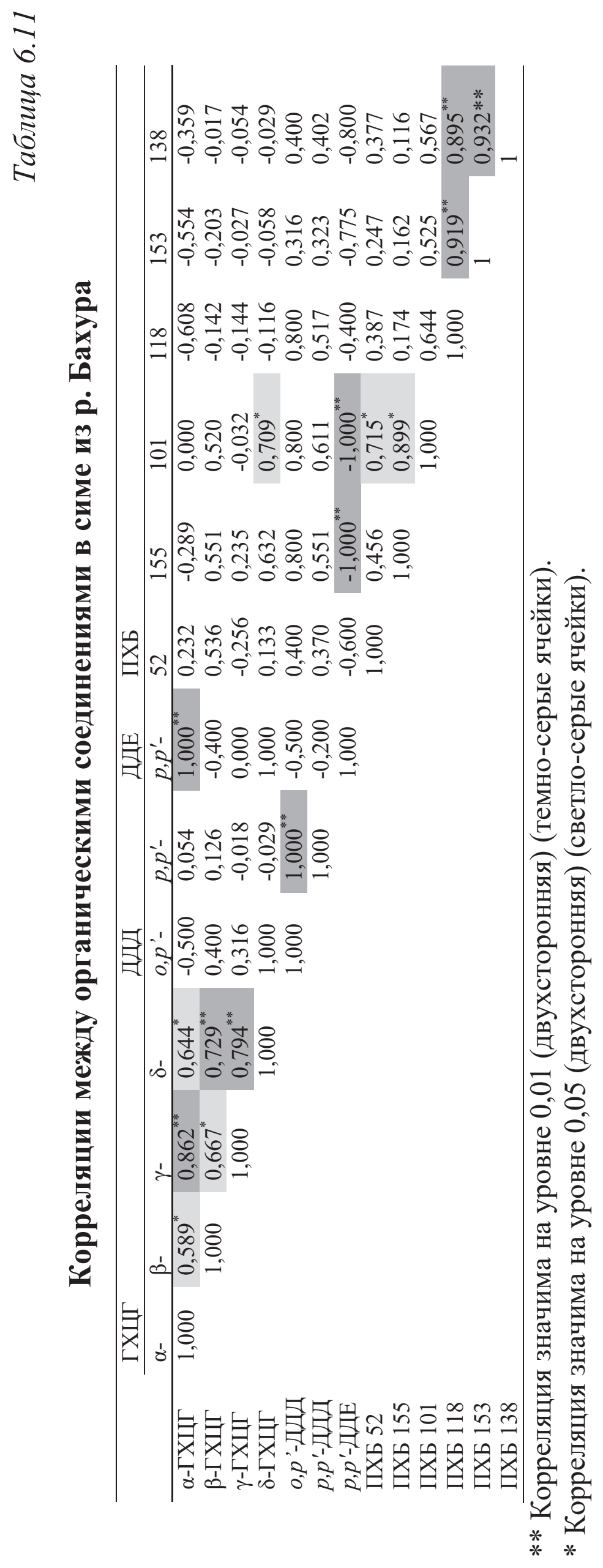


Таким образом, основное поступление ДДТ и ПХБ в организм симы вероятно произошло во время нагула. Об этом свидетельствует большие концентрации этих соединений именно в мышцах рыб, отражающих давнее загрязнение.

Чавыча (Oncorhynchus tshawytscha). Образцы отбирались в западной части Берингова моря (побережье п-ова Камчатка) (2010 г) и р. Камчатка (2018 г). В 2010 г. анализировались концентрации ХОП в мышцах и печени, в 2018 - ХОП и ПХБ в мышцах, печени и гонадах. СО3 обнаружены во всех исследованных образцах (табл. 6.12, 6.13).

В чавыче из западной части Берингова моря ХОП обнаружены во всех исследованных образцах в диапазоне от 151,2 до 4219 со средним значением $1277,7 \pm 1026,4$ нг/Г липидов. Основную часть ХОП составлял

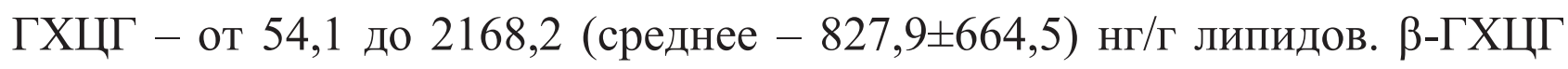
был ниже пределов обнаружения во всех исследованных органах. Из ДДТ и его метаболитов обнаружен только $p$, $p$ '-ДДЕ в широком диапазоне - от 66,6 до 3022,1 (среднее - 449,8 $\pm 596,8$ ) нг/г липидов.

Уровни ХОП в мышцах чавычи варьировали от 265,0 до 2435,4 (среднее - 1240,9 799,8$)$ нг/Г липидов, в печени - от 151,2 до 4219,0 (среднее - 1304,7 $\pm 1192,7$ ) нг/г липидов (рис. 6.15). Суммарные концентра-

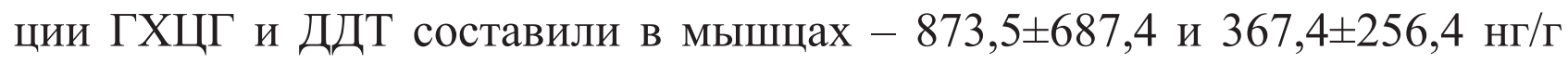

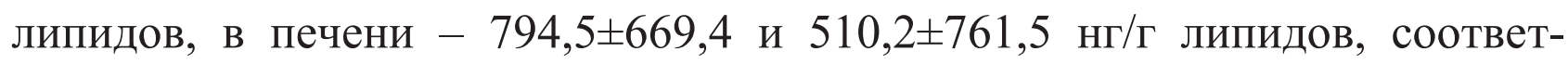
ственно. Средние суммарные концентрации ХОП в мышцах и печени статистически не различались.

В чавыче из $\boldsymbol{p}$. Камчатка диапазон концентраций ХОП варьировал от 7,7 до 70,8 со средним значением $31,4 \pm 23,1$ нг/Г липидов. Большую часть ХОП составлял ГХЦГ, варьировавший в пределах 6,4-70,8 (среднее -

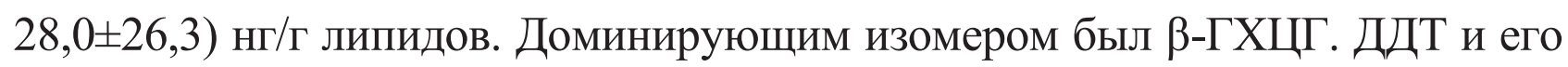
метаболиты обнаружены фрагментарно в мышцах и печени и отсутствуют в гонадах. Уровни ДДТ варьировали от 0,4 до 41,4 со средней концентрацией $12,9 \pm 19,1$ нг/г липидов. Наиболее определяемым метаболитом был

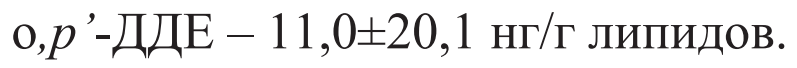




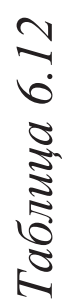

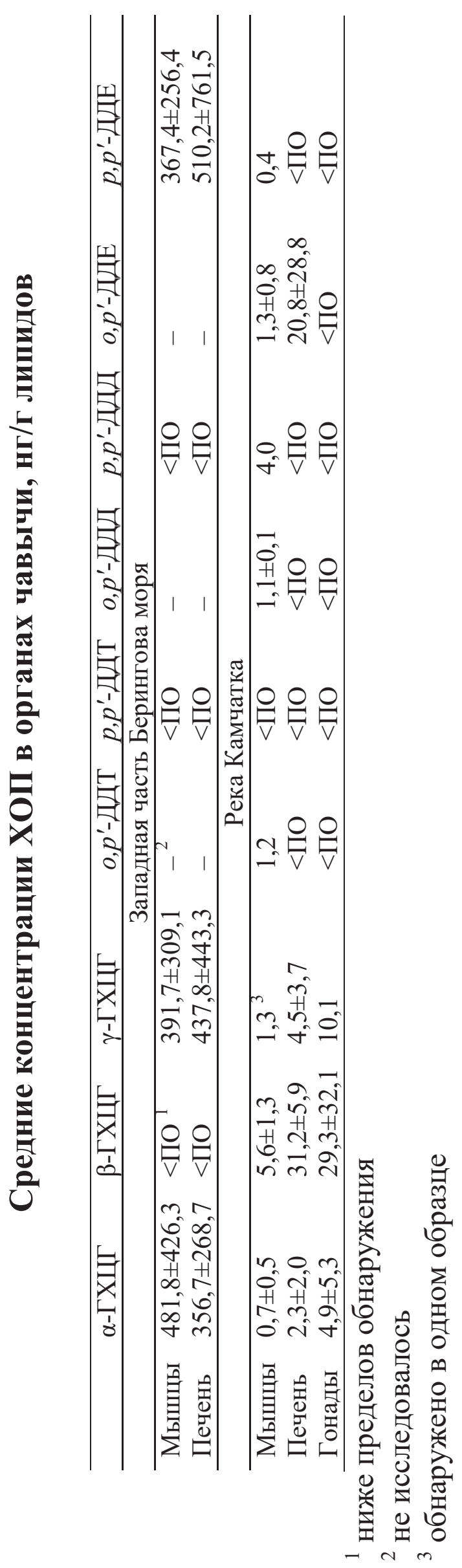

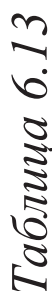

है

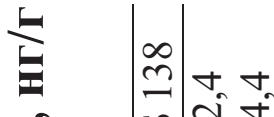

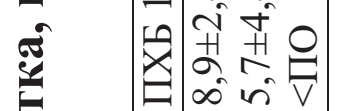

5

in 0

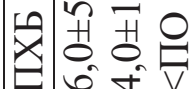

$\frac{0}{5}$

莗

은 $n$

華苦

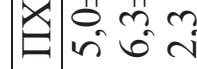

in

琝

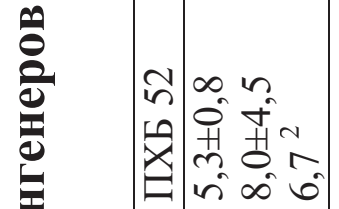

se

ง

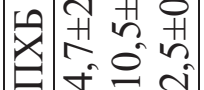

อ

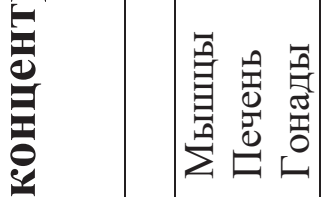

预

릉

气

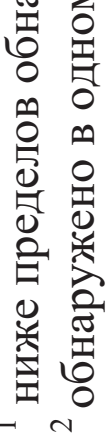




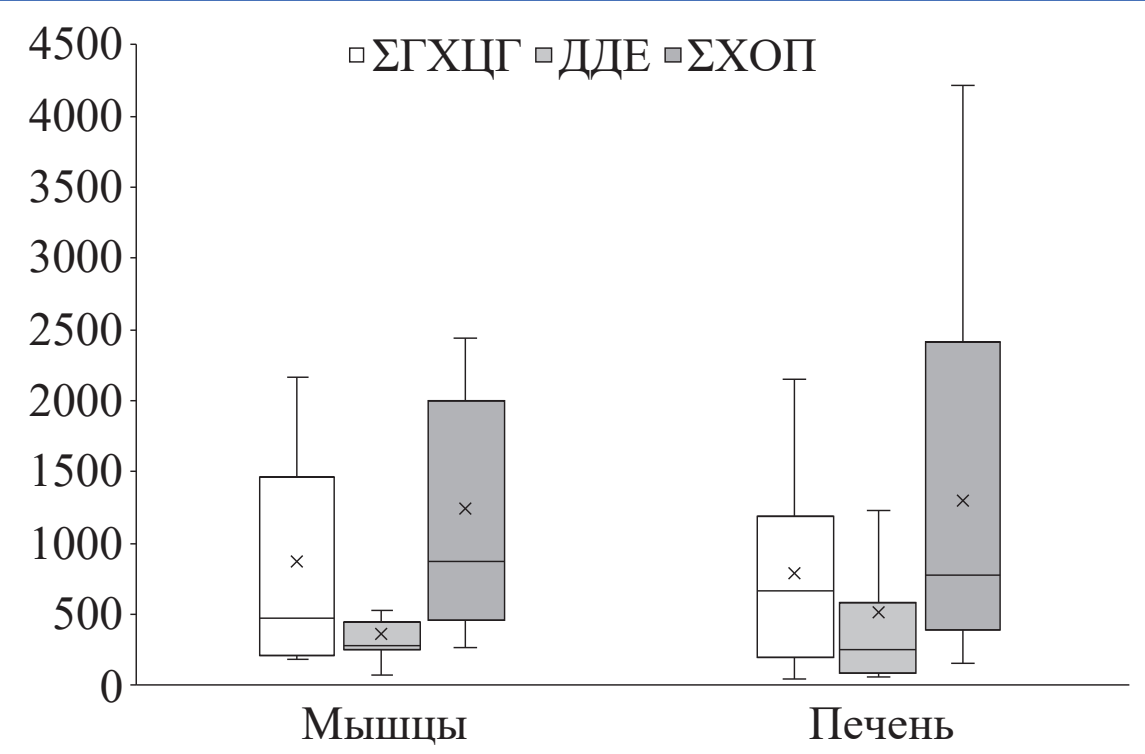

Puc. 6.15. Средние концентрации ГХЦГ, ДДЕ и ХОП в органах чавычи из западной части Берингова моря, нг/г липидов

В мышщах диапазон уровней ХОП варьировал от 8,5 до 15,6 (среднее -

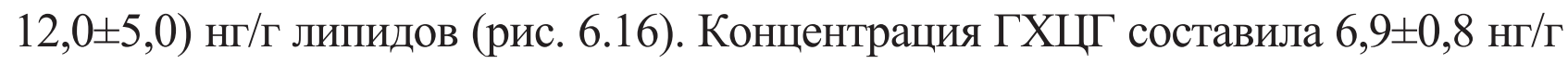
липидов. $\gamma$-ГХЦГ обнаружен в одном образце с концентрацией 1,3 нг/Г липидов. ДДТ и его метаболиты определялись фрагментарно. ДДТ составил $5,1 \pm 4,2$ нг/г липидов. Наиболее определяемыми метаболитами были $о, p$-ДДД и $о, p$-ДДЕ $-1,1 \pm 0,1$ и $1,3 \pm 0,8$ нг/г липидов, соответственно. В печени чавычи концентрации ХОП достоверно $(\mathrm{p} \leq 0,05)$ выше, чем в мышцах и варьировали от 30,2 до 46,1 со средним значением 39,1 18,1 нг/Г липидов. Суммарные

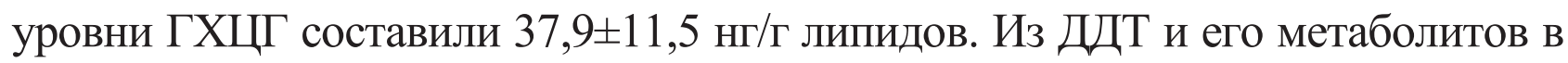
печени обнаружен только о, ${ }^{\prime}$-ДДЕ - 20,8 $\pm 28,8$ нг/Г липидов. В гонадах ХОП варьировали от 7,7 до 70,8 (среднее - 39,3 444,6 ) нг/г липидов и были представлены только ГХЦГ.

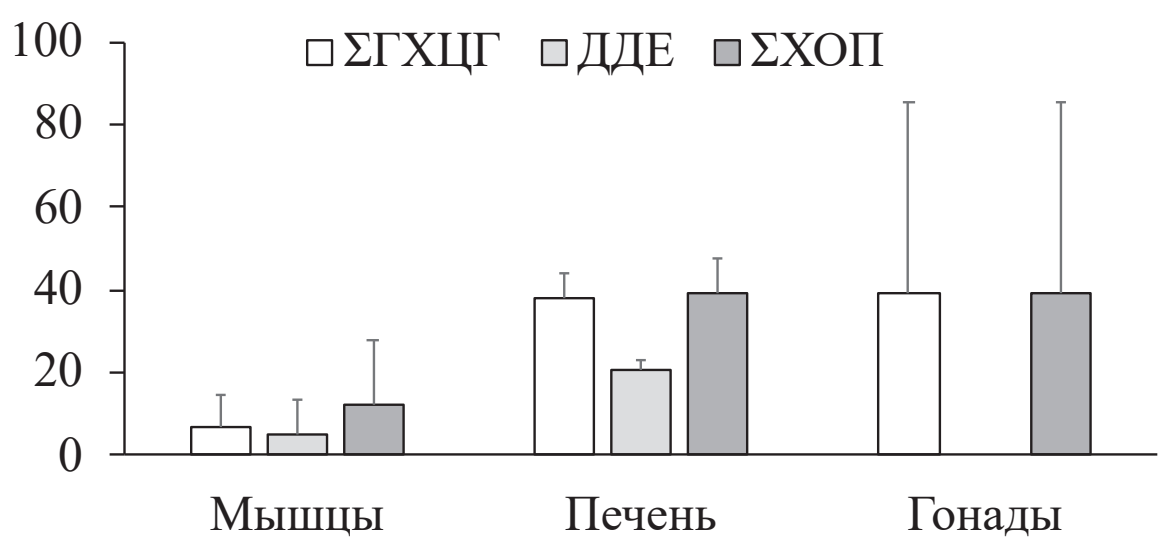

Puc. 6.16. Средние концентрации ГХЦГ, ДДТ и ХОП в органах чавычи из р. Камчатка, нг/г липидов 
Суммарные концентрации ПХБ в органах чавычи из р. Камчатка ва-

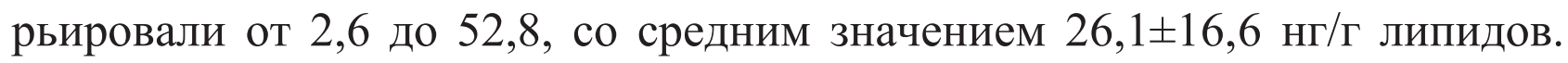
Среди ПХБ, наименее определяемым конгенером являлся ПХБ 155, обнаруженный только в мышцах - 1,0土0,1 нг/Г липидов. ПХБ 143, 180 и 207 были ниже пределов обнаружения.

В мышцах чавычи суммарные концентрации ПХБ варьировали в пределах 15,2-52,8 (среднее - 34,8 $\pm 18,9$ ) нг/Г липидов, в печени - от 15,5 до 38,2 (среднее - 29,0 11,9 ) нг/Г липидов, в гонадах - от 2,6 до 14,5 (среднее - 8,6 6 8,4) нг/Г липидов. Определены как «легкие» (ПХБ 52 и 28), так и «тяжелые» (ПХБ 101, 118, 153, 138) конгенеры (рис. 6.17)

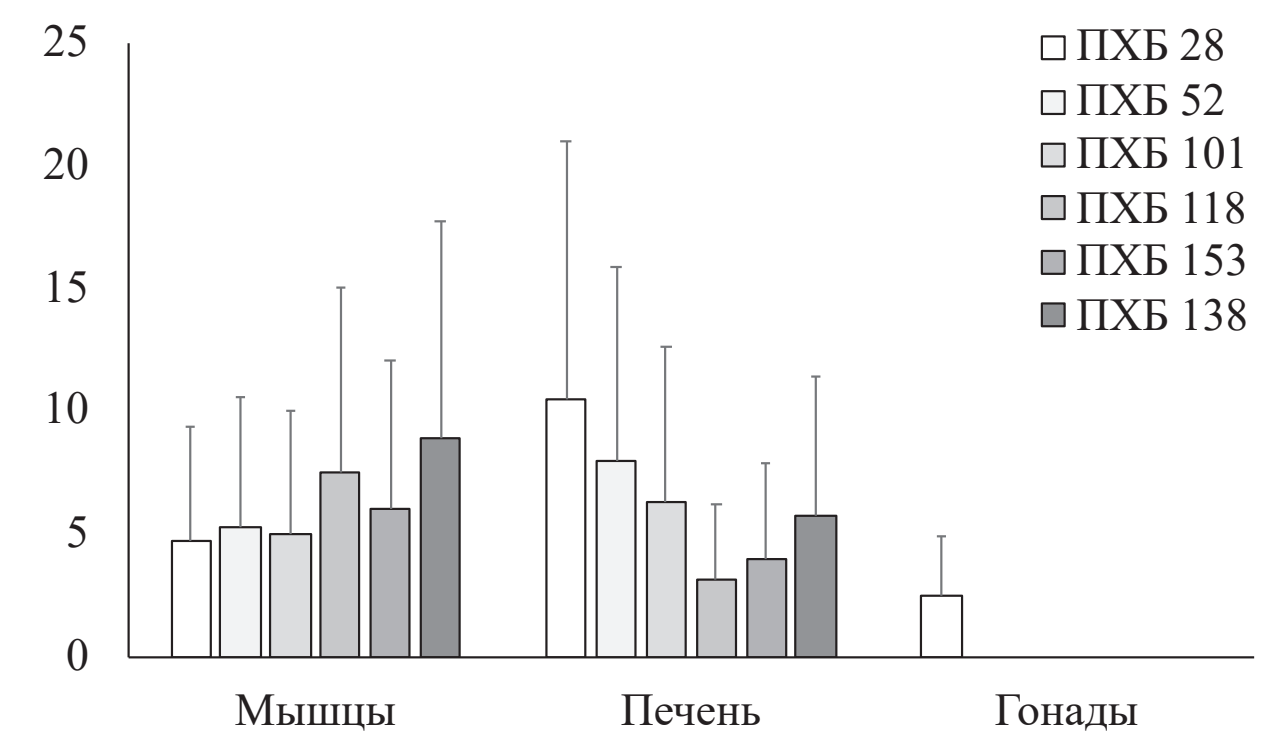

Puc. 6.17. Концентрации наиболее определяемых конгенеров ПХБ в органах чавычи из р. Камчатка, нг/г липидов

Концентрации ХОП в чавыче из Берингова моря (2010 г.) были достоверно $(\mathrm{p} \leq 0,05)$ выше во всех образцах, чем в рыбах из $\mathrm{p}$. Камчатка (2018 г.), то есть явно прослеживается тенденция к уменьшению концентраций пестицидов в органах рыб во времени. Наблюдается тренд снижения концентраций ГХЦГ и ДДТ, что указывает на постепенное выведение ксенобиотиков из экосистем дальневосточных морей России.

Разница в накоплении СО3 между рыбами из Берингова моря и p. Камчатка, как и в случае горбуши, может объясняться влиянием Тихоокеанского мусорного пятна. При миграции через этот район, рыбы поглощают частицы микропластика, содержащие $\mathrm{CO} 3$, что способствует увеличению концентраций ксенобиотиков в их организме. Чавыча, вылов- 
ленная в р. Камчатка в 2018 г., вероятно, нагуливалась в северных, более «чистых» районах, ввиду чего обнаруженные в ней концентрации незначительны. Оценить динамику изменения концентраций ПХБ невозможно, так как исследование этих соединений проводилось только в 2018 году.

Соотношение индивидуальных соединений в органах рыб также изменилось. В рыбах из Берингова моря доминирующим изомером был $\alpha-$ ГХЦГ в то время, как в чавыче из р. Камчатка превалировал уже $\beta$-изомер. Последнее указывает на деградацию исходного соединения (линдана) до наиболее устойчивой формы и его длительную циркуляцию в экосистеме.

В чавыче из Берингова моря из метаболитов ДДТ обнаружен только $p, p$-ДДЕ, в то время как в рыбах из р. Камчатка фрагментарно обнаруживались практически все метаболиты, причем основная часть - в мышцах. Это может отражать как влияние глобального атмосферного переноса, так и локального загрязнения вод р. Камчатка, поскольку известно, что перед нерестом чавыча может залегать на дно нерестового водоема более, чем на месяц [9].

Сильные положительные корреляции $(\mathrm{p} \leq 0,01)$ между индивидуальными соединениями, обнаруженные в органах чавычи из Берингова моря. Корреляции между изомерами ГХЦГ и $p, p^{\prime}$-ДДЕ, вероятнее всего связаны с единым источником или районом поступления токсикантов, как и в случае кеты и горбуши.

В чавыче из р. Камчатка обнаружены сильные положительные корреляции $(\mathrm{p} \leq 0,01)$ между $\alpha-, \beta$ - и $\gamma$-изомерами ГХЦГ (табл. 6.14), что также указывает на одновременное поступление в организм рыб. о, $p$-ДДД показал очень сильные отрицательные корреляции $(\mathrm{p} \leq 0,01)$ с ПХБ 28 и ПХБ 52. Это может быть связано с превращение ДДД в указанные конгенеры ПХБ или с возможным вытеснением последних во время биоаккумуляции ксенобиотиков. Помимо отрицательных корреляций, o,p'-ДДД сильно коррелировал (прямая связь) $(\mathrm{p} \leq 0,01)$ с ПХБ 118, ПХБ 153 и ПХБ 138. Это, вероятнее всего, свидетельствует о едином источнике поступления и может отражать влияние стоков со свалок твердых бытовых отходов во время преднерестовой отлежки в водоеме. ПХБ 118 показал сильную корреляцию с $\gamma$-ГХЦГ (обратная) (p $\leq 0,01)$ и ПХБ 153 (прямая) ( $\leq 0,05)$. Это говорит о том, что источники ХОП и ПХБ различные. 
Таблиияа 6.14

Корреляции между органическими соединениями

в органах чавычи из р. Камчатка

\begin{tabular}{|c|c|c|c|c|c|c|c|c|c|}
\hline & \multicolumn{3}{|c|}{ ГХЦГ } & \multirow{2}{*}{$\begin{array}{l}\text { ДДД } \\
o, p^{\prime}-\end{array}$} & \multicolumn{5}{|l|}{ ПХБ } \\
\hline & $\alpha-$ & $\beta-$ & $\gamma-$ & & 28 & 52 & 118 & 153 & 138 \\
\hline$\alpha_{-}{ }^{1}$ & 1,000 & $0,829^{*}$ & $1,000^{* *}$ & $-1,000$ & $-0,257$ & $-0,300$ & $-0,700$ & 0,000 & 0,000 \\
\hline$\beta-{ }^{1}$ & & 1,000 & $1,000^{* *}$ & $-1,000$ & 0,086 & 0,200 & $-0,029$ & 0,200 & $-0,800$ \\
\hline$\gamma-1$ & & & 1,000 & 0 & $-0,200$ & $-0,500$ & $-1,000^{* *}$ & $-0,500$ & $-0,500$ \\
\hline ДД ${ }^{2}$ & & & & 1,000 & $-1,000^{* *}$ & $-1,000^{* *}$ & $1,000^{* *}$ & $1,000^{* *}$ & $1,000^{* *}$ \\
\hline $28^{3}$ & & & & & 1,000 & 0,000 & $-0,400$ & $-0,800$ & $-0,800$ \\
\hline $52^{3}$ & & & & & & 1,000 & $-0,300$ & $-0,800$ & $-0,800$ \\
\hline $118^{3}$ & & & & & & & 1,000 & $0,900^{*}$ & $-0,100$ \\
\hline $153^{3}$ & & & & & & & & 1,000 & 0,000 \\
\hline $138^{3}$ & & & & & & & & & 1,000 \\
\hline
\end{tabular}

** Корреляция значима на уровне 0,01 (двухсторонняя) (темно-серые ячейки);

* Корреляция значима на уровне 0,05 (двухсторонняя) (светло-серые ячейки);

${ }^{1}$ ГХЦГ; ${ }^{2} o, p$ '-ДДД; ${ }^{3}$ ПХБ

Нерка (Oncorhynchus nerka). Образцы отбирались в западной части Берингова моря (побережье п-ова Камчатка) (2011 г), оз. Азабачье (п-ов Камчатка) (2017 г.) и р. Камчатка (восточное побережье п-ова Камчатка) (2018 г.). В 2010 г. анализировались концентрации ХОП в мышцах и печени, в 2017 и 2018 гг. - ХОП и ПХБ в мышцах, печени и гонадах. СО3 обнаружены во всех исследованных образцах (табл. 6.15, 6.16).

В нерке из западной части Берингова моря ХОП обнаружены во всех исследованных образцах в широком диапазоне от 41 до 7103,7 со средним значением $3052,5 \pm 2474,2$ нг/г липидов. Основную часть ХОП составляли изомеры ГХЦГ, суммарные концентрации которых варьировали от 41 до 6581,9 (среднее - 2864,4 2336,2 ) нг/Г липидов. Из ДДТ и его метаболитов обнаружен только $p$, $p$-ДДЕ в широком диапазоне от 64,3 до 927,8 (среднее значение - 332,8 \pm 295 ) нг/г липидов.

В мышцах диапазон уровней ХОП варьировал от 165,7 до 3020,1 со средней концентрацией 1640,5 $\pm 1221,1$ нг/Г липидов (рис. 6.18). ГХЦГ и ДДЕ составили $1567,3 \pm 1186,8$ и $117,1 \pm 62,7$ нг/г липидов, соответственно. В печени диапазон ХОП варьировал от 41 до 7103,7 (среднее $3805,7 \pm 2669,6)$ нг/Г липидов. Уровни ДДЕ и ГХЦГ обнаружены в концен-

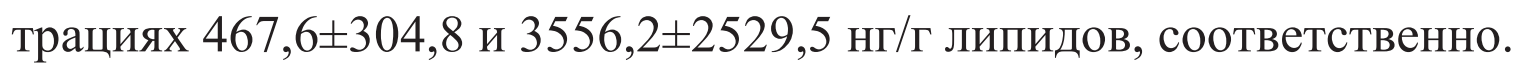




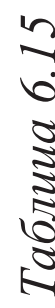

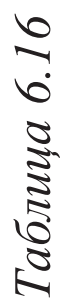

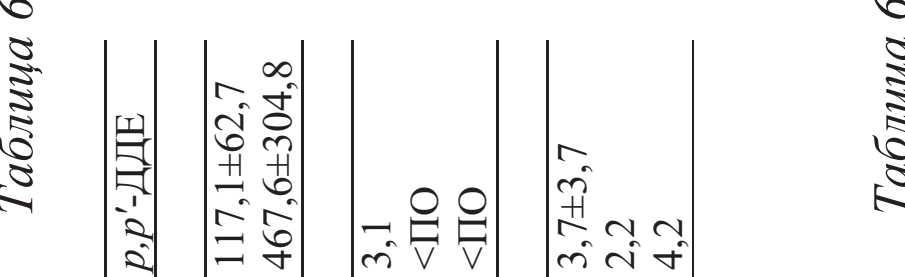

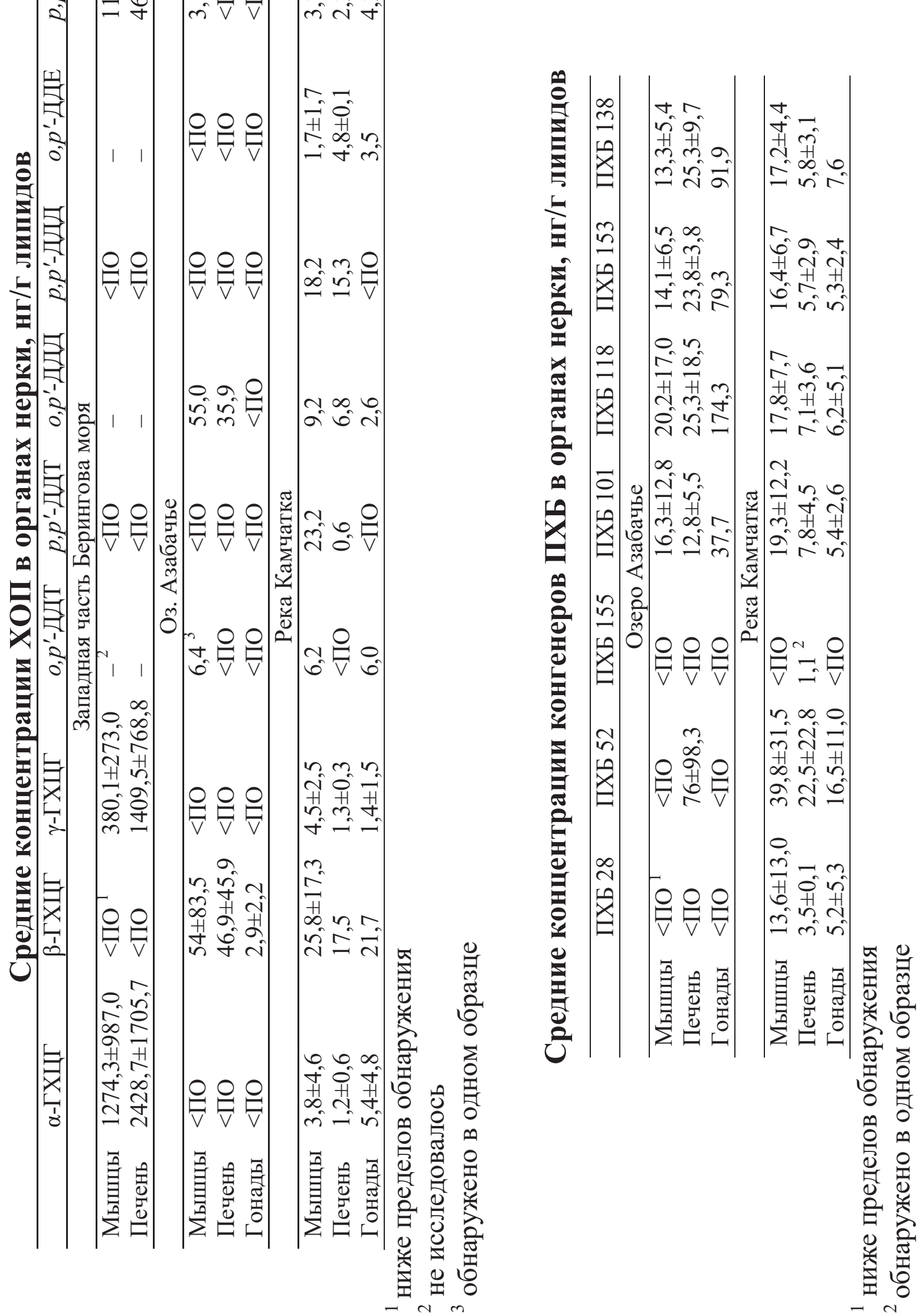




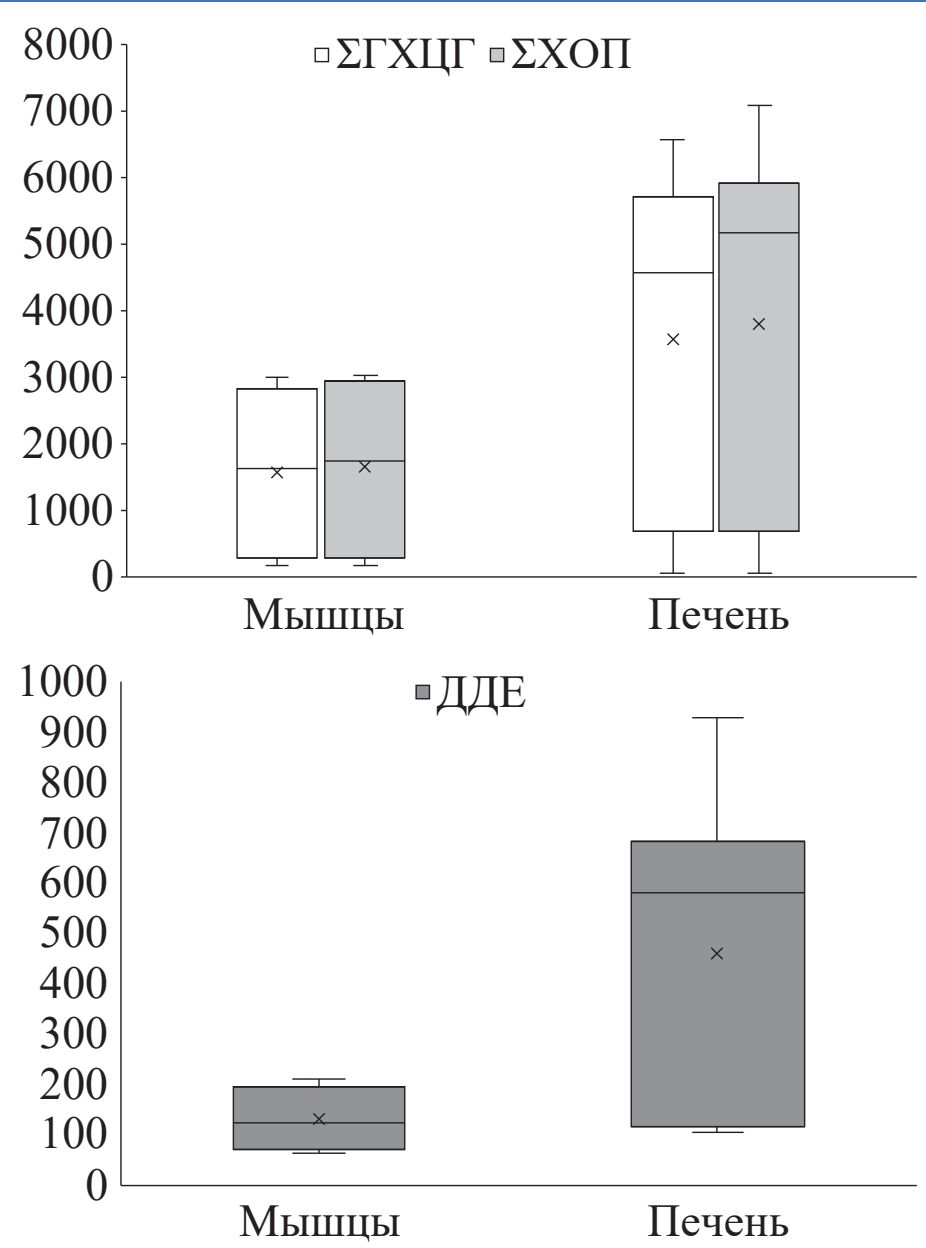

Рис. 6.18. Концентрации ГХЦГ, ХОП (А) и ДДЕ (Б) в органах нерки из Берингова моря, нг/Г липидов

В нерке из оз. Азабачье диапазон ХОП во всех органах варьировал в пределах 1,4-208,6 (среднее значение - 51,1土77,5) нг/г липидов. Из всех изомеров ГХЦГ обнаружена только $\beta$-форма с диапазоном от 1,4 до 150,4

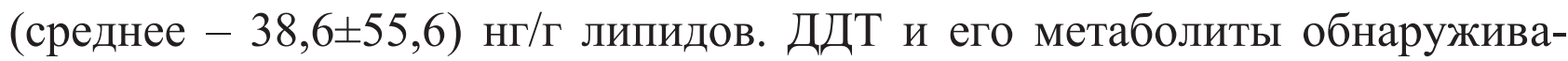
лись единично: $о, p^{\prime}$-ДДТ - 6,4; o, $p^{\prime}$-ДДД - 35,9 и 55; $p, p^{\prime}$-ДДЕ - 3,1 нг/г липидов. Их сумма составила $33,5 \pm 26,0$ нг/г липидов.

В мышцах диапазон концентраций ХОП варьировал от 6,6 до 208,6 (среднее $-75,5 \pm 115,3$ ) нг/г липидов (рис. 6.19). Уровни $\beta$-ГХЦГ составили $54,0 \pm 83,5$ нг/г липидов. Из ДДТ и его метаболитов обнаружены $о, p$ '-ДДТ (6,4 нг/г липидов) и о,p'-ДДД (35,9 и 55 нг/г липидов). В печени концен-

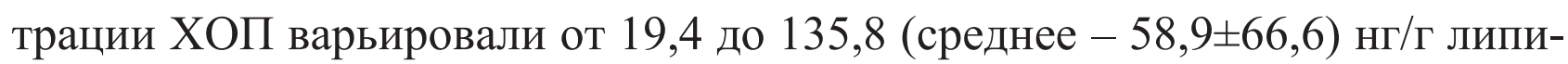
дов. $\beta$-ГХЦГ составил $46,9 \pm 45,9$ нг/г липидов. Из ДДТ и его метаболитов обнаружен только p,p'-ДДЕ - 3,1 нг/г липидов. В гонадах ХОП были представлены только $\beta$-ГХЦГ - 2,9 $\pm 2,2$ нг/г липидов. 


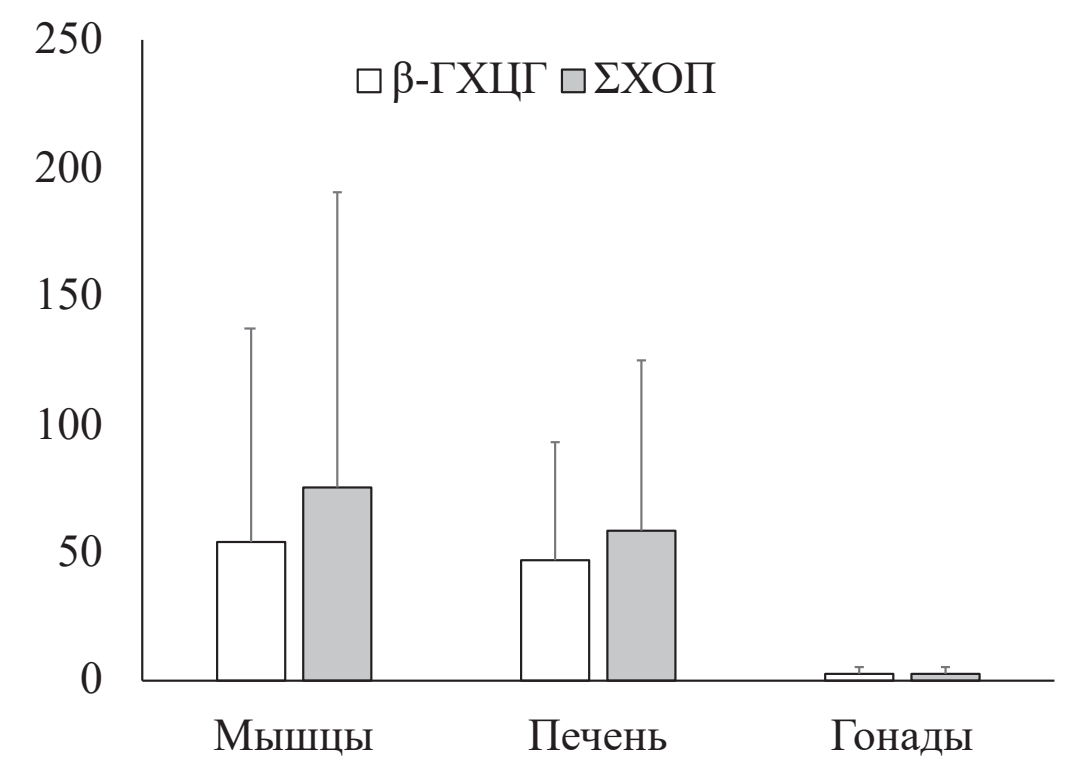

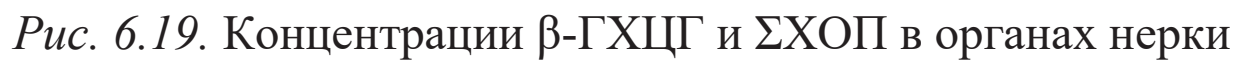
из оз. Азабачье, нг/г липидов

Уровни ПХБ в органах нерки из оз. Азабачье варьировали от 17,8 до 383,2 со средней концентрацией $134,2 \pm 135,6$ нг/г липидов. Наименее определяемым конгенером был ПХБ 52. Конгенеры 28, 155, 143, 180 и 207 были ниже пределов обнаружения.

В мышцах нерки из оз. Азабачье суммарные концентрации ПХБ находились в пределах 34,3-110,0 (среднее - 63,9土40,4) нг/Г липидов, в пе-

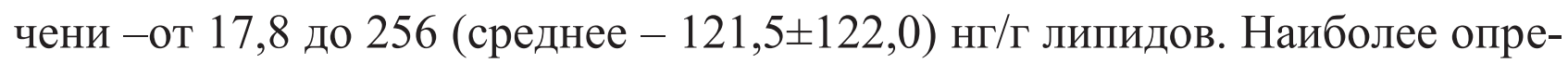
деляемыми ПХБ были 101, 118, 153 и 138 конгенеры (рис. 6.20). В гонадах конгенеры ПХБ обнаружены только в одном образце с концентрациями: ПХБ 101 - 37,7; ПХБ 118 - 174,3; ПХБ 153 - 79,3; ПХБ 138 - 91,9 нг/Г липидов.

В нерке из р. Камчатка диапазон ХОП варьировал от 18,4 до 117,4 со средним значением 40,7 $\pm 38,1$ нг/Г липидов. Суммарные концентрации изомеров ГХЦГ находились в пределах 2,4-51,4 (среднее - 21,0 18,8 ) нг/Г липидов. Доминирующим изомером был $\beta$-ГХЦГ. Большую часть ХОП составляли ДДТ и его метаболиты с диапазоном концентраций от 1,5 до 66,1 (среднее - 23,7 26,1 ) нг/г липидов. Наиболее часто определялись $o, p$ '-ДДЕ и $p, p$ '-ДДЕ - 3,3 $\pm 1,8$ и 3,4 2,3 нг/г липидов, соответственно.

В мышцах концентрации ХОП варьировали от 18,4 до 117,4 со сред-

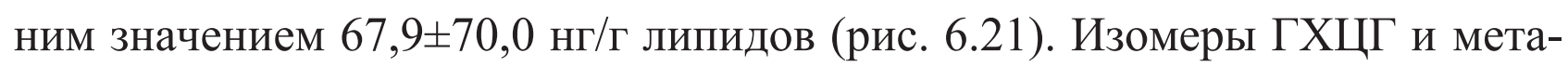
болиты ДДТ составляли примерно равные части - 34,1 $\pm 24,4$ и $33,8 \pm$ 
45,6 нг/г липидов, соответственно. В печени диапазон ХОП составлял от 24,6 до 32,3 , со средней концентрацией $28,4 \pm 5,5$ нг/г липидов. Изомеры ГХЦГ, ДДТ и его метаболитов составили $11,2 \pm 12,0$ и 17,2 $\pm 17,5$ нг/г липидов, соответственно. В гонадах диапазоны концентраций ХОП варьировали в пределах 18,7-33 (среднее - 25,8 $\pm 10,1$ ) нг/Г липидов. ГХЦГ составил $17,7 \pm 21,6$ нг/г липидов. Из метаболитов ДДТ обнаружены $о, p$ '-ДДТ, $o, p$ 'ДДД, $o, p$ '-ДДЕ и $p, p$ '-ДДЕ - 6, 2,6, 3,5 и 4,2 нг/г липидов, соответственно.

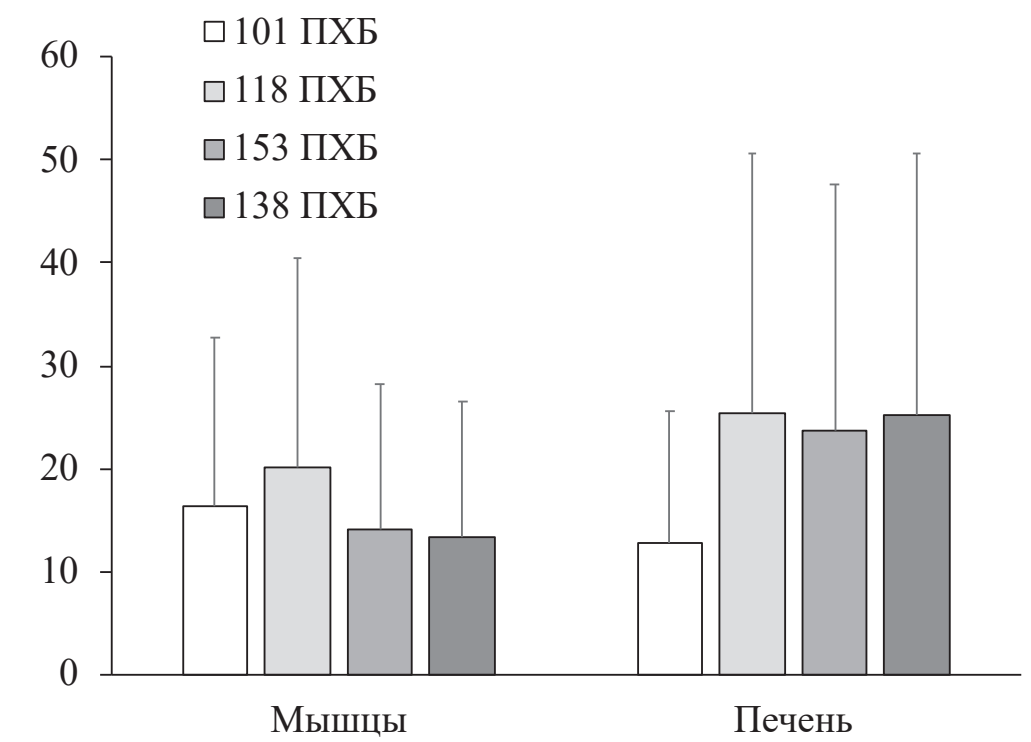

Puc. 6.20. Средние концентрации наиболее определяемых конгенеров в органах нерки из оз. Азабачье, нг/г липидов

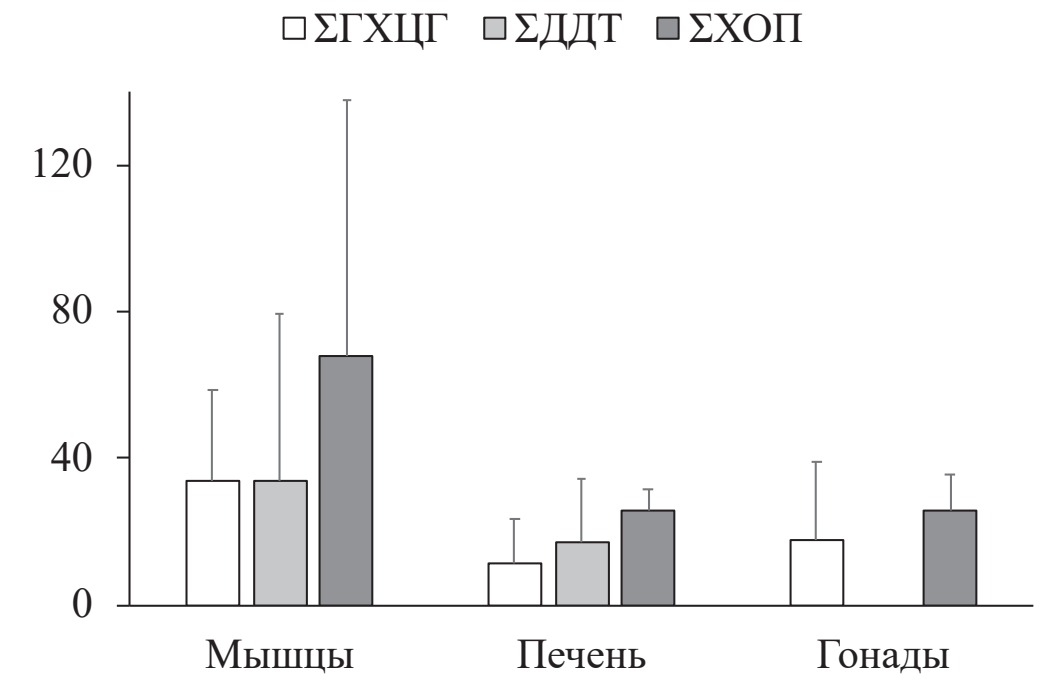

Puc. 6.21. Средние концентрации ГХЦГ, ДДТ и ХОП в органах нерки из р. Камчатка, нг/г липидов 
Суммарные концентрации ПХБ в органах нерки из р. Камчатка варьировали от 26,3 до 133,4 нг/Г липидов со средним значением 73,0 44,5 . ПХБ 155 обнаружен в одном образце с концентрацией 1,1 нг/Г липидов. ПХБ 143, 180 и 207 были ниже пределов обнаружения.

В мышцах уровни ПХБ находились в пределах 114,4-133,4 с суммарной концентрацией $123,9 \pm 13,4$ нг/Г липидов. В печени ПХБ варьировали от 26,3 до 79,3 со средним значением 52,8 $\pm 37,5$ нг/г липидов. ПХБ 155 обнаружен в одном образце печени - 1,1 нг/Г липидов. В гонадах диапазон ПХБ варьировал от 27,3 до 57,3 (среднее - 42,3 $\pm 21,2$ ) нг/г липидов. Во всех образцах обнаружены 28, 52, 101, 118 и 153 ПХБ (рис. 6.22). ПХБ 138 обнаружен во всех пробах мышц и печени.

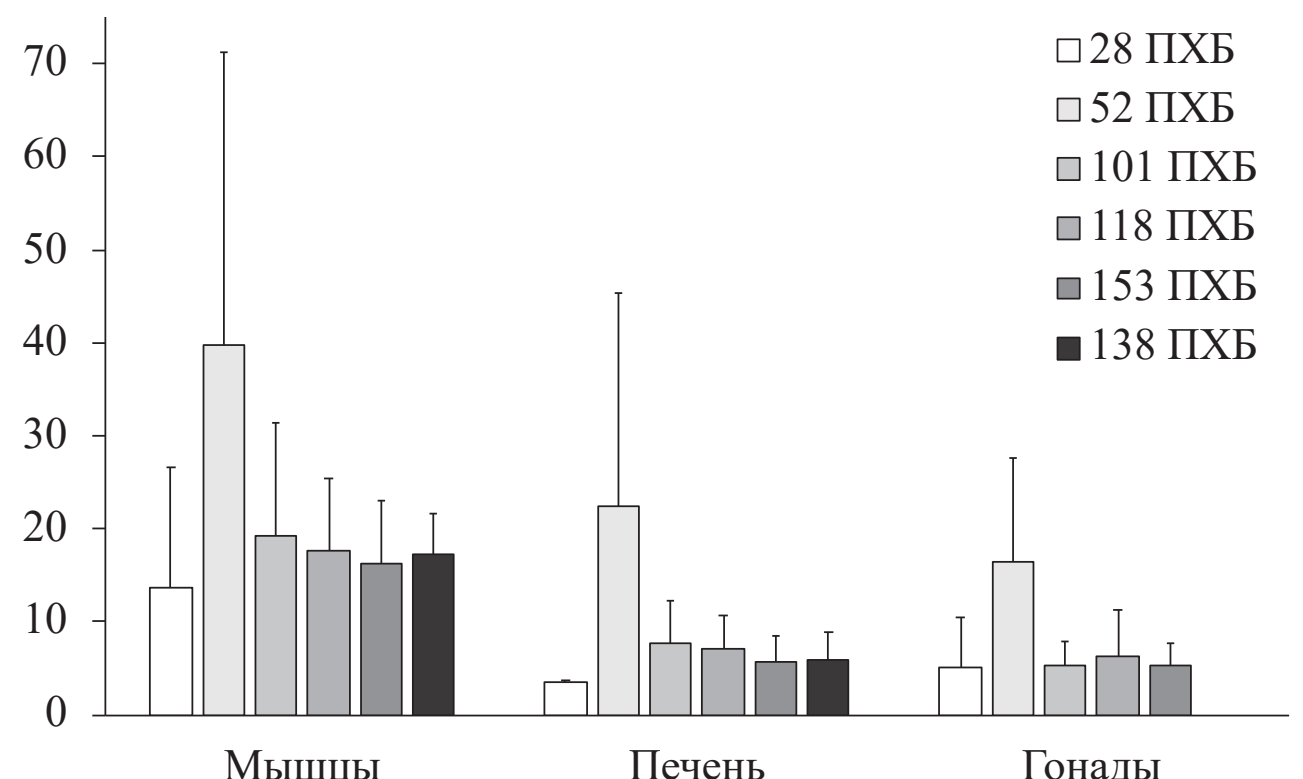

Puc. 6.22. Средние концентрации конгенеров ПХБ в органах нерки из р. Камчатка, нг/г липидов

Уровни ксенобиотиков в органах нерки достоверно различались $(\mathrm{p} \leq 0,05)$ только в Беринговом море - концентрации ХОП в печени выше, чем мышцах.

Сравнение концентраций в органах нерки из различных частей даль-

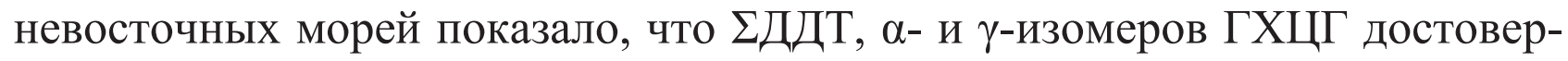
но $(\mathrm{p} \leq 0,05)$ выше в нерке из Берингова моря, чем в таковых из оз. Азабачье и р. Камчатка (рис. 6.23). 
Из конгенеров ПХБ достоверные $(\mathrm{p} \leq 0,05)$ различия в концентрациях по району показал только ПХБ 153, концентрации которого были выше в оз. Азабачье, чем в р. Камчатка (рис. 6.24).

Если же рассмотреть изменение концентраций СО3 во времени, то явно виден тренд к снижению уровней ГХЦГ и ДДТ от 2011 года к 2018, причем снижение ГХЦГ более резкое, чем ДДТ. Между 2017 и 2018 годом также наблюдается тенденция к уменьшению концентраций ХОП (уровни ГХЦГ падают более резко, чем ДДТ), однако статистически значимой разницы между 2017 и 2018 гг. не наблюдается. Суммарные концентрации ПХБ также уменьшаются от 2017 к 2018 гг., но статистически не различаются.

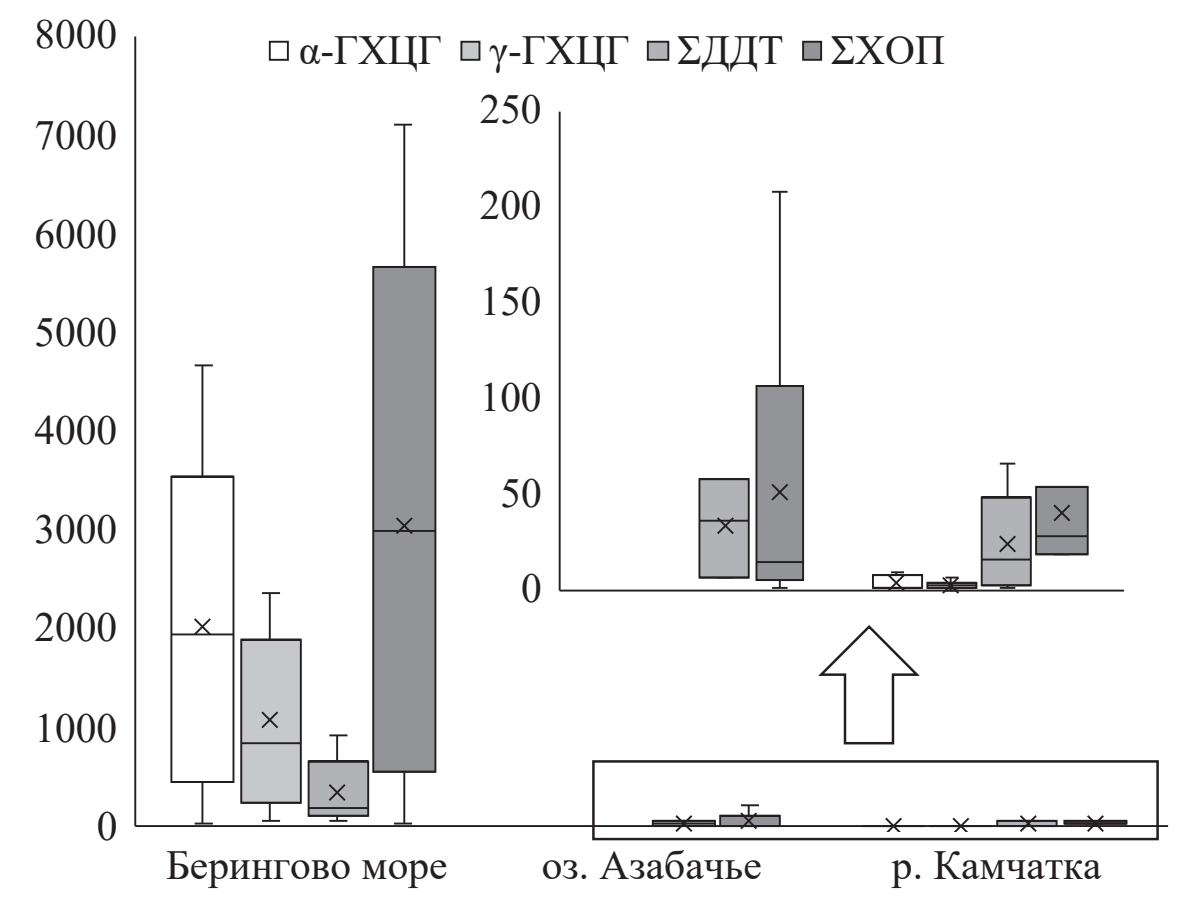

Puc. 6.23. Концентрации изомеров ГХЦГ, ДДТ и ХОП в нерке из различных районов дальневосточных морей, нг/г липидов

Корреляции между индивидуальными соединениями в органах нерки из Берингова моря показали сильную взаимосвязь между $\alpha$ - и $\gamma$ ГХЦГ, $\gamma$-ГХЦГ и $p, p$ '-ДДЕ, что указывает на единый источник поступления соединений в экосистему и организм рыб.

В нерке из оз. Азабачье достоверные корреляции обнаружены только между тяжелыми конгенерами ПХБ: 101 и 118 ( $\leq \leq 0,01) ; 138$ и 101( $\mathrm{p} \leq 0,05)$; 138 и 118 ( $\mathrm{p} \leq 0,05) ; 138$ и 153 ( $\mathrm{p} \leq 0,01)$ (табл. 6.17). Это свидетельствует о едином источнике поступления соединений в экосистему и организм нерки. 


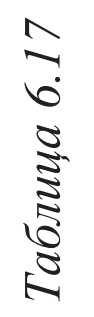

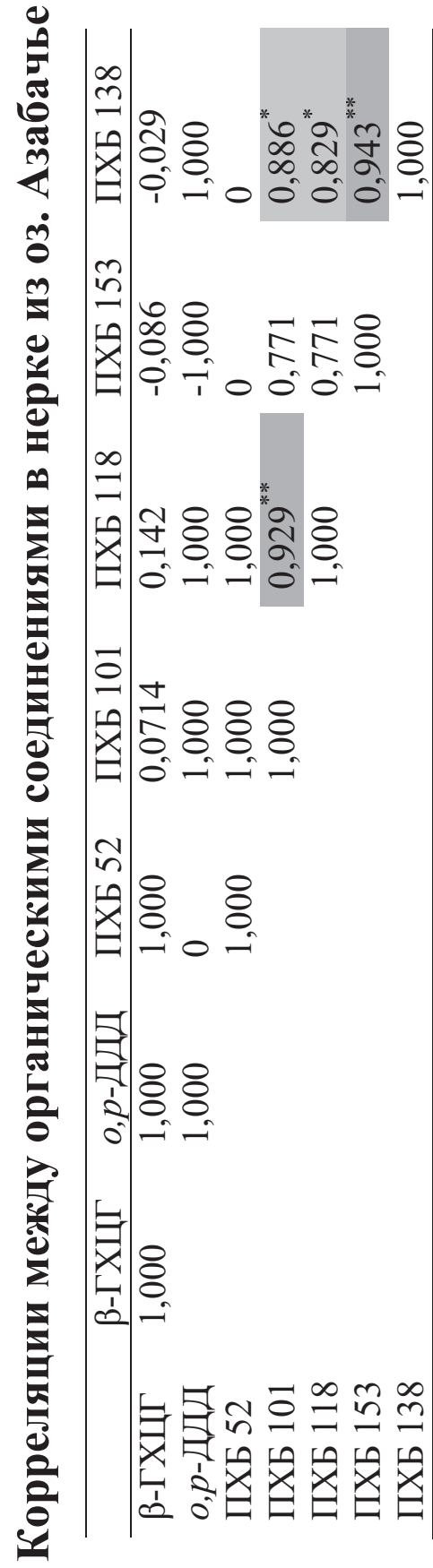

窎

仓ु

焉

迎

담

臣

응 응

瓷

鱿余

至

0

空

蛋

需

焉

崖罢

2

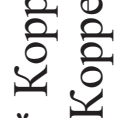

* *

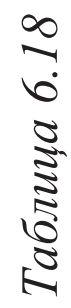

烍

色

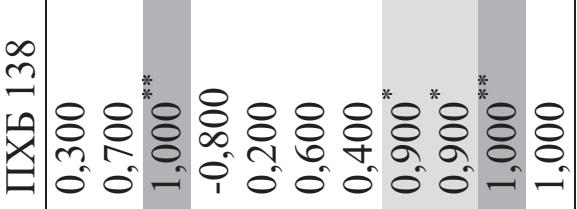

เที่

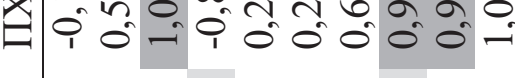

$\infty$

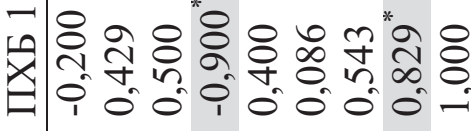

$\dot{2}$

응

告

* i

$\sum$

خे

帘

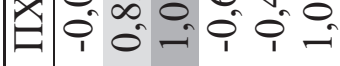

닐

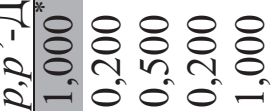

且

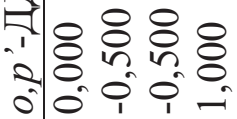

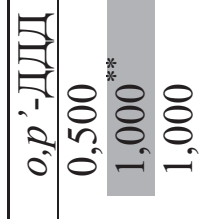

$E$

Хิ

Tे

刍

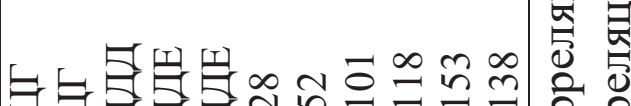

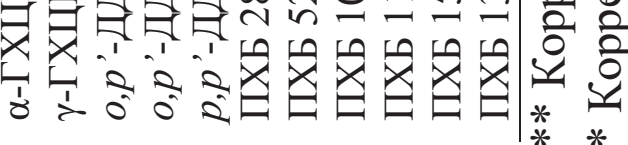




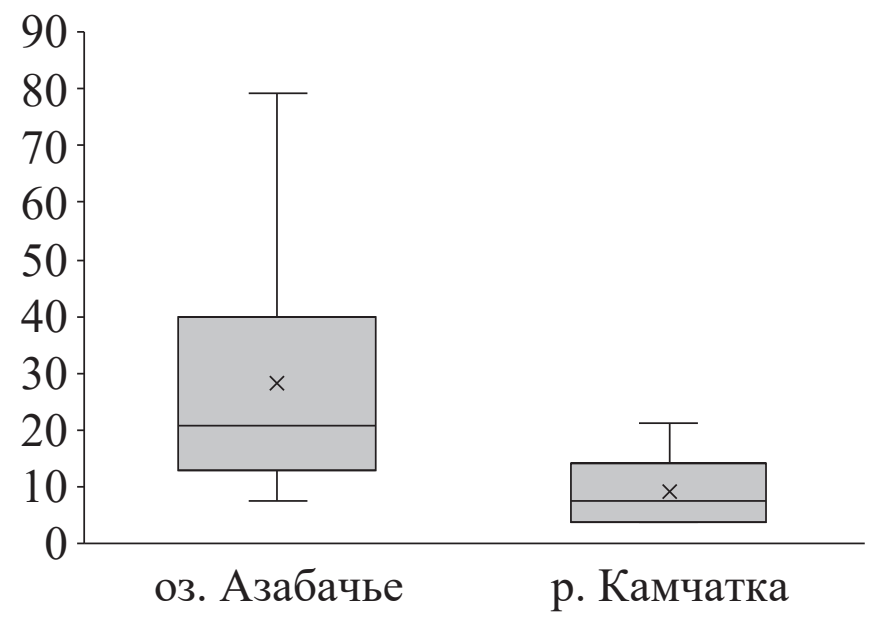

Pис. 6.24. Концентрации (медианы) ПХБ 153 в нерке из оз. Азабачье и р. Камчатка, нг/г липидов

В нерке из р. Камчатка также обнаружены достоверные корреляции (табл. 6.18). Положительные корреляции между «ХОП-ХОП», ХОП-ПХБ» и «ПХБ-ПХБ» в основном указывают на единый источник поступления ксенобиотиков. Можно предположить, что основным источником этих соединений являются стоки со свалок твердых бытовых отходов.

Таким образом, на сегодняшний день нагрузка СО3 на дальневосточные моря России значительно снизилась. Во всех исследованных видах видна тенденция к уменьшению концентраций СО3, что, вероятнее всего, отражает последствия государственных и федеральных мероприятий по уменьшению использования этих соединений. Обнаруженные корреляции позволяют предположить, что ксенобиотики активно деградируют как под действием абиотических факторов окружающей среды, так и посредством защитных функций организма гидробионтов. Тем не менее говорить о полном выходе СО3 из экосистем мирового океана рано, так как он все еще остается конечным резервуаром всех загрязняющих веществ.

\subsection{2. Межвидовые различия в аккумуляции СОЗ тихоокеанскими лососями Охотского и Берингова морей}

Род тихоокеанских лососей включает в себя 6 видов (горбуша, кета, сима, нерка, кижуч и чавыча), широко распространенных в северной части Тихого океана. Все лососи размножаются в пресных водоемах единожды и 
погибают после нереста. Время нагула каждого вида в океанических водах различается: у горбуши - 1,5 года, у кеты - 3, у симы - 2,5; у нерки - 4,5, у чавычи - 5 лет [9]. Разница в уровнях накопления СО3 у разных видов тихоокеанских лососей, прежде всего, может объясняться продолжительностью нагула, и, соответственно, разным накоплением ксенобиотиков в течение жизни (например, чавыча до 99 \% всех поллютантов накапливает именно в море [15]). Другим важным фактором в накоплении ксенобиотиков является «жирность» рыб, поскольку СО3 - липофильные ксенобиотики.

В последнее время, работ, направленных на определение стойких органических загрязняющих веществ в лососях, становится все меньше. В наиболее современных публикациях объектом исследования диких лососей является чавыча - самый крупный и долгоживущий вид, имеющий наибольшее промысловый в странах Северной Америки и Европы [12, 15, $30,47]$; выращенных - семга. Горбуша и кета изучаются либо как компонент пищевой цепи, либо во время мониторинговых программ (Например, Fish Monitoring Program на Аляске) $[11,21]$. Сима исследуется только учеными Японии, так как этот вид, распространенный только в азиатских водах. Список исследуемых образцов также обширен - от отдельных органов до всей тушки целиком, что затрудняет сравнение результатов. В связи с этим результаты наших исследований (табл. 6.19) представлены в виде средних концентраций СОЗ в каждом исследованном органе.

При сравнении уровней аккумуляции СО3 во всех органах лососей, в образцах 2010-2013 гг. выявляется следующая закономерность в изменении концентраций ХОП по видам:

$$
\text { Горбуша }<\text { Кета }<\text { Чавыча }<\text { Нерка }
$$

что может быть связано с различиями в содержании липидов в органах рыб и геохимическими особенностями среды исследованных районов. В то же время эта закономерность распределения поллютантов по видам рыб из оз. Азабачье и р. Камчатка нарушалась и выглядела иначе:

Нерка < Горбуша; Чавыча Кета < Нерка, соответственно.

Этот факт связан с разным возрастом рыб и количеством липидов в тканях.

Распределение СО3 по липидам органов рыб почти во всех образцах соответствует следующему порядку:

$$
\text { мышщуы < печень < икра < гонады самцоов. }
$$


Таблица 6.19

Концентрации СО3 (нг/г липидов), обнаруженные в тихоокеанских лососях дальневосточных морей России

\begin{tabular}{|c|c|c|c|c|c|c|}
\hline Вид & Год & Район & Орган & इГХЦГ & इДДТ & $\Sigma$ इПХБ \\
\hline \multirow[t]{11}{*}{ Горбуша } & \multirow[t]{4}{*}{2012} & \multirow{4}{*}{$\begin{array}{l}\text { Охотское море } \\
\text { (прикурильские } \\
\text { воды) }\end{array}$} & Мышцы & $132 \pm 49$ & $9 \pm 6$ & -1 \\
\hline & & & Печень & $259 \pm 144$ & $30 \pm 21$ & - \\
\hline & & & Икра & $279 \pm 139$ & $10 \pm 6$ & - \\
\hline & & & Гонады & $600 \pm 60$ & $44 \pm 5$ & - \\
\hline & \multirow[t]{7}{*}{2017} & \multirow{3}{*}{$\begin{array}{l}\text { оз. Азабачье } \\
\text { (п-ов Камчатка) }\end{array}$} & Мышцы & $18 \pm 12$ & $45 \pm 65$ & $33 \pm 17$ \\
\hline & & & Печень & $69 \pm 70$ & $<\Pi^{2}$ & $37 \pm 45$ \\
\hline & & & Гонады & $52 \pm 34$ & $65^{3}$ & $596 \pm 203$ \\
\hline & & \multirow{4}{*}{$\begin{array}{l}\text { p. Поронай (во- } \\
\text { сточное побережье } \\
\text { о. Сахалин) }\end{array}$} & Мышцы & $23 \pm 28$ & $6 \pm 7$ & $19 \pm 8$ \\
\hline & & & Печень & $45 \pm 40$ & $5 \pm 4$ & $18 \pm 21$ \\
\hline & & & Икра & $39 \pm 53$ & $3 \pm 3$ & $25 \pm 11$ \\
\hline & & & Гонады & $84 \pm 37$ & $3 \pm 2$ & $6 \pm 4$ \\
\hline \multirow[t]{8}{*}{ Кета } & \multirow[t]{4}{*}{2013} & \multirow{4}{*}{$\begin{array}{l}\text { Охотское море } \\
\text { (прикурильские } \\
\text { воды) }\end{array}$} & Мышцы & $111 \pm 41$ & $14 \pm 7$ & - \\
\hline & & & Печень & $166 \pm 80$ & $21 \pm 9$ & - \\
\hline & & & Икра & $1472 \pm 587$ & $<\Pi О$ & - \\
\hline & & & Гонады & $2628 \pm 1342$ & $333 \pm 40$ & - \\
\hline & \multirow[t]{4}{*}{2018} & \multirow[t]{4}{*}{ p. Камчатка } & Мышцы & $2 \pm 2$ & $4 \pm 5$ & $41 \pm 5$ \\
\hline & & & Печень & $6 \pm 7$ & $3 \pm 3$ & $27 \pm 9$ \\
\hline & & & Икра & 4 & 0,3 & 68 \\
\hline & & & Гонады & $3 \pm 3$ & $<\Pi О$ & $29 \pm 27$ \\
\hline \multirow[t]{4}{*}{ Сима } & \multirow[t]{4}{*}{2017} & \multirow{4}{*}{$\begin{array}{l}\text { p. Бахура } \\
\text { (восточное побе- } \\
\text { режье о. Сахалин) }\end{array}$} & Мышцы & $12 \pm 12$ & $8 \pm 9$ & $24 \pm 12$ \\
\hline & & & Печень & $75 \pm 46$ & 8 & $25 \pm 45$ \\
\hline & & & Икра & $14 \pm 2$ & $3 \pm 1$ & $31 \pm 1$ \\
\hline & & & Гонады & $305 \pm 179$ & $<\Pi \mathrm{O}$ & 30 \\
\hline \multirow[t]{5}{*}{ Чавыча } & \multirow[t]{2}{*}{2010} & \multirow{2}{*}{$\begin{array}{l}\text { Берингово море } \\
\text { (западная часть) }\end{array}$} & Мышцы & $873 \pm 687$ & $367 \pm 256$ & - \\
\hline & & & Печень & $794 \pm 669$ & $510 \pm 762$ & - \\
\hline & \multirow[t]{3}{*}{2018} & \multirow[t]{3}{*}{ р. Камчатка } & Мышцы & $7 \pm 1$ & $5 \pm 4$ & $7 \pm 1$ \\
\hline & & & Печень & $38 \pm 12$ & $21 \pm 29$ & $29 \pm 12$ \\
\hline & & & Гонады & $39 \pm 45$ & $<\Pi O$ & $9 \pm 8$ \\
\hline \multirow[t]{8}{*}{ Нерка } & \multirow[t]{2}{*}{2011} & \multirow{2}{*}{$\begin{array}{l}\text { Берингово море } \\
\text { (западная часть) }\end{array}$} & Мышцы & $1567 \pm 1187$ & $117 \pm 63$ & - \\
\hline & & & Печень & $3556 \pm 2529$ & $468 \pm 305$ & - \\
\hline & \multirow[t]{3}{*}{2017} & \multirow{3}{*}{$\begin{array}{l}\text { оз. Азабачье } \\
\text { (п-ов Камчатка) }\end{array}$} & Мышцы & $54 \pm 84$ & $32 \pm 37$ & $64 \pm 40$ \\
\hline & & & Печень & $47 \pm 46$ & 36 & $122 \pm 122$ \\
\hline & & & Гонады & $3 \pm 2$ & $<\Pi O$ & 383 \\
\hline & \multirow[t]{3}{*}{2018} & \multirow[t]{3}{*}{ р. Камчатка } & Мышцы & $34 \pm 24$ & $34 \pm 46$ & $124 \pm 13$ \\
\hline & & & Печень & $11 \pm 12$ & $17 \pm 17$ & $53 \pm 37$ \\
\hline & & & Гонады & $18 \pm 22$ & 16 & $42 \pm 21$ \\
\hline
\end{tabular}

${ }^{1} \overline{\text { не исследовалось; }{ }^{2} \text { ниже пределов обнаружения; }{ }^{3} \text { обнаружено в одном образце }}$

Сравнение общего количества ХОП в мышцах и печени всех четырех видов рыб 2010-2013 гг. вылова показало, что у горбуши и кеты средние значения концентраций значимо не различаются, но они достоверно 
$(\mathrm{p} \leq 0,05)$ меньше, чем у чавычи, а у последней - меньше, чем у нерки (рис. 6.25). Горбуша и кета были собраны в начале лета в районе Южных Курил, во время нерестовых миграций, когда органы уже начинают расходовать липиды. Перед нерестом лососи расходуют до $80 \%$ своих резервных липидов, при этом удельная концентрация токсиканта на 1 г липидов увеличивается и может достигать значений, опасных для жизни рыб [13]. Образцы нерки и чавычи были собраны в западной части Берингова моря осенью, в октябре-ноябре, когда рыбы нагуливаются в море, где могут провести несколько лет. За это время концентрация токсикантов в органах последовательно возрастает не только в метаболически активной печени, но и в мышцах.

В мышцах и печени лососей 2017-2018 гг. вылова уровни содержания ХОП статистически не различались (рис. 6.26). Наиболее высокие концентрации ХОП в печени обнаружены у симы, что может быть связано с самым большим количеством липидов (до 20 \%) в этом органе среди всех исследованных рыб. В мышцах наибольшие концентрации ксенобиотиков обнаружены у нерки, что, в свою очередь, может отражать увеличение удельной концентрации токсикантов, в ходе перераспределения липидов при формировании половых продуктов. На это указывает обнаруженная «жирность» органа - до 1,1% липидов. Суммарные концентрации ПХБ в мышцах показали достоверные $(\mathrm{p} \leq 0,05)$ различия среди всех исследованных лососей, причем наибольшие концентрации также обнаружены в нерке (рис. 6.27). В печени уровни токсиканта статистически не различались.

В половых продуктах закономерность «больше липидов-больше CO3» не прослеживается из-за меньшей «жирности» гонад самцов, по сравнению с икрой. В работе [24] разница в накоплении СО3 между половыми продуктами самцов и самок объяснялась тем, что во время созревания икры самки мобилизуют большее количество липидов, и к нересту икра составляет до 20 \% массы всей рыбы. Таким образом, CO3 «разбавляются» и распределяются в большей части органа, поэтому их концентрации меньше, чем в гонадах самцов. При этом указанное распределение токсикантов по органам не постоянно. Так, в работе [16] уровни ПХБ в мышцах были в два раза выше таковых в половых продуктах, а другие авторы [26] не обнаружили различий в концентрациях поллютантов между гонадами самцов и самок. Однако в послед- 
СОВРЕМЕННЫЕ УРОВНИ СТОЙКИХ ОРГАНИЧЕСКИХ ЗАГРЯЗНЯЮЩИХ ВЕЩЕСТВ (СОЗ) В РЫБАХ ДАЛЬНЕВОСТОЧНЫХ МОРЕЙ РОССИИ

нем исследовании отмечается, что во время отбора образцов рыбы не были готовы к нересту.

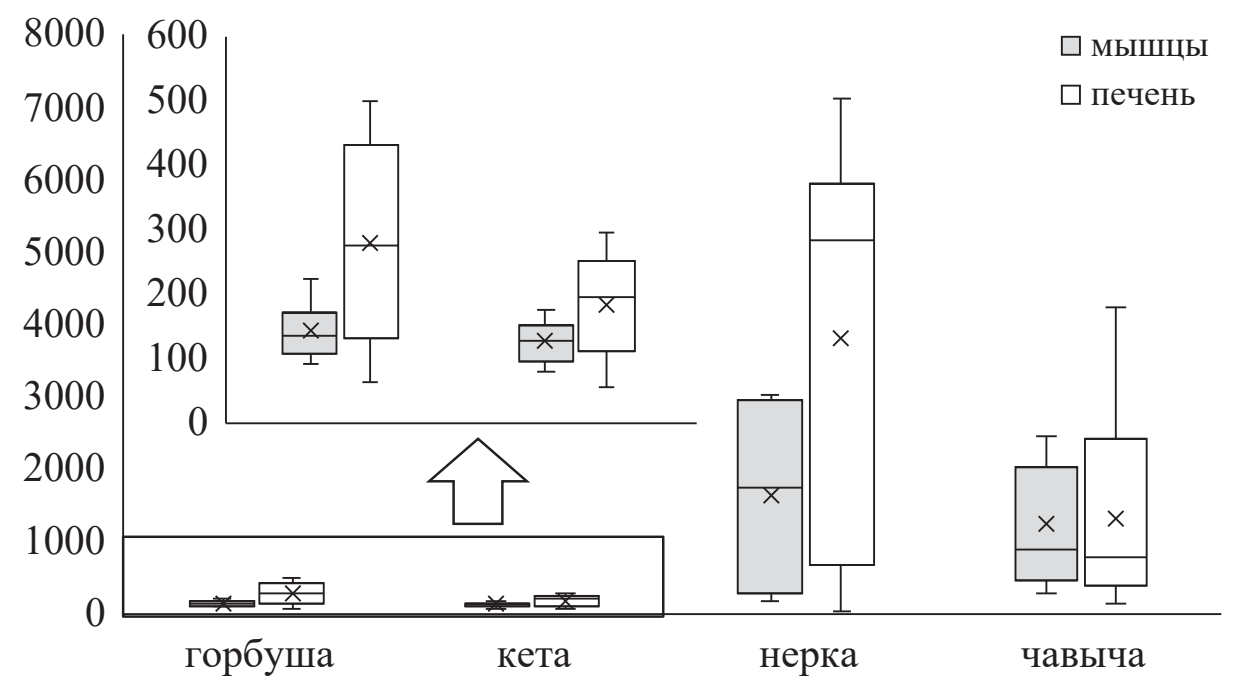

Puс. 6.25. Суммарные концентрации ХОП (ГХЦГ+ДДТ) (медиана) в органах тихоокеанских лососей 2010-2013 годов вылова, нг/г липидов

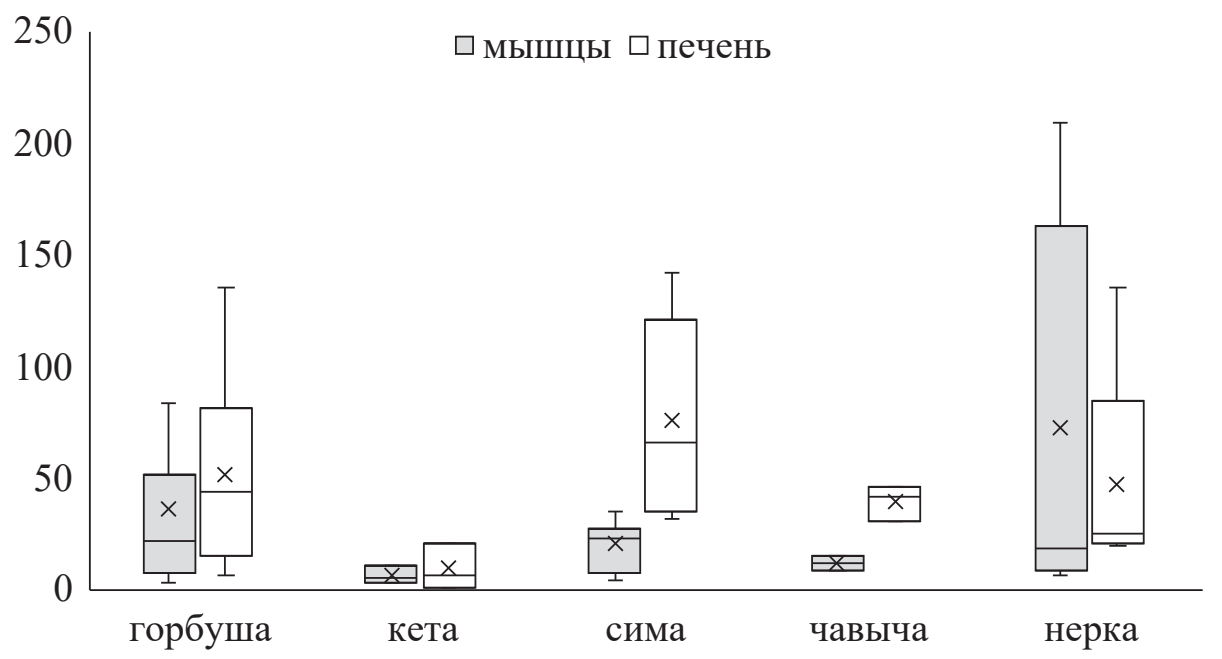

Pис. 6.26. Суммарные концентрации ХОП (ГХЦГ+ДДТ) (медиана) в органах тихоокеанских лососей 2017-2018 гг. вылова, нг/г липидов 


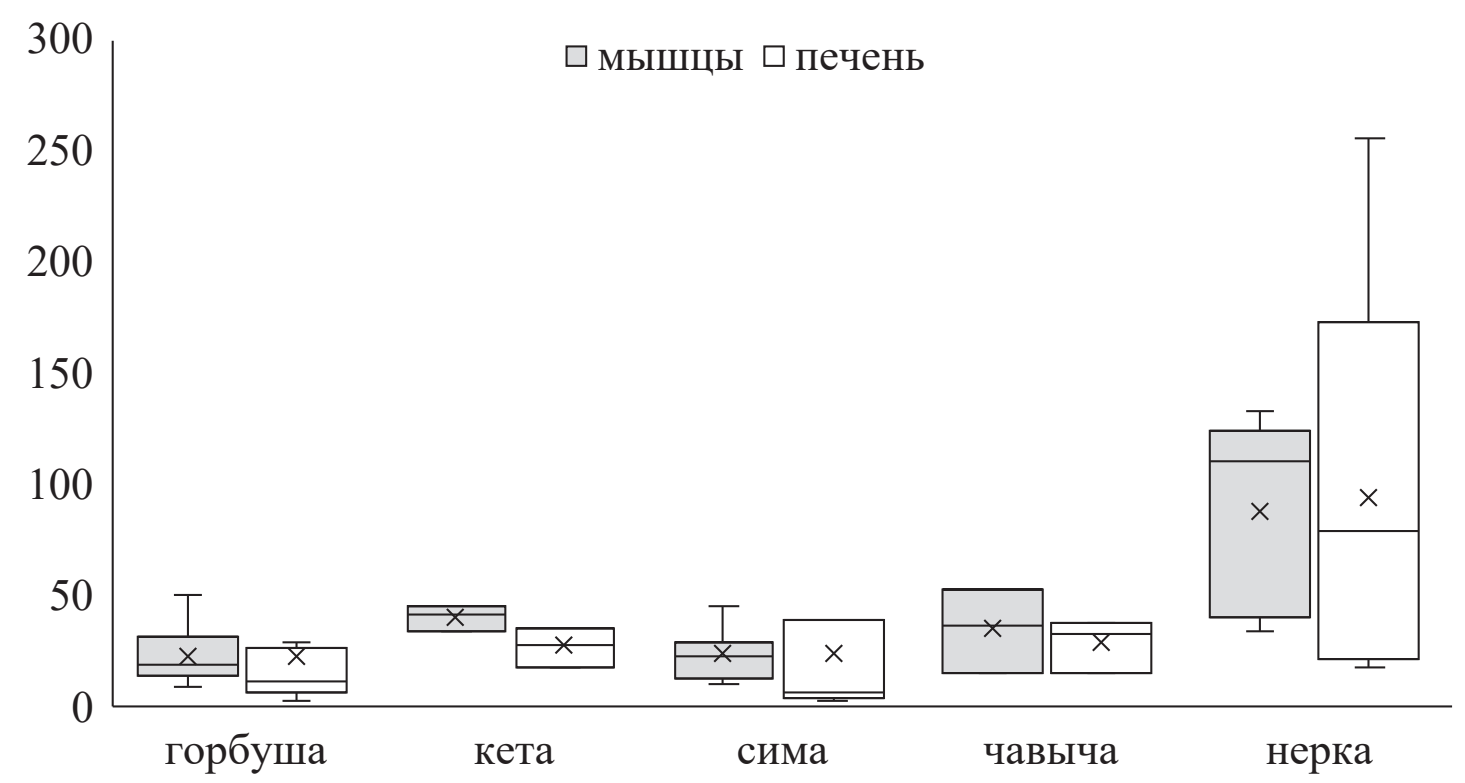

Рис. 6.27. Суммарные концентрации ПХБ (медиана) в органах тихоокеанских лососей 2017-2018 гг. вылова, нг/Г липидов

Данные о концентрациях СО3 в органах тихоокеанских и атлантических лососей различных районов мира представлены в таблице 6.20. Сравнение содержания загрязнителей в органах лососевых рыб из ДВ морей с данными для других регионов Мирового океана показывает, что в дальневосточных рыбах ГХЦГ превалирует над ДДТ, в то время как почти во всех других районах ситуация противоположная. На северном побережье российского Дальнего Востока практически не использовали ДДТ, в отличие от линдана ( $\gamma$-ГХЦГ) или технического ГХЦГ (доминирует $\alpha$-форма), которые, в отличие от ДДТ, обладают большей летучестью, и выявляются, как правило, в северных и умеренных широтах. На территории России присутствуют могильники пестицидов и ядохимикатов, расположенные на о. Сахалин и п-ове Камчатка $[4,8]$, что также может оказывать влияние на накопление поллютантов в водных массах и морских организмах, в том числе рыбах. Воздушный перенос с суши тоже является источником пестицидов, поступающих в экосистемы морей. На территории Китая долгое время использовался и используется до сих пор технический ГХЦГ. Его остаточные количества постоянно обнаруживаютея как в наземных, так и в морских организмах. Так, в донных отложениях оз. Байкал концентрации ГХЦГ в 3 раза превышают уровень ДДТ [10]. 
Таблица 6.20

Суммарные концентрации СО3 (нг/г липидов) в мышцах тихоокеанских и атлантических лососей из различных районов

\begin{tabular}{|c|c|c|c|c|c|c|c|}
\hline Вид & Орган & $\begin{array}{l}\text { Год отбо- } \\
\text { ра }\end{array}$ & Район отбора & $\Sigma Г Х Ц Г ~$ & гДДТ & $\Sigma \Pi$ इПБ & Ссылка \\
\hline \multirow[t]{2}{*}{ Горбуша } & Мышцы & $1999-2000$ & Чукотское море & 22 & 29 & 42 & [25] \\
\hline & & 2013 & Аляска & 42 & 38 & - & [20] \\
\hline Кета & Тушка & $2006-2010$ & Остров Татуш (США) & $-{ }^{1}$ & 100 & 385 & [21] \\
\hline \multirow[t]{3}{*}{ Сима } & Мышцы & 2003 & Бухта Отсучи (Япо- & 20 & 80 & - & [40] \\
\hline & Печень & & ния) & 21 & 105 & - & \\
\hline & Мышцы & $2008-2010$ & Река Нагара (Япония) & - & - & 600 & [36] \\
\hline \multirow[t]{10}{*}{ Чавыча } & Мышцы & $1975-2013$ & Озеро Онтарио (США) & - & - & 7701 & [47] \\
\hline & Тушка ${ }^{3}$ & $1999-2000$ & $\begin{array}{l}\text { Рыбоводный завод Ки- } \\
\text { тимат (Канада) }\end{array}$ & - & - & 397 & [30] \\
\hline & Мышцы & 2000 & $\begin{array}{l}\text { Пролив Джонстон } \\
\text { (Канада) }\end{array}$ & 23 & 15 & 91 & [15] \\
\hline & Тушка & & $\begin{array}{l}\text { Пролив Джорджии } \\
\text { (США) }\end{array}$ & 125 & 504 & 1383 & \\
\hline & Мышцы & 2001 & Река Кредит (Канада) & $<\Pi О$ & 170 & 371 & [39] \\
\hline & Тушка & 2005-2009 & Река Коламбия (США) & $<\Pi^{2}$ & 1800 & 4100 & [28] \\
\hline & Тушка & 2006-2010 & $\begin{array}{l}\text { Остров Протекшн } \\
\text { (США) }\end{array}$ & - & 700 & 944 & [21] \\
\hline & Мышцы & 2007 & Река Шусвап (Канада) & 10 & 67 & 75 & [31] \\
\hline & Икра & & & 8 & 46 & 63 & \\
\hline & Тушка $^{3}$ & 2008 & $\begin{array}{l}\text { Рыбоводный завод } \\
\text { Рэпид Ривер (США) }\end{array}$ & 135 & 850 & 780 & [12] \\
\hline \multirow[t]{6}{*}{ Нерка } & Мышцы & 2007 & Река Адамс, нерести- & 2 & 830 & 437 & [31] \\
\hline & Икра & & лище (Канада) & 4 & 86 & 134 & \\
\hline & Мышцы & 2012 & Толмачевское водо- & 2 & 23 & 44 & [6] \\
\hline & Печень & & хранилище (п-ов Кам- & 1 & 11 & 27 & \\
\hline & Икра & & чатка) & 2 & 15 & 29 & \\
\hline & Гонады & & & 3 & 33 & 56 & \\
\hline \multirow[t]{4}{*}{ Семга ${ }^{3}$} & Мышцы & 1999 & Шотландия & 19 & 250 & 460 & [27] \\
\hline & Мышцы & 1999 & Норвегия & 10 & 47 & 279 & \\
\hline & Мышцы & 2001 & Ирландия & 39 & 49 & 284 & \\
\hline & Мышцы & 2003-2004 & Канада & 14 & 212 & 115 & [43] \\
\hline \multirow[t]{5}{*}{ Чавыча ${ }^{4}$} & Мышцы & 2002 & Река Кенай (США) & 2 & 10 & 11 & [41] \\
\hline & Икра & & & 4 & 8 & 9 & \\
\hline & Тушка & 2013-2014 & $\begin{array}{l}\text { Великие озера (Мичи- } \\
\text { ган и Гурон) (США) }\end{array}$ & - & - & 380 & [19] \\
\hline & Мышцы & 2007 & $\begin{array}{l}\text { Северная Патагония } \\
\text { (Чили) }\end{array}$ & - & - & 28 & [37] \\
\hline & Икра ${ }^{3}$ & 2004-2014 & $\begin{array}{l}\text { Рыбоводный завод } \\
\text { Салмон Ривер Фиш } \\
\text { (США) }\end{array}$ & - & - & 1,6 & [18] \\
\hline
\end{tabular}

1 не исследовалось

2 ниже пределов обнаружения

3 выращенная

${ }^{4}$ нг/г сырой массы 
При сравнении уровней ПХБ в лососях из дальневосточных морей и других районов Мирового океана видно, что практически во всех образцах Дальнего Востока России концентрации этих поллютантов меньше. Исключение составляет лишь горбуша из оз. Азабачье, где суммарная концентрация ПХБ составила 596 нг/г липидов. Заметим, что большая часть рыб, с которыми проводилось сравнение, выловлены в Атлантике. При изучении аккумуляции пестицидов у лососей, мигрирующих к Американском континенту, авторы обращают внимание на высокую урбанизацию прибрежных районов, и, как следствие, загрязнение нерестовых водотоков. При этом развитие икры и последующий рост мальков также происходят в загрязненной воде, что существенно сказывается на жизнестойкости молоди [21] и повышает концентрации СО3 в их органах. Так, в работе [28] показано, что с увеличением возраста мальков чавычи, концентрации ПХБ значительно возрастают: от 1300 до 4100 нг/Г липидов.

В настоящее время значительную часть лососевых на мировом рынке представляют атлантические лососи, выращенные в садках. Содержание ХОП в их органах строго контролируется, однако загрязнение среды обитания приводит к аккумуляции токсикантов в объектах аквакультуры [27]. Сравнение уровней содержания СО3 в тихоокеанских лососях с семгой показывает, что концентрации ПХБ в мышцах последней выше, чем у исследованных в работе видов. Заметим, что семга, с которой проводится сравнение, выращена в садках, а значит имела минимальный контакт с открытыми океаническими водами. Более высокие уровни ПХБ в тканях выращиваемых атлантических лососей могут быть связаны как с высоким содержанием липидов в их тканях (до 20 \%) [31], так и с высокой антропогенной нагрузкой в прибрежной зоне, где расположены садки с лососями. Концентрации ДДТ почти во всех тихоокеанских лососях ниже, чем таковые в семге. Исключение составляет лишь чавыча 2010 г. вылова. Концентрации ГХЦГ в тихоокеанских лососях, в среднем, выше, чем в атлантических.

Таким образом, уровни ГХЦГ в тихоокеанских лососях дальневосточных морей России в целом выше, чем в лососевых из других районов Мирового океана, что отражает широкое использование линдана и технического ГХЦГ на побережье Дальнего Востока России в ХХ веке. Концентрации ДДТ, напротив, ниже, по сравнению с мировым уровнем и, чаще всего отражают глобальный перенос ксенобиотиков водными и воздушными массами. Концентрации ПХБ в тихоокеанских лососях Дальнего 
Востока не показали единой тенденции к повышению или понижению их уровней, по сравнению с миром. Однако в литературе отмечается, что содержание этих загрязняющих веществ выше в закрытых водоемах с низким водообменом (великие озера США) [47], странах с высоким использованием ПХБ-содержащих материалов в прошлом (Япония) [36], в районах выращивания рыбы, и на рыбоводных заводах $[12,30]$.

\section{2. Камбалы (род Hippoglossoides)}

Палтусовидные камбалы (Hippoglossoides Gottsche, 1835) выловлены в восточной (у берегов Камчатки) и южной (у берегов Курильских островов) частях Охотского моря, в зал. Невельского у юго-западного побережья о. Сахалин (Татарский пролив) и в б. Рифовая залива Петра Великого (Японском море) летом в 2016-2018 гг.

Охотское море. Концентрации ХОП в рыбах восточной части Охотского моря находились в диапазоне 13,6-433,7 нг/г липидов со средней концентрацией 99,8 $\pm 125,4$ нг/г липидов. Суммарные уровни ГХЦГ и ДДТ составляли от 13,6 до 158 (среднее 50,2 \pm 52 ) и от 0,55 до 276 (среднее $62 \pm 89,2)$ нг/Г липидов, соответственно. Диапазон концентраций ХОП в рыбах из южной части Охотского моря составлял 11,4-141 нг/г липидов

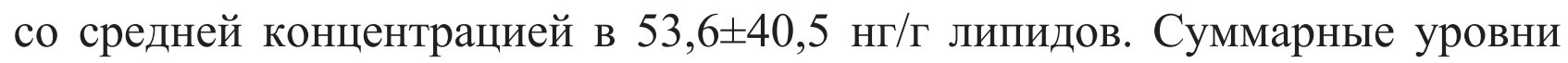
ГХЦГ и ДДТ изменялись от 3,3 до 103 (среднее 35,5 $\pm 36,7$ ) и от 1,2 до 44,8 (среднее $-20,1 \pm 16,8)$ нг/г липидов, соответственно.

Из изомеров ГХЦГ в восточной части Охотского моря наиболее определяемой была $\beta$-форма с концентрацией $13,6-157,8$ нг/г липидов (среднее - 49,38 $\pm 50,7$ нг/Г липидов) (рис. 6.28). $\alpha$-ГХЦГ определен только в одном образце в концентрации 7,9 нг/г липидов. Содержание $\gamma$-ГХЦГ было ниже пределов обнаружения во всех образцах. Среди ДДТ и его метаболитов $o, p^{\prime}$-ДДТ, $p, p^{\prime}$-ДДТ и $p, p^{\prime}$-ДДЕ были ниже пределов обнаружения во всех исследованных пробах. Концентрации $o, p$ '-ДДД и $p, p$ '-ДДД варьировали в диапазоне от 6,24 до 45,21 (среднее - 23,12 $\pm 19,1$ ) и 12,8276 (среднее - 72,3 $\pm 114,2$ ) нг/г липидов, соответственно. $о, p$ '-ДДЕ обнаружен в двух образцах в концентрациях 0,55 и 41,68 нг/г липидов. 
В южной части Охотского моря ГХЦГ представлен $\alpha$ - и $\beta$-изомерами

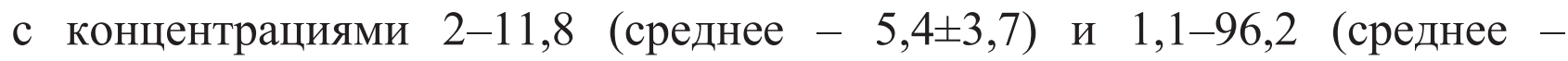
$40,4 \pm 37)$ нг/Г липидов, соответственно (рис. 6.28). Уровни $\gamma$-ГХЦГ были ниже пределов обнаружения во всех исследованных образцах. Среди ДДТ и его метаболитов концентрации $о, p$-ДДТ были ниже пределов обнару-

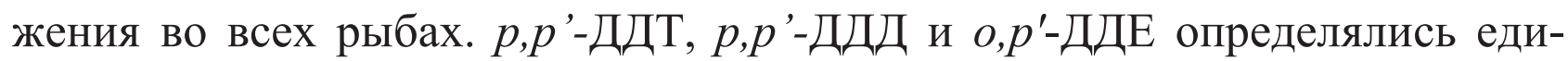
нично в концентрациях 7,1, 22,8 и 33 нг/Г липидов, соответственно. Концентрации $о, p^{\prime}$-ДДД варьировали в диапазоне от 2 до 44,8 нг/г липидов, со средней концентрацией $16,7 \pm 17,6$ нг/г липидов. $p, p$ '-ДДЕ обнаружен в диапазоне концентраций 1,22-6,8 нг/г липидов, со средней концентрацией 4,3 $\pm 2,3$ нг/г липидов.

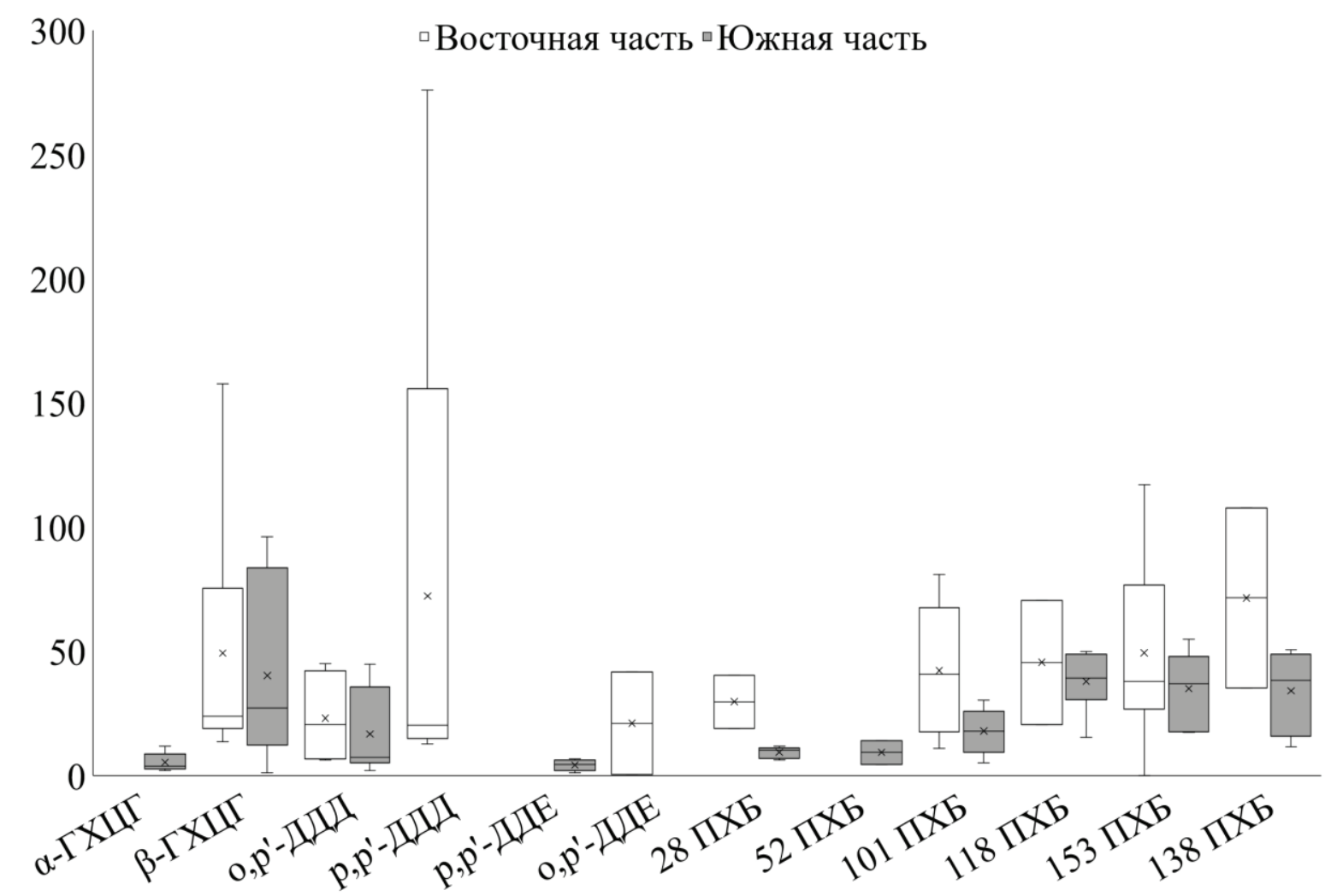

Puc. 6.28. Концентрации СО3 в камбалах Охотского моря, нг/г липидов

Сумма концентраций ПХБ в камбалах из восточной части Охотского моря варьировала от 23,5 до 279,1 (среднее - 124,5 $\pm 90,8$ ) нг/Г липидов. ПХБ представлены, в основном, 101 и 153 конгенерами. 28, 52, 155, 118, 138 и 180 ПХБ обнаруживались эпизодически (в одном-двух образцах) в концентрациях: 28 - 40,5 и 19,1; 52 - 32,7; 155 - 71,2; 118 - 20,6 и 70,6; $138-107,8$ и 35,3; $180-66,3$ нг/г липидов. Концентрации ПХБ 207 были ниже пределов обнаружения во всех исследованных пробах. Концентра- 
ции ПХБ 101 и ПХБ 153 варьировали от 11 до 81 (среднее - 42,3 $\pm 27,1$ ) и от 49,4 до 117,2 (среднее - 49,4 $\pm 36,8$ ) нг/г липидов, соответственно.

Сумма концентраций ПХБ в образцах из южной части Охотского мо-

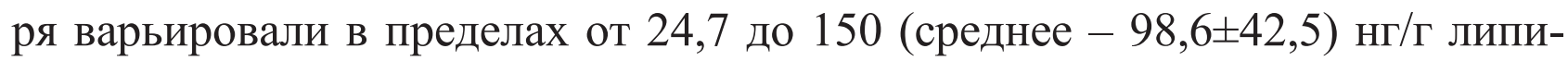
дов. ПХБ представлен 28, 101, 118, 153 и 138 конгенерами в концентрациях 6,2-11,9, 5,2-30,3, 15,4-50, 17,5-55 и 34,4-50,7 нг/г липидов, соответственно. Средние концентрации составили 9,4 2 2,3, $18 \pm 8,8,38 \pm 12,6,35 \pm 15,2$ и $44 \pm 7,2$ нг/Г липидов, соответственно (рис. 6.28). ПХБ 52, 155 и 180 обнаруживались эпизодически в следующих концентрациях: 52 - 14,2 и 4,6; 155 16,$9 ; 180$ - 17,3 и 11,7 нг/г липидов, соответственно. Концентрации ПХБ 143 и ПХБ 207 были ниже пределов обнаружения во всех образцах.

Татарский пролив. Диапазон концентраций ХОП в образцах из Татарского пролива составлял от 37,4 до 555,1 нг/Г липидов (среднее-

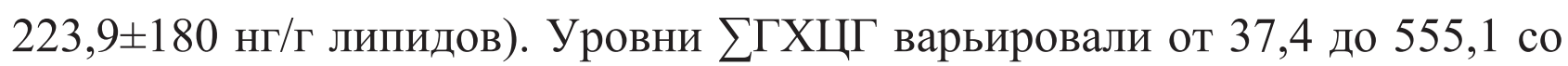
средним значением $221,3 \pm 181,8$ нг/г липидов. ДДТ и его метаболиты обнаружены в трех образцах и представлены $p, p^{\prime}$-ДДД и $p, p$ '-ДДЕ с концентрациями: $p, p^{\prime}$-ДДД - 15; p,p'-ДДЕ - 5,8 и 12,9 нг/Г липидов. ГХЦГ в образцах из Татарского пролива представлен только $\beta$-изомером с диапазоном концентраций 37,4-555,1 нг/г липидов, среднее - 221,3 $\pm 181,8$ нг/г липидов (рис. 6.29).

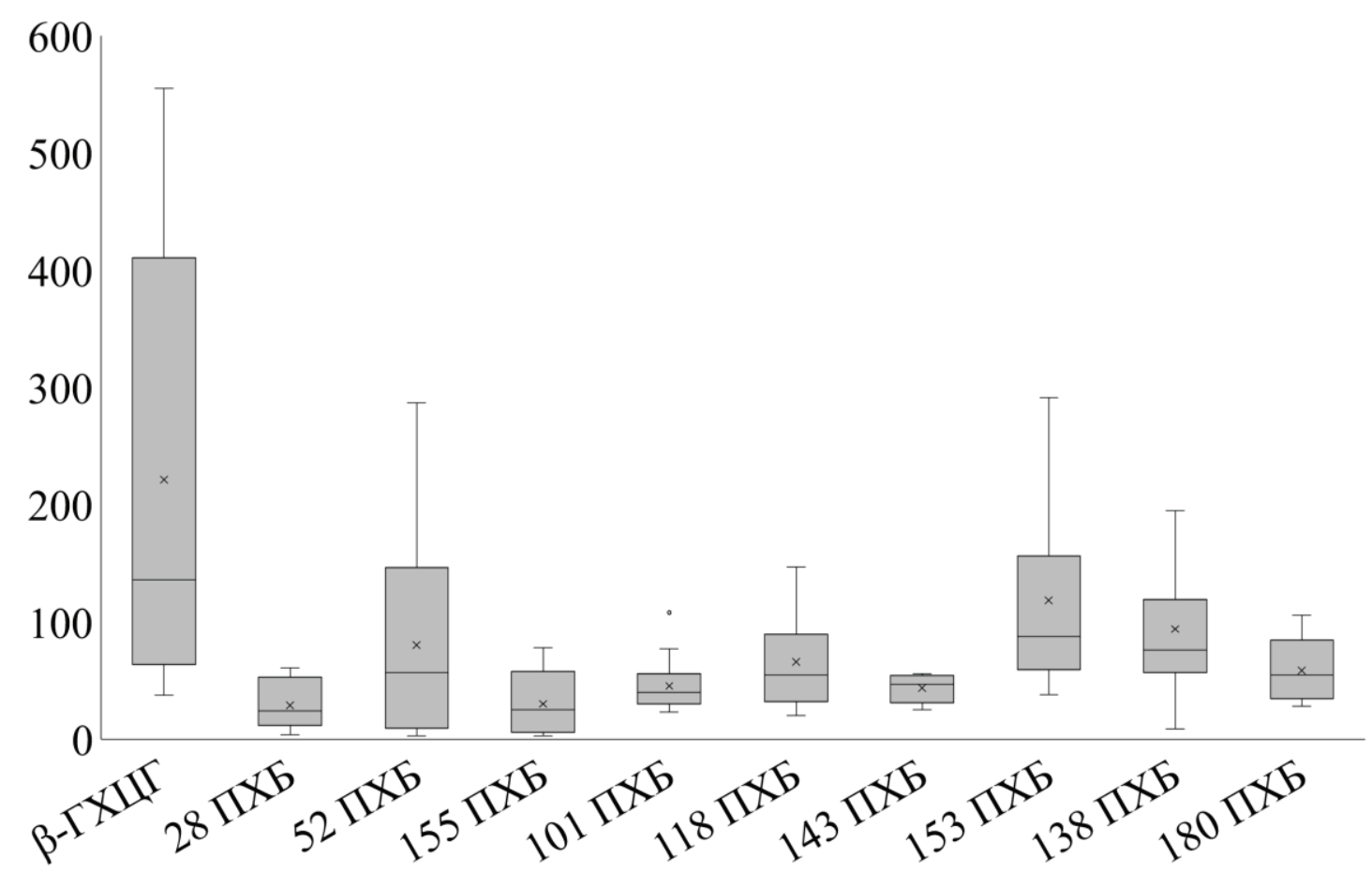

Pис. 6.29. Концентрации СО3 в камбалах Татарского пролива, нг/г липидов 
Диапазон суммы концентраций ПХБ составлял 193,4-1383,9 нг/г липидов (со средним значением в $454,9 \pm 317,1$ нг/г липидов). В камбалах из Татарского пролива обнаружены 28, 52, 155, 101, 118, 143, 153, 138 и 180 конгенеры ПХБ. Концентрация ПХБ 207 была ниже предела обнаружения во всех образцах. Концентрации конгенеров варьировали: для 28 - от 4,1 до $61 ; 52$ - от 3,1 до 286,6; 155 - от 2,7 до 78; 101 - от 23 до 107,9; 118 - от 19,5 до 325,$5 ; 143$ - от 25,4 и 56,3; 153 - от 38 до 291,2; 138 - от 8,7 до 423,4 и для 180 - от 28,4 до 105,6 нг/Г липидов, соответственно. Средние концентрации составили $28,8 \pm 20,8,80,3 \pm 82,6,30 \pm 28,45,4 \pm 22,7,84,5 \pm 79,6$, $43,8 \pm 12,7,118,3 \pm 72,2,121,2 \pm 109,4$ и $58,7 \pm 29,4$ нг/Г липидов, соответственно (рис. 6.29). 101 ПХБ обнаружен во всех образцах.

Зал. Петра Великого, Японское море. Диапазон концентраций ХОП в рыбах из б. Рифовая, зал. Петра Великого составлял 37,8-192,8 нг/г липидов со средней концентрацией 102,1 \pm 50 нг/Г липидов. Изомеры ГХЦГ и ДДТ и его метаболиты обнаружены во всех пробах. Уровни

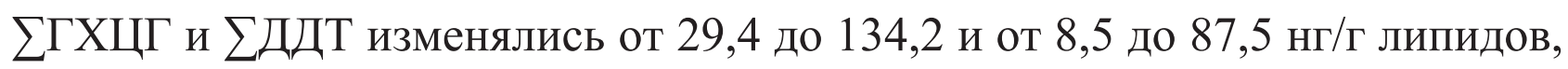

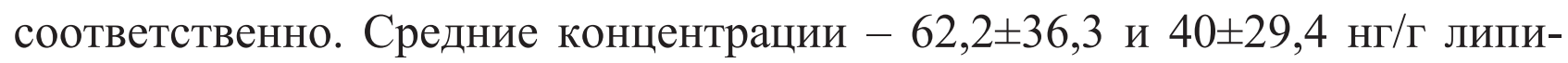
дов, соответственно.

В камбалах из Японского моря обнаружены все изомеры ГХЦГ. Концентрации $\alpha-$, $\beta$ - и $\gamma$-изомеров варьировали в пределах: 0,4-4,7; 26,7126,$9 ; 0,9-6,1$ нг/г липидов, соответственно. Средние концентрации составили для $\alpha$-ГХЦГ $-2 \pm 1,4, \beta$-ГХЦГ $-59,2 \pm 34,6, \gamma$-ГХЦГ $-2,2 \pm 2,2$ нг/г липидов (рис. 6.30). $\beta$-изомер обнаружен во всех исследованных пробах.

Из ДДТ и его метаболитов не был обнаружен $о, p$ '-ДДТ, а $p, p$ '-ДДТ найден только в одном образце (5,6 нг/г липидов). Диапазоны концентраций $o, p$ '-ДДД, $p, p^{\prime}$-ДДД, $o, p$ '-ДДЕ и $p, p^{\prime}$-ДДЕ варьировали в пределах: 1,3-37,5; 5,6-52,4; 1-33,7; 3,6-46,6 нг/г липидов, соответственно. Средние концентрации составили: $11,6 \pm 11,9,18,7 \pm 17,5,7,4 \pm 10,1$ и $15,7 \pm 16,4$ нг/г липидов, соответственно (рис. 6.30).

Концентрации ПХБ изменялись от 421,3 до 3715,6 нг/г липидов. Средняя концентрация - 1615,7 $\pm 1176,8$ нг/Г липидов. ПХБ представлены 28, 52, 155, 101, 118, 143, 153, 138 и 180 конгенерами. Содержание ПХБ 207 было ниже пределов обнаружения во всех образцах. Концентрации конгенеров варьировали: 28 ПХБ - от 2,7до 405,4; 52 ПХБ - от 7,3 до 287,3; 155 ПХБ - от 3,1 до 10,8; 101 ПХБ - от 40,2 до 206,6; 118 ПХБ - от 53 до 581,4; 143 ПХБ - от 11,4 до 45,5; 153 ПХБ - от 125,7 до 848,9; 
138 ПХБ - от 126,3 до 936,2; 180 ПХБ - от 27,7 до 1834,7 нг/Г липидов.

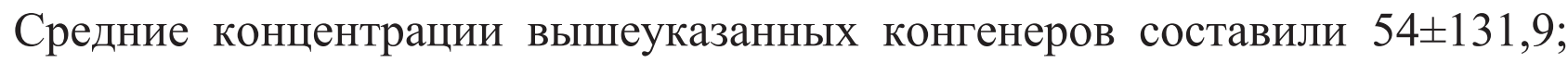
$53,8 \pm 88,4 ; \quad 6,4 \pm 3,4 ; \quad 117,1 \pm 57,6 ; \quad 241,4 \pm 182,7 ; \quad 25,5 \pm 14,5 ; \quad 387,4 \pm 265,1 ;$ $428,7 \pm 279,2 ; 318,4 \pm 579,2$ нг/Г липидов, соответственно (рис. 6.30).

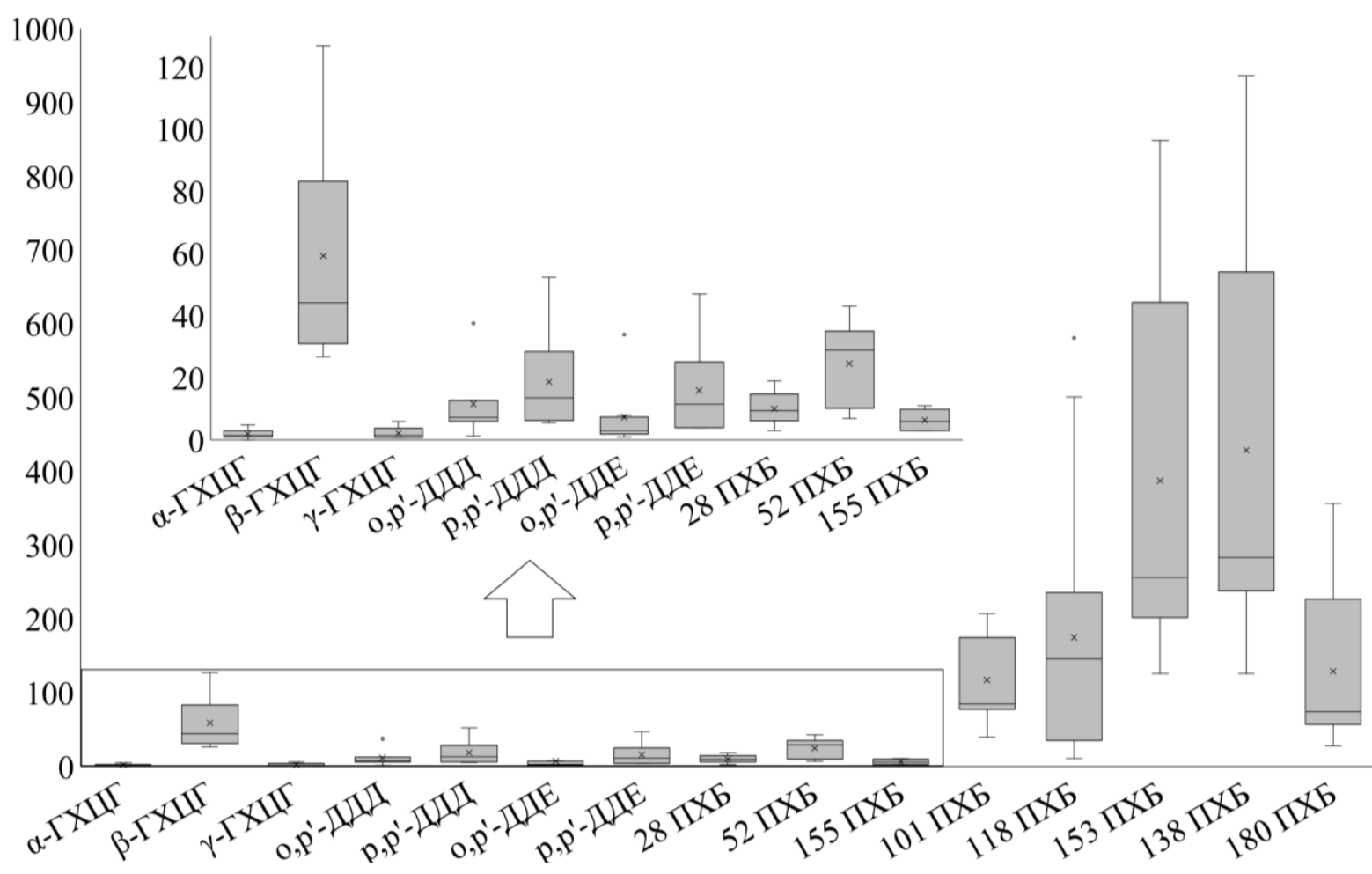

Puc. 6.30. Концентрации СОЗ в камбалах Японского моря, нг/г липидов

Камбаловые (семейство Pleuronectidae) относятся к наиболее часто встречающимся представителям донной ихтиофауны, заселяющим весь шельф и материковый склон. Основной особенностью биологии камбал является их малоподвижный образ жизни: они лежат на грунте или плавают, оставаясь при этом в пределах своего ареала, совершая лишь сезонные миграции в глубоководные районы и, таким образом, могут выступать биоиндикаторами локального загрязнения. По характеру питания камбаловые разделяются на три большие группы: хищники, виды со смешанным питанием (большеротые камбалы) и типичные бентофаги (малоротые камбалы) [9]. Изучаемые нами палтусовидные камбалы (род Hippoglossoides) относятся к группе камбал со смешанным типом питания: в составе пищи встречаются как типично бентосные (креветки, двустворчатые моллюски и др.), так и планктонные животные. Также пищей камбал нередко становится молодь сельди, корюшки и другие мелкие рыбы. Пищевой спектр сильно зависит от места обитания. У юго-востока Саха- 
лина и в Японском море в питании преобладают исключительно моллюски, в то время как в юго-восточной части Берингова моря палтусовидная камбала в нижних отделах шельфа и на свале потребляет в основном иглокожих и чилимов, на мелководье - планктонные организмы [7, 9]. Таким образом, различия в накоплении СО3 в камбалах из разных мест могут быть связаны как с антропогенной нагрузкой на район обитания, так и со способностью к биоаккумуляции у потребляемых организмов.

В восточной части Охотского моря в рыбах обнаружены наибольшие концентрации ДДТ и умеренные - ГХЦГ, что может быть связано с расположением на полуострове Камчатка хранилищ ядохимикатов и пестицидов, где захоронены альдрин, дильдрин, гексахлорбензол и хлорорганические пестициды $[2,4]$. ДДД был наиболее встречаемым метаболитом ДДТ; ГХЦГ же был представлен наиболее стойким $\beta$-изомером, что говорит о длительной циркуляции обоих токсикантов в экосистеме и распаде исходных соединений до более устойчивых форм. Нарушение герметичности захороненных резервуаров и испарение токсикантов с последующим атмосферным переносом, возможно, являются основными источниками загрязнения в этом районе, так как сельское хозяйство на западной стороне полуострова Камчатка мало развито из-за неблагоприятных природных условий. Поступление ПХБ в Охотское море может быть обусловлено как активной судоходной деятельностью, так и испарением из пластификаторов. На текущий момент на территории Камчатского края отсутствуют мусороперерабатывающие заводы, мусор захоранивают на специальных полигонах, откуда возможны утечки [2].

Южная часть Охотского моря является наиболее чистым в отношении исследованных СО3 районом и характеризуется низким содержанием ДДТ, ГХЦГ и ПХБ в рыбах. Юг Охотского моря расположен далеко от всех наземных источников загрязнения. Помимо этого, в районе наблюдается активная гидродинамика и обмен вод с Тихим океаном через Курильские проливы, что может перераспределять СОЗ в водной толще. Концентрации ксенобиотиков в мышцах камбал из южной части Охотского моря могут быть приняты как фоновые и использоваться для оценки загрязнения других морских районов [34].

Наиболее неожиданными и интересными являются данные по содержанию ХОП в мышцах камбал из Татарского пролива. В образцах практически отсутствовал ДДТ, что позволяет оценивать район как непод- 
верженный серьезному загрязнению этим пестицидом. Однако в этих же образцах обнаружены самые высокие уровни ГХЦГ (рис. 6.31). При этом ГХЦГ представлен только $\beta$-изомером, что говорит о длительной циркуляции токсиканта в экосистеме.
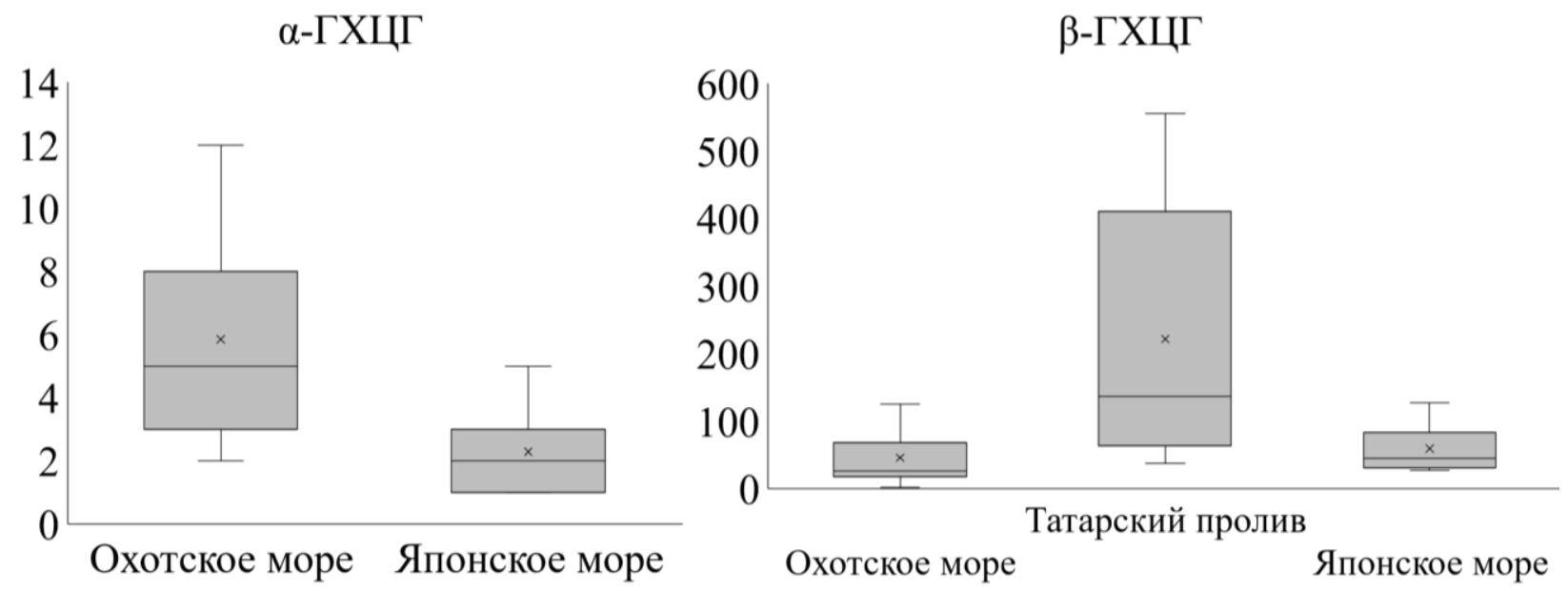

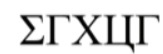

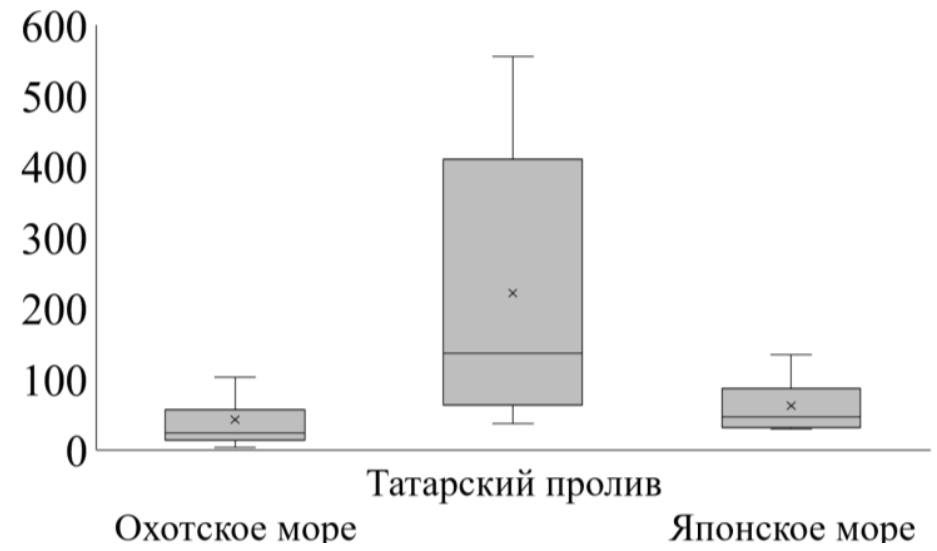

Puc. 6.31. Концентрации ГХЦГ в камбалах исследуемых районов, нг/г липидов

Крупные сельскохозяйственные предприятия как со стороны о. Сахалин, так и со стороны материка находятся вдали от пролива. Однако, согласно постановлению администрации Сахалинской области (22 сентября 2008 г.), на территории острова существуют полигоны размещения пришедших в негодность или запрещенных к использованию пестицидов, хранение которых (на момент постановления), осуществлялось с нарушениями, способными привести к серьезному загрязнению окружающей среды $[3,8]$. Скорее всего, источником загрязнения пролива стали именно они, что привело к попаданию ГХЦГ в экосистему Татарского пролива. На это указывает и обнаруженный $\beta$-изомер ГХЦГ, считающийся наиболее 
устойчивым. Другим источником ГХЦГ могут быть течения, выносящие воды Японского моря через Татарский пролив в Охотское море.

Концентрации ПХБ в камбалах из Татарского пролива в несколько раз выше, чем в рыбах из Охотского моря, но заметно ниже, чем из Японского. Высокие концентрации ПХБ могут быть связаны с активным судоходством и возможным влиянием свалок бытовых отходов на западном побережье Сахалина (на территории Сахалинской области существует 54 санкционированных и 37 несанкционированных свалок) [3].

Татарский пролив - важный промысловый район, где осуществляется активная рыболовная и транспортная деятельность. Теплое течение из Японского моря и холодное из Охотского, «зажатость» между материком и островом, оказывают значительное влияние на накопление токсикантов в этом районе. Таким образом, основным источником ПХБ в водах Татарского пролива, вероятно, является именно суда.

В камбалах Японского моря из метаболитов ДДТ обнаружены ДДД и ДДЕ, из изомеров ГХЦГ - $\alpha-, \beta$ - и $\gamma$-изомеры. Приморский края является развитым в сельскохозяйственном отношении регионом, и в середине XX века здесь широко использовались пестициды, в том числе и хлорорганические. Эти устойчивые соединения могли остаться в почвах и сейчас выносятся в акваторию Японского моря путем речных и поверхностных стоков. Кроме того, на территории края существуют места захоронения пестицидов, которые могут быть еще одним источником поступления токсикантов в среду. И, наконец, согласно Стокгольмской конвенции, развивающиеся страны Азии (наши соседи) могут использовать ДДТ для защиты населения от переносчиков малярии и ГХЦГ как лечебное средство от вшей и чесотки [44]. Японское море выходит к берегам Китая, Северной и Южной Кореи, а с южной стороны через Корейский пролив связано с Восточно-Китайским морем. Пестициды могут попадать в морские экосистемы путем атмосферного переноса, речных стоков и течений из Восточно-Китайского моря, несущих их остатки с сельскохозяйственных угодий, а также с промышленными и поверхностными стоками. Наиболее существенным источником ДДТ и ГХЦГ может быть Китай. Так, авторы из Китая [22] показали, что наибольшую опасность для биоты со стороны Китая несет именно ДДТ. В мышцах камбал ДДТ был представлен его метаболитами - ДДД и ДДЕ, и лишь в одном случае был обнаружен ДДТ, что говорит о давности загрязнения и распаде исходного соединения. 
Наиболее актуальными являются данные о концентрации ПХБ в мышцах рыб из Японского моря. Выявленные уровни этих поллютантов в мышцах камбал из Японского моря на порядок величин выше, чем в рыбах из Охотского моря и Татарского пролива (рис. 6.32). На берегах Японского моря (юг Приморского края) расположено огромное количество баз отдыха и так называемых «диких» пляжей. Ежегодно на побережье приезжают тысячи людей как с Дальнего Востока, так и из других регионов России. При этом многие из них останавливаются на «диких» пляжах, где своевременный вывоз мусора и отходов жизнедеятельности не производится. Кроме того, на побережье функционируют нефтеперерабатывающий завод и угольные порты, которые также могут оказывать влияние на водную среду и её обитателей. Помимо этого, Японское море является транспортной артерией и районом промыслового рыболовства, что может быть причиной его загрязнения бифенилами.

Сравнение выявленных нами средних концентраций ХОП с данными для других районов Мирового океана показало, что уровни ДДТ в рыбах из всех наших районов значительно ниже, чем в Атлантическом океане, Балтийском и Желтом морях [14, 33, 49], но на порядок величин выше, чем в беринговоморской ихтиофауне [23] (табл. 6.21). Средние уровни $\alpha-$ и $\gamma$-ГХЦГ в рыбах сопоставимы во всех сравниваемых данных. Концентрации $\beta$-ГХЦГ в исследованиях, с которыми проводилось сравнение [14, 23 ], не указаны. В работе [49] уровень $\beta$-изомера был ниже предела обнаружения $(<0,002$ нг/г сырой массы), в исследовании [33] уровни токсиканта не указаны. Однако в изученных нами районах дальневосточных морей

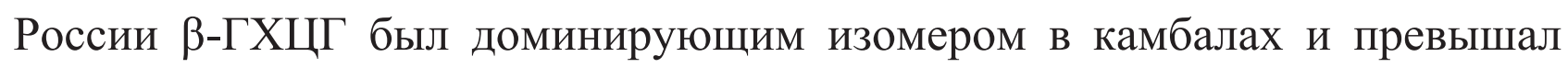
сумму концентраций ГХЦГ в мышцах камбал из Желтого моря [14].

Уровни содержания ПХБ в мышцах рыб из Охотского моря не превышали концентраций, обнаруженных в камбалах Атлантического океана и Балтийского моря $[33,49]$, но значительно превосходили таковые в обитателях Желтого и Берингова морей $[14,23]$. Суммарный уровень ПХБ в рыбах из Татарского пролива находится между таковыми в Гданьской бухте и устье реки Висла (Балтийское море). В рыбах Японского моря максимальные уровни ПХБ значительно выше, чем в Балтийском, Беринговом, Желтом морях и Атлантическом океане. Столь высокая разница средних концентраций в рыбах из разных районов обитания говорит о серьезном антропогенном прессе на экосистему б. Рифовая и всего япономорского района в целом. 
В ходе статистической обработки найденные концентрации поллютантов в рыбах сравнивались как внутри районов, так и между собой с использованием двустороннего критерия Краскала-Уоллиса (рис. 6.33).

101 ПХБ

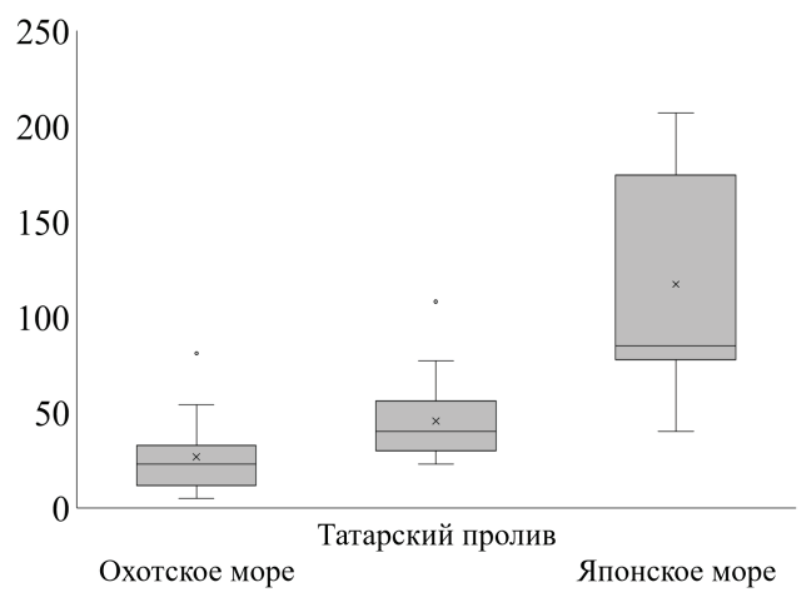

138 ПХБ

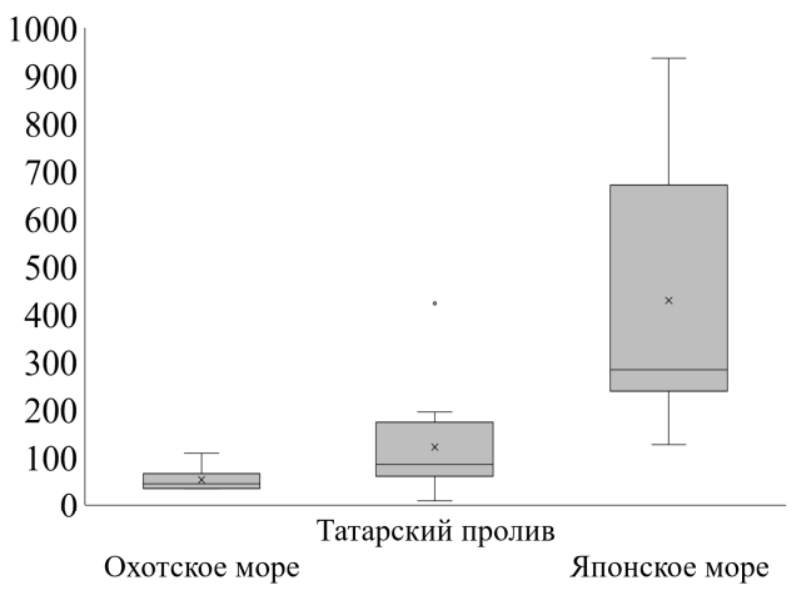

ऽПХБ

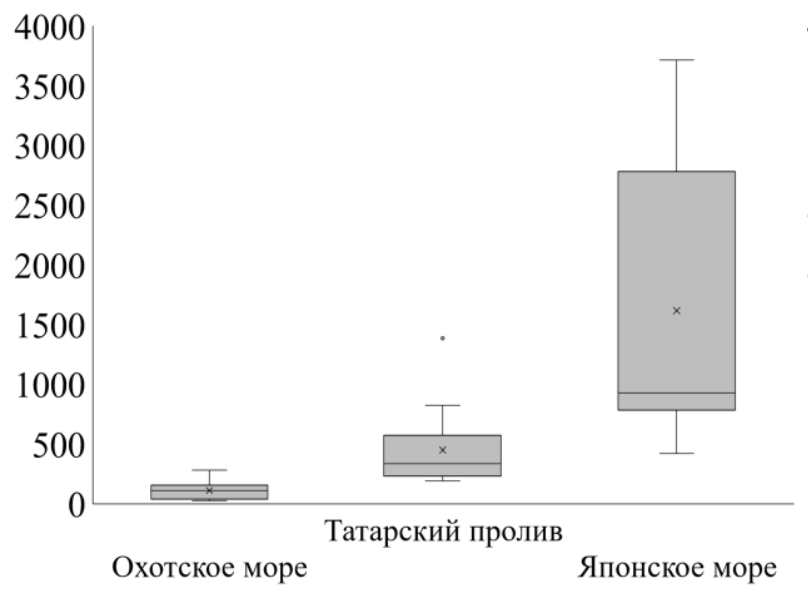

118 ПХБ

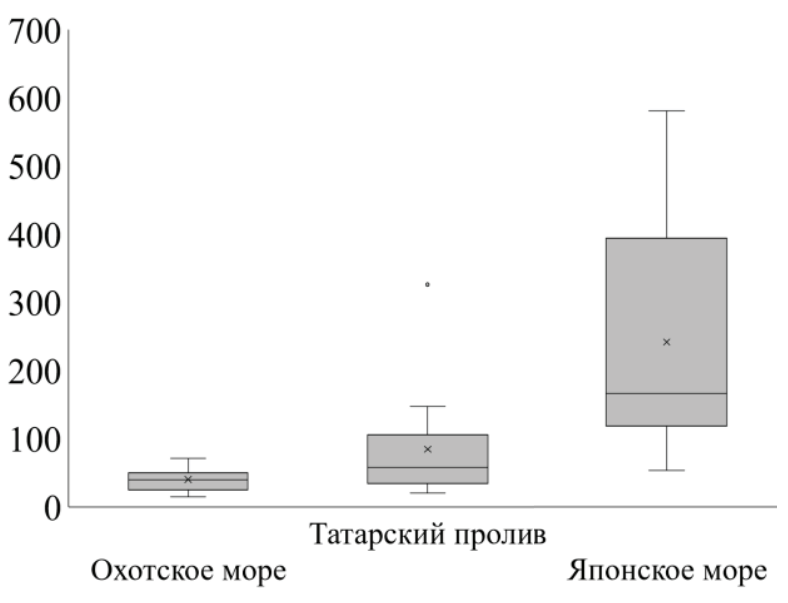

153 ПХБ

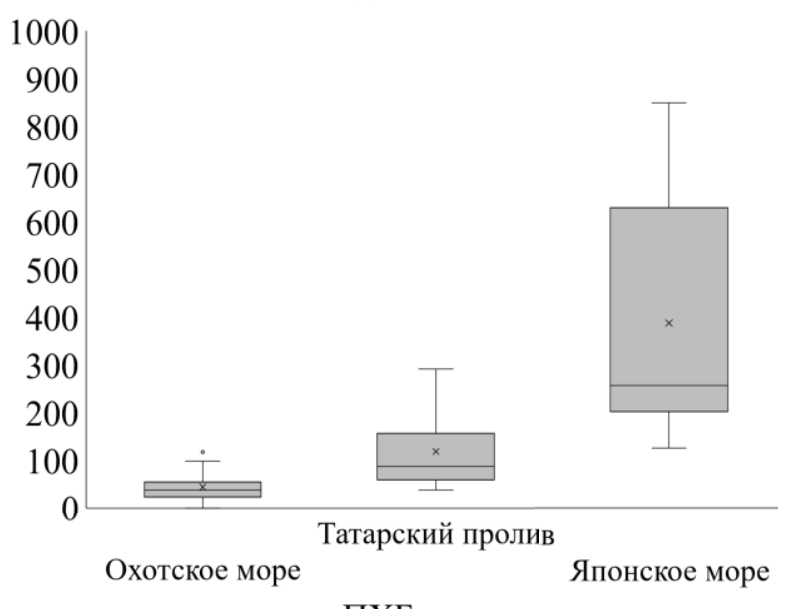
ПХБ

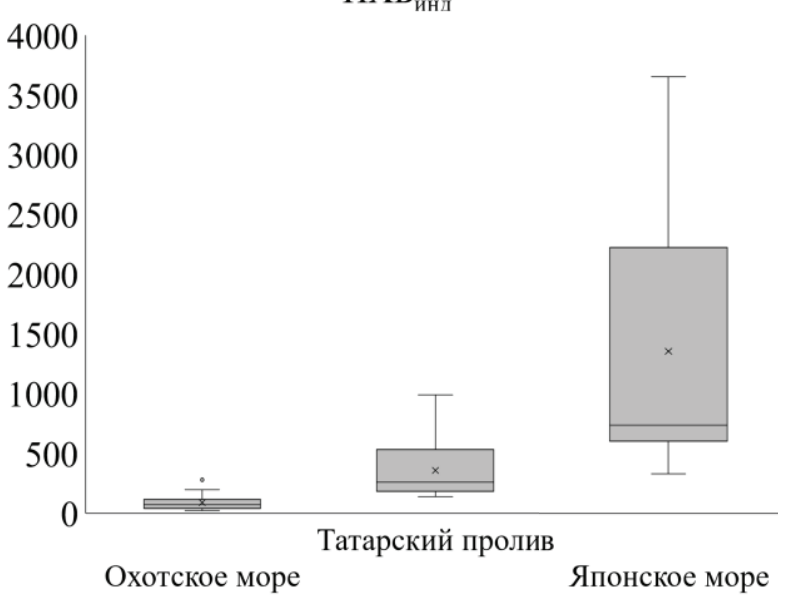

Рис. 6.32. Концентрации тяжелых конгенеров ПХБ, $\Sigma П Х Б_{\text {инд }}$ и $\Sigma$ ПХБ в камбалах из обследованных районов, нг/г липидов 
Таблица 6.21

Средние концентрации ХОП и ПХБ в мышцах камбал из различных районов Мирового океана, нг/г липидов

\begin{tabular}{|c|c|c|c|c|c|c|c|}
\hline \multirow[t]{2}{*}{ Вид } & \multirow{2}{*}{$\begin{array}{l}\text { Район исследо- } \\
\text { вания }\end{array}$} & \multirow[t]{2}{*}{ гДДТ } & \multicolumn{3}{|c|}{ ГХЦГ } & \multirow[t]{2}{*}{$\Sigma \Pi Х Б$} & \multirow[t]{2}{*}{ Источник } \\
\hline & & & $\alpha-$ & $\beta-$ & $\gamma-$ & & \\
\hline $\begin{array}{l}\text { Речная камбала } \\
\text { (Platichthys }\end{array}$ & $\begin{array}{l}\text { Балтийское } \\
\text { море }\end{array}$ & 579 & 1,3 & -1 & 0,8 & 258,5 & [33] \\
\hline \multirow[t]{2}{*}{ flesus) } & $\begin{array}{l}\text { Балтийское } \\
\text { море }\end{array}$ & 732,2 & 1,4 & - & 0,73 & 373,2 & \multirow[t]{2}{*}{ [49] } \\
\hline & $\begin{array}{l}\text { Северная часть } \\
\text { Атлантики }\end{array}$ & 140,9 & 2,3 & - & 1,8 & 518,2 & \\
\hline $\begin{array}{l}\text { Звездчатая кам- } \\
\text { бала (Platichthys } \\
\text { stellatus) }\end{array}$ & Баренцево море & 4,5 & 0 & & & 15,1 & [23] \\
\hline $\begin{array}{l}\text { Рогатая камбала } \\
\text { (Pleuronichthys } \\
\text { cornutus) }\end{array}$ & Желтое море & 122 & $13^{2}$ & & & 7,5 & [14] \\
\hline \multirow{3}{*}{$\begin{array}{l}\text { Палтусовидная } \\
\text { камбала } \\
\text { (Hippoglossoides } \\
\text { robustus) }\end{array}$} & Охотское море & 39,8 & 5,8 & 45,4 & - & 111,6 & \multirow{3}{*}{$\begin{array}{l}\text { Эта } \\
\text { работа }\end{array}$} \\
\hline & $\begin{array}{l}\text { Татарский про- } \\
\text { лив }\end{array}$ & - & - & 221,3 & - & 347,5 & \\
\hline & Японское море & 40,0 & 2,0 & 59,2 & 2,2 & 1615,7 & \\
\hline
\end{tabular}

${ }_{1}^{1}$ Не обнаружено или не исследовалось;

${ }^{2}$ Сумма всех изомеров ГХЦГ

Все «Тяжелые» конгенеры ПХБ показали достоверные различия концентраций в рыбах во всех районах исследования при $\mathrm{p} \leq 0,05$, что говорит о разных источниках загрязнения и различной величине антропогенного пресса в каждом из них. Концентрации $\alpha$ - и $\beta$-изомеров ГХЦГ в рыбах достоверно различаются в каждом из районов. В то же время для уровней содержания ДДТ и его метаболитов в рыбах достоверных различий по районам не выявлено.

Корреляционный анализ (табл. 6.22-6.24) между всеми поллютантами в камбалах показал, что ряд конгенеров ПХБ имеет сильные отрицательные связи с ХОП, что говорит о возможном превращении одних соединений в другие. Известно, например, что ДДТ и его метаболиты могут трансформироваться в ПХБ в верхних слоях атмосферы (воздействие ультрафиолета) и в морской воде (воздействие ультрафиолета и микроорганизмов) [5]. Положительные корреляции, обнаруженные между ГХЦГ и ДДТ и различными конгенерами ПХБ друг с другом, свидетельствуют о единых источниках поступления и совместном попадании в окружающую среду. Наблюдающаяся в некоторых случаях сильная положительная корреляция между 
ГХЦГ и ПХБ, ДДТ и ПХБ также может указывать на единые источники поступления, например - атмосферный перенос [14, 38, 48].

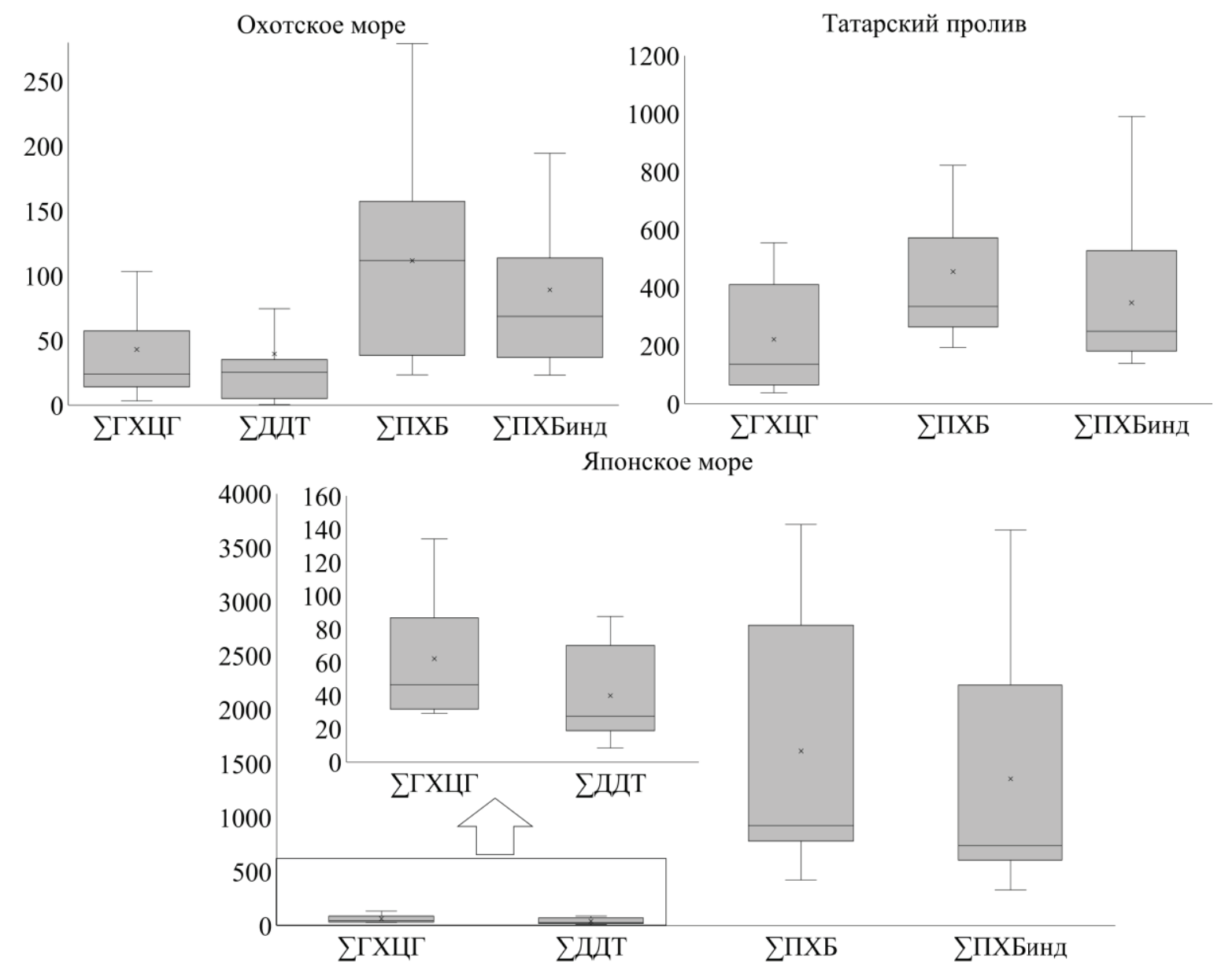

Pис. 6.33. Суммарные концентрации СОЗ в камбалах из разных районов, нг/г липидов

Некоторые исследователи сообщали о сильной корреляции между p,p'-ДДЕ и ПХБ 153 в тканях ракообразных, камбал и тресковых, предполагая, что эти поллютанты имеют единый источник поступления и указывают на фон загрязнения в районе наблюдений [48]. Другие авторы считают, что положительная корреляция может говорить не только о едином источнике поступления, но и о сходных путях биоаккумуляции и биомагнификации $[14,38]$. Установленная нами корреляция, скорее всего, говорит о едином источнике загрязнения. Несмотря на то, что ДДТ и ПХБ используются в разных отраслях экономики и попадают в экосистемы из разных источников, их положительная связь может свидетельствовать об их существенном и совместном поступлении из свалок ТБО. 


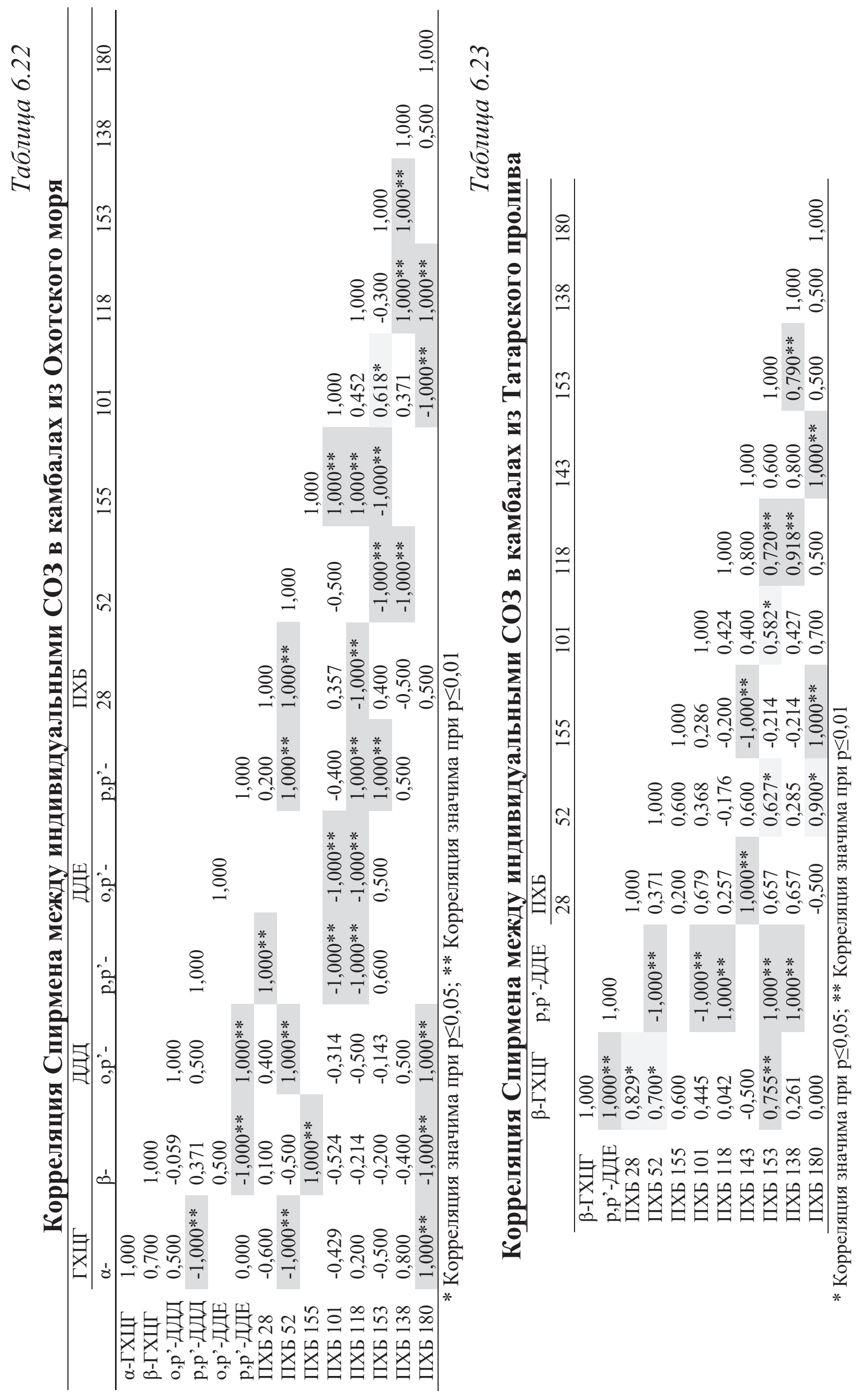




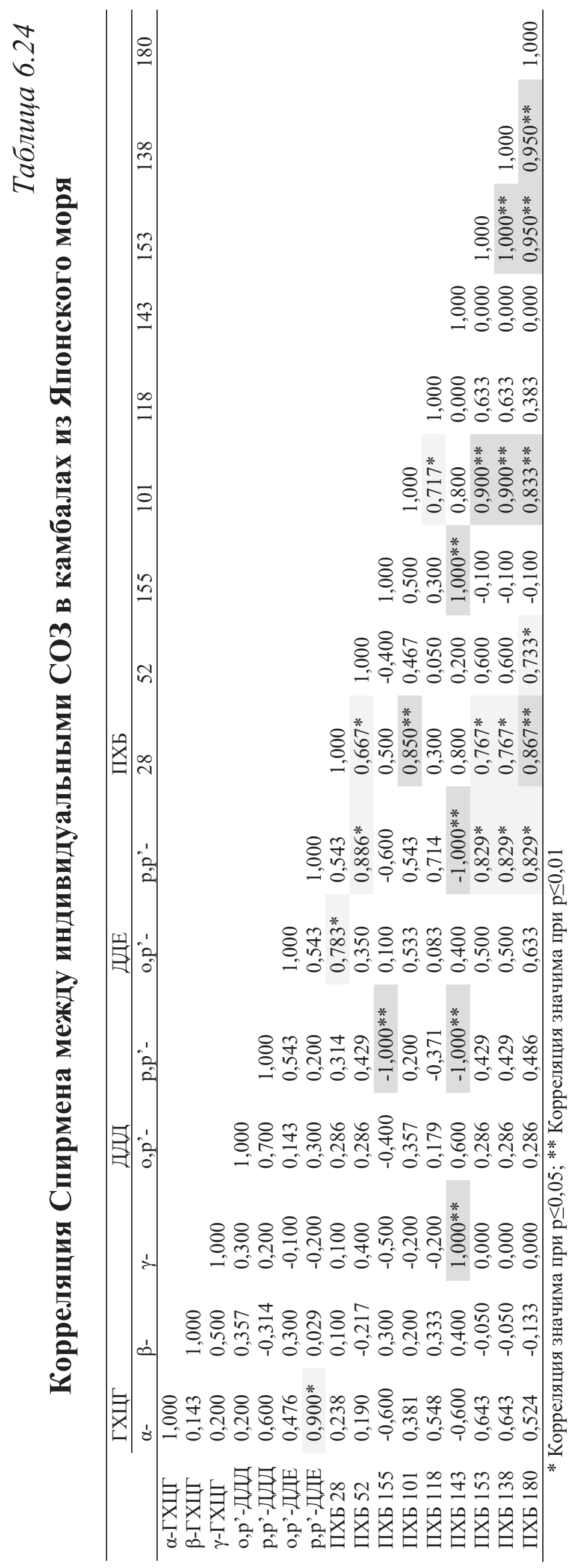




\section{3. Заключение}

Аккумуляция стойких высокотоксичных соединений может оказывать влияние на здоровье взрослых особей, успешность их размножения, выживание потомства. Продолжение мониторинга биоаккумуляции СО3 в лососевых непосредственно на нерестилищах даст новые сведения об этом малоизученном факторе, способном оказать влияние на общий запас и вылов ценной группы промысловых рыб. Ксенобиотики не должны иметь фоновых концентраций в окружающей среде, однако накопление СО3 в органах рыб является отражением глобального фона токсикантов, сформировавшегося как на планете в целом, так и в Мировом океане, поэтому уровни содержания этих соединений в камбалах южной части Охотского моря (прикурильские воды), характеризующейся отсутствием прямых источников загрязнения и активной гидродинамикой, могут быть приняты как «фоновые». При этом, в органах и тканях камбал отражается локальное загрязнение, так как они ведут почти «оседлый» образ жизни.

\section{4. Список литературы}

1. Ворожбит, О.Ю. Рыбная промышленность Дальнего Востока России: современное состояние, проблемы и перспективы конкурентоспособности / О.Ю. Ворожбит, Т.Е. Даниловских, И.А. Кузьмичева [и др.]. Владивосток: Изд-во ВГУЭС, 2016. - 156 с.

2. Доклад о состоянии окружающей среды в камчатском крае в 2018 году. - Петропавловск-Камчатский: Министерство природных ресурсов и экологии Камчатского края, 2019. - 395 с.

3. Зубцова, И.Л. Размещение отходов на территории Сахалинской области / И.Л. Зубцова // Вологдинские чтения. - 2008. - № S. - С. 109-118.

4. Информационный отчет по объекту «Мониторинг Козельского полигона захоронения ядохимикатов и пестицидов». - Елизово: ООО «Недра», 2018. - 49 с.

5. Кросби, Д. Перенос и превращение пестицидов в атмосфере / Д. Кросби. // Миграция и превращения пестицидов в окружающей сре- 
де: труды I Всесоюзного совещания. - М.: Гидрометеоиздат, 1979. С. $5-10$.

6. Мамонтова, Е.А. Хлорорганические пестициды и полихлорированные бифенилы в тканях жилой формы нерки Толмачевского водохранилища, п-ов Камчатка / Е.А. Мамонтова, Е.В. Лепская, Е.Н. Тарасова [и др.]. // Биология внутренних вод. - 2018. - № 2. - С. 76-83.

7. Напазаков, В.В. Питание и пищевые отношения камбал в западной части Берингова моря в летне-осенний период / В.В. Напазаков, В.И. Чучукало // Известия ТИНРО. - 2002. - Т. 130. - С. 595-617.

8. О долгосрочной областной целевой программе «Отходы производства и потребления сахалинской области (2009-2015)»: [Постановление Администрации Сахалинской области: принят 22 сентября 2008 года N 293-па]. - Южно-Сахалинск, 2008.

9. Фадеев, Н.С. Справочник по биологии и промыслу рыб северной части Тихого океана / Н.С. Фадеев. - Владивосток: ТИНРО-центр, 2005. - 366 с.

10. Цыденова, О.В. Загрязнение бассейна озера Байкал: хлорорганические пестициды / О.В. Цыденова, В.Б. Батоев, Л. Вайсфлог, К.-Д. Венцель // Химия в интересах устойчивого развития. - 2003. - Т. 11. C. 349-352.

11. Apeti, D.A. Assessment of contaminant body burdens and histopathology of fish and shellfish species frequently used for subsistence food by Alaskan Native communities / D.A. Apeti, S.I. Hartwell, S.M. Myers [et al.]. North Pacific Research Board Final Report, 2013. - 63 p.

12. Arkoosh, M.R. Trends in organic pollutants and lipids in juvenile Snake River spring Chinook salmon with different outmigrating histories through the Lower Snake and Middle Columbia Rivers / M.R. Arkoosh, S. Strickland, A.V. Gaest [et al.] // Science of the Total Environment. - 2011. V. 409. - P. 5086-5100.

13. Brett J.R. Energetics / In: Groot C., Margolis L., Clarke W.C. eds. Physiological ecology of Pacific salmon. - University of British Columbia, Vancouver, BC, Canada, 1995. - P. 3-68.

14. Byun, G.-H. Biomagnification of persistent chlorinated and brominated contaminants in food web components of the Yellow Sea / G.-H. Byun, H.B. Moon, J.H. Choi // Marine Pollution Bulletin. - 2013. - V. 73. - P. 210-219.

15. Cullon, D.L. Persistent organic pollutants in chinook salmon (Oncorhynchus tshawytscha): implications for resident killer whales of British Co- 
lumbia and Adjacent waters / D.L. Cullon, M.B. Yunker, C. Alleyne [et al.] // Environmental Toxicology and Chemistry. - 2009. - V. 28. - No. 1. - P. 148-161.

16. Debruyn, A. Magnification and toxicity of PCBs, PCDDs, and PCDFs in upriver-migrating Pacific Salmon / A. Debruyn, M. Ikonomou, F. Gobas // Environmental Science \& Technology. - 2004. - V. 38. - P. 6217-6224.

17. Donets, M.M. Organochlorine compounds in flounders of genus Hippoglossoides Gottsche, 1835 from the Far Eastern seas of Russia / M.M. Donets, V.Yu. Tsygankov, M.D. Boyarova [et al.] // Marine Biological Journal. - 2020. V. 5. - No. 1. - P. 29-42.

18. Garner, A.J. Trends of polychlorinated dioxins, polychlorinated furans, and dioxin-like polychlorinated biphenyls in Chinook and Coho salmonid eggs from a Great Lakes tributary / A.J. Garner, J.J. Pagano // Environmental Pollution. - 2019. - V. 247. - P. 1039-1045.

19. Gerig, B.S. Environmental context and contaminant biotransport by Pacific salmon interact to mediate the bioaccumulation of contaminants by stream-resident fish / B.S. Gerig, D.T. Chaloner, D.J. Janetski [et al.] // Journal of Applied Ecology. - 2017. - V. 55. - P. 1846-1859.

20. Gerlach, B. Fish Monitoring Program / B. Gerlach. - Alaska Department of Environmental Conservation. Fish Tissue Testing Program, 2013.

21. Good, T.P. Persistent organic pollutants in forage fish prey of rhinoceros' auklets breeding in Puget Sound and the northern California Current / T.P. Good, S.F. Pearson, P. Hodum [et al.] // Marine Pollution Bulletin. - 2014. V. 86. - P. 367-378.

22. Grung, M. Pesticide levels and environmental risk in aquatic environments in China - A review / M. Grung, Y. Lin, H. Zhang [et al.] // Environment International. - 2015. - V. 81. - P. 87-97.

23. Hartwell, S.I. Benthic habitat contaminant status and sediment toxicity in Bristol Bay, Alaska / S.I. Hartwell, A.D. Apeti, A.S. Pait, T. Radenbaugh, R. Britton // Regional Studies in Marine Science. - 2018. - V. 24. - P. 343-354.

24. Hendry, A. Secondary sexual characters, energy use, senescence, and the cost of reproduction in sockeye salmon / A. Hendry, O. Berg // Canadian Journal of Zoology. - 1999. - V. 77. - P. 1663-1675.

25. Hoekstra, P.F. Trophic transfer of persistent organochlorine contaminants (OCs) within an Arctic marine food web from the southern BeaufortChukchi Seas / P.F. Hoekstra, T.M. O'Hara, A.T. Fisk [et al.] // Environmental Pollution. - 2003. - V. 124. - P. 509-522. 
26. Jackson, L. PCB congeners in Lake Michigan Coho (Oncorhynchus kisutch) and Chinook (Oncorhynchus tshawytscha) salmon / L. Jackson, S. Carpenter, J. Manchester-Neesving, C. Stow // Environmental Science \& Technology. - 2001. - V. 35. - P. 856-862.

27. Jacobs, M.M. Investigation of selected persistent organic pollutants in farmed Atlantic salmon (Salmo salar), salmon aquaculture feed, and fish oil components of the feed / M.M. Jacobs, A. Covaci, P. Schepens // Environmental Science and Technology. - 2002. - V. 36. - P. 2797-2805.

28. Johnson, L. Persistent Organic Pollutants in Juvenile Chinook Salmon in the Columbia River Basin: Implications for Stock Recovery / L. Johnson, B. Anulacion, M. Arkoosh // Transactions of the American Fisheries Society. 2013. - V. 142. - P. 21-40.

29. Kelly, B.C. Mercury and other trace elements in farmed and wild salmon from British Columbia, Canada / B.C. Kelly, M.G. Ikonomov, D.A. Higgs, J. Oakes, C. Dubetz // Environmental Toxicology and Chemistry. 2008. - V. 27. - P. 1361-1370.

30. Kelly, B.C. Persistent organic pollutants in aquafeed and Pacific salmon smolts from fish hatcheries in British Columbia, Canada / B.C. Kelly, M.P. Fernandez, M.G. Ikonomou, W. Knapp // Aquaculture. - 2008 - V. 285. - P. 224-233.

31. Kelly, B.C. Tissue residue concentrations of organohalogens and trace elements in adult Pacific salmon returning to the Fraser River, British Columbia, Canada / B.C. Kelly, M.G. Ikonomou, N. MacPherson [et al.] // Environmental Toxicology and Chemistry. - 2010. - V. 30. - P. 367-376.

32. Khristoforova N.K., Tsygankov V.Yu., Boyarova M.D., Lukyanova O.N. Concentrations of Trace Elements in Pacific and Atlantic Salmon // Oceanology. - 2015. - V. 55. - №5. - P. 679-685.

33. Kopko, O. Variability of biological indices, biomarkers, and organochlorine contaminants in flounder (Platichthys flesus) in the Gulf of Gdańsk, southern Baltic Sea / O. Kopko, H. Dabrowska // Chemosphere. - 2018. - V. 194. - P. 701-713.

34. Lukyanova, O.N. Organochlorine pesticides and polychlorinated biphenyls in the Bering flounder (Hippoglossoides robustus) from the Sea of Okhotsk / O.N. Lukyanova, V.Yu. Tsygankov, M.D. Boyarova // Marine Pollution Bulletin. - 2018. - V. 137. - P. 152-156.

35. Malde, M.K. Calcium from salmon and cod bone is well absorbed in young healthy men: a double-blinded randomized crossover design / 
M.K. Malde, S. Bügel, M. Kristensen [et al.] // Nutrition \& Metabolism. 2010. - V. 7. - No. 61. 9 p.

36. Matsumoto, R. Polychlorinated biphenyl (PCB) concentrations and congener composition in masu salmon from Japan: A study of all 209 PCB congeners by high-resolution gas chromatography/high-resolution mass spectrometry (HRGC/HRMS) / R. Matsumoto, N.P. Cam Tu, S. Haruta, M. Kawano, I. Takeuchi // Marine Pollution Bulletin. - 2014. - V. 85 - P. 549-557.

37. Montory, M. PCBs and PBDEs in wild Chinook salmon (Oncirhynchus tshawytscha) in the Northern Patagonia, Chile / M. Montory, E. Habit, P. Fernandez, J.O. Grimalt, R. Barra // Chemosphere. - 2010. - V. 78. - P. 11931199.

38. Moon, H.-B. Human health risk of polychlorinated biphenyls and organochlorine pesticides resulting from seafood consumption in South Korea, 2005-2007 / H.-B. Moon, H.S. Kim, M. Choi, J. Yu, H.G. Choi. // Food and Chemical Toxicology. - 2009. - V. 47. - P. 1819-1825.

39. O'Toole, S. Release of persistent organic contaminants from carcasses of Lake Ontario Chinook salmon (Oncorhynchus tshawytscha) / S. O'Toole, C. Metcalfe, I. Craine, M. Gross // Environmental Pollution. - 2006. - V. 140. P. 102-113.

40. Oka, M. Concentrations of Persistent Organic Pollutants in Masu Salmon, Oncorhynchus masou / M. Oka, T. Arai, Y. Shibata, N. Miyazaki // Bulletin of Environmental Contamination and Toxicology. - 2009. - V. 83. P. 393-397.

41. Rice, S. Assessing the potential for remote delivery of persistent organic pollutants to the Kenai River in Alaska / S. Rice, A. Moles // Alaska Fishery Research Bulletin. - 2006. - V. 12. - P. 153-157.

42. Rios, L. M. Quantitation of persistent organic pollutants adsorbed on plastic debris from the Northern Pacific Gyre's "eastern garbage patch" / L.M. Rios, Jones P.R., C. Moore [et al.] // Journal of Environmental Monitoring. - 2010. - V. 12. - P. 2189-2312.

43. Susan, D.S. PCBs, PCDD/Fs, and Organochlorine Pesticides in Farmed Atlantic Salmon from Maine, Eastern Canada, and Norway, and Wild Salmon from Alaska / D.S. Susan, D. Brenner, M.L. Berger [et al.] // Environmental Science \& Technology. - 2006. - V. 40. - P. 5347-5354.

44. Tripathi, V. Restoring HCHs polluted land as one of the priority activities during the UN-International Decade on Ecosystem Restoration (2021- 
2030): A call for global action / V. Tripathi, S.A. Edrisi, R. Chaurasia [et al.] // Science of The Total Environment. - 2019. - V. 689. - P. 1304-1315.

45. Tsygankov, V.Yu. Bioindicators of organochlorine pesticides (OCPs) in the Sea of Okhotsk and the western Bering Sea / V.Yu. Tsygankov, M.D. Boyarova, O.N. Lukyanova, N.K. Khristoforova // Archives of Environmental Contamination and Toxicology. - 2017. - V. 73. - P. 176-184.

46. Tsygankov, V.Yu. Organochlorine pesticides in marine ecosystems of the Far Eastern Seas of Russia (2000-2017) / V.Yu. Tsygankov // Water Research. - 2019. V. 161. - P.43-53.

47. Visha, A. A Bayesian assessment of polychlorinated biphenyl contamination of fish communities in the Laurentian Great Lakes / A. Visha, N. Gamdhi, S.P. Bhasvar, G.B. Arhonditsis // Chemosphere. - 2018. - V. 210. P. 1193-1206.

48. Voorspoels, S. Levels and profiles of PCBs and OCPs in marine benthic species from the Belgian North Sea and the Western Scheldt Estuary / S. Voorspoels, A. Covaci, J. Maervoet, I. De Meester, P. Schepens // Marine Pollution Bulletin. - 2004. - V. 49. - P. 393-404.

49. Waszak, I. Comparison of common persistent organic pollutants (POPs) in flounder (Platichthys flesus) from the Vistula (Poland) and Douro (Portugal) River estuaries / I. Waszak, H. Dabrowska, K. Komar-Szymczak // Marine Pollution Bulletin. - 2014. - V. 81. - P. 225-233. 
https://doi.org/10.24866/7444-4891-2/195-210

\title{
ГЛАВА 7
}

\section{БИОТРАНСПОРТ СТОЙКИХ ОРГАНИЧЕСКИХ ЗАГРЯЗНЯЮЩИХ ВЕЩЕСТВ (СОЗ) ТИХООКЕАНСКИМИ ЛОСОСЯМИ СЕВЕРО-ЗАПАДНОЙ ЧАСТИ ТИХОГО ОКЕАНА}

\author{
В.Ю. Цыганков ${ }^{1,2}$, М.М. Донец ${ }^{1}$, А.Н. Гумовский ${ }^{1}$, \\ Н.К. Христофорова ${ }^{2}$
}

Наряду с атмосферным переносом в Мировом океане определенное значение имеет биотранспорт СО3 морскими организмами, совершающими длительные миграции. В первую очередь это лососевые рыбы, количество которых в субарктическом регионе Тихого океана в последнее десятилетие достигает 1,5 млн т. Лососи, погибающие после нереста в реках и озеpax, оставляют на нерестилищах загрязняющие вещества, общий объем

${ }^{1}$ Школа биомедицины, Дальневосточный федеральный университет (ДВФУ), 690922, Владивосток, о. Русский, п. Аякс, 10. E-mail: tsig_90@mail.ru.

${ }^{2}$ Школа естественных наук, Дальневосточный федеральный университет (ДВФУ), 690922, Владивосток, о. Русский, п. Аякс, 10.

${ }^{1}$ School of Biomedicine, Far Eastern Federal University, 10 Ajax Bay, Russky Island Vladivostok, Russia,690922. E-mail: tsig_90@mail.ru.

${ }^{2}$ School of School of Natural Sciences, Far Eastern Federal University, 10 Ajax Bay, Russky Island Vladivostok, Russia, 690922.

Для циитирования: Цыганков В.Ю., Донец М.М., Гумовский А.Н., Христофорова Н.К. Биотранспорт стойких органических загрязняющих веществ (СО3) тихоокеанскими лососями северо-западной части Тихого океана // Стойкие органические загрязняющие вещества (CO3) в Дальневосточном регионе: моря, организмы, человек : монография / В.Ю. Цыганков, М.М. Донец, Н.К. Христофорова [и др.] ; науч. ред. В.Ю. Цыганков. - Владивосток : Изд-во Дальневост. федерал. ун-та, 2020. - С. 195-210. https://doi.org/10.24866/7444-4891-2/195-210.

For citing: Tsygankov V.Yu., Donets M.M., Gumovskiy A.N., Khristoforova N.K. Biotransport of Persistent Organic Pollutants (POPs) by Pacific Salmon of the Northwest Pacific // Persistent organic pollutants (POPs) in the Far Eastern Region: Seas, Organisms, Human : monograph / V.Yu. Tsygankov, M.M. Donets, N.K. Khristoforova [et al.] ; ed. by V.Yu. Tsygankov. - Vladivostok : Publishing House of the Far Eastern Federal University, 2020. - P. 195-210. - https://doi.org/10.24866/7444-4891-2/195-210. 
которых может быть значительным. В главе рассчитано общее количество CO3, переносимых лососями на российское побережье северо-западной части Тихого океана, показана роль последних в транспорте токсикантов с моря на сушу, и выявлен экологический риск для локальных экосистем.

Ключевые слова: ГХЦГ; ДДТ; ПХБ; биотранспорт; тихоокеанские лососи; северо-западная часть Тихого океана.

\title{
CHAPTER 7. Biotransport of Persistent Organic Pollutants (POPs) by Pacific Salmon of the Northwest Pacific
}

\author{
V.Yu. Tsygankov ${ }^{1,2}$, M.M. Donets ${ }^{1}$, A.N. Gumovskiy ${ }^{1}$, \\ N.K. Khristoforova ${ }^{1,3}$
}

Along with the atmospheric transport in the World Ocean, the biotransport of POPs by marine organisms making long-term migrations is of certain importance. First of all, these are salmon, the number of which in the subarctic region of the Pacific Ocean in the last decade has reached 1.5 million tons. Dying after spawning in rivers and lakes, salmon leave pollutants on spawning grounds. In the chapter, the total amount of POPs transported by salmon to the Russian coast of the northwestern Pacific Ocean is calculates, their role in the transport of toxicants from the sea to land are shows, and the environmental risk for local ecosystems is identifies.

Keywords: HCHs; DDTs; PCBs; biotransport; Pacific salmon; Northwest Pacific

Биогеохимические круговороты элементов в биосфере происходят под действием основных экологических факторов. Уникальным примером направленного переноса биогенных элементов в океане являются нерестовые миграции анадромных рыб, в том числе тихоокеанских лососей, у которых нагул происходит в океане, а нерест и раннее развитие - в пресной воде, в реках и озерах. Погибающие после нереста многие миллионы экземпляров рыб оставляют на нерестилищах в составе своих тушек и скелета значительные количества минеральных компонентов и органического вещества. Подобная «морская помпа» по переносу биогенов рассматрива- 
ется как эволюционный механизм, обеспечивающий успешность развития икры и выживания молоди в пресной воде $[8,12]$.

Во время нагула в океане и особенно перед нерестовой миграцией лососи аккумулируют резервные липиды, как для удовлетворения энергетических затрат, так и для развития гонад во время миграций. Одновременно с накоплением липидов аккумулируются и липофильные СО3 из морской среды $[11,13]$. СО3 накапливаются в органах животных и вызывают различные негативные биологические эффекты, нарушая основные метаболические процессы и снижая успешность репродукции [17]. Присутствие токсикантов в районах нагула лососей, удаленных от хозяйственной деятельности, является следствием сформировавшегося глобального фона пестицидов, переносимых ветрами из районов использования (тропическая и субтропическая зоны) на огромные расстояния в умеренные широты. Мигрирующие рыбы могут выступать как векторы, переносящие органические поллютанты в процессе биотранспорта от субтропических и южнобореальных к бореальным и субарктическим экосистемам.

Расчет количества перенесенных СО3 выполнен на основе данных о содержании таковых во всем организме лососей (Глава 6).

\section{1. Биотранспорт ХОП в 2008-2012 гг.}

Можно выделить два различных вектора переноса поллютантов в океане - атмосферный и биотранспорт, которые различаются по нескольким важным показателям. Во-первых, поллютанты в лососях могут напрямую использоваться при биоаккумуляции, поскольку икра лососей, их тушки и скелеты непосредственно служат пищей для хищников. В отличие от этого, при атмосферном переносе поллютанты подвергаются различным физико-химическим воздействиям, что меняет эффективность переноса по пищевым цепям. Во-вторых, при биотранспорте возможен перенос на весьма длительные расстояния неустойчивых в химическом отношении веществ, или таких соединений, которые не способны к атмо- 
сферному переносу (нелетучие вещества, например, хлорированные жирные кислоты, которые легко аккумулируются в жировой ткани рыб) [13].

Тихоокеанские лососи в силу особенностей своей жизненной стратегии постоянно осуществляют и будут осуществлять перенос стойких загрязняющих веществ в районы нерестилищ на материке. Это явление имеет как фундаментальный характер, поскольку изменяет основные биогеохимические циклы переноса вещества с моря на сушу, так и прикладное значение: попадание пестицидов на нерестилища может повлиять на успех размножения лососей, что скажется в конечном счете на их промысловых запасах.

Расчет количества перенесенных пестицидов 2008-2010 гг. выполнен на основе данных о содержании ХОП во всем организме кеты и горбуши, как в наиболее массовых видах. Их доля в общем подходе при нерестовых миграциях составляет более $80 \%$. Содержание в них ХОП пересчитывалось из нг/г липидов в нг/г сырой массы. Для расчета биотранспорта 2011 и 2012 гг. к первым двум видам добавлены нерка и чавыча.

Количество лососей, мигрирующих к российскому побережью, варьирует год от года, но структура подхода сохраняется - 60-65\% составляет горбуша, 20-25\% - кета, 10-12\% - нерка, и небольшая доля приходится на кижуча и чавычу. Кета и горбуша составляют основу подхода на восточной Камчатке, восточном Сахалине, материковом побережье Охотского моря, в бассейне Амура [6, 7]. Количество рыбы, пропущенной на нерест в отдельных районах Дальнего Востока в 2008-2012 гг., приведено в таблицах 7.1-7.3.

Именно эта рыба, пропущенная на нерест, погибнет на нерестилищах и послужит пищей для многих организмов, связывая таким образом морские и наземные пищевые цепи, или, иначе говоря, перенося органическое вещество из океана на сушу. Данные о заполнении нерестилищ лососями во всей Северной Пацифике приводятся в открытых отчетах Северо-Тихоокеанской комиссии по анадромным рыбам (NPAFC).

Содержание ХОП как средняя сумма ГХЦГ+ДДЕ в горбуше составляла 68,85 нг/Г, в кете - 182,5 нг/г сырой массы. Средний вес одного экземпляра нерестовой горбуши равен 1,3 кг, кеты - 3,5 кг. Расчеты показывают, что одна горбуша содержит до 90 мкг пестицидов, кета - до 640 мкг. Для нерки и чавычи провести анализ целой туши рыбы не представлялось возможным. Поэтому было определено среднее количество жира в рыбе - 
в нерке 1,6 \%, по нашим данным, и в чавыче $10 \%$, по справочным данным. На основании этого были рассчитаны общие суммарные количества пестицидов в мышцах этих видов рыб: чавыча - 124,1 нг/г; нерка - 20,33 нг/г сырой массы. Мышечная ткань составляет более 75\%, поэтому общее содержание в мышцах будет примерно соответствовать таковому в тушке. Если масса одной нерки - 4 кг, то общее содержание пестицидов в рыбе 81,3 мкг. Следует отметить, что образцы нерки были собраны в июле, во время нерестовых миграций, когда масса рыб составляла около 1 кг, и содержание пестицидов было минимальным. Для одной чавычи массой 7 кг общее содержание ХОП будет составлять 870 мкг.

Таблицуа 7.1

Заполнение нерестилищ кетой и горбушей (тыс. экз.)

в российской зоне дальневосточных морей в 2008-2010 гг.

\begin{tabular}{lllllll}
\hline Район & Кета & \multicolumn{5}{c}{ Горбуша } \\
\cline { 2 - 7 } & 2008 & 2009 & 2010 & 2008 & 2009 & 2010 \\
\hline Восточная Камчатка & 399,56 & 2953,67 & 404,95 & 2914,9 & 94497 & 8757 \\
Западная Камчатка & 722 & 715,8 & 391,6 & 38948,8 & 118,6 & 46441 \\
$\begin{array}{l}\text { Охотское море (Магаданская } \\
\text { область) }\end{array}$ & 3860 & 8827 & 5931 & 3225,4 & 28042,5 & 1926 \\
Курильские острова & & & & & & \\
Восточный Сахалин & 105 & 72,6 & 261,2 & 1431,9 & 1216,4 & 2009 \\
Бассейн Амура & 478,5 & 513,5 & 481,5 & 8782,7 & 18478,7 & 11708 \\
Западная часть Берингова моря & 3999,9 & 1942,9 & 2191,5 & 70,2 & 170,0 & 60 \\
\hline
\end{tabular}

Таблица 7.2

Заполнение нерестилищ лососями на российском побережье ДВ морей (тыс. экз.) в 2011 г.

\begin{tabular}{lllll}
\hline Район & Горбуша & Кета & Нерка & Чавыча \\
\hline Западная часть Берингова моря & 10000 & 2310 & 500 & \\
Восточная Камчатка & 53549 & 393,1 & 308,8 & 7,7 \\
Курильские острова & 1387,8 & 265,1 & & \\
Западная Камчатка & 1212,7 & 479,9 & 2342,7 & 16,1 \\
Охотское море & 18744,5 & 4790 & 22 & \\
(Магаданская область) & & & & \\
Восточный Сахалин & 12926,1 & 156,0 & & \\
Бассейн р. Амур & 7982,7 & 6137,1 & & \\
Приморье & 213,7 & 60,2 & & \\
Юго-Западный Сахалин & 176,6 & 2,6 & & \\
\hline
\end{tabular}

Тогда общее количество ХОП, переносимое, например, в 2009 г., только горбушей и кетой на восточную Камчатку составляет 10,4 кг, в 
бассейн Амура - более 13 кг, на материковое побережье Охотского моря 8,1 кг (табл. 7.4, 7.5). В 2011 г. максимальное количество ХОП перенесено горбушей на восточную Камчатку $-4,8$ кг, а в 2012 г. - кетой в бассейн Амура, 4,2 кг. (табл. 7.6).

Таблица 7.3

\section{Заполнение нерестилищ лососями на российском побережье} ДВ морей (тыс. экз.) в 2012 г.

\begin{tabular}{lllll}
\hline Район & Горбуша & Кета & Нерка & Чавыча \\
\hline Восточная Камчатка & 8077,5 & 223,1 & 634,7 & 7,9 \\
Курильские острова & 1481,0 & & & \\
Западная Камчатка & 19636,7 & 235,1 & 2133,3 & 26,7 \\
Охотское море & 19755,5 & 4643,2 & 47,4 & \\
(Магаданская область) & & & & \\
Восточный Сахалин & 12141,2 & & \\
Бассейн р. Амур & 9347,4 & 6545,2 & & \\
Приморье & 2046,2 & 61,9 & & \\
Юго-Западный Сахалин & 1394,2 & & & \\
\hline
\end{tabular}

Таблища 7.4

Количество хлорорганических пестицидов (кг) в кете и горбуше, мигрирующих на тихоокеанское побережье России (2008-2010)

\begin{tabular}{lcccccc}
\hline \multicolumn{1}{c}{ Район } & \multicolumn{3}{c}{ Кета } & \multicolumn{3}{c}{ Горбуша } \\
\cline { 2 - 7 } & 2008 & 2009 & 2010 & 2008 & 2009 & 2010 \\
\hline Восточная Камчатка & 0,26 & 1,89 & 0,26 & 0,26 & 8,51 & 0,79 \\
Западная Камчатка & 0,46 & 0,46 & 0,25 & 3,50 & 0,01 & 4,10 \\
Охотское море & 2,47 & 5,65 & 3,80 & 0,29 & 2,52 & 0,17 \\
(Магаданская область) & 0,07 & 0,05 & 0,17 & 0,13 & 0,11 & 0,18 \\
Курильские острова & 0,31 & 0,33 & 0,31 & 0,79 & 1,66 & 1,05 \\
Восточный Сахалин & 1,76 & 12,81 & 6,90 & 0,10 & 0,26 & 0,85 \\
Бассейн Амура & 2,56 & 1,24 & 1,40 & 0,01 & 0,02 & 0,01 \\
Западная часть Берингова моря & $\mathbf{7 , 9}$ & $\mathbf{2 2 , 4}$ & $\mathbf{1 3 , 1}$ & $\mathbf{5 , 1}$ & $\mathbf{1 3 , 1}$ & $\mathbf{7 , 1}$ \\
Итого & & & & & & \\
\hline
\end{tabular}

В 2008 г. поступление пестицидов за счет лососей в различные районы тихоокеанского побережья России варьировало от 0,52 до 4 кг, а в 2009 - от 0,47 до 13 кг, в 2010 - от 0,35 до 7,75 кг. За три года наибольшее количество пестицидов пришло в бассейн Амура, около 23 кг (рис. 7.1). Высокие подходы лососей в последние годы определяют ежегодный пере- 
нос пестицидов на сушу от 13 до 30 кг. Таким образом, общее содержание пестицидов на каждом нерестилище увеличивается.

Таблица 7.5

Общее количество хлорорганических пестицидов (кг), переносимых кетой и горбушей на тихоокеанское побережье России в 2008-2010 гг.

\begin{tabular}{llll}
\hline Район & 2008 & 2009 & 2010 \\
\hline Восточная Камчатка & 0,52 & 10,39 & 1,05 \\
Западная Камчатка & 3,96 & 0,47 & 4,35 \\
Охотское море (Магаданская область) & 2,76 & 8,17 & 3,97 \\
Курильские острова & 0,20 & 0,16 & 0,35 \\
Восточный Сахалин & 1,10 & 1,99 & 1,36 \\
Бассейн Амура & 1,86 & 13,07 & 7,75 \\
Западная часть Берингова моря & 2,57 & 1,26 & 1,41 \\
Итого & $\mathbf{1 3 , 0}$ & $\mathbf{3 5 , 5}$ & $\mathbf{2 0 , 2}$ \\
\hline
\end{tabular}

Таблища 7.6

Общее количество пестицидов (кг), перенесенных лососями на российское побережье ДВ морей в 2011-2012 гг.

\begin{tabular}{|c|c|c|c|c|c|}
\hline Район & Горбуша & Кета & Нерка & Чавыча & $\Sigma$ इХП \\
\hline \multicolumn{6}{|c|}{2011} \\
\hline Западная часть Берингова моря & 0,9 & 1,5 & 0,04 & & 2,44 \\
\hline Восточная Камчатка & 4,8 & 0,3 & 0,03 & 0,007 & 5,137 \\
\hline Курильские острова & 0,1 & 0,2 & & & 0,3 \\
\hline Западная Камчатка & 0,1 & 0,3 & 0,2 & 0,01 & 0,61 \\
\hline $\begin{array}{l}\text { Охотское море } \\
\text { (Магаданская область) }\end{array}$ & 1,7 & 3,1 & 0,002 & & 4,802 \\
\hline Восточный Сахалин & 1,2 & 0,1 & & & 1,3 \\
\hline Бассейн р. Амур & 0,7 & 3,9 & & & 4,6 \\
\hline Приморье & 0,02 & 0,04 & & & 0,06 \\
\hline Юго-Западный Сахалин & 0,02 & 0,002 & & & 0,022 \\
\hline Всего & 9,54 & 9,442 & 0,272 & 0,017 & 19,271 \\
\hline \multicolumn{6}{|c|}{2012} \\
\hline Восточная Камчатка & 0,73 & 0,14 & 0,05 & 0,01 & 0,93 \\
\hline Курильские острова & 0,13 & & & & 0,13 \\
\hline Западная Камчатка & 1,77 & 0,15 & 0,17 & 0,02 & 2,11 \\
\hline $\begin{array}{l}\text { Охотское море } \\
\text { (Магаданская область) }\end{array}$ & 1,78 & 2,97 & 0,004 & & 4,75 \\
\hline Восточный Сахалин & 1,09 & & & & 1,09 \\
\hline Бассейн р. Амур & 0,84 & 4,19 & & & 5,03 \\
\hline Приморье & 0,18 & 0,04 & & & 0,22 \\
\hline Юго-Западный Сахалин & 0,13 & & & & 0,13 \\
\hline Всего & 6,65 & 7,49 & 0,23 & $\mathbf{0 , 0 3}$ & 14,40 \\
\hline
\end{tabular}


В 2011 г. общее количество пестицидов составило 19,1 кг, в 2012 14,4 кг. Наибольшее количество пестицидов поступает в бассейн р. Амур, на восточную Камчатку, на континентальное побережье Охотского моря (рис. 7.2). Таким образом, общее содержание пестицидов на каждом нерестилище постепенно уменьшается с каждым годом, но зависит от общего подхода рыбы.

Вылов лососевых в российских водах в последние годы оставался стабильно высоким: 2009 - 542, 2010 - 325, 2011 - 504, 2012 - 438 и 2013 - около 400 тыс. т. Эта величина соответствует 40-60 кг пестицидов, которые по пищевой цепи в конечном счете также рассеиваются на суше.

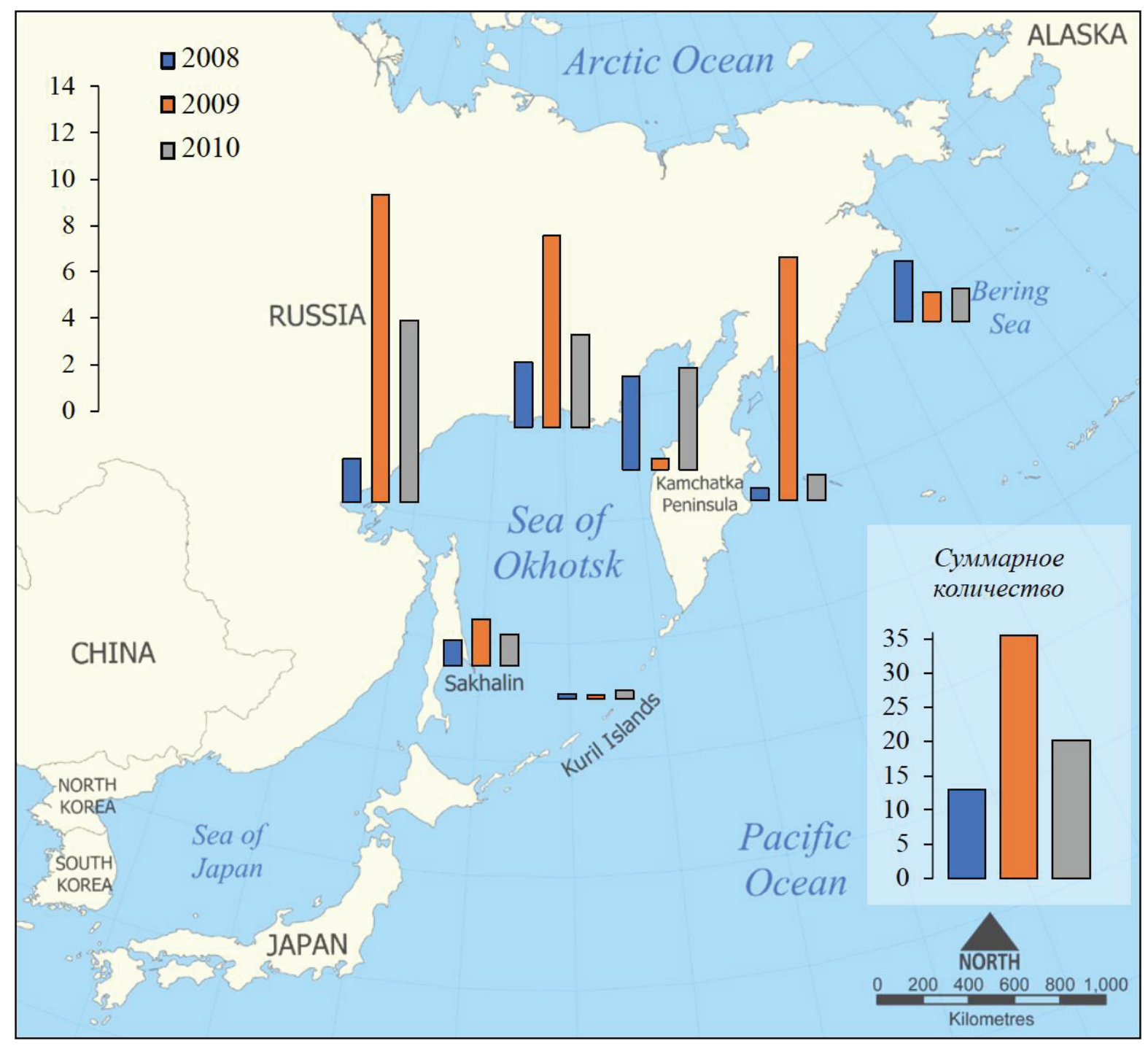

Puc. 7.1. Распределение пестицидов (кг), перенесенных лососями, по основным районам нерестилищ на российском побережье дальневосточных морей за 2008-2010 гг. 
В настоящее время лососи - самые массовые рыбы верхнего слоя эпипелагиали Северной Пацифики. Пищевые ресурсы этого слоя водных масс, который относительно слабо заселен другими видами, достаточны для прокорма большого количества рыб [7]. При исследовании мигрирующих рыб показано, что состав изотопов углерода и азота в органах лососей на нерестилищах сходен с таковым в районах нагула, в морях или океанических районах [16], т. е. лососи переносят питательные вещества из океана в реки и озера.

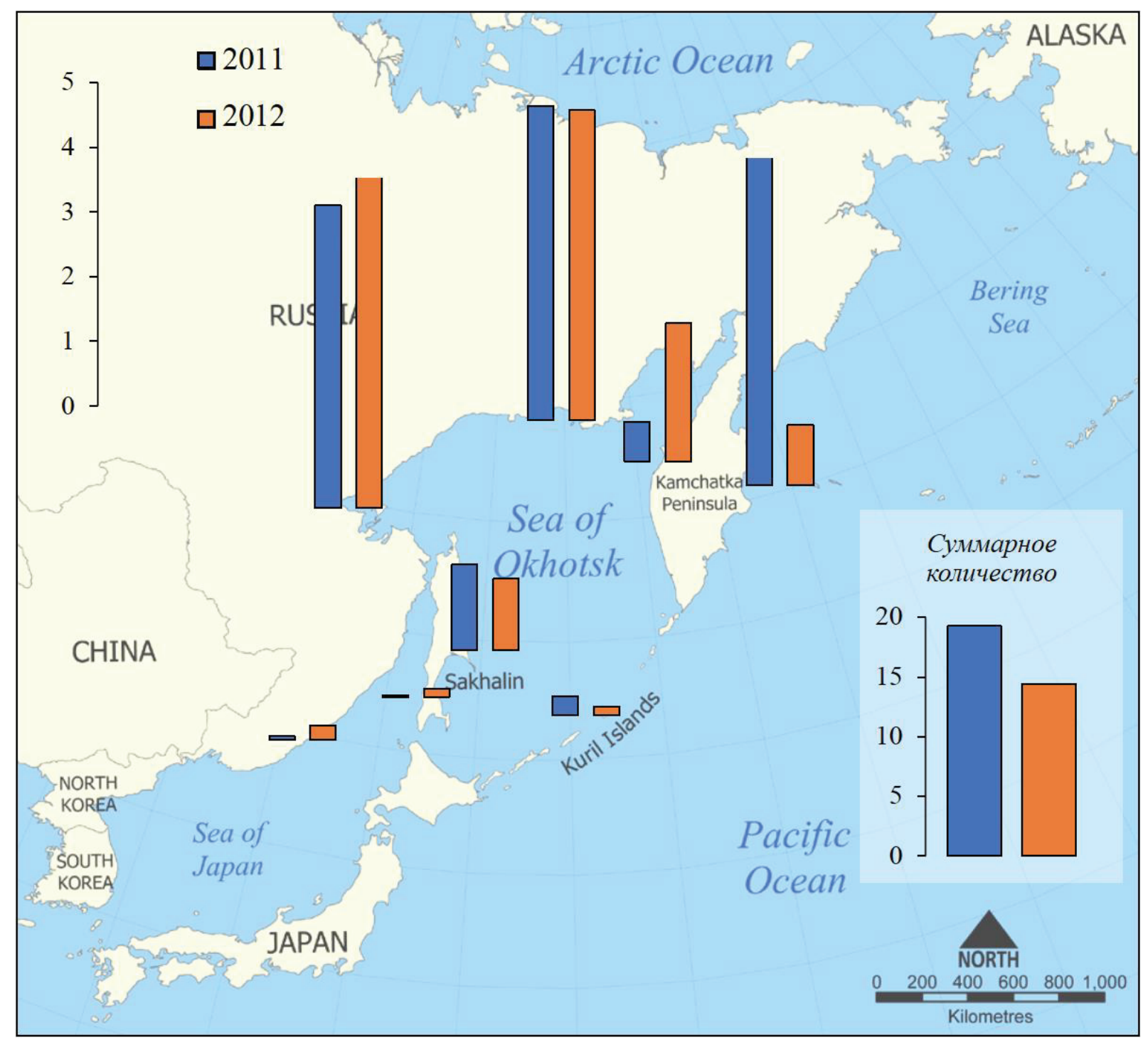

Puc. 7.2. Распределение пестицидов (кг), перенесенных лососями, по основным районам нерестилищ на российском побережье дальневосточных морей за 2011-2012 гг.

В основном морское распределение лососей соответствует сезонному распространению водных масс в пределах оптимального для лососей 
диапазона температуры воды, от 2-4 до $15-20^{\circ} \mathrm{C}$. Однако миграционные процессы зависят от многих факторов, например, сезона, климатических особенностей года, биологического и физиологического состояния рыб, их возраста, наличия кормовых объектов и других. Определенный вклад в миграционное поведение и успешность нереста может вносить и накопление поллютантов.

Именно в этом слое могут концентрироваться атмосферные выпадения и оседающие на минеральных и органических частицах взвеси поллютанты. На юге границей ареалов лососей являются $38-40^{\circ}$ с.ш. Эта зона соприкасается с районом так называемого Большого тихоокеанского мусорного пятна, расположенного между $140^{\circ}$ в.д. $-160^{\circ}$ з.д. и $35^{\circ}-42^{\circ}$ с.ш. На этом участке сконцентрированы залежи пластика и других отходов, принесенные водами Северо-Тихоокеанской системы течений. Фоторазложение пластика ведет к выделению в воду хлорорганических и полиароматических соединений, а также эстроген-подобных веществ, которые адсорбируются на частицах взвеси в эпипелагиали и могут аккумулироваться лососевыми рыбами [9, 10, 14].

\section{2. Биотранспорт CO3 в 2018 г.}

В 2018 году количество лососей в Дальневосточном рыбохозяйственном бассейне, пришедших на нерест, составило 677,2 тыс. т. Распределение лососей по районам представлено в таблице 7.7. Особенностью этого года является преимущественный подход лососей на западную Камчатку (Охотское море) и восточную Камчатку (Северо-западная часть Тихого океана). Высокие подходы отмечены также на Сахалине и континентальной части Охотского моря (Магаданская область). Еще одной особенностью 2018 года стало отсутствие лососей на нерестилищах Амура: при норме кеты 50 экземпляров на 100 м плотность составила от 0,07 до 0,12 на 100 м [1].

Лососи, мигрирующие на нерест, частично вылавливаются в путину, частично проходят на нерест в места нерестилищ в реках и озерах на побережье. Именно лососи, прошедшие на нерестилища, осуществляют перенос биогенов в малокормные нерестовые районы и, таким образом, свя- 
зывают океанические и наземные экосистемы. Оставшиеся после нереста тушки лососей служат пищей медведям и другим животным прибрежной зоны, а также разлагаются редуцентами и поступают в биогеохимический круговороты по всему побережью.

Таблица 7.7

\section{Заполнение нерестилищ лососями}

на российском побережье ДВ морей (тыс. экз.) в 2018 г.

\begin{tabular}{llll}
\hline Район & Нерка & Кета & Горбуша \\
\hline Западная часть Берингова моря & 450 & 2700 & 1000 \\
Восточная Камчатка & 686,1 & 696 & 41396 \\
Курильские о-ва & - & 307,5 & 1955,5 \\
Западная Камчатка & 2415 & 1184 & 112362 \\
Охотское море (Магаданская область) & - & 1430 & 8071 \\
Восточный Сахалин & - & 218,3 & 10287,9 \\
Приморье & - & 80 & 550 \\
Юго-Западный Сахалин & - & 294,5 & 10,6 \\
\hline
\end{tabular}

$-{ }^{1}$ нет данных

Известно, что наряду с питательными веществами, лососи аккумулируют в органах и загрязняющие вещества, в том числе стойкие органические загрязняющие вещества типа ХОП и ПХБ. Лососи захватывают их из морской среды в ходе миграций в открытом океане, где СО3 выпадают на поверхность вследствие ветрового переноса из районов применения в субтропических и тропических широтах $[3,11,13]$. СО3 способны накапливаться в органах рыб и оказывать различные негативные биологические эффекты, нарушая основные метаболические процессы и снижая успешность репродукции [17].

В 2018 г. пестициды и ПХБ определялись только в лососях, собранных вблизи устья р. Камчатка на восточном побережье п-ова Камчатка в северо-западной части Тихого океана. По нашим данным, среднее количество ХОП в мышцах нерки составляет 10,1 нг/г, в мышцах кеты - 2,5 нг/г, в мышцах горбуши - 4,0 нг/Г сырой массы. Средний вес одной особи нерки оставляет 2,2 кг, кеты - 2,8 кг, горбуши - 1,2 кг (по данным NPAFC 2018 г.). Следовательно, количество ХОП в одном экземпляре нерки составляет 22,2 мкг, кеты - 7 мкг, горбуши - 4,8 мкг.

Тогда общее количество ХОП, переносимых неркой к российскому побережью в 2018 г. (табл. 7.8) составляет 0,08 кг, кетой 0,05 кг., горбушей 0,084 кг. Всего три вида рыб переносят почти 1 кг ХОП. Наибольшее количество поступает на восточную и западную Камчатку. 
На основании общего содержания ХОП, найденном в рыбах, выловленных в те годы, в 2008 г. перенос составил 13 кг, 2009 - 35,5 кг, 2010 20 кг, 2011 - 19 кг, 2012 - 14 кг [4]. В 2018 г перенос составил всего 1 кг, и общее содержание ХОП в мышцах рыб было значительно ниже, чем в предыдущие годы. Это дает основание заключить, что снижение переноса ХОП лососями отражает общую тенденцию сокращения «пестицидного» фона на планете в целом, и в Тихом океане в частности, как следствие сокращения производства и применения пестицидов в большинстве стран в соответствии с решениями Стокгольмской конвенции [2].

Таблица 7.8

Общее количество пестицидов (кг), перенесенных лососями на российское побережье ДВ морей в 2018 г.

\begin{tabular}{lllll}
\hline Район & Нерка & Кета & Горбуша & Всего \\
\hline Западная часть Берингова моря & 0,010 & 0,019 & 0,005 & 0,034 \\
Восточная Камчатка & 0,015 & 0,005 & 0,199 & 0,219 \\
Курильские о-ва & - & 0,002 & 0,009 & 0,012 \\
Западная Камчатка & 0,054 & 0,008 & 0,539 & 0,601 \\
Охотское море (Магаданская область) & - & 0,010 & 0,039 & 0,049 \\
Восточный Сахалин & - & 0,002 & 0,049 & 0,051 \\
Приморье & - & 0,001 & 0,003 & 0,003 \\
Юго-Западный Сахалин & - & 0,002 & 0,000 & 0,002 \\
Всего & $\mathbf{0 , 0 8}$ & $\mathbf{0 , 0 5}$ & $\mathbf{0 , 8 4}$ & $\mathbf{0 , 9 7}$ \\
\hline \multicolumn{1}{c}{${ }^{1}$ нет данных } & & & &
\end{tabular}

В отличие от хлорорганических пестицидов полихлорированные бифенилы продолжают использоваться человеком и аккумулируются в биоте. Постоянное поступление ПХБ в морскую среду в различных районах связано с активностью судоходства. По нашим данным, среднее количество ПХБ в теле лососей выше, чем уровень ХОП (табл. 7.9).

Для нерки средняя концентрация составляет 18,4 мкг/кг сырой массы, кеты - 9,1 мкг/кг, горбуши - 86 мкг/кг. Распределение этих соединений между видами отличается от такового для ХОП, где наибольшая концентрация определена у нерки. В целом нерка приносит к российскому побережью 0,07 кг ПХБ, кета - 0,06 кг, горбуша - 15,1 кг.

Наибольшее количество поступает на восточную и западную Камчатку. Общее количество ПХБ, переносимое лососями к Российскому побережью, составляет 15,23 кг, что в 15 раз больше, чем ХОП. Содержание 
ПХБ в органах лососей дальневосточного бассейна и, соответственно, биотранспорт этих соединений ранее мы не измеряли, и представить долговременные изменения этих показателей не представляется возможным. Можно отметить, что у жилой формы нерки (кокани) из Толмачевского водохранилища на п-ове Камчатка содержание ПХБ в мышцах составляло от 23 до 43 нг/г липидов, что также подтверждает аккумуляцию ПХБ лососевыми в данном регионе [5].

Таблица 7.9

\section{Общее количество ПХБ (кг), перенесенных лососями} на российское побережье ДВ морей в 2018 г.

\begin{tabular}{lcccc}
\hline Район & Нерка & Кета & Горбуша & Всего \\
\hline Западная часть Берингова моря & 0,008 & 0,025 & 0,086 & 0,119 \\
Восточная Камчатка & 0,013 & 0,006 & 3,560 & 3,579 \\
Курильские о-ва & - & 0,003 & 0,168 & 0,171 \\
Западная Камчатка & 0,044 & 0,011 & 9,663 & 9,718 \\
Охотское море (Магаданская область) & - & 0,013 & 0,694 & 0,707 \\
Восточный Сахалин & - & 0,002 & 0,885 & 0,887 \\
Приморье & - & 0,001 & 0,047 & 0,048 \\
Юго-Западный Сахалин & - & 0,003 & 0,001 & 0,004 \\
Всего & $\mathbf{0 , 0 7}$ & $\mathbf{0 , 0 6}$ & $\mathbf{1 5 , 1 0}$ & $\mathbf{1 5 , 2 3}$ \\
\hline
\end{tabular}

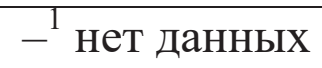

Наши результаты показывают (рис. 7.3), что присутствие ХОП и ПХБ в морской среде приводит к их неизбежной аккумуляции в биоте. Загрязнение прибрежных вод в последние годы значительно снизилось в связи с мерами по запрещению использования СО3 (на основании результатов определения поллютантов в лососях 2010 и 2018 гг.). Однако в открытом океане этот процесс выражен гораздо слабее [15]. Океан все еще остается конечным резервуаром, принимающим стойкие токсиканты, и биоаккумуляция СО3 в океане по пищевым цепям продолжается. Лососи являются удобным объектом для мониторинга циркуляции СО3 в биосфеpe. Органические поллютанты оказываются прочно встроенными в направленный транспорт биогенов, осуществляемый лососями и связывающий океанические и наземные экосистемы. Ежегодное попадание СО3 в районы нерестилищ и постоянное увеличение их концентрации в локальных зонах определяет возможность экологического риска для определенных популяций, успех нереста которых может быть снижен вследствие токсичности среды. 


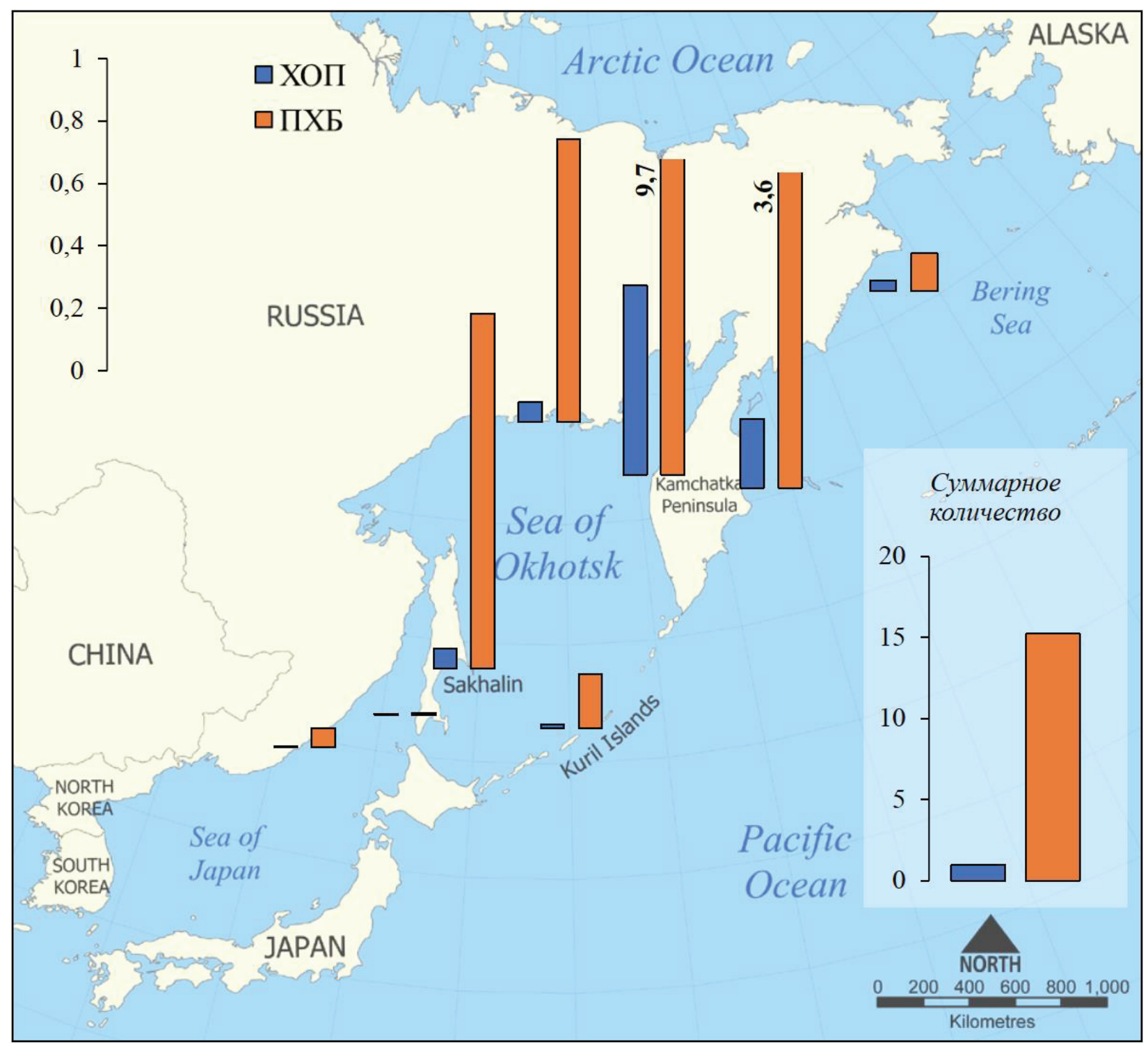

Рис. 7.3. Распределение ХОП и ПХБ (кг), перенесенных лососями, по основным районам нерестилищ на российском побережье дальневосточных морей за 2018 г.

\section{3. Список литературы}

1. Амур истощен: запас лососевых может не восстановиться [Электронный ресурс]. - WWF России, 2018. - Режим доступа: https://www.dvnovosti.ru/khab/2018/12/11/92182/.

2. Конвенция о принятии международных мер в отношении отдельных стойких органических загрязнителей. - Стокгольм, 2001. - 44 с. 
3. Лукьянова, О.Н. Биотранспорт пестицидов тихоокеанскими лососями в северо-западной Пацифике / О.Н. Лукьянова, В.Ю. Цыганков, М.Д. Боярова, Н.К. Христофорова // Доклады Академии наук. - 2014. Т. 456. - № 3. - С. 363-365.

4. Лукьянова, О.Н. Тихоокеанские лососи рода Oncorhynchus как вектор переноса стойких загрязняющих веществ в океане / О.Н. Лукьянова, В.Ю. Цыганков, М.Д. Боярова, Н.К. Христофорова // Вопросы ихтиологии. - 2015. - Т. 55. - № 3. - С. 351-355.

5. Мамонтова, Е.А. Хлорорганические пестициды и полихлорированные бифенилы в тканях жилой формы нерки Толмачевского водохранилища, п-ов Камчатка / Е.А. Мамонтова, Е.В. Лепская, Е.Н. Тарасова [и др.]. // Биология внутренних вод. - 2018. - № 2. - С. 76-83.

6. Шунтов, В.П. Тихоокеанские лососи в морских и океанических экосистемах / В.П. Шунтов, О.С. Темных. - Владивосток: ТИНРО-Центр, 2008. - T. 1. -481 c.

7. Шунтов, В.П. Тихоокеанские лососи в морских и океанических экосистемах / В.П. Шунтов, О.С. Темных. - Владивосток: ТИНРО-Центр, 2011. - T. 2. -473 c.

8. Cederholm, C.J. Pacific salmon carcasses: essential contributions of nutrients and energy for aquatic and terrestrial ecosystems / C.J. Cederholm, M.D. Kunz, T. Murota, A. Sibatanim // Fisheries. - 1999. - V. 24. - P. 6-15.

9. Choy, C.A. Plastic for dinner? Observation of frequent debris ingestion by pelagic predatory fishes from the central North Pacific / C.A. Choy, J.C. Drazen // Marine Ecology Progress Series. - 2013. - V. 485. - P. 155-153.

10. Derraik, J.G.B. The pollution of the marine environment by plastic debris: a review / J.G.B. Derraik // Marine Pollution Bulletin. - 2002. - V. 44. P. 842-852.

11. Ewald, G. Biotransport of organic pollutants to an Inland Alaska Lake by migrating Sockeye Salmon (Oncorhynchus nerka) / G. Ewald, P. Larsson, H. Linge [et al.] // Arctic. - 1998. - V. 51. - No. 1. - P. 40-47.

12. Helfield, J.M. Effects of salmon-derived nitrogen on riparian forest growth and implications for stream productivity / J.M. Helfield, R.J. Naiman // Ecology. - 2001. - V. 82. - P. 2403-2409.

13. Krummel, E.M. Delivery of pollutants by spawning salmon / E.M. Krummel, R.W. Macdonald, L.E. Kimpe [et al.] // Nature. - 2003. V. 425. - P. 255-256. 
14. Moore, C. A comparison of plastic and plankton in the North Pacific Central Gyre / C. Moore, S.L. Moore, M.K. Leecaster, S.B. Weisberg // Marine Pollution Bulletin. - 2001. - V. 42. - No. 12. - P. 1297-1300.

15. Tanabe, S. Contamination by Persistent Toxic Substances in the Asia-Pacific Region / S. Tanabe // Persistent Organic Pollutants in Asia: Sources, Distributions, Transport and Fate. - A. Li, S. Tanabe, G. Jiang, J.P. Giesy and P.K.S. Lam (Editors). - Developments in Environmental Science. - 2007. - V. 7. - P. 773-817.

16. Veldhoen, N. Gene expression profiling and environmental contaminant assessment of migrating Pacific salmon in the Fraser River watershed of British Columbia / N. Veldhoen, M. Ikonomou, C. Dubetzb [et al.] // Aquatic Toxicology. - 2010. - V. 97. - P. 212-225.

17. Wong, M.H. Persistent toxic substances: sources, fates and effects / M.H. Wong, M.A. Armour, R. Naidu, M. Man // Reviews on Environmental Health. - 2012. - V. 27. - No. 4. - P. 207-213. 


\title{
ГЛАВА 8
}

\section{ХЛОРОРГАНИЧЕСКИЕ ПЕСТИЦИДЫ (ХОП) В МОРСКИХ ПТИЦАХ И МЛЕКОПИТАЮЩИХ ОХОТСКОГО И БЕРИНГОВА МОРЕЙ}

\author{
В.Ю. Цыганков ${ }^{1,2}$, М.Д. Боярова ${ }^{1}$, М.М. Донещ, \\ Н.К. Христофорова ${ }^{2}$
}

В главе приведены результаты определения изомеров ГХЦГ, ДДТ и его метаболитов в органах морских птиц (Larus schistisagus, Aethia cristatella, Aethia pusilla, Fulmarus glacialis, Oceanodroma furcata) и морских млекопитающих (Eschrichtius robustus, Odobenus rosmarus divergens) из Охотского и Берингова морей. Показано, что видовые особенности аккумуля-

${ }^{1}$ Школа биомедицины, Дальневосточный федеральный университет (ДВФУ), 690922, Владивосток, о. Русский, п. Аякс, 10. E-mail: tsig_90@mail.ru.

${ }^{2}$ Школа естественных наук, Дальневосточный федеральный университет (ДВФУ), 690922, Владивосток, о. Русский, п. Аякс, 10.

${ }^{1}$ School of Biomedicine, Far Eastern Federal University, 10 Ajax Bay, Russky Island Vladivostok, Russia,690922.E-mail: tsig_90@mail.ru.

${ }^{2}$ School of School of Natural Sciences, Far Eastern Federal University, 10 Ajax Bay, Russky Island Vladivostok, Russia, 690922.

Для ичитирования: Цыганков В.Ю., Боярова М.Д., Донец М.М., Христофорова Н.К. Хлорорганические пестициды (ХОП) в морских птицах и млекопитающих Охотского и Берингова морей // Стойкие органические загрязняющие вещества (CO3) в Дальневосточном регионе: моря, организмы, человек : монография / В.Ю. Цыганков, М.М. Донец, Н.К. Христофорова [и др.] ; науч. ред. В.Ю. Цыганков. - Владивосток : Изд-во Дальневост. федерал. ун-та, 2020. - С. 211-233. https://doi.org/10.24866/7444-4891-2/211-233.

For citing: Tsygankov V.Yu., Boyarova M.D., Donets M.M., Khristoforova N.K. Organochlorine pesticides (OCPs) in seabirds and marine mammals of the Sea of Okhotsk and the Bering sea // Persistent organic pollutants (POPs) in the Far Eastern Region: Seas, Organisms, Human: monograph / V.Yu. Tsygankov, M.M. Donets, N.K. Khristoforova [et al.] ; ed. by V.Yu. Tsygankov. - Vladivostok : Publishing House of the Far Eastern Federal University, 2020. - P. 211-233. - https://doi.org/10.24866/7444-4891-2/211-233. 
ции липофильных ксенобиотиков в значительной степени обусловлены характером пищи и общим содержанием жира в органах.

Ключевые слова: ГХЦГ; ДДТ; морские птицы; морские млекопитающие; Охотское море; Берингово море.

\title{
CHAPTER 8. ORGANOCHLORINE PESTICIDES (OCPS) IN SEABIRDS AND MARINE MAMMALS FROM THE SEA OF OKHOTSK AND THE BERING SEA
}

\author{
V.Yu. Tsygankov ${ }^{1,2}$, M.D. Boyarova ${ }^{1}$, M.M. Donets ${ }^{1}$, \\ N.K. Khristoforova ${ }^{1,3}$
}

In this chapter, research results of $\mathrm{HCH}$ isomers, DDT and its metabolites in the organs of seabirds (Larus schistisagus, Aethia cristatella, Aethia pusilla, Fulmarus glacialis, Oceanodroma furcata) and marine mammals (Eschrichtius robustus, Odobenus rosmarus divergens), which collected in the Sea of Okhotsk and the Bering Sea, are presented. The specific features in the accumulation of lipophilic xenobiotics are associated with the nutritional factor and the total fat content in individual organs.

Keywords: HCHs; DDTs; seabirds; marine mammals; the Sea of Okhotsk; the Bering Sea.

На рубеже 1960-70 гг. в разных регионах мира наблюдалась массовая гибель популяций диких птиц. Одной из ее причин оказалось применение стойких органических загрязняющих веществ (СО3), в частности, хлорорганических пестицидов (ХОП). Их широко использовали в качестве инсектицидов для борьбы с переносчиками малярии, в сельском и коммунальном хозяйстве. Эти антропогенные вещества, являясь липофильными соединениями, способны накапливаться в объектах окружающей среды и оказывать негативное влияние на живые организмы. В результате отравле- 
ния эндрином погибли куропатки и фазаны; дильдрином - белоголовые орланы и гуси; ДДТ (дихлордифенилтрихлорэтан) - бакланы, пеликаны и чайки; линданом (ГХЦГ - гексахлорциклогексан) - скворцы $[3,10]$.

После запрета использования и производства ряда пестицидов гибель птиц значительно снизилась, но случаи отравления продолжались. Оказалось, что на территориях, загрязненных ХОП, птицы особенно чувствительны к другим группам химических и биологических повреждающих агентов. Так, присутствие ДДЕ (дихлордифенилдихлорэтилен) маскирует эффект отрицательного воздействия ртути на размножение птиц [3, 6].

Летальные дозы пестицидов видоспецифичны и находятся в диапазоне от 4 (для желтушника и японского перепела) до 65 мг/кг (для воробьев). В ряде экспериментов были выявлены критические концентрации ХОП в мозге птиц [23].

В Великобритании впервые была отмечена корреляция между истончением яичной скорлупы и ухудшением воспроизводства в популяциях сокола-сапсана и ястреба-перепелятника в местах использования стойких хлорорганических инсектицидов. Толщина скорлупы уменьшилась к концу 1960-х гг., по сравнению с 1940 г., у 9 из 17 исследованных особей на 5-19\% [15]. Исследования в США и Канаде также выявили степень истончения скорлупы яиц: толщина и вес скорлупы у многих видов птиц уменьшились на 20\% [22, 23].

Птицы широко используются как биоиндикаторы для мониторинга загрязнения окружающей среды хлорорганическими поллютантами. Птицы могут быть как промежуточным, так и завершающим звеном трофической цепи. Питаясь живыми организмами, за счет биомагнификации они накапливают в своих органах более высокие концентрации токсичных веществ [25]. В зависимости от типа питания (фитофаги, планктонофаги, рыбоядные и др.) и характера миграций (перелетные и локальные) в органах и тканях птиц меняется и содержание СО3. В отсутствие локальных источников загрязнения, аккумуляция СО3 свидетельствует о глобальном загрязнении в результате трансграничного атмосферного переноса и транспорта поллютантов морскими течениями $[12,15]$.

Среди исследователей, занимающихся проблемами глобального загрязнения природной среды и влиянием этого процесса на животный мир, давно утвердилось мнение об Арктике как регионе-мишени. Своих источников антропогенного загрязнения Арктика практически не имеет, но она 
подвержена постоянному воздействию мощных переносов из более южных широт. Различные поллютанты воздушным или водным путем, а также за счет миграции организмов (так называемый «биотранспорт») легко достигают арктического региона, быстро включаясь в обмен веществом и энергией, оказывают негативное воздействие на экосистемы и их обитателей, в том числе млекопитающих [2, 5, 18, 22, 28, 29, 30].

Морских млекопитающих можно считать удобными видами для долгосрочного мониторинга загрязнения морской среды СОЗ. Они могут использоваться как индикаторы глобального загрязнения, так и биомониторы временных трендов в изменении загрязнения биосферы [26, 27].

\section{1. Морские птицы}

Нами исследован 41 образец органов пяти видов морских птиц - тихоокеанской чайки (Larus schistisagus), большой конюги (Aethia cristatella), конюги-крошки (Aethia pusilla), глупыша (Fulmarus glacialis) (белой и темной морфы), серой качурки (Oceanodroma furcata), собранных в июне и октябре 2012 г. в Охотском море с побережья Западной Камчатки и Курильских островов. В зависимости от размера птиц исследованы разные органы: перо, перо с кожей, мышцы, печень, тушки целиком (внутренние органы с перьями).

Пестициды обнаружены во всех образцах. Общее содержание в различных органах варьировало от 28 до 16095 нг/г липидов. В перьях диапазон значений составил 28-8289 нг/Г, в перьях с кожей - 1567-16095 нг/Г, в печени - 1679-2478 нг/г, в мышцах - 2230-3000 нг/г, в гомогенате органов - 12,5-15112 нг/г. Средние суммарные концентрации пестицидов в отдельных органах приведены на рисунке 8.1.

ДДТ обнаружен только в перьях глупышей, пойманных в июне, в пределах 975-1978 нг/г. ДДЕ присутствовал во всех образцах от 27 до 15276 нг/г. ДДД в пробах не был обнаружен вовсе.

$\gamma$-ГХЦГ обнаружен только в некоторых пробах: в перьях и перьях с кожей июньских глупышей - 177-467нг/г; в печени тихоокеанской чайки

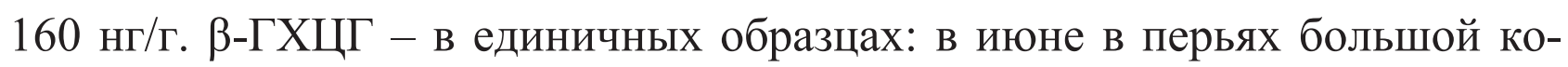


нюги, тушке крошечной конюги; в октябре в печени глупыша. Концентрация $\beta$-ГХЦГ составляла 555-1151 нг/г. $\alpha$-ГХЦГ найден практически во всех образцах в диапазоне от 160 до 3024 нг/г, за исключением глупыша, пойманного в октябре (отсутствует у одной особи в перьях, у другой присутствует только в мышцах) и тихоокеанской чайки (ниже пределов обнаружения в перьях одной особи). Среднее значение суммарной концентрации ХОП в июне (6580 нг/г) почти в 2 раза выше, чем в октябре (3442 нг/г).
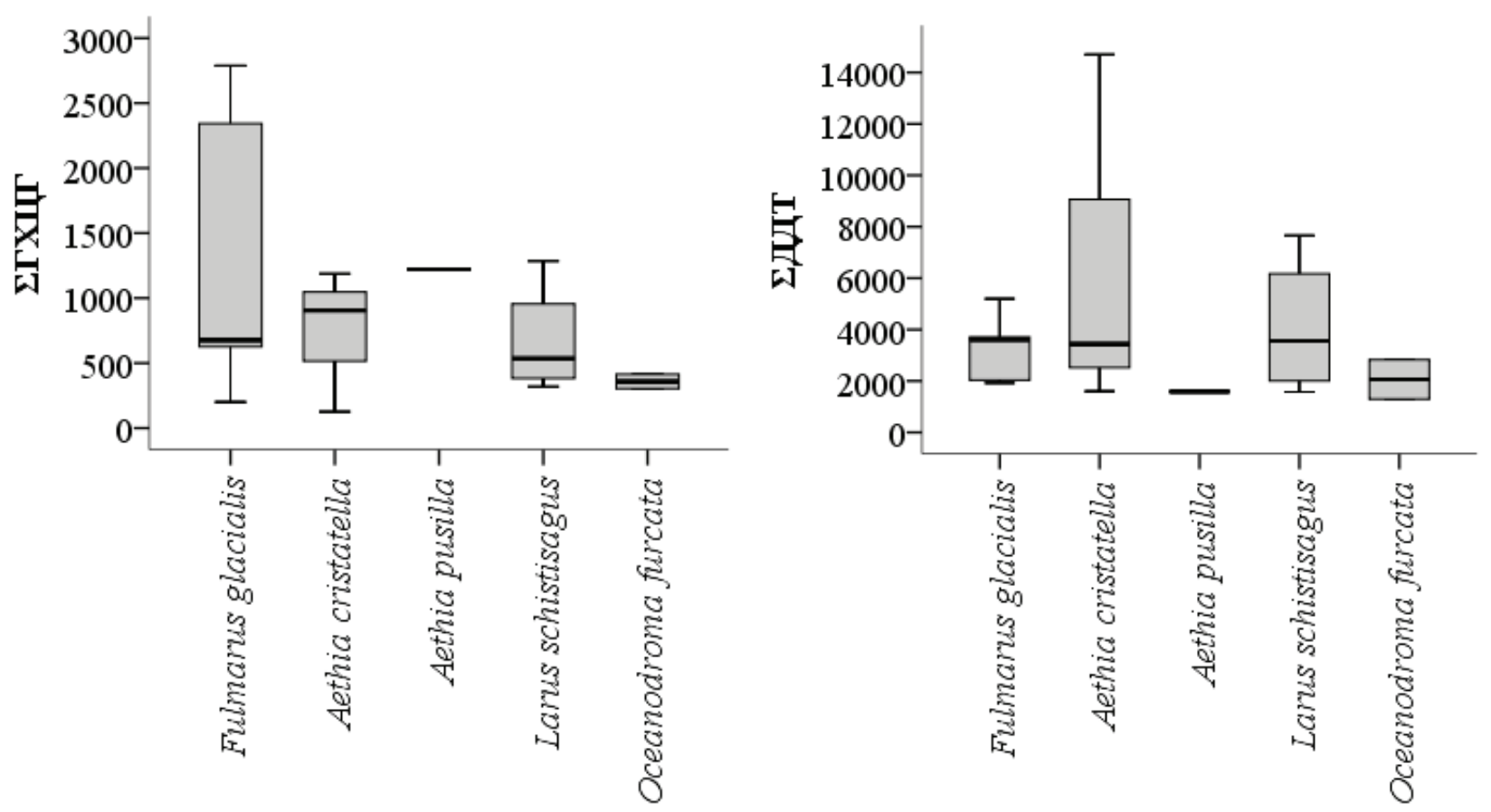

Puc. 8.1. Средняя концентрация (медиана) изомеров ГХЦГ, ДДТ и его метаболитов в органах и тканях птиц, нг/Г липидов

Tихоокеанская чайка Larus schistisagus. Суммарное содержание ХОП во всех органах тихоокеанской чайки находилось в пределах 156710357 нг/Г липидов. Концентрации $\alpha$-ГХЦГ варьировали от 200 до 2017 нг/г, количество $\beta$-ГХЦГ было ниже пределов обнаружения, $\gamma$-ГХЦГ найден в печени у одной из двух особей, где концентрация составила 160 нг/г, коэффициент $\alpha / \gamma-Г Х Ц Г ~-2,7$, что говорит о длительной циркуляции изомеров ГХЦГ в морской среде. Концентрации ДДТ и ДДД были ниже пределов обнаружения, содержание ДДЕ находилось в пределах от 1016 до 8339 нг/г.

Глуnыш Fulmarus glacialis. Диапазон суммарных концентраций ХОП - от 28 до 8135 нг/г липидов. Сумма изомеров ГХЦГ - от 200 до 
3040нг/г: $\alpha$-ГХЦГ - от 200 до 3024 нг/г; $\beta$-ГХЦГ обнаружен в одной из пяти птиц в печени, концентрация составила 555 нг/г; $\gamma$-ГХЦГ обнаружен в трех из пяти особей в перьях и перьях с кожей в пределах от 177 до 467 нг/г. Во всех пробах, где был обнаружен $\gamma$-ГХЦГ, коэффициент $\alpha / \gamma-$ ГХЦГ был выше 1.

Диапазон значений суммы ДДТ и его метаболитов варьировал от 28 до 5625 нг/г липидов: ДДТ найден у трех особей в перьях, диапазон 1440-1978 нг/Г липидов; ДДД - ниже предела обнаружения; ДДЕ варьировал от 28 до 5608 нг/г липидов. Отношение средних концентраций ДДТ и ДДЕ меньше 1, что показывает на «свежее» поступление ДДТ в морскую среду и организм птиц.

Больщая конюга Aethia cristatella. Минимальная суммарная концентрация ХОП составила 1842, максимальная - 16095 нг/г липидов. Диапазон суммарных значений ГХЦГ лежал в пределах 160-2214 нг/Г, $\alpha$-изомера - от 160 до 1062 нг/г. $\beta$-ГХЦГ обнаружен в одной из двух особей в перьях, концентрация составила 115 нг/г, $\gamma$-ГХЦГ - ниже предела обнаружения. ДДТ и ДДД - также ниже пределов обнаружения, диапазон ДДЕ - от 1604 до15276 нг/г.

Конюга-крошка Aethia pusilla. Сумма ХОП лежала в пределах от 2247 до 3499 нг/г. Суммарная концентрация изомеров ГХЦГ варьировала

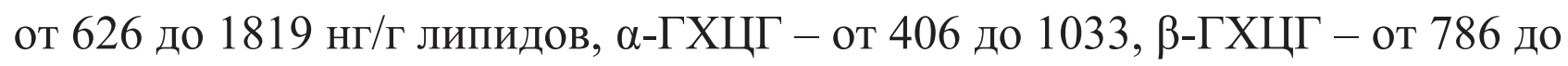
810 нг/г, $\gamma$-ГХЦГ не обнаружен. ДДТ и ДДД - ниже пределов обнаружения, ДДЕ варьирует от 1450 до 1679 нг/г.

Серая качурка Oceanodroma furcata. Исследована одна особь. Диапазон концентраций суммы ХОП - от 1705 до 3128 нг/г. Из изомеров ГХЦГ обнаружен только $\alpha$-изомер - от 303 до 415 нг/г. ДДТ и ДДД - ниже пределов обнаружения, ДДЕ варьирует от 1290 до 2825 нг/г.

Общее содержание пестицидов в тушке (органы и ткани) птиц. Максимальное значение ХОП отмечено у глупышей (5816 нг/г), минимальное - у серой качурки (1705 нг/г). Для ДДТ и его метаболитов выявлена схожая закономерность - максимальные уровни у глупышей (5608 нг/г), минимальные - у серой качурки (1209 нг/г). Наибольшее содержание изомеров ГХЦГ обнаружено у крошечной конюги (1819 нг/Г), наименьшее - у глупыша (208 нг/Г липидов). Средние концентрации ГХЦГ и ДДТ в отдельных органах представлены на рисунке 8.2. 

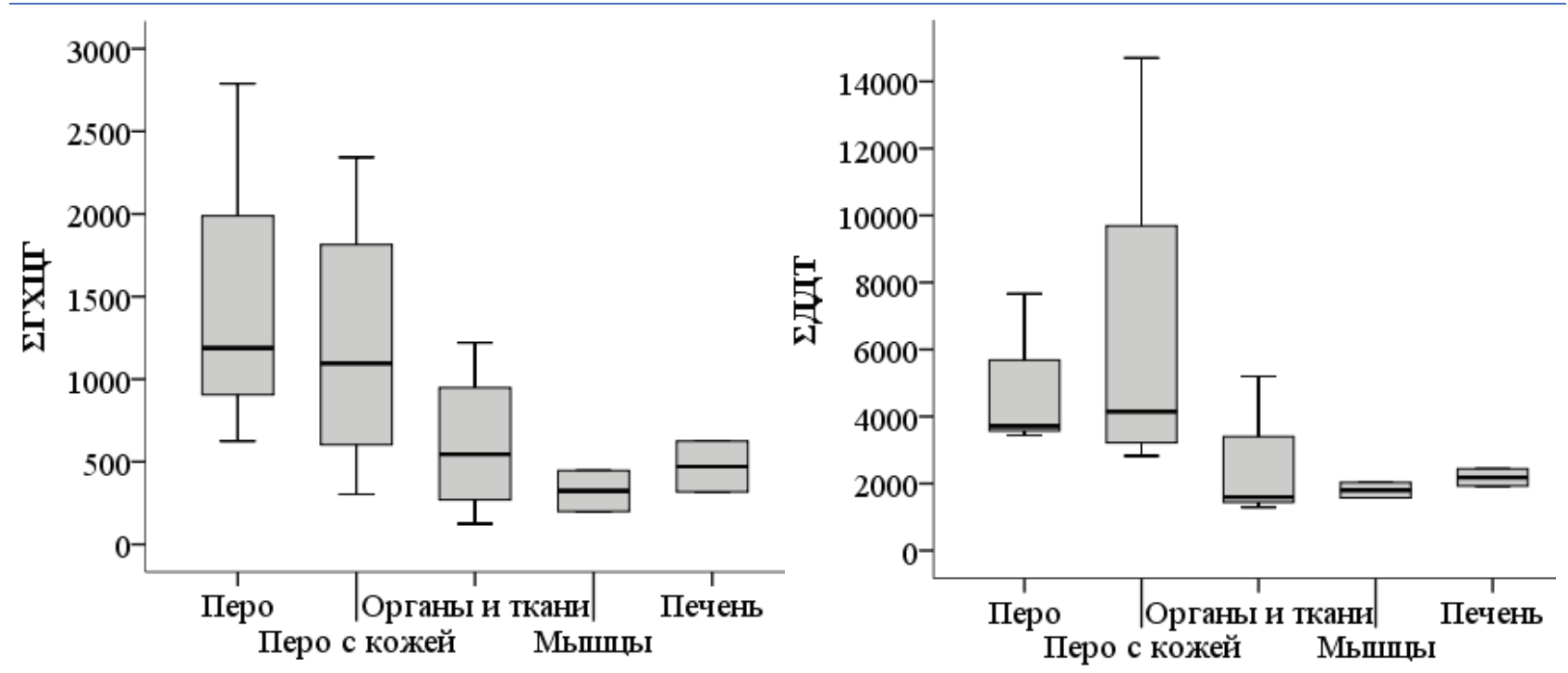

Puс. 8.2. Среднее содержание (медиана) изомеров ГХЦГ, ДДТ и его метаболитов в органах морских птиц, нг/г липидов

Содержание пестицидов в перьях. Самая высокая суммарная концентрация ХОП выявлена в перьях у тихоокеанской чайки (8289 нг/г липидов). У трех глупышей, добытых в июне, концентрации были высокие и близкие $(7119,7916$ и 8135 нг/г липидов), но в октябре концентрация ХОП у них резко снижалась (всего 28 нг/г). Наиболее высокая суммарная концентрация Д ДЕ (единственного выявленного метаболита ДДТ) обнаружена также у тихоокеанской чайки (766 нг/г), наименьшая - у глупыша, добытого в октябре (28 нг/г). Сумма изомеров ГХЦГ достигает максимальной величины у глупышей, добытых в июне (3040 нг/г), минимальной - у большой конюги $(160$ нг/г).

Содержание пестицидов в перьях с кожей. Максимальное суммарное количество ХОП и метаболитов ДДТ обнаружено у большой конюги (16095 и 15276 нг/г, соответственно), минимальное - у тихоокеанской чайки (1567 и 1016 нг/г соответственно). Наибольшее суммарное содержание изомеров ГХЦГ выявлено у глупыша (3047 нг/г), минимальное - у серой качурки (303 нг/г липидов).

ХОП в печени и мышцах определены у двух видов птиц, собранных в октябре: глупыш и тихоокеанская чайка.

Содержание пестицидов в печени. В печени глупыша суммарные количества ХОП (2478 нг/г) и метаболитов ДДТ (1923 нг/г) превышали таковые у чайки (1679 и 1376 нг/г соответственно). Максимальное содержание изомеров ГХЦГ обнаружено в печени тихоокеанской чайки (590 нг/г). 
Содержание пестицидов в мышцах. В мышцах тихоокеанской чайки суммарные количества ХОП (3000 нг/г) и метаболитов ДДТ (2775 нг/г) были выше, чем у глупыша (2230 и 2030 нг/г, соответственно). Сумма изомеров ГХЦГ (410 нг/г) была также выше, чем у глупыша (200 нг/г).

Исследованные виды птиц различаются размерами, образом жизни, и количеством подкожного жира. Известно, что ХОП концентрируются преимущественно в подкожном жире, поэтому у более крупных птиц содержание ХОП больше. Тихоокеанская чайка (средняя длина тела - 64 см) и глупыш (47 см) в перьях с кожей имеют сходные концентрации ХОП (5962 и 5949 нг/г, соответственно). В качурке (22 см), которая значительно меньше этих видов птиц, содержание пестицидов составило 3128 нг/г. Однако накопление и распределение пестицидов в органах птиц может регулироваться и другими дополнительными факторами. Например, у большой конюги размером 26 см, содержание ХОП в перьях с кожей достигало 15604 нг/г. Выяснение причины таких высоких концентраций ХОП у этого вида требует дальнейших исследований.

На содержании пестицидов во внутренних органах птиц отражается и спектр питания. К кормовым объектам глупыша относятся организмы, имеющие высокий коэффициент накопления ХОП (рыбы, икра рыб, моллюски, ракообразные и другие беспозвоночные, падаль, внутренности китов, различные жирные отбросы и т.д.), следствием чего является высокое содержание пестицидов в тушке птиц (5874 нг/г). Большая конюга, конюга-крошка и качурка питаются мелкими ракообразными, морскими беспозвоночными, амфиподами и др., которые аккумулируют пестициды в меньшей степени, чем кормовые объекты глупыша. Отражением этого является и меньшее содержание ХОП во внутренних органах этих видов: 1730, 2804 и 1705 нг/г липидов, соответственно.

Данные об уровнях содержания ГХЦГ и ДДТ в птицах из Охотского моря и других районов Мирового океана представлены в таблице 8.1.

Общее содержание ХОП в тихоокеанской чайке, серой качурке, крошечной конюге из Охотского моря выше, чем в люрике (Alle alle), толстоклювой кайре (Uria lomvia), обыкновенной моевке (Rissa tridactyla) и обыкновенном чистике (Cepphus grylle) из моря Баффина, и ниже, чем в глупыше (Fulmarus glacialis) из моря Баффина, клуше (Larus fuscus) и морской чайке (Larus marinus) из Исландии, бургомистре (Larus hyperboreus) из моря Баффина, белой чайке (Pagophila eburnea) и большом 
поморнике (Stercorarius skua) из Исландии и бургомистре (Larus hyperboreus) из Баренцева моря.

Таблища 8.1

\section{Суммарное содержание хлорорганических пестицидов (ДДТ и ГХЦГ) в морских птицах из различных районов мирового океана, нг/г липидов}

\begin{tabular}{lllll}
\hline Вид & Район & $\sum$ ДДТ & $\sum$ ГХЦГ & Источник \\
\hline Люрик (Alle alle) & Северный & 571,4 & 233,9 & {$[6]$} \\
Толстоклювая кайра (Uria lomvia) & Ледовитый & 1096,7 & 84,3 & \\
Обыкновенный чистик (Cepphus grylle) & океан, море & 1003,3 & 268,3 & \\
Обыкновенная моевка (Rissa tridactyla) & Баффина & 1277,1 & 45,3 & \\
Белая чайка (Pagophila eburnea) & & 7049,3 & 138,1 & \\
Бургомистр (Larus hyperboreus) & & 5956,1 & 449,2 & \\
Глупыш (Fulmarus glacialis) & & 4870,7 & 62,9 & \\
Морская чайка (Larus marinus) & Исландия & 3420 & 0 & [10] \\
Клуша (Larus fuscus) & & 3370 & 36,7 & \\
Большой поморник(Stercorrius skua) & & 54200 & 1400 & \\
Бургомистр (Larus hyperboreus) & Баренцево & 215109 & 1038 & [12] \\
& море & & & \\
Глупыш (Fulmarus glacialis) & Охотское & 3335,3 & 1630,47 & Настоящая \\
Большая конюга (Aethia cristatella) & море & 7575,36 & 884,78 & работа \\
Тихоокеанская чайка & & 3576,41 & 674,66 & \\
(Larus schistisagus) & & & & \\
Серая качурка (Oceanodroma furcata) & & 2017,05 & 377,1 & \\
Конюга-крошка (Aethia pusilla) & & 1583,5 & 1220,97 & \\
\hline
\end{tabular}

В органах и тканях большой конюги общий уровень ХОП ниже, чем у большого поморника из Исландии и бургомистра из Баренцева моря. У глупыша из Охотского моря сумма ХОП выше, чем у глупыша из моря Баффина, но ниже, чем у других птиц из моря Баффина.

Суммарное содержание метаболитов ДДТ у глупыша, тихоокеанской чайки, серой качурки, крошечной конюги, из Охотского моря выше, чем у люрика, толстоклювой кайры, обыкновенной моевки, обыкновенного чистика из моря Баффина, и ниже, чем у глупыша из моря Баффина, клуши из Исландии, морской чайки из Исландии, бургомистра из моря Баффина, белой чайки из Исландии, большого поморника из Исландии, бургомистра из Баренцева Моря. У всех исследованных птиц сумма метаболитов ДДТ ниже, чем у большого поморника из Исландии и бургомистра из Баренцева Моря. 
Концентрация сумм изомеров ГХЦГ у серой качурки выше, чем у обыкновенной моевки, глупыша, клуши, толстоклювой кайры, белой чайки, люрика, обыкновенного чистика и ниже остальных видов. У тихоокеанской чайки и большой конюги из Охотского моря сумма изомеров ГХЦГ выше, чем у обыкновенной моевки, глупыша, клуши, толстоклювой кайры, люрика, белой чайки, обыкновенного чистика, бургомистра из моря Баффина, и ниже, чем у остальных видов. У крошечной конюги из Охотского моря сумма изомеров ГХЦГ выше, чем у поморника из Исландии и ниже остальных видов. У глупыша из Охотского моря сумма изомеров ГХЦГ выше, чем у всех видов.

Во всех исследованных образцах и в данных, приведенных различными авторами (табл. 8.1) прослеживается общая закономерность - сумма изомеров ГХЦГ ниже сумм метаболитов ДДТ.

Все исследованные птицы являются, в основном, оседлыми видами, соответственно, уровень биоаккумуляции хлорорганических соединений птицами Охотского моря отражает уровень загрязнения данного региона. Приведенные в табл. 8.1 виды собраны в сходных широтах Северного полушария. Диапазон концентраций у всех птиц практически сходен, что указывает на близкую загрязненность морской среды в этих широтах.

Видовые особенности в аккумуляции ХОП в первую очередь могут быть связаны с типом питания. Например, бургомистр из Баренцева моря, питающийся рыбой, падалью, мелкими млекопитающими и яйцами других птиц, содержит в своем теле 216157 нг ХОП/Г липидов [12]. Яйца птиц богаты жиром, необходимым для развития эмбриона, соответственно, содержат высокие концентрации ХОП, так как в процессе овогенеза все токсичные вещества вместе с жиром из самки попадают в яйцо, которое может стать пищей других птиц $[16,19]$. Яйца и отдельно скорлупа птиц часто используются как индикаторы загрязнения ХОП, вследствие максимальной аккумуляции пестицидов по сравнению с другими морскими организмами [23].

Большой поморник, пища которого состоит главным образом из рыбы, которую он отнимает у других птиц, накапливает поллютантов до 55600 нг/г [10]. Рыбы, как правило, содержат в своем теле меньше пестицидов, в отличие от птиц и млекопитающих, так как являются невысоким звеном пищевой цепи, соответственно, содержание ХОП в поморнике значительно ниже, чем в бургомистре [44]. 
Обитатели моря Баффина (Северный Ледовитый океан) накапливают меньшее количество ХОП, за счет своей удаленности от потенциальных источников загрязнения. Например, глупыш, который питается ракообразными, рыбой, кальмарами, планктоном, при случае - падалью, содержит токсикантов 4933,5 нг/г [6].

Аккумуляция пестицидов у птиц влияет на различные стороны их физиологии, например, вызывает серьезное ухудшение репродуктивной функции и истончение скорлупы яиц, что приводит к нарушению эмбрионального развития и потере потомства [23]. Разный уровень аккумуляции ХОП у отдельных видов отражает различную степень загрязнения районов обитания. Видовые особенности в аккумуляции липофильных ксенобиотиков в немалой степени обусловлены как спектром питания, так и общим содержанием жира в отдельных органах. Обнаружение заметных концентраций ХОП в морских птицах Охотского моря, изолированного от активной сельскохозяйственной деятельности, служит свидетельством общего глобального фона СО3, сформировавшегося на планете в настоящее время.

\section{2. Морские млекопитающие}

Исследованы образцы органов (мышцы и печень) семи особей серого кита, добытых в сентябре 2010 г., и восьми особей тихоокеанского моржа, добытых в сентябре 2011 г. в прибрежных водах п. Лорино (Мечигменский залив, Чукотский автономный округ, Берингово море) местными охотниками-китобоями.

Международная китобойная комиссия (International Whaling Commission - IWC) предоставила исключительное право добывать серого кита чукотско-калифорнийской популяции коренным жителям Чукотки (Россия) и Аляски (США) для удовлетворения традиционных потребностей и поддержания традиционного уклада жизни. 


\subsection{1. Серый кит (Eschrichtius robustus)}

Пестициды обнаружены во всех пробах. Диапазон концентраций ХОП в органах кита был широким. Концентрации в печени значительно выше, чем в мышцах (рис. 8.3). Вероятно, это связано с детоксицирующими свойствами печени, в которой происходит основная деградация токсикантов в организме.
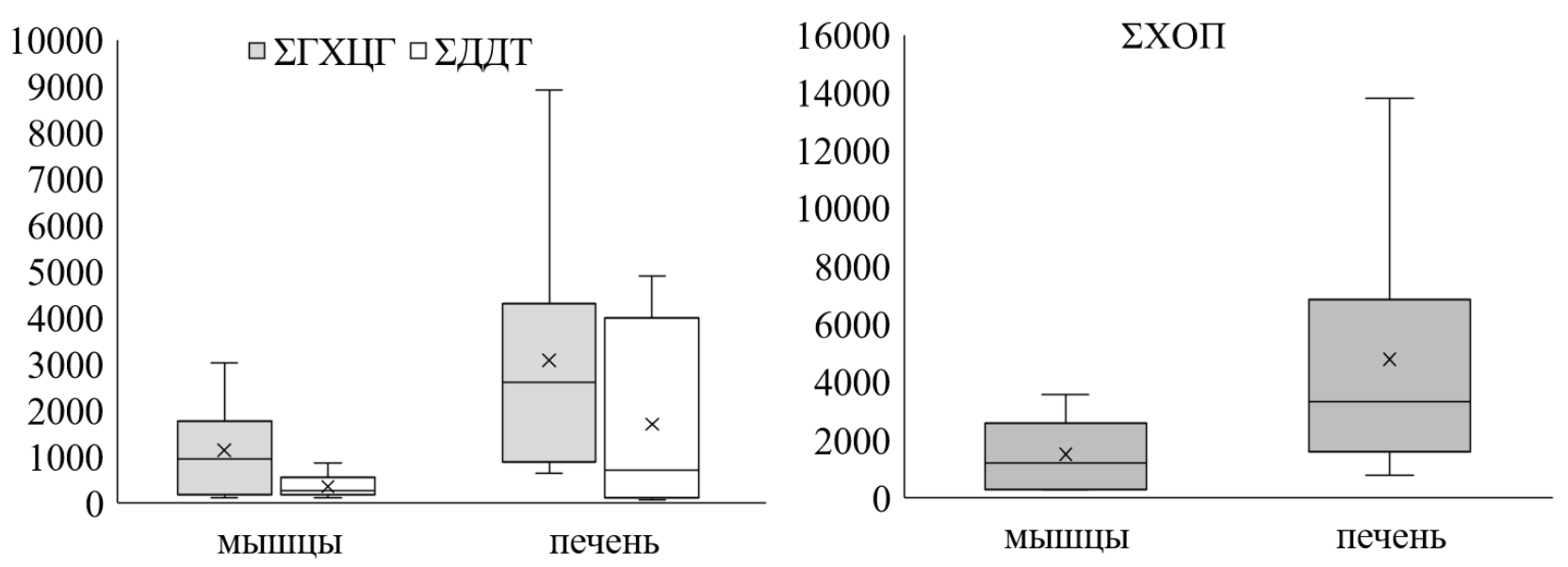

Puc. 8.3. Суммарное содержание ГХЦГ, ДДТ и ХОП в мышцах и печени серого кита, нг/Г липидов

В целом, мы наблюдаем тенденцию увеличения содержания поллютантов в мышцах и печени у более крупных особей по сравнению с особями меньшего размера (рис. 8.4). Эта же зависимость наблюдается и с увеличением возраста, так как млекопитающие накапливают токсиканты в течение всей жизни.

У самок тенденция к увеличению концентрации пестицидов наблюдается до наступления половой зрелости. После наступления репродуктивного возраста концентрации ХОП выходят на плато или даже уменьшаются [8]. Серые киты достигают половой зрелости в возрасте 5-10 лет, в среднем 8 лет [1]. Исследованные нами образцы органов и тканей были взяты у неполовозрелых самок, поэтому мы наблюдали только увеличение концентрации ХОП с возрастом.

Концентрация пестицидов в мышцах находилась в диапазоне 2973581 нг/г липидов, в печени - 769-13808 нг/г липидов (табл. 8.2 и рис. 8.5).

Статистически достоверных половых различий в содержании ГХЦГ и ДДТ в мышцах не обнаружено, однако имеется тенденция к увеличению концентрации ксенобиотиков в самцах (кроме ДДТ и ДДД, которые не 
обнаружены). В печени самцов, по сравнению с самками, достоверно выше только концентрация $\alpha$-ГХЦГ ( $\mathrm{p}=0,05)$, однако, как можно видеть, концентрация всех остальных ксенобиотиков увеличивается в самцах. Низкая статистическая достоверность полученных результатов, вероятно, связана с малым количеством выборок.
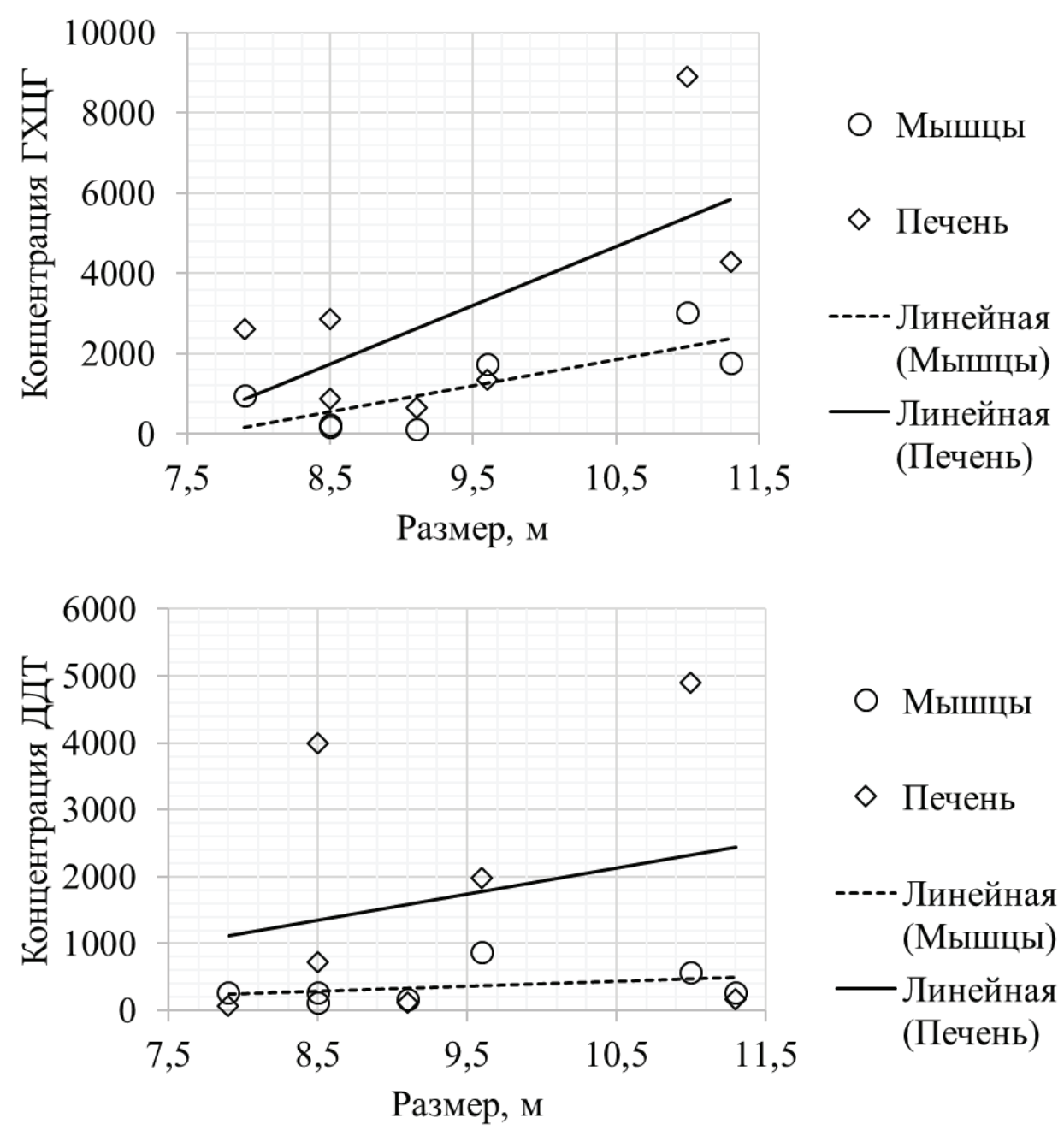

Puc. 8.4. Зависимость концентрации ГХЦГ и ДДТ в органах серого кита от размера тела

Общее содержание различных хлорорганических пестицидов в мышцах и печени серого кита показано в таблице 8.2.

Статистически достоверные различия между мышцами и печенью обнаружены только $\beta$-ГХЦГ ( $\mathrm{p}=0,002)$. Что касается других загрязняющих веществ, то ДДТ и его метаболиты имеют тенденцию к увеличению в печени, ГХЦГ - в мышцах. 
Таблица 8.2

Средние (числитель) и диапазоны (знаменатель) концентрации ХОП в органах серого кита, нг/г липидов

\begin{tabular}{|c|c|c|c|c|c|c|}
\hline Органы & $\alpha-\Gamma$ ХЦГ & 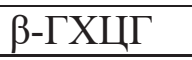 & $\gamma$-ГХЦГ & ДДТ & ДДД & ДДЕ \\
\hline \multirow[t]{2}{*}{ Мышцы } & $728 \pm 733$ & $131 \pm 257$ & $\underline{285 \pm 356}$ & $\underline{44 \pm 117}$ & $<\Pi$ & $\underline{317 \pm 175}$ \\
\hline & $\overline{70-1974}$ & $\overline{\Pi \mathrm{\Pi O}-676}$ & $\overline{14-1043}$ & $\overline{\Pi О-310}$ & & $\overline{121-565}$ \\
\hline \multirow[t]{2}{*}{ Печень } & $\underline{1047 \pm 2257}$ & $1499 \pm 909$ & $535 \pm 881$ & $481 \pm 729$ & $34 \pm 91$ & $\underline{1192 \pm 1243}$ \\
\hline & $72-6160$ & $392-2754$ & ПО-2161 & ПО-1552 & ПО-240 & $71-3132$ \\
\hline
\end{tabular}

ПО - предел обнаружения.
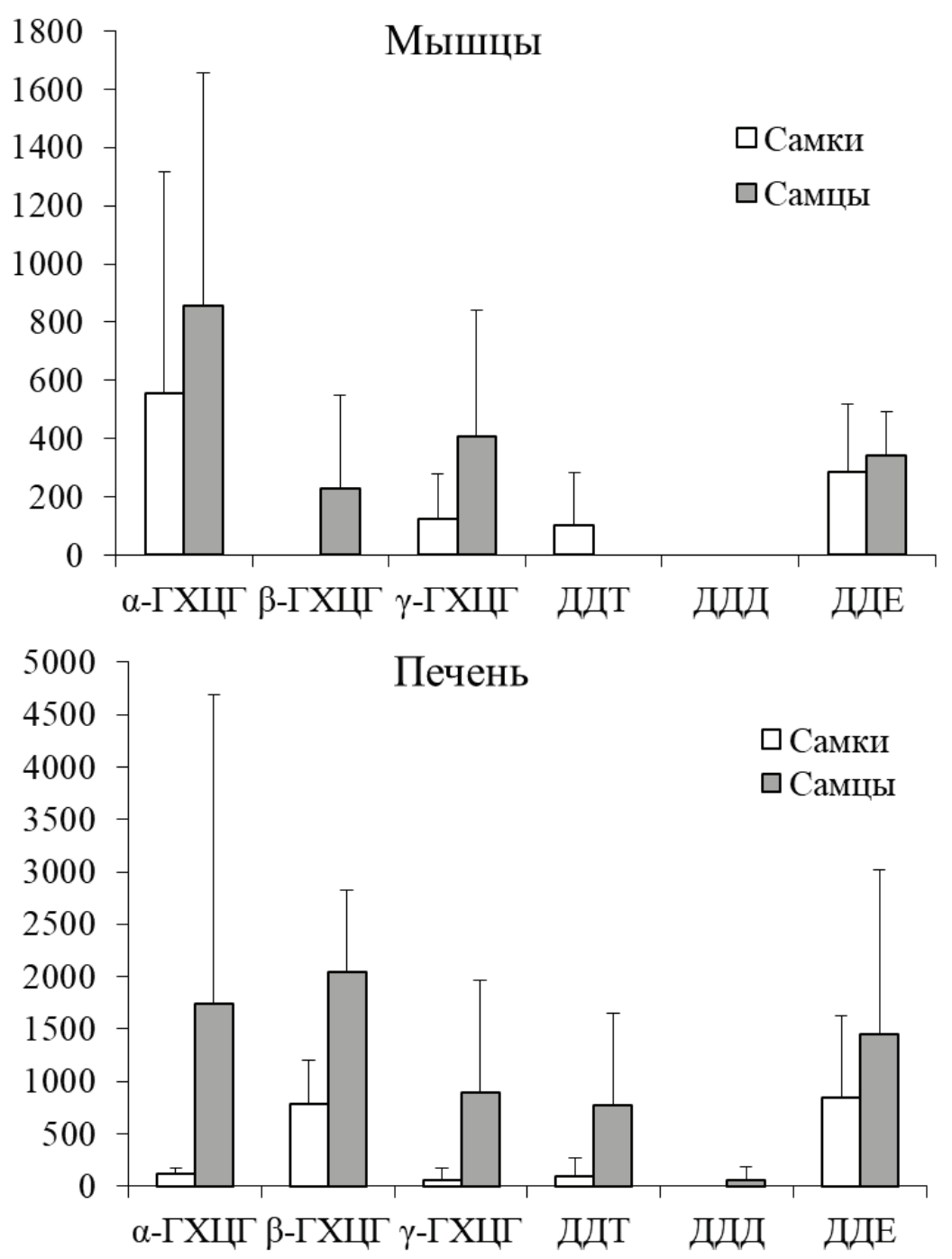

Puc. 8.5. Концентрации ХОП в мышцах и печени самок и самцов серого кита, нг/Г липидов

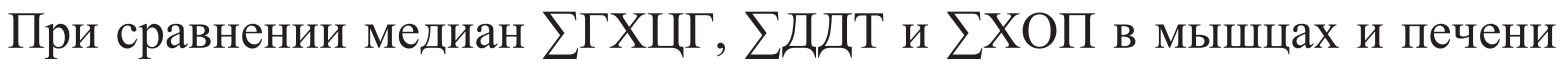
видно, что органы значительно различаются только по содержанию 


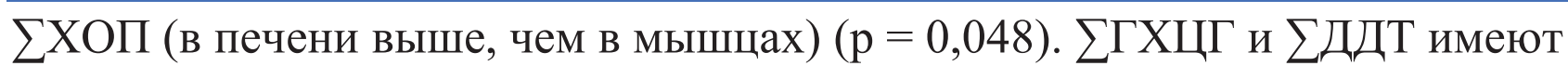
лишь тенденцию к увеличению в печени.

\subsection{2. Тихоокеанский моржс (Odobenus rosmarus divergens)}

Пестициды найдены во всех пробах моржа. Диапазон концентраций ХОП в органах животного находился в широких пределах. Концентрация пестицидов в печени была значительно выше, чем в мышцах. В мышцах самцов и самок суммарные концентрации ХОП сходны (рис. 8.6). Однако средняя концентрация в печени самок выше, чем у самцов. У последних наблюдается тенденция аккумуляции пестицидов с увеличением размера, как в мышцах, так и в печени.

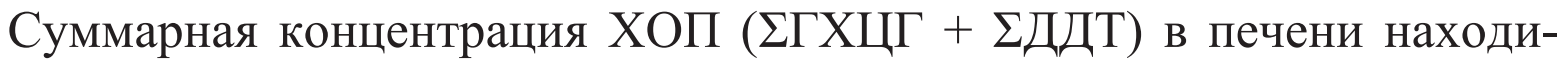
лась в диапазоне 4900-90300 нг/Г липидов. Эта величина существенно превышала диапазон в мышцах - 200-5700 нг/г липидов. В мышцах обнаружены все изомеры ГХЦГ и метаболит ДДТ, в печени - изомеры ГХЦГ, ДДТ и ДДЕ (табл. 8.3 и рис. 8.7$)$.
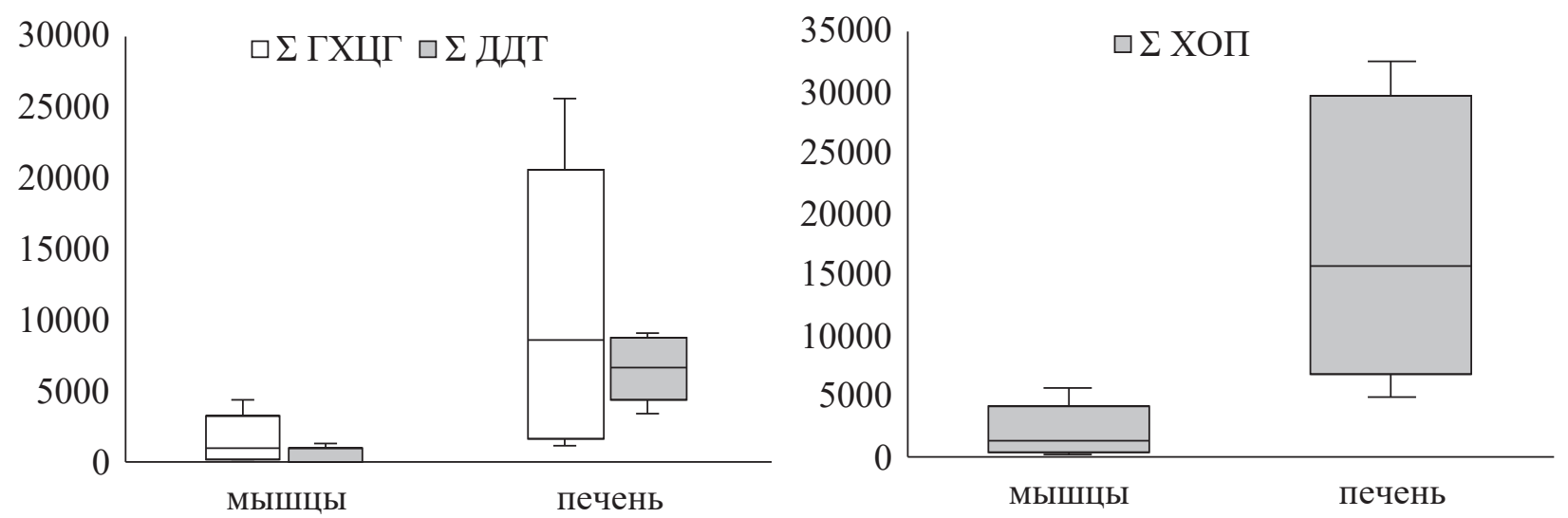

Puc. 8.6. Суммарное содержание ГХЦГ, ДДТ и ХОП

в мышцах и печени тихоокеанского моржа, нг/г липидов

Таблица 8.3

Средние концентрации (числитель) и диапазоны (знаменатель) ХОП

в органах тихоокеанского моржа, нг/Г липидов

\begin{tabular}{|c|c|c|c|c|c|}
\hline \multirow{3}{*}{ Мышцы } & 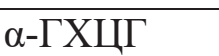 & $\beta$-ГХЦГ & $\gamma$-ГХЦГ & ДДТ & ДДЕ \\
\hline & $\underline{490 \pm 679}$ & $405 \pm 402$ & $728 \pm 986$ & $405 \pm 56$ & $<\Pi \mathrm{C}$ \\
\hline & ПО-1826 & ПО-916 & ПО-2482 & ПО-1287 & \\
\hline \multirow[t]{2}{*}{ Печень } & $\frac{8045 \pm 10647}{216}$ & $\frac{440 \pm 87}{00-2536}$ & $2056 \pm 4085$ & $\frac{4474 \pm 3302}{\square 0161}$ & $\frac{9282 \pm 23546}{\square 067238}$ \\
\hline & 216-25307 & ПО-2536 & ПО-12070 & 9161 & 7238 \\
\hline
\end{tabular}

ПО - предел обнаружения. 


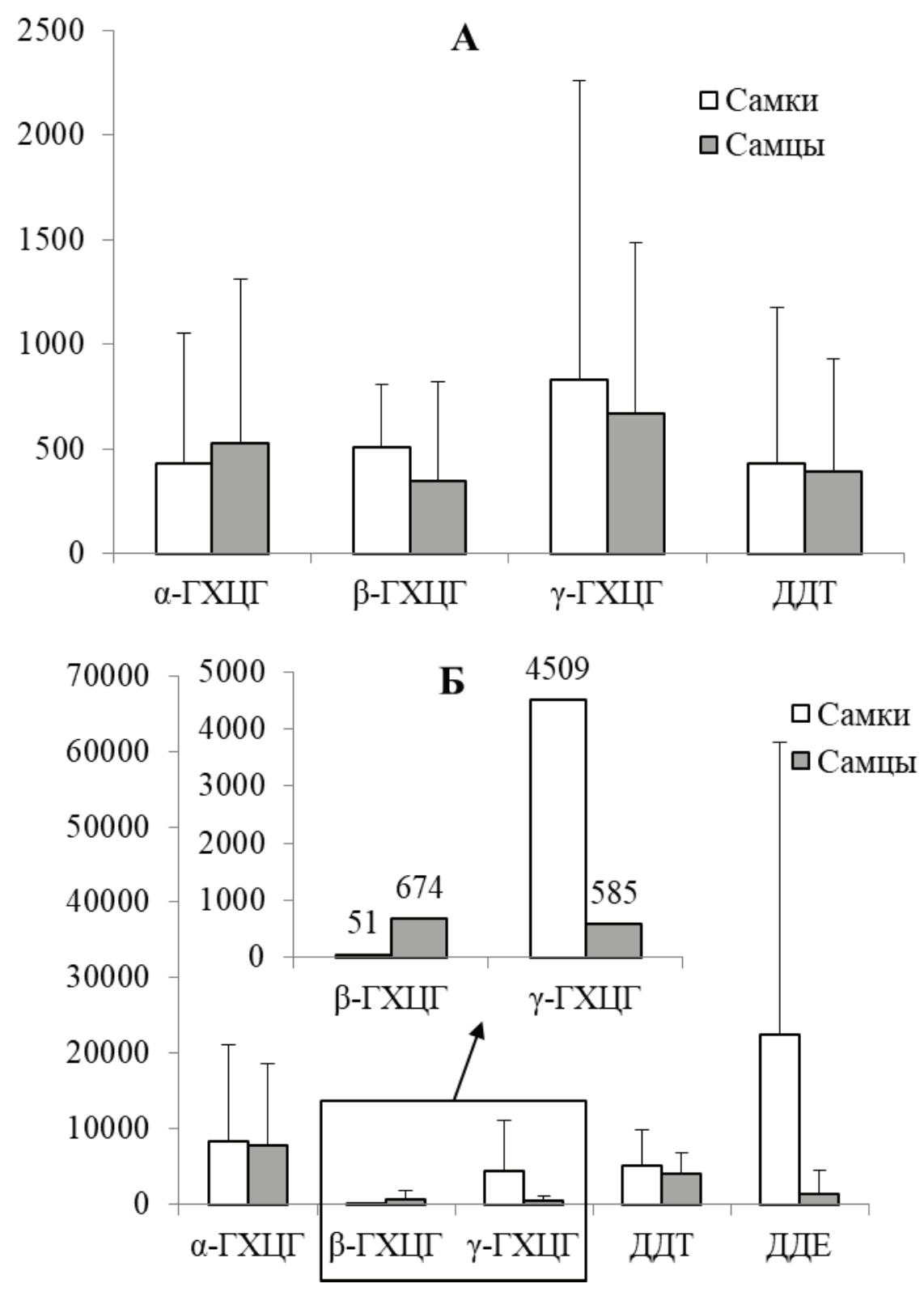

Puc. 8.7. Концентрации ХОП в мышцах (А) и печени (Б) самок и самцов серого кита, нг/Г липидов

Статистически достоверных различий между содержанием токсикантов в мышцах самцов и самок нет, однако концентрация всех поллютантов увеличивается в самках, кроме $\alpha$-ГХЦГ, который увеличивается в самцах (рис. 8.7A). В содержании токсикантов в печени, как и в мышцах, статистически достоверных различий нет, но концентрация всех обнаруженных пестицидов увеличивается в самках, кроме $\beta$-ГХЦГ, концентрация которого увеличивается в самцах (рис. 8.7Б).

Общее содержание различных хлорорганических пестицидов в мышцах и печени тихоокеанского моржа показано в таблице 8.3. Стати- 
стически достоверные результаты при сравнении органов получены только для двух веществ - $\alpha$-ГХЦГ $(\mathrm{p}=0,016)$ и ДДТ $(\mathrm{p}=0,021)$, их концентрация выше в печени. $\gamma$-ГХЦГ и ДДЕ имеют тенденцию к увеличению в печени, $\beta$-ГХЦГ - в мышцах.

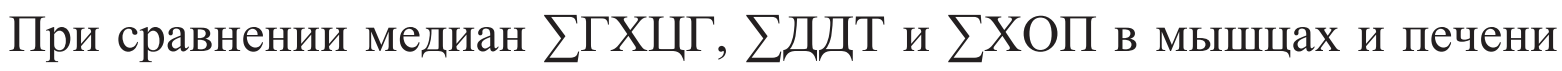
все результаты были статистически достоверны $(\mathrm{p}=0,001-0,036)$ и указывали на преобладание поллютантов в печени.

\subsection{3. Анализ ХОП в органах серого кита и тихоокеанского моржа}

В органах серого кита содержание липидов достигало 4\% в мышцах и 8\% в печени. В органах тихоокеанского моржа - до 6\% в мышцах и до 10\% в печени. Расчеты показали (табл. 8.4), что в среднем суммарное содержание ХОП в жире серого кита - 6290 нг/г, тихоокеанского моржа $26300 \mathrm{нг} / \Gamma$.

Таблица 8.4

\section{Среднее суммарное содержание ХОП в липидной фракции} серого кита и тихоокеанского моржа, нг/г липидов

\begin{tabular}{llll}
\hline Объект исследования & $\sum Г$ ХЦГ & $\sum$ ДДТ & $\sum$ ХОП \\
\hline Серый кит (Eschrichtius robustus) $(M \pm m, N=7)$ & $4220 \pm 1428$ & $2070 \pm 427$ & $6290 \pm 1855$ \\
$\begin{array}{l}\text { Тихоокеанский морж (Odobenus rosmarus } \\
\text { divergens) }(M \pm m, N=8)\end{array}$ & $14140 \pm 4125$ & $12160 \pm 2364$ & $26300 \pm 6489$ \\
\hline
\end{tabular}

Видовые особенности в аккумуляции липофильных ксенобиотиков у морских млекопитающих в немалой степени обусловлены общим содержанием жира в подкожной клетчатке и в отдельных органах. Большое значение также имеет и степень половозрелости особей. Исследованные нами виды имеют сходный ареал, и содержание жира в их органах отличается незначительно, составляя 8-10\%. Следовательно, существенные различия в содержании пестицидов могут быть связаны со стадией репродуктивного цикла и характером питания. Пищей серых китов служат в основном донные ракообразные и другие мелкие бентосные организмы, обитающие как на поверхности, так и в толще мягких грунтов (инфауна). Основу рациона моржа составляют донные беспозвоночные: двустворчатые моллюски, некоторые виды креветок, многощетинковых червей и приапулид, осьминоги и голотурии, а также некоторые виды рыб. Кроме того, 
иногда моржи поедают других тюленей: известны случаи нападения на кольчатую нерпу и детеныша гренландского тюленя [1].

Таким образом, возможными источниками поступления пестицидов в морскую среду в Беринговом море могут являться трансграничный атмосферный перенос и морские течения.

Концентрации ХОП в исследованных млекопитающих значительно ниже, чем таковые у полосатого дельфина (Stenella coeruleoalba) с cеверозападного побережья Японии, у косатки черной (Pseudorca crassidens) с побережья Гавайских островов, у косатки (Orcinus orca) с Восточных прибрежных зон от Калифорнии до Аляски, у беспёрой морской свиньи (Neophocaena phocaenoides) из прибрежной зоны Кореи, у Дюгоня (Dugong dugon) с северо-востока Австралии, у морского льва (Zalophus californianus), морского слона (Mirounga angustirostris) и тюленя обыкновенного (Phoca vitulina) из урбанизированных районов Калифорнии. Однако, это значение больше, чем содержание ХОП у морской свиньи (Phocaena phocaena relicta) и большого дельфина (Tursiops truncatus) из Черного моря и тюленя обыкновенного (Phoca vitulina) из удаленных от загрязнения районов Калифорнии (табл. 8.5).

Из данных таблицы 8.5 видно, что суммарное содержание ДДТ и его метаболитов в органах морских млекопитающих из других районов Мирового океана, как правило, выше, чем сумма изомеров ГХЦГ. Например, у полосатого дельфина из прибрежных вод Японии суммарное количество ДДТ достигает 130000 нг/г, тогда как ГХЦГ - только 520 нг/г. У серого кита и тихоокеанского моржа отмечена обратная закономерность, содержание ГХЦГ заметно преобладает над ДДТ. Количественное преобладание ГХЦГ над ДДТ отмечено также у морских организмов из залива Петра Великого Японского моря $[17,24]$. Эти факты, по-видимому, отражают большее использование линдана и технического ГХЦГ в сельском хозяйстве Дальневосточного региона России.

Таким образом, в органах китов чукотско-калифорнийской популяции и тихоокеанских моржей наблюдается накопление пестицидов, но общий уровень их содержания значительно ниже, чем у морских млекопитающих из других районов Мирового океана. 


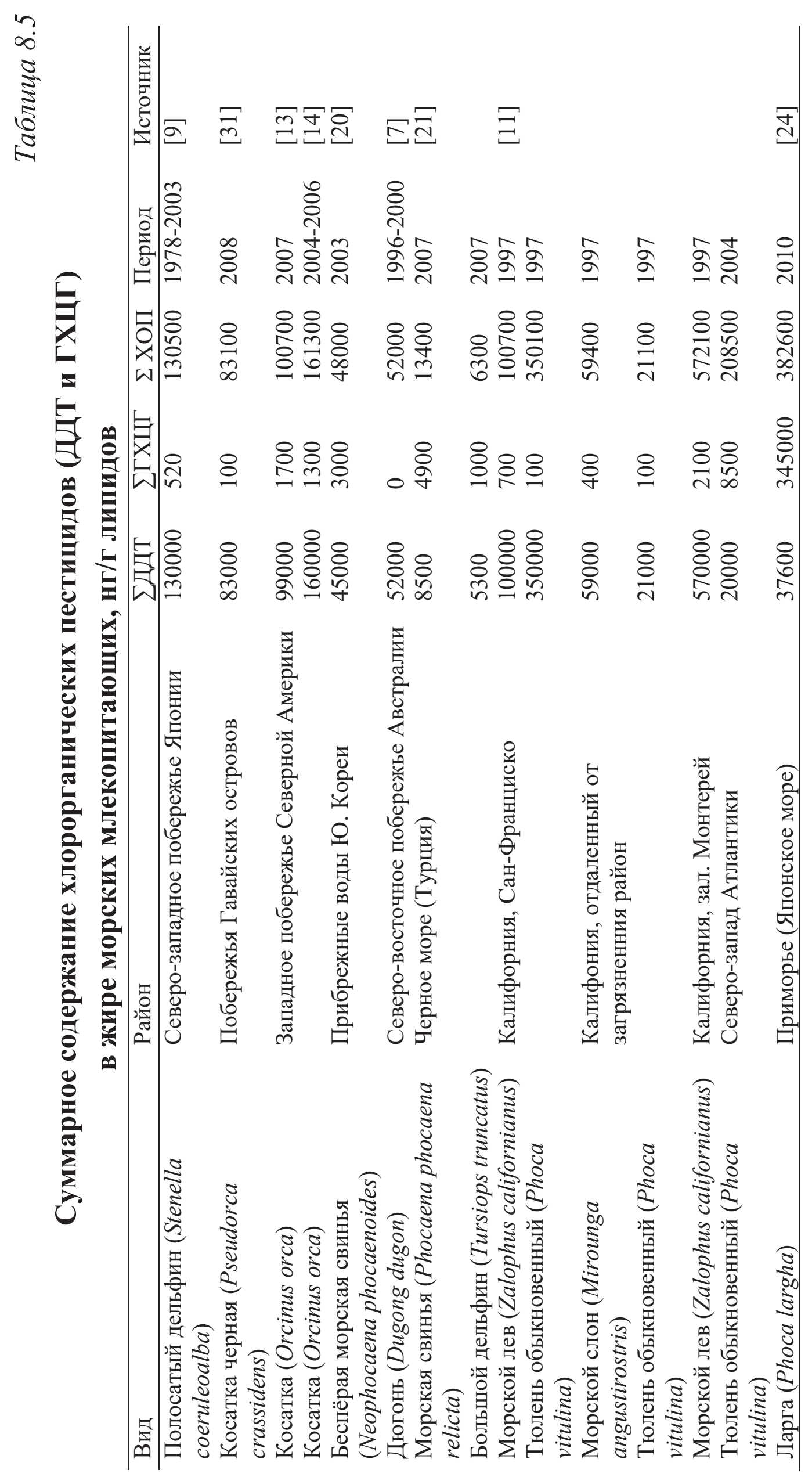




\section{3. Заключение}

Разный уровень аккумуляции пестицидов у отдельных видов птиц в первую очередь отражает пищевые предпочтения, состав рациона, миграции, содержание жира в отдельных органах. Кормовые объекты моржа аккумулируют больше пестицидов в теле, чем компоненты рациона серого кита, так как коэффициенты накопления поллютантов у моллюсков и рыб выше, чем у ракообразных. На основании этого можно заключить, что пищевой фактор является определяющим в различиях аккумуляции пестицидов у китов и моржей. Следовательно, морские птицы и млекопитающие являются моделями глобального загрязнения биосферы хлорорганическими поллютантами, которые подтверждают актуальность международной проблемы загрязнения водной и воздушной сред жизни.

\section{4. Список литературы}

1. Бурдин, А.М. Морские млекопитающие России: справочникопределитель / А.М. Бурдин, О.А. Филатова. - Киров: Кировская областная типография, 2009. - 206 с.

2. Медведев, Н.В. Экологическая токсикология природных популяций птиц и млекопитающих Севера / Н.В. Медведев, Э.В. Ивантер. - М.: Наука, 2007. - 229 с.

3. Ровинский, Ф.Я. Фоновый мониторинг загрязнения экосистем суши хлорорганическими соединениями / Ф.Я. Ровинский, Л.Д. Воронова, М.И. Афанасьев, А.В. Денисова, И.Г. Пушкарь. - Л.: Гидрометеоиздат, 1990. $-270 \mathrm{c}$.

4. Цыганков, В.Ю. Гексахлорциклогексан и ДДТ в морских организмах Охотского и Берингова морей / В.Ю. Цыганков, М.Д. Боярова, О.Н. Лукьянова, Н.К. Христофорова // Известия ТИНРО. - 2014. - Т. 176. P. 225-232.

5. Цыганков, В.Ю. Стойкие токсические вещества в мышцах и печени тихоокеанского моржа Odobenus rosmarus divergens Illiger, 1815 из Берингова моря / В.Ю. Цыганков, М.Д. Боярова, О.Н. Лукьянова // Биология моря. - 2014. - Т. 40. - № 2. - С. 158-161. 
6. Buckman, A.H. Organochlorine contaminants in seven species of Arctic seabirds from northern Baffin Bay / A.H. Buckman, R.J. Norstrom, K.A. Hobson [et al.] // Environmental Pollution. - 2004. - V. 128. - P. 327-338.

7. Haynes, D. Organichlorine and heavy metal concentrations in blubber and liver tissue collected from Queensland (Australia) Dugong (Dugong dugon) / D. Haynes, S. Carter, C. Gaus [et al.] // Marine Pollution Bulletin. - 2005. V. 51. - P. 361-369.

8. Hickie, B.E. Killer Whales (Orcinus orca) Face Protracted Health Risks Associated with Lifetime Exposure to PCBs / B.E. Hickie, P.S. Ross, R.W. Macdonald, J.K.B. Ford // Environmental Science \& Technology. - 2007. V. 41. - P. 6613-6619.

9. Isobe, T. Organohalogen contaminants in striped dolphin (Stenella coeruleoalba) from Japan: Present contamination status, body distribution and temporal trends (1978-2003) / T. Isobe, Y. Ochi, S. Tanabe [et al.] // Marine Pollution Bulletin. - 2009. - No. 58. - P. 396-401.

10. Jorundsdottir, H. Organochlorine Compounds and Their Metabolites in Seven Icelandic Seabird Species - a Comparative Study / H. Jorundsdottir, K. Lofstrand, J. Svavarsson [et al.] // Environmental Science \& Technology. - 2010. - V. 44. - P. 3252-3259.

11. Kajiwara, N. Organochlorine pesticides, polychlorinated biphenyls and butyltin compound in blubber and liver of stranded Californian sea lions, Elephant seals and Harbor seals from coastal California, USA / N. Kajiwara, K. Kannan, M. Muraoka [et al.] // Archives of Environmental Contamination and Toxicology. - 2001. - V. 41. - P. 90-91.

12. Knudsen, L.B. Halogenated organic contaminants and mercury in dead or dying seabirds on Bjornoya (Svalbard) / L.B. Knudsen, K. Sagerup, A. Polder [et al.] - Norwegian polar institute, 2007. - 45 p.

13. Krahn, M.M. Effects of age, sex and reproductive status on persistent organic pollutant concentrations in "Southern Resident" killer whales / M.M. Krahn, M.B. Hanson, R.W. Baird [et al.] // Marine Pollution Bulletin. 2009. - V. 58. - P. 1522-1529.

14. Krahn, M.M. Persistent organic pollutants and stable isotopes in biopsy samples (2004/2006) from Southern Resident killer whales / M.M. Krahn, M.B. Hanson, R.W. Baird [et al.] // Marine Pollution Bulletin. - 2007. - V. 54. P. 1903-1911. 
15. Kunisue, T. Accumulation features of persistent organochlorines in resident and migratory birds from Asia / T. Kunisue, N. Watanabe, A.N. Subramanian [et al.] // Environmental Pollution. - 2003. - V. 125. P. 157-172.

16. Leat, E.H.K. Effects of environmental exposure and diet on levels of persistent organic pollutants in eggs of a top predator in the North Atlantic in 1980-2008 / E.H.K. Leat, S. Bourgeon, K. Borgå [et al.] // Environmental Pollution. - 2011. - V. 159. - No. 5. - P. 1222-1228.

17. Lukyanova, O.N. Persistent organic pollutants in marine ecosystems in Russian Far East: Sources, transport, biological effects / O.N. Lukyanova. LAP Lambert Academic Publishing, 2013. - 108 p.

18. Lukyanova, O.N. Pesticide biotransport by Pacific salmon in the northwestern Pacific Ocean / O.N. Lukyanova, V.Y. Tsygankov, M.D. Boyarova, N.K. Khristoforova // Doklady Biological Sciences. - 2014. - V. 456. - P. 188-190.

19. Morales, L. Persistent Organic Pollutants in gull eggs of two species (Larus michahellis and Larus audouinii) from the Ebro delta Natural Park / L. Morales, M.G. Martrata, J. Olmos [et al.] // Chemosphere. - 2012. - V. 88. No. 11. - P. 1306-1316.

20. Park, B. Organohalogen contaminants in finless porpoises (Neophocaena phocaenoides) from Korean coastal waters: Contamination status, maternal transfer and ecotoxicological implications / B. Park, G. Park, Y. An, H. Choi [et al.] // Marine Pollution Bulletin. - 2010. - V. 60. - P. 768-774.

21. Popa, O.M. Organochlorine pesticides in the Black Sea dolphins / O.M. Popa, A. Trif, N. Marine, N. Ursu // Lucrari stiintifice medicina veterinara. Timisoara. - V. XLI. - 2008. - P. 768-773.

22. Tanabe, S. Bioindicators of POPs / S. Tanabe, A. Subramanian. Japan: Kyoto University Press and Trans Pacific Press, 2006. - 190 p.

23. Tanabe, S. Contamination by Persistent Toxic Substances in the Asia-Pacific Region / S. Tanabe // Persistent Organic Pollutants in Asia: Sources, Distributions, Transport and Fate. - A. Li, S. Tanabe, G. Jiang, J.P. Giesy and P.K.S. Lam (Editors). - Developments in Environmental Science. -2007. - V. 7. - P. 773-817.

24. Trukhin, A.M. Chlorinated pesticides in tissues and organs of spotted seals (Phoca largha Pallas, 1811) from the Sea of Japan / A.M. Trukhin, M.D. Boyarova // Contemporary Problems of Ecology. - 2013. - V. 6. P. 336-342. 
25. Tsygankov, V.Yu. Bioaccumulation of organochlorine pesticides (OCPs) in the northern fulmar (Fulmarus glacialis) from the Sea of Okhotsk / V.Yu. Tsygankov, M.D. Boyarova, O.N. Lukyanova // Marine Pollution Bulletin. $-2016 .-$ V. 110. - P. 82-85.

26. Tsygankov, V.Yu. Bioaccumulation of Persistent Organochlorine Pesticides (OCPs) by Gray Whale and Pacific Walrus from the Western Part of the Bering Sea / V.Yu. Tsygankov, M.D. Boyarova, O.N. Lukyanova // Marine Pollution Bulletin. - 2015. - V. 99. - P. 235-239.

27. Tsygankov, V.Yu. Bioindicators of organochlorine pesticides (OCPs) in the Sea of Okhotsk and the western Bering Sea / V.Yu. Tsygankov, M.D. Boyarova, O.N. Lukyanova, N.K. Khristoforova // Archives of Environmental Contamination and Toxicology. - 2017. - V. 73. - P. 176-184.

28. Tsygankov, V.Yu. Persistent toxic substances in the muscles and liver of the pacific walrus Odobenus rosmarus divergens Illiger, 1815 from the Bering Sea / V.Yu. Tsygankov, M.D. Boyarova, O.N. Lukyanova // Russian Journal of Marine Biology. - 2014. - V. 40. - P. 147-151.

29. Wania, F. Global fractionation and cold condensation of low volatility organochlorine compounds in polar regions / F. Wania, D. Mackay // Ambio. - 1993. - V. 22. - P. 10-18.

30. Wania, F. Tracking the distribution of persistent organic pollutants / F. Wania, D. Mackay // Environmental Science \& Technology. - 1996. - V. 30. No. 9. - P. 390-396.

31. Ylitalo, G.M. High levels persistent organic pollutants measured in blubber of island-associated false killer whales (Pseudorca crassidens) around the main Hawaiian Island / G.M. Ylitalo, R.W. Baird, G.K. Yanagida [et al.] // Marine Pollution Bulletin. - 2009. - No. 58. - P. 1932-1937. 
https://doi.org/10.24866/7444-4891-2/234-248

\section{ГЛАВА 9}

\section{БИОТРАНСФОРМАЦИЯ СТОЙКИХ ОРГАНИЧЕСКИХ ЗАГРЯЗНЯЮЩИХ ВЕЩЕСТВ (СОЗ) В МОРСКИХ ОРГАНИЗМАХ ДАЛЬНЕВОСТОЧНЫХ МОРЕЙ}

\section{В.Ю. Цыганков ${ }^{1}$}

В главе представлены результаты исследований биотрансформации стойких органических загрязняющих веществ (СО3) в морских организмах дальневосточных морей России. Показана «типовая» схема распределения исходных и «распавшихся» СО3 в разных организмах.

Ключевые слова: СОЗ; биотрансформация; распад исходных соединений; морские организмы; дальневосточные моря

${ }^{1}$ Школа биомедицины и Школа естественных наук, Дальневосточный федеральный университет (ДВФУ), 690922, Владивосток, о. Русский, п. Аякс, 10. E-mail: tsig_90@mail.ru

${ }^{1}$ School of Biomedicine and School of Natural Sciences, Far Eastern Federal University, 10 Ajax Bay, Russky Island Vladivostok, Russia, 690922. E-mail: tsig_90@mail.ru

Для ичитирования: Цыганков В. Ю. Биотрансформация стойких органических загрязняющих веществ (CO3) в морских организмах дальневосточных морей // Стойкие органические загрязняющие вещества (CO3) в Дальневосточном регионе: моря, организмы, человек : монография / В.Ю. Цыганков, М.М. Донец, Н.К. Христофорова [и др.] ; науч. ред. В.Ю. Цыганков. - Владивосток : Изд-во Дальневост. федерал. ун-та, 2020. - С. 234-248. - https://doi.org/10.24866/7444-4891-2/234-248.

For citing: Tsygankov V. Yu. Biotransformation of persistent organic pollutants (POPs) in marine organisms of the Far Eastern Seas // Persistent organic pollutants (POPs) in the Far Eastern Region: Seas, Organisms, Human : monograph / V.Yu. Tsygankov, M.M. Donets, N.K. Khristoforova [et al.] ; ed. by V.Yu. Tsygankov. - Vladivostok : Publishing House of the Far Eastern Federal University, 2020. - P. 234248. - https://doi.org/10.24866/7444-4891-2/234-248. 


\section{CHAPTER 9. Biotransformation of persistent organic pollutants (POPs) in marine organisms of the Far Eastern Seas}

\section{V.Yu. Tsygankov ${ }^{1}$}

In the chapter, the results of studies on the biotransformation of persistent organic pollutants (POPs) in marine organisms in the Russian Far Eastern seas are presents. The "typical" scheme of distribution of the original and "decayed" POPs in different organisms is shown.

Keywords: POPs; biotransformation; decay of the starting compounds; marine organisms; Far Eastern seas

Основные механизмы разрушения органических ксенобиотиков в окружающей среде можно условно разделить на абиотические - фотохимические реакции - и биотические процессы метаболического распада с участием живых организмов.

Фотохимическое разложение ХОП, например ДДТ и ГХЦГ, в молекулах которых содержатся ароматические группы и ненасыщенные связи, происходит в результате поглощения солнечной энергии в ультрафиолетовой и видимых областях спектра [25]:

$$
\begin{aligned}
& \text { ДДД } \Leftarrow \text { ДДТ } \Rightarrow \text { ДДЕ } . . \Rightarrow \text { ПХБ }
\end{aligned}
$$

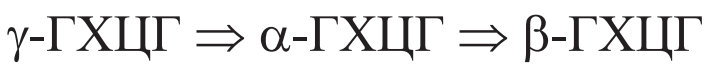

Многие ксенобиотики, в том числе и стойкие органические загрязняющие вещества, попав в организм, подвергаются биотрансформации и выделяются в виде метаболитов. В основе биотрансформации по большей части лежат энзиматические преобразования молекул. Биологический смысл явления - превращение химического соединения в форму, удобную для выведения из организма, и тем самым, сокращение времени его воздействия.

Метаболизм ксенобиотиков проходит в два этапа (рис. 9.1). 
В ходе первого этапа окислительно-восстановительного или гидролитического превращения молекула принимает полярные функциональные группы, что делает ее реакционно-способной и более растворимой в воде. На втором этапе проходят синтетические процессы конъюгации промежуточных метаболитов с эндогенными молекулами, в результате чего образуются полярные соединения, которые выводятся из организма с помощью специальных механизмов экскреции.

\section{ИСХОДНОЕ СОЕДИНЕНИЕ}

\begin{tabular}{l|l} 
Окисление & \\
$\begin{array}{l}\text { Восстановление } \\
\text { Гидролиз }\end{array}$ & $\begin{array}{l}\text { Первый } \\
\text { этап }\end{array}$ \\
&
\end{tabular}

\section{ПРОМЕДУТОЧНЫЕ МЕТАБОЛИТЫ}

Глюкуронидация

Сульфатация

Метилирование

Связь с глутатионом
Второй

этап

\section{КОНЕЧНЫЕ МЕТАБОЛИТЫ}

\section{Puc. 9.1. Этапы метаболизма ксенобиотиков}

Разнообразие каталитических свойств энзимов биотрансформации и их низкая субстратная специфичность позволяет организму метаболизировать вещества различного строения. Вместе с тем, у животных разных видов и человека метаболизм ксенобиотиков проходит далеко не одинаково, поскольку энзимы, участвующие в превращениях этих веществ, часто видоспецифичны.

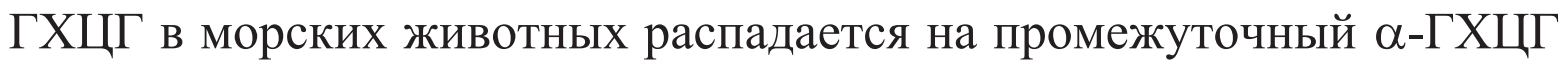
и более стойкий конечный метаболит $\beta$-ГХЦГ. Наличие этих двух изомеров говорит о давнем поступлении этих ксенобиотиков в морские экосистемы и организмы. ДДТ в морских организмах распадается на ДДД, ДДЕ и ДДА (рис. 9.2). Наличие ДДЕ и ДДД будет свидетельствовать о давней циркуляции этих поллютантов в экосистемах и организмах. 


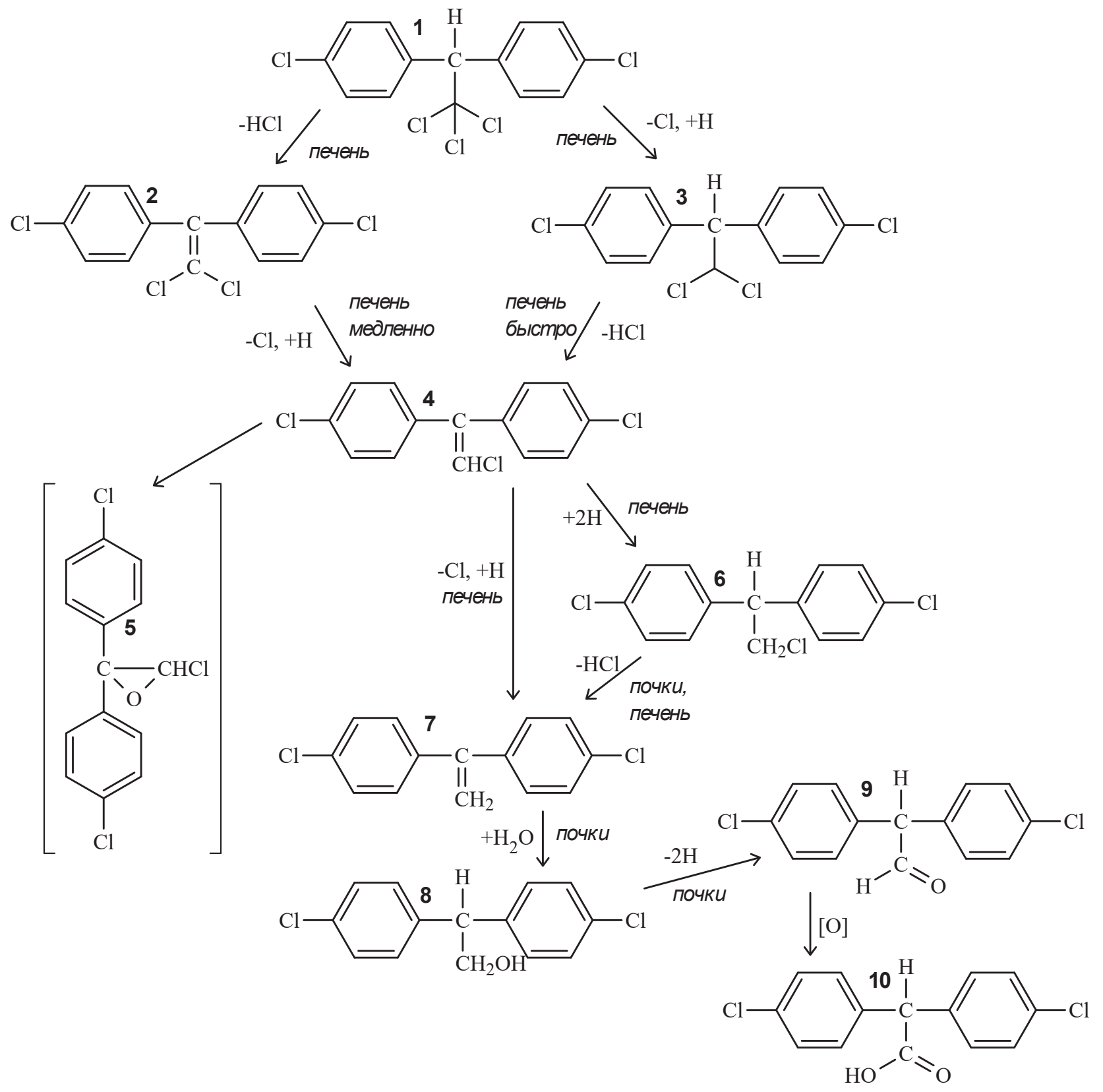

Рис. 9.2. Схема метаболических превращения ДДТ в организме животных [4, 9, 27]. 1 - ДДТ; 2 - ДДЕ; 3 - ДДД; 4 -дихлордифенилхлорэтилен; 5 - эпоксид дихлордифенилхлорэтилена;

6 -дихлордифенилхлорэтан; 7 -дихлордифенилэтилен;

8 - дихлордифенилэтанол; 9 - дихлордифенилэтаналь; 10 - дихлордифенилэтановая (дихлордифенилуксусная) кислота

В отличие от ХОП, полихлорированные бифенилы трансформируются по другим схемам (рис. 9.3). 

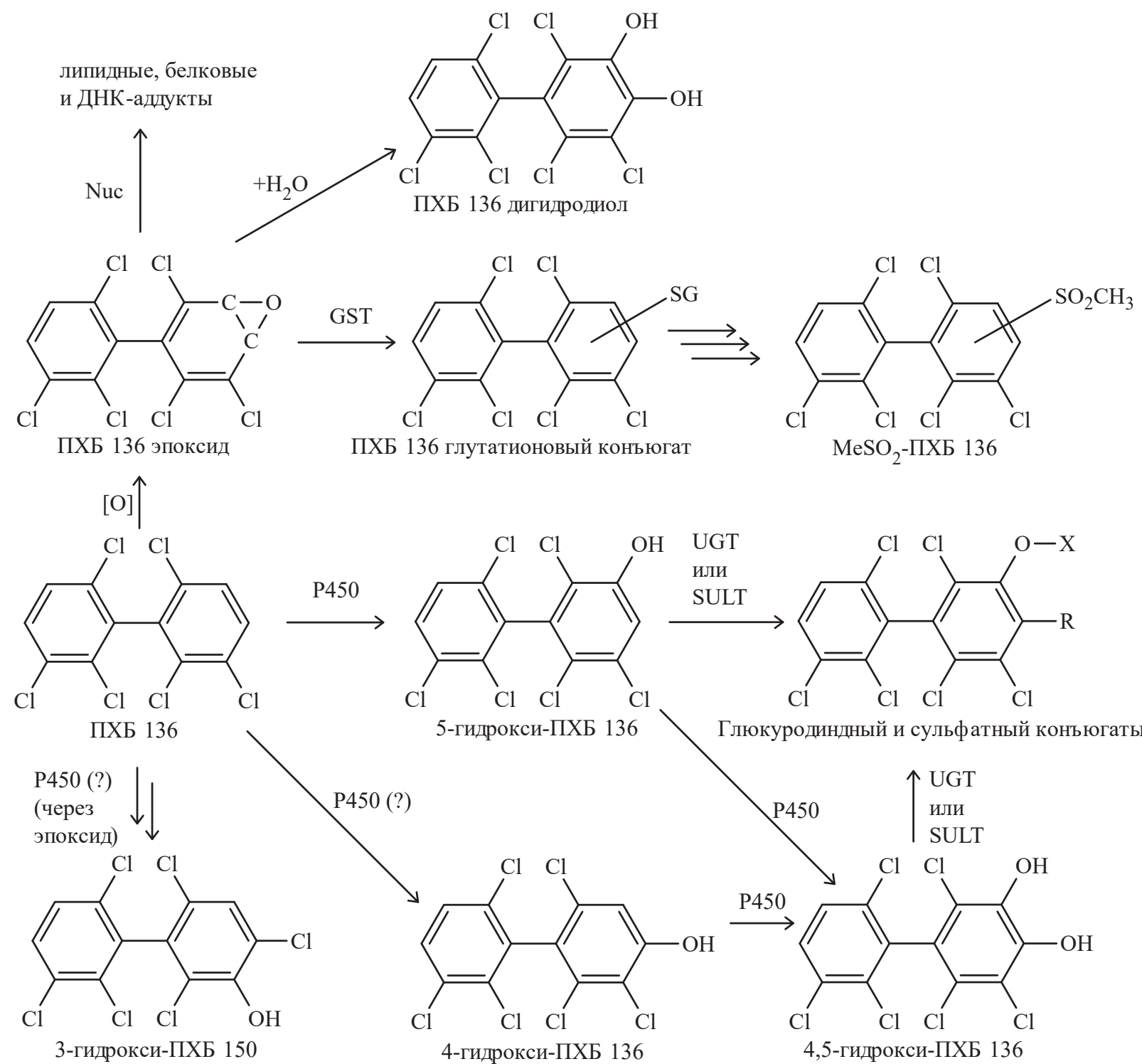

P450<smiles>Oc1cc(Cl)c(Cl)c(-c2c(Cl)ccc(Cl)c2Cl)c1Cl</smiles>

5-гидрокси-ПХБ 136

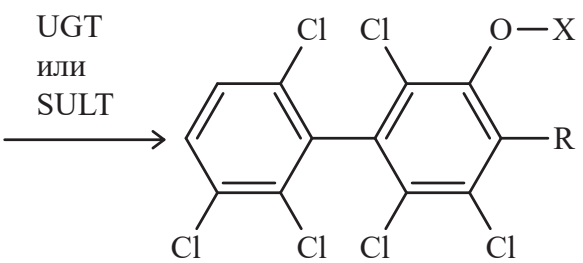

Глюкуродиндный и сульфатный конъюгаты

\section{P450 (?)}
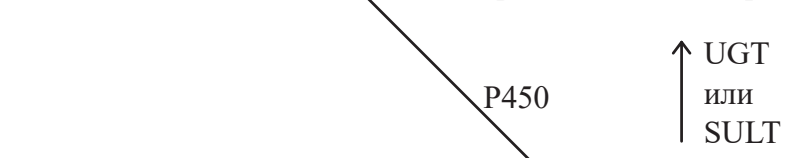

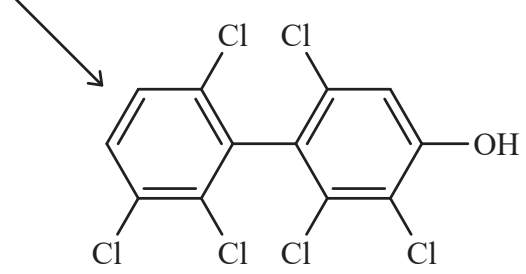

4-гидрокси-ПХБ 136

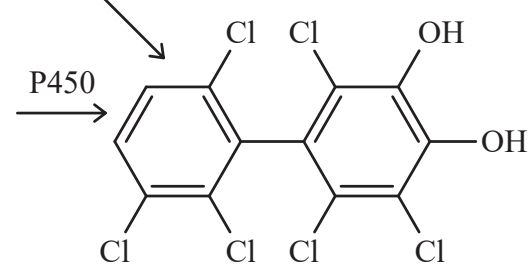

4,5-гидрокси-ПХБ 136

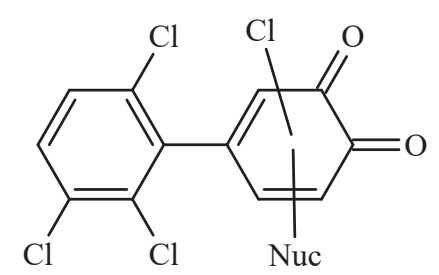

Глутатионовые и липидные конъюгаты, белковые и ДНК-аддукты

Pис. 9.3. Упрощенная схема метаболизма ПХБ 136 [13]: Nuc - клеточный Nили S-нуклеофил; P450 - цитохром P450 (CYP2Bs) фермент; GST - глутатионS-трансфераза; UGT - глюкуронозилтрансфераза; SULT - сульфотрансфераза; ДНК-аддукты - соединение какой-либо молекулы с ДНК 
Характер и динамика распределения ПХБ в окружающей среде во многом определяются их физическими свойствами, такими как химическая инертность, достаточно высокая плотность паров и способность сорбироваться на частицах. Они устойчивы в окружающей среде, малорастворимы в воде, концентрируются в донных отложениях водоемов, небольшая часть их подвергается биотрансформации микроорганизмами и водорослями. Особенно устойчивы высокохлорированные соединения. По мере включения ПХБ в биологические пищевые цепи происходит прогрессивная потеря низкохлорированных компонентов благодаря их селективной биотрансформации. Поэтому в организмах накапливаются наиболее опасные высокохлорированные ПХБ.

\section{1. Биотрансформация СО3 в организмах дальневосточных морей}

Проведенные исследования биотрансформации стойких органических загрязняющих веществ в морских организмах дальневосточных морей России указывают на сходную ситуацию в этих регионах. Как правило в организмах присутствует трансформировавшиеся $\beta$ - и $\alpha$-ГХЦГ, ДДД и ДДЕ, высокохлорированные ПХБ.

Как было показано в предыдущих главах, в морских организмах преобладают в основном метаболиты ГХЦГ и ДДТ. В свою очередь, их появление указывает на давнее загрязнение. Но точно сказать, где произошел распад исходных соединений не представляется возможным. Вещество могло попасть в организм как несколько недель, так и лет назад, что может быть обусловлено локальным, региональным или глобальным загрязнением. Получить представление о локального загрязнения позволяют известные технологии мониторинга с использованием донных рыб и моллюсков. Зная общие закономерности их биологии и экологии, можно рассчитать реальную аккумуляцию и трансформацию токсикантов. Кроме того, для экологических оценок локального загрязнения также можно использовать разницу в уровнях аккумуляции СО3 лососевыми и донными рыбами.

Разница в накоплении СО3 донными и пелагическими рыбами связана с разным содержанием липидов, различием жизненных циклов и возможностями миграции, однако трансформация исходных соединений практически аналогична (рис. 9.4). 

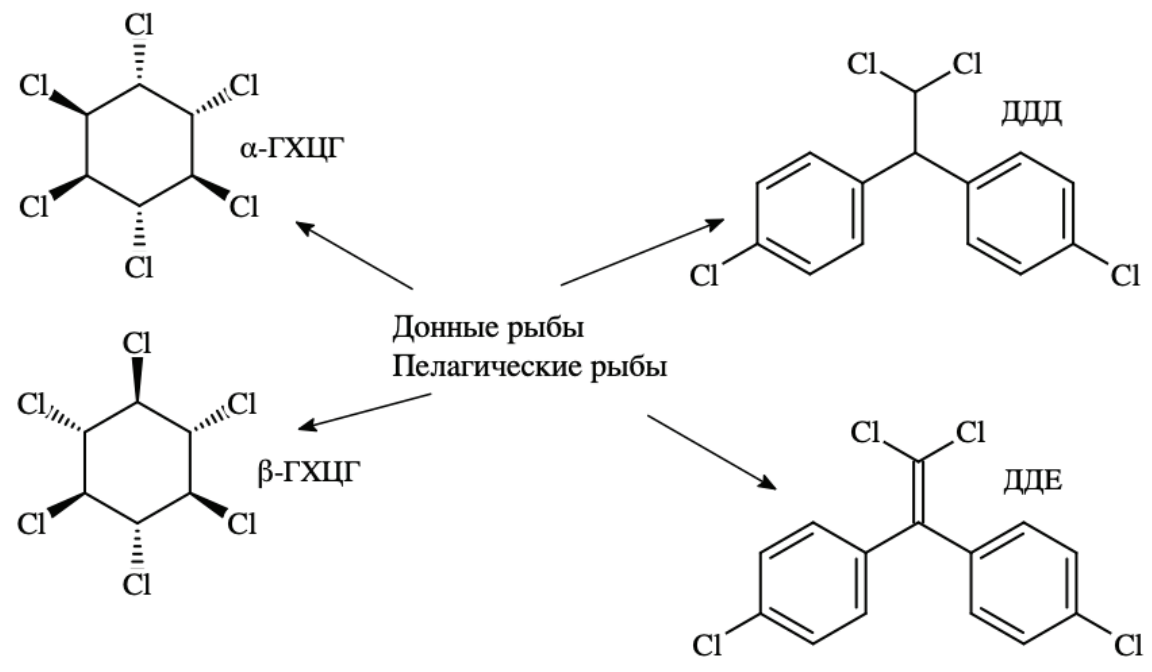

Puc. 9.4. Трансформация СО3 в донных

и пелагических рыбах дальневосточных морей России

Птицы и млекопитающие могут выступать как индикаторы глобального и долгосрочного мониторинга СО3. Эти организмы накапливают ксенобиотики в течение всей жизни. В проведенных нами исследованиях трансформация СО3 в этих организмах указывает на давнее загрязнение и деградацию исходных соединений. Об этом же говорит соотношение изомеров ГХЦГ, ДДТ и его метаболитов (рис. 9.5, 9.6).

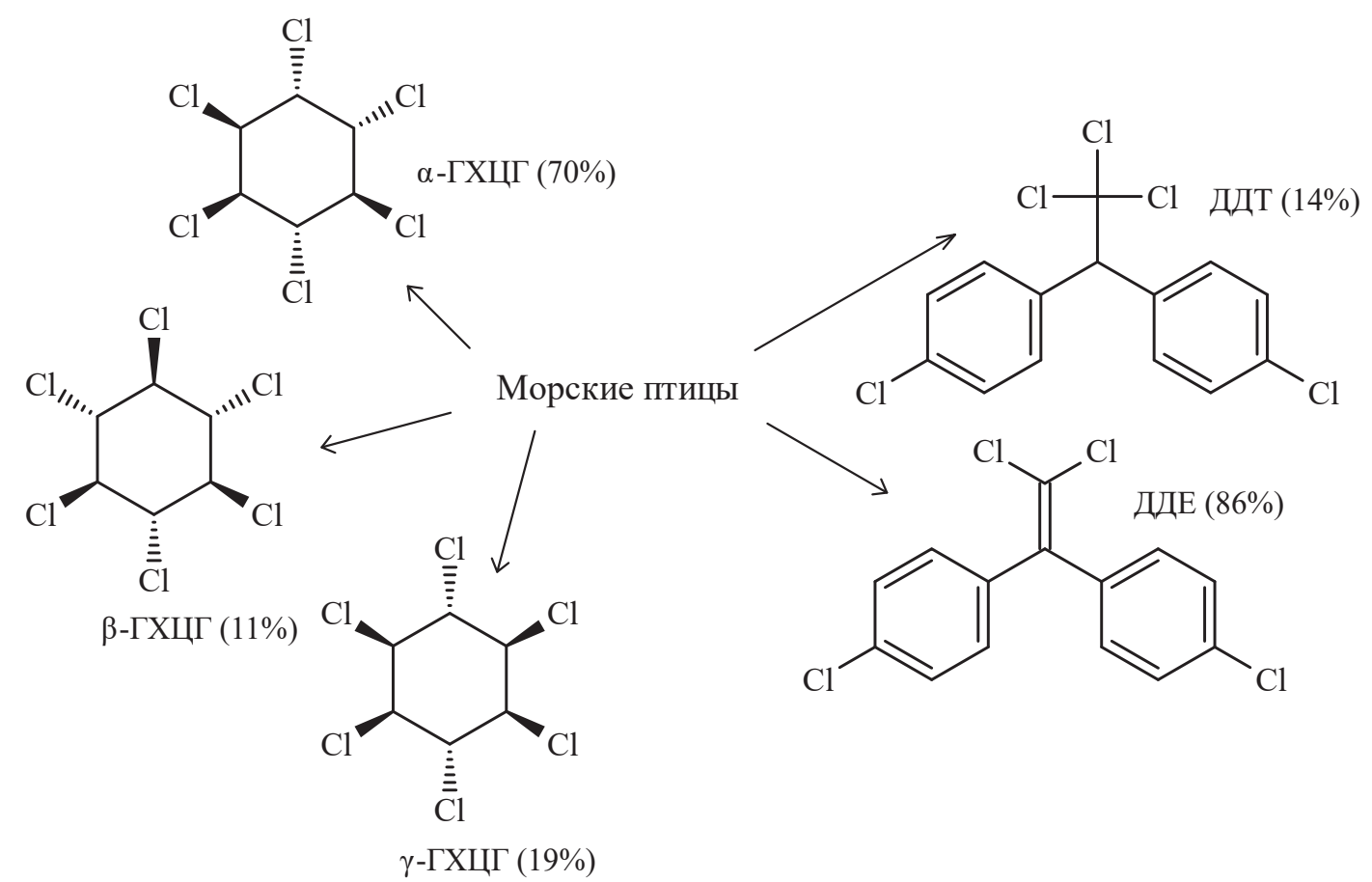

Puc. 9.5. Трансформация СОЗ в морских птицах Охотского моря: $70 \% \alpha-$ и $11 \%$ $\beta$-ГХЦГ указывают на распад линдана ( $\gamma$-ГХЦГ - 19\%); 86\% ДДЕ свидетельствует о распаде исходного ДДТ (14\%) 

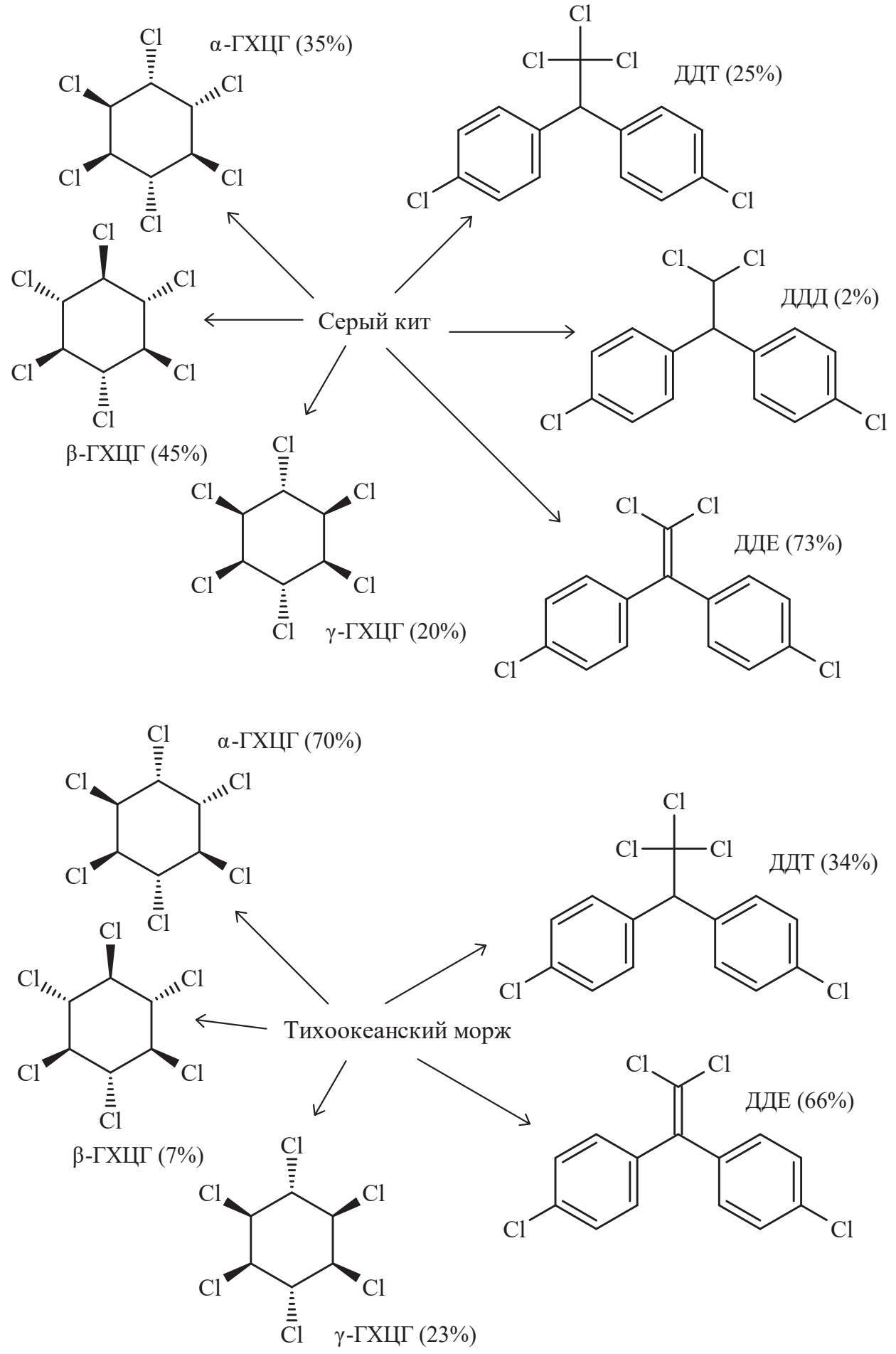

Б

Puc. 9.6. Трансформация СО3 в морских млекопитающих Берингова моря.

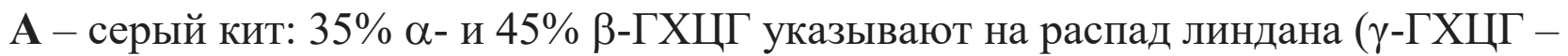
$20 \%) ; 75 \%$ ДДЕ+ДДД свидетельствует о распаде исходного ДДТ (25\%). Б - тихоокеанский морж: $70 \% \alpha-$ и 7\% $\beta$-ГХЦГ указывают на распад линдана $(\gamma$-ГХЦГ - 23\%); 66\% ДДЕ свидетельствует о распаде исходного ДДТ (34\%)

По метаболитам исходных соединений можно также сделать вывод о том, какая смесь СО3 была использована. Например, при повышенной 
концентрации $\gamma$-ГХЦГ в организмах и среде можно предположить свежее загрязнение, или, что в среду поступила смесь ГХЦГ с наибольшим процентом $\gamma$-изомера. Обнаружение $\beta$ - и $\alpha$-ГХЦГ в организмах и среде говорит об использовании технической композиции: различные изомеры ГХЦГ, отличающиеся конформацией цикла, в технической смеси, полученной в результате фотохимического хлорирования, составляют - $\alpha$ -

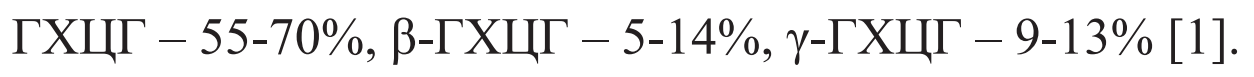

Обнаружение концентраций ДДЕ и ДДД, которые выше таковой дДТ (или при отсутствии его) более точно говорит о давнем загрязнении и трансформации исходного соединения, так как обычный состав технического ДДТ выглядит так: $\boldsymbol{n , n}$-ДДТ - 77,1\%,o,n'-ДДТ - 14,9\%,n,n'-ДДД $0,3 \%, o, n^{\prime}$-ДДД - $0,1 \%, n, n^{\prime}$-ДДЕ - 4,0\%, o, $n^{\prime}$-ДДЕ - 0,1\% и следовые концентрации других соединений [11].

Что касается ПХБ, то их состав в организмах указывает на селективную биотрансформацию и накопление наиболее опасных высокохлорированных ПХБ (рис. 9.7).

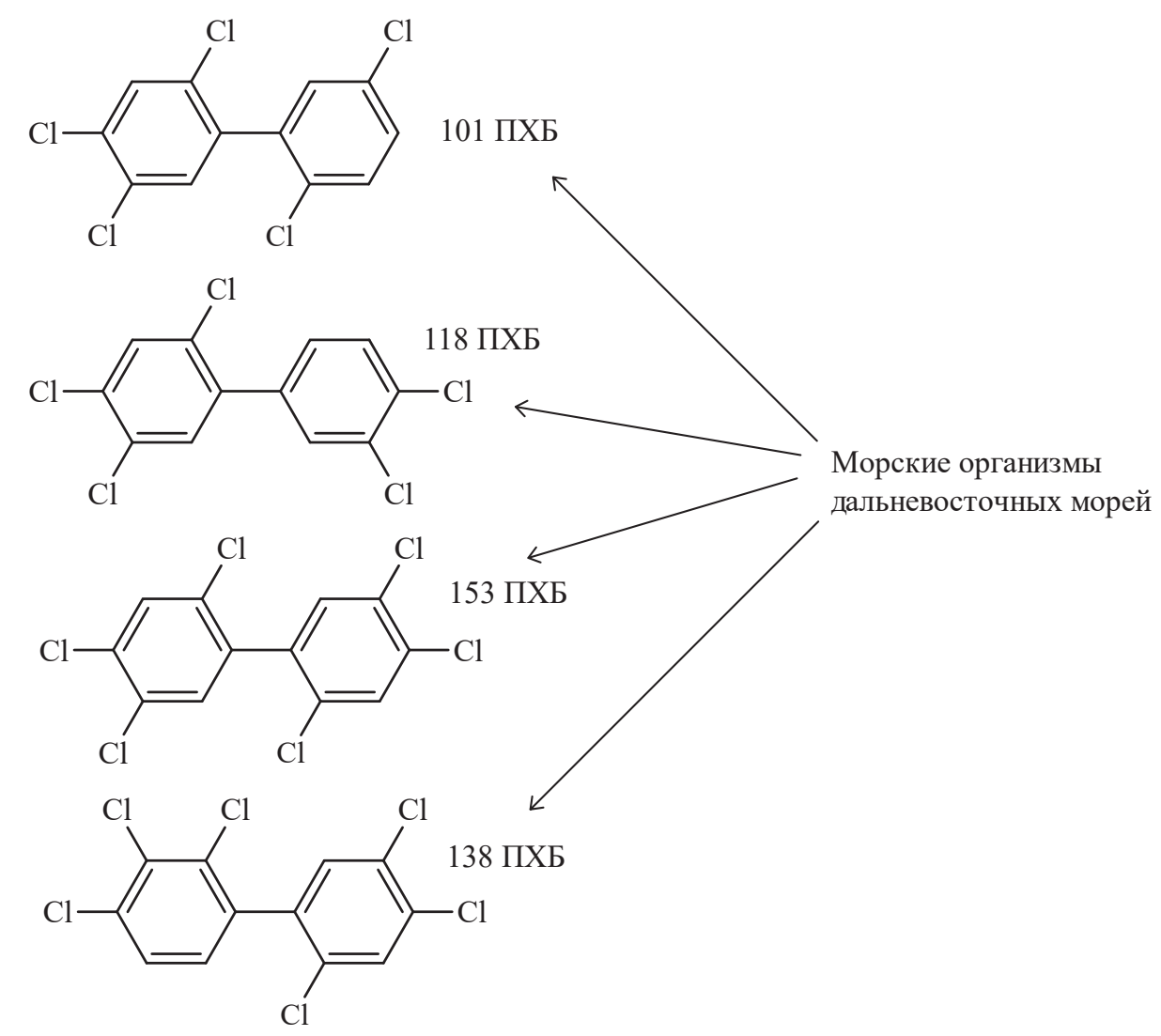

Рис. 9.7. Основные высокохлорированные ПХБ, обнаруженные в морских организмах дальневосточных морей России 


\section{2. Биотрансформация СО3 в мире}

Во второй половине XX века мировой спрос на продовольствие увеличился с ростом населения мира. Это приводит к интенсификации сельского хозяйства наряду с широким распространением сельскохозяйственных химикатов, включая главным образом пестициды [18]. Во всем мире общее потребление $\mathrm{CO} 3$ составляет около двух миллионов тонн в год, из которых 69\% потребляется Европой и США, и только 31\% используется остальными странами. В Южной Азии сельское хозяйство является основным сектором потребления пестицидов, где 14\% мировых сельскохозяйственных земель эксплуатируется с широким использованием пестицидов [3].

Основное использование пестицидов в сельском хозяйстве и здравоохранении для борьбы с различными вредителями и болезнями, которые поражают человека, началось в Индии. Для достижения этой цели производство основных пестицидов началось в 1952 г., а уже в 1958 году было произведено более 5000 тонн пестицидов, особенно таких инсектицидов, как ДДТ и ГХЦГ. В середине 1990-х было зарегистрировано около 145 видов пестицидов, а их производство достигло 85000 тонн. В последнее время потребление пестицидов демонстрирует небольшую тенденцию к снижению, вероятно, из-за перехода фермеров в сторону биопестицидов, природных растительных источников и других альтернативных методов [12]. Сегодня Индия считается крупнейшей страной-производителем пестицидов в Азии и двенадцатой в мире с годовым объемом производства 90000 тонн пестицидов [15]. Кроме того, Индия участвует в производстве, использовании и экспорте ХОП в крупных масштабах, таких как ДДТ [20]. В настоящее время в Индии насчитывается более 125 основных крупных и средних производителей и более 500 пестицидных составов [2]. В зависимости от использованных композиций пестицидов в странах устанавливаются гигиенические нормативы исходных и трансформированных соединений в продукции.

В таблице 9.1 для примера указана трансформация исходных соединений в моллюсках и рыбах из разных регионов планеты в зависимости от используемой композиции пестицидов и ПХБ. 
Биотрансформация ХОП и ПХБ в моллюсках и рыбах из разных районов Мирового океана

\begin{tabular}{|c|c|c|c|}
\hline Вид & Регион & Обнаруженные соединения & Источник \\
\hline \multicolumn{4}{|c|}{ Моллюски } \\
\hline Mytilus galloprovincialis & $\begin{array}{l}\text { Адриатическое } \\
\text { побережье } \\
\text { (Хорватия) }\end{array}$ & 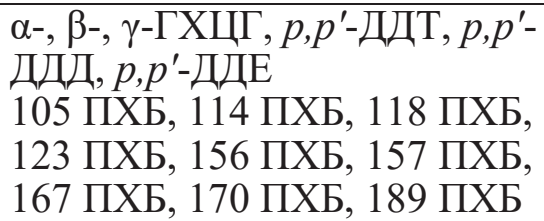 & {$[16]$} \\
\hline Crassostrea gigas & $\begin{array}{l}\text { Французское } \\
\text { Атлантическое } \\
\text { Побережье }\end{array}$ & 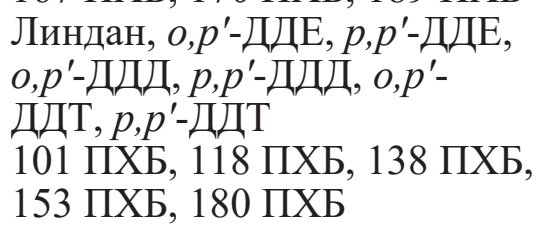 & {$[17]$} \\
\hline Mytilus galloprovincialis & Тунис & 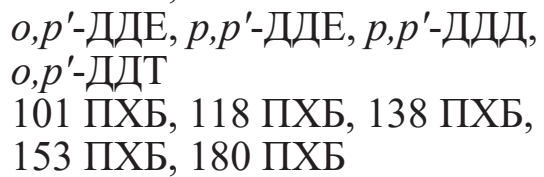 & [5] \\
\hline Adamussium colbecki & $\begin{array}{l}\text { Море Росса, } \\
\text { Антарктида }\end{array}$ & $\begin{array}{l}\text { Тетра-ХБ, Пента-ХБ, Гекса- } \\
\text { ХБ, Гепта-ХБ }\end{array}$ & {$[10]$} \\
\hline $\begin{array}{l}\text { Crassostrea virginica, Myti- } \\
\text { lus galloprovincialis, Mytilus } \\
\text { trossulus, and Mytilus cali- } \\
\text { fornianus }\end{array}$ & $\begin{array}{l}\text { Тихоокеанское } \\
\text { побережье } \\
\text { США }\end{array}$ & $\begin{array}{l}o, p^{\prime}-Д Д Е, p, p^{\prime}-Д Д Е, p, p^{\prime}-\text { ДДД, } \\
o, p^{\prime} \text {-ДДТ }\end{array}$ & {$[24]$} \\
\hline Perna viridis & Индонезия & $p, p^{\prime}$-ДДЕ, $p, p^{\prime}$-ДДД, $p, p^{\prime}$-ДДТ & [7] \\
\hline Crassostrea rivularis & Китай & $\begin{array}{l}\alpha-, \beta-, \gamma-\Gamma \text { ХЦ, } p, p^{\prime}-Д Д Е, p, p^{\prime}- \\
\text { ДДД, } o, p^{\prime} \text {-ДДТ, } p, p^{\prime}-\text {-ДТ }\end{array}$ & [8] \\
\hline \multicolumn{4}{|c|}{ Рыбы } \\
\hline Пресноводные виды рыб & Индия & $\begin{array}{l}\beta \text {-ГХЦГ, } p, p^{\prime}-\text { ДДЕ, } p, p^{\prime}-\text {-ДД, } \\
p, p^{\prime} \text {-ДДТ }\end{array}$ & [23] \\
\hline $\begin{array}{l}\text { Pseudotolithus senegalensis, } \\
\text { Mugil cephalus, Sphyraena } \\
\text { piscatorum }\end{array}$ & Нигерия & 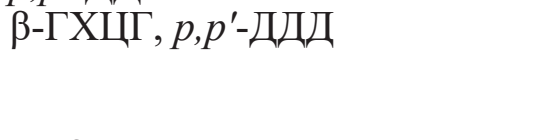 & [26] \\
\hline $\begin{array}{l}\text { Oreochromis mossambicus, } \\
\text { Clarias gariepinus }\end{array}$ & Южная Африка & 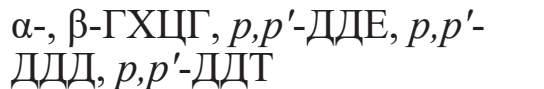 & [6] \\
\hline Промысловые виды рыб & Китай & 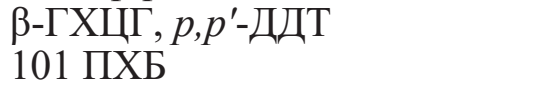 & [21] \\
\hline $\begin{array}{l}\text { Chitala chitala, Channa } \\
\text { striata, Rita rita, Clupisoma } \\
\text { gaura, Sperata seenghala, } \\
\text { Wallago attu, Cirrhinus }\end{array}$ & Пакистан & 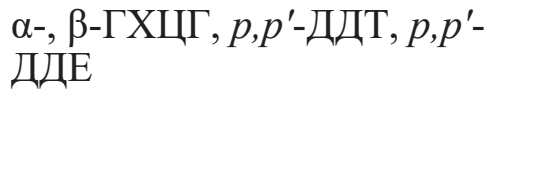 & {$[22]$} \\
\hline $\begin{array}{l}\text { mrigala, Catla catla, Cypri- } \\
\text { nus carpio, Labeo rohita, } \\
\text { Labeo dyocheilus, Cirrhinus } \\
\text { reba }\end{array}$ & & Гекса-ХБ, Тетра-ХБ, Три-ХБ & \\
\hline Salmo salar & Норвегия & 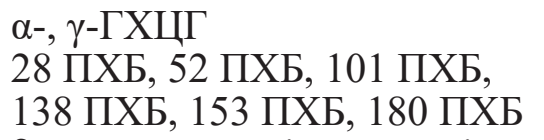 & [19] \\
\hline \multirow{2}{*}{$\begin{array}{l}\text { Oncorhynchus tshawytscha, } \\
\text { O. kisutch, O. nerka, O. keta, } \\
\text { Salmo salar }\end{array}$} & Канада & $\begin{array}{l}\beta-, \gamma-\Gamma Х Ц Г, p, p^{\prime}-Д Д Е, p, p^{\prime}- \\
\text { ДДД }\end{array}$ & [14] \\
\hline & & Пента-ХБ, Тетра-ХБ & \\
\hline
\end{tabular}


Таким образом, в разных регионах планеты могут использоваться разные композиции пестицидов, о чем свидетельствует различная их биотрансформация в среде и организмах. В дальневосточных морях России

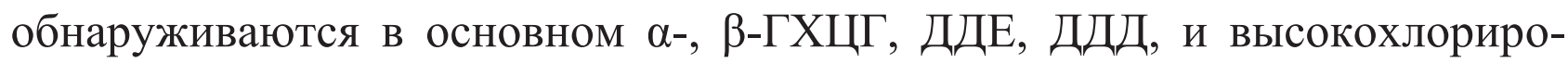
ванные ПХБ (101, 118, 153, 138 ПХБ).

\section{3. Заключение}

Хлорорганические соединения выявляются в основном в «распавшейся» форме, что говорит о выводе этих токсикантов из промышленного и сельскохозяйственного оборота. Наличие ПХБ в организмах дальневосточных морей вероятно обусловлено тем, что в России еще продолжается использование ПХБ-содержащего оборудования (трансформаторы, конденсаторы), однако в последние годы в нашей стране началась их активная утилизация. В энергосистемах топливно-энергетического комплекса России эксплуатируется около 7200 трансформаторов и около 360 тыс. конденсаторов, в которых ПХБ используется в качестве диэлектрика. Согласно требованиям Стокгольмской конвенции, использование ПХБсодержащего оборудования в России будет продолжаться до 2025 г. и к 2028 г. оно должно быть полностью ликвидировано.

\section{4. Список литературы}

1. Лобов, В.П. Пестициды. / В.П. Лобов, Г.А. Ефимов. - Киев: Гостехиздат УССР, 1963. - $276 \mathrm{c.}$

2. Abhilash, P.C. Pesticide use and application: An Indian scenario / P.C. Abhilash, N. Singh // Journal of Hazardous Materials. - 2009. - V. 165. No. 1-3. - P. 1-12.

3. Atapattu, S.S. Agriculture in South Asia and its implications on downstream health and sustainability: A review / S.S. Atapattu, D.C. Kodituwakku // Agricultural Water Management. - 2009. - V. 96. - No. 3. - P. 361-373. 
4. ATSDR. Toxicological profile for DDT, DDE, DDD / Agency for Toxic Substances and Disease Registry (ATSDR). - Atlanta, GA: U.S. Department of Health and Human Services, Public Health Service, 2002.

5. Barhoumi, B. Assessment of pollution in the Bizerte lagoon (Tunisia) by the combined use of chemical and biochemical markers in mussels, Mytilus galloprovincialis / B. Barhoumi, K.L. Menach, C. Clérandeau [et al.] // Marine Pollution Bulletin. - 2014. V. 84. - P. 379-390.

6. Buah-Kwofie, A. Bioaccumulation and risk assessment of organochlorine pesticides in fish from a global biodiversity hotspot: iSimangaliso Wetland Park, South Africa / A. Buah-Kwofie, M.S. Humphries, L. Pillay // Science of The Total Environment. - 2018. - V. 621. - P. 273-281.

7. Dwiyitno. Accumulation patterns of lipophilic organic contaminants in surface sediments and in economic important mussel and fish species from Jakarta Bay, Indonesia / Dwiyitno, L. Dsikowitzky, I. Nordhaus [et al.] // Marine Pollution Bulletin. - 2016. - V. 110. - P. 767-777.

8. Gan, J.L. Distribution and change of DDT and HCH levels in oysters (Crassostrea rivularis) from coast of Guangdong, China between 2003 and 2007 / J.L. Gan, X.P. Jia, T. Jia [et al.] // Journal of Environmental Science and Health, Part B. - 2009. - V. 44. - P. 817-822.

9. Gold, B. Metabolism of a DDT metabolite via a chloroepoxide / B. Gold, T. Leuschen, G. Brunk, R. Gingell // Chemico-Biological Interactions. $-1981 .-$ V. 35. - P. 159-176.

10. Grotti, M. Retrospective biomonitoring of chemical contamination in the marine coastal environment of Terra Nova Bay (Ross Sea, Antarctica) by environmental specimen banking / M. Grotti, S. Pizzini, M.L. Abelmoschi [et al.] // Chemosphere. - 2016. - V. 165. - P. 418-426.

11. Grung, M. Pesticide levels and environmental risk in aquatic environments in China - A review / M. Grung, Y. Lin, H. Zhang [et al.] // Environment International. - 2015. - V. 81. - P. 87-97.

12. Gupta, P. Pesticide exposure - Indian scene / P. Gupta // Toxicology. - 2004. - V. 198. - No. 1-3. - P. 83-90.

13. Kania-Korwel, I. Chiral polychlorinated biphenyls: absorption, metabolism and excretion - a review / I. Kania-Korwel, H.-J. Lehmler // Environmental Science and Pollution Research. - 2016. - V. 23. - P. 2042-2057.

14. Kelly, B.C. Flesh residue concentrations of organochlorine pesticides in farmed and wild salmon from British Columbia, Canada / B.C. Kelly, 
M.G. Ikonomou, D.A. Higgs [et al.] // Environmental Toxicology and Chemistry. -2011 . - V. 30. - P. 2456-2464.

15. Khan, M.J. Use of pesticides and their role in environmental pollution / M.J. Khan, M.S. Zia, M. Qasim // World Academy of Science, Engineering and Technology. - 2010. - V. 72. - P. 122-128.

16. Kljaković-Gašpić, Z. Biomonitoring of organochlorine compounds and trace metals along the Eastern Adriatic coast (Croatia) using Mytilus galloprovincialis / Z. Kljaković-Gašpić, S. Herceg-Romanić, D. Kožul, J. Veža // Marine Pollution Bulletin. - 2010. - V. 60. - P. 1879-1889.

17. Luna-Acosta, A. Persistent organic pollutants in a marine bivalve on the Marennes-Oléron Bay and the Gironde Estuary (French Atlantic Coast)-Part 1: Bioaccumulation / A. Luna-Acosta, H. Budzinski, K. Le Menach [et al.] // Science of The Total Environment. - 2015. - V. 514. - P. 500-510.

18. Merrington, G. Agricultural pollution: environmental problems and practical solutions / G. Merrington, L.W. Nfa, R. Parkinson, M. Redman, L. Winder. - Taylor \& Francis, 2004. - 264 p.

19. Nostbakken, O.J. Contaminant levels in Norwegian farmed Atlantic salmon (Salmo salar) in the 13-year period from 1999 to 2011 / O.J. Nostbakken, H.T. Hove, A. Duinker [et al.] // Environment International. 2015. - V. 74. - P. 274-280.

20. Pozo, K. Assessing seasonal and spatial trends of persistent organic pollutants (POPs) in Indian agricultural regions using PUF disk passive air samplers / K. Pozo, T. Harner, S.C. Lee [et al.] // Environmental Pollution. 2011. - V. 159. - No. 2. - P. 646-653.

21. Qian, Z. Indicator polychlorinated biphenyls (PCBs) and organochlorine pesticides (OCPs) in seafood from Xiamen (China): levels, distributions, and risk assessment / Z. Qian, F. Luo, C. Wu [et al.] // Environmental Science and Pollution Research. - 2017. - V. 24. - P. 10443-10453.

22. Robinson, T. Concentrations and patterns of organochlorines (OCs) in various fish species from the Indus River, Pakistan: A human health risk assessment / T. Robinson, U. Ali, A. Mahmood [et al.] // Science of The Total Environment. - 2016. - V. 541. - P. 1232-1242.

23. Samidurai, J. Levels of organochlorine pesticide residues in fresh water fishes of three bird sanctuaries in Tamil Nadu, India / J. Samidurai, M. Subramanian, D. Venugopal // Environmental Science and Pollution Research. - 2019. - V. 26. - P. 1983-1993. 
24. Sericano, J.L. Temporal trends and spatial distribution of DDT in bivalves from the coastal marine environments of the continental United States, 1986-2009 / J.L. Sericano, T.L. Wade, S.T. Sweet [et al.] // Marine Pollution Bulletin. - 2014. - V. 81. - P. 303-316.

25. Tanabe, S. Contamination by Persistent Toxic Substances in the AsiaPacific Region / S. Tanabe // Persistent Organic Pollutants in Asia: Sources, Distributions, Transport and Fate. - A. Li, S. Tanabe, G. Jiang, J.P. Giesy and P.K.S. Lam (Editors). - Developments in Environmental Science. - 2007. V. 7. - P. 773-817.

26. Unyimadu, J.P. Levels of Organochlorine Pesticides in Brackish Water Fish from Niger River, Nigeria / J.P. Unyimadu, O. Osibanjo, J.O. Babayemi // Journal of Environmental and Public Health. - 2018. V. 2018. - P. 1-9.

27. Walker, C.H. Variation in the intake and elimination of pollutants Organochlorine insecticide / C.H. Walker // Persistent organic pollutants. N.-Y.: Academic Press, 1975. - P. 73-131. 
https://doi.org/10.24866/7444-4891-2/249-262

\title{
ГЛАВА 10
}

\section{НЕЦЕЛЕВОЙ СКРИНИНГОВЫЙ АНАЛИЗ «НОВЫХ» СТОЙКИХ ОРГАНИЧЕСКИХ ЗАГРЯЗНЯЮЩИХ ВЕЩЕСТВ (СОЗ) В ДАЛЬНЕВОСТОЧНЫХ МОРЯХ}

\author{
В.Ю. Цыганков ${ }^{1,2}$, М.М. Донещ
}

Впервые для дальневосточного региона проведен нецелевой скрининговый анализ-поиск «новых» (non-target screening analysis) стойких органических загрязняющих веществ (СО3). Определение «нетрадиционных» $\mathrm{CO} 3$ в окружающей среде указывает на необходимость регулярного контроля с применением качественного и количественного анализа.

Ключевые слова: нецелевой скрининговый анализ; «новые» СО3; «традиционные» $\mathrm{CO}$; дальневосточные моря.

${ }^{1}$ Школа биомедицины, Дальневосточный федеральный университет (ДВФУ), 690922, Владивосток, о. Русский, п. Аякс, 10. E-mail: tsig_90@mail.ru

${ }^{2}$ Школа естественных наук, Дальневосточный федеральный университет (ДВФУ), 690922, Владивосток, о. Русский, п. Аякс, 10.

Для цитирования: Цыганков В.Ю., Донец М.М. Нецелевой скрининговый анализ «новых» стойких органических загрязняющих веществ (СО3) в Дальневосточных морях // Стойкие органические загрязняющие вещества (CO3) в Дальневосточном регионе: моря, организмы, человек : монография / В.Ю. Цыганков, М.М. Донец, Н.К. Христофорова [и др.] ; науч. ред. В.Ю. Цыганков. - Владивосток : Изд-во Дальневост. федерал. ун-та, 2020. - С. 249-262. - https://doi.org/10.24866/7444-48912/249-262.

For citing: Tsygankov V.Yu., Donets M.M. Non-targeting screening analysis of "new" persistent organic pollutants (POPs) in the Far Eastern Seas // Persistent organic pollutants (POPs) in the Far Eastern Region: Seas, Organisms, Human : monograph / V.Yu. Tsygankov, M.M. Donets, N.K. Khristoforova [et al.] ; ed. by V.Yu. Tsygankov. - Vladivostok : Publishing House of the Far Eastern Federal University, 2020. P. 249-262. - https://doi.org/10.24866/7444-4891-2/249-262. 


\section{CHAPTER 10. Non-targeting screening analysis of "new" persistent organic pollutants (POPs) in the Far Eastern Seas}

\section{V.Yu. Tsygankov ${ }^{1,2}$, M.M. Donets ${ }^{1}$}

For the first time for the Far East region, a non-target screening analysis of "new" persistent organic pollutants (POPs) was carried out. The determination of "old" POPs in the environment indicates the need for regular monitoring using qualitative and quantitative analysis.

Keywords: non-target screening analysis; "new” POPs; "old” POPs; Far Eastern seas.

Анализ сложных смесей в образцах окружающей среды является чрезвычайно сложной задачей. Поскольку матрица выборки в большинстве случаев сложная, традиционные следовые аналитические методы были специально разработаны для определенного типа образца и группы веществ. Этот традиционный целевой подход обеспечивает хорошую чувствительность, надежную идентификацию, количественную оценку соединений-мишеней и успешно используется в течение нескольких десятилетий. Однако, этот традиционный подход имеет существенный недостаток, поскольку он всегда будет пропускать все неизвестные соединения или другие нецелевые вещества даже в высоких концентрациях или с сильным токсическим потенциалом. Имеются веские основания полагать, что концентрация неизвестных соединений превышает концентрацию известных. Во многих случаях исследования эффективности показали, что концентрации известных соединений недостаточно велики для объяснения некоторых токсических потенциалов образцов $[1,3]$. Чтобы заполнить этот пробел в знаниях, нецелевые методы скрининга являются очень важными инструментами для экологической химии. В течение последнего десятилетия разработаны новые аналитические аппаратные и программные средства, которые делают нецелевой подход к экранированию гораздо более реалистичным и доступным сегодня, чем в предыдущие годы. Иссле- 
дования СО3 в настоящее время наряду с «традиционными приоритетными загрязнителями» сосредоточены на «новых загрязнителях» окружающей среды, которые присутствуют в среде на следовых уровнях, но обладают высокой токсичностью. В литературе мало сообщений, в которых используется режим полного сканирования для нецелевого скрининга токсичных соединений в живых организмах $[2,4,5]$.

В течение последнего десятилетия масс-спектрометрия (МС), основанная на технологии времени пролета (time of flight (TOF-MS)), стала более доступной, стабильной и полезной для экологического анализа. TOFMS приобретает полный масс-спектр с гораздо лучшей чувствительностью, чем стандартная квадрупольная ловушка $\mathrm{MC}$, и делает его универсальным инструментом как для целевого, так и для нецелевого анализа загрязняющих веществ окружающей среды. В сочетании с газовой или жидкостной хроматографией (GC-MS или LC-MS) можно выделить и обнаружить очень широкий диапазон химических соединений.

В нецелевом подходе, который также называется «неизвестным скринингом», информация о загрязняющих веществах в образце отсутствует. Информация о веществах выводится исключительно из хроматограмм и масс-спектров. Информация, полученная из MS-детектора, обычно огромна и требует автоматической оценки записанных файлов данных. NIST/EPA/NIH/PESTICIDES/AMDIS (автоматические идентификационные библиотеки) - это программное обеспечение, которое не только идентифицирует скрытые соединения, но и ускоряет оценку полномасштабного анализа на основе GC-MS и является надежным инструментом для экологических и токсикологических исследований.

\section{1. «Новые» СОЗ в дальневосточных морях России}

В нашем исследовании был использован GC-MS (Shimadzu GCMSQP2010 Ultra). Примеры хроматограммы при нецелевом скрининговом анализе представлены на рисунках 10.1 и 10.2. 


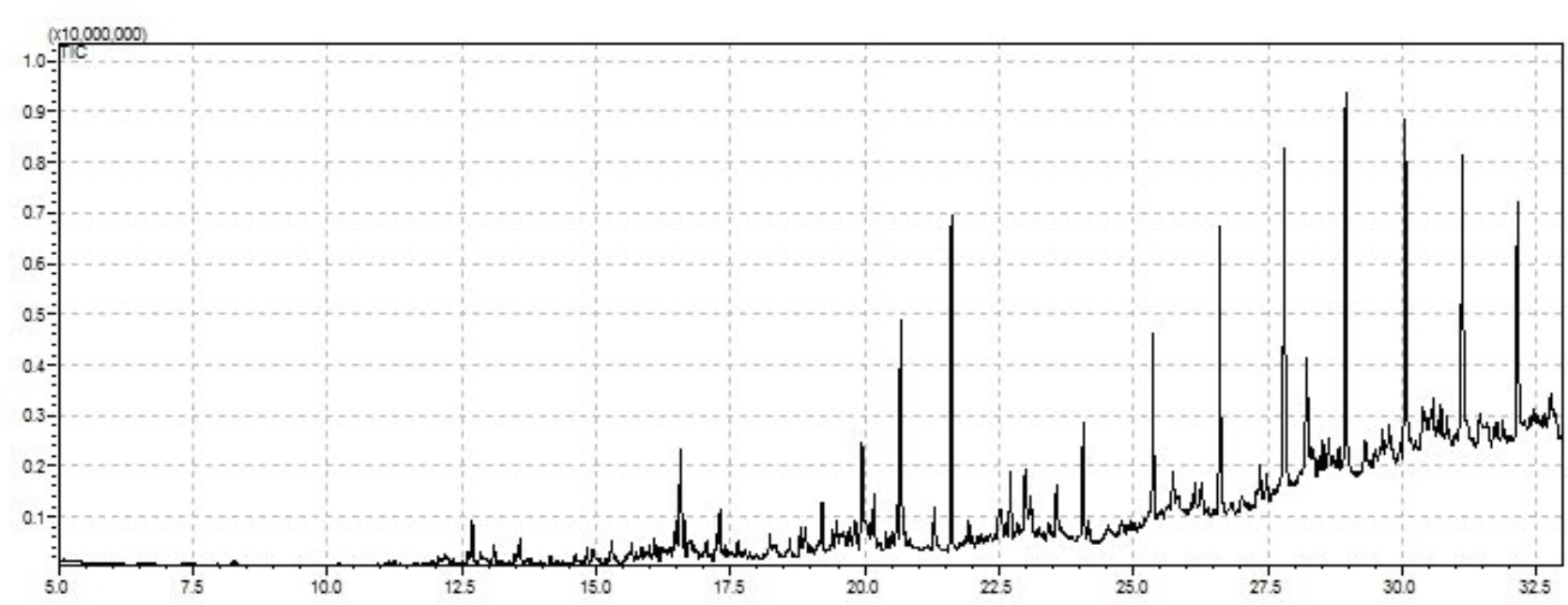

Puc. 10.1. Неразмеченная хроматограмма пробы (пример) при нецелевом скрининговом анализе на Shimadzu GCMS-QP2010 Ultra

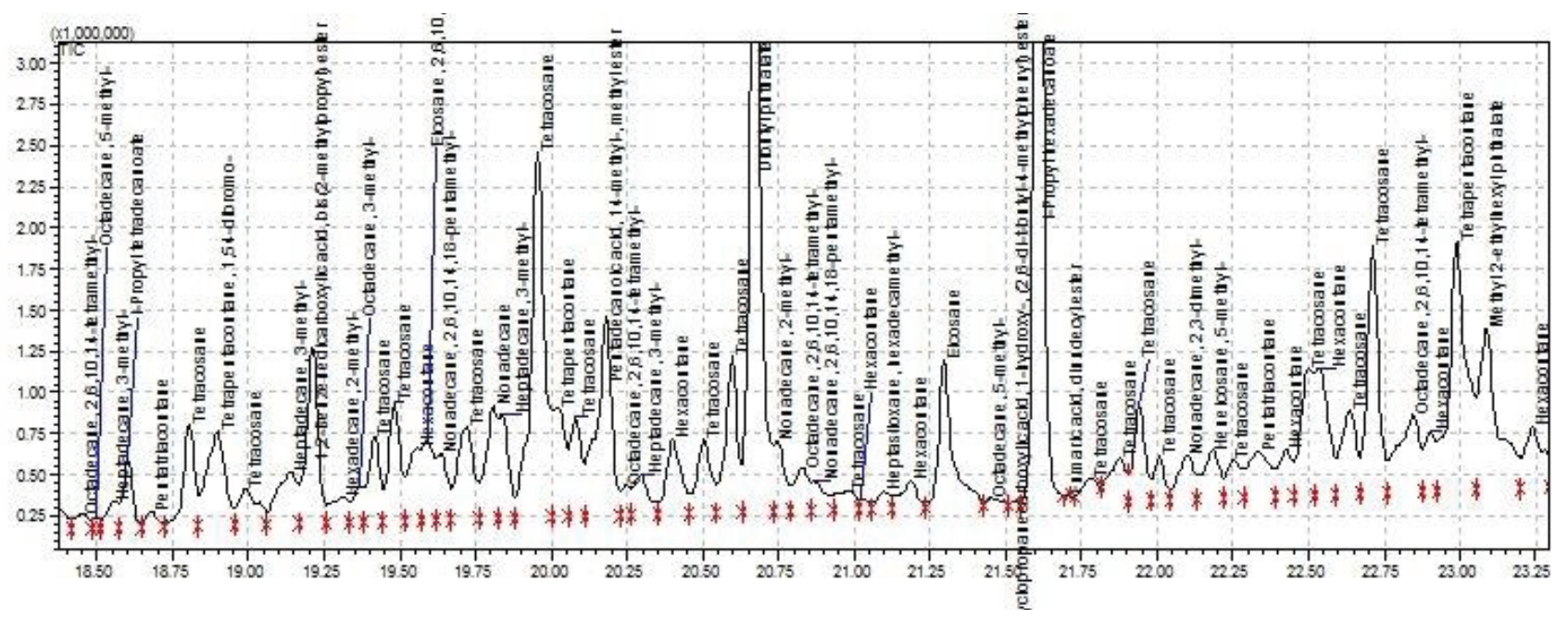

Puc. 10.2. Размеченная хроматограмма пробы (пример) при нецелевом скрининговом анализе на Shimadzu GCMS-QP2010 Ultra

За 10 лет изучения СО3 в дальневосточных морях нами собран банк проб, который насчитывает около 10000 образцов. Пробоподготовку использовали стандартную, описанную в Главе 2, только при качественной идентификации использовали не стандарты, а библиотеки NIST/EPA/NIH/PESTICIDES/AMDIS (автоматические идентификационные библиотеки). Пробы из банка отбирались выборочно по матрицам рыбы, птицы, человек. Достоверность обнаруженных соединений смотрели по соответствию их стандартным веществам (не менее $80 \%$ ) из библиотеки. «Традиционные» $\mathrm{CO} 3$, обнаруженные при нецелевом анализе представлены в таблице 10.1. Спектр «новых» СО3 представлен в таблице 10.2. 
Таблица 10.1

\section{Наиболее часто встречающиеся «традиционные» органические соединения при нецелевом скрининге проб из дальневосточных морей}

\begin{tabular}{|c|c|}
\hline $\begin{array}{l}\text { Название } \\
\text { вещества, } \\
\text { номер CAS }\end{array}$ & Другие названия (по CAS Common Chemistry и PubChem) \\
\hline$\alpha-Г Х Ц Г ~$ & $(1 \alpha, 2 \alpha, 3 \beta, 4 \alpha, 5 \beta, 6 \beta)-1,2,3,4,5,6-$ Hexachlorcyclohexan; $(1 \alpha, 2 \alpha, 3 \beta, 4 \alpha, 5 \beta, 6 \beta)-$ \\
\hline $319-84-6$ & $\begin{array}{l}\text { 1,2,3,4,5,6-Hexachlorocyclohexane; }(1 \alpha, 2 \alpha, 3 \beta, 4 \alpha, 5 \beta, 6 \beta)-1,2,3,4,5,6- \\
\text { hexaclorociclohexano; ALPHA-1,2,3,4,5,6-HEXACHLORCYCLOHEXAN; } \\
\text { Cyclohexane, } 1,2,3,4,5,6 \text {-hexachloro-, }(1 \alpha, 2 \alpha, 3 \beta, 4 \alpha, 5 \beta, 6 \beta)-; \text { Cyclohexane, } \\
\text { 1,2,3,4,5,6-hexachloro-, } \alpha \text {-; Hexachlorocyclohexane; } \alpha-1,2,3,4,5,6- \\
\text { Hexachlorocyclohexane; } \alpha \text {-666; } \alpha \text {-Benzenehexachloride; } \alpha \text {-Benzohexachloride; } \alpha \text { - } \\
\text { BHC; } \alpha \text {-HCH; } \alpha \text {-Hexachloran; } \alpha \text {-Hexachlorane; } \alpha \text {-Hexachlorcyclohexane; } \alpha- \\
\text { Hexachlorocyclohexane; } \alpha \text {-Lindane. }\end{array}$ \\
\hline 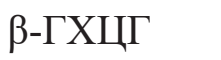 & $(1 \alpha, 2 \beta, 3 \alpha, 4 \beta, 5 \alpha, 6 \beta)-1,2,3,4,5,6-$ Hexachlorcyclohexan; $(1 \alpha, 2 \beta, 3 \alpha, 4 \beta, 5 \alpha, 6 \beta)-$ \\
\hline $319-85-7$ & $\begin{array}{l}\text { 1,2,3,4,5,6-Hexachlorocyclohexane; }(1 \alpha, 2 \beta, 3 \alpha, 4 \beta, 5 \alpha, 6 \beta)-1,2,3,4,5,6- \\
\text { hexaclorociclohexano; BETA-1,2,3,4,5,6-HEXACHLORCYCLOHEXAN; } \\
\text { Cyclohexane, } 1,2,3,4,5,6 \text {-hexachloro-, }(1 \alpha, 2 \beta, 3 \alpha, 4 \beta, 5 \alpha, 6 \beta)-; \text { Cyclohexane, } \\
\text { 1,2,3,4,5,6-hexachloro-, } \beta \text {-; Hexachlorocyclohexane; } \beta-1,2,3,4,5,6- \\
\text { Hexachlorocyclohexane; } \beta-666 ; \beta \text {-Benzene hexachloride; } \beta \text {-BHC; } \beta \text {-HCH; } \beta \text { - } \\
\text { Hexachloran; } \beta \text {-Hexachlorobenzene; } \beta \text {-Hexachlorocyclohexane; } \beta \text {-Lindane. }\end{array}$ \\
\hline$\gamma$-ГХЦГ & $(1 \alpha, 2 \alpha, 3 \beta, 4 \alpha, 5 \alpha, 6 \beta)-1,2,3,4,5,6-$ Hexachlorocyclohexane; $1,2,3,4,5,6-\mathrm{G}-$ \\
\hline $58-89-9$ & $\begin{array}{l}\text { HEXACHLOROCYCLOHEXANE; 1,2,3,4,5,6-Hexachlorocyclohexane; 666; Aal- } \\
\text { indan; Aficide; Agrocide; Agrocide III; Agrocide WP; Ameisenmittel Merck; Apara- } \\
\text { sin; Aphtiria; Aplidal; BHC; BHC (insecticide); Celanex; Chloresene; Codechine; } \\
\text { Cyclohexane, 1,2,3,4,5,6-hexachloro-, }(1 \alpha, 2 \alpha, 3 \beta, 4 \alpha, 5 \alpha, 6 \beta)-\text {; Cyclohexane, } \\
\text { 1,2,3,4,5,6-hexachloro-, } \gamma \text {-; DBH; Detmol Extract; Entomoxan; Esoderm; Fenoform } \\
\text { forte; Gamacid; Gamacide; Gamacide } 20 \text {; Gamene; Gamma benzene hexachloride; } \\
\text { Gamma-HCH; Gammalin; Gexane; HCC; HCCH; HCH; Heclotox; Hexatin; Lidano } \\
\text { (HCH); Lidenal; Lindafor; Lindane; Lindane (g-BHC or g-HCH); Lindane [cyclohex- } \\
\text { ane, 1,2,3,4,5,6-hexachloro-(1 } \alpha, 2 \alpha, 3 \beta, 4 \alpha, 5 \alpha, 6 \beta)-] ; \gamma-1,2,3,4,5,6- \\
\text { Hexachlorocyclohexane; } \gamma-666 ; \gamma \text {-Benzene hexachloride; } \gamma \text {-Benzohexachloride; } \gamma \text { - } \\
\text { BHC; } \gamma \text {-HCH; } \gamma \text {-HCH or } \gamma \text {-BНС и др. }\end{array}$ \\
\hline$\delta$-ГХЦГ & $(1 \alpha, 2 \alpha, 3 \alpha, 4 \beta, 5 \alpha, 6 . \beta)-1,2,3,4,5,6-H e x a c h l o r o c y c l o h e x a n e ;(1 \alpha, 2 \alpha, 3 \alpha, 4 \beta, 5 \alpha, 6 \beta)-$ \\
\hline $319-86-8$ & $\begin{array}{l}\text { 1,2,3,4,5,6-Hexachlorcyclohexan; }(1 \alpha, 2 \alpha, 3 \alpha, 4 \beta, 5 \alpha, 6 \beta)-1,2,3,4,5,6- \\
\text { hexachlorocyclohexane; }(1 \alpha, 2 \alpha, 3 \alpha, 4 \beta, 5 \alpha, 6 \beta)-1,2,3,4,5,6 \text {-hexaclorociclohexano; } \\
\text { Cyclohexane, 1,2,3,4,5,6-hexachloro-, }(1 \alpha, 2 \alpha, 3 \alpha, 4 \beta, 5 \alpha, 6 \beta)-; \text { Cyclohexane, } \\
\text { 1,2,3,4,5,6-hexachloro-, } \delta \text {-; Delta-BHC; Hexachlorocyclohexane; } \delta \text {-1,2,3,4,5,6- } \\
\text { Hexachlorocyclohexane; } \delta \text {-666; } \delta \text {-Benzene hexachloride; } \delta \text {-BHC; } \delta \text {-HCH; } \delta \text { - } \\
\text { Hexachlorocyclohexane; } \delta \text {-Lindane. }\end{array}$ \\
\hline$o, p$ '-ДДТ & (.+-.)-1-(o-Chlorophenyl)-1-(p-chlorophenyl)-2,2,2-trichloroethane; (.+-.)-o,p'-DDT; \\
\hline $789-02-6$ & $\begin{array}{l}\text { 1-(2-Chlorophenyl)-1-(4-chlorophenyl)-2,2,2-trichloroethane; 1-(o-Chlorophenyl)-1- } \\
\text { (p-chlorophenyl)-2,2,2-trichloroethane; 1,1,1-Trichloro-2-(o-chlorophenyl)-2-(p- } \\
\text { chlorophenyl)ethane; 2-(2-Chlorophenyl)-2-(4-chlorophenyl)-1,1,1-trichloroethane; } \\
\text { 2,2,2,o,p'-Pentachlorethylidenbisbenzol } \\
\text { 2,2,2,o,p'-pentachloroethylidenebisbenzene; 2,2,2,o,p'-pentacloroetilidenbisbenceno; } \\
\text { 2,4'-DDT; 2,4'-Dichlorodiphenyltrichloroethane; Benzene, 1-chloro-2-[2,2,2- } \\
\text { trichloro-1-(4-chlorophenyl)ethyl]-; Ethane, 1,1,1-trichloro-2-(o-chlorophenyl)-2-(p- } \\
\text { chlorophenyl)-; NSC 33446; NSC 57644; o,p'-Chlorophenothane; o,p'-DDT }\end{array}$ \\
\hline p,p’-ДДТ & 1,1,1-Trichloro-2,2-bis(4-chlorophenyl) ethane; 1,1,1-Trichloro-2,2-bis(p- \\
\hline
\end{tabular}


50-29-3 chlorophenyl)ethane; 1,1,1-Trichloro-2,2-di(p-chlorophenyl)ethane; 1,1-Bis(4chlorophenyl)-2,2,2-trichloroethane 1,1-Bis(p-chlorophenyl)-2,2,2-trichloroethane; 2,2,2-Trichloro-1,1-bis(4-chlorophenyl)ethane; 2,2-bis(p-Chlorophenyl)-1,1,1trichloroethane; 4,4'-DDT; 4,4'-Dichlorodiphenyltrichloroethane; 4,4Dichlorodiphenyl-trichloroethane; Aavero-extra; Agritan; Arkotine; Benzene, 1,1'(2,2,2-trichloroethylidene)bis[4-chloro-; Benzene, 1,1'-(2,2,2-

trichloroethylidene)bis[4-chloro-; Benzene, 1,1'-(2,2,2-trichloroethylidene)bis[4chloro-; Benzochloryl; Bovidermol; Chlorophenothane; Chlorphenothan; Chlorphenotoxum; Citox; D.D.T.; DDT; Deoval; Detox; Detox (pesticide); Detoxan; Dibovin; Dichlorodiphenyltrichloroethane; Dicophane; ENT-1506; Estonate; Ethane, 1,1,1trichloro-2,2-bis(4-chlorophenyl)-; Ethane, 1,1,1-trichloro-2,2-bis(p-chlorophenyl)-; ETHANE, 1,1-BIS(4-CHLOROPHENYL)-2,2,2-TRICHLORO-; Gesafid; NSC 8939; p,p'-DDT; p,p'-Dichlorodiphenyltrichloroethane; p,p'-

Dichlorodiphenyltrichloromethylmethane и др.

o,p'-ДДД 1-(2-Chlorophenyl)-1-(4-chlorophenyl)-2,2-dichloroethane; 1-(o-Chlorophenyl)-1-(p53-19-0 chlorophenyl)-2,2-dichloroethane; 1,1-Dichloro-2-(o-chlorophenyl)-2-(pchlorophenyl)ethane; 2-(2-Chlorophenyl)-2-(4-chlorophenyl)-1,1-dichloroethane; 2(p-Chlorophenyl)-2-(o-chlorophenyl)-1,1-dichloroethane; 2,4'-

Dichlorodiphenyldichloroethane; Benzene, 1-chloro-2-[2,2-dichloro-1-(4chlorophenyl)ethyl]-; Benzene, 1-chloro-2-[2,2-dichloro-1-(4-chlorophenyl)ethyl]-; CB 313; Chloditan; Chlodithane; Ethane, 1,1-dichloro-2-(o-chlorophenyl)-2-(pchlorophenyl)-; Lysodren; Mitotan; Mitotan; mitotane; mitotano; NSC 38721; o,p'DDD; o,p'-Dichlorodiphenyldichloroethane; o,p'-TDE; Opeprim.

p,p'-ДДД 1,1'-(2,2-Dichloroethylidene)bis[4-chlorobenzene]; 1,1-Bis(4-chlorophenyl)-2,2$72-54-8$ dichloroethane; 1,1-Bis(p-chlorophenyl)-2,2-dichloroethane; 1,1-Dichloro-2,2-bis(4chlorophenyl)ethane; 1,1-Dichloro-2,2-bis(p-chlorophenyl)ethane; 2,2-Bis(4chlorophenyl)-1,1-dichloroethane; 2,2-bis(para-Chlorophenyl)-1,1-dichloroethane; 2,2-Bis(p-chlorophenyl)-1,1-dichloroethane; 4,4'-DDD; 4,4'-

Dichlorodiphenyldichloroethane; 4,4'-TDE; Benzene, 1,1'-(2,2dichloroethylidene)bis[4-chloro-; Benzene, 1,1'-(2,2-dichloroethylidene)bis[4-chloro-; Benzene, 1,1'-(2,2-dichloroethylidene)bis[4-chloro-; DDD; Dichlorodiphenyl dichloroethane; Dichlorodiphenyldichloroethane; DICHLORODIPHENYLDICHLOROETHANE (DDD); Dilene; Ethane, 1,1-dichloro-2,2-bis(p-chlorophenyl)-; ME 1700; NSC 8941; p,p'-DDD; p,p'-Dichlorodiphenyldichloroethane; p,p'Dichlorodiphenylethylene dichloride; p,p'-TDE; Rhothane; TDE; TDE (1,1DICHLORO-2,2-BIS(P-CHLOROPHENYL)ETHANE); UN 2761

o,p'-ДДЕ 1,1-Dichloro-2-(o-chlorophenyl)-2-(p-chlorophenyl)ethylene; 2-(2-Chlorophenyl)-23424-82-6 (4-chlorophenyl)-1,1-dichloroethylene; 2,2,o,p'-tetrachlorovinylidenebisbenzene; 2,2,o,p'-Tetrachlorvinylidenbisbenzol; 2,2,o,p'-tetraclorovinilidenobisbenceno; 2,4'DDE; 2,4'-Dichlorodiphenyldichloroethylene; Benzene, 1-chloro-2-[2,2-dichloro-1(4-chlorophenyl)ethenyl]-; Ethylene, 1,1-dichloro-2-(o-chlorophenyl)-2-(pchlorophenyl)-; NSC 59908; o,p'-DDE.

p,p'-ДДЕ 1,1'-(Dichloroethenylidene)bis(4-chlorobenzene); 1,1-Bis(4-chlorophenyl)-2,272-55-9 dichloroethene; 1,1-BIS-(4-CHLORPHENYL)-2,2-DICHLOR-AETHEN; 1,1-Bis(pchlorophenyl)-2,2-dichloroethylene; 1,1-Dichloro-2,2-bis(p-chlorophenyl)ethylene; 1,1-Dichloro-2,2-di(p-chlorophenyl)ethylene; 2,2-bis(4-Chlorophenyl)-1,1dichloroethylene; 2,2-bis(p-chlorophenyl)-1,1-dichloroethylene; 2,2-Bis(pchlorphenyl)-1,1-dichlorethylen; 2,2-bis(p-clorofenil)-1,1-dicloroetileno; 2,2Dichloro-1,1-bis(4-chlorophenyl)ethylene; 4,4'-DDE; 4,4'-

Dichlorodiphenyldichloroethylene; Benzene, 1,1'-(2,2-dichloroethenylidene)bis[4chloro-; Benzene, 1,1'-(dichloroethenylidene)bis(4-chloro-; Benzene, 1,1'- 
(dichloroethenylidene)bis[4-chloro-; Benzene, 1,1'-(dichloroethenylidene)bis[4chloro-; Benzene, 1,1'-(dichloroethenylidene)bis[4-chloro-; DDE; Dichloro diphenyl dichloroethane; DICHLORODIPHENYLDICHLOROETHYLENE (DDE); Ethylene, 1,1-dichloro-2,2-bis(p-chlorophenyl)-; Ethylene, 1,1-dichloro-2,2-bis(pchlorophenyl)-,; NSC 1153; p,p'-DDE; p,p'-Dichlorodiphenyldichloroethylene; UN 2761

ПХБ 28 1,1'-Biphenyl, 2,4,4'-trichloro-; 2,4,4'-Trichlorbiphenyl; 2,4,4'-Trichloro-1,1'-

7012-37-5 biphenyl; 2',4,4'-Trichlorobiphenyl; 2,4,4'-trichlorobiphenyl; 2,4,4'trichlorobiphenyle; 2,4,4'-triclorobifenilo; 4,2',4'-Trichloro-1,1'-biphenyl; 4,2',4'Trichlorobiphenyl; Biphenyl, 2,4,4'-trichloro-; CB 28; K 28; PCB 28

ПХБ 52 1, 1'-Biphenyl, 2,2',5,5'-tetrachloro-; 2,2',5,5'-TCB; 2,2',5,5'-Tetrachloro-1,1'-biphenyl; 35693-99-3 2,2',5,5'-Tetrachlorobiphenyl; 2,5,2',5'-Tetrachlorobiphenyl; CB 52; K 52; PCB 52 ПХБ 155 2,2',4,4',6,6'-hexachlorobiphenyl; 2,4,6,2',4',6'-hexachlorobiphenyl; 246-HCB; PCB33979-03-2 155

ПХБ 101 1,1'-Biphenyl, 2,2',4,5,5'-pentachloro-; 2,2',4,5,5'-PCB; 2,2',4,5,5'-Pentachloro-1,1'37680-73-2 biphenyl; 2,2',4',5,5'-Pentachlorobiphenyl; 2,2',4,5,5'-Pentachlorobiphenyl; 2,4,5,2',5'Pentachlorobiphenyl; 2,5,2',4',5'-Pentachlorobiphenyl; CB 101; K 101; PCB 101

ПХБ 118 1,1'-Biphenyl, 2,3',4,4',5-pentachloro-; 2,3',4,4',5-Pentachloro-1,1'-biphenyl; 31508-00-6 2,3',4,4',5-Pentachlorobiphenyl; 2,4,5,3',4'-Pentachlorobiphenyl; 3,4,2',4',5'Pentachlorobiphenyl; Biphenyl, 2,3',4,4',5-pentachloro-; CB 118; PCB 118

ПХБ 143 2,2',3,4,5,6'-Hexachlorobiphenyl; 1,1'-Biphenyl, 2,2',3,4,5,6'-hexachloro-; 1,1'-

68194-15-0 Biphenyl,2,2',3,4,5,6'-hexachloro-; 2,2',3,4,5,6'-Hexachloro-1,1'-biphenyl; 1,2,3,4tetrachloro-5-(2,6-dichlorophenyl)benzene; PCB 143 (2,2',3,4,5,6'Hexachlorobiphenyl)

ПХБ 153 1,1'-Biphenyl, 2,2',4,4',5,5'-hexachloro-; 1,1'-Biphenyl, 2,2',4,4',5,5'-hexachloro-; 35065-27-1 2,2',4,4',5,5'-HEXACHLORBIPHENYL; 2,2',4,4',5,5'-Hexachloro-1,1'-biphenyl; 2,2',4,4',5,5'-Hexachlorobiphenyl; 2,4,5,2',4',5'-Hexachlorobiphenyl; Biphenyl, 2,2',4,4',5,5'-hexachloro-; CB 153; K 153; PCB 153; UN 2315

ПХБ 138 1,1'-Biphenyl, 2,2',3,4,4',5'-hexachloro-; 2,2',3,4,4',5'-Hexachloro-1,1'-biphenyl; 35065-28-2 2,2',3',4,4',5-Hexachlorobiphenyl; 2,2',3,4,4',5'-Hexachlorobiphenyl; 2,3,4,2',4',5'Hexachlorobiphenyl; 2,4,5,2',3',4'-Hexachlorobiphenyl; CB 138; K 138; PCB 138 ПХБ 180 1,1'-Biphenyl, 2,2',3,4,4',5,5'-heptachloro-; 2,2',3,4,4',5,5'-Heptachloro-1,1'-biphenyl; 35065-29-3 2,2',3,4,4',5,5'-Heptachlorobiphenyl; 2,3,4,5,2',4',5'-Heptachlorobiphenyl; CB 180; K 180 ; PCB 180 


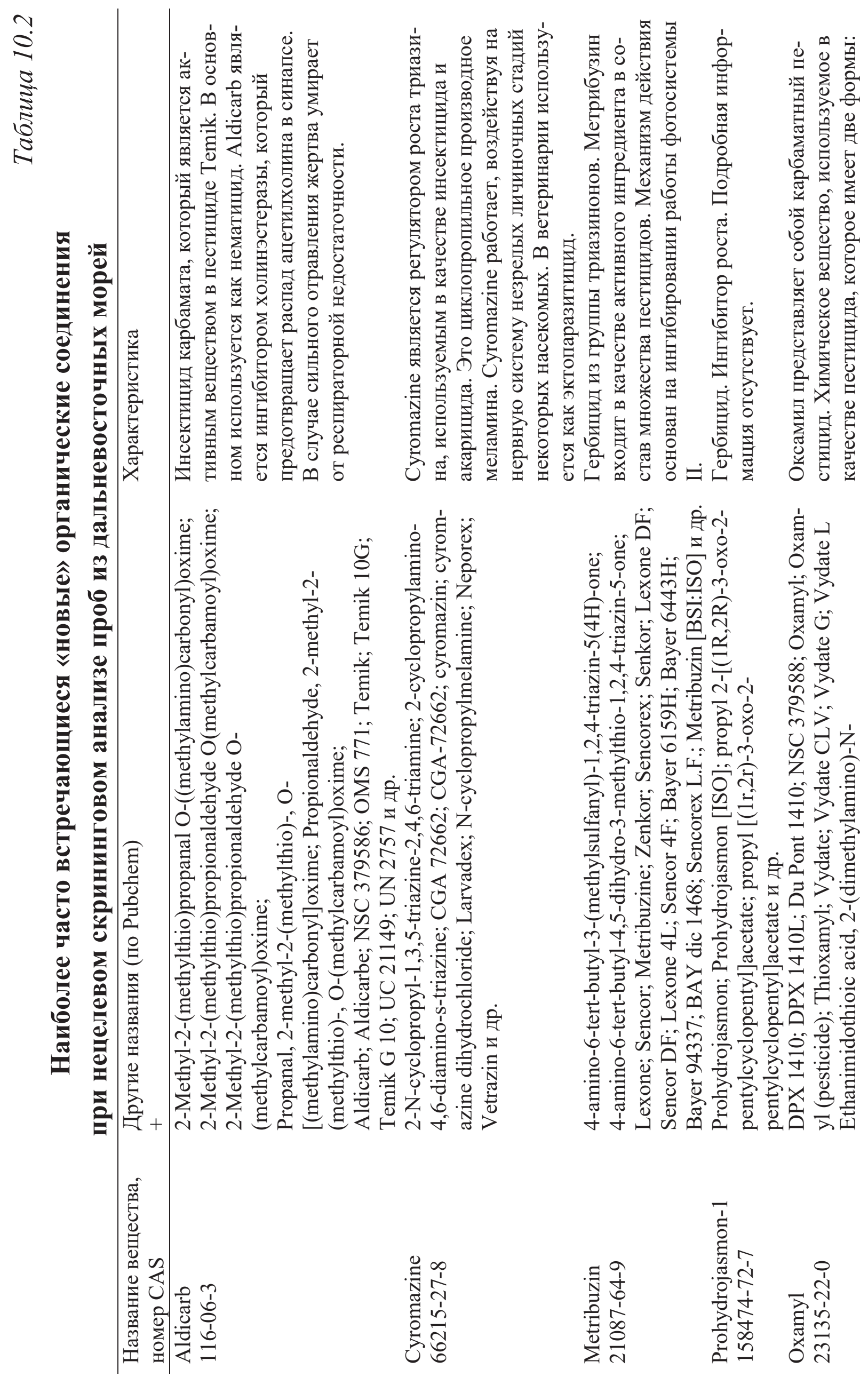



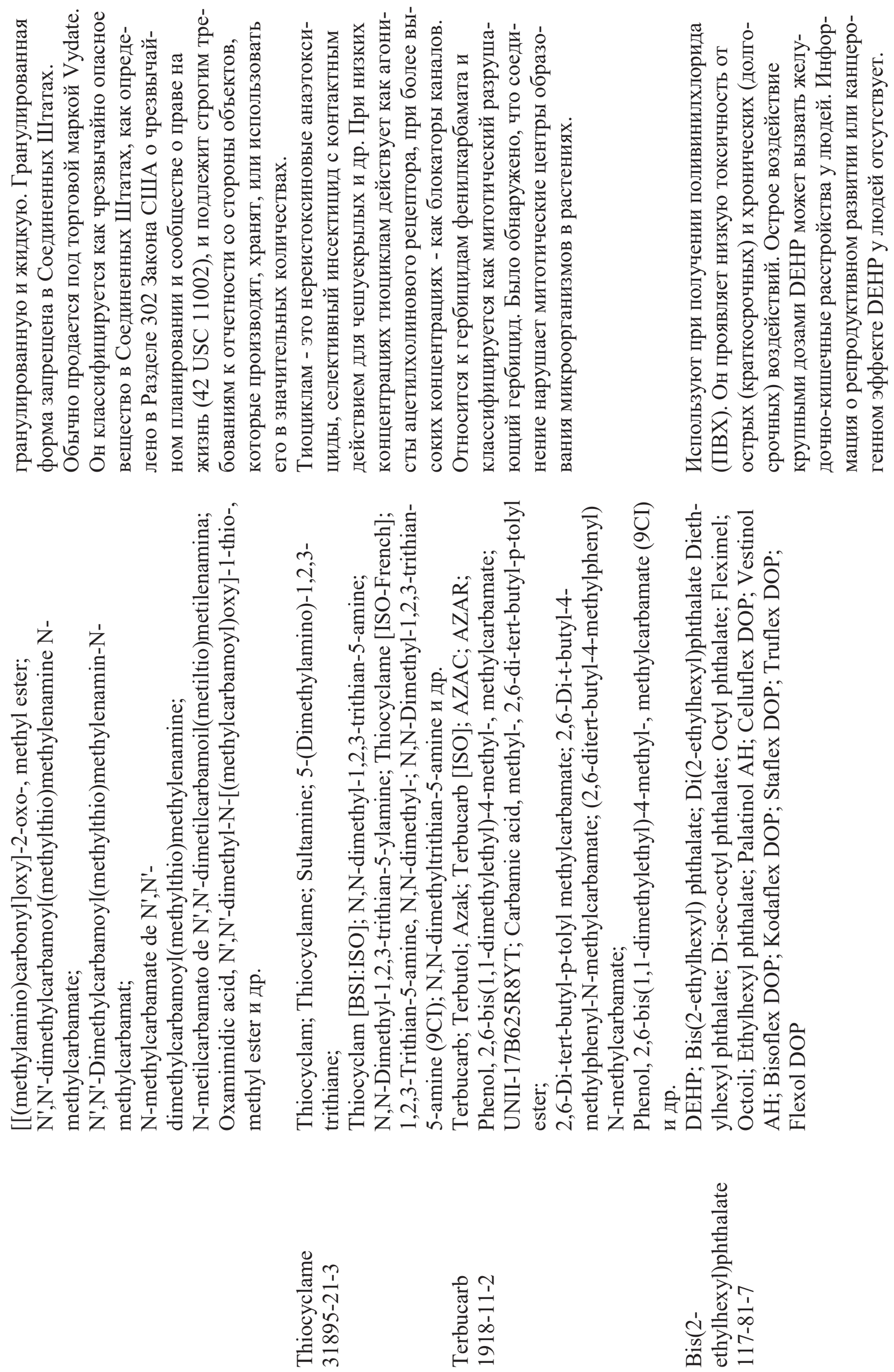


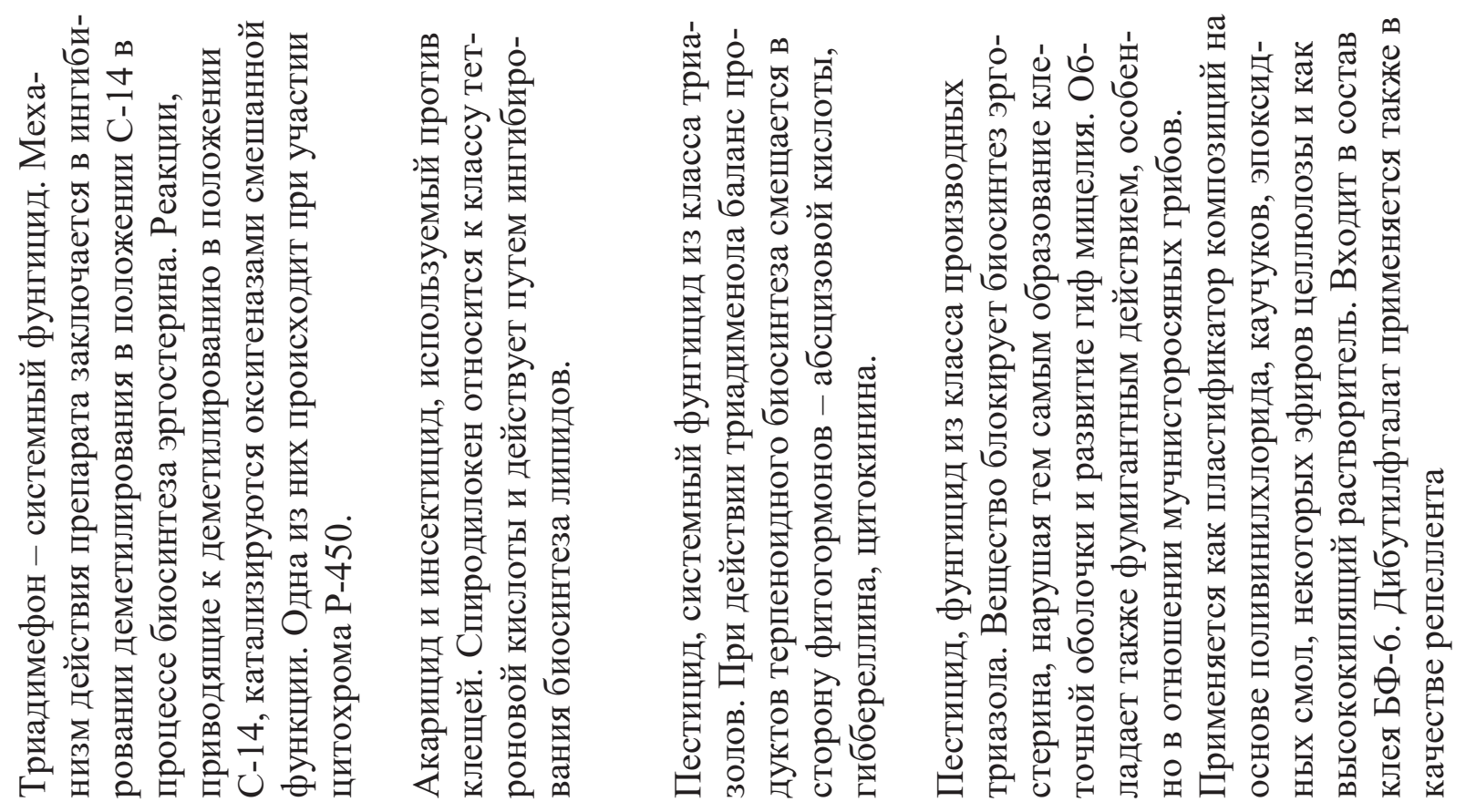

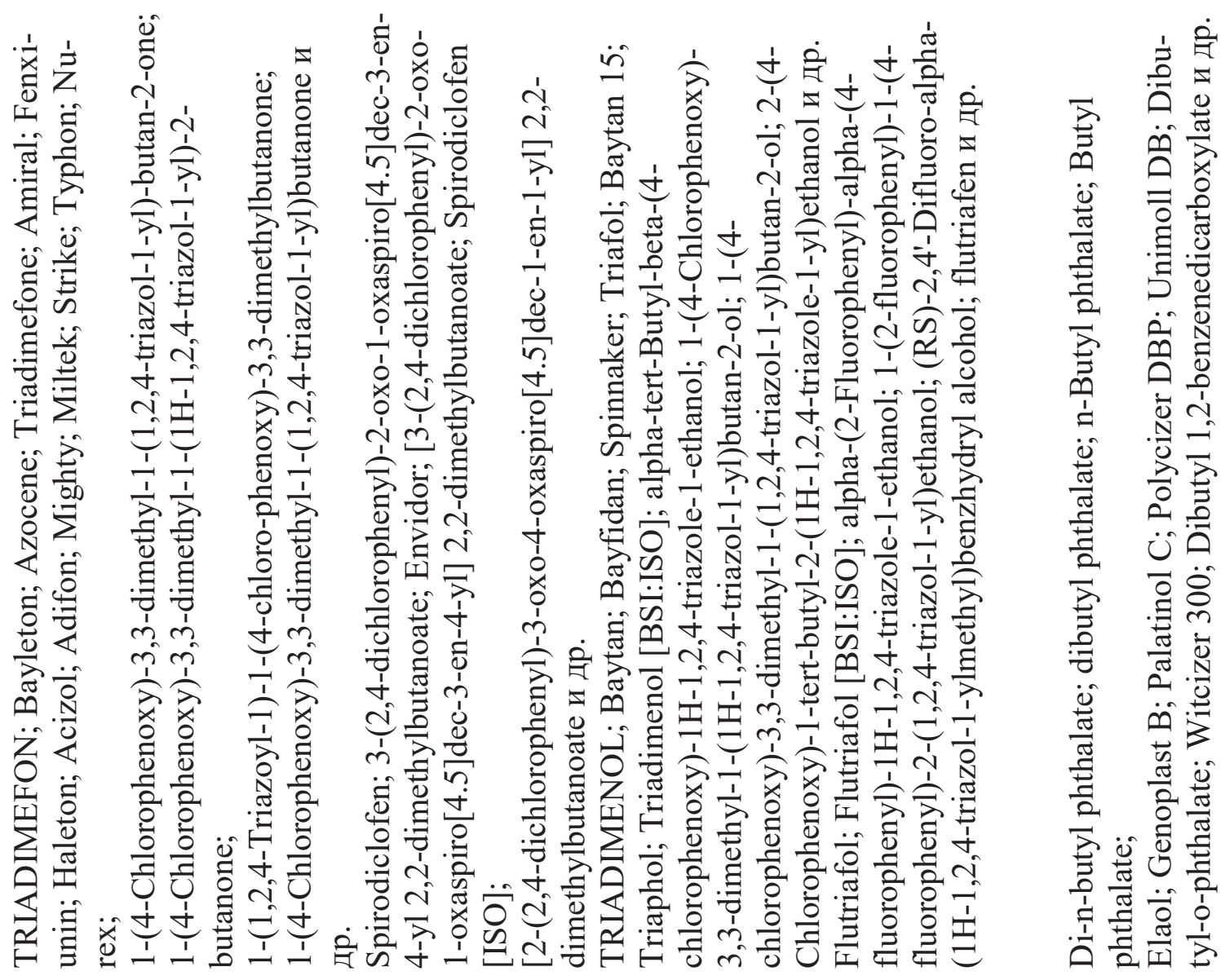

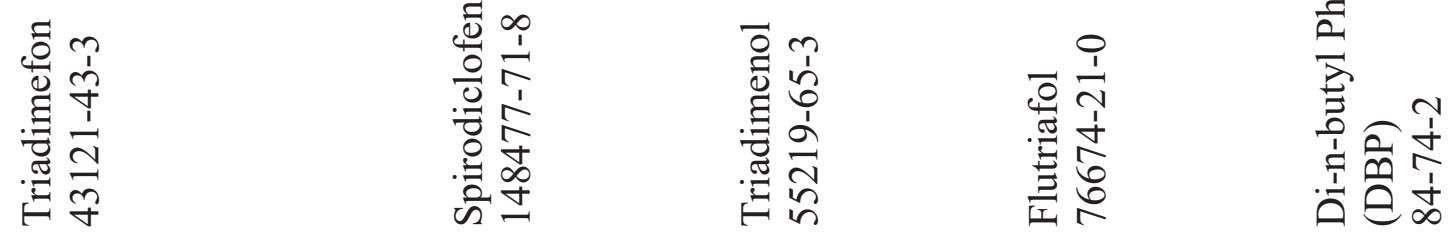



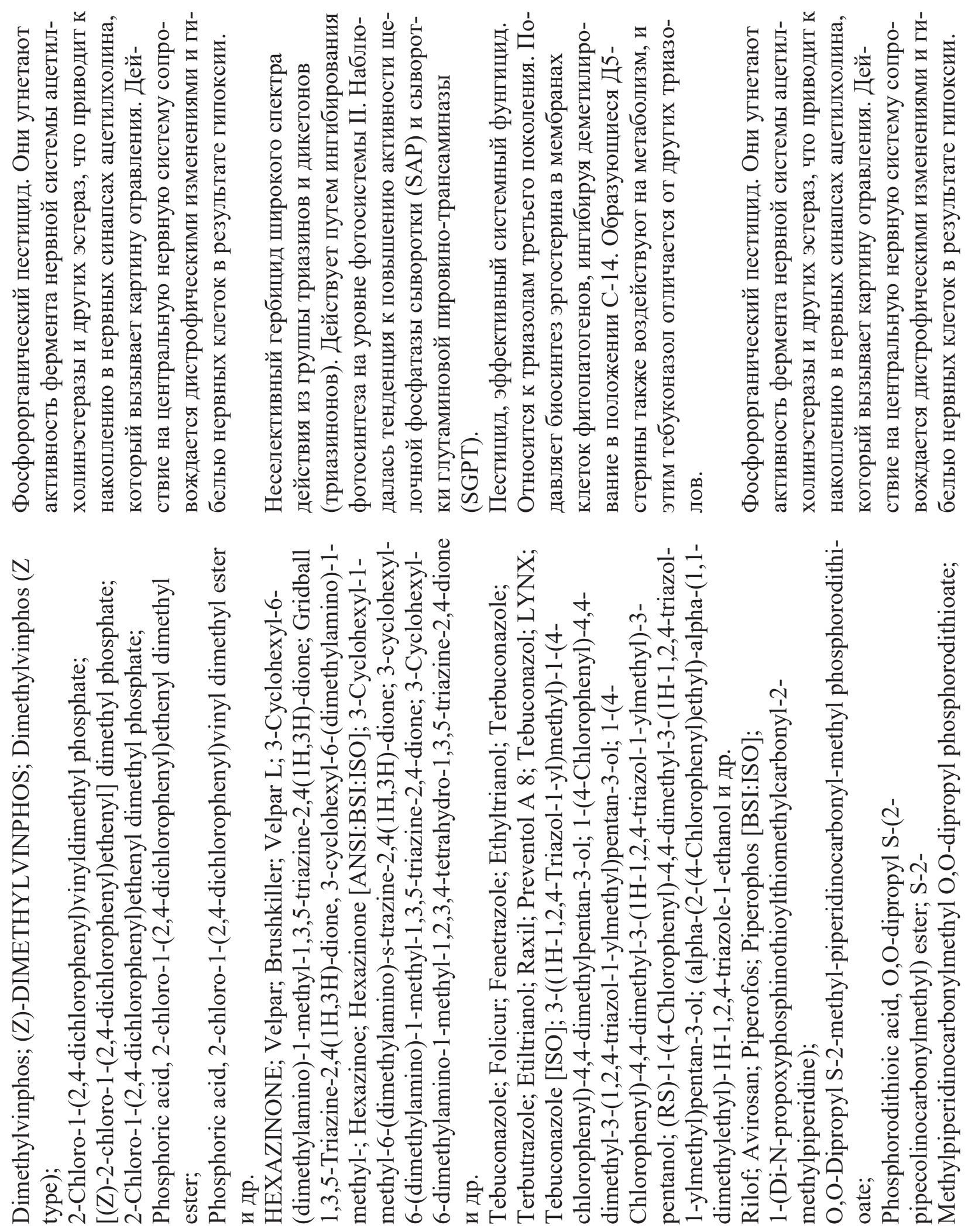

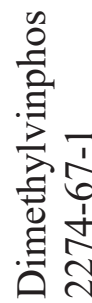
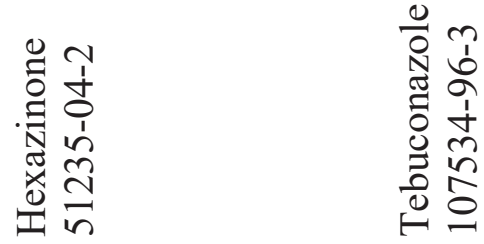

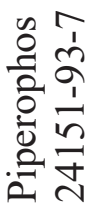



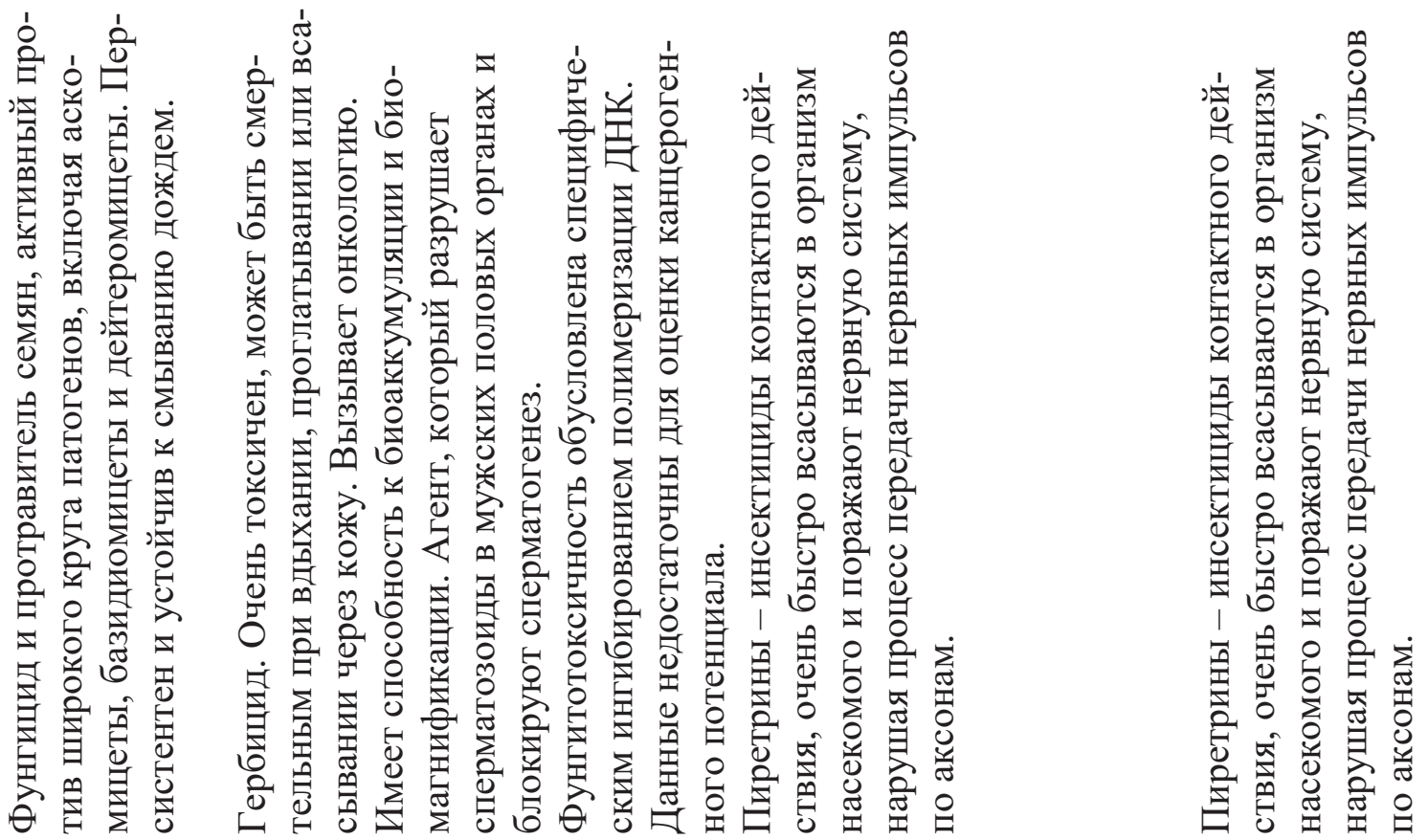

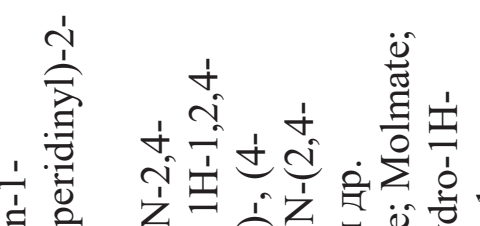

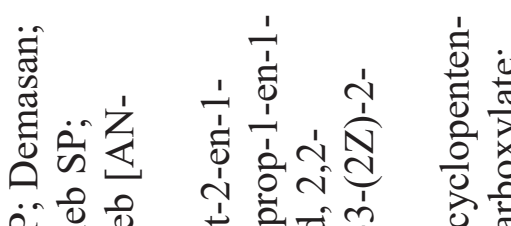

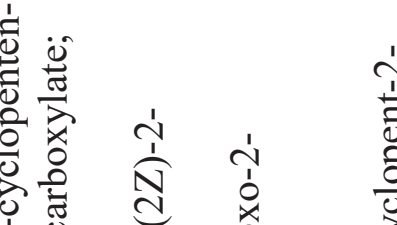

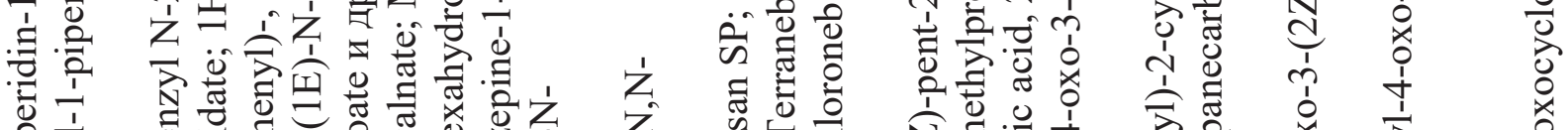

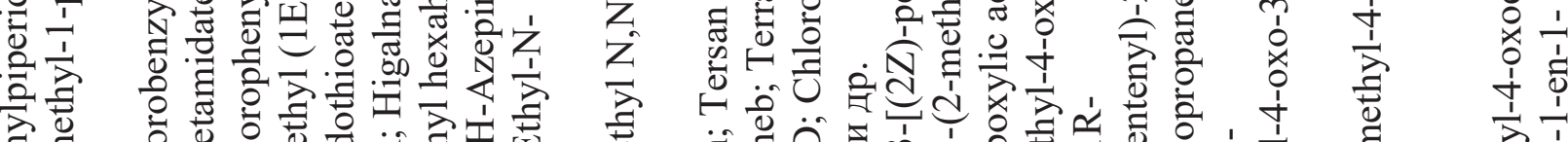

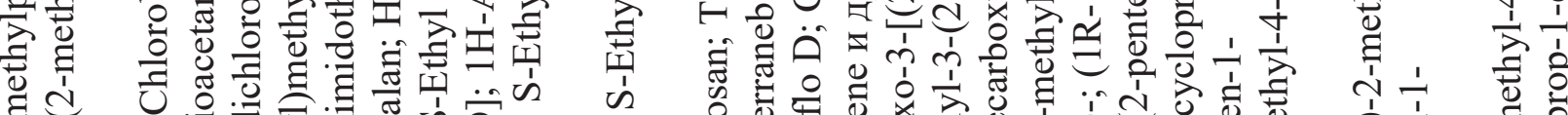

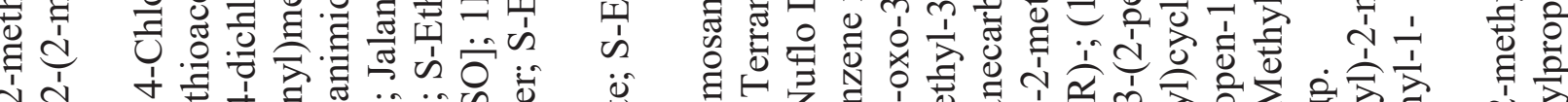

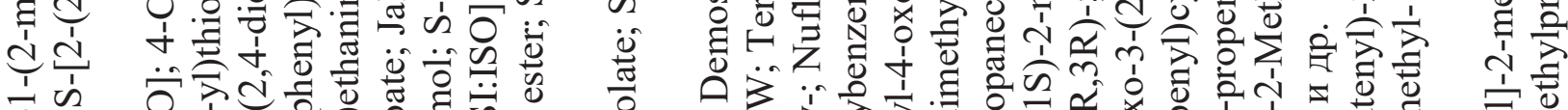

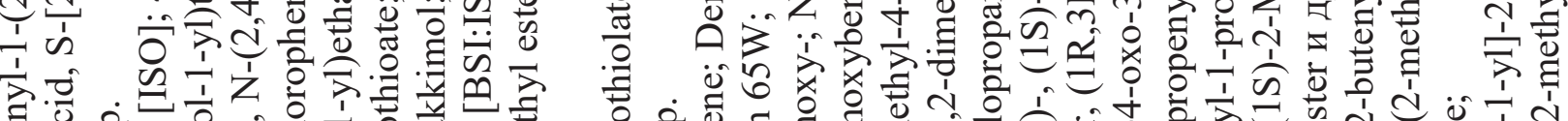

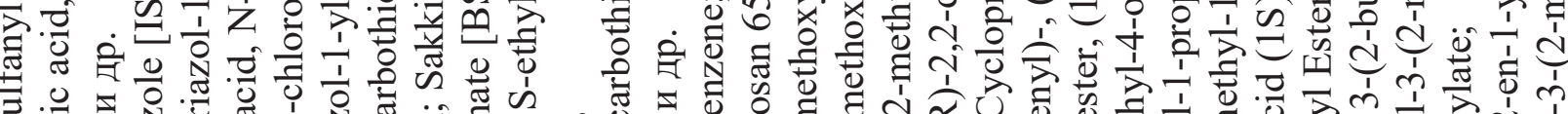

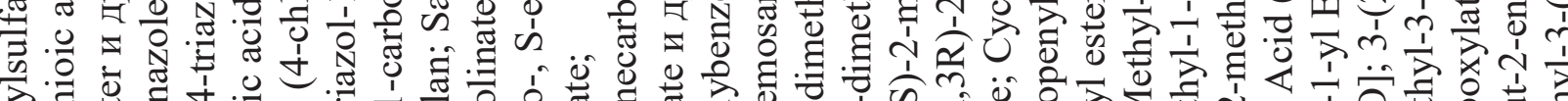

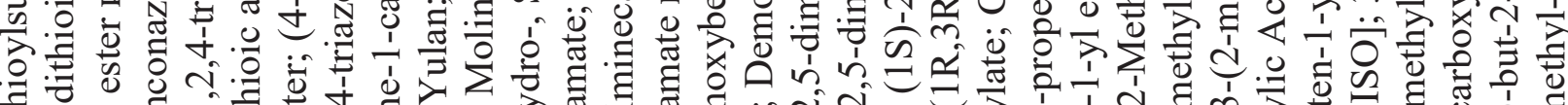

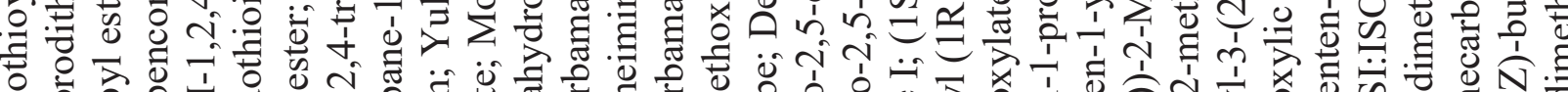

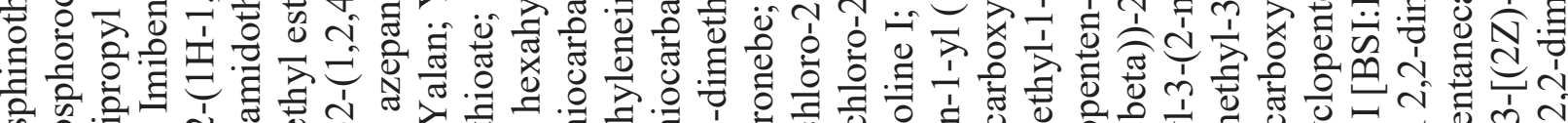
क

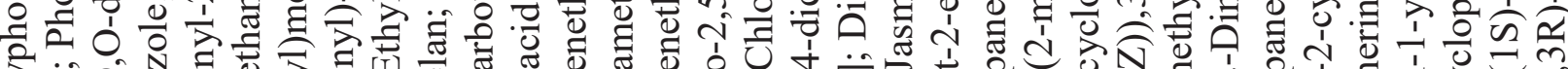

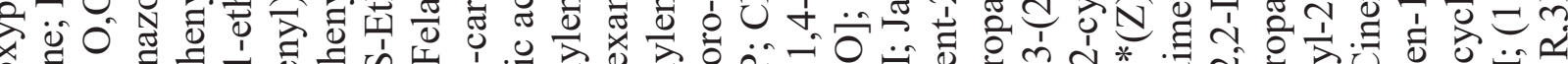
ô

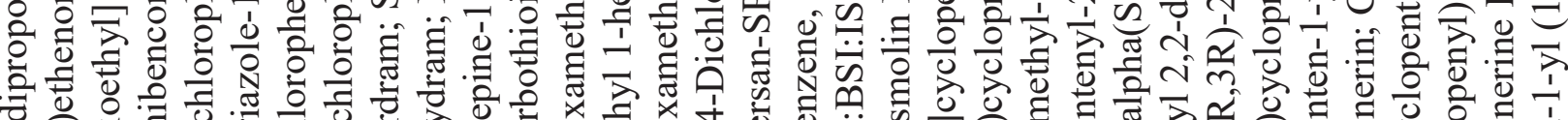

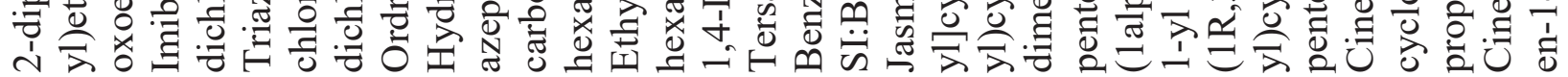
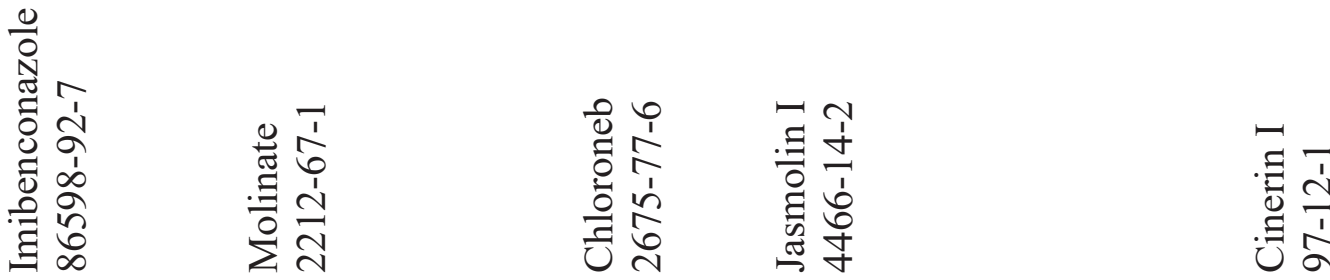


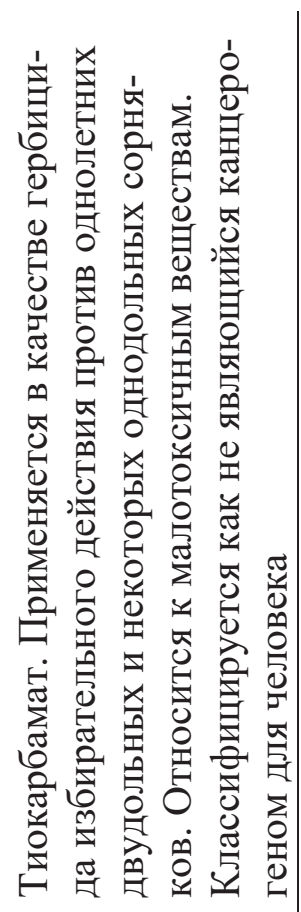

$\stackrel{1}{n} \quad z^{\prime}$

总

文

过芯芯矛苛的

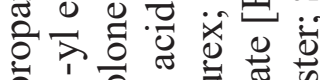

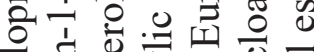

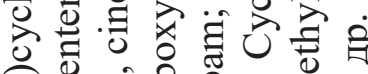

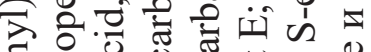

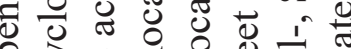

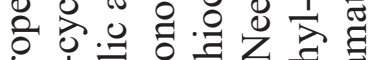

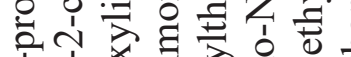

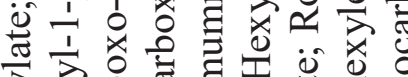

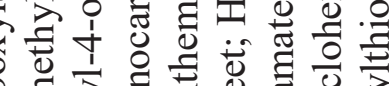

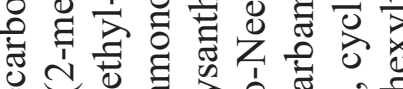

త్ర

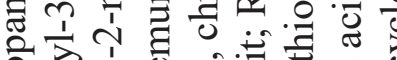

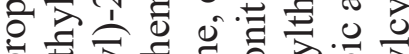

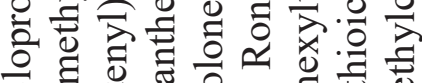

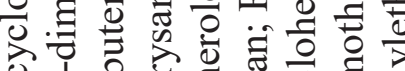

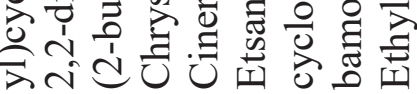

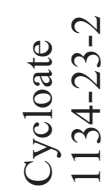




\section{2. Заключение}

Нецелевой скрининговый анализ липофильных ксенобиотиков проведен впервые для дальневосточного региона. Наличие всех указанных соединений в пробах говорит о присутствии различных СО3 в окружающей среде и живых организмах, и требует регулярного контроля с применением качественного и количественного анализа. Большинство этих поллютантов не являются запрещенными, поэтому их количества в окружающей среде должны быть строго регламентированы, чтобы избежать негативных последствий для живых организмов, в том числе человека.

\section{3. Список литературы}

1. Bader, T. General strategies to increase the repeatability in non-target screening by liquid chromatography-high resolution mass spectrometry / T. Bader, W. Schulz, K. Kümmerer, R. Winzenbacher // Analytica Chimica Acta. 2016. - V. 935. - P.173-186.

2. Blum, K.M. Non-target screening and prioritization of potentially persistent, bioaccumulating and toxic domestic wastewater contaminants and their removal in on-site and large-scale sewage treatment plants / K.M. Blum, P.L. Andersson, G. Renman [et al.] // Science of The Total Environment. 2017. - V. 575. - P. 265-275.

3. Kunzelmann, M. Non-targeted analysis of unexpected food contaminants using LC-HRMS / M. Kunzelmann, M. Winter, M. Aberg, K.E. Hellenäs, J. Rosén // Analytical and Bioanalytical Chemistry. - 2018. - V. 410. P. 5593-5602.

4. Rager, J.E. Linking high resolution mass spectrometry data with exposure and toxicity forecasts to advance high-throughput environmental monitoring / J.E. Rager, M.J. Strynar, S. Liang [et al.] // Environment International. 2016. - V. 88. - P. 269-280.

5. Singer, H.P. Rapid Screening for Exposure to "Non-Target" Pharmaceuticals from Wastewater Effluents by Combining HRMS-Based Suspect Screening and Exposure Modeling / H.P. Singer, A.E. Wössner, C.S. McArdell, K. Fenner // Environmental Science \& Technology. - 2016. - V. 50. - P. 6698-6707. 
https://doi.org/10.24866/7444-4891-2/263-282

\title{
ГЛАВА 11
}

\section{ЭКОЛОГИЧЕСКИЕ РИСКИ ОТ СТОЙКИХ ОРГАНИЧЕСКИХ ЗАГРЯЗНЯЮЩИХ ВЕЩЕСТВ (СОЗ) В МОРСКИХ ОРГАНИЗМАХ СЕВЕРО-ЗАПАДНОЙ ЧАСТИ ТИХОГО ОКЕАНА}

\author{
М.М. Донеи , В.Ю. Цыганков
}

В главе представлены результаты расчета экологического риска для здоровья при употреблении населением Дальнего Востока (ДВ) тихоокеанских лососей, камбал и морских млекопитающих, содержащих стойкие органические загрязняющие вещества (CO3). Риск повышения вероятности развития рака обнаружен для всех исследованных организмов. Необходим мониторинг СО3 и их влияние на здоровья жителей ДВ России.

Ключевые слова: СОЗ, ДДТ, ГХЦГ, ПХБ, экологические риски для здоровья, тихоокеанские лососи, камбалы, морские млекопитающие.

${ }^{1}$ Школа биомедицины, Дальневосточный федеральный университет (ДВФУ), 690922, Владивосток, о. Русский, п. Аякс, 10. E-mail: maksim.donecz@mail.ru.

${ }^{2}$ Школа естественных наук, Дальневосточный федеральный университет (ДВФУ), 690922, Владивосток, о. Русский, п. Аякс, 10.

${ }^{1}$ School of Biomedicine, Far Eastern Federal University, 10 Ajax Bay, Russky Island Vladivostok, Russia,690922.E-mail: maksim.donecz@mail.ru.

${ }^{2}$ School of School of Natural Sciences, Far Eastern Federal University, 10 Ajax Bay, Russky Island Vladivostok, Russia, 690922.

Для цитирования: Донец М.М., Цыганков В.Ю. Экологические риски от стойких органических загрязняющих веществ (CO3) в морских организмах северо-западной части Тихого океана // Стойкие органические загрязняющие вещества (CO3) в Дальневосточном регионе: моря, организмы, человек : монография / В.Ю. Цыганков, М.М. Донец, Н.К. Христофорова [и др.] ; науч. ред. В.Ю. Цыганков. Владивосток : Изд-во Дальневост. федерал. ун-та, 2020. - С. 263-282. - https://doi.org/10.24866/74444891-2/263-282.

For citing: Donets M.M., Tsygankov V.Yu. Environmental health risks from persistent organic pollutants (POPs) in marine organisms from the Northwest Pacific Ocean // Persistent organic pollutants (POPs) in the Far Eastern Region: Seas, Organisms, Human : monograph / V.Yu. Tsygankov, M.M. Donets, N.K. Khristoforova [et al.] ; ed. by V.Yu. Tsygankov. - Vladivostok : Publishing House of the Far Eastern Federal University, 2020. - P. 263-282. -https://doi.org/10.24866/7444-4891-2/263-282. 


\title{
CHAPTER 11. Environmental health risks from persistent organic pollutants (POPs) in marine organisms from the Northwest Pacific Ocean
}

\author{
M.M. Donets ${ }^{1}$, V.Yu. Tsygankov ${ }^{1,2}$
}

The chapter presents the results of environmental health risk assessment from the consumption of Pacific salmon, flounders and marine mammals containing persistent organic pollutants (POPs) by the population of the Far East. The incremental lifetime cancer risk was found for all studied organisms. Monitoring of POPs and their impact on the health of residents of the Russian Far East is required.

Keywords: POPs, DDTs, HCHs, PCBs, environmental health risks, Pacific salmon, flounders, marine mammals

Понимание воздействия поллютантов из окружающей среды на здоровье человека требует знаний взаимосвязей в цепочке «источник загрязнения-последствия для здоровья» [13]. Ее можно описать как концептуальную основу для оценки риска для здоровья человека, которая объединяет знания и методы из химии, физиологии, биологии, математики, физики, медицины и других соответствующих дисциплин.

Оценка экологического риска для здоровья человека - сложный многофакторный процесс, который учитывает физико-химические свойства вещества (полученные экспериментально или с помощью моделей), способы поступления в организм, зависимость доза-эффект, потенциал биоаккумуляции, распространение и поведение в окружающей среде. Несмотря на множество переменных в процессе оценки риска, она обеспечивает методологический подход для определения безопасных уровней воздействия различных контаминантов, не допуская снижение качества жизни и здоровья населения [7].

Bce CO3 это вещества с высокой токсичностью, способные к биоаккумуляции и биомагнификации, в связи с чем они концентрируются в ор- 
ганизме человека, даже если их уровни в пище ниже допустимых [8]. Несмотря на высокую актуальность подобных исследований, в России они практически не проводятся.

Оценка рисков для здоровья включает в себя следующие этапы:

1. Идентификация опасности (качественная идентификация того, какие потенциальные угрозы здоровью могут быть вызваны конкретными физическими, биологическими или химическими агентами).

2. Оценка воздействия (оценка воздействия этих агентов на человека).

3. Характеристика взаимосвязи доза-эффект (оценка активности, вероятности конкретного вида вреда на единицу воздействия агента или агентов).

4. Характеристика риска (описание ожидаемого воздействия агентов на здоровье, количественное и качественное описание неопределенности).

За оценкой почти всегда следует управление риском. Задача оценки риска для здоровья - определить, является ли оцененный риск приемлемым, а в случае неприемлемости - принять меры по его снижению.

\section{1. Методика расчета экологического риска для здоровья}

Для оценки экологического риска для здоровья рассчитываются коэффициент опасности $(H Q)$ и коэффициент риска развития рака в течение жизни (ILCR). HQ показывает возможность возникновения острого отравления в течение года, ILCR указывает на увеличение вероятности развития онкологических заболеваний от поступления поллютантов в организм человека в течение всей жизни $[17,25]$.

$H Q$ и $I L C R$ рассчитываются без учета поступления ХОП и ПХБ через другие источники (вода, воздух, контакт с кожей) и показывают возможные неблагоприятные последствия для здоровья только от употребления «загрязненной» пищи. HQ рассчитывается по формуле:

$$
H Q=\frac{E D I}{T D I}
$$


где $E D I$ - среднее употребление токсиканта с пищей, мг/кг в день; TDI количество токсичного вещества, не вызывающего отравления у человека, мг/кг в день $[17,25]$. При значении $H Q>0,2$ риск отравления для людей потенциально существует. Среднесуточное употребление (EDI) рассчитывали следующим образом:

$$
E D I=\frac{C_{f o o d} \cdot I R_{f o o d} \cdot A F_{G I T} \cdot D_{d} \cdot D_{y}}{B W \cdot 365 \cdot L E}
$$

где $C_{f o o d}-$ концентрация токсиканта в рыбе, мг/кг; $I R_{f o o d}-$ среднее употребление рыбы, кг/день; $A F_{G I T}$ - фактор адсорбции токсиканта в желудочно-кишечном тракте (принимается равным 1, если отсутствуют другие данные); $D_{d}$ - количество дней, в которые происходит употребление загрязненной рыбы, дни; $D_{y}$ - длительность употребления загрязненной рыбы, лет (для расчета коэффициента опасности не учитывается и принимается равным 1, для расчета риска развития рака принимается равным 65 годам); $B W$ - средний вес тела человека, кг (по данным Росстата для населения Дальнего Востока средний вес тела составляет 70 кг); $L E$ - средняя продолжительность жизни, лет (по данным Росстата, для местного населения Дальнего Востока составляет 70 лет).

ILCR рассчитывается следующим образом:

$$
I L C R=E D I \cdot S F_{\text {oral }},
$$

где $S F_{\text {oral }}$ - канцерогенный потенциал, показывающий, насколько повышается риск развития рака при поглощении токсиканта, кг в день/мг. Если ILCR $>1 \cdot 10^{-5}$, риск потенциально возможен.

В работе использовали модифицированный инструмент для расчета риска Persistent Organic Pollutants Toolkit (рис. 11.1, 11.2). 
Use this tool to calculate the Hazard Quotient $(H Q$ ) for a threshold contaminant (see training material for more information).

If a Hazard Quotient greater than 0.2 is calculated, a risk to human health potentially exists.

- Accidental Soil Ingestion Dose Calculation (show).

- Water Ingestion Dose Calculation (show).

- Food Ingestion Dose Calculation (show).

- Inhalation of contaminated particles Dose Calculation (show)

- Dermal contact with contaminated soil Dose Calculation (show).

\section{Calculation of Hazard Quotient:}

$\mathrm{HQ}=\frac{\left(\text { Dose }_{\text {Soillngestion }}+\text { Dose }_{\text {Wateringestion }}+\text { Dose }_{\text {Foodlngestion }}+\text { Dose }_{\text {Particlelnhalation }}+\text { Dose }_{\text {DermalContact }}\right)}{\text { TDI }}$ TDI

TDI =

Dose $_{\text {Soillngestion }}=$

Dose $_{\text {Waterlngestion }}=$

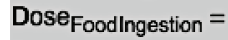

Dose $_{\text {Particlelnhalation }}=$

Dose $_{\text {DermalContact }}=$

Total Dose $=$ mg/kg - day Tolerable daily intake (TDI) (see Table: Health Canada's TDIs, or US EPA's

Error: footer could not be retrieved!

Puc. 11.1. Инструмент для расчета коэффициента опасности (HQ)

$\downarrow$ Use this tool to calculate the Incremental Lifetime Cancer Risk (ILCR) for a non-threshold contaminant (see training material for more information ).

If an Incremental Lifetime Cancer Risk greater than $1 \times 10^{-5}$ is calculated, a cancer risk potentially exists.

- Accidental Soil Ingestion Dose Calculation (show).

- Water Ingestion Dose Calculation (show).

- Food Ingestion Dose Calculation (show).

- Inhalation of contaminated particles Dose Calculation (show)

- Dermal contact with contaminated soil Dose Calculation (show).

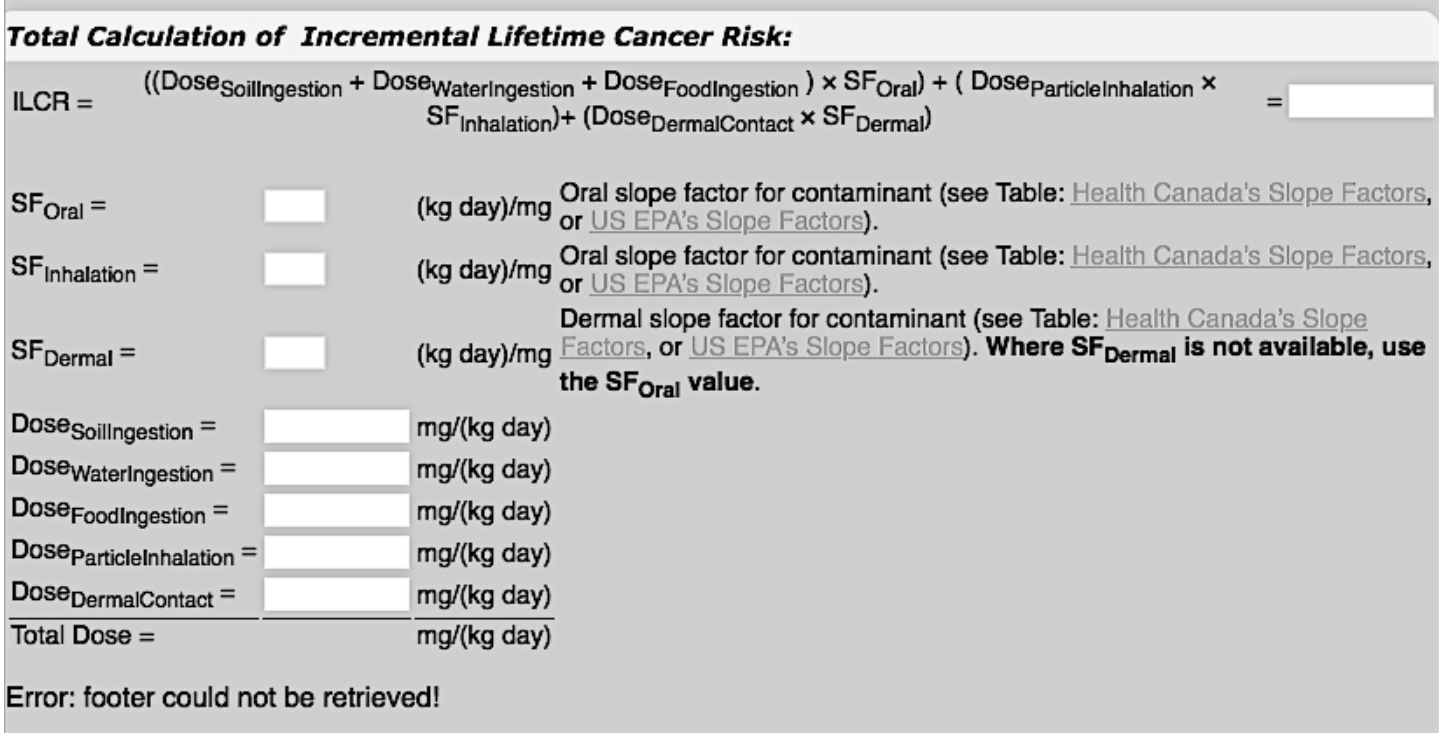

Puc. 11.2. Инструмент для расчета риска развития рака на протяжении всей жизни (ILCR) 


\section{2. Экологические риски от СОЗ для здоровья жителей Дальнего Востока}

\subsection{1. Тихоокеанские лососи}

Водные экосистемы считаются конечными «акцепторами» СО3 [19] и, ввиду своей лиофильности, концентрируются в тканях гидробионтов, в частности рыб. Во многих странах рыба и рыбопродукты составляют основу рациона местного населения (например, в Японии, Индонезии и др.). В связи с этим практически по всему миру осуществляется государственное регулирование предельно допустимых концентраций (ПДК) СО3 (в частности - ХОП и ПХБ) в тканях морских организмов (табл. 11.1). В России существует множество санитарно-гигиенических нормативов, направленных на обеспечение продовольственной безопасности пищевых продуктов. Наиболее важными документами, устанавливающими гигиенические требования к рыбе и нерыбным объектам морского промысла, являются СанПин 2.3.2.1078-01, ТР ТС 021/2011 и ТР ЕАЭС 040/2016. [4-6].

Тихоокеанские лососи относятся к национальным богатствам России. Это наиболее популярные виды рыб, занимающие 2-3 место по вылову после минтая и сельди [1]. При этом, во всех исследованных нами лососевых рыбах обнаруживаются СО3, что может потенциально вызывать различные негативные эффекты для здоровья населения.

Дальний Восток России является рекордсменом по употреблению рыбы и рыбопродуктов по всей стране и опережает средние показатели по регионам на 9 кг/год (29 кг/год на Дальнем Востоке против 20 кг/год в среднем по России) [1]. Это показывает необходимость проведения постоянной оценки экологического риска от употребления рыбы и рыбопродуктов, особенно - тихоокеанских лососей, ввиду их широкого распространения и популярности.

Для расчета экологического риска для здоровья жителей Дальнего Востока от употребления тихоокеанских лососей принято абсолютное значение 29 кг филе на человека в год, так как на сегодняшний день отсутствует информация о среднем употреблении каждого отдельного органа рыбы. Данные для расчета риска от лососей взяты из Главы 6 . Для расчета риска концентрации токсикантов представлены в мг/кг сырой массы (табл. 11.2). 
Гигиенические требования (допустимые концентрации) к безопасности рыбы и рыбной продукции по содержанию ХОП и ПХБ в России и других странах, нг/г сырой массы

\begin{tabular}{|c|c|c|c|c|}
\hline $\begin{array}{l}\text { Страна / } \\
\text { Организация }\end{array}$ & Вещество & ПДК & Примечание & Ссылка \\
\hline \multirow[t]{20}{*}{ Россия } & ГХЦГ ${ }^{1}$ & 200 & Виды продукции из морской рыбы и мясо & {$[6]$} \\
\hline & & & $\begin{array}{l}\text { морских млекопитающих (кроме печени и } \\
\text { рыбного жира); Икра, молоки рыб и продук- } \\
\text { ты из них; Аналоги икры. }\end{array}$ & \\
\hline & & 100 & Рыбный жир & \\
\hline & & 1000 & Печень рыб и продукты из нее & \\
\hline & ДДТ ${ }^{2}$ & 2000 & $\begin{array}{l}\text { Осетровые, лососевые, сельдь жирная - все } \\
\text { виды продукции (кроме печени, икры и мо- } \\
\text { локи), в т.ч. сушеная, копченая, соленая, пря- } \\
\text { ная, маринованная, рыбная кулинария и дру- } \\
\text { гая продукция, готовая к употреблению }\end{array}$ & \\
\hline & & 400 & $\begin{array}{l}\text { Икра и молоки рыб (всех видов) и продукты } \\
\text { из них; Аналоги икры }\end{array}$ & \\
\hline & & 3000 & Печень рыб и продукты из нее & \\
\hline & ПХБ ${ }^{3}$ & 2000 & $\begin{array}{l}\text { Виды рыбной продукции (кроме печени и } \\
\text { рыбного жира) и мяса морских млекопитаю- } \\
\text { щих, в т.ч. сушеная продукция }\end{array}$ & \\
\hline & & 5000 & Печень рыб и продукты из нее & \\
\hline & & 3000 & Рыбный жир & \\
\hline & ГХЦГ & 200 & $\begin{array}{l}\text { Рыба живая, рыба-сырец, охлажденная, мо- } \\
\text { роженная, фарш, филе, мясо морских млеко- } \\
\text { питающих }\end{array}$ & {$[4]$} \\
\hline & & 200 & $\begin{array}{l}\text { Икра и молоки рыб (всех видов) и продукты } \\
\text { из них; Аналоги икры. }\end{array}$ & \\
\hline & & 1000 & Печень рыб и продукты из нее & \\
\hline & дДТ & 2000 & $\begin{array}{l}\text { Рыба живая, рыба-сырец, охлажденная, мо- } \\
\text { роженная, фарш, филе, мясо морских млеко- } \\
\text { питающих (осетровые, лососевые, сельдь) }\end{array}$ & \\
\hline & & 2000 & $\begin{array}{l}\text { Икра и молоки рыб (всех видов) и продукты } \\
\text { из них; Аналоги икры }\end{array}$ & \\
\hline & & 3000 & Печень рыб и продукты из нее & \\
\hline & ПХБ & 2000 & $\begin{array}{l}\text { Виды рыбной продукции (кроме печени и } \\
\text { рыбного жира) и мяса морских млекопитаю- } \\
\text { щих, в т.ч. сушеная продукция }\end{array}$ & \\
\hline & & 3000 & Рыбный жир & \\
\hline & & 5000 & Печень рыб и продукты из нее & \\
\hline & ПХБ & 2000 & $\begin{array}{l}\text { Все виды пищевой рыбной продукции (кроме } \\
\text { печени и жира пищевого из рыбы), в т.ч. су- } \\
\text { шеная продукция }\end{array}$ & {$[5]$} \\
\hline \multirow[t]{2}{*}{ США } & ДД $\mathrm{T}^{4}$ & 5000 & Съедобная часть & [11] \\
\hline & ПХБ & 2000 & Рыба и моллюски & {$[10]$} \\
\hline \multirow[t]{3}{*}{ Канада } & ГХЦГ ${ }^{5}$ & 100 & Все виды рыб & [9] \\
\hline & ддт & 5000 & Все виды рыб & \\
\hline & ПХБ & 2000 & Все виды рыб & \\
\hline \multirow{4}{*}{$\begin{array}{l}\text { Австралия, } \\
\text { Новая Зелан- } \\
\text { дия }\end{array}$} & ГХЦГ & 10 & Все виды рыб & [14] \\
\hline & Линдан & 1000 & Все виды рыб & \\
\hline & ДДТ ${ }^{7}$ & 1000 & Все виды рыб & \\
\hline & ПХБ & 500 & Все виды рыб & {$[15]$} \\
\hline
\end{tabular}


Глава 11

\begin{tabular}{lllll}
\hline Тайланд & ГХЦГ & 500 & Все виды рыб & {$[24]$} \\
& ДДТ & 5000 & Все виды рыб & \\
Китай & ГХЦГ & 100 & Продукты морского происхождения & {$[22]$} \\
& ДДТ & 500 & Продукты морского происхождения & \\
& ПХБ & 500 & Морские животные и продукты из них & {$[21]$} \\
Гонконг & ДДТ & 18000 & Рыба, морепродукты и продукты из них & {$[16]$} \\
ВОЗ $^{10}$ & ГХЦГ & 200 & & {$[26]$} \\
Германия & ГХЦГ & 500 & & {$[18]$} \\
& ДДТ & 5000 & & \\
ФАО/ВОЗ & & {$[20]$} \\
$\mathrm{CREM}^{11}$ & ДДТ и & & \\
$\mathrm{EC}^{13}$ & ДДТ & 200 & Все виды рыб & {$[23]$} \\
\hline
\end{tabular}

${ }^{1}$ ГХЦГ (сумма $\alpha-, \beta-, \gamma$-изомеров).

2 ДДТ и его метаболиты (ДДД и ДДЕ).

${ }^{3}$ Сумма всех конгенеров ПХБ

${ }^{4}$ Действующий уровень ДДТ, ДДД и ДДЕ используется как для индивидуальных пестицидов, так и для суммы. Однако при подсчете общей суммы, концентрации ДДТ, ДДД и ДДЕ ниже 200 нг/г не учитываются.

${ }^{5}$ В таблице допустимых уровней содержания загрязняющих веществ в рыбе и рыбных продуктах, ГХЦГ (сумма изомеров) обозначен как «Прочие сельскохозяйственные химикаты или их производные».

${ }^{6}$ ГХЦГ (все изомеры, исключая ү-ГХЦГ, линдан).

${ }^{7}$ Сумма $p, p^{\prime}$-ДДТ, $о, p^{\prime}$-ДДТ, $p, p^{\prime}$-ДДЕ и $p, p^{\prime}$-ДДД.

${ }^{8}$ Сумма $\alpha-, \beta-, \gamma-, \delta$-изомеров ГХЦГ

${ }^{9}$ Сумма ПХБ 28, ПХБ 52, ПХБ 101, ПХБ 118, ПХБ 138, ПХБ 153 и ПХБ 180

${ }^{10}$ Всемирная организация здравоохранения.

11 Продовольственная и сельскохозяйственная организация Объединенных Наций (ФАО) и ВОЗ.

12 Консультирование и исследования в области экологического менеджмента/центр по продвижению импорта из развивающихся стран

${ }^{13}$ Европейский Союз.

Концентрации в горбуше 2017 г. вылова представляют собой суммарные уровни токсикантов из оз. Азабачье и р. Поронай, так как при приобретении рыбы зачастую отсутствует возможность узнать точное место вылова рыбы. Стоит отметить, что при пересчете концентраций на сырую массы, ни одно из соединений не превысило допустимых уровней гигиенических нормативов.

Результаты расчетов экологического риса для горбуши, кеты, симы, чавычи и нерки представлены в таблицах 11.3-11.7. 
Таблийа 11.2

Средние концентрации пестицидов и ПХБ в мышцах тихоокеанских лососей различных годов вылова, мг/кг сырой массы

\begin{tabular}{|c|c|c|c|c|c|c|c|c|}
\hline \multirow[t]{2}{*}{ Вид } & \multirow{2}{*}{$\begin{array}{l}\text { Год } \\
\text { отбора }\end{array}$} & \multicolumn{7}{|c|}{ Концентрация, мг/кг сырой массы } \\
\hline & & 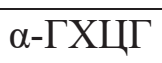 & 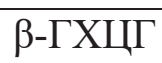 & 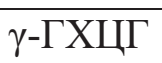 & ДДТ ${ }^{1}$ & ДДД & ДДЕ & $\Sigma \Pi$ इПБ \\
\hline \multirow[t]{2}{*}{ Горбуша } & 2012 & 0,025 & 0,0049 & 0,0031 & $<\Pi^{2}$ & $<\Pi \mathrm{O}$ & 0,0023 & $-{ }^{3}$ \\
\hline & 2017 & 0,002 & 0,0006 & 0,00008 & 0,00047 & 0,00027 & 0,0014 & 0,00164 \\
\hline \multirow[t]{2}{*}{ Кета } & 2013 & 0,021 & 0,014 & 0,0065 & $<\Pi \mathrm{O}$ & $<\Pi \mathrm{O}$ & 0,0047 & - \\
\hline & 2018 & 0,0002 & 0,00002 & 0,00001 & $<\Pi О$ & $<\Pi О$ & 0,00002 & 0,0002 \\
\hline Сима & 2017 & 0,0006 & 0,00025 & 0,00012 & 0,00046 & 0,0005 & 0,00016 & 0,00205 \\
\hline \multirow[t]{2}{*}{ Чавыча } & 2010 & 0,007 & $<\Pi \mathrm{O}$ & 0,0076 & $<\Pi \mathrm{O}$ & $<\Pi О$ & 0,0056 & - \\
\hline & 2018 & 0,00003 & 0,00023 & 0,00005 & 0,00005 & 0,00012 & 0,00006 & 0,00142 \\
\hline \multirow[t]{3}{*}{ Нерка } & 2011 & 0,017 & $<\Pi О$ & 0,00272 & $<\Pi О$ & $<\Pi O$ & 0,0016 & - \\
\hline & 2017 & $<\Pi \mathrm{O}$ & 0,00038 & $<\Pi О$ & 0,00004 & 0,00039 & 0,00002 & 0,0005 \\
\hline & 2018 & 0,00003 & 0,00023 & 0,00004 & 0,00026 & 0,00024 & 0,00005 & 0,00108 \\
\hline
\end{tabular}

' сумма $o, p$ ' и $p, p$ ' изомеров

2 ниже пределов обнаружения

${ }^{3}$ не исследовалось

Таблийа 11.3

Оценка экологического риска от СО3, обнаруженных в мышцах (филе) горбуши для местного населения Дальнего Востока России

\begin{tabular}{|c|c|c|c|c|}
\hline Соединение & EDI для HQ & HQ & EDI для ILCR & ILCR \\
\hline \multicolumn{5}{|c|}{2012} \\
\hline$\alpha$-ГХЦГ & $2,9 \cdot 10^{-5}$ & $9,6 \cdot 10^{-2}$ & $2,7 \cdot 10^{-5}$ & $1,7 \cdot 10^{-4}$ \\
\hline 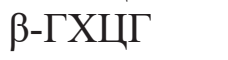 & $5,5 \cdot 10^{-6}$ & $1,8 \cdot 10^{-2}$ & $5,2 \cdot 10^{-6}$ & $9,4 \cdot 10^{-6}$ \\
\hline$\gamma$-ГХЦГ & $3,6 \cdot 10^{-6}$ & $1,2 \cdot 10^{-2}$ & $3,4 \cdot 10^{-6}$ & $4,4 \cdot 10^{-6}$ \\
\hline ДДЕ & $2,6 \cdot 10^{-6}$ & $5,3 \cdot 10^{-3}$ & $2,5 \cdot 10^{-6}$ & $8,4 \cdot 10^{-7}$ \\
\hline \multicolumn{5}{|c|}{2017} \\
\hline 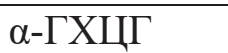 & $2,2 \cdot 10^{-6}$ & $7,2 \cdot 10^{-3}$ & $2,0 \cdot 10^{-6}$ & $1,3 \cdot 10^{-5}$ \\
\hline 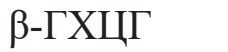 & $6,8 \cdot 10^{-7}$ & $2,3 \cdot 10^{-3}$ & $6,4 \cdot 10^{-7}$ & $1,2 \cdot 10^{-6}$ \\
\hline$\gamma$-ГХЦГ & $8,8 \cdot 10^{-8}$ & $2,9 \cdot 10^{-4}$ & $8,3 \cdot 10^{-8}$ & $1,1 \cdot 10^{-7}$ \\
\hline ДДТ & $5,4 \cdot 10^{-7}$ & $1,1 \cdot 10^{-3}$ & $5,1 \cdot 10^{-7}$ & $1,7 \cdot 10^{-7}$ \\
\hline ДДД & $3,1 \cdot 10^{-7}$ & $6,2 \cdot 10^{-4}$ & $2,9 \cdot 10^{-7}$ & $7,0 \cdot 10^{-8}$ \\
\hline ДДЕ & $1,6 \cdot 10^{-6}$ & $3,2 \cdot 10^{-3}$ & $1,5 \cdot 10^{-6}$ & $5,1 \cdot 10^{-7}$ \\
\hline इПХБ & $1,9 \cdot 10^{-6}$ & $1,4 \cdot 10^{-2}$ & $1,8 \cdot 10^{-6}$ & $3,5 \cdot 10^{-6}$ \\
\hline ПДК & & 0,2 & & $1 * 10^{-5}$ \\
\hline
\end{tabular}

Как видно, риск потенциального развития рака в течение жизни от употребления тихоокеанских лососей, обнаружен для всех рыб 20102012 гг. вылова. Причем обуславливают его именно изомеры ГХЦГ (преимущественно - $\alpha$-форма). Рыба 2017-2018 гг., в целом, безопасна, что от- 
ражает снижение концентраций СО3 в органах тихоокеанских лососей и в окружающей среде в целом. Исключение составляет горбуша 2017 г. (риск

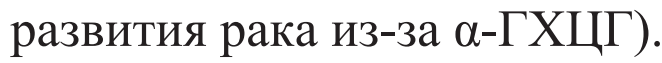

Таблицуа 11.4

Оценка экологического риска от СОЗ, обнаруженных

в мышцах (филе) кеты для местного населения

Дальнего Востока России

\begin{tabular}{|c|c|c|c|c|}
\hline Соединение & EDI для HQ & HQ & EDI для ILCR & ILCR \\
\hline \multicolumn{5}{|c|}{2013} \\
\hline 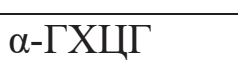 & $2,4 \cdot 10^{-5}$ & $8,0 \cdot 10^{-2}$ & $2,2 \cdot 10^{-5}$ & $1,4 \cdot 10^{-4}$ \\
\hline$\beta$-ГХЦГ & $1,6 \cdot 10^{-5}$ & $5,4 \cdot 10^{-2}$ & $1,5 \cdot 10^{-5}$ & $2,7 \cdot 10^{-5}$ \\
\hline$\gamma$-ГХЦГ & $7,4 \cdot 10^{-6}$ & $2,5 \cdot 10^{-2}$ & $7,0 \cdot 10^{-6}$ & $9,1 \cdot 10^{-6}$ \\
\hline ДДЕ & $5,4 \cdot 10^{-6}$ & $1,1 \cdot 10^{-2}$ & $5,0 \cdot 10^{-6}$ & $1,7 \cdot 10^{-6}$ \\
\hline \multicolumn{5}{|c|}{2018} \\
\hline$\alpha$-ГХЦГ & $2,1 \cdot 10^{-7}$ & $6,9 \cdot 10^{-4}$ & $2,0 \cdot 10^{-7}$ & $1,2 \cdot 10^{-6}$ \\
\hline$\beta$-ГХЦГ & $2,3 \cdot 10^{-8}$ & $7,6 \cdot 10^{-5}$ & $2,1 \cdot 10^{-8}$ & $3,9 \cdot 10^{-8}$ \\
\hline$\gamma$-ГХЦГ & $6,1 \cdot 10^{-9}$ & $2,0 \cdot 10^{-5}$ & $5,7 \cdot 10^{-9}$ & $7,5 \cdot 10^{-9}$ \\
\hline ДДЕ & $2,6 \cdot 10^{-8}$ & $5,3 \cdot 10^{-5}$ & $2,5 \cdot 10^{-8}$ & $8,5 \cdot 10^{-9}$ \\
\hline इПХБ & $2,8 \cdot 10^{-7}$ & $2,2 \cdot 10^{-3}$ & $2,6 \cdot 10^{-7}$ & $5,3 \cdot 10^{-7}$ \\
\hline ПДк & & 0,2 & & $1 \cdot 10^{-5}$ \\
\hline
\end{tabular}

Таблица 11.5

\section{Оценка экологического риска от СОЗ, обнаруженных}

\section{в мышцах (филе) симы 2017 г. вылова для местного населения}

\section{Дальнего Востока России}

\begin{tabular}{|c|c|c|c|c|}
\hline Соединение & EDI для HQ & HQ & EDI для ILCR & ILCR \\
\hline$\alpha-Г Х Ц Г ~$ & $7,2 \cdot 10^{-7}$ & 0,00241 & $6,8 \cdot 10^{-7}$ & $4,3 \cdot 10^{-6}$ \\
\hline$\beta$-ГХЦГ & $2,9 \cdot 10^{-7}$ & 0,00097 & $2,7 \cdot 10^{-7}$ & $4,9 \cdot 10^{-7}$ \\
\hline$\gamma$-ГХЦГ & $1,4 \cdot 10^{-7}$ & 0,00045 & $1,3 \cdot 10^{-7}$ & $1,7 \cdot 10^{-7}$ \\
\hline ДДТ & $5,2 \cdot 10^{-7}$ & 0,00105 & $4,9 \cdot 10^{-7}$ & $1,7 \cdot 10^{-7}$ \\
\hline дДД & $5,7 \cdot 10^{-7}$ & 0,00113 & $5,3 \cdot 10^{-7}$ & $1,3 \cdot 10^{-7}$ \\
\hline ДДЕ & $1,8 \cdot 10^{-7}$ & 0,00037 & $1,7 \cdot 10^{-7}$ & $5,9 \cdot 10^{-8}$ \\
\hline 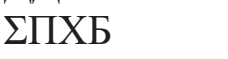 & $2,3 \cdot 10^{-6}$ & 0,01799 & $2,2 \cdot 10^{-6}$ & $4,4 \cdot 10^{-6}$ \\
\hline ПДК & & 0,2 & & $1 \cdot 10^{-5}$ \\
\hline
\end{tabular}

Как уже указывалось, для расчетов использовалось абсолютное значение 29 кг мяса рыбы/год и, вероятно, реального риска развития онкологии именно от СO3, содержащихся в тихоокеанских лососях нет. Тем не менее, результаты расчетов показывают, что потенциальный риск возможен. Это, в свою очередь говорит о необходимости внедрения системы оценки рисков в нормативную базу России и актуализацию существую- 
щих нормативных документов, устанавливающих требования к безопасности пищевой продукции, в частности - к рыбе и морепродуктам.

Таблица 11.6

Оценка экологического риска от СО3, обнаруженных в мышцах (филе) чавычи для местного населения Дальнего Востока России

\begin{tabular}{|c|c|c|c|c|}
\hline Соединение & EDI для HQ & HQ & EDI для ILCR & ILCR \\
\hline \multicolumn{5}{|c|}{2010} \\
\hline 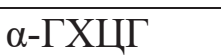 & $8,0 \cdot 10^{-6}$ & $2,7 \cdot 10^{-2}$ & $7,5 \cdot 10^{-6}$ & $4,7 \cdot 10^{-5}$ \\
\hline$\gamma$-ГХЦГ & $8,7 \cdot 10^{-6}$ & $2,9 \cdot 10^{-2}$ & $8,2 \cdot 10^{-6}$ & $1,1 \cdot 10^{-5}$ \\
\hline ДДЕ & $6,4 \cdot 10^{-6}$ & $1,3 \cdot 10^{-2}$ & $6,0 \cdot 10^{-6}$ & $2,0 \cdot 10^{-6}$ \\
\hline \multicolumn{5}{|c|}{2018} \\
\hline$\alpha$-ГХЦГ & $3,3 \cdot 10^{-8}$ & $1,1 \cdot 10^{-4}$ & $3,1 \cdot 10^{-8}$ & $2,0 \cdot 10^{-7}$ \\
\hline 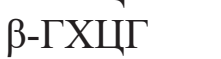 & $2,6 \cdot 10^{-7}$ & $8,6 \cdot 10^{-4}$ & $2,4 \cdot 10^{-7}$ & $4,4 \cdot 10^{-7}$ \\
\hline 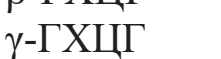 & $6,2 \cdot 10^{-8}$ & $2,1 \cdot 10^{-4}$ & $5,8 \cdot 10^{-8}$ & $7,6 \cdot 10^{-8}$ \\
\hline ДДТ & $5,6 \cdot 10^{-8}$ & $1,1 \cdot 10^{-4}$ & $5,3 \cdot 10^{-8}$ & $1,8 \cdot 10^{-8}$ \\
\hline ДДД & $1,4 \cdot 10^{-7}$ & $2,8 \cdot 10^{-4}$ & $1,3 \cdot 10^{-7}$ & $3,2 \cdot 10^{-8}$ \\
\hline ДДЕ & $7,0 \cdot 10^{-8}$ & $1,4 \cdot 10^{-4}$ & $6,6 \cdot 10^{-8}$ & $2,2 \cdot 10^{-8}$ \\
\hline इПХБ & $1,6 \cdot 10^{-6}$ & $1,2 \cdot 10^{-2}$ & $1,5 \cdot 10^{-6}$ & $3,1 \cdot 10^{-6}$ \\
\hline ПДК & & 0,2 & & $1 \cdot 10^{-5}$ \\
\hline
\end{tabular}

Таблицุа 11.7

Оценка экологического риска от СОЗ, обнаруженных

в мышцах (филе) нерки для местного населения Дальнего Востока России

\begin{tabular}{|c|c|c|c|c|}
\hline Соединение & EDI для HQ & HQ & EDI для ILCR & ILCR \\
\hline \multicolumn{5}{|c|}{2012} \\
\hline$\alpha-Г Х Ц Г ~$ & $1,9 \cdot 10^{-5}$ & $6,4 \cdot 10^{-2}$ & $1,8 \cdot 10^{-5}$ & $1,1 \cdot 10^{-4}$ \\
\hline$\gamma$-ГХЦГ & $3,1 \cdot 10^{-6}$ & $1,0 \cdot 10^{-2}$ & $2,9 \cdot 10^{-6}$ & $3,8 \cdot 10^{-6}$ \\
\hline ДДЕ & $1,8 \cdot 10^{-6}$ & $3,6 \cdot 10^{-3}$ & $1,7 \cdot 10^{-6}$ & $5,7 \cdot 10^{-7}$ \\
\hline \multicolumn{5}{|c|}{2017} \\
\hline$\beta$-ГХЦГ & $4,4 \cdot 10^{-7}$ & $1,5 \cdot 10^{-3}$ & $4,1 \cdot 10^{-7}$ & $7,4 \cdot 10^{-7}$ \\
\hline ДДТ & $5,1 \cdot 10^{-8}$ & $1,0 \cdot 10^{-4}$ & $4,8 \cdot 10^{-8}$ & $1,6 \cdot 10^{-8}$ \\
\hline дДД & $4,4 \cdot 10^{-7}$ & $8,9 \cdot 10^{-4}$ & $4,2 \cdot 10^{-7}$ & $1,0 \cdot 10^{-7}$ \\
\hline ДДЕ & $2,5 \cdot 10^{-8}$ & $5,0 \cdot 10^{-5}$ & $2,4 \cdot 10^{-8}$ & $8,0 \cdot 10^{-9}$ \\
\hline 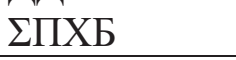 & $5,2 \cdot 10^{-7}$ & $4,0 \cdot 10^{-3}$ & $4,9 \cdot 10^{-7}$ & $9,7 \cdot 10^{-7}$ \\
\hline \multicolumn{5}{|c|}{2018} \\
\hline 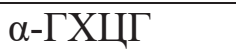 & $3,8 \cdot 10^{-8}$ & $1,3 \cdot 10^{-4}$ & $3,6 \cdot 10^{-8}$ & $2,3 \cdot 10^{-7}$ \\
\hline 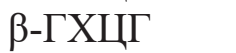 & $2,6 \cdot 10^{-7}$ & $8,6 \cdot 10^{-4}$ & $2,4 \cdot 10^{-7}$ & $4,4 \cdot 10^{-7}$ \\
\hline$\gamma$-ГХЦГ & $4,5 \cdot 10^{-8}$ & $1,5 \cdot 10^{-4}$ & $4,3 \cdot 10^{-8}$ & $5,5 \cdot 10^{-8}$ \\
\hline ДДТ & $2,9 \cdot 10^{-7}$ & $5,9 \cdot 10^{-4}$ & $2,8 \cdot 10^{-7}$ & $9,4 \cdot 10^{-8}$ \\
\hline дДД & $2,7 \cdot 10^{-7}$ & $5,5 \cdot 10^{-4}$ & $2,6 \cdot 10^{-7}$ & $6,2 \cdot 10^{-8}$ \\
\hline ДДЕ & $5,4 \cdot 10^{-8}$ & $1,1 \cdot 10^{-4}$ & $5,1 \cdot 10^{-8}$ & $1,7 \cdot 10^{-8}$ \\
\hline$\Sigma$ इХБ & $1,2 \cdot 10^{-6}$ & $9,5 \cdot 10^{-3}$ & $1,2 \cdot 10^{-6}$ & $2,3 \cdot 10^{-6}$ \\
\hline ПДК & & 0,2 & & $1 \cdot 10^{-5}$ \\
\hline
\end{tabular}




\subsection{2. Камбаль}

Дальневосточные моря (Японское, Охотское и Берингово) являются основными промысловыми зонами Российской Федерации. Вылавливаемые на Дальнем Востоке камбалы относятся к наиболее важным для промысла объектам, составляя 9,5 \% общего объёма вылова рыбы в регионе [1]. Объём вылова, разнообразие видов и невысокая цена на рынке предопределяют их особое значение в структуре питания местного населения. Один из важнейших видов камбал - палтусовидная камбала рода Hippoglossoides, широко распространённая в Охотском и Японском морях, а также в Татарском проливе. Нами исследованы уровни СО3 в мышцах южной (H. dubius) и северной (H. robustus) палтусовидных камбал (глава 6). Для расчета экологического риска концентрации токсикантов пересчитаны на сырую массу (табл. 11.8).

Согласно полученным данным, концентрации ХОП и ПХБ в камбалах из всех исследованных районов не превышают гигиенических нормативов, установленных в России [4]. Среднесуточное поступление токсиканта (EDI), коэффициент риска (HQ) и риск развития рака в течении жизни (ILCR) при употреблении мяса палтусовидных камбал из всех исследованных районов представлены в таблице 11.9.

Таблицьа 11.8

\section{Средние концентрации исследованных СО3}

в мышцах камбал, мг/кг сырой массы

\begin{tabular}{|c|c|c|c|c|c|c|}
\hline Район & 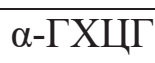 & 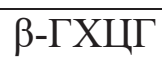 & $\gamma$-ГХЦГ & ДДД & ДДЕ & ПХБ \\
\hline Восток Охотского моря & -1 & $1,0 \cdot 10^{-4}$ & - & $1,0 \cdot 10^{-4}$ & - & $2,5 \cdot 10^{-4}$ \\
\hline Юг Охотского моря & $3,9 \cdot 10^{-5}$ & $2,9 \cdot 10^{-4}$ & - & $1,3 \cdot 10^{-4}$ & $7,2 \cdot 10^{-5}$ & $7,1 \cdot 10^{-4}$ \\
\hline Татарский пролив & - & $3,8 \cdot 10^{-4}$ & - & - & - & $7,8 \cdot 10^{-4}$ \\
\hline Японское море & $1,2 \cdot 10^{-5}$ & $3,7 \cdot 10^{-4}$ & $1,4 \cdot 10^{-5}$ & $9,3 \cdot 10^{-5}$ & $6,7 \cdot 10^{-5}$ & $1,0 \cdot 10^{-2}$ \\
\hline ПДК & $0,2^{3}$ & & & $2,0^{4}$ & & $2,0^{5}$ \\
\hline
\end{tabular}

1 концентрации ниже пределов обнаружения оборудования;

2 предельно допустимая концентрация [4];

3 для суммы всех изомеров;

4 для суммы всех метаболитов;

5 для суммы всех конгенеров. 
Таблица 11.9

Оценка экологического риска для жителей Дальнего Востока России при употреблении камбал из дальневосточных морей России

\begin{tabular}{lcccc}
\hline Токсикант & EDI для HQ & HQ & EDI для ILCR & ILCR \\
\hline \multicolumn{5}{c}{ Восток Охотского моря } \\
\hline$\beta$-ГХЦГ & $1,14 \cdot 10^{-7}$ & 0,0004 & $1,08 \cdot 10^{-7}$ & $1,94 \cdot 10^{-7}$ \\
ДДД & $1,17 \cdot 10^{-7}$ & 0,0002 & $1,1 \cdot 10^{-7}$ & $2,64 \cdot 10^{-8}$ \\
ПХБ & $2,88 \cdot 10^{-7}$ & 0,0022 & $2,71 \cdot 10^{-7}$ & $5,43 \cdot 10^{-7}$ \\
\hline \multicolumn{5}{c}{ Юг Охотского моря } \\
\hline$\alpha$-ГХЦГ & $4,46 \cdot 10^{-8}$ & 0,0001 & $4,2 \cdot 10^{-8}$ & $2,65 \cdot 10^{-7}$ \\
$\beta$-ГХЦГ & $3,33 \cdot 10^{-7}$ & 0,0011 & $3,13 \cdot 10^{-7}$ & $5,64 \cdot 10^{-7}$ \\
ДДД & $1,45 \cdot 10^{-7}$ & 0,0003 & $1,37 \cdot 10^{-7}$ & $3,28 \cdot 10^{-8}$ \\
ДДЕ & $8,28 \cdot 10^{-8}$ & 0,0002 & $7,8 \cdot 10^{-8}$ & $2,65 \cdot 10^{-8}$ \\
ПХБ & $8,13 \cdot 10^{-7}$ & 0,0063 & $7,66 \cdot 10^{-7}$ & $1,53 \cdot 10^{-6}$ \\
\hline \multicolumn{5}{c}{ Татарский пролив } \\
\hline$\beta$ ПГХЦГ & $4,34 \cdot 10^{-7}$ & 0,0014 & $4,09 \cdot 10^{-7}$ \\
ПХБ & $8,92 \cdot 10^{-7}$ & 0,0069 & $8,4 \cdot 10^{-7}$ & $7,36 \cdot 10^{-7}$ \\
\hline \multicolumn{5}{c}{ Японское море } \\
\hline$\alpha$-ГХЦГ & $1,4 \cdot 10^{-8}$ & 0,00005 & $1,32 \cdot 10^{-8}$ \\
$\beta$-ГХЦГ & $4,22 \cdot 10^{-7}$ & 0,0014 & $3,97 \cdot 10^{-7}$ & $8,31 \cdot 10^{-8}$ \\
$\gamma$-ГХЦГ & $1,59 \cdot 10^{-8}$ & 0,0001 & $1,5 \cdot 10^{-8}$ & $1,15 \cdot 10^{-7}$ \\
ДДД & $1,06 \cdot 10^{-7}$ & 0,0002 & $1,0 \cdot 10^{-7}$ & $2,4 \cdot 10^{-8}$ \\
ДДЕ & $7,61 \cdot 10^{-8}$ & 0,0002 & $7,17 \cdot 10^{-8}$ & $2,44 \cdot 10^{-8}$ \\
ПХБ & $1,15 \cdot 10^{-5}$ & 0,0885 & $1,08 \cdot 10^{-5}$ & $2,17 \cdot 10^{-5}$ \\
Допустимый уровень & HQ<0,2 & \\
\hline
\end{tabular}

Согласно полученным данным, HQ был меньше 0,2 во всех случаях. Однако в камбалах из б. Рифовая (Японское море) зафиксировано превышение допустимых уровней ILCR чуть более, чем в 2 раза из-за больших уровней накопления ПХБ. Это говорит о необходимости включения методики оценки риска для здоровья в доказательную методологическую базу нормативных документов РФ. На сегодняшний день существует острая необходимость в проведении природоохранных мероприятий в этой бухте (снижение количества отдыхающих, замена старых трансформаторов, использующих ПХБ на более новые, снижение судоходства в этом районе) и тщательная проверка вылавливаемой здесь рыбы.

\subsection{3. Морские млекопитающие}

В настоящее время особенностью Российского Севера является параллельное ведение двух противоположных типов хозяйствования. Одно из них - традиционное, другое - современное, что отражается на рационе питания местного населения [2]. 
Традиционный рацион коренного населения крайнего Севера формировался столетиями и за счет недоступности легкоусваиваемых углеводов состоял, в основном, из жиров и белка. Во внутренних частях континента потребность людей в эссенциальных пищевых компонентах удовлетворялась, в первую очередь, за счет оленеводства и охоты, на побережье Российского Севера основными источниками пищи являлись морские организмы. Появление легкодоступных продуктов (макароны, крупы, овощи), богатых углеводами, привело к снижению уровней потребления традиционной «варварской» пищи (мяса китов, моржей и тюленей). В противовес привычной пище народов Российского Севера ставились привычные современным людям продукты пищевой промышленности, производимые в более южных районах страны [3], что в свою очередь привело к значительному падению потребления продуктов из морских млекопитающих (по данным 2008 г. - с 83,6 до 52 кг/год на человека). Развал СССР и последовавший за этим экономический кризис практически полностью оборвали поставки продуктов в районы крайнего Севера и заставили коренное население вновь обратить свое внимание на традиционные источники пищи.

На сегодняшний день не существует официальной статистики потребления коренным населением Чукотки мяса и субпродуктов морских млекопитающих. Однако согласно работе [3], до 80 \% местного населения отдает предпочтение традиционной кухне, в том числе использующей продукты морского зверобойного промысла - китов и моржей. В связи с этим, для исследованных особей серого кита и тихоокеанского моржа рассчитывались максимально допустимые уровни потребления (кг/мес на одного человека), при которых существует потенциальный риск развития рака в течение жизни (ILCR) или возникновение острого отравления (HQ). Оценка коэффициентов HQ и ILCR проводилась раздельно, поскольку они учитывают разные величины и могут проявляться при разных уровнях употребления.

Концентрации поллютантов, обнаруженных нами в мышцах и печени самок и самцов серых китов и тихоокеанских моржей (Глава 8) в мГ/кг сырой массы указаны в таблице 11.10. Стоит отметить, что уровни поллютантов в мясе исследованных млекопитающих не превышали санитарногигиенических нормативов Российской Федерации. 
Таблийа 11.10

Уровни СО3, обнаруженные в мышцах (числитель)

и печени (знаменатель) серого кита и тихоокеанского моржа, мг/кг сырой массы

\begin{tabular}{llllll}
\hline Вид & $\alpha$-ГХЦГ & $\beta$-ГХЦГ & $\gamma$-ГХЦГ & ДДТ & ДДЕ \\
\hline Серый кит & $\underline{0,025 \pm 0,026}$ & $\underline{0,016 \pm 0,011}$ & $\underline{0,010 \pm 0,012}$ & $\overline{-}$ & $\underline{0}$ \\
& $0,017 \pm 0,037$ & $0,025 \pm 0,015$ & $0,021 \pm 0,016$ & $0,018 \pm 0,012$ & $0,020 \pm 0,020$ \\
Тихоокеанский & $\underline{0,014 \pm 0,017}$ & $\underline{0,016 \pm 0,007}$ & $\underline{0,029 \pm 0,025}$ & $\underline{0,027 \pm 0,005}$ & $\overline{\overline{1}}$ \\
морж & $0,421 \pm 0,557$ & $0,046 \pm 0,059$ & $0,144 \pm 0,241$ & $0,268 \pm 0,156$ & $1,944 \pm 2,229$ \\
ПДК & $\frac{0,2^{2}}{1,0}$ & & & $\frac{0,2^{3}}{3,0}$ & \\
\hline
\end{tabular}

недостаточно образцов для оценки риска

2 сумма $\alpha$-, $\beta$ - и $\gamma$-изомеров ГХЦГ

3 сумма ДДТ и его метаболитов

Расчет максимального потребления мяса и печени серых китов и тихоокеанских моржей (отдельно для самцов и самок) для оценки потенциальной возможности развития рака в течение жизни производился, путем подбора такого среднемесячного потребления, при котором значение коэффициента потенциального риска развития рака в течение жизни для

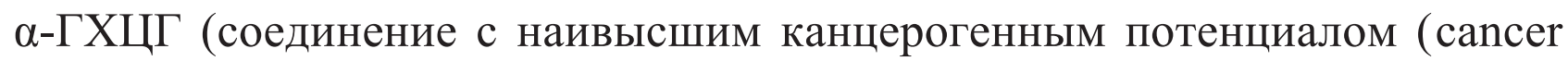
slope factor) среди всех обнаруженных соединений) составляло $1,0 \cdot 10^{-5}$ (значение указывающее на индивидуальный риск). При оценке риска острого отравления среднесуточное потребление определяли, основываясь на наибольших концентрациях отдельных изомеров ГХЦГ, как имеющих наименьшую допустимую суточную дозу (для изомеров ГХЦГ 0,0003, для ДДЕ - 0,0005). Результаты расчетов указаны в таблицах 11.11 и 11.12 .

Согласно расчетам, потенциальный риск развития отравления наблюдается при употреблении мяса и печени серого кита $-5,0$ и 5,1, тихоокеанского моржа - 4,4 и 0,11 кг/мес, соответственно. Аналогичные показатели для потенциального риска развития рака в течение жизни для кита - 0,14 и 0,21; тихоокеанского моржа - 0,26 и 0,01 кг/год, соответственно. Во всех случаях повышение потенциального риска развития рака в течение жизни происходило за счет $\alpha$-ГХЦГ. 
Максимальные уровни потребления органов млекопитающих, при которых возникает риск отравления

\begin{tabular}{|c|c|c|c|c|}
\hline Вид & CO3 & $\begin{array}{l}\text { Допустимое } \\
\text { потребление, } \\
\text { кг/месяц }{ }^{1}\end{array}$ & $\begin{array}{l}\text { EDI для HQ } \\
1\end{array}$ & $\mathrm{HQ}^{1}$ \\
\hline $\begin{array}{l}\text { Тихоокеанский } \\
\text { морж } \\
\text { (Odobenus } \\
\text { rosmarus) }\end{array}$ & $\begin{array}{l}\alpha \text {-ГХЦГ } \\
\beta \text {-ГХЦГ } \\
\gamma \text {-ГХЦГ } \\
\text { ДДТ } \\
\text { дДЕ }\end{array}$ & $\frac{5,0}{5,1}$ & 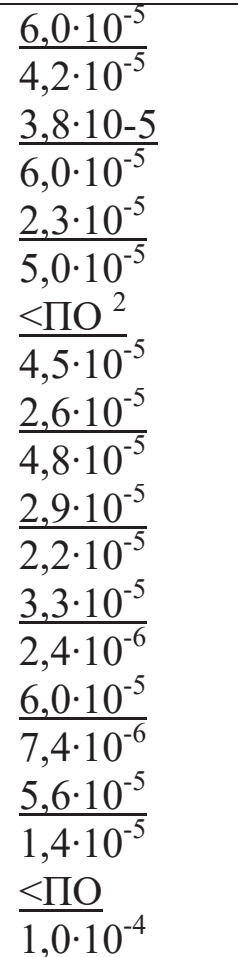 & 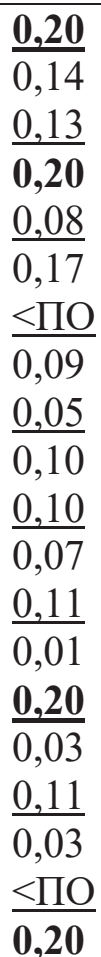 \\
\hline
\end{tabular}

${ }^{1}$ в числителе - значение для мышц, в знаменателе - для печени

${ }^{2}$ ниже пределов обнаружения

Согласно данным работы [3], среднегодовое потребление мяса кита составляет 4,3 кг/мес на человека. Полученные нами результаты показывают, что уровни потребления мяса морских млекопитающих не способны вызвать острое отравление организма, однако потенциально могут способствовать развитию онкологических заболеваний. Допустимые уровни потребления печени кита и моржа находятся на очень низком уровне как в отношении потенциального риска отравления, так и повышения риска развития онкологических заболеваний. На сегодняшний день существует высокая необходимость в постоянном мониторинг СО3 в органах морских млекопитающих, (в особенности - использующихся в пищу), оценка риска для здоровья коренных жителей Чукотского автономного округа, а также государственные меры по снижению риска здоровью местным жителям ЧАО. 
Максимальные уровни потребления органов млекопитающих, при которых потенциально возможно развитие

\begin{tabular}{|c|c|c|c|c|}
\hline \multicolumn{5}{|c|}{ раковых заболеваний } \\
\hline Вид & $\mathrm{CO} 3$ & 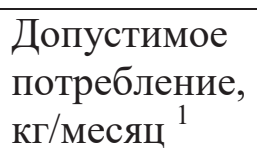 & $\begin{array}{l}\text { EDI для } \\
\text { ILCR }^{1}\end{array}$ & ILCR $^{\top}$ \\
\hline \multirow{9}{*}{$\begin{array}{l}\text { Серый кит } \\
\text { (Eschrichtius } \\
\text { robustus) }\end{array}$} & 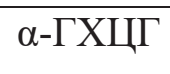 & 0,14 & $\frac{1,6 \cdot 10^{-6}}{10^{-6}}$ & $1,0 \cdot 10^{-5}$ \\
\hline & В-ГХШГ & 0,21 & $\begin{array}{l}1,6 \cdot 10^{-6} \\
10 \cdot 10^{-6}\end{array}$ & $\mathbf{1 , 0 \cdot 1 0 ^ { - 5 }}$ \\
\hline & & & $2,3 \cdot 10^{-6}$ & $4,1 \cdot 10^{-6}$ \\
\hline & $\gamma-Г Х Ц Г ~$ & & $6,2 \cdot 10^{-7}$ & $8,1 \cdot 10^{-7}$ \\
\hline & & & $1,9 \cdot 10^{-6}$ & $2,5 \cdot 10^{-6}$ \\
\hline & ДДТ & & $\leq \Pi^{2}$ & $\leq \Pi \mathrm{O}$ \\
\hline & & & $\overline{1,7 \cdot 10^{-6}}$ & $\overline{5,8 \cdot 10^{-7}}$ \\
\hline & ДДЕ & & $\underline{6,9 \cdot 10^{-7}}$ & $2,4 \cdot 10^{-7}$ \\
\hline & & & $1,8 \cdot 10^{-6}$ & $6,2 \cdot 10^{-7}$ \\
\hline \multirow{10}{*}{$\begin{array}{l}\text { Тихоокеанский } \\
\text { морж } \\
\text { (Odobenus } \\
\text { rosmarus) }\end{array}$} & 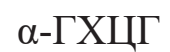 & $\underline{0,26}$ & $1,6 \cdot 10^{-6}$ & $1,0 \cdot 10^{-5}$ \\
\hline & & 0,01 & $1,6 \cdot 10^{-6}$ & $1,0 \cdot 10^{-5}$ \\
\hline & 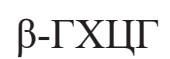 & , & $1,8 \cdot 10^{-6}$ & $\underline{3,3 \cdot 10^{-6}}$ \\
\hline & & & $1,7 \cdot 10^{-7}$ & $3,1 \cdot 10^{-7}$ \\
\hline & $\gamma$-ГХЦГ & & $\underline{3,3 \cdot 10^{-6}}$ & $\underline{4,3 \cdot 10^{-6}}$ \\
\hline & & & $5,4 \cdot 10^{-7}$ & $7,0 \cdot 10^{-7}$ \\
\hline & ДДТ & & $\underline{3,1 \cdot 10^{-6}}$ & $1,0 \cdot 10^{-6}$ \\
\hline & & & $1,0 \cdot 10^{-6}$ & $3,4 \cdot 10^{-7}$ \\
\hline & ДДЕ & & $<\Pi \mathrm{O}$ & $\leq \Pi \mathrm{O}$ \\
\hline & & & $\overline{7,3 \cdot 1} 0^{-6}$ & $\overline{2,5 \cdot 1} 0^{-6}$ \\
\hline
\end{tabular}

\section{3. Заключение}

Оценка экологического риска для здоровья - это новый прогрессивный метод оценки качества и безопасности пищевых продуктов, основывающийся на фундаментальных знаниях медицины, токсикологии и экологии, что рекомендует его для включения в нормативную базу Российской Федерации. Несмотря на значительное снижение уровней СО3 в Мировом океане, для всех исследованных организмов, употребляемых человеком в пищу на Дальнем Востоке России обнаружен потенциальный риск развития онкологических заболеваний. Наибольшую опасность представляют мясо и печень млекопитающих, используемых в пищу коренными народами Чукотского автономного округа. Наименьшую опасность показали камбалы, выловлен- 
ные в дальневосточных морях России - риск обнаружен только для рыб из Японского моря, прибрежные воды которого считаются загрязненными или сильно загрязненными. Тихоокеанские лососи, как мигрирующие виды, меньше подвержены локальным источникам загрязнения морской среды и отражают общую тенденцию к выведению СО3 из экосистем Мирового океана. Однако несмотря на снижение загрязненности, риск теоретически возможен при их употреблении на уровне 29 кг/год. Для снижения потенциальной опасности для здоровья населения Дальнего Востока рекомендуется государственное вмешательство и управление рисками.

\section{4. Список литературы}

1. Ворожбит, О.Ю. Рыбная промышленность Дальнего Востока России: современное состояние, проблемы и перспективы конкурентоспособности / О.Ю. Ворожбит, Т.Е. Даниловских, И.А. Кузьмичева [и др.]. Владивосток: Изд-во ВГУЭС, 2016. - 156 с.

2. Дударев, А.А. Персистентные полихлорированные углеводороды и тяжелые металлы в арктической биосфере: основные закономерности экспозициии репродуктивное здоровье коренных жителей / А.А. Дударев // Биосфера. - 2009. - Т. 1. - № 2. - С. 186-202.

3. Козлов, А.И. Диета Чукотки / А.И. Козлов, В. Нувано, Э. Здор // Химия и жизнь. - 2008. - № 4. - С. 42-45.

4. СанПиН 2.3.2.1078-01 Санитарно-эпидемиологические правила и нормативы (с изменениями на 6 июля 2011 года). - М.: Минздрав России, 2002. $-154 \mathrm{c}$.

5. ТР ЕАЭС 040/2016 Технический регламент Евразийского экономического союза «О безопасности рыбы и рыбной продукции». - Москва: Совет Евразийской экономической комиссии, 2016. - 84 с.

6. ТР ТС 021/2011 Технический регламент Таможенного союза «О безопасности пищевой продукции». - Москва: Комиссия Таможенного союза, 2011. - 265 с.

7. Bourgeois, M. Human Health Risk Assessment / M. Bourgeois, G. Johnson, R. Harbison // International Encyclopedia of Public Health. Elsevier, 2017. - P. 84-94. 
8. Byun, G.-H. Biomagnification of persistent chlorinated and brominated contaminants in food web components of the Yellow Sea / G.-H. Byun, H.-B. Moon, J.-H. Choi, J. Hwang, C.-K. Kang // Marine Pollution Bulletin. 2013. - V. 73. - P. 210-219.

9. C.F.I.A. Standards and Methods Manual [Electronic resource]. - Government of Canada, 2012. - Access mode: https://www.inspection.gc.ca/foodsafety-for-industry/archived-food-guidance/fish-and-

seafood/manuals/standards-and-

methods/eng/1348608971859/1348609209602?chap=7\#s20c7. - Date of the application: 13.08.2020.

10. Code of Federal Regulations. Title 21 - Food and Drugs. Chapter IFood and Drug Administration Department of Health and Human Services. Subchapter B - Food for Human Consumption. Section 109.30 Tolerances for polychlorinated biphenyls (PCB's) [Electronic resource]. - USA: Food and Drug Administration, Department of Health and Human Services, 2018. - Access mode: https://www.accessdata.fda.gov/scripts/cdrh/cfdocs/cfcfr/C FRSearch.cfm?fr=109.30. - Date of the application: 13.08.2020.

11. Compliance Policy Guide. Sec. 575.100 Pesticide Residues in Food and Feed - Enforcement Criteria (Compliance Policy Guide 7141.01) [Electronic resource]. - USA: Food and Drug Administration, 2018. - Access mode: https://www.fda.gov/regulatory-information/search-fda-guidancedocuments/compliance-policy-guide-sec-575100-pesticide-residues-food-andfeed-enforcement-criteria-compliance/. - Date of the application: 13.08.2020.

12. Daba, D. Multi Residue Analysis of Pesticides in Wheat and Khat Collected from Different Regions of Ethiopia / D. Daba, A. Hymete, A.A. Bekhit [et al.] // Bulletin of Environmental Contamination and Toxicology. - 2011. - V. 86. - P. 336-341

13. Dong, Z. Uncertainties in human health risk assessment of environmental contaminants: A review and perspective / Z. Dong, Y. Liu, L. Duan, D. Bekele, R. Naidu // Environment International. - 2015. - V. 85. - P. 120-132.

14. Federal Register of Legislation. Australia New Zealand Food Standards Code - Schedule 19 - Extraneous residue limits // Food Standards Gazette. - 2017. - № FSC96. - n.d.

15. Federal Register of Legislation. Australia New Zealand Food Standards Code - Schedule 21 - Extraneous residue limits // Food Standards Gazette. 2017. - № FSC96. - n.d. 
16. First Hong Kong Total Diet Study: Organochlorine Pesticide Residues. - Hong Kong: Centre for Food Safety, Food and Environmental Hygiene Department, 2014. - 40 p.

17. Health Canada Federal Contaminated Site Risk Assessment in Canada, Part II: Health Canada Toxicological Reference Values (TRVs) and Chemical-Specific Factors, Version 2.0. - Ottawa, Ontario: Health Canada, 2020.

18. Kasozi, G.N. Organochlorine Residues in Fish and Water Samples from Lake Victoria, Uganda / G.N. Kasozi, B.T. Kiremire, F.W.B. Bugenyi [et al.] // Journal Environmental Quality. - 2006. - V. 35. - P. 584-589.

19. Lukyanova, O.N. Organochlorine pesticides and polychlorinated biphenyls in the Bering flounder (Hippoglossoides robustus) from the Sea of Okhotsk / O.N. Lukyanova, V.Yu. Tsygankov, M.D. Boyarova // Marine Pollution Bulletin. - 2018. - V. 137. - P. 152-156.

20. Mwevura, H. Organochlorine pesticide residues in sediments and biota from the coastal area of Dar es Salaam city, Tanzania / H. Mwevura, O.C. Othman, G.L. Mhehe // Marine Pollution Bulletin. - 2002. - V. 45 - - P. 262-267.

21. National Food Safety Standard for Maximum Levels of Contaminants in Foods (GB 2762-2017). - Beijing: National Health and Family Planning Commission, Ministry of Agriculture, China Food and Drug Administration. - 17 p.

22. National food safety standard for Maximum Residue Limits for Pesticides in Foods (GB 2763-2016). - Beijing: National Health and Family Planning Commission, Ministry of Agriculture, China Food and Drug Administration. $-218 \mathrm{p}$.

23. Ogwok, P. Pesticide Residues and Heavy Metals in Lake Victoria Nile Perch, Lates niloticus, Belly Flap Oil / P. Ogwok, J.H. Muyonga, M.L. Sserunjogi // Bull Environ Contam Toxicol. - 2009. - No. 82 (5). P. 529-533.

24. Tanabe, S. Organochlorine pesticide and polychlorinated biphenyl residues in foodstuffs from Bangkok, Thailand / S. Tanabe, K. Kannan, M.S. Tabucanon [et al.] // Environmental Pollution - 1991. - V. 72. - P. 191-203.

25. US EPA IRIS United States Environment Protection Agency (USEPA)'s Integrated Risk Information System. - USA: Environment Protection Agency, 2007.

26. Yahia, D. Multi pesticide and PCB residues in Nile tilapia and catfish in Assiut city, Egypt / D. Yahia, E.E. Elsharkawy // Science of The Total Environment. - 2014. - V. 466-467. - P. 306-314. 
https://doi.org/10.24866/7444-4891-2/283-316

\title{
ГЛАВА 12
}

\section{СТОЙКИЕ ОРГАНИЧЕСКИЕ ЗАГРЯЗНЯЮЩИЕ ВЕЩЕСТВА (СОЗ) В ОРГАНИЗМЕ ЧЕЛОВЕКА: ОПЫТ РОССИИ И БЫВШИХ СОВЕТСКИХ РЕСПУБЛИК}

\author{
Ю.П. Гумовская ${ }^{1}$, А.Н. Гумовский \\ В.Н. Цыганков ${ }^{1,2}$, А.В. Полевщиков
}

В обзоре приведены данные о распространенности и использовании СО3 в России. Описаны актуальные биомониторинговые исследования СО3 в органах и тканях человека. Рассмотрены результаты российских и советских исследований о влиянии ксенобиотиков на человеческий организм. Пик изучения острого воздействия токсикантов на здоровье человека пришелся на 1960-1970 гг. В 1980-1990 гг. появляются работы, изучающие хроническое их воздействие.

Ключевые слова: СОЗ; биомониторинг; здоровье человека; влияние на организм.

${ }^{1}$ Школа биомедицины, Дальневосточный федеральный университет (ДВФУ), 690922, Владивосток, о. Русский, п. Аякс, 10. E-mail: nup1@yandex.ru.

2 Школа естественных наук, Дальневосточный федеральный университет (ДВФУ), 690922, Владивосток, о. Русский, п. Аякс, 10.

3 Отдел иммунологии, Институт экспериментальной медицины (ИЭМ), 197376, СанктПетербург, улица Академика Павлова, 12.

Для цичтирования: Гумовская Ю.П., Гумовский А.Н., Цыганков В.Ю., Полевщиков А.В. Стойкие органические загрязняющие вещества $(\mathrm{CO} 3)$ в организме человека: опыт России и бывших Советских республик // Стойкие органические загрязняющие вещества (CO3) в Дальневосточном регионе: моря, организмы, человек : монография / В.Ю. Цыганков, М.М. Донец, Н.К. Христофорова [и др.] ; науч. ред. В.Ю. Цыганков. - Владивосток : Изд-во Дальневост. федерал. ун-та, 2020. - С. 283-316. https://doi.org/10.24866/7444-4891-2/283-316.

For citing: Gumovskaya Yu.P., Gumovskiy A.N., Tsygankov V.Yu., Polevshchikov A.V. Persistent organic pollutants (POPs) in the human body: the experience of Russia and the ex-USSR republics // Persistent organic pollutants (POPs) in the Far Eastern Region: Seas, Organisms, Human : monograph / V.Yu. Tsygankov, M.M. Donets, N.K. Khristoforova [et al.] ; ed. by V.Yu. Tsygankov. - Vladivostok : Publishing House of the Far Eastern Federal University, 2020. - P. 283-316. - https://doi.org/10.24866/7444-4891-2/283-316. 


\title{
CHAPTER 12. Persistent organic pollutants (POPs) in the human body: the experience of Russia and the ex-USSR republics
}

\author{
Yu.P. Gumovskaya ${ }^{1}$, A.N. Gumovskiy ${ }^{1}$, \\ V.Yu. Tsygankov ${ }^{1,2}$, A.V. Polevshchikov ${ }^{3}$
}

Persistent organic pollutants (POPs) are anthropogenic compounds, which negatively impact on all living organisms and are a global environmental problem. In human body, as a representative of the top of the trophic chain, POPs enter with alimentary, inhalation and contact ways and cause mutagenic, teratogenic and embryotoxic effects. The review data on the prevalence and use of POPs in Russia are presented. The current biomonitoring studies of POPs in human organs and tissues are described. The results of Russian and USSR studies of xenobiotics effect on the human body are considered. The active study of the acute effects of toxicants on human health was in the 1960-1970s. In 1980-1990 publications about chronic impact this compounds are appear.

Key words: POPs; biomonitoring; human health; effect on the body.

\section{Список сокращений:}

ВПР - врожденные пороки развития;

ГН - гигиенические нормативы;

ГХЦГ - гексахлорциклогексан;

ДДЕ - дихлордифенилдихдорэтилен;

ДДТ - дихлордифенилтрихдорэтан;

ЖКТ - желудочно-кишечный тракт;

ЛДГ - лактатдегидрогеназа;

ЛОР - ларингооторинология;

ПДК - предельно допустимая концентрация;

ПХБ - полихлорированные бифенилы;

ПХДД - полихлорированные дибензо-п-диоксины;

$\mathrm{CO} 3$ - стойкие органические загрязняющие вещества;

ХОП - хлорорганические пестициды;

ХОС - хлорорганические соединения;

ЦНС - центральная нервная система. 
В условиях современной цивилизации экологические факторы влияют на здоровье человека на 40-50 \%. Загрязнение окружающей среды одна из основных причин роста заболеваний, приводящих к ослаблению и модификации защитных функций и адаптационных резервов организма человека $[17,24]$. В течение второй половины XX века происходило неконтролируемое загрязнение биосферы продуктами распада пестицидов хлорорганической группы [37].

Пестициды - стойкие органические загрязняющие вещества (CO3), оказывающие повреждающее действие на всех уровнях организации живой материи. Их накопление в окружающей среде представляет глобальную проблему. Вследствие своей токсичности, стабильности в окружающей среде и липофильности они являются общеметаболическими ядами с выраженным побочным мутагенным и канцерогенным действием [56, 76].

Мировое сообщество приняло ряд документов, предусматривающих разработку и осуществление глобальных мер, направленных на уменьшение аккумуляции СО3 в окружающей среде и связанных с ними рисков. В рамках «Конвенции о стойких органических загрязнителях» (Стокгольмская конвенция) ведется глобальный мониторинг уровня СО3 в разных средах обитания, организмах животных, растений и человека, что является предметом широких и многогранных научных проектов [126].

Россия в рамках Стокгольмской конвенции проводит биомониторинг СО3 на всей своей территории. В настоящее время исследованы все звенья морских и наземных трофических уровней [130-133], однако до сих пор остается открытым вопрос о влиянии СО3 на здоровье человека как конечное звено пищевой цепи. Несмотря на значительный объем проводимых в стране исследований $[7,21,26,32,34,52,79,94$, $116,133]$, массив полученных результатов по наличию СО3 на разных уровнях пищевой цепи и в организме человека требует систематизации и обобщения. Дополнительные исследования по-прежнему нужны и для оценки медицинского значения выявленных концентраций СОЗ. В связи с этим цель обзора - систематизация результатов мониторинговых исследований в России с участием человека как биоиндикатора $\mathrm{CO} 3$, а также обобщение данных о возможных патологиях, связанных с воздействием этих ксенобиотиков на организм человека. 


\section{1. Распространенность и использование СОЗ в России}

В России зарегистрировано около 1500 наименований пестицидов, представляющих собой моновещества, их разнообразные композиции, а также препараты биологического действия на основе фитопатогенных штаммов микроорганизмов, грибов и др. [29]. Сведения об основных группах пестицидов обобщены в табл. 12.1.

Таблийа 12.1

\section{Классификация пестицидов по назначению, способу проникновения и характеру действия [104]}

\begin{tabular}{|c|c|}
\hline Группа & Назначение, способ проникновения и характер действия \\
\hline \multicolumn{2}{|r|}{ Инсектицчиды } \\
\hline Контактного действия & Вызывают гибель вредных насекомых при контакте \\
\hline Кишечного действия & $\begin{array}{l}\text { Вызывают гибель вредных насекомых при попадании в ки- } \\
\text { шечник }\end{array}$ \\
\hline Системного действия & $\begin{array}{l}\text { Способны продвигаться по сосудистой системе растения и } \\
\text { отравлять поедающих его насекомых }\end{array}$ \\
\hline Фумиганты & $\begin{array}{l}\text { Действуют в газообразном состоянии через органы дыхания } \\
\text { насекомых }\end{array}$ \\
\hline \multicolumn{2}{|r|}{ Гербицицыь } \\
\hline Контактного действия & Вызывают гибель сорных растений при контакте \\
\hline Системного действия & $\begin{array}{l}\text { Способны продвигаться по сосудистой системе растения и } \\
\text { вызывать его гибель }\end{array}$ \\
\hline Почвенного действия & $\begin{array}{l}\text { Действуют на корневую систему растений или на прораста- } \\
\text { ющие семена }\end{array}$ \\
\hline $\begin{array}{l}\text { Избирательного дей- } \\
\text { ствия }\end{array}$ & Поражают только определенные виды растений \\
\hline Сплошного действия & Уничтожают всю растительность \\
\hline \multicolumn{2}{|r|}{ Фунгицииды } \\
\hline Контактного действия & Используют для борьбы с патогенными грибами \\
\hline Системного действия & $\begin{array}{l}\text { Способны продвигаться по сосудистой системе растений и } \\
\text { убивать патогенные грибы }\end{array}$ \\
\hline Защитного действия & Способны защищать от воздействий патогенных грибов \\
\hline Лечебного действия & $\begin{array}{l}\text { Способны давать лечебный эффект при действии патогенных } \\
\text { грибов }\end{array}$ \\
\hline \multicolumn{2}{|r|}{ Другие группь } \\
\hline Ларвициды & Уничтожают личинок и гусениц насекомых \\
\hline Акарициды & Уничтожают растительноядных клещей \\
\hline Овициды & Уничтожают яйца вредных насекомых и клещей \\
\hline Нематоциды & Уничтожают круглых червей \\
\hline $\begin{array}{l}\text { Зооциды, } \\
\text { или родентициды }\end{array}$ & Уничтожают грызунов \\
\hline Моллюстициды & Уничтожают моллюсков \\
\hline Бактерициды & Уничтожают болезнетворные бактерии \\
\hline
\end{tabular}


СТОЙКИЕ ОРГАНИЧЕСКИЕ ЗАГРЯЗНЯЮЩИЕ ВЕЩЕСТВА (СОЗ) В ОРГАНИЗМЕ ЧЕЛОВЕКА: ОПЫТ РОССИИ И БЫВШИХ СОВЕТСКИХ РЕСПУБЛИК

На территории Российской Федерации действует Каталог пестицидов и агрохимикатов, разрешенных к применению Министерством сельского хозяйства РФ. При этом, как видно из табл.4.1, понятие «пестициды» трактуется достаточно широко. К ним относят как средства защиты, так и стимуляторы роста. Все вещества в каталоге зарегистрированы в соответствии с Федеральным Законом № 109 от 19.06.1997 г. «О безопасном обращении с пестицидами и агрохимикатами». В 2018 г. постановлением Главного санитарного врача введены новые Гигиенические нормативы (ГН) 1.2.3539-18 для пестицидов, в то время как до 2016 г. применение пестицидов и химикатов регулировалось ГН 1.2.3111-13 [18].

Многие пестициды уже не применяются в силу низкой эффективности или высокой токсичности, что закреплено в соответствующих международных соглашениях. Тем не менее инвентаризация 2003 г. выявила, что на территории России хранится 24000 т запрещенных к использованию пестицидов и/или средств с истекшим сроком годности. Одновременно дополнительные опасения вызывает тот факт, что 60 \% складов не отвечает санитарным нормам и требованиям безопасности. Масштабное и зачастую бесконтрольное и неоправданное применение пестицидов привело к тому, что на $60 \%$ обследованных территорий отмечается превышение уровней ПДК пестицидов в разных средах. К числу наиболее проблемных территорий относятся регионы самого активного земледелия, вносящие решающий вклад в производство сельхозпродукции в стране, в том числе Краснодарский край (2700 т хранящихся на складах неутилизированных запрещенных к применению или устаревших пестицидов), Ростовская, Воронежская и Курганская области, Алтайский край (до 1000 т в каждом из регионов) [87].

Данные литературы свидетельствуют, что в подавляющем большинстве случаев наиболее загрязненная среда - почва сельхозугодий $[47,105]$. Однако важными дополнительными источниками СО3 могут быть участки лесных пожаров, горящие свалки бытовых отходов и даже небольшие костры на приусадебных и дачных участках [47]. Так, согласно отчету Министерства природных ресурсов и экологии РФ «Состояние загрязнения пестицидами объектов природной среды Российской Федерации» в 2017 г. исследованы почвы различного типа из 39 субъектов РФ. Превышение ПДК по пестицидам обнаружено на территории 11 субъектов Российской Федерации (в 2016 г. - на территории 12 субъектов) [97]. 
Другим важным примером распространенности СО3 в России остаются полихлорированные бифенилы (ПХБ) - один из наиболее распространенных и опасных для окружающей среды и человека классов СО3. Их смеси обладают уникальными физическими и химическими свойствами, обеспечивающими удобство хранения и применения (невоспламеняемость, устойчивость к действию кислот и щелочей, низкая растворимость в воде, широкие диэлектрические характеристики). Именно это определяет их повсеместное использование в промышленности. ПХБ устойчивы к гидролизу и биотрансформации в воде, но со временем при фотолизе в процессе ряда последовательных реакций ПХБ могут стать источником более токсичных соединений - полихлорированных дибензо-п-диоксинов (ПХДД) [71].

Главными источниками загрязнения ПХБ являются многочисленные гидроэлектростанции, железные дороги и промышленные предприятия, производящие и использующие конденсаторы и трансформаторы. Часть ПХБ образуется как побочный продукт в процессе сжигания мусора. В результате проведенной инвентаризации ПХБ и ПХБ-содержащего оборудования в РФ в 2000 г. выявлено наличие около 7500 трансформаторов и 340000 конденсаторов, в которых содержатся около 21000 т ПХБ. Однако, согласно экспертной оценке, реальное количество ПХБ значительно выше и составляет не менее 28000 т [72, 90].

В Советском Союзе, в странах СНГ и Российской Федерации до 2011 г. ПХБ широко использовались в промышленности при производстве трансформаторов. Основные производства находились в городах Серпухов (Россия), Усть-Каменогорск (Казахстан), Гюмри (Азербайджан)), на лакокрасочных заводах в Ярославле, Челябинске, Загорске, Котовске (все - Россия), заводах по изготовлению смазок (Нижний Новгород, Санкт-Петербург, Оренбург, Уфа, Пермь, все - Россия) [42]. В настоящее время наибольшее количество ПХБ обнаружено в Поволжском и Уральском регионах, за ними идут Центральный, Восточно-Сибирский, Северо-Кавказский и ВолгоВятский регионы [64].

С принятием Федерального закона РФ № 164 от 27 июня 2011 года «О ратификации Стокгольмской конвенции о стойких органических загрязнителях (СО3)» Россия взяла на себя обязательства по уничтожению запасов ПХБ. До 2025 г. содержащее ПХБ электротехническое оборудование должно быть выведено из эксплуатации, до 2028 г. - уничтожены со- 
держащие ПХБ отходы. В России контроль выбросов поллютантов в атмосферу осуществляется по специальным программам. Исследование отобранных проб проводится в аккредитованных на проведение анализа диоксинов и ПХБ лабораториях, расположенных в Москве, СанктПетербурге, Обнинске и Уфе [55].

Важной характеристикой токсических эффектов ПХБ является подавление иммунитета. Поступление ПХБ в организм человека также провоцирует развитие рака различной локализации, поражений печени, почек, нервной системы, кожи (нейродермиты, экземы, сыпи). Попадая в организм плода и ребенка, ПХБ проявляют тератогенные эффекты и способствуют появлению врожденных уродств, отставанию в развитии, дисфункции иммунитета, поражению кроветворения. ПХБ также обладают мутагенным действием, что негативно влияет на здоровье последующих поколений.

\section{2. Биомониторинг СО3 в организме человека}

Во многих странах большинство СО3 запрещено или ограничено к применению. В 2006 г. Всемирная организация здравоохранения (ВО3) приняла решение о продолжении применения самого известного хлорорганического пестицида ДДТ в 12 странах мира, в том числе в Индии, Северной Корее и некоторых южноафриканских государствах [126]. Эти CO3 могут попадать в Россию за счет трансграничного переноса, морскими течениями, мигрирующими организмами и с продуктами питания $[120,121]$.

CO3 могут поступать в организм человека алиментарным, ингаляционным и контактным путем через поврежденные и даже неповрежденные кожные покровы. Их воздействию подвергаются как сельские жители, живущие поблизости от мест обработок, так и широкий круг населения вследствие широкого бытового применения [54]. Типичным примером для анализа распространения СО3 в организме человека являются хлорорганические пестициды (ХОП). 
Биологический мониторинг, являющийся интегральным показателем загрязнения накопления ХОП в организме человека, проводится в четырех самых крупных аграрных субъектах Южного Федерального Округа: Краснодарском крае, Астраханской, Волгоградской и Ростовской областях. К сожалению, отсутствуют данные по республикам Адыгея и Калмыкия, земли которых подвергаются процессам природного и антропогенного опустынивания, что уже дало основание признать их зонами экологического бедствия [49, 118, 124].

Кратковременное превышение ПДК пестицидов в 1-2 раза способствует возникновению локальных очагов экологически обусловленных заболеваний $[37,39,74]$. Установлена достоверная прямая связь между заболеваемостью и общей нагрузкой пестицидами на организм человека [36, 123].

С 1998 г. биомониторинг по хлорорганическим соединениям проводится в бывших республиках СССР: Республиках Казахстан [39], Беларусь $[11,34]$, и Армения [92], Украине [22], Кыргызской республике [21, 57, 94]. Имеются данные по биологическому мониторингу Алтайского края [96], Архангельской области [51, 122], Байкальского региона, Иркутской области [52, 53], Дальнего Востока [129, 131, 132, 134], Мурманской (Кольская Лапландия) [23, 25, 28], Орловской [109], Самарской [ 46, 78, $80,125]$ областей, Чукотки [24, 112].

Данные проводимых в настоящее время наблюдений обобщены в табл. 12.2 .

В 1960-1980 гг. были выполнены многочисленные отечественные научно-исследовательские работы, в которых изучалось влияние пестицидов на отдельные органы и системы человека - мозг [3], печень [45, 69], глаза [63], кожу [111], кровь [70], иммунную систему [84, 106], репродуктивную систему $[85,86]$, нервную систему $[9,43]$, вестибулярный аппарат [100], а также на углеводный обмен и окислительные процессы [83].

Высокая растворимость в жирах и низкая растворимость в воде обуславливают задержку ДДТ в жировой ткани. В целом консументы высоких пищевых уровней имеют тенденцию к накоплению больших количеств ДДТ по сравнению с продуцентами и консументами низших пищевых уровней [84]. Отмечается, что в растительной пище диоксинов и ПХБ значительно меньше (растения плохо усваивают липофильные вещества), что прослеживается и при анализе биоматериала людей-вегетарианцев, которые не употребляют животных продуктов [67]. 
СТОЙКИЕ ОРГАНИЧЕСКИЕ ЗАГРЯЗНЯЮЩИЕ ВЕЩЕСТВА (СОЗ) В ОРГАНИЗМЕ ЧЕЛОВЕКА: ОПЫТ РОССИИ И БЫВШИХ СОВЕТСКИХ РЕСПУБЛИК

Таблица 12.2

Концентрация хлорорганических соединений в биологических жидкостях и материалах у жителей разных регионов России и бывших союзных республик

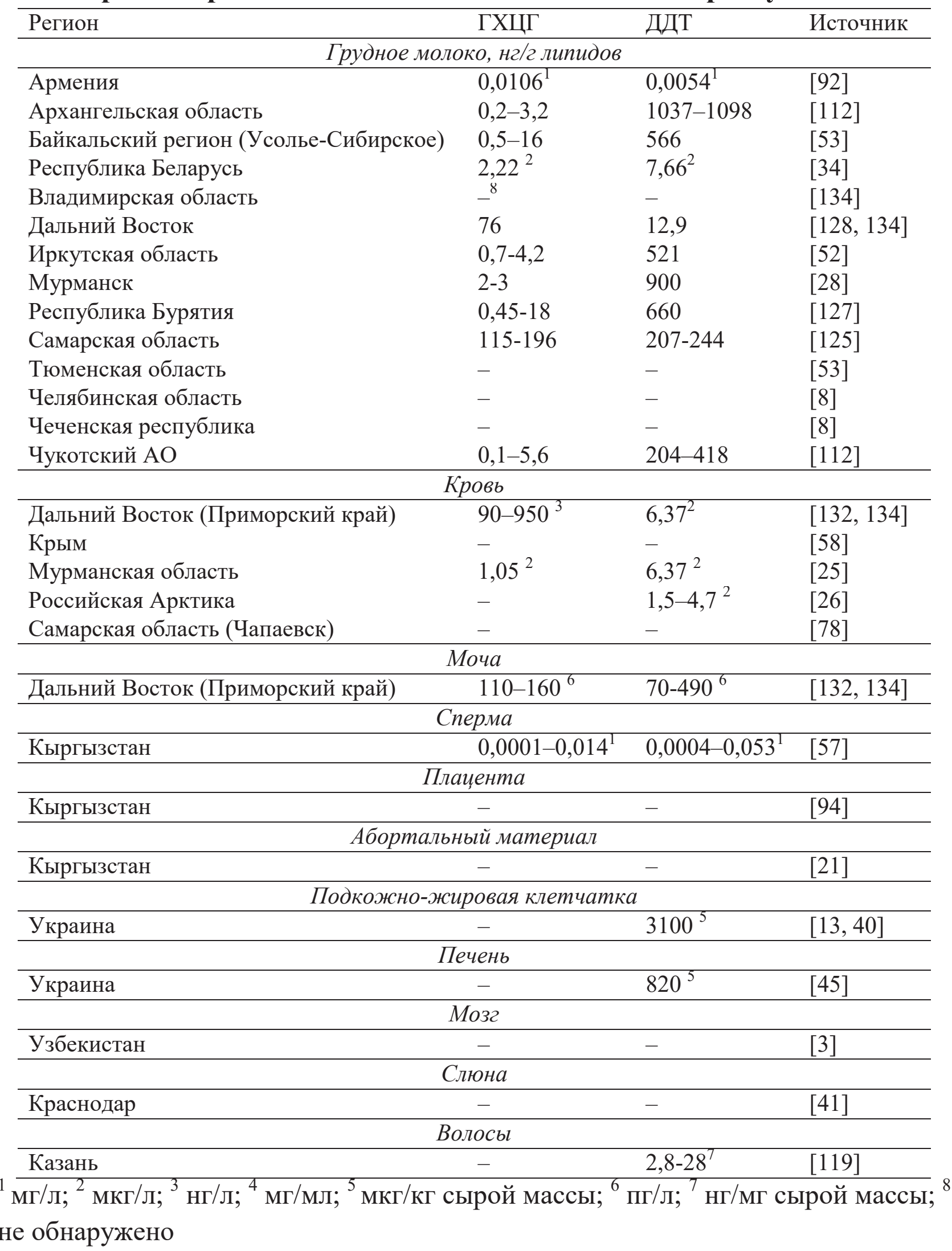


В 2005 г. в Московской медицинской академии им. И.М. Сеченова методами газожидкостной хроматографии и хромато-масс-спектрометрии определено содержание ДДТ и его метаболита ДДЕ в 49 официальных фитопрепаратах (жидких экстрактах и настойках) из травы тысячелистника, чабреца, листьев крапивы, плодов калины и боярышника. Установлено, что абсолютные концентрации ДДТ в жидких экстрактах и настойках достигали 0,45 нг/г, ДДЕ - 3,07 нг/г [20].

Угрозу для здоровья населения может представлять систематическое воздействие поллютантов даже на уровнях, не превышающих гигиенических нормативов. Соответственно, расчет риска для здоровья человека должен охватывать суммарную оценку комплексной нагрузки вдыхаемого загрязненного воздуха, а также поступление веществ с питьевой водой и продуктами питания [31,35].

Из-за невозможности проведения исследования столь широкого спектра объектов существуют рекомендации для анализа СО3 в воздухе, воде, грудном молоке и крови человека [114]. В эпидемиологической практике для оценки степени давности поступления в организм ДДТ обычно используется соотношение 4,4-ДДЕ/4,4-ДДТ в крови и грудном молоке; чем выше этот показатель, тем ниже концентрация исходного 4,4ДДТ и тем дольше длится экспозиция [82].

Для оценки давности поступления пестицидов в экосистему используют отношение концентраций $\alpha$ - и $\gamma$-изомеров ГХЦГ. Значение коэффициента более единицы свидетельствует о давнем присутствии ХОП в среде; значение ниже единицы, т. е. преобладание $\gamma$-изомера, характерно для «свежего» поступления [82]. Относительно большие количества $\beta$-изомера по сравнению с другими ГХЦГ-формами отражают давнее его использование и выраженную биотрансформацию микробиологическим путем [16].

Многолетние наблюдения свидетельствуют также о том, что сывороточные уровни отдельных хлорорганических поллютантов, в частности $\beta$ ГХЦГ, тесно связаны с биомаркерами метаболизма углеводов и липидов, например концентрацией гормона лептина, и степенью инсулинорезистентности среди подростков, проживающих в г. Чапаевске, известном очаге химической опасности [115]. 


\section{3. Российские исследования воздействия СО3 на организм}

Некоторые ученые отмечает выраженную способность СО3 к биоаккумуляции [108]. При их комбинированном воздействии на органы наблюдается простое суммирование содержания $\mathrm{CO}$, которое наблюдалось бы при раздельном поступлении.

Существует много признаков и симптомов хронической интоксикации, которые зависят от пути поступления токсикантов в организм [50]:

- кожные проявления - хлоракне, гиперпигментация, гинеркератоз;

- печеночный синдром - фиброз печени, поражение поджелудочной железы, повышение уровней трансаминазы и триглицеридов в крови, повышенное содержание холестерина, расстройство пищеварения (рвота, тошнота, нарушения стула, непереносимость алкоголя и жирной пищи);

- сердечно-сосудистый синдром - одышка и сердцебиение, миокардиодистрофия, артериальная гипотония;

- респираторный синдром - поражения верхних дыхательных путей, хронический токсический бронхит, который характеризуется диффузной атрофией слизистой оболочки, снижением скоростных показателей вентиляции, повышением вязкостного сопротивления.

\subsection{1. Кожный покров (дерма)}

Хлоракне - известное специфическое повреждение кожи в виде повышенного отложения пигмента, патологического расширения пор и повышенной чувствительности у лиц, имевших контакт с хлорорганическими соединениями [98].

\subsection{2. Сердечно-сосудистая система}

Хроническое воздействие СО3 на организм человека увеличивает частоту и усугубляет течение заболеваний сердечно-сосудистой системы коронарной недостаточности, гипертонической болезни, атеросклероза сосудов [12]. В 1986 г. при исследовании атерогенных свойств СОЗ были отмечены характерные закономерности в нарушении липидного обмена, которые, возможно, ускоряют развитие и отягощают течение атеросклероза [107]. Позже, в 1990 г., эта гипотеза подтвердилась в исследованиях И.Д. Гадалиной: поллютанты вызывают биохимические изменения, харак- 
терные для ранних проявлений атеросклероза, причем меньшая доза ксенобиотика дает более выраженный атерогенный эффект [15].

CO3 обладают прямым положительным инотропным действием на миокард [4, 10]. Согласно биохимическим исследованиям установелен рост активности ЛДГ (лактатдегидрогеназа) в миокарде на 90-й день интоксикации СО3 и уменьшение уровня ЛДГ в сыворотке крови, что свидетельствует об определенных нарушениях и перестройке биоэнергетических процессов в кардиомиоцитах. Повреждение митохондриальных мембран (как наружных, так и внутренних) влечет за собой нарушения окислительного фосфорилирования, утилизации АТФ миофибриллами и др. Эти изменения, в свою очередь, приводят к снижению энергии сокращения миофибриллярного аппарата, нарушению возбуждения, связанного с сокращением и расслаблением миокарда. Энергетическая недостаточность компенсируется за счет развития гигантских форм митохондрий, гипертрофии миофибрилл [107].

\subsection{3. Нервная система}

Поражения нервной системы характерны для действия всех СО3. При хронических отравлениях наблюдаются разнообразные функционально-динамические нарушения со стороны нервной системы: диффузное поражение (энцефалополиневропатия) с рассеянными мелкоочаговыми органическими симптомами; полный симптомокомплекс вегетативно-астенического синдрома в виде снижения работоспособности, бессонницы, повышенной раздражительности, лабильности артериального давления, гипергидроза, гиперрефлексии и других расстройств. Наиболее тяжелые патологические изменения при отравлении хлорорганическими ядохимикатами возникают в структурах ЦНС, которые во многом сходны с клиникой энцефалита с преимущественным поражением подкорковой области [4]. При тяжелых формах интоксикации может развиться гипоталамический синдром (гипергликемия, артериальная гипертония, ожирение) [4].

Следует учитывать, что некоторые СО3 обладают отдаленным нейротоксическим действием. Исследования когнитивных функций населения, проживающего в экологически неблагополучных трех поселках Талгарского района, показали, что почти 70 \% жителей имели низкий уро- 
СТОЙКИЕ ОРГАНИЧЕСКИЕ ЗАГРЯЗНЯЮЩИЕ ВЕЩЕСТВА (СОЗ) В ОРГАНИЗМЕ ЧЕЛОВЕКА: ОПЫТ РОССИИ И БЫВШИХ СОВЕТСКИХ РЕСПУБЛИК

вень устойчивости и концентрации внимания при усвоении информации, значительное и существенное снижение работоспособности из-за доминирования процесса торможения в ЦНС, что характерно для переутомления или астенизации организма [39].

\subsection{4. Иммунная система}

Стойкое подавление активности иммунной системы свойственно большинству ксенобиотиков. Этот эффект отмечается даже при действии низких малотоксичных доз [99]. Доказано отрицательное влияние СО3 на иммунную систему человека, ведущее к атипичному течению различных инфекционных и неинфекционных заболеваний, сопровождающихся повышением риска развития аутоиммунных патологий $[65,99]$.

При интоксикации поллютантами наблюдается лимфопения, затрагивающая все классы лимфоцитов (Т-, В-, NK-клетки). На протяжении четырех месяцев и более сохраняются изменения иммунитета после кратковременного контакта с ксенобиотиками. При длительном воздействии пестицидов нарушения в иммунной системе сохраняются в течение 2-10 лет [99].

В работах М. Исраилова [38] показано, что у лиц, проживающих в зонах активного применения пестицидов, выявляются стойкие и глубокие нарушения иммунной системы, приводящие к развитию затяжной пневмонии. Соответственно, патологии респираторной системы являются индикаторами экологически неблагополучной воздушной среды [66].

Многолетние международные исследования в Арктическом регионе убедительно доказали развитие иммунодефицитных состояний, вызванных отравлением СО3 взрослого населения, в рационе которого присутствуют рыба и мясо морских животных. Страдают также грудные дети, получающие токсиканты с молоком матери [113].

\subsection{5. Выделительная система}

В районах интенсивного применения СО3 чаще регистрируются нарушения функционального состояния почек в форме снижения клубочковой фильтрации и угнетения азотовыделительной функции. Многократно возрастают дисметаболические нефропатии, чаще встречаются аномалии органов мочевой системы, патологические изменения биохимических 
показателей мочи [148]. Частота инфекционно-воспалительных заболеваний почек в зонах интенсивного применения пестицидов или непосредственного контакта с ними - 12,5\%, в зоне средней интенсивности применения $-7,9 \%$, в «чистых» зонах $-1,6 \%[6,48]$. При клинико-эпидемиологическом исследовании проживающих в регионах использования пестицидов были выявлены признаки острых инфекционно-воспалительных заболеваний почек с тяжёлым течением в 6,5\% случаев [88].

Гистологические и цитоэнзиматические изменения в структурах нефронов позволяют предполагать проникновение пестицидов внутрь эндотелия капилляров клубочков в процессе фильтрации крови и в эпителий канальцев при реабсорбции ультрафильтрата. При этом большее нефротоксическое воздействие оказывает ГХЦГ, связанное с выраженным угнетением ферментов, участвующих в фильтрационно-реабсобционносекреторных процессах в нефронах [77].

\subsection{6. Репродуктивное здоровье мужчин}

Интерес к поиску взаимосвязи между СО3 и мужским бесплодием вызван тем, что практически все антропогенные поллютанты дают гонадои эмбриотоксический эффект, связанный с наличием у них гормоноподобных свойств, которые получили название «гормоноподобные ксенобиотики» (ГПК), или «гормоны внешней среды» [61, 62]. Многие исследователи связывают мужское бесплодие с действием пестицидов, в частности ДДТ [59]. В зонах, загрязненных СО3, заболеваемость мужским бесплодием в 2-2,5 раза (первичным мужским бесплодием - на 8-10\%) выше, чем в экологически чистых зонах. ХОП из спермы у больных мужским бесплодием выявлены в 75,4\% случаев против $4,3 \%$ в контроле. Заболеваемость бесплодием коррелирует с содержанием в сперме СО3, что может быть одной из причин мужского бесплодия [95].

Медленные темпы выведения СО3 способствуют увеличению концентрации этих веществ с возрастом. Однако выведение ксенобиотиков у мужчин и женщин различно [81]. В организме мужчин в течение жизни накапливается больше СО3. А. А. Дударев отмечает более высокое содержание ХОС в крови мужчин по сравнению с женщинами тех же возрастных групп [27]. Это может быть связано с присутствием в рационе мужчин большего количества мяса и рыбы, а также с тем, что женский орга- 
СТОЙКИЕ ОРГАНИЧЕСКИЕ ЗАГРЯЗНЯЮЩИЕ ВЕЩЕСТВА (СОЗ) В ОРГАНИЗМЕ ЧЕЛОВЕКА: ОПЫТ РОССИИ И БЫВШИХ СОВЕТСКИХ РЕСПУБЛИК

низм может частично выводить ХОС с грудным молоком и частично передавать запасенные вещества потомству [130, 132].

При воздействии СО3 на организм мужчин нарушаются процессы сперматогенеза [57, 93]. По мере возрастания загрязнения повышается процент патоспермии, причем количество пациентов с полным отсутствием в эякуляте сперматозоидов (азооспермия) увеличивается практически в пять раз.

\subsection{7. Пищеварительный тракт}

Отмечается, что для многих токсичных веществ гематосаливарный барьер не становится препятствием. Выявлена прямая связь содержания пестицидов в сыворотке крови и ротовой жидкости для $\alpha$-ГХЦГ и $\gamma$ ГЦХГ. Дальнейшие сравнительные исследования показали, что слюна околоушной железы содержит названные изомеры в более высокой концентрации, чем ротовая жидкость, и коррелирует с концентрацией пестицида в сыворотке с более высоким коэффициентом корреляции. Также в смешанной слюне были обнаружены ДДТ и его метаболиты [41]. Одновременно у жителей сельских районов, подвергающихся выраженному воздействию пестицидов, диагностировали наличие кариеса в 78,3\%, пародонтоза - 82,2\%, стоматита - 62,7\%, патологической стираемости зубов в 22,2\%, в контрольном районе указанные заболевания были выявлены в $48,3,15,4,6,4$ и 0\% соответственно [30].

Действие $\mathrm{CO} 3$ на печень способно привести к развитию токсического гепатита. Токсический гепатит нарушает состав желчи и вызывает синдром холестаза. Возможно также развитие токсического панкреатита. Повреждение поджелудочной железы связано с повышением давления в системе панкреатических протоков вследствие дискинезии желудочнокишечного тракта (ЖКТ) и дистонии сфинктера Одди [66].

3.M. Омарова предположила определенные механизмы воздействия СО3. Прямое повреждающее действие на слизистую оболочку ЖКТ приводит к воспалительным и эрозивно-язвенным изменениям. Повреждение слизистой оболочки ведет к нарушению моторики, развивается дискинезия желудка, кишечника и желчевыводящих путей. Дистония сфинктера Одди приводит к нарушению оттока секрета от поджелудочной железы. Следующий механизм вовлечения ЖКТ в патологический процесс - воз- 
действие СО3 непосредственно на нервную систему с развитием вегетативных расстройств и нарушений моторики органов пищеварения [66].

\subsection{8. Онкологические заболевания}

Период максимального применения СО3 (1980-1995 гг.) показал, что с насыщением окружающей среды пестицидами растет количество онкологических заболеваний [1].

Исследования, проведенные в Курской области [2], свидетельствуют о наличии связи между ростом заболеваемости раком желудка и молочной железы и количеством вносимых в почву пестицидов. В другом регионе, в условиях сельской местности юга Кыргызстана, одной из главных причин развития рака молочной железы у много рожавших являются ХОП [68]. На основании полученных фактов было предложено считать частоту рака молочной железы чувствительным критерием загрязнённости окружающей среды пестицидами [17]. В различных районах Таджикистана анализ распространенности острой лейкемии показал, что ведущим фактором в развитии этой патологии стало масштабное использование химических удобрений [60]. Занятость родителей в сельском хозяйстве, сопряженная с производственным контактом с пестицидами, также может повышать риск развития онкологических заболеваний у детей [89].

\subsection{9. Репродуктивное здоровье жсенщин и беременность}

Изменения показателей репродуктивного здоровья отражают состояние среды обитания, характеризуя мутагенность и эмбриотоксичность факторов и их способность подавлять адаптационные механизмы организма [44]. О значительных изменениях здоровья беременных женщин, проживающих в условиях воздействия загрязненной окружающей среды, сообщается в Челябинской (Челябинск, Магнитогорск, Карабаш), в Свердловской областях (Кировград, Нижний Тагил), страдает здоровье женщин, проживающих вблизи химических заводов в Тамбовской, Иркутской и других областях $[5,26,94]$.

Изучение влияния комбинированных пестицидов на репродуктивную функцию женщин, работавших в цехах протравителей семян, показало, что осложнения беременности встречались в 3,5 раза чаще, чем в контрольной группе. При гистологическом исследовании в плаценте обнару- 
живаются деструктивные изменения (инфаркты, облитерация сосудов и пр.), снижающие ее функциональные возможности, что становится одной из причин перинатальной патологии [14].

Контакты беременных женщин с пестицидами увеличивают частоту осложнений беременности и родов, вызывают мертворождаемость, аномалии у новорожденных, ведут к ухудшению комплексных показателей состояния здоровья детей $[98,110]$. У 100\% исследованных беременных женщин Украины обнаружили ДДТ в периферической крови в концентрациях от 0,28 (в Полтаве) до 6 мкг/л (в Киеве) [22]. Наиболее тяжелые осложнения при беременности, родах и в послеродовом периоде выявлены при обнаружении алдрина и ДДТ [98].

ХОП способны проходить через плацентарный барьер [83, 103]. Изучения мертворожденных выявили среднее содержание ДДТ в подкожно-жировой ткани плода (3100 мкг/кг), что мало отличалось от содержания его в подкожно-жировой клетчатке оперированных взрослых людей (4330 мкг/кг) [40]. В печени мертворожденных детей концентрация ДДТ составляла в среднем 820 мкг/кг [41]. ГХЦГ также преодолевает плацентарный барьер [126]. Пестициды увеличивают высвобождение катехоламинов из синаптических нервных окончаний, проникают через плацентарный барьер, вызывая структурно-метаболические нарушения в тканях плаценты, оказывая токсическое действие на плод и провоцируя выкидыши [102].

В Кыргызской Республике у 39,2\% беременных женщин из плаценты выявили ХОП, концентрация которого достигала 2,27 мг/кг. Чем выше содержание ХОП в плаценте, тем чаще отмечалась патология у беременных. Установлена корреляция между обнаружением ХОП в плацентах и гинекологическими осложнениями в послеродовом периоде [94].

В 30,5\% случаев в абортальных материалах, полученных после прерывания беременности (в первые два месяца до образования плаценты), обнаружено наличие ксенобиотиков, в 5,33\% - выявлена высокая концентрация хлорорганических пестицидов, в 2,66\% - патология эмбриона (врожденные пороки) (табл. 12.3) [21].

Четкие различия выявлены и после родов. Если в крови женщин обнаруживался ГХЦГ, то процент асфиксии новорожденных возрастал вдвое (12,0\%). У первородящих (с ГХЦГ в крови) рождалось значительно больше детей с аномалиями развития (2,56\% при 0,15\% в контроле) [101]. 


\section{Содержание пестицидов}

в исследуемых абортальных материалах [21]

\begin{tabular}{llll}
\hline Концентрация ХОП в & Количество & \multicolumn{2}{l}{ Из них обнаружен ХОП } \\
\cline { 4 - 5 } абортальном материале & обследованных & Количество \% \\
\hline Всего обследовано & 75 & 23 & 30,6 \\
Из них ХОП в пределах 0,1 мг/кг & 75 & 4 & 5,33 \\
Из них обнаружено ВПР & 75 & 2 & 2,66 \\
Из них ХОП свыше 0,1 мг/кг & 75 & 17 & 22,6 \\
\hline
\end{tabular}

Высокие уровни поллютантов вызывают негативные сдвиги в демографической ситуации. Так, с увеличением пестицидных нагрузок растет смертность ( $\mathrm{r}=0,82, \mathrm{p}<0,05)$, а рождаемость падает $(\mathrm{r}=-0,67, \mathrm{p}=0,046)$ [108].

Наиболее чувствительным индикатором оценки состояния здоровья популяции, влияния на него факторов внешней среды являются показатели здоровья новорожденных, в частности, распространенности врожденных пороков развития. Доказано, что врожденные патологии связаны с влиянием хлорорганических пестицидов на беременных и женщин детородного возраста [21]. Уровень первичной заболеваемости детей врожденными аномалиями, болезнями органов пищеварения, эндокринной системы коррелирует с площадью обработки пашни пестицидами и минеральными удобрениями в регионе [102]. Для уменьшения поступления пестицидов М. Х. Хамидов [101] рекомендовал удлинить интервал между беременностями до трех лет, говоря о «желательности наступления зачатия в зимний и весенний периоды года».

\subsubsection{0. Грудное молоко}

Особую проблему педиатрии составляет риск остаточного содержания пестицидов в продуктах питания, особенно детского. Чем младше ребенок, тем больше относительная доза пестицида, которую он получает в равных со взрослыми условиях [66].

В районах с повышенными показателями СО3 возрастает число детей с заболеваниями ЛОР-органов (хронический фарингит, трофический ринит, синусит, ларингит, ангина и хронический тонзиллит, отит). Рост воспалительных заболеваний среднего уха отмечается у детей эскимосов, питающихся молоком матерей, а также морской рыбой и мясом морских животных, содержащими повышенные концентрации пестицидов [113]. 
Грудное молоко как объект наблюдения имеет ряд преимуществ, поскольку отбор проб представляет собой неинвазивный метод, не связанный с техническими и инструментальными сложностями. Уровни СО3 в грудном молоке считаются индикатором их нагрузки на материнский организм [73]. У матерей, в грудном молоке которых был обнаружен ДДТ, чаще рождались дети малого веса и недоношенные $(26,5 \pm 2,7 \%)$, чем у матерей, в молоке которых этот ксенобиотик не обнаружен $(13,1 \pm 3,7 \%)$ [3]. Это подтверждено исследованиями И. А. Застенской с соавт. [33], которые показали выраженную отрицательную зависимость между степенью загрязнения грудного молока ДДТ и весом ребенка при рождении.

Выявлено высокое содержание ДДТ в грудном молоке жительниц Казахстана, что в целом характерно для бывших республик СССР [18, 19]. При мониторинге ХОП в пробах грудного молока рожениц республики Армения частота обнаружения основных загрязнителей ( $\gamma$-изомер ГХЦГ и ДДЕ) составляла $100 \%$; частота определения ДДТ увеличилась по сравнению с 2009 г. и составила 71,4\%. При этом обнаруживаемые остаточные количества ХОП оказались на порядок и выше, чем в 2009 г.: $\gamma$-изомер ГХЦГ - 0,0147 мг/л; ДДЕ - 0,0169 мг/л; ДДТ - 0,0039 мг/л [91].

У новорожденных, питающихся грудным молоком, суточная доза ПХБ может в 10-100 раз превышать таковую у их матерей. Для новорожденных, метаболические потенции которых еще не столь развиты, основным механизмом удаления ПХБ из организма является регулярный «жирный стул» [117].

Е. А. Мамонтова с соавт. [52] отмечают, что на уровень содержания ПХБ в грудном молоке влияет диета матери. Традиционно население поселков на берегах Байкала использует в своем рационе жир нерпы и голомянки. Концентрации ПХБ в их жире намного выше, чем в промысловых видах рыб. В грудном молоке жительниц побережья оз. Байкал уровень ПХБ сравним только с уровнями ПБХ в молоке жительниц Фарерских островов, в основной рацион которых входят жир и мясо морских рыб, млекопитающих и птиц, а также жительниц г. Серпухова, работавших на трансформаторном заводе, где в производстве использовалась техническая смесь ПХБ (совол), а также жительниц Фарерских островов, в рацион которых входит жир и мясо морских рыб, млекопитающих и птиц. 


\section{4. Заключение}

Человек находится в верхней части пищевой цепи, поэтому именно он подвергается наибольшей опасности воздействия СОЗ. В связи с этим оценка влияния ксенобиотиков на здоровье населения по-прежнему актуальна [79].

Пестициды, поступающие в организм человека по миграционным и транслокационным цепочкам, могут оказывать мутагенное действие, увеличивать количество точечных мутаций и хромосомных аберраций в соматических и половых клетках, приводить к развитию новообразований, спонтанным абортам и перинатальной гибели плода, врожденным аномалиям, бесплодию [34]. Согласно сложившейся практике, оценка мутагенности пестицидов основана на определении мутагенных свойств отдельных действующих компонентов, входящих в состав их препаративных форм. Вопрос о дополнительном исследовании препаративных форм, включающих несколько действующих веществ, представляется крайне актуальным [75].

Пик изучения острого воздействия пестицидов на здоровье человека пришелся на 1960-1970 годы ХХ века. В 1980-1990 гг. появляются работы, изучающие хроническое их воздействие. В последние годы число их резко снизилось. Сегодня в городах России биомониторинговые исследования либо не проводятся, либо проводятся непостоянно, что не дает полной картины по стране. Также практически нет новых публикаций о влиянии СО3 на здоровье населения с применением современных методов [80].

Таким образом, существует необходимость разработки и введения на законодательном уровне системы постоянного государственного биомониторинга, включающего анализ окружающей среды, живых организмов и человека как биоиндикатора аккумуляции, биотрансформации и долговременных эффектов СО3. 


\section{5. Список литературы}

1. Абдуллаев, Р.Б. Аральский кризис: проблемы экологической культуры и здоровья / Р.Б. Абдуллаев, Ш.Б. Дусчанов, Д.С Маткаримова [и др]. - Ургенч, 2012. - 120 с.

2. Адамович, В.Л. Экологическая тактика применения пестицидов в сельском хозяйстве и пути предупреждения вредных последствий / В.Л. Адамович. - Брянск, 1986. - 215 с.

3. Азизова, О.М. Морфологические изменения в головном мозге при хронической интоксикации пестицидами: автореф. дис. ... д-ра. мед. наук / О.М. Азизова. - Самарканд, 1981. - 34 с.

4. Азовскова, Т.А. Профессиональные интоксикации пестицидами / Т.А. Азовскова, Н.В. Вакурова, Н.Е. Лаврентьева. - Самара: ООО «СамЛюксПринт», 2014. - 78 с.

5. Айламазян, Э.К. Влияние экологической обстановки на репродуктивное здоровье женщины. Новый взгляд на проблему / Э.К. Айламазян, Т.В. Беляева, Е.Г. Виноградова // Вестник Российской ассоциации акушеров-гинекологов. - 1996. - № 2. - С. 13-16.

6. Аллазов, С.А. Острые инфекционно-воспалительные заболевания почки в условиях воздействия пестицидов (клинико-экспериментальное исследование): автореф. дис. ... докт. мед. наук / С.А. Аллазов. - Москва, 1992. -28 c.

7. Амирова, 3.К. Новые стойкие органические супертоксиканты и их влияние на здоровье человека / 3.К. Амирова, О.А. Сперанская, Ш.Н. Галимов. - Москва, 2016. - 169 с.

8. Амирова, З.К. Содержание ПХДД/Ф и ПХБ-ВОЗ в плазме крови и грудном молоке жителей Чеченской республики / З.К. Амирова, И.Я. Шахтамиров // Юг России: экология, развитие. -2012. - № 2. - С. 125-129.

9. Атабаев, Ш.Т. Гигиеническое изучение объектов внешней среды при применении пестицидов в условиях жаркого климата и оздоровительно-профилактические мероприятия: дис. ... докт. мед. наук / Ш.Т. Атабаев. - Ташкент, 1967. - 44 с.

10. Ахмедов, Б.Х. Показатели периферической крови у крыс при хронической интоксикации пестицидами / Б.Х. Ахмедов, К.К. Салиев // Медицинский журнал Узбекистана. - 2000. - № 3. - С. 89-90.

11. Баркатина, Е.Н. Содержание остаточных количеств хлорорганических пестицидов в основных продуктах питания, грудном молоке и жи- 
ровой ткани жителей Беларуси / Е.Н. Баркатина, А.Л. Перцовский, В.И. Мурох // Хранение и переработка сельхозсырья. - 2002. - № 7. С. 29-32.

12. Бойкулов, М.Ч. Сравнительная характеристика аорты крыс в норме и при воздействии пестицидов / М.Ч. Бойкулов // Морфология. 2004. - № 4. - С. 22.

13. Васьковская, Л.Ф. Химико-биологическая характеристика накопления и распределения ДДТ в организме человека: дис. ... канд. биол. наук / Л.Ф. Васьковская. - Киев, 1971. - 192 с.

14. Вержанский, П.С. Влияние комбинированных пестицидов (фентиурам, хомецин и др.) на репродуктивную функцию и профилактика осложнений у женщин, работающих на химическом предприятии: автореф. дис... канд. мед. наук / П.С. Вержанский. - Харьков, 1979. - 22 с.

15. Гадалина, И.Д. Некоторые методические подходы к оценке кардиотоксического эффекта пестицидов с учетом возрастного фактора / И.Д. Гадалина // Гигиена и санитария. -1990. - № 7. - С. 77-78.

16. Галиулин, Р.В. Эколого-геохимическая оценка “отпечатков" стойких хлорорганических пестицидов в системе почва-поверхностная вода / Р.В. Галиулин, Р.А. Галиулина // Агрохимия. - 2008. - № 1. - С 52-58.

17. Гичев, Ю.П. Загрязнение окружающей среды и экологическая обусловленность патологии человека / Ю.П. Гичев // Экология. Серия аналитических обзоров мировой литературы. - 2003. - № 68. - С. 1-138.

18. ГН 1.2.3111-13 "Гигиенические нормативы содержания пестицидов в объектах окружающей среды (перечень)" (с изменениями на 13 июля 2016 года). - М.: Федеральный центр гигиены и эпидемиологии Роспотребнадзора, 2014. - 131 с.

19. Гончарук, Е.И. Использование системы мать-плод-новорожденный для изучения комбинированного действия пестицидов и других химических веществ / Е.И. Гончарук, Г.И. Сидоренко, М.В. Голубчиков, А.С. Прокопович // Гигиена и санитария. - 1990. - № 6. - С. 4-7.

20. Гравель, И.В. Оценка перехода ДДТ и его метаболитов в жидкие экстракты и настойки из лекарственного растительного сырья / И.В. Гравель // Традиционная медицина. - 2005. - № 1. - С. 28-31.

21. Дарбишев, Э.П. Влияние хлорорганических пестицидов на рождаемость детей с врожденной патологией в Ошской области / Э.П. Дарбишев, А.М. Ешиев // Актуальные проблемы и достижения в медицине: 
сборник научных трудов по итогам международной научно-практической конференции. - Самара: Инновационный центр развития образования и науки, 2017. - С. 96-99.

22. Демченко, В.Ф. Гигиенические аспекты биомониторинга хлорорганических пестицидов: дис. ... канд. биол. наук / В.Ф. Демченко. Киев, 1989. - 332 с.

23. Дударев, А.А. Специфика экспозиции к дихлородифеиилтрихлорэтану коренных жителей прибрежной и материковой Чукотки / А. А. Дударев, В. С. Чупахин, 3. С. Иванова, Г. Б. Лебедев // Гиена и санитария. 2012. - № 2. - C 15-20.

24. Дударев, А.А. Здоровье человека в связи с загрязнением Арктики - результаты и перспективы международных исследований под эгидой АМАП / А.А. Дударев, Й.О. Одланд // Экология человека. - 2017. - № 9. C. 3-14.

25. Дударев, А.А. Особенности экспозиции к полихлорированным бифенилам коренных жителей прибрежной и материковой Чукотки / А.А. Дударев, В.С. Чупахин, 3.С. Иванова, Г.Б. Лебедев // Гигиена и санитария. - 2012. - № 4. - С. 22-28.

26. Дударев, А.А. Оценка влияния экспозиции к стойким токсичным веществам на исход беременности, соотношение полов новорожденных и менструальный статус коренных жительниц Чукотки / А.А. Дударев, В.С. Чупахин // Гигиена и санитария. - 2014. - № 1. - С. 36-40.

27. Дударев, А.А. Персистентные полихлорированные углеводороды и тяжелые металлы в Арктической биосфере: основные закономерности экспозиции и репродуктивное здоровье коренных жителей // Биосфеpa. - 2009. - № 2. - С. 186-202.

28. Дударев, А.А. Уровни экспозиции к стойким органическим загрязнителям (СО3) населения Печенгского района Мурманской области / А.А. Дударев, Е.В. Душкина, Ю.Н. Сладкова, В.С. Чупахин Л.А. Лукичева // Токсикологический вестник. - 2016. - Т. 3. - С. 2-9.

29. Ежегодник «Состояние загрязнения пестицидами объектов природной среды Российской Федерации в 2016 году». - Обнинск: ФГБУ «НПО «Тайфун»», 2017. - 80 с.

30. Жуматов, У. Состояние органов полости рта при воздействии на организм хлор- и фосфорорганических пестицидов: автореф. дис. ... канд. мед. наук / У. Жуматов. - Ташкент, 1982. - 46 с. 
31. Журба, О.М. Социально-гигиенические аспекты определения остаточных количеств хлорорганических пестицидов в пищевой продукции / О.М. Журба, Н.А. Тараненко // Бюллетень ВСНЦ СО РАМН. - 2007. № $1 .-$ С. 56-58.

32. Застенская, И.А. Изучение влияния полихлорированных бифенилов и тяжелых металлов на показатели иммунной системы в эксперименте / И.А. Застенская, Н.П. Пивень, В.В. Кочубинский, А.В. Кочубинский // Токсикологический вестник. - 2014. - № 2. - С. 28-31.

33. Застенская, И.А. Потенциальная роль эпидемиологический исследований и биологического мониторинга в гигиеническом нормировании / И.А. Застенская, В.В. Кочубинский // Актуальные проблемы транспортной медицины. - 2010. - № 2 (20). - С. 90-94.

34. Застенская, И.А. Хлорорганические пестициды: биологический мониторинг и мониторинг окружающей среды в оценке воздействия на здоровье новорожденных / И.А. Застенская // Здоровье и окружающая среда. - 2009. - № 14. - С. 540-547.

35. Захаренков, В.В. Определение приоритетности природоохранных мероприятий на основе оценки риска для здоровья населения промышленного города / В.В. Захаренков, В.В. Кислицына // Успехи современного естествознания. - 2014. - № 2. - С. 12-15.

36. Иванов, А.В. Состояние здоровья населения на территориях интенсивного применения пестицидов / А.В. Иванов, В.В. Васильев // Гигиена и санитария. - 2005. - № 2. - С. 24-27.

37. Инелова, 3.А. Фитоценозная биоиндикация загрязненных пестицидами почв (Талгарский район Алматинская область) / З.А. Инелова, А.А. Нуржанова, Р.Д. Жамабалинова [и др.] // Вестник КазНУ. Серия экологическая. - 2010. - Т. 29. - № 3. - С. 29-33.

38. Исраилова, М. Клинико-иммунологические особенности течения и лечения затяжных пневмоний у больных, проживающих в зоне применения пестицидов: автореферат дис. ...канд.мед.наук / М. Исраилова. Москва, 1992. - 19 с.

39. Капышева, У.Н. Влияние многолетнего пестицидного загрязнения окружающей среды на здоровье человека / У.Н. Капышева, Ш.К. Бахтиярова, Б.И. Жаксымов // Международный журнал прикладных и фундаментальных исследований. - 2019. - № 3. - С. 56-60.

40. Комарова, Л.И. Носительство ДДТ и некоторые стороны его влияния на организм: дис. ... канд. мед. наук / Л.И. Комарова - Киев, 1969. - 12 с. 
41. Коротько, Г.Ф. Саливадиагностика - ренессанс неинвазивных технологий // Кубанский научный медицинский вестник. - 2006. - № 9. C. 145-149.

42. Корпакова, И.Г. Содержание стойких хлорорганических пестицидов и полихлорбифенилов в акватории лицензионного участка ООО «НК «Приазовнефть» в Азовском море / И.Г. Корпакова, Л.И. Короткова, А.А. Ларин [и др.] // Защита окружающей среды в нефтегазовом комплекce. -2015 . - № 11. - С. 48-54.

43. Краснюк, Е.П. Клиника и лечение хронических интоксикаций у рабочих производства ДДТ: дис. ... канд. мед. наук / Е.П. Краснюк. - Киев, 1961. - $16 \mathrm{c}$.

44. Кузмин, Д.В. Сравнительный анализ репродуктивного здоровья женщин, проживающих в районах расположения алюминиевого производства / Д.В. Кузмин // Гигиена и санитария. - 2007. - № 3. - С. 13-15.

45. Кузьминская, У.А. Биохимическая характеристика субклеточных культур печени при воздействии пестицидов: (К механизму действия хлорорганических и карбаматных пестицидов): автореф. дис. ... д-ра мед. наук / У.А. Кузьминская. - Киев, 1975. - 42 с.

46. Лазарева, Н.В. Взаимозависимые патогенетические риски влияния экотехнологических факторов на соматическое и репродуктивное здоровье человека / Н.В. Лазарева, О.И. Линева // Медицинский альманах. 2017. - № 6 (51). - С. 63-68.

47. Ларионов, К.В. Распространение пестицидов в экосистеме Краснодарского края и минимизация их воздействия на окружающую среду: автореф. дис. ... канд. хим. наук / К.В. Ларионов. - Краснодар, 2008. - 22 с.

48. Латыпова, Р.И. Функциональное состояние почек у лиц, работающих с комплексом хлор- и фосфорорганических пестицидов / Р.И. Латыпова // Медицинский журнал Узбекистана. - 1971. - № 11. - С. 19-23.

49. Лидерман, Е.М. Анализ экологических условий обусловленности здоровья населения Южного Федерального округа в аспекте организации региональной системы медико-социальной реабилитации / Е.М. Лидерман, М.В. Забелин // Здравоохранение, образование и безопасность. 2018. - №1 (13). - С. 7-20.

50. Лотков, В.С. Клинико-патогенетические особенности хронического воздействия хлорированных углеводородов на органы дыхания и другие системы организма (экспериментально-клиническое исследование): автореф. дисс... докт. мед. наук / В.С. Лотков. - Самара, 2000. - 38 с. 
51. Лыжина, А.В. Химическое загрязнение продуктов питания и его влияние на здоровье населения Архангельской области / А.В. Лыжина, Р.В. Бузинов, Т.Н. Унгуряну, А.Б. Гудков // Экология человека. - 2012. № 12. - C. 3-9.

52. Мамонтова, Е.А. Содержание стойких органических загрязнителей в грудном молоке жительниц Иркутской области / Е.А. Мамонтова, Е.Н. Тарасова, М.И. Кузьмин [и др.] // Гигиена и санитария. - 2010. - № 1. C. 35-38.

53. Мамонтова, Е.А. Эколого-гигиеническая оценка последствий загрязнения стойкими органическими соединениями промышленного города (на примере г. Усолье-Сибирское): II. Продукты питания, биосубстраты жителей, оценка рисков здоровью / Е.А. Мамонтова, Е.Н. Тарасова, А.А. Мамонтов // Экологическая химия. - 2017. - Т. 26. - № 1. - С. 41-52.

54. Павлов, А.В. Справочник по пестицидам: (Гигиена применения и токсикология) / под ред. А.В. Павлова. - Киев.: Урожай, 1986. - 431 с.

55. Международный проект по ликвидации СО3 - IPЕР. // [Электронный ресурс]. URL: https://ipen.org/sites/default/files/documents/1 rus_time_to_act_obsolete_pesticides-ru.pdf.

56. Мельников, Н.Н. Пестициды. Химия, технология, применение / Н.Н. Мельников. - М.: Книга по Требованию, 2013. - 697 с.

57. Мирзакулов, Д.С. Особенности влияния хлорогранических соединений и их метаболитов на состояние фертильности мужчин, проживающих в Орской области Кыргызстана / Д.С. Мирзакулов, А.А. Эшбаев, Ш.С. Мирзокулов, Р.К. Калматов // Современые проблемы науки и образования. - 2016. - № 3. - С. 66.

58. Московчук, О.Б. Корреляционные взаимосвязи показателей иммунного статуса родильниц с содержанием хлорорганических пестицидов в крови / О.Б. Московчук, К.М. Московчук, В.Ф. Демченко, Е.В. Евстафьева // Таврический медико-биологический вестник. - 2012. Т. 15. № 3. - С. 176-178.

59. Мошанский, В.Ф. Дифференциальная диагностика двух форм некроспермии / В.Ф. Мошанский, С.А. Каган, О.Л. Тектинский [и др.] // Урология и нефрология. - 1987. - № 4. - С. 57-59.

60. Мустафакулова, Н.И. Факторы риска развития и особенности клинического течения лейкозов в республике Таджикистан / Н.И. Мустафакулова, Т.И. Меликова, Н.С. Мустафакулова // Вестник Авиценны. 2015. - № 1. - С. 67-70. 
61. Никитин, А.И. Загрязнители биосферы и их влияние на репродуктивную функцию человека / А.И. Никитин // Биосфера. - 2009. - № 2. С. 218-229.

62. Никитин, А.И. Факторы среды и репродуктивная система человека (ответственность перед будущими поколениями) / А.И. Никитин. СПб.: ЭЛБИ-СПб, 2008. - 216 с.

63. Нуритдинова, Ф. Состояние органа зрения у лиц, с интоксикацией пестицидами, работающих в сельском хозяйстве Узбекистана: (Клиническое и экспериментальное исследование): автореф. дис. ... д-ра мед. наук / Ф. Нуритдинова. - Ташкент, 1974. - 29 с.

64. О мерах по обеспечению выполнения Российской Федерацией обязательств, предусмотренных Стокгольмской конвенцией о стойких органических загрязнителях от 22 мая 2001 г. (В редакции постановлений Правительства Российской Федерации от 13.05.2015 № 464, от 19.09.2016 № 946, от 20.11.2018 № 1391, от 11.02.2019 № 113).

65. Овчинникова, Е.Л. Мониторинг качества и безопасности пищевых продуктов как составная часть социально-гигиенического мониторинга / Е.Л. Овчинникова, Н.В. Резанова, А.В. Брусенцова // СибирьВосток. - 2003. - № 10. - С. 31-36.

66. Омарова, 3.М. Влияние пестицидов на здоровье детей. // Российский вестник перинатологии и педиатрии. - 2010. - № 1. - С. 59-64.

67. Оникиенко, Ф.А. Состояние некоторых сторон углеводного обмена и окислительных процессов при воздействии на организм отдельных хлорорганических инсектицидов: автореф. дис. ... канд. биол. наук / Ф.А. Оникиенко. - Киев, 1966. - 18 с.

68. Паизова, 3.М. Влияние загрязнения окружающей среды хлорорганическими пестицидами на развитие рака молочной железы у женщин, в зависимости от количества родов, в условиях юга Кыргызстана / 3.М. Паизова, Р.М. Тойчуев // Журнал научных статей «Здоровье и образование в XXI веке» (Серия медицина), - 2012. -Т. 14. - № 1. - С. 160.

69. Парамончик, В.М. Функциональное состояние печени у лиц, подвергающихся воздействию некоторых хлорорганических соединений в условиях их производства: автореф. дис. ...канд. мед. наук / В.М. Парамончик. - Киев, 1968. - 17 с.

70. Перхурова В.П. Исследование по токсикологии карбофоса и комбинированному действию промежуточных продуктов его производства: автореф. дис. ... канд. мед. наук / В.П. Перхурова. - Куйбышев, 1974. - 17 с. 
71. Приказ Госкомэкологии РФ от $13.04 .99 \mathrm{~N} 165$ «О рекомендациях для целей инвентаризации на территории Российской Федерации производств, оборудования, материалов, использующих или содержащих ПХБ, а также ПХБ-содержащих отходов».

72. Приказ от 23.02.99 № 76 «О проведении на территории Российской Федерации инвентаризации производств, оборудования, материалов, использующих или содержащих полихлорированные бифенилы (ПХБ), а также ПХБ-содержащие отходы». URL: https://base.garant.ru/2156961/.

73. Пуэрто, К.П. Уровни ДДТ и его метаболитов в биологической среде человека / К.П. Пуэрто, А.М.Д. Фернандес, А.М. Хименес [и др.] // Гигиена и санитария. - 1990. - № 10. - С. 73-75.

74. Ракитский, В.Н. Прогностический риск токсического воздействия пестицидов на здоровье работающих // Медицина труда и промышленная экология. - 2015. - № 10. - С. 5-17.

75. Ракитский, В.Н. Современные методические подходы в оценке мутагенности пестицидов / В.Н. Ракитский, Н.А. Илюшина, Ю.А. Ревазова // Гигиена и санитария. - 2017.- Т. 96 (11). - С. 1017-1020.

76. Ракитский, В.Н. Морфофункциональные критерии действия на организм факторов окружающей среды / В.Н. Ракитский, Н.И. Николаева. М.: Медицина, 2001. - 182 с.

77. Расулов, М.Т. Морфологическая и гистоэнзиматическая характеристика почек при хроническом воздействии пестицидов гексахлорциклогексана, хлорофоса и медного купороса / М.Т. Расулов, М.А. Шахназаров, А.М. Шахназаров, Б.Г. Магомедгаджиев // VII научно-практическая конференция памяти профессора С.А. Абусуева «Проблемы экологической медицины». - Махачкала: Дагестанский государственный медицинский университет, 2017. - С. 242-245.

78. Ревич, Б.А. Диоксины, фураны и ПХБ в крови подростков Чапаевска - первые результаты проспективного эпидемиологического исследования / Б.А. Ревич, О.В. Сергеев, Р. Хнузер // Токсикологический вестник. - 2006. - № 5(80). - С. 2-8.

79. Ревич, Б.А. Здоровье населения и загрязнение окружающей среды стойкими органическими загрязнителями / Б.А. Ревич, А.А. Шелепчиков // Гигиена и санитария. - 2008. - № 4. - С. 26-32.

80. Ревич, Б.А. Инновационные эколого-эпидемиологические технологии оценки влияния диоксинов на здоровье детей / Б.А. Ревич, 
О.В. Сергеев, А.А. Шелепчиков // Экология человека. - 2012. - № 8. C. 42-49.

81. Ревич, Б.А. СОЗ и оценки воздействия на здоровье населения: некоторые результаты работ в России / Б.А. Ревич, О.В. Сергеев, А.А. Шелепчиков // Сборник трудов IV токсикологического съезда токсикологов России. - 2013.

82. Ровинский, Ф.Я. Фоновый мониторинг загрязнения экосистем суши хлорорганическими соединениями / Ф.Я. Ровинский, Л.Д. Воронова, М.И. Афанасьев [и др.]. - Л.: Гидрометеоиздат, 1990. - 270 с.

83. Росивая, Л. Трансплацентарный переход пестицидов в человеческий эмбрион / Л. Росивая, А. Соколай [и др.] // Чехословацкая медицина. 1983. - № 1. - С. 1-7.

84. Рузыбакеев, Р.М. Иммунодефицитные состояния при хронических интоксикациях пестицидами и проблема их коррекции: (Клиникоэкспериментальное исследование): автореф. дис. ... д-ра. мед. наук / Р.М. Рузыбакеев. - Ташкент-Москва, 1987. - 32 с.

85. Сарайманова, 3.С. Влияние некоторых ядохимикатов на половую сферу (клинико-экспериментальное исследование): автореф. дис. ... канд. мед. наук. / 3.С. Сарайманова. - Ташкент, 1971. - 22 с.

86. Саттарова, С.Ш. Влияние некоторых пестицидов на половую систему, репродуктивную функцию, внутриутробное развитие, развитие плода и потомства: автореф. дис. ... канд. мед. наук / С.Ш. Саттарова. Ташкент, 1981. - 23 с.

87. Семеренко, С.А. Экология и защита растений // Масличные культуры / С.А. Семеренко // Научно-технический бюллетень Всероссийского научно-исследовательского института масличных культур. - 2015. № 4 (164). - С. 103-137.

88. Ситдыкова, М.Э. Влияние хлорорганических пестицидов на некоторые урологические заболевания / М.Э. Ситдыкова, С.А. Аллазов, Д.Р. Саяпова // Казанский медицинский журнал. - 2010. - Т. 91 - № 3. - С. 372-374.

89. Соленова, Л.Г. Факторы онкологического риска у детей и подходы к профилактике их воздействия / Л.Г. Соленова // Педиатрия. - 2011. T. 90. - № 4. - С. 120-126.

90. Сперанская, О. Стойкие органические загрязнители: обзор ситуации в России [Интернет]. Международный проект по ликвидации СО3 / O. Сперанская, О. Цитцер // [Электронный ресурс]. URL: www.ipen.org. 
91. Тадевосян, Н.С. Вопросы накопления и обнаружения некоторых стойких органических загрязнителей у сельских жителей Армении / Н.С. Тадевосян, А.Э. Тадевосян, А.Н Джанджапанян [и др.] // Вестник КазНМУ. - 2012. - № 3. - С. 212.

92. Тадевосян, Н.С. Мониторинг загрязнения окружающей среды в Армении и некоторые вопросы репродуктивного здоровья и цитогенетического статуса организма / Н.С. Тадевосян, С.А. Мурадян, А.Э. Тадевосян [и др.] // Гигиена и санитария. - 2012. - Т.91. - № 5. - С. 48-51.

93. Тер-Аванесов, Г.В. Проблемы репродуктивного здоровья мужчин: практическое руководство / Г.В. Тер-Аванесов. - М.: ООО «Тэлси», 2004. - $111 \mathrm{c}$.

94. Тойчуев, Р.М. Влияние содержания хлорорганических пестицидов в плаценте на течение беременности и роды у женщин / Р.М. Тойчуев // Гигиена и санитария. - 2015. - № 6. - С. 106-108.

95. Тойчуев, Р.М. Распространенность бесплодия у мужчин, проживающих в условиях загрязнения окружающей среды хлорорганическими пестицидами / Р.М. Тойчуев, Д.С. Мирзакулов, Т.Р. Пайзилдаев // Гигиена и санитария. - 2015. - № 6. - С. 99-101.

96. Ушаков, А.А. Гигиеническая оценка неблагоприятных социальных, санитарно-гигиенических факторов окружающей среды на территории Алтайскиго края / А.А. Ушаков, В.В. Турбинский, И.Г. Пащенко, А.С. Катунина // Анализ риска здоровью. - 2015. - № 4 (12). - С. 50-61.

97. Федеральная служба по гидрометеорологии и мониторингу окружающей среды (Росгидромет). Обзор состояния и загрязнения окружающей среды в Российской Федерации за 2018 год. - М: Росгидромет, 2019. - 225 с.

98. Федоров, Л.А. Пестициды - токсический удар по биосфере и человеку / Л.А. Федоров, А.В. Яблоков. - М.: Наука, 1999. - 461 с.

99. Хаитов, Р.М. Экологическая иммунология / Р.М. Хаитов, Б.В. Пинегин, Х.И. Истамов. - М.: Изд-во ВНИРО, 1995. - 218 с.

100. Хакимов А.М. Состояние вестибулярного анализатора у работающих с хлорорганическими и фосфорорганическими пестицидами: (Клиническое и экспериментальное исследование): автореф. дис. ... канд. мед. наук / А.М. Хакимов. - Ташкент, 1975. - 24 с.

101. Хамидов, М.Х. Детородная функция, исход беременности и родов для плода и новорожденного у женщин, занятых выращиванием и 
возделыванием хлопчатника: автореф. дис. ... д-ра мед. наук / М.Х. Хамидов. - Самарканд, 1986. - 46 с.

102. Хамитова, Р.Я. Заболеваемость населения в условиях длительного применения пестицидов / Р.Я. Хамитова, Г.Т. Мирсаитова // Здравоохранение Российской Федерации. - 2014. - Т. 58. - № 1. - С. 38-42.

103. Худолей В.В. Экологически опасные факторы / В.В. Худолей, И.В. Мизгирев. - СПб.: Publishing House, 1996. - 111 с.

104. Цыганков, В.Ю. Химические и экологические аспекты стойких органических загрязняющих веществ: учебное пособие / В.Ю. Цыганков, М.Д. Боярова, О.Н. Лукьянова. - Владивосток, 2015. - 103 с.

105. Черных, А.М. Угрозы здоровью человека при использовании пестицидов (Обзор) / А.М. Черных // Гигиена и санитария. - 2003. - № 5. С. 25-28.

106. Шафеев, М.Ш. Влияние некоторых пестицидов и их комбинаций на показатели иммунитета и неспецифической реактивности организма: автореф. дис. ... канд. мед. наук / М.Ш. Шафеев. - Казань, 1978. - 20 с.

107. Шицкова, А.П. Гигиеническая оценка кардиотоксического действия некоторых пестицидов / А.П. Шицкова, Н.И. Николаева, И.Д. Гадалина // Гигиена и санитария. - 1986. - № 6. - С. 4-7.

108. Шумейко, А.Я. Экологическая оценка взаимодействия пестицидов и радиации в агроэкосистемах Брянской области: автореферат дис. ... канд. сельскохоз. наук / А.Я. Шумейко. - Брянск, 2004. - 22 с.

109. Шушпанов, А.Г. Влияние запрещенных к применению пестицидов на здоровье человека / А.Г. Шушпанов // Технология и товароведение инновационных пищевых продуктов. - 2011. - № 6 (11) - С. 73-77.

110. Юдаев, А.И. Полихлорированные бифенилы и диоксины - суперэкотоксиканты XXI века / А.И. Юдаев // Энергия: экономика, техника, экология. - 2010. - № 1. - С. 60-65.

111. Юсупова Ф.Д. Вопросы гигиены труда и ранние клиникофункциональные и биохимические изменения кожи при воздействии некоторых пестицидов: автореф. дис. ... канд. мед. наук / Ф.Д. Юсупова. Ташкент, 1988. - 17 с.

112. AMAP Assessment 2002: Persistent organic pollutants in the Arctic. - Norway, Oslo: AMAP, 2004.

113. AMAP Assessment 2015: Human Health in the Arctic. - Oslo: AMAP, 2015. 
114. Barr, D.B. Strategies for biological monitoring of exposure for contemporary use pesticides / D.B. Barr, J.R. Barr, W.J. Driskell [et al.] // Toxicology and Industrial Health. - 1999. - V. 15. - P. 168-79.

115. Burns, J. Association Between Chlorinated Pesticides in the Serum of Prepubertal Russian Boys and Longitudinal Biomarkers of Metabolic Function / J. Burns, P. Williams, S. Korrick [et al.] // American Journal of Epidemiology. - 2014. - V. 180. - P. 909-919.

116. Dudarev, A.A. Public health practice report: water supply and sanitation in Chukotka and Yakutia, Russian arctic // International Journal of Circumpolar Health. - 2018. V. 77. - No. 1. - P. 1423826.

117. Ginsberg, G. Incorporating pharmacokinetic differences between children and adults in assessing children's risks to environmental toxicants / G. Ginsberg, D. Hattis, B. Sonawane // Toxicology and Applied Pharmacology. - 2004. - V. 198. - No. 2. - P. 164-183.

118. Krauthacker, B. Organochlorine pesticides and PCBs in human milk collected from mothers nursing hospitalized children / B. Krauthacker, E. Reiner, A. Votava-Raić [et al.] // Chemosphere. -1998. - V. 37. - No. 1. P. 27-32.

119. Le Phuoc Cuong. Экомониторинг пестицидов в волосах вьетнамцев, проживающих в г. Дананг (Вьетнам) и в г. Казань / Le Phuoc Cuong, М.И. Евгеньев, Ф.М. Гумеров [и др]. // Вестник казанского технологического университета. - 2011. - №18. - С. 31-37.

120. Lukyanova, O.N. Pacific salmon as a vector in the trasnsfer of persistent organic pollutants in the ocean / O.N. Lukyanova, V.Yu. Tsygankov, M.D. Boyarova, N.K. Khristoforova // Journal of Ichthyology. - 2015. - V. 55. No. 3. P. 425-429.

121. Lukyanova, O.N. Pesticide biotransport by Pacific salmon in the northwestern Pacific Ocean / O.N. Lukyanova, V.Yu. Tsygankov, M.D. Boyarova, N.K. Khristoforova // Doklady Biological Sciences. - 2014. V. 456. - No. 1. - P. 188-190.

122. Polder, A. Spatial and temporal changes of chlorinated pesticides, PCBs, dioxins (PCDDs/PCDFs) and brominated flame retardants in human breast milk from northern Russia / A. Polder, G.W. Gabrielsen, J.Ø. Odland [et al.] // Science of the Total Environment. - 2008. - V. 391. - P. 41-54.

123. Ruder, A.M. Gliomas and farm pesticide exposure in men: the upper midwest health study / A.M. Ruder, M.A. Waters, M.A. Butler [et al.] // 
Archives of Environmental Health: An International Journal. - 2004. - V. 59. No. 12. - P.650-657.

124. Saleh, M.A. Breast Milk as a Biomarker for Monitoring Human Exposure to Environmental Pollutants / M.A. Saleh, A.M. Afify, A. Ragab [et al.]. - In: Biomarkers for Agrochemicals and Toxic Substances, American Chemical Society. - 1996. - P. 114-125.

125. Sergeyev, O. POPs in human milk in Chapaevsk, Russia, five years following cessation of chemical manufacturing and decade of remediation program, pilot study / O. Sergeyev, A. Shelepchikov, T. Denisova [et al.] // Organohalogen Compounds. - 2008. - V. 7. - P. 1946-1949.

126. Stockholm Convention on Persistent Organic Pollutants (Text and Annexes) [Internet]. UNEP; 2001. URL: http://chm.pops.int/

127. Tsydenova, O.V. Organohalogen Compounds in Human Breast Milk from Republic of Buryatia, Russia / O.V. Tsydenova, A. Sudaryanto, N. Kajiwara [et al.] // Environmental Pollution. - 2007. - V. 46. - P. 225-235.

128. Tsygankov, V.Yu. Bioaccumulation of POPs in human breast milk from south of the Russian Far East and exposure risk to breastfed infants / V.Yu. Tsygankov, Y.P. Gumovskaya, A.N. Gumovskiy [et al.] // Environmental Science and Pollution Research. - 2020. - V. 27. - P. 5951-5957.

129. Tsygankov, V.Yu. Bioindicators of Organochlorine Pesticides in the Sea of Okhotsk and the Western Bering Sea / V.Yu. Tsygankov, M.D. Boyarova, O.N. Lukyanova, N.K. Khristoforova //Archives of Environmental Contamination and Toxicology. - 2017. - V. 73. - No. 2. - P. 176-184.

130. Tsygankov, V.Yu. Hexachlorocyclohexane $(\mathrm{HCH})$ in human blood in the south of the Russian Far East / V.Yu. Tsygankov, M.D. Boyarova, P.F. Kiku, M.V. Yarygina // Environmental Science and Pollution Research. - 2015. V. 22. - P. 14379-14382.

131. Tsygankov, V.Yu. Organochlorine pesticides in marine ecosystems of the Far Eastern Seas of Russia (2000-2017) / V.Yu. Tsygankov // Water Research. - 2019. V. 161. - P.43-53.

132. Tsygankov, V.Yu. Selected Organochlorines in Human Blood and Urine in the South of the Russian Far East / V.Yu. Tsygankov, N.K. Khristoforova, O.N. Lukyanova [et al.] // Bulletin of Environmental Contamination and Toxicology. - 2017. - V.99. - P.460-464.

133. Tsygankov, V.Yu. Trace concentrations of organochlorine compounds in biological liquids of the Russian Far East residents / 
V.Yu. Tsygankov, M.V. Yarygina, O.N. Lukyanova [et al.] // Ekologiya Cheloveka (Human Ecology). - 2019. - V. 1. - P. 15-19.

134. Yufit, S. Contamination of human milk with PCDDs, PCDFs and PCBs in two Russian cities / S. Yufit, R. van Leeuwen, R. Malisch, D.P. Samsonov // Organohalogen Compounds. - 2002. - V. 56. - P. 333-336. 
https://doi.org/10.24866/7444-4891-2/317-338

\title{
ГЛАВА 13
}

\section{СТОЙКИЕ ОРГАНИЧЕСКИЕ ЗАГРЯЗНЯЮЩИЕ ВЕЩЕСТВА (СОЗ) В ОРГАНИЗМЕ ЖИТЕЛЕЙ ПРИБРЕЖНЫХ РАЙОНОВ ДАЛЬНЕГО ВОСТОКА РОССИИ}

\author{
В.Ю. Цыганков ${ }^{1,2}$, М.Д. Боярова ${ }^{1}$, М.М. Донещ \\ Ю.П. Гумовская ${ }^{1}$, А.Н. Гумовский ${ }^{1}$, И.П. Коваль ${ }^{1}$, \\ Н.К. Христофорова ${ }^{2,}$, П.Ф. Кику ${ }^{1}$ В.В. Усов ${ }^{1}$
}

Национальные программы мониторинга стойких органических загрязняющих веществ (CO3) в организме человека осуществляются в разных странах. В настоящее время в России мониторинг проводится в отдельных

\footnotetext{
${ }^{1}$ Школа биомедицины, Дальневосточный федеральный университет (ДВФУ), 690922, Владивосток, о. Русский, п. Аякс, 10. E-mail: tsig_90@mail.ru.

2 Школа естественных наук, Дальневосточный федеральный университет (ДВФУ), 690922, Владивосток, о. Русский, п. Аякс, 10.

${ }^{1}$ School of Biomedicine, Far Eastern Federal University, 10 Ajax Bay, Russky Island Vladivostok, Russia, 690922. E-mail: tsig_90@mail.ru.

${ }^{2}$ School of School of Natural Sciences, Far Eastern Federal University, 10 Ajax Bay, Russky Island Vladivostok, Russia, 690922.

Для циитирования: Цыганков В.Ю., Боярова М.Д., Донец М.М., Гумовская Ю.П., Гумовский А.Н., Коваль И.П., Христофорова Н.К., Кику П.Ф., Усов В.В. Стойкие органические загрязняющие вещества (СО3) в организме жителей прибрежных районов Дальнего Востока России // Стойкие органические загрязняющие вещества (СО3) в Дальневосточном регионе: моря, организмы, человек : монография / В.Ю. Цыганков, М.М. Донец, Н.К. Христофорова [и др.] ; науч. ред. В.Ю. Цыганков. Владивосток : Изд-во Дальневост. федерал. ун-та, 2020. - С. 317-338. https://doi.org/10.24866/7444-4891-2/317-338.

For citing: Tsygankov V.Yu., Boyarova M.D., Donets M.M., Gumovskaya Yu.P., Gumovskiy A.N., Koval I.P., Khristoforova N.K., Kiku P.F., Usov V.V. Persistent organic pollutants (POPs) in the body of residents of the Russian Far East coastal regions // Persistent organic pollutants (POPs) in the Far Eastern Region: Seas, Organisms, Human : monograph / V.Yu. Tsygankov, M.M. Donets, N.K. Khristoforova [et al.] ; ed. by V.Yu. Tsygankov. - Vladivostok : Publishing House of the Far Eastern Federal University, 2020. - P. 317-338. - https://doi.org/10.24866/7444-4891-2/317-338.
} 
регионах. По Дальнему Востоку России опубликованы только предварительные данные о накоплении СО3 в организме человека. В главе показаны результаты исследования содержания СО3 в крови и грудном молоке жителей Дальнего Востока России.

Ключевые слова: СО3; биомониторинг; кровь; грудное молоко; жители Дальнего Востока.

\section{CHAPTER 13. Persistent organic pollutants (POPs) in the body of residents of the Russian Far East coastal regions}

V.Yu. Tsygankov ${ }^{1,2}$, M.D. Boyarova ${ }^{1}$, M.M. Donets ${ }^{1}$, Yu.P. Gumovskaya ${ }^{1}$, A.N. Gumovskiy', I.P. Koval', N.K. Khristoforova ${ }^{1,3}$, P.F. Kiku ${ }^{1}$, V.V.Usov ${ }^{1}$

National monitoring programs for persistent organic pollutants (POPs) in humans are implemented in different countries. At present, in Russia, monitoring is carried out in some regions. For the Russian Far East, only preliminary data on the accumulation of POPs in the human body have been published. In the chapter, the results of a study of the content of POPs in the blood and breast milk of residents of the Russian Far East are shows.

Keywords: POPs; biomonitoring; blood; breast milk; residents of the Russian Far East.

Проблема накопления СО3 в организме человека весьма актуальна, поскольку эти вещества обладают потенциальными тератогенными, канцерогенными, гормональными, неврологическими и иммунологическими свойствами $[6,15,31]$. Основной источник поступления поллютантов в организм человека - пища. Предположительно около 90 \% общего загрязнения происходит через пищу и только $10 \%$ - за счет ингаляции и кожной абсорбции [35]. 
Несмотря на многочисленные работы по обнаружению токсикантов в тканях и органах человека, механизмы поступления и уровни аккумуляции загрязнителей, а также их воздействие остаются недостаточно изученными или находятся на уровне теорий $[11,12,14,41,42]$. Хотя на использование этих соединений введены запреты и ограничения в большинстве стран, из-за стойкости и сохранения в биосфере их негативное действие на организмы продолжается.

Юг Дальнего Востока России - сельскохозяйственно развитая территория, где хлорорганические пестициды использовали на полях до их запрета. Помимо этого, регион соседствует с Китаем, где данные вещества до сих пор продолжают применяться для борьбы с вредителями сельского хозяйства и переносчиками болезней.

Национальные программы мониторинга XОС в организме человека осуществляются в разных странах, например, Чешской республике [11, 12], Республике Корея [14]. В России аналогичные исследования также проводятся [3, 4, 7, 27, 28].

\section{1. СОЗ в крови жителей Дальнего Востока}

Для выявления воздействия факторов среды на человека часто из биологических жидкостей рассматриваются моча и кровь, которые обеспечивают гомеостатические функции организма [44].

Пробы отбирались в 2019 г. Возраст жителей - от 18 до 30 лет. Число мужчин и женщин - 35 и 41, соответственно. Содержание липидов в

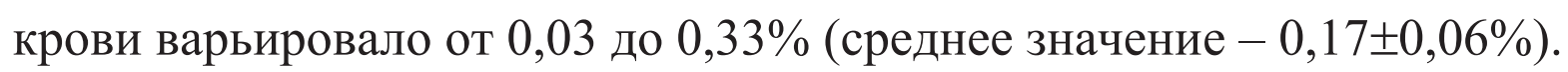

Хлорорганические соединения были обнаружены у 63 человек, то есть почти в $83 \%$ выборки. Найдены $\alpha-, \beta-, \gamma-, \delta$-ГХЦГ, ДДЕ и 52 ПХБ в 41, 92, 60, 52, 27, 40\% выборки, соответственно.

Суммарные концентрации СОЗ варьировали от 56 до 2475,8 нг/Г липидов (среднее значение - 886,4 \pm 572 нг/г липидов).

Суммарные концентрации ГХЦГ находились в пределах 16,9-1130,2 нг/г липидов (среднее значение - 414,8 282 нг/г липидов). Уровни $\alpha-, \beta-$,

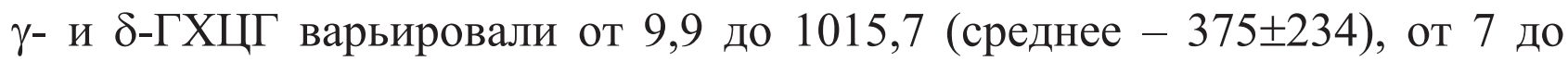




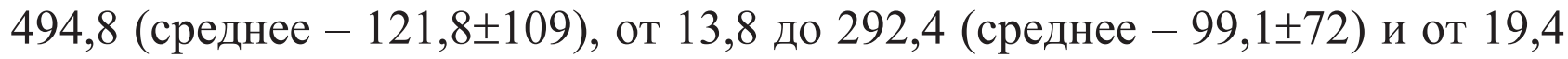
до 468,2 (среднее - 143,1 \pm 98 ), соответственно (рис. 13.1).

Содержание и распределение отдельных изомеров ГХЦГ указывает на давность загрязнения (длительная циркуляция) $(\alpha+\beta)$, а также на активный распад линдана $(\gamma<\delta)$ (рис. 13.2).

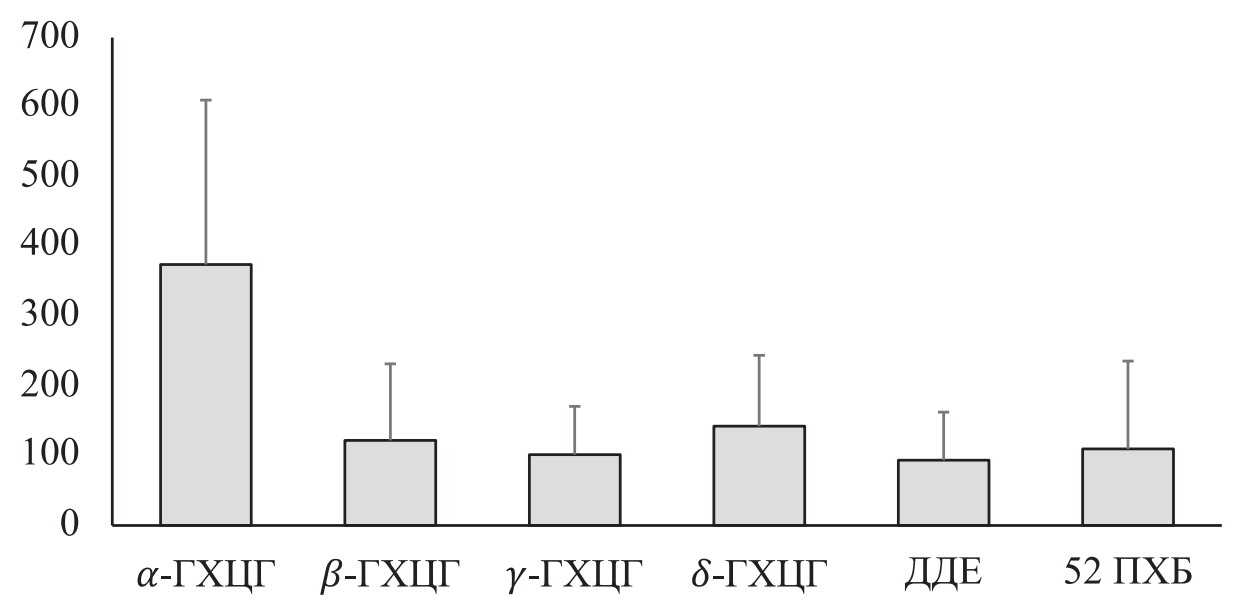

Pис. 13.1. Средние концентрации индивидуальных СО3 в крови жителей Приморского края, нг/г липидов

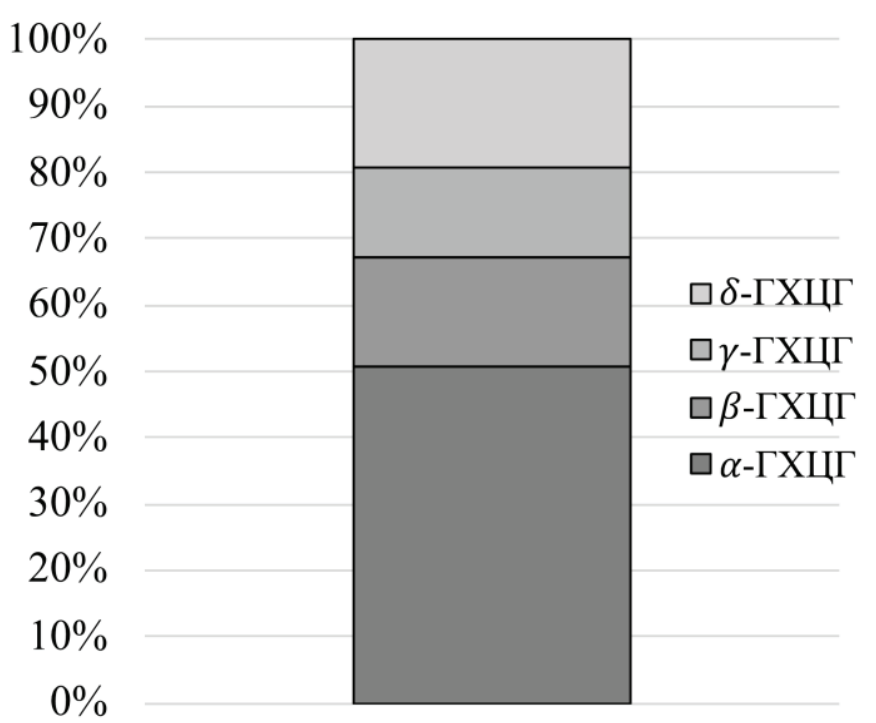

Рис. 13.2. Соотношение изомеров ГХЦГ в крови жителей Приморского края 
Как видно на рис. 13.2, сумма $\alpha$ - и $\beta$-изомеров достигает почти $70 \%$, т.е. этот пестицид давно циркулирует в экосистеме и распался до метаболитов уже на 2/3.

Из метаболитов ДДТ в крови обнаружен только ДДЕ, диапазон концентраций которого 1,9-213,1 (среднее - 92 \pm 68 нг/г липидов). Этот факт указывает на отсутствие свежего загрязнения и распад исходного ДДТ. Из конгенеров ПХБ обнаружен 52 ПХБ, концентрации которого варьировали от 28,9 до 483,4 (среднее - 110,9 \pm 122 нг/г липидов). Этот конгенер является водорастворимым (поэтому его наличие в крови ожидаемо) и позже будет выведен из организма с мочой. Однако в нашем начальном изучении содержания СО3 в организме человека выявлено, что с мочой из организма выводятся всего лишь пикограммы токсикантов, остальное количество «запасается» в жировых тканях [39].

Концентрации хлорорганических соединений, являющихся липофильными, имеют связь с содержанием липидов (рис. 13.3). Хотя зависимость статистически не подтверждается, тем не менее прослеживается общая тенденция увеличения концентрации СО3 с содержанием липидов.

Статистически достоверных возрастных и половых различий в накоплении CO3 не выявлено, вероятно это связано с тем, что разницы в возрасте на 10 лет не достаточно для оценки временных трендов накопления СО3 (рис. 13.4).

Гексахлорциклогексан в середине XX века применяли в виде технической смеси, где доли его изомеров составляли: $\alpha-55-70 \%, \beta-5-14 \%$, $\gamma-9-13 \%$ [1]. Его использование в Китае, Индии и других странах продолжается из-за отсутствия экономически рентабельных и экологически чистых альтернативных методов борьбы с насекомыми - переносчиками инфекций [14]. С 1990 года производство пестицидов в Китае увеличивалось и сейчас составляет $2,2 \cdot 10^{6}$ т/год [22]. Запрет на использование ДДТ в российском сельском хозяйстве был введен в 1971 году, ГХЦГ - в 1990-м $[3,4]$.

Полученные данные позволили убедиться в отсутствии экологического риска для здоровья человека в регионе на основе сравнения с пороговыми значениями ХОС в крови по международным стандартам: концентрация ДДТ в плазме - 200 мкг/л [15]; ГХЦГ и ДДТ в цельной крови - от 0,3 до 0,9 мкг/л и от 1,5 до 31 мкг/л соответственно [19]. 
52 ПХБ

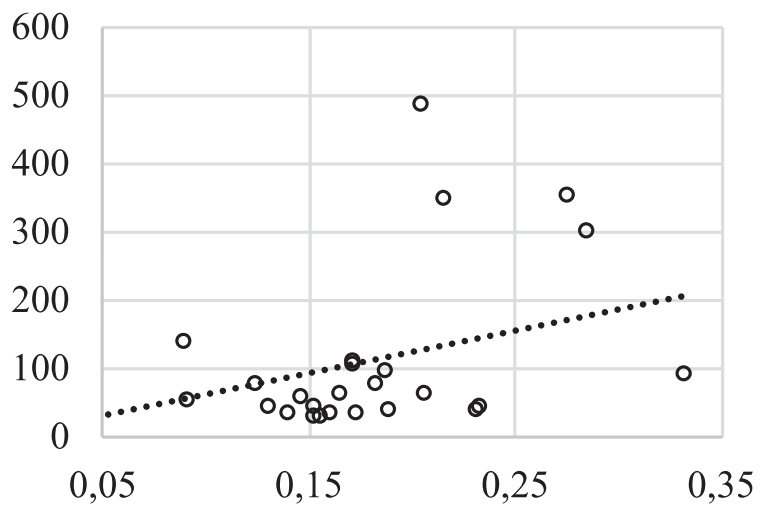

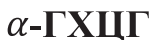

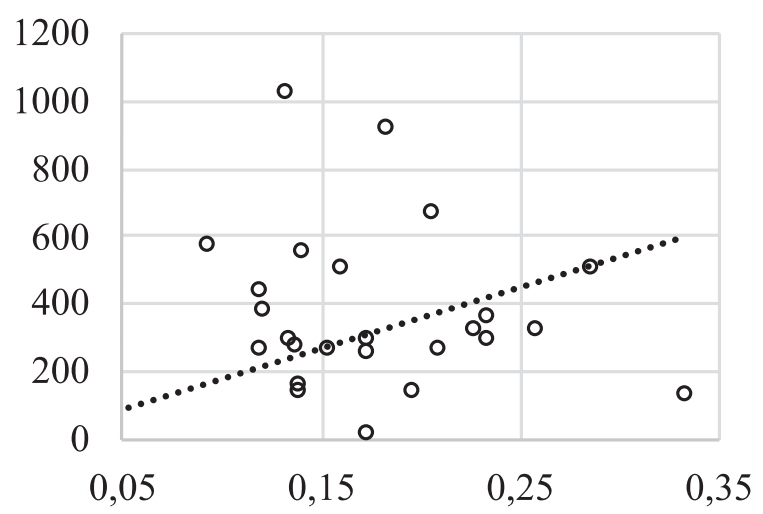

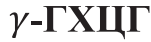

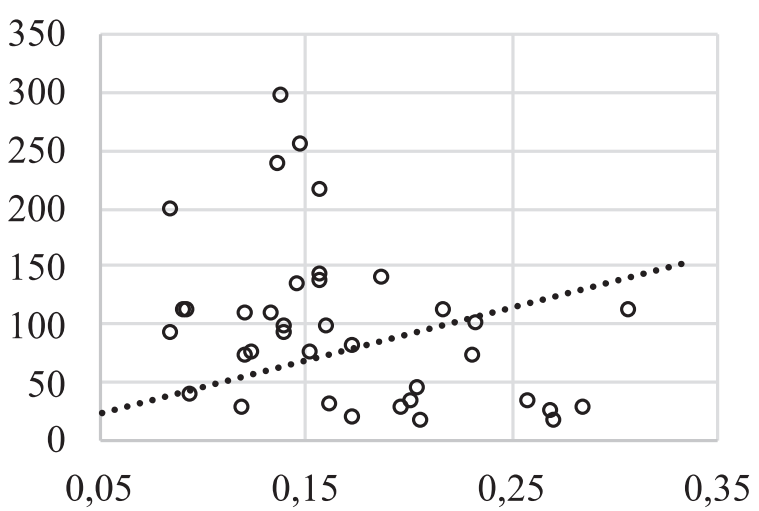

ДДЕ

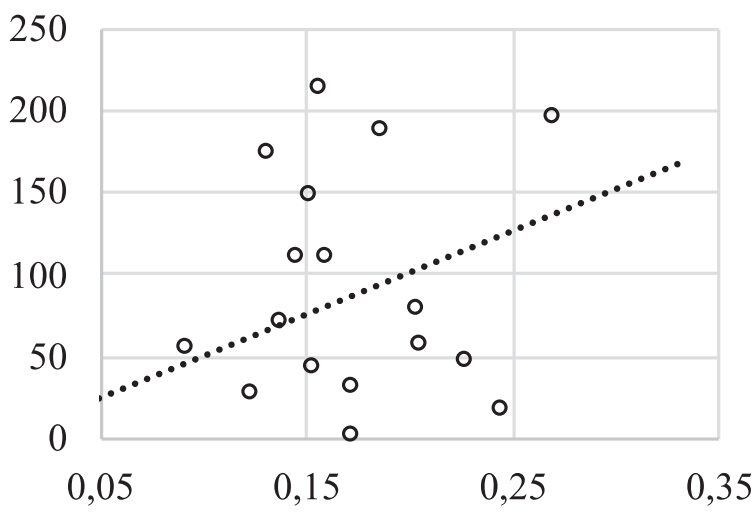

$\beta$-ГХЦГ

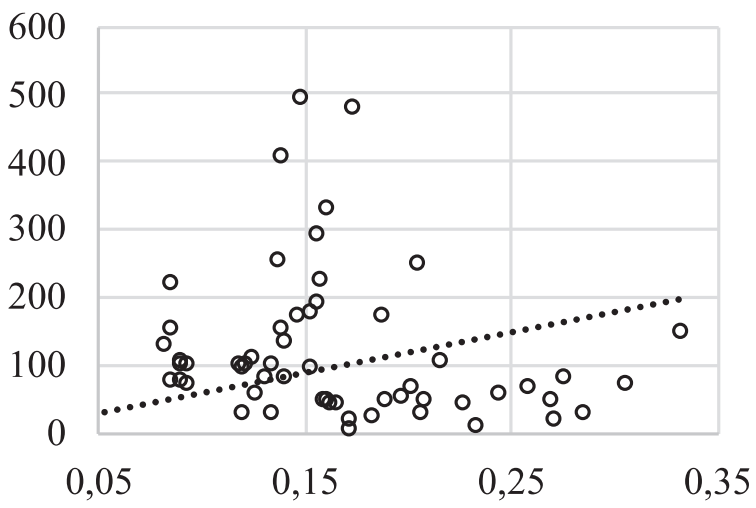

$\delta$-ГХЦГ

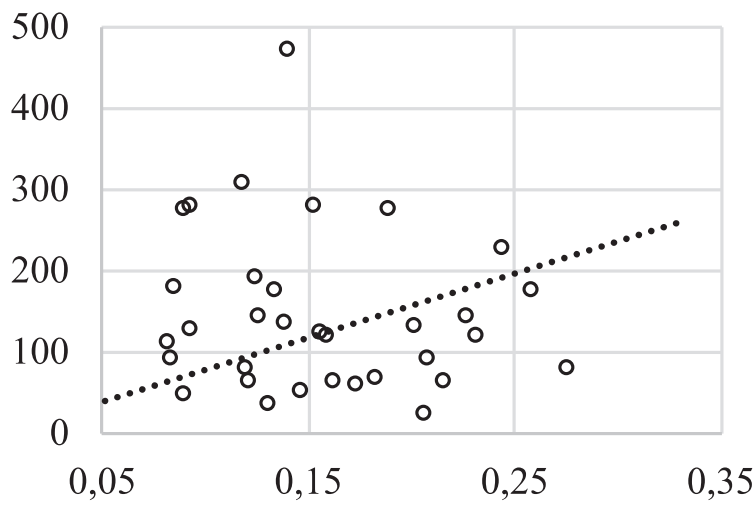

Puc. 13.3. Зависимость концентрации индивидуальных СО3 (ось $\mathrm{X}-$ нг/г липидов) от содержания липидов (ось $\mathrm{Y}-\%$ ) в крови жителей Приморского края 

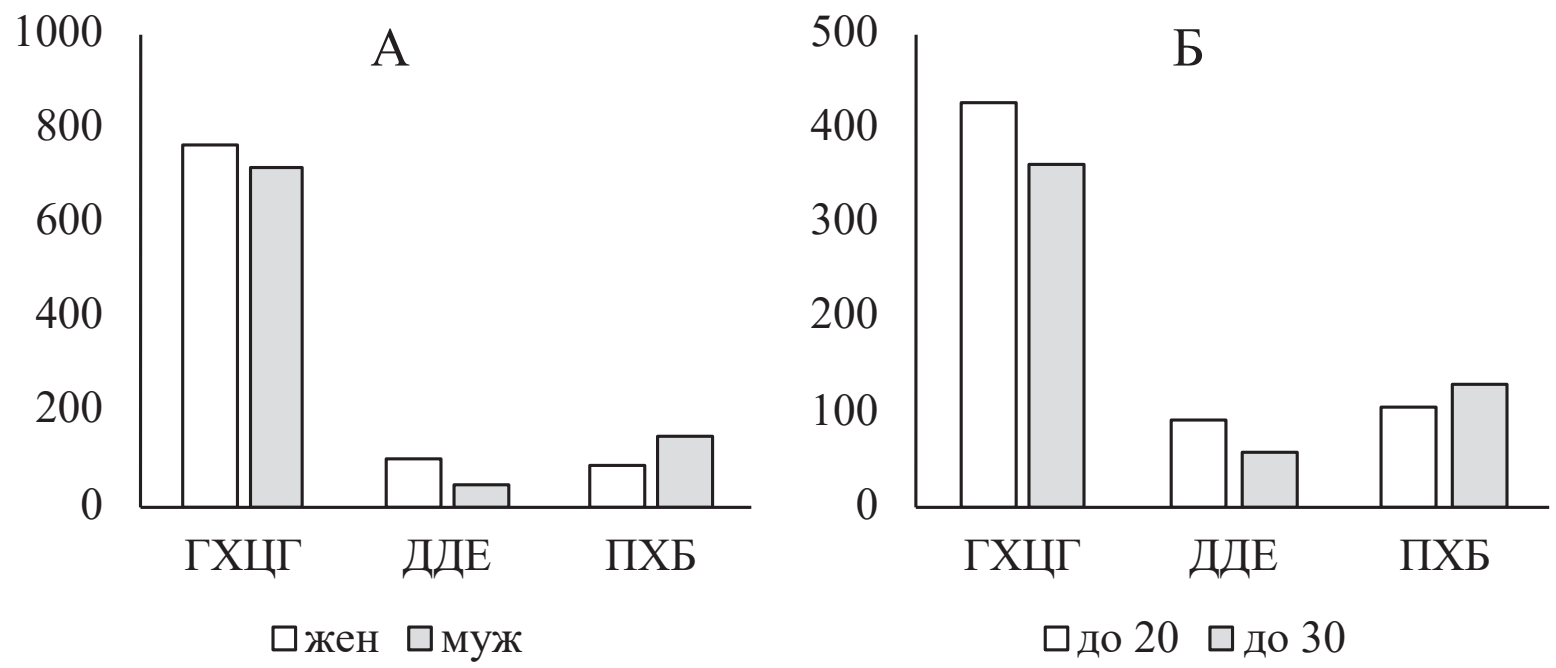

Puc. 13.4. Средние концентрации СОЗ в крови жителей Приморского края по полу (А) и возрасту (Б), нг/г липидов

Сравнение полученных нами данных (табл. 13.1), пересчитанных на нг/г липидов (диапазон концентраций - от 56 до 2476; средняя концентрация ХОС - 886; медиана - 780 нг/г липидов), с результатами других авторов показало, что меньшее содержание ХОС в крови жителей юга Дальнего Востока России, однако, по медиане больше, чем в Великобритании и Японии.

Таблица 13.1

Концентрации хлорорганических соединений в крови жителей разных регионов мира, нг/г липидов

\begin{tabular}{lllll}
\hline Регион & Диапазон & Среднее значение & Медиана & Источник \\
\hline Приморский край, Россия & $56-2476$ & 886 & 780 & Эта работа \\
Мексика & $1600-182600$ & 23100 & 13800 & {$[41]$} \\
Румыния & $446-47120$ & - & - & {$[16]$} \\
Испания & - & 6187 & 4123 & {$[34]$} \\
Великобритания & $10-2720$ & - & 115 & {$[36]$} \\
Швейцария & - & 887 & - & {$[20]$} \\
Япония & - & 151 & 210 & {$[18]$} \\
\hline
\end{tabular}

Таким образом, концентрации СО3 в крови жителей присутствуют и обнаруживаются до 83\% в выборке. Вероятно, это связано с развивающимися странами, которые продолжают использовать СО3 ввиду отсутствия более безопасных аналогов. 


\section{2. Грудное молоко}

Согласно рекомендациям ВО3, одним из наиболее достоверных индикаторов воздействия СО3 на здоровье человека является определение их содержания в крови и женском молоке [5].

Приморский край. Проведено эколого-аналитическое изучение образцов грудного молока у жительниц юга Дальнего Востока России (Приморский край) - у 29 женщин в 2017 г. и 37 - в 2018 г., которое выявило $100 \%$ наличие СО3 в молоке. Исследование является этапом регулярного мониторинга стойких органических загрязняющих веществ в связи с Планом выполнения Российской Федерацией обязательств, предусмотренных Стокгольмской конвенцией о стойких органических загрязнителях (№ 529 от 03.10.2017 «Об утверждении Плана выполнения Российской Федерацией обязательств, предусмотренных Стокгольмской конвенцией о стойких органических загрязнителях»).

Женщины были в возрасте от 20 до 49 лет. Количество женщин в возрастных группах 20-9, 30-39, 40-49 лет в 2017 году составило 10, 11, 5 человек, в 3 пробах возраст матери неизвестен, и в 2018 году соотношение возрастных групп составило 10, 25, 2 чел.

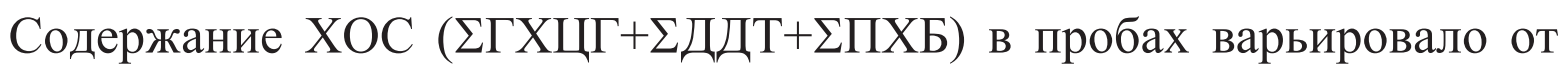
23 до 878,3 (среднее значение - 151,4) нг/г липидов (табл. 13.2). Диапазо-

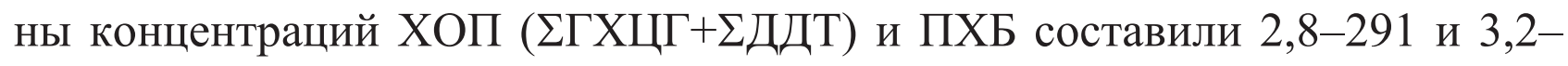
720 нг/г липидов, соответственно. Средние значения ХОП и ПХБ - 80,1 и 74,9 нг/г липидов, соответственно.

Суммарное содержание хлорорганических пестицидов - это сумма

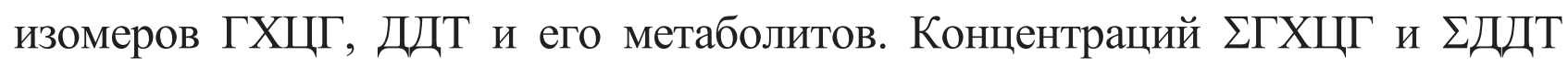
находились в диапазонах 2,84-291 и 1,1-83 нг/Г липидов, соответственно.

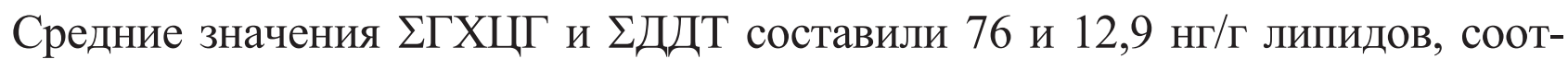
ветственно. Все изомеры ГХЦГ были обнаружены в грудном молоке. Наиболее часто определяемая форма - $\beta$-ГХЦГ. Концентрации $\alpha-$, $\beta$ - и $\gamma$ ГХЦГ находились в диапазоне 0,3-6,6, 2,8-290 и 0,8-26 нг/Г липидов, соответственно. ДДТ и его метаболиты были ниже предела обнаружения в 50\% проб. В основном определялся o,p' и $p, p^{\prime}$-ДДЕ (в 29 и 23\% проб, соответственно). Их концентрации варьировали от 0,7 до 22 и 0,5 до 29 нг/г липидов, соответственно. $o, p^{\prime}$-ДДТ, $o, p$ '-ДДД и $p, p^{\prime}$-ДДД обнаружен в двух пробах и их концентрации составили 3,62 и 1,1 нг/г, 2,2 и 1,4 нг/г, 34,4 и 25,7

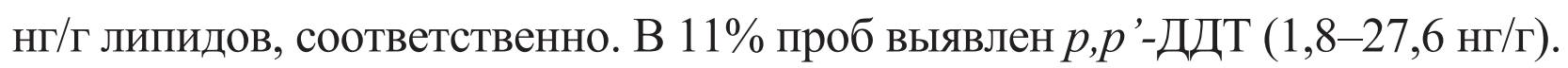


Таблийа 13.2

\section{Содержание хлорорганических соединений (ХOC)}

\section{в грудном молоке жительниц Приморского края, нг/г липидов}

\begin{tabular}{|c|c|c|c|c|c|c|}
\hline \multirow[t]{3}{*}{ Токсикант } & \multicolumn{3}{|l|}{2017} & \multicolumn{3}{|l|}{2018} \\
\hline & \multicolumn{3}{|c|}{ Возрастные группы } & \multicolumn{3}{|c|}{ Возрастные группы } \\
\hline & $20-29$ & $30-39$ & $40-49$ & $20-29$ & $30-39$ & $40-49$ \\
\hline$\alpha-Г Х Ц Г ~$ & - & - & - & $0,6 \pm 0,1$ & $1,2 \pm 0,2$ & $0,7 \pm 0,03$ \\
\hline 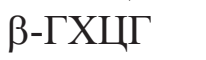 & $36,3 \pm 15,4$ & $66,6 \pm 14,2$ & $47,4 \pm 6,6$ & $62,2 \pm 13,5$ & $91,5 \pm 11,7$ & $114,1 \pm 72,2$ \\
\hline$\gamma$-ГХЦГ & - & - & - & $7,9 \pm 2,2$ & $7,6 \pm 2,2$ & - \\
\hline$o, p^{\prime}$-ДДТ & - & $2,3 \pm 0,2$ & - & - & - & - \\
\hline$p, p$-ДДТ & $10,2 \pm 2,2$ & $2,2 \pm 0,01$ & - & - & - & - \\
\hline$o, p$ '-ДДД & - & - & - & - & - & - \\
\hline$p, p$ '-ДДД & - & - & - & - & - & - \\
\hline$o, p$-ДДЕ & - & - & - & $9,3 \pm 0,5$ & $8,9 \pm 1,5$ & - \\
\hline$p, p$-ДДЕ & $17,7 \pm 2,3$ & $3,5 \pm 0,2$ & - & - & $9,1 \pm 2,1$ & - \\
\hline ПХБ 28 & - & $2 \pm 0,2$ & - & $14,5 \pm 6,0$ & $4,8 \pm 1,1$ & - \\
\hline ПХБ 52 & $47,2 \pm 6,6$ & $16,8 \pm 5,4$ & $11,9 \pm 4,1$ & $26,4 \pm 11,4$ & $12,3 \pm 3,2$ & $12,6 \pm 3,3$ \\
\hline ПХБ 101 & $12,8 \pm 3,3$ & $9,7 \pm 3,9$ & - & $3,05 \pm 0,8$ & $11,9 \pm 2,2$ & - \\
\hline ПХБ 118 & $49,9 \pm 24,4$ & $23,6 \pm 5,1$ & $20,8 \pm 8,1$ & $6,7 \pm 0,8$ & $9,1 \pm 1,2$ & $11,2 \pm 2,1$ \\
\hline ПХБ 138 & $48,3 \pm 22,5$ & $38,1 \pm 15,2$ & $15,2 \pm 2,8$ & $7,9 \pm 1,4$ & $15,5 \pm 2,5$ & $26,5 \pm 14,2$ \\
\hline ПХБ 143 & - & - & - & - & - & - \\
\hline ПХБ 153 & $49,2 \pm 21,5$ & $28,8 \pm 6,4$ & $32,7 \pm 11,2$ & $7,6 \pm 1,1$ & $16,7 \pm 2,4$ & $23,3 \pm 10,4$ \\
\hline ПХБ 155 & $25,0 \pm 9,8$ & $2,3 \pm 0,03$ & - & $16,8 \pm 4,8$ & $25,6 \pm 12,5$ & - \\
\hline ПХБ 180 & - & $12,8 \pm 3,9$ & - & - & $12,9 \pm 2,5$ & - \\
\hline ПХБ 207 & - & - & - & - & - & - \\
\hline
\end{tabular}

«-»- ниже предела обнаружения

Полихлорированные бифенилы (ПХБ) обнаружены практически во всех пробах. Концентрации 143 и 207 ПХБ были ниже предела детектирования. Содержание низкохлорированных 28 и 52 ПХБ (молекулы которых содержат до 4 атомов хлора) находились в диапазонах 1-35 и 1,8-130 нг/г липидов, соответственно. Диапазоны концентраций высокохлорированных 101, 118, 138, 153, 155 и 180 ПХБ составили 1,8-95, 2,5-253, 2,9-169, 3,4-163, 2,3-49 и 7-19 нг/Г липидов, соответственно.

В 2017 году было исследовано 29 проб грудного молока. Содержание ХОС варьировало от 22,6 до 878,3 (среднее - 144,1) нг/Г липидов. Диапазоны концентраций ХОП и ПХБ составили 2,8-158 и 16,3-720,3 нг/г липидов, соответственно; средние концентрации ХОП и ПХБ - 53,8 и

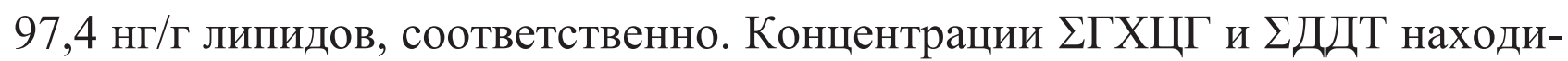

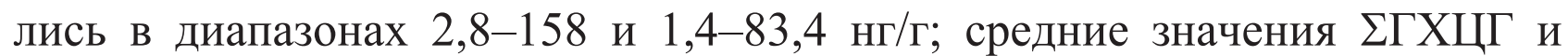
гДДТ - 51 и 17,9 нг/г липидов. 
В 2018 году было исследовано 37 проб грудного молока. Содержание ХОС в пробах находилось в пределах от 23,7 до 412,5 (среднее $157,11)$ нг/Г липидов. Диапазоны концентраций ХОП и ПХБ составили 10,8-291,1 и 3,2-177,5 нг/Г липидов, соответственно; средние концентрации ХОП и ПХБ - 99,2 и 57,89 нг/г липидов, соответственно. Концентра-

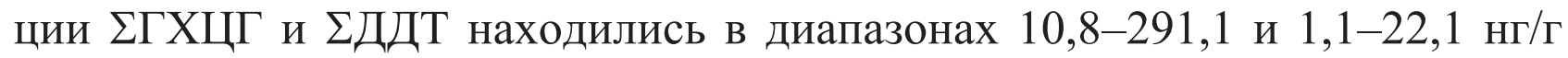
липидов; средние - 92,9 и 10,6 нг/г липидов, соответственно.

При изучении корреляции между концентрациями ХОС и липидов зависимости не выявлено. Общее содержание ХОП в 2018 г. выше, чем в 2017 г. ( $\mathrm{p}=0,035)$. ГХЦГ, как самый определяемый среди искомых соединений компонент, в 2018 г был обнаружен во всех пробах, а в 2017 году только в 84\% проб. Концентрации ГХЦГ и ДДТ в 2018 были значительно выше, чем в 2017 г. (p=0,016 и $\mathrm{p}=0,008)$ (рис. 13.5, 13.6). Содержание ГХЦГ и ДДТ в 2018 выше таковых в 2017 г. ( $\mathrm{p}=0,008$ и $\mathrm{p}=0,001)$. Этот факт указывает на возможное их применение этих ХOC на территории Дальнего Востока, а также в Южном Китае и Индии.

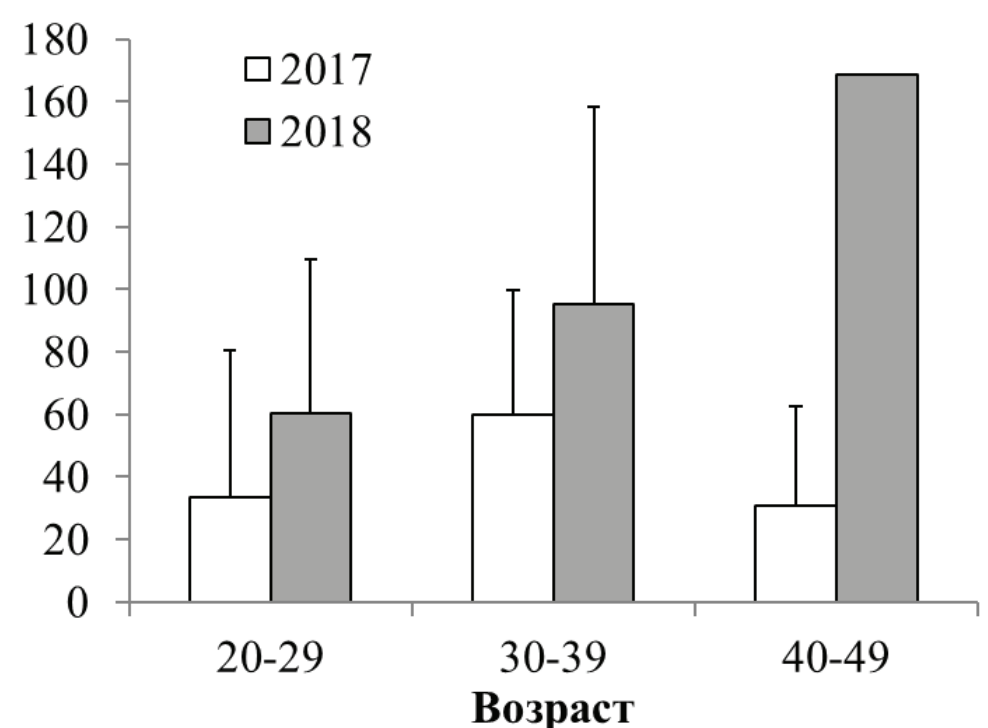

Рuc. 13.5. Среднее содержание изомеров гексахлорциклогексана (ГХЦГ) в грудном молоке, нг/г липидов

По данным Министерства здравоохранения Российской Федерации, в настоящее время значительные объемы ДДТ хранятся на территориях Приморского края, Хабаровского края и на других территориях Азиатской части России. По результатам наших исследований видно, что суммарная концентрация ДДТ уменьшается. Понижение содержания ДДТ и его мета- 
болитов указывает на уменьшение или неиспользование поллютантов этой группы в сельском хозяйстве.
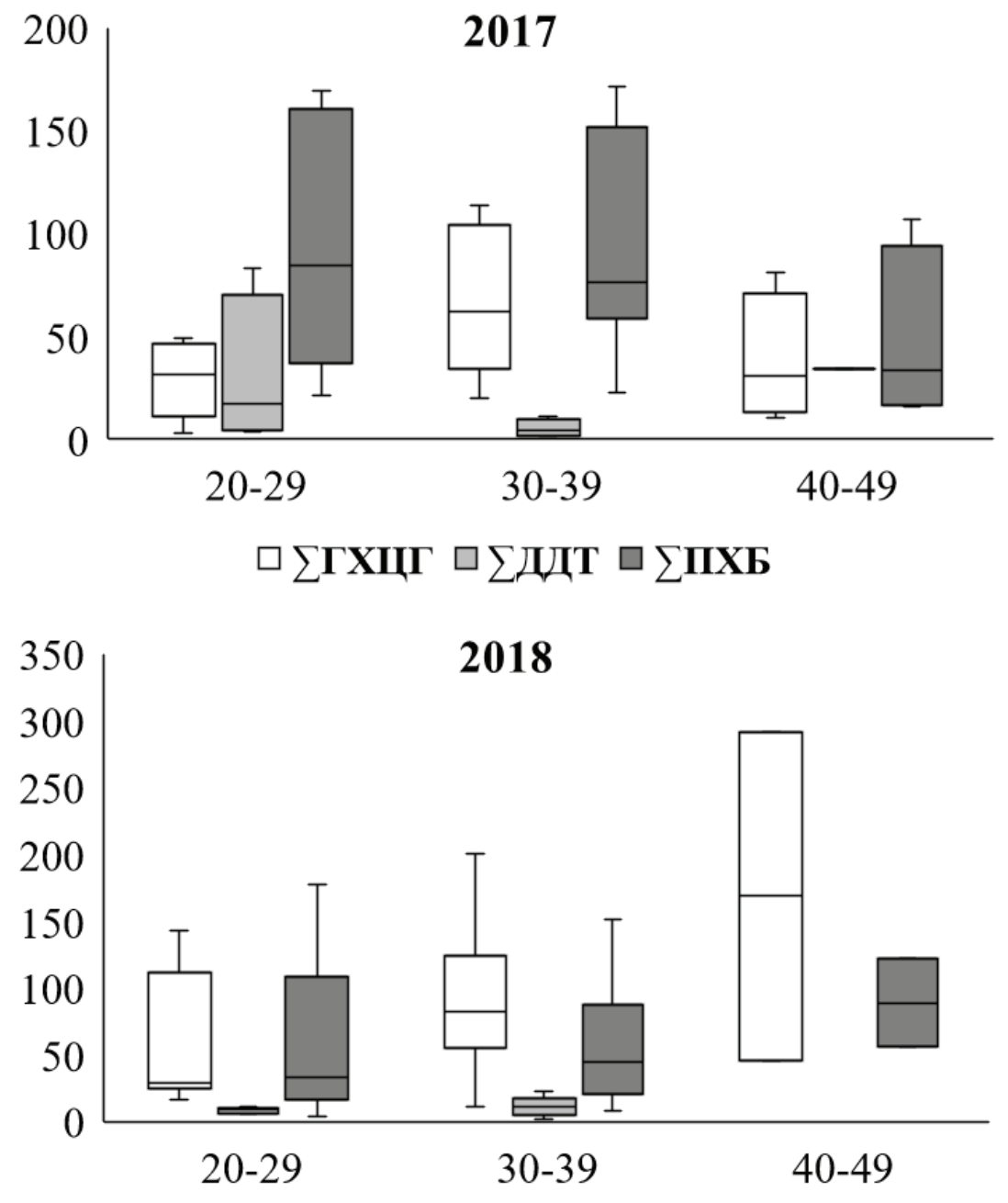

Возрастные группы

Рис. 13.6. Общее содержание ГХЦГ, ДДТ и ПХБ (медиана) в грудном молоке в 2017 и 2018 годах, нг/г липидов

Суммарная концентрация ПХБ в 2018 году была ниже таковой в 2017 г. (рис. 13.7). Это связано, вероятно, с выведением из эксплуатации ПХБ-содержащего оборудования и уменьшением использования таких технологий утилизации, как сжигание бытовых и промышленных отходов. Также, из результатов видно, что 30\% общей концентрации ПХБ занимают низкохлорированные конгенеры (рис. 13.7). Как известно, уменьшение растворимости в воде происходит с увеличением хлора [26]. Соответственно, низкохлорированные ПХБ быстрее выводятся мочевой системой. Высокохлорированные (тяжелые) ПХБ аккумулируются липидами организма и, практически, не выводятся с мочой. Это свойство 
указывает на передачу соединений с молоком матери к ребенку, увеличивая возможные риски для здоровья.
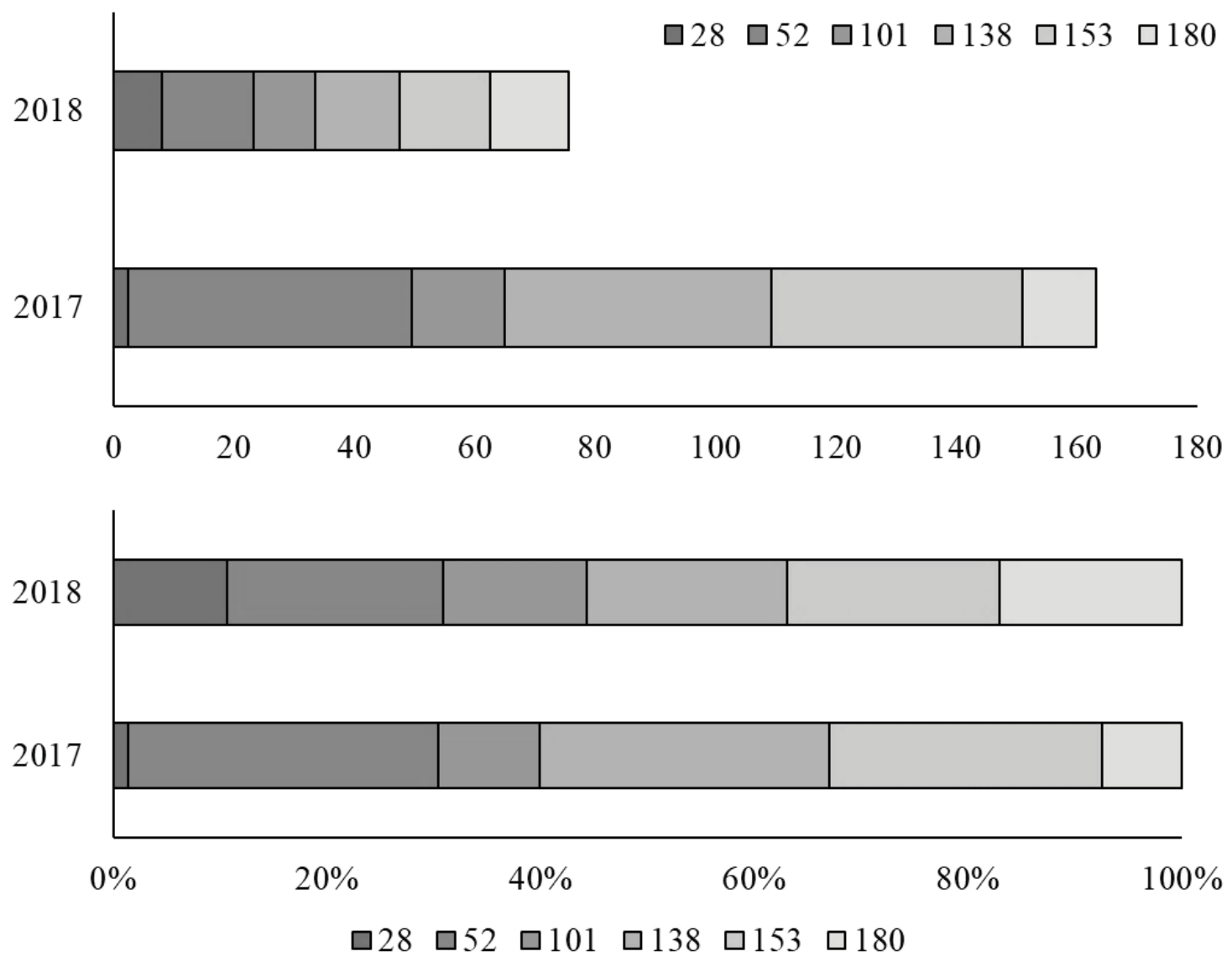

Puc. 13.7. Концентрации (нг/г липидов) и соотношение (\%) низкои высокохлорированных индикаторных ПХБ

Чукотский АО. В 2019 году проведено эколого-аналитическое исследование образцов грудного молока 26 женщин, проживающих в Чукотском автономном округе (ЧАО). Возраст женщин от 15 до 44 лет. Количество женщин в возрастных группах «до 30 лет», «после 30 лет» составило 15 и 10 человек, соответственно. В одном образце возраст матери не известен.

Хлорорганические соединения (ХОС) обнаружены во всех образцах.

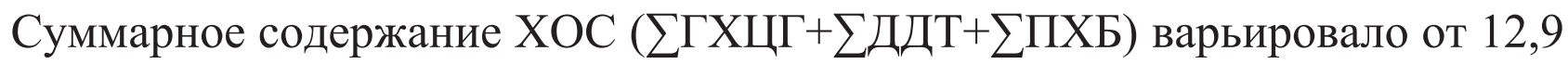

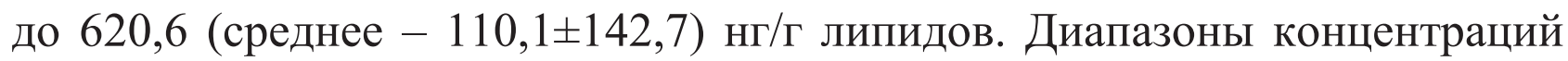

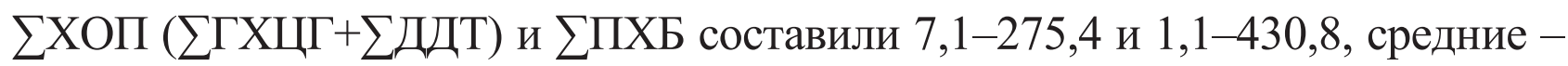
$41,3 \pm 51,9$ и 74,1 $\pm 112,4$ нг/г липидов, соответственно.

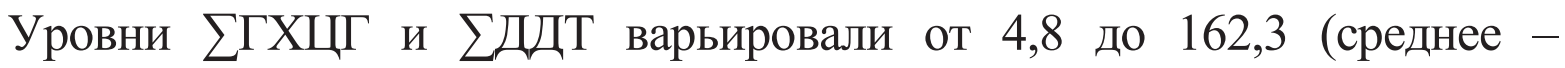
$31,1 \pm 30,5$ ) и от 1,5 до 113,1 (среднее - 13,7 $\pm 25,8$ ) нг/Г липидов, соответственно. В грудном молоке обнаружены $\alpha-, \beta-, \gamma-$ и $\delta$-ГХЦГ. Среди них наиболее 
часто встречалась $\beta$-форма, обнаруженная во всех исследованных образцах, наименее $-\alpha$-ГХЦГ. Концентрации $\alpha$-, $\beta$-, $\gamma$ - и $\delta$-изомеров ГХЦГ варьировали в пределах 9,2-32,2, 1,3-162,3, 1,4-11,8 и 0,8-6,8 нг/Г липидов, соответствен-

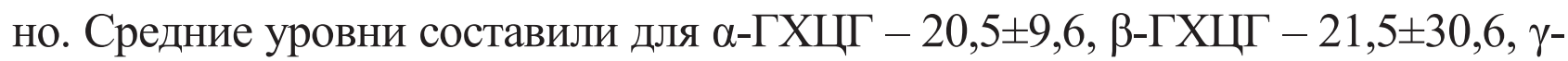
ГХЦГ $-4,2 \pm 2,8$ и $\delta$-ГХЦГ $-2,4 \pm 1,7$ нг/г липидов. Среди метаболитов ДДТ не обнаружены $p, p^{\prime}$-ДДТ, $о, p^{\prime}$-ДДД и $p, p^{\prime}$-ДДД. $о, p^{\prime}$-ДДТ и $о, p^{\prime}$-ДДЕ обнаружены в двух образцах с концентрациями $33,8,56,0$ и 3,0, 9,4 нг/г липидов, соответственно. Наиболее часто встречался $p, p$ '-ДДЕ, уровни которого варьировали от 1,5 до 57,1 (среднее значение - 9,8 $\pm 12,9$ ) нг/Г липидов.

Полихлорированные бифенилы обнаружены практически во всех образцах. 155, 101 и 207 конгенеры ПХБ были ниже пределов обнаружения во всех исследованных пробах. ПХБ 28 и ПХБ 143 выявлены в двух образцах с концентрациями 3,5, 30,8 и 3,6, 45,0 нг/г липидов, соответственно; ПХБ 180 в трех - 26,8, 60,2 и 75,0 нг/г липидов. Диапазоны ПХБ 52, ПХБ 118, ПХБ 153 и ПХБ 138 составили 1,1-9,8 (среднее - 5,2 2 2,8),

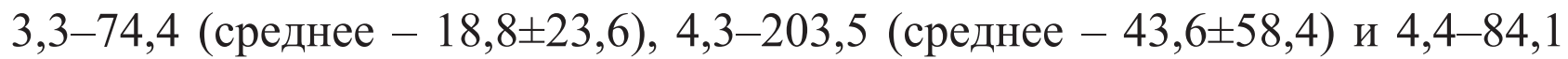
(среднее $-24,1 \pm 26,1)$ нг/г липидов, соответственно.

Концентрации $\sum$ ХОС в грудном молоке женщин до 30 лет находились в пределах 12,9-459,2 (среднее - 99,8 $\pm 124,9$ ) нг/г липидов. Уровни $\sum$ ХОП и $\sum$ ПХБ варьировали от 9,9 до $51,4(28,8 \pm 14,8)$ и от 1,1 до 430,8

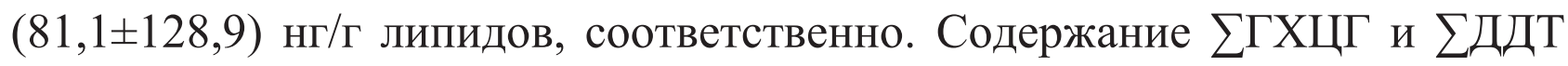
находилось в пределах 5,2-52,1 $(24,8 \pm 14,6)$ и $1,5-11,6(5,4 \pm 3,1)$ нг/г липидов, соответственно.

Содержание $\sum$ ХOC в грудном молоке женщин старше 30 лет варьиро-

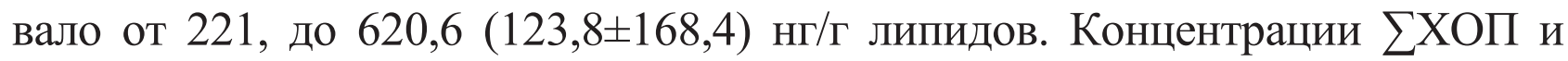
$\sum$ ПХБ находились в диапазонах от 7,1 до $275,4(58,0 \pm 76,0)$ и от 9,4 до 345,2

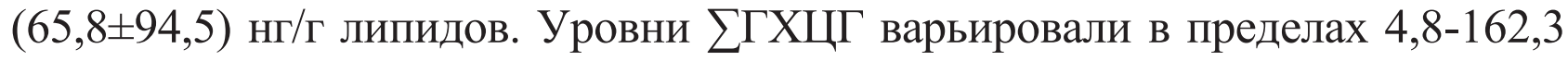
$(39,4 \pm 43,2)$ нг/г липидов, $\Sigma$ ДТ - 2,3-113,1 $(24,8 \pm 37,6)$ нг/г липидов.

При статистическом анализе корреляций между концентрациями липидов и ХОС в грудном молоке не обнаружено. Сравнение уровней поллютантов в образцах разных возрастных групп показало достоверные различия только между значениями $\beta$-ГХЦГ (рис. 13.8), содержание которого достоверно выше у женщин старше 30 лет $(\mathrm{p}=0,046)$.

Высокие уровни $\beta$-ГХЦГ у женщин старше 30 по сравнению с более молодыми (рис 13.8, 13.9) могут быть связаны с деградацией линдана в организме с возрастом. Среди метаболитов ДДТ наиболее часто обнаруживался $p, p$ '-ДДЕ, что говорит о давности поступления исходного поллю- 
танта в среду и его деградации. Более высокие уровни $p, p$ '-ДДЕ в грудном молоке женщин старше 30 лет (рис. 13.8) (статистически незначимо), вероятнее всего, указывает на биомагнификацию и распад ДДТ.

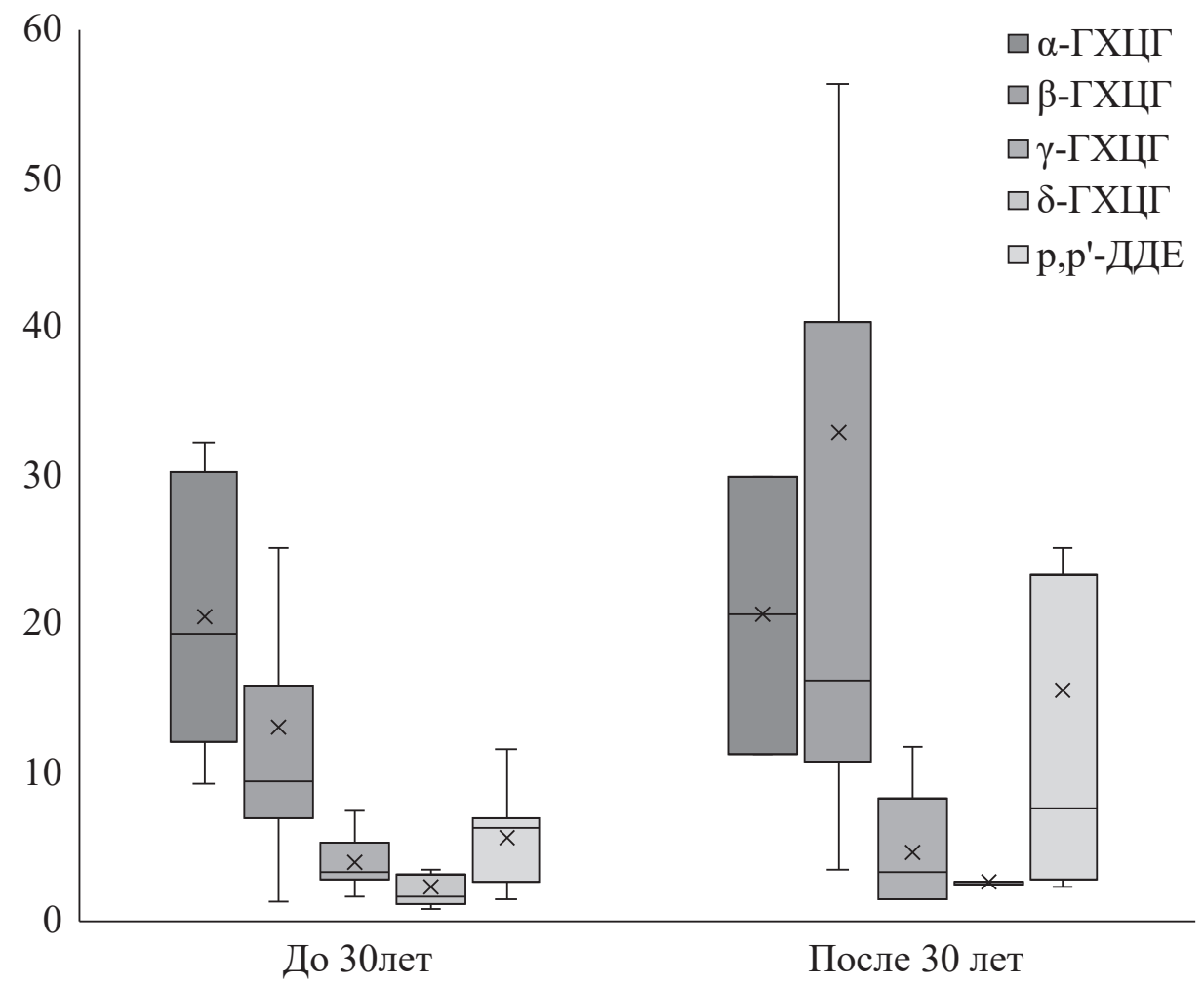

Pис. 13.8. Среднее содержание (медиана) изомеров ГХЦГ и ДДЕ в грудном молоке женщин ЧАО, нг/г липидов

Среди конгенеров ПХБ доминировали высокохлорированные ПХБ 118, ПХБ 153 и ПХБ 138 (рис. 13.10, 13.11). Уровни ПХБ 52 в грудном молоке сопоставимы у женщин обеих возрастных групп. ПХБ 143 обнаружен только в грудном молоке более молодых женщин. Средние уровни ПХБ 153 и ПХБ 138 имеют тенденцию к увеличению у женщин до 30 лет. (статистически не значимо).

Более высокие концентрации ПХБ в грудном молоке более молодых женщин могут быть связаны с количеством родов до момента исследования. Известно, что основными путями экскреции СО3 из организма женщин является перенос через плаценту (переход токсиканта от матери к плоду) и выведение с грудным молоком в период лактации [32, 33]. Вероятнее всего, у женщин более зрелого возраста роды были не первыми, в связи с чем концентрация полихлорированных бифенилов в грудном молоке меньше. 
СТОЙКИЕ ОРГАНИЧЕСКИЕ ЗАГРЯЗНЯЮЩИЕ ВЕЩЕСТВА (СОЗ) В ОРГАНИЗМЕ ЖИТЕЛЕЙ ПРИБРЕЖНЫХ РАЙОНОВ ДАЛЬНЕГО ВОСТОКА РОССИИ

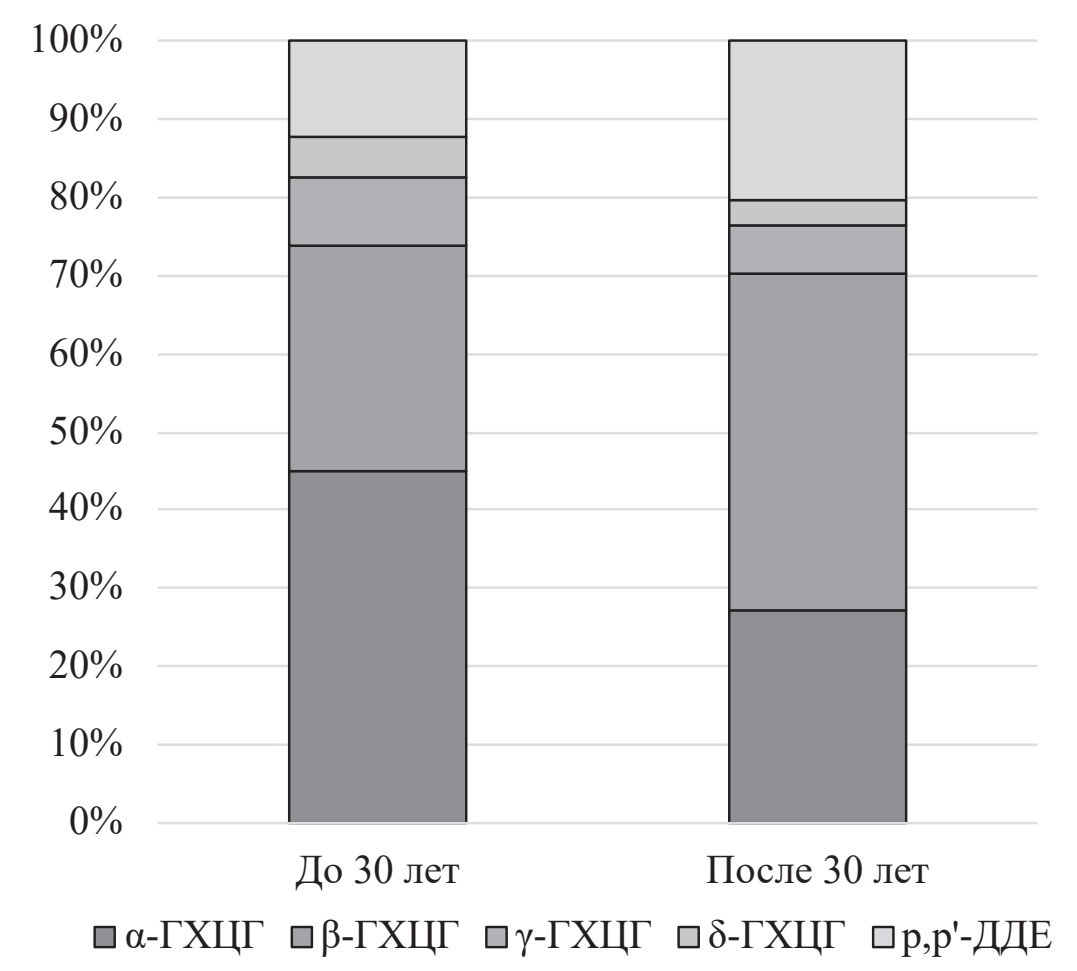

Рис. 13.9. Распределение ХОП

в грудном молоке женщин двух возрастных групп, \%

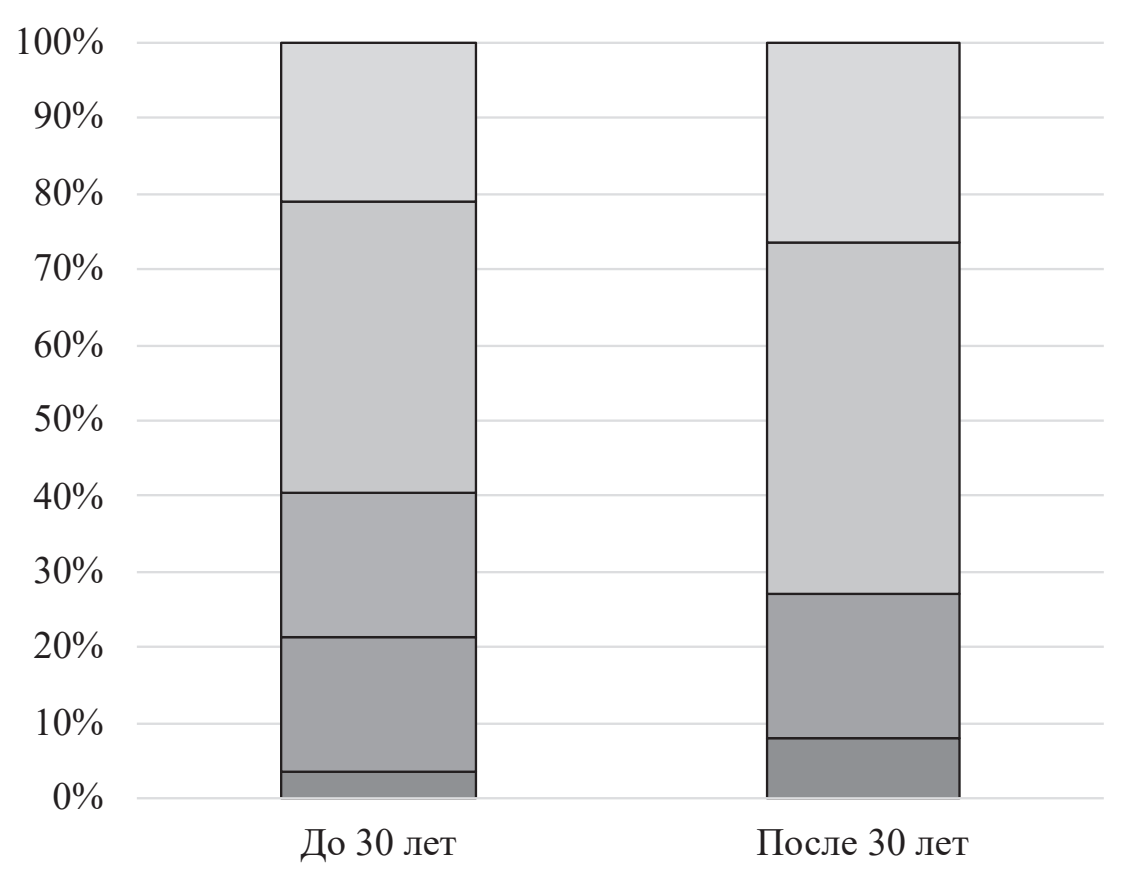

口ПХБ 52 口ПХБ 118 घПХБ 143 घПХБ 153 口ПХБ 138

Рис. 13.10. Распределение обнаруженных конгенеров ПХБ

в грудном молоке женщин двух возрастных групп, \% 


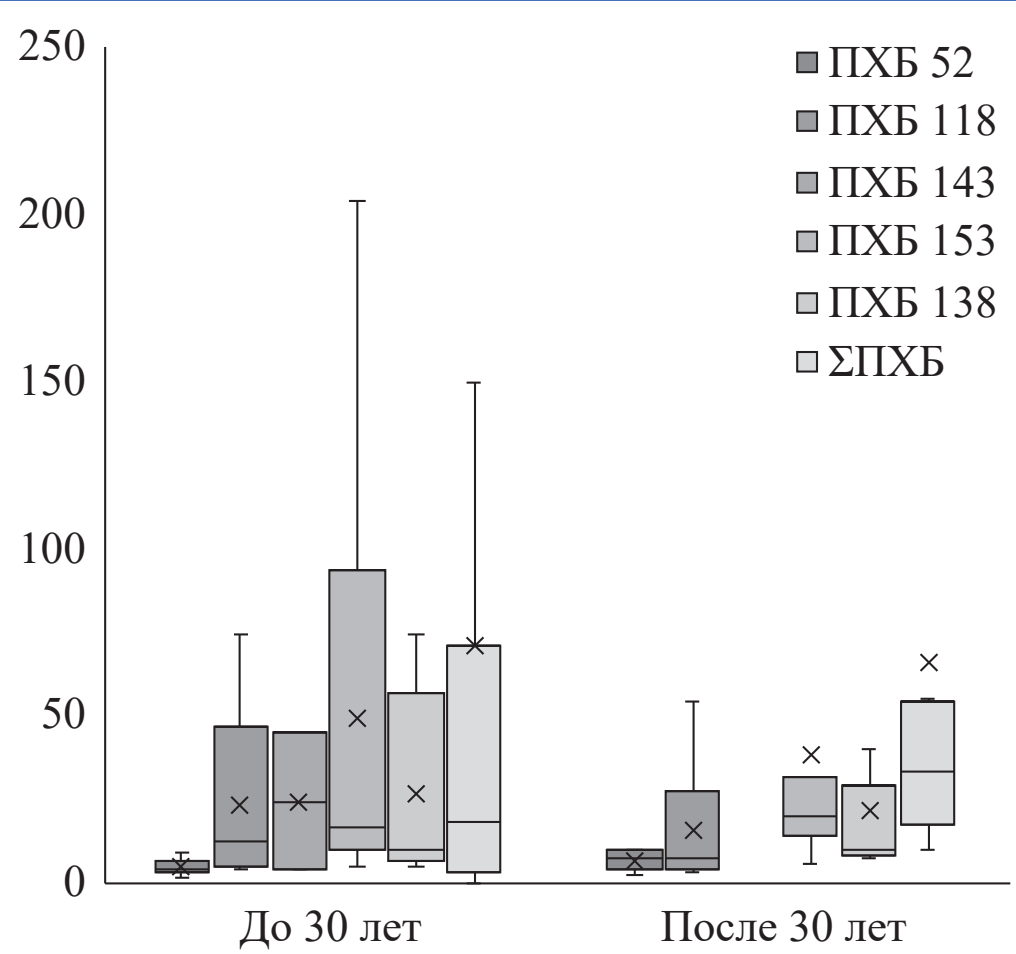

Puc. 13.11. Средние концентрации (медианы) конгенеров ПХБ в грудном молоке женщин ЧАО, нг/Г липидов

При сравнении данных с результатами исследований СО3 авторов

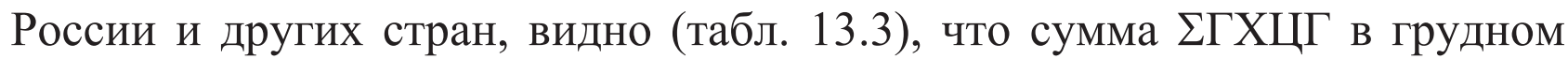
молоке жительниц Чукотского автономного округа меньше таковых в Приморском крае, Республики Бурятия, Индии, Вьетнаме, Японии, Китае, и выше, чем в Иркутской области, Хорватии, Чехии, Норвегии, Танзании, Корее и Тайване. Концентрации ГХЦГ в ЧАО сходны с Пакистаном.

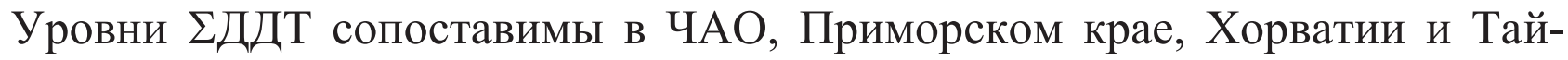
ване, где уровни поллютанта не превышают 20 нг/г липидов.

Концентрации ГХЦГ практически во всех странах меньше, чем ДДТ, в то время, как на Дальнем Востоке России ситуация обратная. В случае Приморского края (развитая сельскохозяйственная территория, где ранее активно применялись пестициды) это может быть связано с большим использованием ГХЦГ в сельском хозяйстве и аккумуляцией поллютантов в продуктах питания растительного и животного происхождения в результате общей биомагнификации ксенобиотиков [38, 40$]$.

Чукотский автономный округ - малоразвитый в аграрном отношении регион из-за суровых природных условий. В связи с этим применение здесь средств защиты растений не носило массового характера. Однако в работе Дударева [2] указываются данные региональных ветеринарных служб, кото- 
рые свидетельствуют об интенсивном использовании в 1960-70-х гг. в оленеводческих хозяйствах препаратов, содержащих ХОП (в частности - ДДТ и ГХЦГ), для опрыскивания оленей для защиты от овода. Достоверные результаты о содержании в них СО3 отсутствуют, однако имеющаяся информация позволяет предположить сопутствующее загрязнение почв, что до сих пор отражается на местных жителях этого региона. Кроме того, низкая температура значительно уменьшает интенсивность испарения и действует для CO3 как «холодная ловушка», что приводит к концентрированию летучих и полулетучих поллютантов в северных широта [2]. Очевидно, в связи с этим ХОП до сих пор обнаруживаются в организме местного населения.

Таблийа 13.3

\section{Содержание СО3 в грудном молоке из регионов России} и других стран (нг/г липидов)

\begin{tabular}{|c|c|c|c|c|c|c|}
\hline Регион & Год & 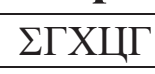 & इДДТ & $\Sigma П Х Б_{\text {инд }}^{1}$ & $\Sigma \Pi Х Б_{\text {общ }}$ & Источник \\
\hline Чукотский АО & 2019 & 31,1 & 13,7 & 59,6 & 74,1 & Эта работа \\
\hline Приморье & 2017-2018 & 76 & 12,9 & 19,9 & 77,8 & \\
\hline Иркутская область & 1997-2009 & 4,3 & 534 & 255,5 & 409,3 & {$[27]$} \\
\hline Республика Бурятия & 2003-2004 & 810 & 660 & - & 240 & [37] \\
\hline Хорватия & 2011-2014 & 3,4 & 16,8 & 25,3 & 66 & [23] \\
\hline \multirow[t]{2}{*}{ Чехия } & 2010 & $11^{3}$ & $219,3^{2}$ & 280,5 & 280,5 & {$[8]$} \\
\hline & 2011 & $9,6^{3}$ & $232,4^{2}$ & 253 & 253 & \\
\hline Норвегия & 2002-2009 & $12,3^{5}$ & $167^{2}$ & - & 541,6 & {$[25]$} \\
\hline Танзания & 2012 & 0,9 & 135 & 4,5 & 4,5 & [29] \\
\hline \multirow[t]{2}{*}{ Индия } & 2015-2016 & 46,6 & 490 & - & 127,3 & [9] \\
\hline & 2011-2012 & $199,6^{3}$ & $1914,2^{4}$ & - & - & {$[10]$} \\
\hline Корея & 2011-2012 & 19,5 & 104,2 & - & 14,4 & [24] \\
\hline Тайвань & $2013-2016$ & 0,51 & $9,8^{4}$ & - & - & [13] \\
\hline Пакистан & 2015 & 26,7 & 83,8 & - & - & [43] \\
\hline Вьетнам & $2007-2008$ & $140^{5}$ & 1200 & - & 84 & [21] \\
\hline Япония & & 126 & 172 & - & 31 & \\
\hline Япония & 2008-2009 & 63 & - & - & 112 & [17] \\
\hline Китай & $2007-2008$ & 688 & - & - & 46 & \\
\hline
\end{tabular}

Концентрации ПХБ в грудном молоке жительниц ЧАО находятся практически на одном уровне таковыми у женщин Приморского края, Хорватии и некоторых странах азиатско-тихоокеанского региона, в то время как в европейской части России и Европе содержание этих поллютантов выше. При этом в ЧАО индикаторные ПХБ составляют, в среднем, $80 \%$ от общего количества ПХБ, тогда как в Приморском крае - в среднем $26 \%$, что говорит 
о значительном вкладе техногенных источников поступления ПХБ в окружающую среду в ЧАО. Вероятнее всего, такое соотношение указывает на воздействие активного судоходства и локальное влияние действующих трансформаторов, конденсаторов, гидравлических систем и прочего ПХБиспользующего оборудования. Еще одним серьезным источником полихлорированных бифенилов в северной части Дальнего Востока мог быть так называемый «северный завоз» горюче-смазочных материалов и иных технических жидкостей, превративший близлежащие территории многих поселков в свалки брошенной бочкотары, в содержимом которой присутствуют, в частности, примеси ПХБ, попадающие в почвы, грунтовые воды, реки и моря [2]. Из-за различной токсичности отдельных конгенеров ПХБ риски для здоровья человека от их воздействия могут изменяться в зависимости от концентрации и характера загрязнения окружающей среды. Особенно восприимчивыми к воздействию СОЗ являются младенцы, основой питания которых, в норме, является грудное молоко, что указывает на необходимость продолжения экологического биомониторинга поллютантов.

\section{3. Список литературы}

1. Брагинский, Л.П. Миграция стойких пестицидов в пресноводных экосистемах / Л.П. Брагинский, Ф.Я. Комаровский, Ю.К. Пищолка, О.В. Маслова // Миграция загрязняющих веществ в почвах и сопредельных средах: труды всесоюзного совещания. - Л.: Гидрометеоиздат, 1980. - С. 226-231.

2. Дударев, А.А. Персистентные полихлорированные углеводороды и тяжелые металлы в арктической биосфере: основные закономерности экспозициии репродуктивное здоровье коренных жителей / А.А. Дударев // Биосфера. - 2009. - Т. 1. - № 2. - С. 186-202.

3. Лыжина, А.В. Химическое загрязнение продуктов питания и его влияние на здоровье населения Архангельской области / А.В. Лыжина, Р.В. Бузинов, Т.Н. Унгуряну, А.Б. Гудков // Экология человека. - 2012. № 12. - С. 3-9.

4. Мамонтова, Е.А. Содержание стойких органических загрязнителей в грудном молоке жительниц Иркутской области / Е.А. Мамонтова, 
Е.Н. Тарасова, М.И. Кузьмин [и др.] // Гигиена и санитария. - 2010. - № 1. C. 35-38.

5. Ревич, Б.А. Инновационные эколого-эпидемиологические технологии оценки влияния диоксинов на здоровье детей / Б.А. Ревич, О.В. Сергеев, А.А. Шелепчиков // Экология человека. - 2012. - № 8. - С. 42-49.

6. Чащин, В.П. Социально-экономические и поведенческие факторы риска нарушений здоровья среди коренного населения Крайнего Севера / В.П. Чащин, А.А. Ковшов, А.Б. Гудков, Б.А. Моргунов // Экология человека. - 2016. - № 6. - С. 3-8.

7. Чащин, М.В. Основные тенденции изменения концентраций стойких токсичных веществ в крови коренного населения Арктики / М.В. Чащин, В.П. Чащин, В.Н. Фёдоров [и др.] // Экология человека. 2012. - № 6. - C. 3-7.

8. Banyiová, K. Long-term time trends in human intake of POPs in the Czech Republic indicate a need for continuous monitoring / K. Banyiová, M. Cerná, O. Mikeš [et al.] // Environment International. - 2017. - V. 108. P. 1-10.

9. Bawa, P. Persistent Organic Pollutants Residues in Human Breast Milk from Bathinda and Ludhiana Districts of Punjab, India / P. Bawa, J.S. Bedi, J.P.S. Gill [et al.] // Archives of Environmental Contamination and Toxicology. - 2018. - V. 75. - P. 512-520.

10. Bedi, J.S. Pesticide residues in human breast milk: Risk assessment for infants from Punjab, India / J.S. Bedi, J.P.S. Gill, R.S. Aulakh [et al.] // Science of The Total Environment. - 2013. - V. 463-464. - P. 720-726.

11. Cerná, M. Human biomonitoring in the Czech Republic: An overview / M. Cerná, A. Krsková, M. Čejchanová [et al.] // International Journal of Hygiene and Environmental Health. - 2012. - V. 215. - P. 109-119.

12. Cerná, M. Human biomonitoring system in the Czech Republic / M. Cerná, V. Spěvácková, A. Batáriová [et al.] // International Journal of Hygiene and Environmental Health. - 2007. - V. 210. - P. 495-499.

13. Chen, M.-W. Association between Organochlorine Pesticide Levels in Breast Milk and Their Effects on Female Reproduction in a Taiwanese Population / M.-W. Chen, H. Santos, D. Que [et al.] // International Journal of Environmental Research and Public Health. - 2018. - V. 15. - P. 931.

14. Choi, W. Exposure to environmental chemicals among Korean adultsupdates from the second Korean National Environmental Health Survey (2012- 
2014) / W. Choi, S. Kim, Y.-V. Baek [et al.] // International Journal of Hygiene and Environmental Health. - 2017. - V. 220. - P. 29-35.

15.DDT and its derivatives: environmental aspects. - WHO: World Health Organization, 1989. -98 p.

16. Dirtu, A.C. Organohalogenated pollutants in human serum from Iassy, Romania and their relation with age and gender / A.C. Dirtu, R. Cernat, D. Dragan [et al.] // Environment International. - 2006. - V. 32. - P. 797-803.

17. Fujii, Y. Comparative survey of levels of chlorinated cyclodiene pesticides in breast milk from some cities of China, Korea and Japan / Y. Fujii, Y. Ito, K.H. Harada [et al.] // Chemosphere. - 2012. - V. 89. - P. 452-457.

18. Fukata $\mathrm{H}$. to measure PCBs and organochlorine pesticide concentrations in human umbilical cords for fetal exposure assessment / H. Fukata, M. Omori, H. Osada [et al.] // Environmental Health Perspectives. - 2005. V. 113. - P. 297-303.

19. GHBC. Aktualisierung der Referenzwerte Für PCB-138, -153, -180 im Vollblut sowie Referenzwerte für $\mathrm{HCB}, \beta-\mathrm{HCH}$ und DDE im Vollblut // Bundesgesundheitsblatt - Gesundheitsforschung - Gesundheitsschutz. - 2003. V. 46. - P. 161-168.

20. Glynn, A.W. Serum concentrations of organochlorines in men: a search for markers of exposure / A.W. Glynn, A. Wolk, M. Aune [et al.] // Science of the Total Environment. - 2000. - V. 263. - P. 197-208.

21. Haraguchi, K. Levels and regional trends of persistent organochlorines and polybrominated diphenyl ethers in Asian breast milk demonstrate POPs signatures unique to individual countries / K. Haraguchi, A. Koizumi, K. Inoue [et al.] // Environment International. - 2009. - V. 35. - P. 1072-1079.

22. Hu, L.M. Occurrence and distribution of organochlorine pesticides (OCPs) in surface sediments of the Bohai Sea, China / L.M. Hu, G. Zhang, B.H. Zheng [et al.] // Chemosphere. - 2009. - V. 77. - P. 663-672.

23. Jovanović, G. Introducing of modeling techniques in the research of POPs in breast milk - A pilot study / G. Jovanović, S.H. Romanić, A. Stojić [et al.] // Ecotoxicology and Environmental Safety. - 2019. - V. 172. - P. 341-347.

24. Kim, S. Association between maternal exposure to major phthalates, heavy metals, and persistent organic pollutants, and the neurodevelopmental performances of their children at 1 to 2 years of age- CHECK cohort study / S. Kim, S. Eom, H.-J. Kim [et al.] // Science of The Total Environment. - 2018. V. 624. - P. 377-384. 
25. Lenters, V. Early-life exposure to persistent organic pollutants (OCPs, PBDEs, PCBs, PFASs) and attention-deficit/hyperactivity disorder: A multipollutant analysis of a Norwegian birth cohort / V. Lenters, N. Iszatt, J. Forns [et al.] // Environment International. - 2019. - V. 125. - P. 33-42.

26. Lukyanova, O.N. Organochlorine pesticides and polychlorinated biphenyls in the Bering flounder (Hippoglossoides robustus) from the Sea of Okhotsk / O.N. Lukyanova, V.Yu. Tsygankov, M.D. Boyarova // Marine Pollution Bulletin. - 2018. - V. 137. - P. 152-156.

27. Mamontova, E.A. PCBs and OCPs in human milk in Eastern Siberia, Russia: Levels, temporal trends and infant exposure assessment / E.A. Mamontova, E.N. Tarasova, A.A. Mamontov // Chemosphere. - 2017. - V. 178. - P. 239-248.

28. Mamontova, E.A. The influence of soil contamination on the concentrations of PCBs in milk in Siberia / E.A. Mamontova, E.N. Tarasova, A.A. Mamontov [et al.] // Chemosphere. - 2007. - V. 67. - P. S71-S78.

29. Muller, M.H.B. Prenatal exposure to persistent organic pollutants in Northern Tanzania and their distribution between breast milk, maternal blood, placenta and cord blood / M.H.B. Muller, A. Polder, O.B. Brynildsrud [et al.] // Environmental Research. - 2019. - V. 170. - P. 433-442.

30. Negoita, T.G. Distribution of polychlorinated biphenyls (PCBs) and organochlorine pesticides in soils from the East Antarctic coast / T.G. Negoita, A. Covaci, A. Gheorghe, P. Schepens // Journal of Environmental Monitoring. 2003. - V. 5. - No. 2. - P. 281-286.

31. Nicholson, W.J. Human Health Effects of Polychlorinated Biphenyls / W.J. Nicholson, P.J. Landrigan // Dioxins and Health / ed. Schecter A. - Boston, MA: Springer US, 1994. - P. 487-524.

32. Polychlorinated biphenyls and polybrominated biphenyls / IARC Working Group on the Evaluation of Carcinogenic Risks to Humans. - Lyon, France, 2013. $-510 \mathrm{p}$.

33. Porpora, M. Placental Transfer of Persistent Organic Pollutants: A Preliminary Study on Mother-Newborn Pairs / M. Porpora, R. Lucchini, A. Abballe [et al.] // International Journal of Environmental Research and Public Health. - 2013. - V. 10. - No. 2. - P. 699-711.

34. Porta, M. Differences in serum concentrations of organochlorine compounds by occupational social class in pancreatic cancer / M. Porta, M.B. de Basea, F.G. Benavides [et al.] // Environmental Research. - 2008. -V. 108. P. 370-379. 
35. Tanabe, S. Contamination by Persistent Toxic Substances in the AsiaPacific Region / S. Tanabe // Persistent Organic Pollutants in Asia: Sources, Distributions, Transport and Fate. - A. Li, S. Tanabe, G. Jiang, J.P. Giesy and P.K.S. Lam (Editors). - Developments in Environmental Science. - 2007. - V. 7. - P. 773-817.

36. Thomas, G.O. Organohalogen chemicals in human blood from the United Kingdom / G.O. Thomas, M. Wilkinson, S. Hodson [et al.] // Environmental Pollution. - 2006. - V. 141. - P. 30-41.

37. Tsydenova, O.V. Organohalogen compounds in human breast milk from Republic of Buryatia, Russia / O.V. Tsydenova, A. Sudaryanto, N. Kajiwara [et al.] // Environmental Pollution. - 2007. - V. 146. - P. 225-232.

38. Tsygankov, V.Yu. Bioaccumulation of Persistent Organochlorine Pesticides (OCPs) by Gray Whale and Pacific Walrus from the Western Part of the Bering Sea / V.Yu. Tsygankov, M.D. Boyarova, O.N. Lukyanova // Marine Pollution Bulletin. - 2015. - V. 99. - P. 235-239.

39. Tsygankov, V.Yu. Hexachlorocyclohexane $(\mathrm{HCH})$ in human blood in the south of the Russian Far East / V.Yu. Tsygankov, M.D. Boyarova, P.F. Kiku, M.V. Yarygina // Environmental Science and Pollution Research. - 2015. V. 22. - P. 14379-14382.

40. Tsygankov, V.Yu. Organochlorine pesticide accumulation in seabirds and marine mammals from the Northwest Pacific / V.Yu. Tsygankov, O.N. Lukyanova, M.D. Boyarova // Marine Pollution Bulletin. - 2018. V. 128. - P. 208-213.

41. Waliszewski, S.M. Organochlorine pesticide residue levels in blood serum of inhabitants from Veracruz, Mexico / S.M. Waliszewski, M. Caba, M. Herrero-Mercado [et al.] // Environmental Monitoring and Assessment. 2012. - V. 184. - P. 5613-5621.

42. Wicklund Glynn, A. Serum concentrations of organochlorines in men: a search for markers of exposure / A. Wicklund Glynn, A. Wolk, M. Aune [et al.] // Science of The Total Environment. - 2000. - V. 263. - P. 197-208.

43. Yasmeen, $H$. profile and health vulnerability of female workers who pick cotton by organochlorine pesticides from southern Punjab, Pakistan: Health vulnerability of female workers who pick cotton / H. Yasmeen, A. Qadir, M. Mumtaz [et al.] // Environmental Toxicology and Chemistry. 2017. - V. 36. - P. 1193-1201.

44. Yusa, V. Analytical methods for human biomonitoring of pesticides. A review / V. Yusa, M. Millet, C. Coscolla, M. Rocaet // Analytica Chimica Acta. - 2015. - V. 891. - P. 15-31. 


\section{Информация об авторах}

Боярова Маргарита Дмитриевна - канд. биол. наук, доцент, заместитель руководителя Испытательного центра «Океан» Инженерной школы, доцент Департамента пищевых наук и технологий Школы биомедицины (Дальневосточный федеральный университет), Владивосток.

Бусарова Олеся Юрьевна - канд. биол. наук, доцент, доцент кафедры экологии и природопользования Института рыболовства и аквакультуры (Дальневосточный государственный технический рыбохозяйственный университет), Владивосток.

Гумовская Юлия Петровна - канд. мед. наук, доцент, доцент Департамента фундаментальной медицины Школы биомедицины (Дальневосточный федеральный университет), Владивосток.

Гумовский Александр Николаевич - научный сотрудник лаборатории экобиотехнологии Школы биомедицины (Дальневосточный федеральный университет), Владивосток.

Донец Максим Михайлович - лаборант-исследователь лаборатории экобиотехнологии Школы биомедицины, лаборант лаборатории физико-химических испытаний Испытательного центра «Океан» Инженерной школы (Дальневосточный федеральный университет), Владивосток.

Кику Павел Федорович - д-р мед. наук, профессор, Почетный работник высшего профессионального образования РФ, директор Департамента общественного здоровья и профилактической медицины Школы биомедицины (Дальневосточный федеральный университет), Владивосток.

Коваль Ирина Петровна - канд. мед. наук, доцент Департамента клинической медицины Школы биомедицины (Дальневосточный федеральный университет), Владивосток.

Литвиненко Анна Владимировна - канд. биол. наук, доцент, доцент Кафедры экологии, биологии и природных ресурсов (Сахалинский государственный университет), Южно-Сахалинск. 
Лягуша Марина Сергеевна - аспирант кафедры физической и аналитической химии Школы естественных наук (Дальневосточный федеральный университет), Владивосток.

Лях Владимир Алексеевич - канд. техн. наук, доцент Департамента пищевых наук и технологий Школы биомедицины (Дальневосточный федеральный университет), Владивосток.

Полевщиков Александр Витальевич - д-р биол. наук, профессор, лауреат 3олотой медали Российского научного общества иммунологов, заведующий Отделом иммунологии (Институт экспериментальной медицины), СанктПетербург.

Усов Виктор Васильевич - д-р мед. наук, доцент, профессор Департамента клинической медицины Школы биомедицины (Дальневосточный федеральный университет), Владивосток.

Христофорова Надежда Константиновна - д-р биол. наук, профессор, заслуженный деятель науки РФ, Почетный работник высшего профессионального образования РФ, лауреат национальной премии «Профессор года - 2018», заведующая Международной кафедрой ЮНЕСКО «Морская экология», профессор Кафедры экологии Школы естественных наук (Дальневосточный федеральный университет), ведущий научный сотрудник лаборатории геохимии (Тихоокеанский институт географии), Владивосток.

Цыганков Василий Юрьевич - канд. биол. наук, доцент, заведующий лабораторией экобиотехнологии, доцент Департамента пищевых наук и технологий Школы биомедицины, доцент кафедры экологии Школы естественных наук (Дальневосточный федеральный университет), Владивосток.

Черняев Андрей Павлович - канд. хим. наук, заведующий лаборатории молекулярного анализа, доцент кафедры физической и аналитической химии Школы естественных наук (Дальневосточный федеральный университет), Владивосток. 


\section{Contributors}

Margarita D. Boyarova - PhD (biological sciences), Associate Professor, Deputy Head of the Testing Center "Ocean" of the School of Engineering, Associate Professor of the Department of Food Sciences and Technologies of the School of Biomedicine (Far Eastern Federal University), Vladivostok.

Olesya Yu. Busarova - PhD (biological sciences), Associate Professor of the Department of Ecology and Nature Management of the Institute of Fisheries and Aquaculture (Far Eastern State Technical Fisheries University), Vladivostok.

Yulia P. Gumovskaya - PhD (medical sciences), Associate Professor of the Department of Fundamental Medicine of the School of Biomedicine (Far Eastern Federal University), Vladivostok.

Alexander N. Gumovskiy - Researcher of the Laboratory of Environmental biotechnology of the School of Biomedicine (Far Eastern Federal University), Vladivostok.

Maksim M. Donets - laboratory assistant of the Laboratory of Environmental biotechnology of the School of Biomedicine, laboratory assistant of the Laboratory of Physicochemical Analysis of the Testing Center "Ocean" of the School of Engineering (Far Eastern Federal University), Vladivostok.

Pavel F. Kiku - Dr. Sci., Professor, Honorary Worker of Higher Professional Education of the Russian Federation, Director of the Department of Public Health and Preventive Medicine of the School of Biomedicine (Far Eastern Federal University), Vladivostok.

Irina P. Koval - PhD (medical sciences), Associate Professor of Department of Clinical Medicine of the School of Biomedicine (Far Eastern Federal University), Vladivostok.

Anna V. Litvinenko - PhD (biological sciences), Associate Professor of the Department of Ecology, Biology and Natural Resources (Sakhalin State University), Yuzhno-Sakhalinsk. 
Marina S. Liagusha - postgraduate student of the Department of Physical and Analytical Chemistry of the School of Natural Sciences (Far Eastern Federal University), Vladivostok.

Vladimir A. Lyakh - PhD (technical sciences), Associate Professor of the Department of Food Sciences and Technologies of the School of Biomedicine (Far Eastern Federal University), Vladivostok.

Alexandr V. Polevshchikov - Dr. Sci., Professor, Laureate of the Gold Medal of the Russian Scientific Society of Immunologists, Head of the Department of Immunology (Institute of Experimental Medicine), St. Petersburg.

Viktor V. Usov - Dr. Sci., Professor of the Department of Clinical Medicine of the School of Biomedicine (Far Eastern Federal University), Vladivostok.

Nadezhda K. Khristoforova - Dr. Sci., Professor, Honored Scientist of the Russian Federation, Honorary Worker of Higher Professional Education of the Russian Federation, Laureate of the National Prize "Professor of the Year - 2018", Head of the UNESCO International Chair "Marine Ecology", Professor of the Department of Ecology of the School of Natural Sciences (Far Eastern Federal University), Leading Researcher of the Laboratory of geochemistry (Pacific Institute of Geography), Vladivostok.

Vasiliy Yu. Tsygankov - PhD (biological sciences), Associate Professor, Head of the Laboratory of Environmental biotechnology, Associate Professor of the Department of Food Sciences and Technologies the School of Biomedicine, Associate Professor of the Department of Ecology of the School of Natural Sciences (Far Eastern Federal University), Vladivostok.

Andrei P. Cherniaev - PhD (chemical sciences), Head of the Laboratory of Molecular Analysis, Associate Professor of the Department of Physical and Analytical Chemistry of the School of Natural Sciences (Far Eastern Federal University), Vladivostok. 
Цыганков Василий Юрьевич,

Донец Максим Михайлович,

Христофорова Надежда Константиновна и др.

\section{СТОЙКИЕ ОРГАНИЧЕСКИЕ ЗАГРЯЗНЯЮЩИЕ ВЕЩЕСТВА (СОЗ) В ДАЛЬНЕВОСТОЧНОМ РЕГИОНЕ: МОРЯ, ОРГАНИЗМЫ, ЧЕЛОВЕК}

Монография 
Подписано в печать 19.10.2020 г. Формат 60×84 / 16. Усл. печ. л. 20,00. Тираж 500 экз. (1-й завод 1-100). Заказ 250.

Дальневосточный федеральный университет 690922, Приморский край, г. Владивосток, о. Русский, п. Аякс, 10.

Отпечатано в Дальневосточном федеральном университете 690922, Приморский край, г. Владивосток, о. Русский, п. Аякс, 10. (Типография Издательства ДВФУ, 690091, г. Владивосток, ул. Пушкинская, 10) 